Álvaro A. C. MARIANO

\title{
ABUSO DE VOTO NA RECUPERAÇÃO JUDICIAL
}

\author{
TESE DE DOUTORADO
}

Orientador: Prof. Dr. PAUlo Fernando CAMPos SALLES DE Toledo

UNIVERSIDADE DE SÃO PAULO

SÃO PAULO

2012 
Álvaro A. C. MARIANO

\section{ABUSO DE VOTO NA RECUPERAÇÃO JUDICIAL}

Tese apresentada à Banca Examinadora da Faculdade de Direito da Universidade de São Paulo, como exigência parcial para a obtenção do título de Doutor em Direito Comercial, sob orientação do Professor Doutor Paulo Fernando Campos Salles de Toledo.

UNIVERSIDADE DE SÃO PAULO

SÃo PAULO

2012 
Banca examinadora 


\section{ABREVIATURAS}

Al. Alínea

Art. Artigo

c. Comma

c/c Cumulado com

CC Código Civil (Lei n. 10.406, de 10.1.2002)

CC/16 Código Civil revogado (Lei n.3.071, de $\left.1^{\circ} .1 .1916\right)$

CCom Código Comercial (Lei n. 556, de 25.6.1850)

CDC Código de Defesa e Proteção do Consumidor (Lei n. 8.078, de 11-91991)

Cf. Confira

CLT Consolidação das Leis do Trabalho (Dec-Lei n. 5.452, de $1^{\circ} .5 .1943$ )

CPC Código de Processo Civil (Lei n. 5.869, de 11.1.1973)

CR Constituição da República Federativa do Brasil, de 5-10-1988

CTN Código Tributário Nacional (Lei n. 5.172, de 25-10-1966)

Dec. Decreto

Dec.-Lei Decreto-Lei

g.n. Grifo(s) nosso(s)

Inc. Inciso

LDC Lei de Defesa da Concorrência (Lei n. 8.884, de 11.6.1994, ainda em vigor)

LC Lei complementar

LF Lei de Falências revogada (Dec-Lei n. 7.661, de 21.6.1945) 
LICC Lei de Introdução ao Código Civil (Dec-Lei n. 4.656, de 4-9-1942)

LL Lei de Locações (Lei n. 8.245, de 18-10-1991)

LPI Lei de Propriedade Industrial (Lei n. 9.279, de 14-5-1996)

LRF Lei de Recuperação de Empresas e Falência (Lei n. 11.101, de 9.2.2005)

LRP Lei de Registros Públicos (Lei n. 6.015, de 31-12-1973)

LRPEM Lei de Registro Público das Empresas Mercantis e Atividades Afins (Lei n. 8.934, de 18-11-1994)

LSA Lei das Sociedades por Ações (Lei n. 6.404, de 15.12.1976)

N. Nota (de rodapé)

n. Número

RDM Revista de Direito Mercantil, Econômico e Finaceiro

RT Revista dos Tribunais

ss. Seguintes

v. Verbete 
ÍNDICE

$\begin{array}{ll}\text { CAPÍTULO PRIMEIRO - Introdução } & 11\end{array}$

CAPÍTULO SEGUNDO - Abuso de Direito na Teoria Geral 12

$\begin{array}{ll}\text { 2.1. Terminologia } & 13\end{array}$

2.2. O direito subjetivo e o poder funcional 16

2.2.1. Direito subjetivo: posição jurídica subjetiva ativa complexa $\quad 16$

2.2.1.1. As posições jurídicas elementares 18

2.2.1.2. As posições jurídicas complexas $\quad 21$

2.2.1.3. Direito subjetivo: escorço histórico 23

2.2.2. Poder funcional e a funcionalização do direito subjetivo 26

2.3. Abuso de direito: origem e evolução 30

2.3.1. Teorias 33

2.4. Abuso de direito no Código Civil de $1916 \quad 35$

2.5. Abuso de direito no Código Civil de $2002 \quad 39$

2.5.1. Abuso de direito na legislação precedente $\quad 40$

2.5.2. Abuso de direito como ato ilícito 41

2.5.3. Abuso de direito como cláusula geral 45

2.5.4. Os requisitos 48

2.5.4.1. O "direito" e a conduta comissiva ou omissiva 48

2.5.4.2. Elemento subjetivo e elemento objetivo 50

2.5.4.3. A prescindibilidade do dano 56

2.5.4.4. Do excesso manifesto $\quad 59$

2.6. Efeitos jurídicos da prática de atos abusivos 71

CAPÍTULO TERCEIRO - Abuso de Voto no Direito Societário 73

3.1. A formação da vontade nas sociedades anônimas

3.1.1. A teoria orgânica $\quad 74$

$\begin{array}{ll}\text { 3.1.2. Dos diversos órgãos } & 78\end{array}$

$\begin{array}{ll}\text { 3.1.3. Os órgãos deliberativos } & 79\end{array}$

3.1.3.1. O poder de controle $\quad 81$

3.1.3.1.1. Do controle externo 91

3.1.3.2. Assembleias especiais 96 
3.1.3.3. Assembleia especial de debenturistas

97

3.1.4. Os órgãos administrativos 103

3.1.5. Os órgãos de fiscalização 106

3.2. Interesse social 107

3.2.1. "Interesse" 108

3.2.2. O interesse "social" 117

3.2.2.1. As teorias institucionalistas 118

3.2.2.2. Teorias contratualistas 127

3.2.2.3. Teorias modernas 132

3.2.2.4. Interesse social na Lei n. ${ }^{\circ} 6.404 / 76$

3.3. As deliberações sociais 136

3.3.1. O voto 137

3.3.1.1. Voto: direito subjetivo ou poder funcional 141

3.3.1.1.1. Direito subjetivo 142

3.3.1.1.2. Poder funcional 147

3.3.1.1.3. Outras teorias 149

3.3.1.2. Declaração unilateral 151

3.3.1.2.1. O voto e a formação da vontade unitária coletiva 151

3.3.1.2.2. Declaração de verdade ou de vontade 164

3.3.1.2.3. Formas de emissão 165

3.3.1.2.4. Voto aberto ou secreto 166

3.3.1.2.5. Representação 167

$\begin{array}{ll}\text { 3.3.1.3. Sistemas de voto } & 170\end{array}$

3.3.1.3.1. Valor do voto 170

3.3.1.3.2. Princípio da unidade do voto 177

3.3.1.4. Votação, apuração e proclamação 179

3.3.1.5. Vícios de voto 183

3.3.1.5.1. Invalidade de assembleia, deliberação e voto 183

3.3.1.5.2. Invalidade de voto 186

3.3.1.6. Voto abusivo e voto em conflito de interesses:

precedentes 189

3.3.1.7. Voto abusivo na Lei n. ${ }^{\circ}$ 6.404/76 192

3.3.1.7.1. Dispositivo aplicável à generalidade

$\begin{array}{ll}\text { dos acionistas } & 196\end{array}$ 
3.3.1.7.2. Condutas abusivas

3.3.1.7.3. Elemento objetivo e elemento subjetivo

3.3.1.7.4. Vantagem indevida e prejuízo real ou potencial 198

CAPÍTULO QUARTO - Abuso de Voto na Recuperação Judicial 203

4.1. Recuperação judicial e as negociações estruturadas

4.1.1. O procedimento como mecanismo de estruturação das negociações

203

4.1.2. A natureza jurídica do instituto 208

4.2. O “interesse" recuperacional 218

4.2.1. As finalidades da recuperação judicial 219

4.2.1.1. Objetivo instrumental: a recuperação do devedor 222

4.2.1.2. Objetivos próximos e mediatos: os credores

e a função social 223

4.2.2. Os interesses difusos 226

4.2.3. O interesse dos credores $\quad 229$

4.2.3.1. Instauração do concurso: vontade exclusiva do devedor 231

4.2.3.2. O interesse comum dos credores 232

4.2.4. O interesse do devedor 235

4.3. A falência como meio de preservação da empresa 236

4.3.1. A “nova” falência 237

4.3.2. Os princípios enunciados pelo art. 75 da Lei n. ${ }^{\circ} 11.101 / 05 \quad 239$

4.3.3. Continuação provisória da atividade $\quad 244$

4.3.4. Realização do ativo logo após a arrecadação 248

4.3.5. A ordem de preferência na alienação dos ativos 253

4.3.6. Inexistência de sucessão do adquirente do estabelecimento 255

4.4. Órgãos na recuperação judicial 257

$\begin{array}{ll}\text { 4.5. O administrador judicial } & 259\end{array}$

4.5.1. Breve histórico 259

4.5.2. A Lei n. $^{\circ}$ 11.101/05: principais novidades 262

4.5.3. Natureza jurídica $\quad 262$

4.5.3. Nomeação do administrador judicial: profissionalização 263

4.5.4. Critério para nomeação 264

4.5.5. Impedimentos para exercício da função 267 
4.5.6. Investidura

4.5.7. Substituição e destituição do administrador judicial

4.5.8. Remuneração

4.5.9. Atribuições

4.5.10. Responsabilidade do administrador judicial

4.6. Assembleia geral de credores

4.6.1. Características

4.6.2. Integrantes e direito de presença, voz e voto

4.6.3. Sistema de voto e quorum

4.6.4. O problema da separação de classes 285

4.6.5. O problema da deliberação estratificada 286

4.6.6. O problema do cram down 288

4.7. Abuso de voto e conflito de interesses 291

4.8. Voto do credor pela falência e abuso de voto 295

RESUMO 298

ABSTRACT 299

RIASSUNTO 


\section{CAPÍTULO PRIMEIRO - INTRODUÇÃO}

A Lei n. ${ }^{\circ}$ 11.101/05 tem sido festejada pela oportuna introdução no sistema jurídico brasileiro de mecanismos de reorganização da empresa em crise e, em especial, a modalidade mais complexa, a recuperação judicial (arts. 47 e ss.). O instituto guarda diferenças marcantes em relação à concordata, alternativa à falência no sistema do Decreto-Lei n. ${ }^{\circ}$ 7.661/45. Entre elas, destaca-se o deslocamento do centro decisório sobre a concessão da medida do Poder Judiciário para a comunhão de credores. A estes cabe decidir pelo acatamento ou não do plano de reerguimento apresentado pelo devedor.

Essa decisão pode decorrer da inação dos credores: caso não apresentem objeção ao plano dentro do prazo legal, ele restará aprovado. No mais das vezes, contudo, a decisão é proferida por um órgão plural do tipo colegial, a assembleia geral de credores. Esse órgão da comunhão de credores, observado o método assemblear, delibera sobre os mais altos assuntos da recuperação judicial, especialmente o plano de recuperação.

Paralelamente a esse instituto, a vigente Lei de Recuperação de Empresas e Falências alterou substancialmetne o instituto da falência, para imbui-la também da preservação da empresa. É o que deflui do art. 75.

Por isso, o voto contrário à recuperçaão judicial, que se destine à quebra, mesmo aquele proferido por credor único em uma classe - que virtualmente exerce o poder de "veto" - não pode ser considerado, de per si, abusivo. A lei impõe ao credor o dever de, na recuperação judicial, procurar o atendimento à função social da empresa em recuperação. Seu direito político de voto na recuperçaão deve, portanto, atender também a essa finalidade. Sucede que a o voto pela falência não pode ser considerado um voto contrário à função social, já que também ela tem essa função por força dos princípios insculpidos pelo art. 75 .

Para o exame da questão, faz-se um estudo prévio do abuso de direito na teoria geral do direito e, em seguida, do abuso de voto nas companhias. Um e outro capítulo conteém elementos que, ao depois, são aproveitados no quarto capítulo, ao tratar do interesse na recuperação judicial e o exercício do voto pelo devedor. 


\section{CAPÍTULO SEGUNDO - ABUSO DE DIREITO NA TEORIA GERAL}

A evolução experimentada pelo instituto do abuso de direito, a partir do século XIX, é hoje quase unissonamente aplaudida pela doutrina ${ }^{1}$. Apontado como resultante das contradições do capitalismo naquele século ${ }^{2}$, esse fato histórico é visto pela doutrina como manifestação de uma espécie de "mudança de patamar" no direito. O sistema jurídico, até então individualista, absolutista e fechado ${ }^{3}$, por decorrência do positivismo estrito herdado das codificações liberais daquele tempo, cedeu forçosamente espaço à reclamada relatividade dos direitos ${ }^{4}$. Engendrou-se assim a hipótese aparentemente contraditória de negativa de proteção legal a uma conduta realizada dentro dos limites formais de um direito subjetivo.

Para a promoção inicial dessa profunda mudança, foi decisiva a atuação dos tribunais, notadamente na França ${ }^{5}$. Noções anteriormente desenvolvidas pelo direito romano $^{6}$ e durante a Idade Média (a teoria da emulatio), e que não tiveram lugar no sistema oitocentista, foram então retomadas por decisões judiciais. De início restritos a matéria de propriedade imobiliária ${ }^{7}$, os julgados prolongaram-se posteriormente a outros campos do direito privado (contratos, obrigações em geral, família ${ }^{8}$ ) e, por efeito de suas reiterações, esboçaram os traços do princípio (da proibição) do abuso de direito - ao depois,

\footnotetext{
${ }^{1}$ Humberto ThEODORo JR., Comentários ao Novo Código Civil, v. 3, tomo 2, Rio de Janeiro, Forense, 2005, p. 111.Quando de sua aparição (como teoria), no entanto, afirma Pietro RESCIGNO que o abuso de direito conheceu as reações mais extremadas: "l'esaltazione ha raggiunto toni mistici, la critica è stata severa, desna di preoccupazioni e di terrore." In: L'abuso del diritto, in Rivista di diritto civile, ano XI, 1965, 1ª parte, Padrova, Cedam, p. 205. Nada obstante o louvor generalizado, Orlando GoMES alertava, já no século $\mathrm{XX}$, para emprego excessivo do instituto. Verbis: "A extensão dada à teoria do abuso de direito tem determinado exageros contra os quais se levanta a voz sensata de eminentes juristas. A sedução que a teoria exerce sobre os espiritos, por seu teor moralizante, está conduzindo a extremos condenáveis." In: Introdução ao Direito Civil, Rio de Janeiro, Forense, 1999, p. 134.

${ }^{2}$ P. Rescigno, L'abuso del diritto, in Rivista di diritto civile, ano XI, 1965, $1^{\mathrm{a}}$ parte, Padrova, Cedam, p. 207. Endossando o entendimento: Jorge Manuel CoutinHo DE ABREU, Do Abuso de Direito - Ensaio de um Critério em Direito Civil e nas Deliberações Sociais, Coimbra, Almedina, 2006, p. 13.

${ }^{3}$ Francisco Amaral, Direito Civil - Introdução, $7^{\mathrm{a}}$ Ed., Rio de Janeiro, Renovar, 2008, p. 243.

${ }^{4}$ Orlando GoMes, Introdução ao Direito Civil, Rio de Janeiro, Forense, 1999, p. 131.

${ }^{5}$ Salvatore PATTI, L'abuso del diritto, in Digesto delle disciplina privatische, Torino, UTET, 1987, p. 2.

${ }^{6}$ Alexandre Augusto de Castro e CORREA, Abuso de Direito (direito romano) (verbete), in Enciclopédia Saraiva do Direito, v. 2, São Paulo, Saraiva, pp. 48. Pedro Baptista MARTins, O Abuso do Direito e o Ato Ilícito, Rio de Janeiro, Freitas Bastoso, 1941, p. 21.

${ }^{7}$ Salvatore PATTI, L'abuso del diritto, in Digesto delle disciplina privatische, Torino, UTET, 1987, p. 2.

${ }^{8}$ Sergio CaVAlieri Filho, Programa de Responsabilidade Civil, São Paulo, Atlas, 2009, p. 153.
} 
esquadrinhado e teorizado pela doutrina ${ }^{9}$ e, ainda após, agasalhado pela ordem jurídica posta.

À consolidação do instituto em direito privado, seguiu-se sua extensão a outros ramos do direito (processo civil $^{10}$ e administrativo ${ }^{11}$, por exemplo) e hoje é reconhecidamente tema concernente à teoria geral do direito ${ }^{12}$ e encontra aplicação jurisprudencial mesmo nos ordenamentos jurídicos que, ao contrário do nosso, não contêm previsão positivada ${ }^{13}$.

Particularmente, para os limites da presente tese, importa sublinhar o vasto desenvolvimento que alcançou o tema também em matéria societária. Com efeito, o abuso pelo sócio no exercício do voto nas assembleias sociais tem sido há décadas objeto de numerosas obras doutrinárias ${ }^{14}$. Todo o conhecimento desenvolvido nesse âmbito fornece agora subsídio para o exame de semelhante questão nas deliberações tomadas pelos credores em assembleia própria nos processos de recuperação judicial. Antes, contudo, passa-se à averiguação de seus contornos no direito privado em geral e, particularmente, em matéria de direito subjetivo.

\subsection{Terminologia}

\footnotetext{
${ }^{9}$ Eduardo JoRdẽo, Repensando a Teoria do Abuso de Direito, Salvador, Juspodium, 2006, p. 61.

${ }^{10}$ José Olímpio de CASTRo Filho, Abuso de Direito no Processo Civil, Rio de Janeiro, Forense, 1960, pp. 31-32: "A teoria, posto existisse antes a repressão do abuso também no processo civil (vide, adiante, histórico, n. ${ }^{\circ} 18$ ), recebeu-a, sem dúvida, esta ciência [processo civil] daquela [direito privado].” Andressa Paula SENNA, $O$ abuso de direito e a litigância de má-fé como impeditivos à marcha processual e ao resultado justo da prestação jurisdicional, in Revista de Direito Privado, ano 10, n. 40, outubro-dezembro de 2009, pp. 9-59.

${ }^{11}$ Por todos, veja-se Ricardo Marcondes MARTins, Abuso de Direito e a Constitucionalização do Direito Privado, São Paulo, Malheiros, 2010, p. 60.

${ }^{12}$ Eduardo JoRDÃo, Repensando a Teoria do Abuso de Direito, Salvador, Juspodium, 2006, p. 31. Francisco Cavalcanti PONTES DE MIRANDA, embora tratando especificamente dos artigos 159 e 160, inc. I, $2^{\mathrm{a}}$ parte, do Código Civil de 1916, afirma que a disciplina sobre abuso de direito "apanha o direito comercial e público" e, ainda, o processo civil. Cf. Tratado de Direito Privado, t. II, Rio de Janeiro, Borsoi, 1970, p. 292.

13 “(...) a verdade é que a aplicação jurisprudencial da teoria [do abuso de direito] se pode dizer quase universal.” In: Teófilo de Castro DUARTE, O Abuso do Direito e as Deliberações Sociais - Ensaio Jurídico, Coimbra, Coimbra Editora, 1955, p. 75.

${ }^{14}$ Trata-se ainda de "abuso de maioria" e "abuso de minoria". Vejam-se: Teófilo de Castro DUARTE, $O$ Abuso do Direito e as Deliberações Sociais - Ensaio Jurídico, Coimbra, Coimbra Editora, 1955; Jorge Manuel Coutinho DE ABReu, Do Abuso de Direito - Ensaio de um Critério em Direito Civil e nas Deliberações Sociais, Coimbra, Almedina, 2006; Aldo FERRARI, L'abuso del diritto nelle società, Padova, CEDAM, 1998; Marcelo Vieira Von ADAMEK, Abuso de Minoria em Direito Societário - Abuso das Posições Subjetivas Minoritárias, tese de doutorado, São Paulo, mimeo, 2010; Luiz Gastão Paes de Barros LEÃes, Abuso da Minoria em Aumento de Capital, in Pareceres, v. 2, São Paulo, Singular, 2004, pp. 12111225, Abuso de Poder da Minoria, op. cit., pp. 1243-1256.
} 
Existe divergência na doutrina quanto à terminologia ${ }^{15}$ - que, diga-se, é aproximadamente a mesma em todo direito continental europeu ${ }^{16}$. Observa Aldo FERRARI que se, por um lado, os termos que compõem a expressão sempre suscitaram interesse, por outro não menos frequentemente ensejaram críticas ${ }^{17}$. Entre estas, é abundantemente citada a censura feita por Marcel PLANIOL, que dizia ser a expressão logomáquica (constituir uma “logomachie”), isto é, vã, sem sentido, "brincadeira de palavras".

Sustentava o francês que os dois termos eram entre si inconciliáveis, por $\operatorname{contraditórios~}^{18}$. A mesma conduta, dizia, não poderia, a um só tempo, ser conforme o direito e contrária a ele. Não conviveriam licitude e ilicitude em um mesmo proceder. Em suas palavras: "le droit cesse où l'abus commence", o direito acaba onde o abuso começa. Tratar-se-ia, pois, de questão lógica jurídica e a expressão não poderia, por conseguinte, significar o fenômeno ${ }^{19}$.

Mesmo Piero RESCIGNO admite que, analisando as palavras que a compõem, a expressão é "intimamente contraddittoria”, ao menos "alla prima impressione "20 . Jorge Manuel COUTINHO DE ABREU tem-na também por infeliz, "já que o

\footnotetext{
${ }^{15}$ Anota Álvaro Villaça AZEVEDo que, no direito romano, primitivamente, o verbo abuti (abusar) significava usar com bastante intensidade - daí, por exemplo, a propriedade implicar o ius utendi, fruendi et abutendi (direito de usar, fruir e abusar). Seu sentido, no entanto, modificou-se com o tempo e passou a designar o uso indevido, excessivo (o autor lembra a famosa frase de Marto Tullio Cícero, das Catilinárias: Quousque tandem Catilina abutere patientia nostra, Até quando, Catilina, abusarás de nossa paciência), o que moveu os autores a alterar, no conceito de propriedade, a expressão ius abutendi por ius disponendi, como , aliás, foi integrado aos Códigos Civis brasileiros de 1916 e 2002. In: Código Civil Comentado, v. 2, São Paulo, Atlas, 2003, p. 363.

${ }^{16}$ Assim: abuso do direito, em Portugal; abus des droits, na França; abuso del derecho, na Espanha; e l'abuso del diritto, na Itália (admitidas as variações, com e sem emprego do artigo definido).

Admitidas as variantes quanto ao uso do artigo definido, usa-se "abuso de(o) direito" em Portugal;

${ }^{17}$ L'abuso del diritto nelle società, Padova, CEDAM, 1998, p. 1.

18 "Sa formule 'usage abusif des droit' est une logomachie, car si j'use de mon droit, mon acte est licite; et, quand il est illicite, c'est que je dépasse mon droit et que j'agis sans droit, injuria, comme disait la loi aquilia." In Traitè élémentaire de droit civil, t. II, Paris: Librariei Générale de Droit \& de Jurisprudence, 1907, p. 281.

${ }^{19}$ As objeções de M. PLANIOL à terminologia conduziram muitos que o interpretaram a afirmar que o francês era contrário ao instituto do abuso de direito. P. B. MARTINS, por exemplo, assevera textualmente: "Mas a crítica do eminente civilista, patrocinada por autoridades de prol, não se limitou à suposta imprecisão de linguagem. Ela foi mais longe. (...) $O$ direito cessa onde o abuso começa e o uso abusivo de um direito qualquer não seria possível pela razão irrefutável de que um só e mesmo ato não pode ser, a um tempo, conforme e contrário ao direito." In: Abuso do Direito e O Ato Ilícito, Rio de Janeiro, Freitas Bastos, 1941, p. 203. Essa interpretação, todavia, parece não ajustar-se com o que efetivamente ensinou o mestre francês. J. M. COUTINHO DE ABREU tacha de truncada e incorreta essa exegese. Em comprovação, transcreve o seguinte trecho do Traité élémentaire de droit civil, t. II (Paris, 1926, p. 298): "Negar o uso abusivo dos direitos não é tentar fazer passar por permitidos os actos prejudiciais muito variados que a jurisprudência reprimiu; é somente fazer esta observação de que todo o acto abusivo, apenas porque é ilícito, não é o exercício dum direito, e que o abuso de direito não constitui uma categoria jurídica distinta do acto ilícito. (...) No fundo, toda gente está de acordo; somente onde uns dizem: 'Há uso abusivo dum direito', os outros dizem: 'Há um acto exercido sem direito'. Defende-se uma ideia justa com uma fórmula falsa." In: Do Abuso de Direito Ensaio de um Critério em Direito Civil e nas Deliberações Sociais, Coimbra, Almedina, 2006, pp. 45-46, n. 92.

${ }^{20}$ L'abuso del diritto, in Rivista di diritto civile, ano XI, 1965, $1^{\text {a }}$ parte, Padrova, Cedam, p. 206.
} 
abuso quer dizer, em rigor, mau uso, e o fenómeno não traduz efectivamente um uso ou exercício de um direito",21.

Posição diversa defendeu L. JossERAND, um dos mais profusamente citados doutrinadores nessa matéria e um dos pioneiros a estudá-la no início do século passado na França. Para ele, não há contradição e a expressão é perfeitamente lógica, porquanto a hipótese é conduta conforme o direito subjetivo, mas contrária ao direito visto no seu conjunto, enquanto corpo de regras sociais obrigatórias ${ }^{22}$. Assim a aparente contrariedade de sentidos se esvai: o abuso não se refere ao direito subjetivo, ao qual se reportaria o termo "direito" na consagrada expressão (o qual não seria infringido, pois que observados seus limites intrínsecos), mas ao direito em conjunto - isto é, o direito objetivo $^{23}$ (que não consta da expressão). Nas palavras de E. JORDÃO, para L JOSSERAND, "Um ato conforme ao direito subjetivo poderia estar em desconformidade com o direito objetivo, considerado em sua totalidade ${ }^{, 24}$. Ainda sobre a doutrina do civilista francês, Pedro A. MARTINS explica que "o ato pode ser, ao mesmo tempo, conforme ao direito positivo e contrário ao complexo de princípios jurídicos ${ }^{, 25}$.

Em favor da expressão, manifestou-se ainda CASTANHEIRA NEVES, para quem sua aparente incoerência é oportuna por traduzir "justamente" a "contradição entre o cumprimento da estrutura formalmente definidora de um direito e a violação concreta do fundamento que material-axiologicamente constitui esse mesmo direito" ${ }^{26}$. Semelhante entendimento externa Humberto THEODORO JR. ${ }^{27}$

Em que pesem os argumentos contrários e favoráveis ao emprego da

${ }^{21}$ Do Abuso de Direito - Ensaio de um Critério em Direito Civil e nas Deliberações Sociais, Coimbra, Almedina, 2006, p. 47.

${ }^{22}$ Ele ensina que "et l'acte abusif est tout simplesment celui qui, accompli em vertu d'un droit subjectif dont les limites ont été rrespectées, est cependant contraire au droit envisagé dans son ensemble et em tant que juricitè, c'est-à-dire em tant que corps de règles sociales obligatoires." E conclui: "On peut parfaitement avoir pour soi tel droit determine et cependant avoir contre soi le droit tout entier

${ }^{23}$ Com ironia, comenta Jorge Manuel CoutinHo DE ABREU a explicação de Louis JosSERAND: "É pelo menos arrojado garantir a logicidade de um acto ser simultaneamente conforme a um direito subjetivo e desconforme com o direito em geral - sendo certo que é este que prevê ou reconhece aquele!'. In: Do Abuso de Direito - Ensaio de um Critério em Direito Civil e nas Deliberações Sociais, Coimbra, Almedina, 2006, p. 46.

${ }^{24}$ Repensando a Teoria do Abuso de Direito, Salvador, Juspodium, 2006, p. 68.

${ }^{25}$ O Abuso do Direito e O Ato Ilícito, Rio de Janeiro, Freitas Bastos, 1941, p. 204.

${ }^{26}$ Apud Jorge Manuel Coutinho de ABreu, Do Abuso de Direito - Ensaio de um Critério em Direito Civil e nas Deliberações Sociais, Coimbra, Almedina, 2006, pp. 46-47.

27 Diz ele que o termo direito, multívoco, pode significar assim uma situação disciplinada como a prerrogativa reconhecida ao titular desta posição: não deixa de ser o titular da posição aquele que dela abusa (segue sendo proprietário aquele que abusa da propriedade) e, conclui, "é justamente pelo cotejo entre o uso inadequado e o fim sócio-econômico de seu direito que se detecta o vício do abuso do direito cometido pelo proprietário contra o vizinho”. In: Comentários ao Novo Código Civil, v. 3, Rio de Janeiro, Forense, 2005, p. 111. 
expressão, o debate irremediavelmente perdeu importância - ao menos estritamente quanto à linguagem. Embora encerre deveras uma contradição - que é evidente e não apenas aparente -, o fato é que foi ela consagrada por seu reiterado uso em diversos países ao longo do século XX, e não apenas pelas respectivas jurisprudências e doutrinas, mas também pelos próprios textos de lei (cada vez mais numerosos) que disciplinaram o instituto. Está, pois, enraizada em nossa cultura jurídica e, de qualquer sorte, não se pode negar, como observa Jorge Manuel CoUTINHO DE ABREU, que ela "não deixa de ser sugestiva" - e, conclui o português, "afinal, o importante é saber-se o que a expressão significa..., ${ }^{, 28}$.

Superada, assim, a controvérsia sobre seu emprego, uma derradeira nota a respeito da expressão tem lugar - e apenas para fins de estipulação, nos limites do presente trabalho. De regra, preferimos a forma abuso de direito à outra, abuso do direito $^{29}$. Posto que esta tenha uso, mesmo no direito comparado (em italiano: abuso del diritto; em espanhol: abuso del derecho), aquela parece-nos mais adequada à significação do caráter geral do instituto. A forma contrata, de preposição e artigo definido, todavia, tem predileção quando referente a direito específico ${ }^{30}$.

Outras formas mais extensas, conquanto mais exatas - como abuso no exercício do direito ou exercício abusivo do direito -, não são igualmente aqui adotadas, de regra. Nesse caso, o critério é a inconveniência da excessiva extensão (a fórmula sintética parece mais adequada) e o pouco uso no meio jurídico.

\subsection{O direito subjetivo e o poder funcional}

\subsubsection{Direito subjetivo: posição jurídica subjetiva ativa complexa}

Não há hodiernamente ramo no direito imune à aplicação do instituto em exame; trata-se, como dito, de matéria atinente à teoria geral $^{31}$. É indisputável, ademais, que não apenas do direito subjetivo propriamente dito se pode abusar, mas também de

\footnotetext{
${ }^{28}$ Do Abuso de Direito - Ensaio de um Critério em Direito Civil e nas Deliberações Sociais, Coimbra, Almedina, 2006, p. 47.

${ }^{29}$ Esta fórmula foi preferida por Tatina Bonatti PERES para intitular seu artigo, mesmo tendo por objeto a teoria em geral. Cf. Abuso do Direito, in Revista de Direito Privado, ano 11, n. 43, julho-setembro de 2010, p. 9 .

${ }_{30}$ Assim, "abuso do direito de recorrer no processo civil brasileiro", por exemplo.

${ }^{31}$ Eduardo JoRDÃO, Repensando a Teoria do Abuso de Direito, Salvador, Juspodium, 2006, p. 31.
} 
outras posições jurídicas ${ }^{32}$.

Nada obstante, o direito subjetivo é, como assenta José de Oliveira ASCENSÃo, a situação jurídica "paradigmática" "33. Como "manifestação e um meio de actuação da autonomia da vontade" ${ }^{34}$ e destinado à persecução do interesse próprio (egoístico) do titular e engendrado, foi ele a base sobre a qual o instituto do abuso de direito ao longo da história desenvolveu-se $\mathrm{s}^{35}$.

De se sublinhar que a noção de direito subjetivo, produto doutrinário do século $\mathrm{XIX}^{36}$, constituiu historicamente a afirmação no plano jurídico da liberdade individual - que é sua base axiológica -, já então consolidada política (liberalismo) e economicamente (capitalismo). Verificou-se, no entanto, que a exacerbação dessa liberdade resultara faticamente em condutas que, não obstante cingidas à circunscrição formal do direito subjetivo, constituíam atos meramente emulativos ou que, de qualquer modo, extrapolavam os limites valorativos e finalidades que fundamentaram o direito. Essa circunstância tornou premente a necessidade de mitigar tais indesejáveis exageros objetivo almejado no desenvolvimento, entre outros, da figura do abuso de direito. É, pois, por aí que se inicia o presente estudo.

Retratado em sua anatomia, o direito subjetivo não é uma categoria jurídica simples, mas uma estrutura complexa ${ }^{37}$ que pode ser decomposta em elementos

\footnotetext{
${ }^{32}$ Louis JosserAnd, De l'esprit des droits et de leur relativitè, Paris, Dalloz, 1939, pp. 322-323; Fernando Augusto CunHa DE SÁ, Abuso de Direito, Lisboa, Ministério das Finanças, 1973, p. 547; Eduardo JoRDÃO, Repensando a Teoria do Abuso de Direito, Salvador, Juspodium, 2006, p. 32; Aldo FERRARI, L'abuso del diritto nelle società, Milão, CEDAM, 1998, p. 26; Jorge Manuel CouTINHO DE ABREU, Do Abuso de Direito - Ensaio de Um Critério em Direito Civil e nas Deliberações Sociais, Coimbra, Almedina, 2006, p. 72.

${ }^{33}$ Direito Civil - Teoria Geral, v. 3, São Paulo, Saraiva, 2010, p. 215.

${ }_{34}^{34}$ Carlos Alberto da Mota PINTO, Teoria Geral do Direito Civil, Coimbra, Coimbra, 1991, p. 169.

35 Fernando Augusto CUNHA DE SÁ justifica o estudo do abuso de direito a partir da figura do direito subjetivo por razões de "comodidade". Explica: "Foi através de uma abertura à essência íntima e à natureza própria do direito subjectivo que progressivamente se veio avançando em ordem à descoberta da noção de abuso de direito e à sua delimitação perante a figura mais ampla da antijuridicidade e, posteriormente, à sua confrontação funcional com outras realidade dele muito próximas e por vezes com ele confundidas." Cf. Abuso de Direito, Lisboa, Ministério das Finanças, 1973, pp. 547-548.

${ }^{36} \mathrm{Na}$ verdade, trata-se do resultado de elaboração iniciada na Idade Média, pelos glosadores, que revisitaram o Corpus iuris civilis romano (Francisco AMARAL, Direito Civil - Introdução, Rio de Janeiro, Renovar, 2008, p. 225); embora os romanos tenham identificado a idéia de atribuição jurídica às pessoas e atribuído notória relevância à actio, não chegaram a desenvolver a noção teórica de direito subjetivo (José Carlos MoreIRA Alves, Direito Romano, v. 1, Rio de Janeiro, Forense, 1998, p. 88). O Renascimento conduziu a uma crescente "subjetivação" do direito, em decorrência do individualismo, ensina Francisco AMARAL (Direito Civil - Introdução, p. 226), e a progressiva afirmação das liberdades, a partir das teorias políticas de Thomas HoBBES e dos movimentos de ruptura do século XVIII (liberdade de comércio e na indústria, livreconcorrência), favoreceu a concepção de liberdade individual como valor sensível e da qual, já no século XIX, o direito subjetivo é o seu reconhecimento (Francisco AMARAL, Direito Civil - Introdução, p. 226).

${ }^{37}$ Preleciona José de Oliveira AsCENSÃO: "Mas, além das posições jurídicas simples, há também posições jurídicas complexas. As posições jurídicas surgem até normalmente integradas em complexos, portanto criando posições jurídicas coletivas. É o que se passa desde logo com o direito subjetivo, realidade
} 
menores, indivisos. Convém, pois, pôr em revista esses componentes ${ }^{38}$.

\subsubsection{As posições jurídicas elementares}

Para tanto, o ponto de partida é a relação jurídica, figura alçada a elemento central do direito pela Escola das Pandectas. Consagrada pelo Código Civil alemão $^{39}$, de 1896 (o BGB, Bürgerliches Gesetzbuch) ${ }^{40}$, essa concepção conduziu à disciplina da matéria privada de maneira sistematicamente diversa daquela adotada pelo legislador francês do Code Civile, de 1804, para quem o sujeito era a figura nuclear ${ }^{41}$. Como é sabido, o Brasil perfilhou o sistema germânico no diploma de 1916 e manteve a mesma diretriz em $2002^{42}$, apesar da desabrida influência do congênere italiano de 1942.

A relação jurídica não é concebida senão como uma espécie de relação social $^{43}$, qualificada embora pela disciplina que lhe impõe o Direito ${ }^{44}$. Entre as diversas relações intersubjetivas sociais, a jurídica sobreleva-se por constituir (entre outras) mecanismo de controle social ${ }^{45}$. Isso, porque atribui a um de seus sujeitos a preponderância

complexa e orgânica, que funciona como a fonte de posições jurídicas simples, como veremos." Cf. Direito Civil-Teoria Geral, v. 3, São Paulo, Saraiva, 2010, p. 47.

${ }_{38}$ Para esse exame, nos limites desse trabalho, parte-se do esquema proposto por Wesley Newcomb HOHFELD e desenvolvido por Giuseppe LUMIA em sua obra Lineamenti di teoria e ideologia del diritto. Embora também tratado por outros autores (conforme se verá, no curso da exposição), o exame do direito subjetivo a partir da relação jurídica e sua decomposição em posições jurídicas simples foi excelentemente teorizado por LUMIA - razão por que foi ele a base fundamental para a explanação que se segue. Tal estrutura técnico-jurídica, que, ver-se-á adiante, tem por fundamento as posições jurídicas, simples e complexas, não é isenta de crítica. Francisco AMARAL, após examiná-las, afirma: "Essa visão positiva encontra-se hoje superada por uma perspectiva axiológica, na qual se valora para fins de eficácia jurídica, não só as disposições normativas mas, principalmente, o comportamento das pessoas juridicamente relacionadas. É a chamada ética da situação.” Cf. Direito Civil - Introdução, Rio de Janeiro, Renovar, 2008, p 223. Também Orlando GOMES afirma que a sistematização baseada na relação jurídica está em "franco declínio" (Cf. Introdução ao Direito Civil, Rio de Janeiro, Forense, 1999, p. 94). Nada obstante, e na mesma linha do civilista baiano (que, apesar da crítica, utiliza-a: "esse tratamento metodológico é adotado ainda na cátedra e no livro"), optamos por abraçar essa base teórica para o melhor esquadrinhamento do direito subjetivo e do poder funcional e posterior exame da natureza do voto e de seu exercício abusivo, nas assembleias societárias e da recuperação judicial.

${ }^{39}$ Fala-se em "sistematização germânica" ou em "plano de Savigny". Cf. Daniel M. Boulos, Abuso do Direito no Novo Código Civil, São Paulo, Método, 2006, p. 81.

${ }^{40}$ Orlando GoMES, Introdução ao Direito Civil, Rio de Janeiro, Forense, 1999, p. 93.

${ }^{41}$ Por oposição ao sistema alemão, fala-se "sistematização romano-francesa" ou "plano de Gaio". Cf. Daniel M. Boulos, Abuso do Direito no Novo Código Civil, São Paulo, Método, 2006, p. 81.

${ }^{42}$ Donde a separação do código em duas partes, sendo a primeira ("geral") destinada à disciplina dos elementos da relação jurídica.

43 "A utilidade do princípio vem pois a reduzir-se unicamente àquela que enunciamos: a de levar à integração da relação jurídica, como espécie, no campo da relação social. ’In: José de Oliveira ASCENSÃO, Direito Civil - Teoria Geral, v. 3, São Paulo, Saraiva, 2010, p. 35.

${ }^{44}$ Carlos Alberto da Mota Pinto, Teoria Geral do Direito Civil, Coimbra, Coimbra, 1991, p. 167. Citando SAVIGNY, afirma José de Oliveira ASCENSÃo que a relação jurídica, quanto à matéria, é a própria relação social; quanto à forma, é "a idéia de direito que a rege". Cf. Direito Civil - Teoria Geral, v. 3, São Paulo, Saraiva, 2010, p. 35.

${ }^{45}$ Elementos de teoria e ideologia do direito, São Paulo, Martins Fontes, 2003, p. 99. 
ou supremacia (jurídica) sobre o outro ${ }^{46}$ e, assim, soluciona o conflito de interesses (materialmente considerado) ${ }^{47}$, tendo em vista a garantia oferecida pelo sistema (ação em sentido material). Aquele primeiro sujeito é o titular do interesse subordinante; o último, do interesse subordinado ${ }^{48}$. A garantia é o poder de efetivação coercitiva do conteúdo da relação ${ }^{49}$.

A origem da relação jurídica é o fato jurídico em sentido lato, isto é, o evento sobre o qual incide a norma jurídica e do qual, por conseguinte, procedem os efeitos jurídicos - entre os quais a própria relação jurídica ${ }^{50}$ (que, em si mesma, é a eficácia jurídica - mínima, aliás - desse fato ${ }^{51}$ ). E porque é efeito, a relação jurídica atribui aos sujeitos que dela participam as respectivas posições jurídica subjetivas ${ }^{52}$, que são seus elementos mais simples ${ }^{53}$.

Posição jurídica subjetiva é o locus que cada um dos sujeitos ocupa na relação jurídica ${ }^{54}$ e 55 . As posições elementares, ensina a doutrina, podem ser ativas ou

\footnotetext{
${ }^{46}$ Manuel A. Domingues DE ANDRAdE, Teoria Geral da Relação Jurídica, v. 1, Coimbra, Almedina, 1974, p. 18.

${ }^{47}$ Salvatore PATTI ensina: "L'attribuzione di un diritto rappresenta uma scelta dell'ordinamento giuridico tra interessi contrapposti. Il titolare dell'interesse privilegiato può esercitare Il diritto che gli è stato riconosciuto nel modo che ritiene più conveniente, entro i limiti fissati dalla lege. L'ordinamento giuridico garantisce La realizzazione dei diritti." Cf: Abuso del diritto (verbete), in Digesto delle discipline privatische - sezione civile, Torino, UTET, 1987, pp. 1.

${ }^{48}$ Alcides TOMASETTI JR., A 'propriedade privada' entre o Direito Civil e a Constituição, in Revista de Direito Mercantil, v. 126, p. 123.

49 "A sua efectivação [da relação jurídica] pode fazer-se mediante recurso a providências coercitivas, adequadas a proporcionarem a satisfação correspondente ao sujeito activo da relação, isto é, a relação jurídica está dotada de garantia." Cf. Carlos Alberto da MotA PINTO, Teoria Geral do Direito Civil, Coimbra, Coimbra, 1991, p. 168.

${ }^{50}$ Francisco Cavalcanti PONTES DE MIRANDA define-o: "Fato jurídico é, pois, o fato ou complexo de fatos sobre o qual incidiu a regra jurídica; portanto, o fato de que dimana, agora, ou mais tarde, talvez condicionalmente, ou talvez não dimane, eficácia jurídica.. não importa se é singular, ou complexo, desde que, conceptualmente, tenha unidade." Cf. Tratado de Direito Privado, v. 1, Rio de Janeiro, Borsoi, 1970, p. 77.

${ }^{51}$ É o "vínculo de atributividade" de que trata Miguel REALE, Lições Preliminares de Direito, São Paulo, Saraiva, 1999, p. 219.

${ }^{52}$ Há quem prefira "situação jurídica". Assim Francisco AmARAL (Direito Civil - Introdução, Rio de Janeiro, Renovar, 2008, pp. 221-250). Observa ele: "O fato jurídico é, portanto, causa de criação e de transformação dos direitos. Quando certas conseqüências jurídicas se ligam a determinadas situações, configuram-s as situações jurídicas, que nada mais são do que as situações existenciais qualificadas ou legitimadas pelo direito" (pp. 221-222). E conceitua: “As situações jurídicas são, assim, conjuntos de direitos ou de deveres que se atribuem a determinados sujeitos, em virtude das circunstâncias em que eles se encontram ou das atividades que eles desenvolvem" (p. 222).

53 "Os poderes elementares (também chamados faculdades, por falta de terminologia específica) são as posições ativas mais simples que podemos descortinar nas situações jurídicas." Cf. José de Oliveira ASCENSÃo, Direito Civil - Teoria Geral, v. 3, São Paulo, Saraiva, 2010, p. 47.

54 "Na sua formulação mais simples, posição jurídica é toda a situação de uma pessoa regulada pelo direito." Cf. José de Oliveira AsCEnsão, Direito Civil-Teoria Geral, v. 3, São Paulo, Saraiva, 2010, p. 47.

${ }_{55}$ Giuseppe LuMIA, Elementos de teoria e ideologia do direito, São Paulo, Martins Fontes, 2003, p. 104.
} 
passivas $^{56}$, conforme atribuam direitos ou imponham deveres ${ }^{57}$, conforme, em outras palavras, o interesse de seu titular seja subordinante ou subordinado.

As normas que incidem sobre os fatos e geram as relações e posições jurídicas podem classificar-se segundo diversos critérios. Importa sublinhar aquela que as distingue, segundo o objeto ${ }^{58}$, em normas de comportamento (chamadas normas primárias) e normas de competência (chamadas normas secundárias ou de competência ou, ainda, de estrutura). No primeiro caso, o objeto da norma é constituído diretamente pela conduta de seu destinatário, enquanto, no segundo caso, o objeto imediato da norma são outras normas (e, apenas mediatamente, os comportamentos).

Cada um desses dois tipos de normas gera posições jurídicas elementares de natureza diversa, quer ativas, quer passivas.

Assim, caso a posição jurídica ativa decorra (da incidência) de uma norma de comportamento (primária), pode ela ser uma pretensão, que é o poder atribuído a seu titular de exigir o correlato dever comportamental (o cumprimento da prestação, consistente, pois, em um fazer, não fazer ou dar) a que o outro sujeito está adstrito em atendimento ao interesse daquele primeiro.

Deste primeiro par conceitual, obtém-se um segundo, por negação. Se o sujeito A não pode pretender do sujeito B um certo comportamento, isso significa que este último é titular de uma faculdade, que é uma posição ativa (pois que atribui a seu titular a liberdade de comportar-se segundo sua determinação e não conforme a imposição de uma outra parte ${ }^{59}$ ); e A encontra-se, ergo, em falta de pretensão, que é uma posição passiva pois que lhe é imposto suportar o comportamento de $\mathrm{B}^{60}$.

Já entre as posições jurídicas elementares decorrentes de normas de competência (ou secundárias), os dois pares conceituais formam-se da seguinte maneira. A posição ativa consistente no poder de "ditar" normas ao titular da posição passiva. Este sofre sujeição; aquele é titular do poder formador, também chamado formativo ou, ainda

\footnotetext{
56 "Mesmo as posições complexas, que examinaremos a seguir, podem sempre ser qualificadas por este ponto de vista." Cf. José de Oliveira AsCEnsão, Direito Civil-Teoria Geral, v. 3, São Paulo, Saraiva, 2010 , p. 48.

${ }_{57}^{5}$ Giuseppe LUMIA, Elementos de teoria e ideologia do direito, São Paulo, Martins Fontes, 2003, p. 104.

${ }^{58}$ E não segundo seu destinatário, na lição de Rudolf von JHERING reportada por Giuseppe LUMIA. Cf. Elementos de teoria e ideologia do direito, São Paulo, Martins Fontes, 2003, p. 54.

${ }^{59}$ Ensina Francisco AMARAL: "Faculdades jurídicas são os poderes de agir contidas no direito subjetivo. Consistem em possibilidade de atuação jurídica que o direito reconhece na pessoa que se encontra em determinada situação.” In: Direito Civil - Introdução, Rio de Janeiro, Renovar, 2008, p. 238.

${ }^{60}$ Exemplo: o locador tem pretensão ao pagamento do aluguel pelo locatário, que, destarte, tem o dever comportamental de dar (o valor do locatício). Por outro lado, o este último tem a faculdade de, dentro dos termos ajustados e finalidade pactuada, usar o bem locado como lhe aprouver - comportamento que deve ser suportado pelo locador, que, quanto a esse aspecto, não tem pretensão contra ele.
} 
mais comumente, direito potestativo ${ }^{61,62 \mathrm{e} 63} \mathrm{ou}$, somente, poder. O titular, apenas por sua vontade $^{64}$, pode alterar legitimamente a esfera jurídica (constituindo, modificando ou extinguindo direitos ${ }^{65}$ ) de quem sofre sujeição, sem que este último possa oferecer resistência $^{66}$ e 67 .

Mediante operação lógica de negação desse par, forma-se o seguinte: um dos sujeitos sofre falta de poder formativo e o outro (ativo) é titular da posição de imunidade, porquanto aquele primeiro não lhe poderá "ditar" normas ${ }^{68}$. No quadro dos opostos em seguida, as situações jurídicas elementares podem ser assim esquematizadas:

(1)

Norma de comportamento (primárias)

Ativo: pretensão

Passivo: $\quad \stackrel{\downarrow}{\text { dever de }}$ comportamento
(2)

Normas de competência (secundárias)

$\begin{array}{ccc}\text { poder formativo } & & \text { imunidade } \\ \downarrow & \times & \downarrow \\ \text { sujeição } & & \text { falta de } \\ & & \text { poder }\end{array}$

\subsubsection{As posições jurídicas complexas}

Sucede que as posições jurídicas subjetivas elementares podem combinar-se de modo variado, para dar vida a posições jurídicas subjetivas complexas.

\footnotetext{
${ }^{61}$ Fórmula preferida por José de Oliveira AsCEnSÃo, por exemplo. Cf. Direito Civil - Teoria Geral, v. 3, São Paulo, Saraiva, 2010, p. 51.

${ }^{62}$ Quanto à nomenclatura, observa Francisco AMARAL: "OS direitos potestativos (do italiano potestà, poder) dizem-se também direitos de formação, no sentido de que permitem ao seu titular modificar,d e modo unilateral, uma situação subjetiva de outrem, que, não podendo evitá-lo, deve apenas sujeitar-se.” E completa: "Ao direito potestativo contrapõe-se, portanto, não um dever, mas um estado de sujeição às mudanças que se operam na sua própria esfera. " In: Direito Civil - Introdução, Rio de Janeiro, Renovar, 2008, p. 237.

${ }^{63}$ José de Oliveira AsCENSÃo entende que os direitos potestativos tem a mesma natureza que os direitos subjetivos, mas são autônomos (e, portanto, não são componentes destes). Direito Civil - Teoria Geral, v. 3, São Paulo, Saraiva, 2010, pp. 59-60. Outros doutrinadores entendem-nos diferentes. Cf. Francisco AMARAL, Direito Civil - Introdução, Rio de Janeiro, Renovar, 2008, p. 237.

${ }^{64}$ Diretamente ou mediante decisão judicial. Afirma Carlos Alberto da MOTA PINTO: "Os direitos potestativos são poderes jurídicos de, por um acto livre de vontade, só de per si ou integrado por uma decisão judicial, produzir efeitos jurídicos que inelutavelmente se impõem à contraparte." In: Teoria Geral do Direito Civil, Coimbra, Coimbra, 1991, p. 174. Orlando GoMES cita como exemplo de exercício de direito potestativo mediante decisão judicial a contestação de paternidade. In: Introdução ao Direito Civil, Rio de Janeiro, Forense, 1999, p. 118.

${ }^{65}$ Por exemplo: é poder formador constitutivo o direito de preferência para aquisição conferido pelo locador ao locatário (Lei n. ${ }^{\circ} 8.245 / 91$ : art. 27); é modificativo o poder de escolha das obrigações alternativas (CC: art. 252); por fim, é extintivo o poder de revogar ou renunciar ao mandato (CC: art. 682, inc. I). Cf. Francisco AMARAL, Direito Civil - Introdução, Rio de Janeiro, Renovar, 2008, p. 237; Orlando GOMES, Introdução ao Direito Civil, Rio de Janeiro, Forense, 1999, p. 118; Carlos Alberto da Mota PInTo, Teoria Geral do Direito Civil, Coimbra, Coimbra, 1991, pp. 174-175.

${ }^{66} \mathrm{O}$ titular de poder formador pode alterar a esfera jurídica de quem tem sujeição sem o concurso deste. É exemplo dessa posição jurídica a possibilidade de denúncia vazia pelo locador de contrato de locação por prazo indeterminado.

${ }^{67}$ Francisco AMARAL, Direito Civil - Introdução, Rio de Janeiro, Renovar, 2008, p. 236.

${ }^{68}$ Giuseppe. LuMIA, Elementos de teoria e ideologia do direito, São Paulo, Martins Fontes, 2003, pp. 104107.
} 
Dentre estas últimas, destaca-se o sobredito direito subjetivo, entendido, em linhas gerais, como possibilidade de agir (facultas agendi) protegida pelo ordenamento jurídico (normas agendi).

Estruturalmente, por tratar-se de posição jurídica subjetiva ativa complexa, o direito subjetivo apresenta-se como "um conjunto unitário (e unificador) de situações jurídicas elementares" ${ }^{\circ 9}$. Isso significa que ao sujeito titular de um direito desses é atribuído um conjunto de faculdades, pretensões, poderes formativos e imunidades, que se encontra em coligação habitual e constante.

O direito de propriedade (direito real pleno), por exemplo, compõe-se de faculdades (utilizar a coisa como melhor entender), pretensões (poder exigir que não seja perturbado no desfrutamento da coisa), poderes formativos (a disposição) e imunidades (não pode ser expropriado sem prévia indenização) ${ }^{70}$. É, pois, um direito subjetivo.

Ao direito subjetivo, contrapõe-se o dever jurídico ${ }^{71}$. Se aquele é o instrumento jurídico colocado a serviço do interesse do próprio titular, o este é imposto ao titular para atendimento ao interesse de outrem.

Compreende-se, desse modo, que, substancialmente, a figura jurídica do direito subjetivo corresponde a um imperativo de economia lingüística: trata-se uma fórmula abreviada por que se refere a um conjunto amplo de posições jurídicas ativas elementares $^{72}$.

O traço característico do direito subjetivo não é propriamente o conjunto

\footnotetext{
${ }^{69}$ Giuseppe. LuMIA, Elementos de teoria e ideologia do direito, São Paulo, Martins Fontes, 2003, pp. 104107.

${ }^{70}$ Giuseppe. LuMiA, Elementos de teoria e ideologia do direito, São Paulo, Martins Fontes, 2003, pp. 107108.

${ }^{71}$ Não é raro encontrar na doutrina com a mesma significação o termo "obrigação". No entanto, em sentido mais estrito (e técnico), obrigação é próprio das relações jurídicas ditas "obrigacionais" (distintas das reais, familiares e de sucessão) e consistem no dever comportamental de prestar (dar, fazer ou não fazer).

${ }_{72}$ Giuseppe. LuMIA, Elementos de teoria e ideologia do direito, São Paulo, Martins Fontes, 2003, p. 108. José de Oliveira AsCENSÃo ensina: "Os poderes, juntamente com os deveres, são os elementos mais simples de que a ordem jurídica lança mão quando confia às vontades individuais a obtenção das finalidades que prossegue. É neste sentido que dizemos que ao conteúdo do direito subjetivo pertencem poderes, elementos não autônomos, que poderão ser apreendidos através de processos descritivos. " In: Direito Civil - Teoria Geral, v. 3, São Paulo, Saraiva, 2010, pp. 50-51. Semelhantemente afirma Francisco AMARAL: "Trata-se de uma categoria técnico-jurídica ou metodológica que permite ao jurista e ao prático atuarem com economia, clareza e rapidez no processo de realização do direito, significando a situação em que alguém se acha de poder agir livremente em uma determinada esfera de ação, o que lhe é garantido pelo direito objetivo." In: Direito Civil - Introdução, Rio de Janeiro, Renovar, 2008, p. 224. Palmilha o mesmo caminho Tercio Sampaio FERRAZ JR., que exemplifica: “Assim, a expressão transferir o direito de propriedade funciona como uma espécie de abreviatura teórica que evita o trabalho insano de descrever todas as normas incidientes sobre a situação.” In: Introdução ao Estudo do Direito - Técnica, Decisão, Dominação, São Paulo, Atlas, 1994, p. 151.
} 
de quais posições elementares que ele enfeixa (em que se aproxima do poder funcional, outra posição jurídica complexa), mas a liberdade de que dispõe o titular para exercê-las, ou não, a depender exclusivamente da própria vontade $^{73}$, de acordo com a persecução do próprio interesse e sempre assistido pela ordem jurídica. (Nisto reside, aliás, a origem da corriqueira identificação entre o direito subjetivo - ou o estabelecimento desse conceito - e o individualismo econômico ${ }^{74}$.)

\subsubsection{Direito subjetivo: escorço histórico}

Nesse passo, entretanto, é mister fazer-se breve referência à conhecida disputa entre Friedrich Carl von SAVGNY e Rudolf von JHERING acerca do tema, e os desdobramentos que se seguiram ${ }^{75}$.

A tese de SAVIGNY, assim como de Bernard WINDSCHEID ${ }^{76}$, é a de que o direito subjetivo é o poder da vontade. É a soberania de que dispõe o indivíduo para "impor seus objetivos na ordem jurídica"77. Dentro de seus limites, "reina" o alvedrio do indivíduo, a quem cabe, com exclusividade, decidir sobre seu efetivo exercício e, ainda, criar normas para si próprio $^{78}$ - o que seria o poder de auto-regrar-se. A ordem jurídica assegura a liberdade do titular (de exercer ou não o direito subjetivo) e garante, em caso de exercício, sua efetiva execução.

A principal crítica feita a essa teoria diz respeito à identificação da vontade com o direito subjetivo. Com efeito, situações há em que o sujeito não tem vontade (como o recém-nascido) ou ignora por completo o direito (caso do herdeiro que desconhece a abertura da sucessão) e, ainda assim, é titular de direito subjetivo, devidamente resguardado pela ordem jurídica. O próprio WINDSCHEID reconheceu a

\footnotetext{
73 "Só se nos depara um direito subjectivo quando o exercício do poder jurídico respectivo está dependente da vontade do seu titular”. In: Carlos Alberto Mota PinTo, Teoria Geral do Direito Civil, Coimbra, Coimbra, 1991, p. 169.

${ }^{74}$ Em que pese a observação de Francisco Cavalcanti PONTES DE MIRANDA: "A ordem econômica individualista não é a causa da existência de direitos; apenas é a causa de certa atomicidade deles. $O$ Estado individualista apenas se retrai, para que as personalidades atuem com maior autonomia do que atuaram no passado. Se essa autonomia diminui, nem por isso diminui o número dos direitos subjetivos. "

75 A justificar o estudo histórico, oportuna é a observação de Tercio Sampaio FerRAZ JR.: "em primeiro lugar é preciso ter em mente que a expressão não foi criada pelos juristas conforme um programa teórico, mas herdada por eles, correspondendo a ideias geralmente aceitas.” In: Introdução ao Estudo do Direito Técnica, Decisão, Dominação, São Paulo, Atlas, 1994, p. 150.

${ }^{76}$ Orlando Gomes, Introdução ao Direito Civil, Rio de Janeiro, Forense, 1999, p. 107.

77 José de Oliveira AsCEnsão, Direito Civil-Teoria Geral, v. 3, São Paulo, Saraiva, 2010, p. 51.

${ }^{78}$ Sobre o assunto, esclarece Eduardo JORDÃO: "Por outro lado, a vontade do beneficiário da norma é ainda decisiva para a criação de direitos da primeira espécie, ao exercer atos como alienação de bens ou cessão de créditos." Cf. Repensando a Teoria do Abuso de Direito, Salvador, Juspodium, 2006, p. 36.
} 
fragilidade da explicação inicial e cuidou de reformulá-la e, assim, afirmar que a vontade de que tratava não era a psíquica, mas "vontade normativa", o "poder jurídico de querer"79.

Nada obstante as críticas, credita-se à teoria a concepção, que não mais se perdeu, de que o direito subjetivo é o meio de "autodeterminação" do sujeito.

A outra vertente, que a esta se opôs, capitaneada por JHERING, baseia-se no pressuposto de que o interesse, e não a vontade, constitui a essência do direito subjetivo $^{80}$. De acordo com ele, o direito supõe dois elementos, um formal e outro substancial $^{81}$; este é o núcleo que é por aquele revestido ${ }^{82}$.

A substância do direito subjetivo é, segundo JHERING, não a vontade, mas seu fim prático, sua utilidade ${ }^{83}$. Assim, o titular não é aquele que pode querer, mas o que pode aproveitar $^{84}$. Já a forma do direito subjetivo é a garantia representada pela norma jurídica, a proteção assegurada pelo recurso à Justiça ${ }^{85}$ - os "remédios jurídicos", em outras palavras, "que o Estado confere a todos para a defesa do que lhes é próprio" Dessa conjugação de elementos formal e substancial decorre a fórmula que abrevia esse entendimento, segundo a qual o direito subjetivo é o interesse juridicamente protegido ${ }^{87}$ em que pese o entendimento de August THON, para quem, mais propriamente, o direito subjetivo é a proteção jurídica do interesse subjetivo (e não o interesse) ${ }^{88}$.

Essa teoria confere maior objetividade à noção de direito subjetivo e explica sua atribuição mesmo aos destituídos de vontade: a tutela é de seus interesses e não de sua manifestação volitiva ${ }^{89}$.

Sofreu objeções, ainda assim. Duas, as principais: há situações em que o titular do direito não tem interesse na proteção e há interesses protegidos que não constituem direito subjetivo ${ }^{90}$. Sem embargo, como observa José de Oliveira AsCENSÃO, a

\footnotetext{
${ }^{79}$ Miguel ReAle, Lições Preliminares de Direito, São Paulo, Saraiva, 1999, p. 255.

${ }^{80}$ Miguel ReALe, Lições Preliminares de Direito, São Paulo, Saraiva, 1999, p. 255.

${ }^{81}$ José de Oliveira ASCENSÃo, Direito Civil - Teoria Geral, v. 3, São Paulo, Saraiva, 2010, p. 53.

${ }^{82}$ Miguel ReAle, Lições Preliminares de Direito, São Paulo, Saraiva, 1999, p. 255.

${ }^{83}$ José de Oliveira AsCEnsão, Direito Civil-Teoria Geral, v. 3, São Paulo, Saraiva, 2010, p. 53.

${ }^{84}$ Eduardo JoRDÃO, Repensando a Teoria do Abuso de Direito, Salvador, Juspodium, 2006, p. 37.

85 José de Oliveira AsCEnSÃo, Direito Civil - Teoria Geral, v. 3, São Paulo, Saraiva, 2010, p. 53.

${ }^{86}$ Miguel ReAle, Lições Preliminares de Direito, São Paulo, Saraiva, 1999, p. 256.

${ }^{87}$ Orlando GoMES, Introdução ao Direito Civil, Rio de Janeiro, Forense, 1999, p. 107.

${ }^{88}$ Cf. Eduardo Jordẽo, Repensando a Teoria do Abuso de Direito, Salvador, Juspodium, 2006, p. 40.

${ }^{89}$ Eduardo JoRDÃO, Repensando a Teoria do Abuso de Direito, Salvador, Juspodium, 2006, p. 39.

90 José de Oliveira ASCENSÃO cita os chamados "interesses reflexamente protegidos" e exemplifica: "Assim, a indústria nacional vê o seu interesse na salvaguarda da concorrência estrangeira protegida através de impostos aduaneiros; mas não tem um direito subjetivo a essa proteção, e por isso as taxas alfandegárias podem ser abolidas a todo o momento sem lesão de direitos subjetivos.” Direito Civil - Teoria Geral, v. 3, São Paulo, Saraiva, 2010, p. 54.
} 
contribuição de JHERING - de que "todo direito assenta num interesse do agente que é reconhecido pela ordem jurídica" - igualmente não mais se perdeu.

Outras teorias sucederam essas duas iniciais. Assim, entre outras, a chamada eclética, de Georg JELLINECK, que mesclou os entendimentos anteriores e sustentou que o direito subjetivo é o "interesse protegido que dá a alguém a possibilidade de agir" " Foi ele objeto das mesmas críticas anteriormente feitas às teorias da vontade e do interesse ${ }^{92}$.

Giorgio Del Vechio, por sua vez, desenvolveu teoria própria, próxima àquela segunda formulação de WINDSCHEID, fazendo, no entanto, o reparo de que o direito subjetivo não é o poder da vontade atual ou efetiva, mas da possível ou potencial ${ }^{93}$. Conhecida é ainda a posição de Hans KELSEN, que, por seus pressupostos normativistas, não concebe o direito subjetivo senão como a expressão do dever jurídico imposto ao destinatário da norma ${ }^{94}$. Inadmite, portanto, sua existência como categoria científicojurídica própria ${ }^{95}$. Sem repetir essa negação, Francisco Cavalcanti PONTES DE MIRANDA aduz que a regra jurídica - da qual, uma vez incidida no suporte fático, emanam os efeitos jurídicos - é sempre objetiva e que o direito subjetivo é uma "abstração" destinada a significar o que de "vantajoso" decorre dessa eficácia para o titular e que assim se denomina porque observada "do lado desse alguém, que é o titular dele"

Apesar das críticas à figura do direito subjetivo, e até mesmo sua

${ }_{91}^{91}$ Miguel ReALe, Lições Preliminares de Direito, São Paulo, Saraiva, 1999, p. 257.

92 Oportuna é a observação de Miguel REALE: "O ecletismo é sempre uma soma de problemas, sem solução para as dificuldades que continuam nas raízes das respostas, pretensamente superadas.” In: Lições Preliminares de Direito, São Paulo, Saraiva, 1999, p. 257.

${ }^{93}$ Miguel ReAle, Lições Preliminares de Direito, São Paulo, Saraiva, 1999, p. 257. Observa este autor acerca do teórico: "Dessa forma, fazendo uma distinção entre vontade in acto, e vontade in potentia, Del Vecchio declara que ficam elididas as objeções clássicas formuladas à teoria windscheidiana."

94 José de Oliveira Ascensão, Direito Civil - Teoria Geral, v. 3, São Paulo, Saraiva, 2010, p.55. Miguel REALE, Lições Preliminares de Direito, São Paulo, Saraiva, 1999, p. 259. Nas palavras de Hans KELSEN: "Quer dizer: a conduta do indivíduo em face do qual o dever existe, correlativa da conduta devida, está já conotada na conduta de que forma o conteúdo do dever. Se se designa a relação do indivíduo, em face do qual uma determinada conduta é devida, com o indivíduo obrigado a essa conduta como 'direito', este direito é apenas um reflexo daquele dever." E completa: "Este conceito de um direito subjetivo que apenas é o simples reflexo de um dever jurídico, isto é o conceito de um direito reflexo, pode, como conceito auxiliar, facilitar a representação da situação jurídica. É , no entanto,supérfluo do ponto de vista de uma descrição cientificamente exacta da situação jurídica." In: Teoria Pura do Direito, Coimbra, Armênio Amado, 1984, p. 186.

95: "Este conceito de um direito subjetivo que apenas é o simples reflexo de um dever jurídico, isto é o conceito de um direito reflexo, pode, como conceito auxiliar, facilitar a representação da situação jurídica. É , no entanto, supérfluo do ponto de vista de uma descrição cientificamente exacta da situação jurídica. ” In: Hans Kelsen, Teoria Pura do Direito, Coimbra, Armênio Amado, 1984, p. 187.

${ }^{96}$ São suas palavras: "Rigorosamente, o direito subjetivo foi a abstração, a que sutilmente se chegou, após o exame da eficácia dos fatos jurídicos criadores de direitos. A regra jurídica é objetiva e incide nos fatos; o suporte fáctico torna-se fato jurídico. O que, para além, determinadamente, dessa ocorrência emana, de vantajoso, é direito, já aqui subjetivo, porque se observa do lado desse alguém, que é o titular dele." In: Tratado de Direito Privado, São Paulo, RT, 1974, p. 225. 
negação, é fato indisputável que seu emprego pela doutrina resta consagrado ${ }^{97}$. E a razão para isso não está apenas em suas justificativas históricas ${ }^{98}$, mas também em sua inegável utilidade $^{99}$.

Ele traduz-se, como visto, na expressão jurídica do valor ético da liberdade individual e confere ao indivíduo um "poder de agir" para realização de seus interesses nos limites da lei ${ }^{100}$. Do ponto de vista técnico, colige um conjunto de posições jurídicas que atribui a seu titular esse poder de agir. Trata-se, como ensina Francisco AMARAL, de uma realidade jurídica que se firmou na atividade jurídica ${ }^{101}$, atravessou os últimos dois séculos, sem que sua utilidade fosse negada.

Para os limites dessa tese, o adequado delineamento dessa figura é particularmente relevante, já para a análise do abuso de direito como figura de teoria geral $^{102}$, já porque adiante se fará necessário identificar a que categoria pertence o voto em conclaves assembleares (societários ou não), se ao direito subjetivo, se ao poder funcional.

\subsubsection{Poder funcional e a funcionalização do direito subjetivo}

Não se limitam ao direito subjetivo, como já afirmado, as posições jurídicas complexas. Outra, de singular importância, é o poder funcional, igualmente chamado poder-dever ${ }^{103}$. Também este se compõe de posições jurídicas simples ativas, embora não apenas. Nisso, aliás, reside a distinção entre eles. Diferentemente do direito subjetivo, seu exercício não se destina à satisfação do interesse do próprio titular, mas de terceiros - a quem, por força de norma, tal poder deve favorecer. A estes, portanto, e não ao titular, é atribuível o que resulta de "vantajoso"104 nesse exercício, e do modo como

\footnotetext{
${ }^{97}$ Francisco AMARAL, Direito Civil - Introdução, Rio de Janeiro, Renovar, 2008, p. 228.

98 "No aspecto histórico, são os direitos subjetivos 'produto de um movimento ideológico democrático e liberal, destinado a proteger o individuo contra os excessos do absolutismo estatal'. Na sua origem estão os movimentos políticos do liberalismo e do capitalismo, de que são também manifestações jurídicas as declarações políticas dos direitos do homem e do cidadão." In: Francisco AMARAL, Direito Civil Introdução, Rio de Janeiro, Renovar, 2008,p. 229.

99 “Trata-se de um conceito que não pode ser eliminado." In: Orlando GoMES, Introdução ao Direito Civil, Rio de Janeiro, Forense, 1999, p. 108. No mesmo sentido: Francisco AMARAL, Direito Civil - Introdução, Rio de Janeiro, Renovar, 2008,p. 229.

${ }^{100}$ Francisco AMARAL, Direito Civil - Introdução, Rio de Janeiro, Renovar, 2008,p. 225.

${ }^{101}$ Francisco AMARAL, Direito Civil - Introdução, Rio de Janeiro, Renovar, 2008,p. 229.

${ }^{102}$ Dentro do presente capítulo.

${ }^{103} \mathrm{Ou}$, ainda, ofícios. Cf. Carlos Alberto da Mota PINTo, Teoria Geral do Direito Civil, Coimbra, Coimbra, 1991, p. 169.

${ }^{104}$ José de Oliveira AsCEnSÃo, Direito Civil-Teoria Geral, v. 3, São Paulo, Saraiva, 2010, p. 49.
} 
exigido pela função do direito ${ }^{105}$.

E, porque conferido para persecução de interesse alheio, o titular do poder funcional, ao contrário de quem tem direito subjetivo, não é dotado de liberdade para exercer o poder ou não. Ele tem o dever de fazê-lo ${ }^{106}$.

Veja-se, pois, que, muito embora esta posição jurídica seja ativa ${ }^{107}$ - isto é, encerre posições simples ativas -, contém concomitantemente posição jurídica (simples) passiva. Com efeito, o titular deve perseguir interesses alheios - não se lhe faculta deixar de o fazer ou, menos ainda, exercê-lo no próprio interesse. Seu titular é, pois, devedor de um comportamento. Essa é, em sua análise anatômica, a distinção com o direito subjetivo: ao contrário deste, naquele convivem simultaneamente posições simples ativas e passivas $^{108 \text { e } 109}$.

Exemplos por excelência dos poderes funcionais são aqueles atribuídos aos agentes públicos, que devem perseguir o interesse público e não o próprio ${ }^{110}$. No âmbito do direito privado, são-no o poder familiar, a curatela e a tutela, cujo titular não os deve exercer na persecução do próprio interesse, mas, sim, no interesse do menor, do curatelado e do tutelado ${ }^{111}$. Ainda mais especificamente, no âmbito societário, os integrantes dos órgãos sociais (administradores, membros de conselho fiscal) são titulares de poderes funcionais ${ }^{112}$ (e assim, em que pese certa divergência, entende também Fabio Konder COMPARATO sobre o acionista controlador de sociedade anônima ${ }^{113}$ ). Para estes, a

\footnotetext{
${ }_{105}$ Carlos Alberto da Mota PINTO, Teoria Geral do Direito Civil, Coimbra, Coimbra, 1991, p. 170

106 “Mas aqueles que são investidos de uma autoridade [leia-se 'poder dever'] não estão livres para exercer ou não os poderes a eles conferidos no interesse de outros - eles são obrigados a exercê-los; e a persecução de tais interesses não é confiada ao mero arbítrio do titular da faculdade [leia-se 'do poder'], mas a sua prudente discricionariedade.” In: Giuseppe LuMIA, Elementos de Teoria e Ideologia do Direito, São Paulo, Martins Fontes, 2003, p. 115.

107 Di-lo expressamente José de Oliveira ASCENSÃO: "[Os poderes funcionais] Têm um caráter evidentemente ativo. Mas distinguem-se do direito subjetivo por não visarem atribuir uma vantagem que seja confiada à autonomia do sujeito.” In: Direito Civil - Teoria Geral, v. 3, São Paulo, Saraiva, 2010, p. 49.

108 "Por isso, os poderes funcionais implicam simultaneamente deveres para os seus titulares que os devem exercer (...). ” In: José de Oliveira AsCEnSÃo, Direito Civil-Teoria Geral, v. 3, São Paulo, Saraiva, 2010, p. 50.

${ }^{109}$ Muito clara é a lição de Giuseppe LuMIA: “O conceito de autoridade [leia-se 'poder-dever'] origina-se da conjugação de um poder e de uma obrigação [leia-se 'dever comportamental']. (...) Aquele que é investido de uma autoridade é, portanto, titular de poderes, cujo uso discricionário constitui para ele uma obrigação (...)."

${ }_{110}$ José de Oliveira ASCENSÃo, Direito Civil - Teoria Geral, v. 3, São Paulo, Saraiva, 2010, p. 49.

${ }^{111}$ Carlos Alberto da Mota PINTo, Teoria Geral do Direito Civil, Coimbra, Coimbra, 1991, pp. 169-170.

112 "Órgão é, portanto, o centro de imputação de poderes funcionais exercidos, por um ou mais indivíduos que nele estejam investidos, para formar e manifestar a vontade juridicamente imputável à pessoa jurídica." In: Marcelo Vieira Von ADAMEK, Responsabilidade dos Administradores de S/A e as Ações Correlatas, São Paulo, Saraiva, 2009, p. 11.

113 "O titular do controle exerce a soberania societária. Não vai nisto nenhuma aberração. Ao contrário, a existência de um direito de controle representa um elemento indispensável na economia social (...). mas a todo poder correspondem deveres e responsabilidades próprias, exatamente porque se trata de um direito-
} 
par do delineamento dos poderes, a lei disciplina deveres que em seu exercício devem ser cumpridos $^{114}$.

Em matéria concursal, detém poder-dever o administrador judicial, que, na qualidade de auxiliar da Justiça, deve nos processos de recuperação judicial e falência exercer seu poder em favor da massa falida, do recuperando e dos credores envolvidos ${ }^{115}$.

Ainda a propósito dos poderes funcionais, noticia José de Oliveira ASCENSÃO a existência de divergência doutrinária relevante. Quanto às figuras acima descritas e, em especial, quanto ao poder familiar, há quem entenda tratar-se de direito subjetivo. Isso porque, embora seja um dever legal prover os filhos - cujo cumprimento, portanto, é vinculado e obrigatório e não enseja liberdade de atuação -, consubstancia também ele expediente jurídico para persecução do interesse (espiritual) dos pais, que se sentem realizados no exercício e não poderiam ser concebidos como meros "funcionários".

O tema é relevante porque, embora diga respeito diretamente a figuras já tradicionais no direito, é mote para uma questão mais contemporânea e de acentuada amplitude. A estrutura do poder funcional - que, ao contrário da concepção original do direito subjetivo, admite a convergência em seu bojo de posições jurídicas ativas e passivas -, serve de parâmetro para a compreensão técnica do fenômeno da "funcionalização" dos institutos de direito privado - especialmente relevante, no caso do Brasil, por constituir princípio constitucional de toda a ordem econômica (art. 170, inc. III).

Especificamente quanto ao direito subjetivo, a atribuição a ele de uma “função" (função social da propriedade, por exemplo) implica a imposição de um dever ao titular. Este, que, segundo a concepção clássica do século XIX (como acima explanado), exercê-lo-ia exclusivamente na persecução do próprio interesse, é forçado a considerar nesse exercício também o atendimento a interesse que lhe é alheio ${ }^{116}$. Embora detentor do

função, atribuído ao titular para a consecução de finalidades precisas. Assim também no que diz respeito ao poder de controle, na estrutura da sociedade anônima.” In: Fábio Konder COMPARATO - Calixto SALOMÃO FILHO, O Poder de Controle na Sociedade Anônima, Rio de Janeiro, Forense, 2005. O art. 116, parágrafo único, e o art. 116-A da Lei n. ${ }^{\circ}$ 6.404/76 expressamente impingem deveres ao controlador.

114 Assim, por exemplo, a Lei de Sociedades por Ações (Lei n. ${ }^{\circ}$ 6.404/76) delineia os poderes dos administradores (ex.: arts. 138, $\S 1^{\circ} ; 139$ e 144) e impõe-lhes deveres que naquele exercício devem ser observados (ex.: arts. 153 a 157: “O administrador da companhia deve empregar...”; "o administrador deve servir...”). De igual modo o Código Civil prescreve deveres aos administradores: art. 1.011, por exemplo.

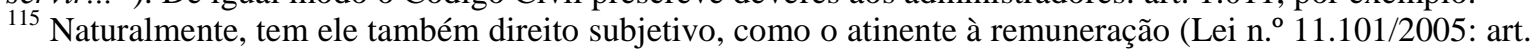
24).

${ }_{116}$ "Função social significa não-individual, sendo critério de valoração de situações jurídicas conexas desenvolvimento das atividades da ordem econômica." Francisco AMARAL, Direito Civil - Introdução, Rio de Janeiro, Renovar, 2008, p. 357. Mencionando a autonomia privada, acrescenta: “(...) significa que o reconhecimento e o exercício desse poder, ao realizar-se na promoção da livre circulação de bens e de prestação de serviços e na auto-regulamentação das relações disso decorrentes, condicionam-se à utilidade 
interesse subordinante, torna-se ele simultaneamente devedor de um comportamento, que limita a tutela daquele interesse e condiciona sua persecução.

Essa mudança acarreta profunda alteração na estrutura técnica tradicional do direito subjetivo ${ }^{117}$. Antes composto exclusivamente por posições elementares ativas, élhe agora enxertada uma posição passiva, que não obsta, mas condiciona o exercício daquelas. Embora detentor do interesse subordinante, o titular torna-se também, como dito, devedor de um comportamento ${ }^{118}$.

E esse "débito comportamental" não indica simplesmente restrições (limites negativos) ao exercício da posição jurídica, mas, antes, impõe ao titular um dever positivo. Não se trata, pois, de mitigar os "poderes" do titular, de retrair a gama original de posições ativas integrantes do "direito", mas de adicionar àquele conjunto (que subsiste íntegro) outra posição jurídica simples - passiva, porém. E essa posição passiva consiste em um comportamento ativo, em um fazer.

O acréscimo dessa posição passiva não resulta, é certo, na aniquilação da tutela jurídica sobre o interesse do $\operatorname{titular}^{119}$ (o que seria a desnaturação do instituto), mas impele a conciliação - de outro modo improvável ou, pelo menos, não necessária - entre ambos os interesses agasalhados pela ordem jurídica.

Essa mudança implica nítida aproximação entre direito subjetivo e poderdever (e reflete a tendência moderna de crescente restrição da autonomia privada ${ }^{120}$ ); todavia, cada qual mantém sua identidade. Apesar da restrição imposta ao direito subjetivo,

social que tal circulação possa representar, com vistas ao bem comum e à igualdade material para todos (...)" (pp. 356-357).

${ }^{117}$ Sobre o assunto, ensina Piero RESCIGNO que 'Il termine 'abuso' acquista um diverso significado,s e mutato Il senso e la nozione del diritto soggettivo, come avviene allorché Il diritto viene transformato, tout court, in funzione sociale. " In: L'abuso del diritto, in Rivista di diritto civile, ano XI, 1965, $1^{\text {a }}$ parte, Padrova, Cedam, p. 220.

${ }^{118}$ Expressa com singular precisão esse enxerto de posição passiva em um típico direito subjetivo o texto da Lei Fundamental alemã, de 1949, que reeditando norma da Constituição de Weimar, de 1919, afirma em seu art. 14, 2a aliena: "Eigentum verpflichtet", isto é, "a propriedade obriga". E segue: "Sein Gebrauch soll augleich dem Wohle der Allgemeinheit dienen." ("Seu uso deve, ao mesmo tempo, servir ao bem-estar geral.")

${ }_{119}$ Para Francisco AMARAL, “A função social é, por tudo isso, um princípio geral, um verdadeiro standard jurídico, uma diretiva mais ou menos flexível, uma indicação programática que não colide nem torna ineficazes os direitos subjetivos, orientando-lhes o respectivo exercício na direção mais consentânea com o bem comum e a justiça social." Em suma: a "possibilidade de se realizarem os interesses sociais, sem desconsiderar ou eliminar os do indivíduo”. In: Direito Civil - Introdução, Rio de Janeiro, Renovar, 2008, p. 358.

${ }^{120}$ Tratando da dicotomia entre direito privado e público, observa SANTI ROMANO: "A esfera do direito privado tende, nos Estados modernos, a restringir-se, em benefício do direito público. Isto ocorre devido ao processo de contínua e progressiva ingerência do Estado em matérias reservadas à autonomia de outrem, ou à transformação da autonomia, meramente lícita em funcional." In: Princípios de Direito Constitucional Geral, trad. Maria Helena Diniz, São Paulo, RT, 1977, p. 102 (sublinhou-se). 
ele ainda se presta precipuamente à satisfação do interesse do titular, enquanto o poder funcional deve dirigir-se exclusivamente ao interesse fixado por lei e nunca ao do titular. Respeitados os limites do fim determinado pelo legislador, o direito subjetivo pode ser exercido se e do modo como entender seu titular - liberdade que não tem lugar no caso do poder-dever.

De todo modo, como assenta Piero Rescigno, essa transformação “abre agilmente a estrada do controle sobre o exercício do direito e o eventual abuso" ${ }^{\text {121 }}$. Isso, porque, em decorrência dessa funcionalização, o exercício do direito em desacordo com o fim infringe a ordem jurídica e gera consequências e efeitos (sanções). No caso brasileiro, o Código Civil expressamente institui como elemento de sua configuração o exercício do direito em desatendimento a seu fim social e econômico (art. 187), o que será abordado mais adiante.

E não são poucos os direitos aos quais a ordem jurídica impõe uma função. Tamanha relevância tem assumido o tema - inclusive em matéria de política legislativa -, que sua disciplina não raro tem alcançado status constitucional, como sucede em diversos ordenamentos e também no Brasil. Função social da propriedade, do contrato, da empresa - particularmente caro ao direito concursal e, ainda, à recuperação -, da recuperação judicial são temas que envolvem a limitação de direitos subjetivos pela atribuição de fim a ser perseguido pelo titular.

Ilustra muito bem essa funcionalização do direito subjetivo, em matéria societária, a disciplina do chamado "poder de controle" pela vigente de Lei de Sociedades por Ações (Lei n. ${ }^{\circ}$ 6.404/76). Caracterizado pelos requisitos do caput do art. 116, ao acionista titular é imposto o atendimento a um conjunto de interesses estranhos a ele (“demais acionistas da empresa, os que nela trabalham”) e até mesmo à própria companhia (“função social”, responsabilidades "para com a comunidade em que atua"). Não se lhe nega a persecução ao próprio interesse, mas esse exercício não pode ser efetivado à revelia dos personagens, na dicção da lei, “cujos direitos e interesses deve lealmente respeitar $e$ atender".

\subsection{Abuso de direito: origem e evolução}

${ }^{121}$ Em italiano: "É evidente che la conversione del diritto soggettivo in funzione apre agevolmente la strada del controllo circa l'esercizio del dirittto e circa l'eventuale abuso." In: In: L'abuso del diritto, in Rivista di diritto civile, ano XI, 1965, $1^{\mathrm{a}}$ parte, Padrova, Cedam, p. 220. 
Sobre a origem histórica da figura do abuso de direito, oportuna é a distinção preliminar destacada por de E. JORDÃo entre "noção" e "teoria"122. O autor credita, e com razão, ao tratamento indiferente das duas acepções a causa de tantas imprecisões e divergências nessa matéria.

Conforme o próprio E. JORDÃo preleciona, noção é a “ideia de existência, percepção empírica de uma realidade, um conhecer primitivo"; teoria, por outro lado, resulta de trabalho científico, isto é, “de sistematização e problematização de um saber"123. É, ergo, bem mais elaborada, complexa e refinada e, na escala histórica do desenvolvimento científico, normalmente sucede o surgimento da noção, que lhe é, pois, anterior no tempo - donde a origem das mencionadas aludidas imprecisões na doutrina.

A noção de abuso de direito é bastante antiga. Trata-se, em linhas gerais, da percepção de que os direitos (subjetivos) são relativos, e não absolutos, e de que lhes devem ser atribuídos limites internos. E, nesses termos, já o Direito Romano compreendida a existência do abuso de direito e o coibia ${ }^{124}$.

Essa constatação dessume-se, por exemplo, de brocardos latinos, como summum ius, summa iniuria (supremo direito, suprema injustiça) ou male enim nostro iure uti non debemus (não devemos fazer mal uso de nosso direito), que se contrapunham ao absolutismo do direito - consagradas em outras máximas, quais neminem laedit quisuo jure utitur (a ninguém prejudica quem exerce seu direito) ou nullus videtur dolo facere quiiure suo utitur (não se pode acusar de dolo a quem faz uso de seu direito). De igual modo, no Digesto encontram-se vedações ao exercício abusivo de direitos ${ }^{125}$.

\footnotetext{
${ }^{122}$ Repensando a Teoria do Abuso de Direito, Salvador, Juspodium, 2006, pp. 55-56.

${ }^{123}$ Repensando a Teoria do Abuso de Direito, Salvador, Juspodium, 2006, p. 56.

${ }^{124}$ Sobre as origens do instituto, afirma o romanista Charles APPLETON que a teoria "est si peu moderne peu sur elle repose toute l'évolution du droit romain, allant eu droit strict ver l'équité”. Apud Louis JOSEERAND, De l'esprit des droits et de leur relativitè, Paris, Dalloz, 1939, p. 3. Tatiana Bonatti PERES comenta: "O que se percebe é que, apesar de não terem desenvolvido uma teoria acerca do abuso do direito, já existia no direito romano uma tendência a condenar o exercício do direito com a exclusiva intenção de causar dano, ou seja, ato emulativo. ” In: Abuso do Direito, in Revista de Direito Privado, ano 11, n. 43, julho-setembro de 2010 , p. 11. Em sentido contrário, afirma Orlando GOMES, para quem o abuso de direito "é construção do pensamento jurídico dos nossos dias", sendo as semelhanças com os brocardos do Direito Romano, nas suas palavras, "acentuadas [pela doutrina atual] sem razão de ser". In: Introdução ao Direito Civil, Rio de Janeiro, Forense, 1999, p. 131.

${ }_{125}$ Assim, cita Eduardo JORDÃO: "De fato, na L. 1, § 12 (Ulpiano), lê-se: 'o proprietário pode abrir sulcos no seu prédio, prejudicando as fontes do vizinho, mas, se o faz para melhorar o seu e não com o ânimo de prejudicar o outro'. Além disso, na L. 2, $\S 9^{\circ}$ (Paulo), tem-se que 'havendo inundação, se as obras do proprietário do prédio invadido ofenderem ao do vizinho, não terá esse a ação aquea pluviae arcenda; salvo se feitas, não para impedi danos ao seu prédio e sim para lesar o outro". In: Repensando a Teoria do Abuso de Direito, Salvador, Juspodium, 2006, pp. 58-59. Pedro A. MARTINS, admitindo, embora, que os romanos reconhecessem a possibilidade de um abuso de direito do próprio direito de propriedade, observa acerca das disposições do Digesto a esse respeito: "Essa noção, porém, como concepção clássica dos direitos
} 
Essas proibições também tiveram lugar no direito medieval, que vedava a prática dos atos de emulação, aqueles atos danosos realizados sem proveito econômico para o agente e com a gratuita e imotivada intenção de simplesmente prejudicar terceiros ( "animus nocendi") ${ }^{126}$ ou sem que o agente tivesse interesse legítimo em agir (hipótese em que a intenção de prejudicar era presumida) ${ }^{127}$. Trata-se da chamada emulatio $^{128}$.

Há ainda registros, na doutrina, de coibições a práticas abusivas no direito muçulmano e no Código da Prússia de $1794^{129}$. Todavia, na evolução histórica que resultou na teoria do abuso de direito - após o que J. O. de CASTRO FILHO chama de "eclipse liberal"130 - destacam-se fundamentalmente as decisões jurisdicionais franceses a partir da segunda metade do século XIX.

Citam-se recorrentemente os casos da falsa chaminé e de ClémentBayard. Em ambos, verificou-se, na prática de atos em princípio estribados na ordem jurídica, a inequívoca e exclusiva intenção de seus agentes prejudicar terceiros. apenas para ilustrar, o primeiro caso, julgado em 1855, refere-se a um proprietário que construiu sobre seu terreno altas chaminés sem nenhuma utilidade prática para si e que tão-somente se prestavam a prejudicar o acesso pelo vizinho à luz solar e ao vento. No segundo caso, que é de 1915, o proprietário, para forçar seu vizinho a lhe comprar o terreno, começou a lhe causar o seguinte incômodo: para evitar que este pudesse fazer uso de seus balões dirigíveis, o pretenso vendedor ergueu altíssimas hastes de madeira em seu terreno.

Esses dois casos destacaram-se por terem limitado justamente do direito de propriedade, que, segundo a tradição liberal francesa e, ainda mais, a dicção do Código Civil napoleônico, atribuía ao titular o direito de "gozar e dispor das coisas da maneira mais absoluta”. Essas decisões abertamente infirmaram o texto legal e relativizaram os poderes do proprietário. Por serem pioneiros e pela engenhosidade que sua fundamentação demandou naquela oportunidade, essas decisões tornaram-se referências na evolução que

subjetivos, não coincide com a idéia atual do abuso do direito." In: Abuso do Direito e o Ato Ilícito, Rio de Janeiro, Freitas Bastos, 1941, p. 25.

${ }^{126}$ Eduardo JoRDÃo, Repensando a Teoria do Abuso de Direito, Salvador, Juspodium, 2006, p. 60.

${ }^{127}$ Tatiana Bonatti Peres, Abuso do Direito, in Revista de Direito Privado, ano 11, n. 43, julho-setembro de 2010 , p. 11.

${ }^{128}$ Daniel M. Boulos, Abuso do Direito no Novo Código Civil, São Paulo, Método, 2006, p. 33. O abuso resultava, assim, da conjugação do seguintes requisitos: (i) exercício de um direito; (ii) dano a terceiros; (iii) relação de causalidade; (iv) o ato fosse inútil para o titular do direito e (v) "que a realização fosse determinada pela intenção de causar um dano a outrem”. Cf. Humberto HEODORO JR., Comentários ao Novo Código Civil, v. 3, tomo 2, Rio de Janeiro, Forense, 2005, p. 117.

${ }^{129}$ Eduardo JoRDÃO, Repensando a Teoria do Abuso de Direito, Salvador, Juspodium, 2006, p. 60.

${ }_{130}$ "Com o advento do liberalismo, em que passou a predominar exageradamente o individualismo, reconhecem vários autores que a evolução do abuso de direito sofreu um eclipse... ”. In: Abuso do Direito no Processo Civil, Rio de Janeiro, Forense, 1960, p. 46. 
resultaria da formulação da teoria do abuso do direito ${ }^{131}$.

A teorização do abuso de direito, todavia, não coube naturalmente aos juízes franceses. Os numerosos estudos doutrinários surgidos a partir do final daquele século e início do seguinte, especialmente na França, é que conduziram ao delineamento da teoria $^{132}$. Conforme já registrado, esses trabalhos - como, de resto, também a jurisprudência - voltavam-se inicialmente ao abuso do direito de propriedade e, ao depois, espraiaram-se para outros direitos e ramos jurídicos. Entre nós, já na primeira metade do século passado surgiram estudos monográficos a esse respeito ${ }^{133}$.

Esse reconhecimento doutrinário e a estruturação sistemática do instituto que se seguiu conduziram à sua crescente aplicação nas decisões judiciais e sua inserção como valor na política legislativa dos diversos países.

\subsubsection{Teorias}

O problema da teoria do abuso de direito reside em explicar a razão por que se pró́be o ato dito abusivo, se sua prática se encontra dentro dos limites de um direito e, portanto, seria em princípio imune à reprovação pela ordem jurídica. Nesse mister, as atenções voltam-se para a delimitação dos critérios que caracterizariam a figura.

Debruçados sobre esse tema, os doutrinadores desenvolveram teses diferentes segundo os pressupostos e critérios - e cujas principais serão adiante resumidamente referidas ${ }^{134}$.

${ }^{131}$ E. JORDÃO observa que a doutrina francesa moderna atribui o desenvolvimento da teoria também a uma lei trabalhista de 1890 que regulamentou a resilição unilateral do contrato de trabalho. In: Repensando a Teoria do Abuso de Direito, Salvador, Juspodium, 2006, p. 61.

${ }^{132}$ Segundo levantamento de Eduardo JORDÃO, a ordem de publicação dos estudos é a seguinte: 1895 Raymond Saleilles publica o Essai d'une théorie générale de l'obligation d'après le projet de Code civil allemand; 1901 - Porchero, De l'abus de droit; 1905 - Louis Josserand, L'abus des droits; 1905 - Georges Ripert, L'exercice des droits et La responsabilitè civile; 1906 - Desserteaux, Abus de droit ou conflits de droit; 1907 - Vallet, l'exercice fautif de droit. Cf. Repensando a Teoria do Abuso de Direito, Salvador, Juspodium, 2006, p. 63.

${ }^{133}$ Ambos já aqui anteriormente citados: a primeira edição de "O Abuso do Direito e O Ato Ilícito", de Pedro A. Martins, é de 1941 e a de "Abuso do Direito no Processo Civil”, de José Olímpio de CAstro Filho, um pouco posterior, é de 1955.

${ }^{134}$ Resumidamente, para não incorrer na crítica feita por Jorge Manuel CoUTINHO DE ABREU, Do Abuso de Direito - Ensaio de um Critério em Direito Civil e nas Deliberações Sociais, Coimbra, Almedina, $2006, \mathrm{p}$. 15: "Tal empresa, além de manifestamente não caber nos quadros deste trabalho, revelar-se-ia, se não erro, de pouco préstimo. (...) Depois, essa apresentação incorreria inevitavelmente em escusadas repetições ou multiplicações (e variando pouco o multiplicando...), dado o seguidismo a este nível bastas vezes verificado (embora,, convenha-se, haja quem muito justamente mereça ser seguido)." 
Elas diferenciam-se por diversos critérios ${ }^{135}$, mas podem ser reunidas em dois grupos principais ${ }^{136}$ : as subjetivistas e as objetivistas. A diferença, nesse caso, está na imprescindibilidade ou não de elemento volitivo na caracterização do abuso - que está presente no primeiro grupo e ausente no segundo.

As teorias subjetivistas foram as primeiras a surgir. Marcadamente próximas da emulatio medieval ${ }^{137}$, desenvolveram-se a partir da sistematização dos critérios apresentados pelas primeiras decisões dos tribunais franceses no século $\mathrm{XIX}^{138}$. Caracterizam-se por centrarem no agente o elemento definidor do instituto.

Em seu interior, no entanto, esse grupo não é uniforme e comporta uma nova divisão, ainda mais específica. Há aquelas teorias subjetivistas que pressupõem a intenção do agente de prejudicar e adotam, portanto, o critério intencional ${ }^{139}$. Para estas, constitui abuso o exercício do direito com o animus de causar danos a terceiros - o que é a forma típica, tradicional dessa figura ou, nas palavras de L. JOSSERAND, “l'aliment normal de l'abus des droits" ${ }^{\prime 140}$. Historicamente, foram as teses pioneiras, que primeiro se estruturam.

Ainda segundo uma perspectiva subjetiva, outra corrente, mais abrangente, sustenta a caracterização do abuso em caso de comportamento meramente culposo, e não necessariamente doloso, do agente. Nesse caso, a incorreção da conduta deriva de falta simples ou falta grave ${ }^{141}$; fala-se, então, em critério técnico ${ }^{142}$.

Noutro extremo estão as teorias objetivistas, que abstraem a intenção do agente. Para estas, a configuração do abuso está no exercício irregular do agente ${ }^{143}$, em um desvio de seu comportamento e não naquilo que ele tenciona. Também em duas correntes divide-se esse grupo. Segundo o critério econômico ou teleológico (funcional ou

\footnotetext{
135 Veja-se, por exemplo, o exame pormenorizado de Fernando Augusto CunHa DE SÁ, Abuso de Direito, Lisboa, Ministério das Finanças, 1973, pp. 285-464.

${ }^{136}$ Daniel M. Boulos acrescenta um terceiro grupo, misto, que "pretende conjugar o critério subjetivo e o objetivo para a aferição da existência do exercício abusivo de um direito subjetivo." Mas o próprio autor aponta a pouca "relevância prática" da corrente e registra que não tem sido lembrada pelos autores. Cf.: Daniel M. Boulos, Abuso do Direito no Novo Código Civil, São Paulo, Método, 2006, p. 41.

${ }_{137}^{17}$ Daniel M. Boulos, Abuso do Direito no Novo Código Civil, São Paulo, Método, 2006, p. 39.

${ }^{138}$ Jorge Manuel Coutinho DE ABReu, Do Abuso de Direito - Ensaio de um Critério em Direito Civil e nas Deliberações Sociais, Coimbra, Almedina, 2006, p. 16.

${ }^{139}$ Louis JosserAND, De l'esprit des droits et de leur relativitè, Paris, Dalloz, 1939, p. 366. Orlando GoMES, Introdução ao Direito Civil, Rio de Janeiro, Forense, 1999, p. 132.

${ }^{140}$ Louis JOSSERAND, De l'esprit des droits et de leur relativitè, Paris, Dalloz, 1939, p. 366.

141 Jorge Manuel Coutinho DE ABReu, Do Abuso de Direito - Ensaio de um Critério em Direito Civil e nas Deliberações Sociais, Coimbra, Almedina, 2006, p. 16.

${ }^{142}$ Louis JosSERAND, De l'esprit des droits et de leur relativitè, Paris, Dalloz, 1939, p. 379.

${ }^{143}$ Rubens Limongi FrançA, Abuso de Direito (verbete), Enciclopédia Saraiva do Direito, v. 2, São Paulo, Saraiva, p. 46.
} 
finalista) ${ }^{144}$, é abusivo, respectivamente, o exercício do direito sem legítimo interesse (decorre da atuação do direito para satisfazer interesse ilegítimo) ou que excede seu fim econômico ou social ${ }^{145}$.

\subsection{Abuso de direito no Código Civil de 1916}

Consagrado expressamente pelo vigente Código Civil de 2002, que lhe atribui dispositivo expresso e específico, a figura do abuso de direito não era, no entanto, inédita no Brasil até a entrada em vigor do referido diploma.

Ainda que timidamente ${ }^{146}$, já o Código Beviláqua ${ }^{147}$ previa-a, bem assim, na opinião de S. RODRIGUES ${ }^{148}$, a Lei de Introdução ao Código Civil.

Quanto ao Código Civil, a matéria era disciplinada essencialmente pelos artigos 100 e 160 , inc. $\mathrm{I}^{149}$, embora outros, de perfil casuístico, sejam amiúde citados pela

${ }^{144}$ Jorge Manuel Coutinho DE ABREu, Do Abuso de Direito - Ensaio de um Critério em Direito Civil e nas Deliberações Sociais, Coimbra, Almedina, 2006, p. 16.

${ }^{145}$ Orlando GoMES, Introdução ao Direito Civil, Rio de Janeiro, Forense, 1999, p. 132.

${ }^{146}$ Comentando a disposição do Código Civil de 1916, Haroldo VALLADÃO, em expressão mais contundente, afirma que, tendo em vista a dimensão já então alcançada pelo "problema do abuso de direito", não poderia ele ser colocado assim "clandestinamente" naquele diploma. Cf. Estudios de derecho civil en honor del Prof. Castan Tobeñas, Pamplona, EUNSA, 1969, pp. 637-640, apud Alexandre GUERRA, Responsabilidade Civil por Abuso do Direito, São Paulo, Saraiva, 2011, p. 130. Pedro A. MARTINS qualifica a disciplina legal de tímida e obscura (O Abuso do Direito e o Ato Ilícito, Rio de Janeiro, Freitas Bastoso, 1941, p. 139).

147 Antes dele, segundo referências de José Olimpio de CASTRO FILHO, havia vedações pontuais a certas condutas abusivas no processo civil; o autor cita, entre outros, a Ordenações Filipinas (Liv. $3^{\circ}$, tít. 34) e Manuelinas (Liv. 3, Tít. 51, § 54) e, depois da Constituição republicana de 1891, alguns códigos de processo estaduais. (Cf. Abuso de Direito no Processo Civil, Rio de Janeiro, Forense, 1960, pp. 73-83.). Também a lide temerária é referida por Pedro A. MARTINS como vestígio do abuso do direito na tradição jurídica brasileira (Cf. O Abuso do Direito e o Ato Ilícito, Rio de Janeiro, Freitas Bastoso, 1941, p. 138). Não no plano positivo, mas de lege ferenda, Alexandre GUERRA menciona a Consolidação de Carlos de Carvalho, de 1899, que, baseado na Ordenação (Filipina) L. 4, Tít. N. 2, determinava em seu art. 1.029 caber indenização em caso de excesso no exercício do direito (Cf. Responsabilidade Civil por Abuso do Direito, São Paulo, Saraiva, 2011, p. 130); Inacio de CARVALHO NETO, por sua vez, alude à defesa feita por Alfredo Valladão em artigo publicado no Jornal do Comércio de 4/2/1912 de inclusão no então projetado Código Civil da figura do abuso de direito (Cf. Abuso do Direito, Curitiba, Juruá, 2007, p. 31).

${ }_{148}$ Direito Civil-Parte Geral, v. 1, São Paulo, Saraiva, 1999, p. 314.

149 Art. 100. Não se considera coação a ameaça do exercício normal de um direito, nem o simples temor reverencial.

Art. 159. Aquele que, por ação ou omissão voluntária, negligência, ou imprudência, violar direito, ou causar prejuízo a outrem, fica obrigado a reparar o dano.

A verificação da culpa e a avaliação da responsabilidade regulam-se pelo disposto neste Código, arts. 1.518 a 1.532 e 1.537 a 1.553. (Redação dada pelo Decreto do Poder Legislativo $n^{\circ} 3.725$, de 15.1.1919)

Art. 160. Não constituem atos ilícitos:

I - os praticados em legítima defesa ou no exercício regular de um direito reconhecido;

II - a deterioração ou destruição da coisa alheia, a fim de remover perigo iminente (arts. 1.519 e 1.520).

Parágrafo único. Neste último caso, o ato será legítimo, somente quando as circunstâncias o tornarem absolutamente necessário, não excedendo os limites do indispensável para a remoção do perigo. 
doutrina $^{150}$ (como os artigos 526, 554, 564, 584, 585, 587, 1530 e $1531^{151}$ ). Enquanto este último encontrava-se topograficamente localizado sob o título pertinente aos atos ilícitos (idêntico ao texto do inc. I do art. 188 do vigente diploma), aquele outro, atinente à coação, estava entre os defeitos dos atos jurídicos (correspondente ao art. 153, do atual código).

A disciplina da ilicitude civil no revogado Código atendida, como hoje, ao pelo princípio da atipicidade ${ }^{152}$, consagrado justamente por seu art. $159^{153}$. Esse dispositivo, em sua primeira parte, delimitava o ato ilícito (absoluto ${ }^{154}$ ), fixando seus elementos e requisitos (tarefa desempenhada pelo art. 186 do vigente diploma), e prescrevia a consequiência jurídica consistente no dever de reparação (o que, no Código de 2002, corresponde ao art. 927).

O dispositivo subseqüente, por sua vez, excepcionava o anterior, arrolando atos jurídicos que, conquanto danosos, eram ainda assim lícitos e, por conseguinte, não ensejavam indenização. Entre esses, assinalado pelo inc. I, $2^{\mathrm{a}}$ parte, estava o "exercício regular de um direito reconhecido".

${ }^{150}$ Vejam-se, por todos, Inacio CARVAlho Neto, Abuso do Direito, Curitiba, Juruá, 2007, p. 32 e Daniel M. Boulos, Abuso do Direito no Novo Código Civil, São Paulo, Método, 2006, p. 86.

${ }^{151}$ Art. 526. A propriedade do solo abrange a do que lhe está superior e inferior em toda a altura e em toda a profundidade, úteis ao seu exercício, não podendo, todavia, o proprietário opor-se a trabalhos que sejam empreendidos a uma altura ou profundidade tais, que não tenha ele interesse algum em impedi-los. (Redação dada pelo Decreto do Poder Legislativo no 3.725 , de 15.1.1919)

Art. 554. O proprietário, ou inquilino de um prédio tem o direito de impedir que o mau uso da propriedade vizinha possa prejudicar a segurança, o sossego e a saúde dos que o habitam.

Art. 564. Quando as águas, artificialmente levadas ao prédio superior, correrem dele para o inferior, poderá o dono deste reclamar que se desviem, ou se lhe indenize o prejuízo que sofrer.

Art. 584. São proibidas construções capazes de poluir, ou inutilizar para o uso ordinário, a água de poço ou fonte alheia, a elas preexistente.

Art. 585. Não é permitido fazer escavações que tirem ao poço ou à fonte de outrem a água necessária. É, porém, permitido fazê-las, se apenas diminuírem o suprimento do poço ou da fonte do vizinho, e não forem mais profundas que as deste, em relação ao nível do lençol d'água.

Art. 587. Todo o proprietário é obrigado a consentir que entre no seu prédio, e dele temporariamente use, mediante prévio aviso, o vizinho, quando seja indispensável à reparação ou limpeza, construção e reconstrução de sua casa. Mas, se daí lhe provier dano, terá direito a ser indenizado.

Art. 1.530. O credor que demandar o devedor antes de vencida a dívida, fora dos casos em que a lei o permita, ficará obrigado a esperar o tempo que faltava para o vencimento, a descontar os juros correspondentes, embora estipulados, e a pagar as custas em dobro.

Art. 1.531. Aquele que demandar por dívida já paga, no todo ou em parte, sem ressalvar as quantias recebidas, ou pedir mais do que for devido, ficará obrigado a pagar ao devedor, no primeiro caso, o dobro do que houver cobrado e, no segundo, o equivalente do que dele exigir, salvo se, por lhe estar prescrito o direito, decair da ação. (Redação dada pelo Decreto do Poder Legislativo no 3.725, de 15.1.1919)

${ }^{152}$ Os Atos Ilícitos, in O Novo Código Civil - Estudos em Homenagem ao Prof. Miguel Reale, coord. Domingos Franciulli Netto - Gilmar Ferreira Mendes - Ives Gandra da Silva Martins, São Paulo, LTr, 2003, p. 152 .

${ }^{153}$ Verbis: “Art. 159. Aquele que, por ação ou omissão voluntária, negligência, ou imprudência, violar direito, ou causar prejuízo a outrem, fica obrigado a reparar o dano.

A verificação da culpa e a avaliação da responsabilidade regulam-se pelo disposto neste Código, arts. 1.518 a 1.532 e 1.537 a 1.553. (Redação dada pelo Decreto do Poder Legislativo $n^{o} 3.725$, de 15.1.1919)"

${ }^{154}$ Decorrente do dever de todos de não prejudicar terceiros, consequiência necessária do princípio da incolumidade das esferas jurídicas. 
Ora, ensinou a doutrina, a interpretação do dispositivo a contrario sensu era de rigor ${ }^{155}$ : se, como expressavam os termos da lei, a regularidade do exercício do direito implicava sua licitude (ainda que resultasse em dano), ilícita seria, ergo, sua prática irregular $^{156}$.

E foi nesses termos, e segundo essa técnica, que o abuso de direito inseriu-se na ordenação jurídica brasileira.

Note-se que, na estrita dicção legal, o disciminem que ensejava a licitude ou não da conduta não estava na natureza da posição jurídica exercida - pois que, está claro, atinente a "um direito reconhecido" -, mas na regularidade ou não de seu exercício. Quer isso significar que o índice de licitude estava no respeito aos limites (intrínsecos) do exercício, e não nos poderes exercidos (enfeixados no direito reconhecido). Por isso, a identidade logo estabelecida pela doutrina entre essa figura - desprovida de designação específica pelo código - e o abuso de direito ${ }^{157}$, conforme já então consagrado pela doutrina estrangeira e nos textos legais que precederam o estatuto civil brasileiro no direito comparado.

Essa fórmula, no entanto, foi objeto de numerosas e pesadas críticas. H. VALLADÃO enxerga verdadeiramente uma inserção "clandestina" do instituto no Código e identifica no acanhamento de sua disciplina a causa do conservadorismo da jurisprudência da época em que escrevia, que, segundo reporta, não aplicava o instituto sem a comprovação do dolo ou da culpa do agente ${ }^{158}$. A escassez quantitativa e qualitativa de julgados brasileiros, se comparados aos europeus, bem como de estudos monográficos do instituto após a promulgação do Código de 1916 também são apontados por D. M. BouLos como conseqüências do tratamento legal abreviado dispensado por aquele diploma ${ }^{159}$. Também Pedro A. MARTINS fez referência ao caráter tímido e obscuro da expressão legal e o já citado H. VALLADÃo ainda criticava a ausência de omissão como modo de abuso de

\footnotetext{
${ }^{155}$ Para Pedro A. MARTins: “A extensão da responsabilidade civil aos atos abusivos é inovação do art. 160, n. I, do código civil, onde, a contrario sensu se aninhou, tímida e obscuramente, a fórmula repressora (...). Se não constituem atos ilícitos os praticados no exercício regular de um direito reconhecido, a eiva inquina, de certo, os atos realizados em virtude do exercício irregular desse direito." In: O Abuso do Direito e o Ato Ilícito, Rio de Janeiro, Freitas Bastos, 1941, pp. 139 e 140. Comentando o Código de 1916, Inacio CARVALHO NETO observa: "Entenderam tais autores que, como não constituíssem atos ilícitos os praticados no exercício regular de um direito, os atos praticados no exercício irregular estariam na órbita da ilicitude." In: Abuso do Direito, Curitiba, Juruá, 2007, p. 31.

${ }_{156}^{15}$ Milton Flávio de Almeida Camargo LAUTENSCHLÄGER, Abuso do Direito, São Paulo, Atlas, 2007, p. 59.

157 “A consagração da doutrina do abuso do direito é, portanto, expressa." In: Pedro A. MARTINS, O Abuso do Direito e o Ato Ilícito, Rio de Janeiro, Freitas Bastos, 1941, p. 1414.

${ }^{158}$ Estudios de derecho civil en honor del Prof. Castan Tobeñas, Pamplona, EUNSA, 1969, pp. 637-640, apud Alexandre GuERRA, Responsabilidade Civil por Abuso do Direito, São Paulo, Saraiva, 2011, p. 130

${ }^{159}$ Abuso do Direito no Novo Código Civil, São Paulo, Método, 2006, p. 86.
} 
direito $^{160}$.

De todo modo, o fato é que historicamente o dispositivo em comento foi pioneiro no tratamento da matéria e, partir dele, o instituto inseriu-se no direito privado brasileiro e espraiou-se para os demais ramos. Cuidaram, pois, os doutrinadores de investigar seus exatos contornos e natureza jurídica, considerando especialmente o que já se havia produzido fora do país.

E não houve consenso, entretanto. Enquanto alguns perfilavam a teoria subjetivista e entendiam que a configuração do abuso de direito dependia de dolo ou culpa do agente, outros, filiados à corrente objetivista, sustentavam ser prescindível o elemento volitivo, bastando o desrespeito à finalidade social ou econômica do direito envolvido.

À primeira corrente, pertenciam, entre outros, Washington de Barros Monteiro e J. M. CARVAlHo SAnTOS, bem como Everardo da Cunha LunA, embora mais flexível que os dois primeiros ${ }^{161}$. Diretriz diferente seguiram Clóvis BEVILÁQUA e PedroA. MARTINS.

Este último observa que a dicção legal assenta-se em uma base puramente objetiva. Assim, defende, o critério do código é a anormalidade do uso do direito, e não a má intenção do sujeito. A irregularidade, assim, decorreria do desatendimento aos "intuitos econômicos ou sociais" de seu direito. Para o autor, citando o texto legal, o que importa é avaliar se o agente, no exercício desse direito, “deixou de ter em conta os interesses antagônicos, mas hierarquizados, da coletividade, desvirtuando, por essa forma, o elemento social que, na formação da regra jurídica, predomina sobre o elemento individual”. E conclui que "averiguar a intenção do agente, verificar se o dano teria resultado de culpa sua, é tarefa que deve ser relevada à psicologia"162.

Em reforço de sua argumentação, o autor ancora-se ainda na lição de Clóvis BEVILÁQUA, a quem atribui a dupla autoridade de "civilista consagrado e de autor do projeto" do Código Civil de 1916. De fato, o jurista citado, ao comentar o diploma e após sintetizar as posições doutrinárias de então acerca do tema e o direito comparado, afirma que o legislador brasileiro adotou a doutrina de SALEILLES ${ }^{163}$, para quem o abuso de

\footnotetext{
${ }^{160}$ Estudios de derecho civil en honor del Prof. Castan Tobeñas, Pamplona, EUNSA, 1969, pp. 637-640, apud Alexandre GuERRA, Responsabilidade Civil por Abuso do Direito, São Paulo, Saraiva, 2011, p. 130

${ }^{161}$ Cláudio Antonio Soares LEVADA, Anotações obre o abuso do direito, in Revista dos Tribunais, São Paulo, ano 80, v. 667, pp. 44-50, maio de 1991.

${ }_{162}$ O Abuso do Direito e o Ato Ilícito, Rio de Janeiro, Freitas Bastoso, 1941, pp. 141-143.

163 Raymond Saleilles, autor da obra pioneira obra sobre o assunto ("Essai d'une théorie générale de l'obligation d'après le projet de Code civil allemand') em 1895.
} 
direito consiste no exercício anormal do direito ${ }^{164}$, não se indagando, pois, do elemento subjetivo ${ }^{165}$. Sendo o direto resultante de "solicitações dos interesses do indivíduo e da sociedade", seu exercício deve seguira "linha média traçada por essas duas solicitações" 166 .

Igual posição tem Sílvio RODRIGUES. Para ele, a evolução doutrinária do instituto alcançou sua plenitude com L. JOSSERAND, com quem faz coro e que admite a ocorrência do abuso quando "ele não é exercido de acordo com a finalidade social para qual foi conferido ${ }^{, 167}$.

Além do referido dispositivo, também o art. 100 do Código Civil de 1916 é geralmente apontado como fonte legal do abuso de direito. Também a essa conclusão apenas se pode chegar a partir de sua interpretação a contrario sensu do texto legal, que em seus termos elide a ocorrência de coação a "ameaça do exercício normal de um direito”. Seu exercício abusivo, portanto, se ameaçado, configuraria o mencionado vício do ato jurídico.

Não resta dúvida de que também nesse caso o legislador contemplou a figura do abuso. Todavia, oportuna é a observação de P. A. MARTins, que assevera tratarse de "disposição que tem por fim exclusivo restringir o conceito legal de coação" e conclui, então, que esse dispositivo "não se poderia estender a todas as formas de ofensa ou violação de direitos de terceiros" "168.

Por fim, merece referência o art. $5^{\circ}$ da Lei de Introdução ao Código Civil, que, embora integrante de outro diploma legal, apartado do estatuto civil - em que pese a denominação original -, está em plena conformidade com as disposições acima analisadas. Prescrevendo norma de interpretação, determina ao juiz que na aplicação da lei atenda "aos fins sociais a que ela se dirige e às exigências do bem comum”. Essa normativa reforça o entendimento de que o abuso de direito caracteriza-se pelo desatendimento teleológico, não sendo imprescindíveis a culpa ou o dolo do agente ${ }^{169}$.

\subsection{Abuso de direito no Código Civil de 2002}

\footnotetext{
${ }^{164}$ Clóvis Beviláqua, Código Civil Comentado, v. 1, Rio de Janeiro, Francisco Alves, 1956, p. 347.

165 Alexandre GuerRA, Responsabilidade Civil por Abuso do Direito, São Paulo, Saraiva, 2011, p. 128.

${ }^{166}$ Clóvis Beviláqua, Código Civil Comentado, v. 1, Rio de Janeiro, Francisco Alves, 1956, p. 347.

${ }^{167}$ Direito Civil - Parte Geral, v. 1, São Paulo, Saraiva, 1999, p. 314.

${ }^{168}$ O Abuso do Direito e o Ato Ilícito, Rio de Janeiro, Freitas Bastos, 1941, p. 139.

169 "Diante disso, o exercício de um direito que não atenda a seu fim social, critério variável no tempo e no espaço, já poderia ser considerado abusivo, mesmo na ausência da norma contida no artigo 160 do Código Civil revogado, bem como dos artigos 187 e 421 do Código Civil em vigor.” Cf. Keila Pacheco FERREIRA, Abuso do direito nas relações obrigacionais, Belo Horizonte, Del Rey, 2007, pp. 140-141.
} 


\subsubsection{Abuso de direito na legislação precedente}

Disciplinado parcamente pelo revogado Código Civil, o abuso de direito mereceu tratamento bem mais generoso pelo vigente ${ }^{170}$, considerado pela doutrina satisfatório $^{171}$ e resultado proveitosa colheita da experiência estrangeira ${ }^{172}$ - notadamente portuguesa $^{173}$ - e nacional.

De se destacar que, antes do atual Código Civil, esparsos e até numerosos dispositivos na ordem positiva brasileira previam hipóteses específicas de prática abusiva, bem como cominava efeitos e sanções. Além dos já mencionados artigos do próprio diploma de 1916, cita-se, entre outros dispositivos, a vedação à reiterada purga da mora pelo locatário de imóvel urbano por ilimitadas vezes ${ }^{174}$, prevista pela Lei n. ${ }^{\circ}$ 8.245/91 (art. 62, parágrafo único). As hipóteses do art. 17 do Código de Processo Civil também constituem exemplos de abuso de direito em matéria processual.

Particularmente nos domínios do Direito Comercial, é referência a norma do art. 20 da revogada Lei de Falências (correspondente ao art. 101 da Lei n. ${ }^{o}$ 11.101/05), que prescrevia o dever de indenização ao credor que requeresse com dolo (vale dizer, com o exclusivo propósito nocivo, com desabrido espírito emulativo) a falência do devedor. O art. 117 da Lei de Sociedades por Ações, por seu turno, prescreve que o controlador "responde pelos danos causados por atos praticados com abuso de poder" e, exemplificativamente, arrolada em seu $\S 1^{\circ}$ condutas consideradas abusivas.

Também a jurisprudência anterior ao Código Civil de 2002 muito contribuiu para a evolução do instituto. Um exemplo, particularmente caro ao Direito Concursal, é a vedação ao credor de requerer a falência do devedor estribado em crédito de pequena monta, na hipótese de impontualidade (LF: art. $1^{\circ}$ ). Consagrado sob a vigência da

\footnotetext{
${ }^{170}$ Destaca Álvaro Villaça AZEVEDO a relevância, no curso histórico entre os dois códigos, do anteprojeto de Código das Obrigações, de 1941, de Orosimbo Nonato, Philadelpho Azevedo e Hahnemann Guimarães. Embora nem sequer tenha chegado à apreciação do Poder Legislativo, regulou a matéria relativa ao abuso de direito e, assim, serviu de documento para a inserção do instituto no sistema jurídico brasileiro - inclusive dissociado da teoria subjetivista e já incorporando o critério finalista. Cf. Código Civil Comentado, v. 2, São Paulo, Atlas, 2003, p. 363. O aproveitamento desses estudos na elaboração do Anteprojeto que resultou na Lei n. ${ }^{\circ}$ 10.406/02 é confirmada por seu presidente, Miguel REALE, como diretriz seguida. Cf. Visão Geral do Código Civil, in: Gisele de Melo Graga Tapai (coord.), Novo Código Civil brasileiro - Estudo Comparativo com o Código Civil de 1916, Constituição Federal, Legislação Codificada e Extravagante, São Paulo, RT, 2003, pp. 11-12.

${ }^{171}$ Caio Mario da Silva PereIRA, Instituições de Direito Civil, v. 1, Rio de Janeiro, Forense, 2006, p. 671.

${ }^{172}$ Por todos, veja-se Silvio de Salvo VenosA, Direito Civil - Parte Geral, São Paulo, Atlas, 2009, p. 539.

173 Alexandre GUERRA reporta a forte inspiração que exerceu sobre o Código brasileiro o congênere lusitano, que em seu artigo $334^{\circ}$ prescreve: "E ilegítimo o exercício de um direito, quando o titular exceda manifestamente os limites impostos pela boa-fé, pelos bons costumes ou pelo fim social ou eoncómico desse direito." Cf. Responsabilidade Civil por Abuso do Direito, São Paulo, Saraiva, 2011, p. 142.

${ }^{174}$ Álvaro Villaça AZEVEDo, Código Civil Comentado, v. 2, São Paulo, Atlas, 2003, p. 365.
} 
antiga Lei de Falências, esse entendimento inspirou o legislador, que a incorporou expressamente na Lei n. ${ }^{0} 11.101 / 05$, em seu art. 94, inc. I (limite mínimo equivalente a quarenta vezes o salário mínimo). Nesse caso, entendeu a jurisprudência que a falência não constitui meio de cobrança; trata-se de medida extrema, que pressupõe a insolvabilidade do devedor. Não era, pois, legítimo seu pedido exclusivamente para obtenção compulsória do pagamento e não para a real instauração do concurso de credores - mormente porque disponível, no sistema jurídico, um meio muito mais adequado e menos gravoso para o devedor (a execução por quantia certa).

Também a teoria da desconsideração da personalidade jurídica, de origem comercialista, é apontada como exemplo de aplicação do abuso de direito ${ }^{175}$. Também foi contemplada pelo Código Civil de 2002 (art. 50), depois de já referida por diversas outras leis expressamente (CDC: art. 28; Lei n. ${ }^{\circ}$ 8.884/94: art. 18; Lei n. ${ }^{\circ}$ 9.605/98: art. $4^{\circ}$ ). Especificamente no campo do Direito Societário, Álvaro Villaça AZEVEDO relembra, com apoio em Francesco GALGANO, a jurisprudência que entende abusiva, por exemplo, a deliberação pela maioria do aumento do capital social de tal ordem que inviabiliza a subscrição e integralização proporcional pela minoria, o que resulta na diluição da participação desta ${ }^{176}$.

No entanto, e mesmo considerando a contribuição do Código Civil de Clóvis Beviláqua, carecia esse conjunto de dispositivos de um caráter unitário e sistemático, que a doutrina entendia devida ao instituto. Esse tratamento suficientemente extenso e sistemático, que é típico e próprio das codificações, foi enfim dispensado pelo vigente diploma.

\subsubsection{Abuso de direito como ato ilícito}

O Código Civil de 2002 disciplinou o abuso de direito entre os atos ilícitos; enquadrou-o, pois, nessa categoria, seguindo, conforme aponta Sergio CAVALIERI FILHO, os precedentes da legislação estrangeira ${ }^{177}$. Não sem oposição, no entanto.

Humberto THEODORO JR. credita a origem dessa orientação às causas do desenvolvimento do instituto. Como se propugnava pela relatividade dos direitos

\footnotetext{
${ }^{175}$ Rubens REQUIÃO, Abuso de direito e fraude através da personalidade jurídica 'disregard doctrine' (verbete), in Enciclopédia Saraiva do Direito, v. 2, São Paulo, Saraiva, p. 63; Sergio CaVAlieri Filho, Programa de Responsabilidade Civil, São Paulo, Atlas, 2009, p. 154.

${ }^{176}$ Código Civil Comentado, v. 2, São Paulo, Atlas, 2003, p. 365.

177 Programa de Responsabilidade Civil, São Paulo, Atlas, 2009, p. 152.
} 
subjetivos e, portanto, por sua limitação, consolidou-se o entendimento de que o titular que ultrapassasse essas fronteiras incorria no "terreno da ilicitude" 178 .

Entre os opositores desse entendimento está, entre nós, por exemplo, Silvio de Salvo VenosA ${ }^{179}$. Eles sustentam que o abuso de direito constitui categoria própria, distinta do ato ilícito (absoluto). Isso, porque, muito embora um e outro possam ensejar o dever de indenização (e possam ser, portanto, fonte de obrigação), o dano é da essência do ato ilícito (ainda quando apenas moral, conforme textualmente dispõe o art. 186 do Código Civil), mas não do abuso ${ }^{180}$. A reprovabilidade deste independe da provocação de dano, que pode ou não ocorrer - e apenas no primeiro caso é que a sanção consistirá no dever de reparar. Nas demais hipóteses, a sanção poderá ter outra natureza ${ }^{181}$.

Observam ainda esses doutrinadores uma diferença de construção científica entre os dois institutos, em virtude da não coincidência dos respectivos âmbitos de incidência ${ }^{182}$. Referem-se eles à circunstância de que o autor de um ato ilícito viola diretamente os limites objetivos traçados pela própria lei. Já quem abusa atende aos limites objetivos do direito, mas fere "ostensivamente a destinação do direito e o espírito da instituição"

Essa corrente restou vencida na elaboração do Código Civil ${ }^{184}$. E mesmo parte seus defensores reconheceu a conveniência do tratamento por ele dispensado ao abuso $^{185}$, uma vez seu enquadramento como espécie do gênero ato ilícito não lhe aniquila a "autonomia dogmática" - que é a preocupação desses partidários ${ }^{186}$. Por outro lado, os partidários do entendimento consagrado pelo diploma legal ${ }^{187}$ registram diferenças nas

\footnotetext{
${ }^{178}$ Humberto HeOdoro JR., Comentários ao Novo Código Civil, v. 3, tomo 2, Rio de Janeiro, Forense, 2005 , p. 119.

${ }^{179}$ Ele é expresso, embora reconheça a conveniência prática da opção do legislador: "O fato de a matéria estar inserida no capítulo dos atos ilícitos em nada o prejudica. De fato, se o abuso de direito não constitui propriamente um ato ilícito e transcende os limites da responsabilidade civil, razão prática impõe que as conseqüencias do abuso sejam as mesmas da reparação por responsabilidade civil." Cf. Direito Civil Parte Geral, São Paulo, Atlas, 2009, p. 539. No mesmo sentido: Alvino LiMA, Culpa e Risco, São Paulo, RT, 1999, passim; Keila Pacheco FERREIRA, Abuso do direito nas relações obrigacionais, Belo Horizonte, Del Rey, 2007, pp. 140-141; Inacio CARVALHO NETO, Abuso do Direito, Curitiba, Juruá, 2007, pp. 186-193.

${ }^{180}$ Keila Pacheco FerreIRA, Abuso do direito nas relações obrigacionais, Belo Horizonte, Del Rey, 2007, p. 31.

${ }^{181}$ Inacio CARVAlHO NETO, Abuso do Direito, Curitiba, Juruá, 2007, p. 195.

${ }^{182}$ Keila Pacheco FERREIRA, Abuso do direito nas relações obrigacionais, Belo Horizonte, Del Rey, 2007, p. 31.

${ }^{183}$ Alvino LIMA, Culpa e Risco, São Paulo, RT, 1999, p. 205.

${ }^{184}$ Sergio CAVAliERI Filho, Programa de Responsabilidade Civil, São Paulo, Atlas, 2009, p. 153.

${ }^{185}$ Sílvio de Salvo Venosa, Direito Civil - Parte Geral, São Paulo, Atlas, 2009, p. 539.

${ }^{186}$ Eduardo JoRDÃo, Repensando a Teoria do Abuso de Direito, Salvador, Juspodium, 2006, p. 102.

${ }^{187}$ Entre os quais: Sergio CAVALIERI FILHO, Programa de Responsabilidade Civil, São Paulo, Atlas, 2009, p. 153 e Humberto HEOdoro JR., Comentários ao Novo Código Civil, v. 3, tomo 2, Rio de Janeiro, Forense, 2005, p. 121.
} 
disciplinas do ato ilícito não-abusivo e do abuso de direito.

Um e outro encontram-se disciplinados sob o título atinente aos atos ilícitos, no Livro III da Parte Geral do Código. Ao artigo 186, que inaugura o referido Título e disciplina o ato ilícito absoluto ("Aquele que, por ação ou omissão, voluntária, negligência ou imprudência, violar direito e causar dano a outrem, ainda que exclusivamente moral, comete ato ilícito.”), segue-se o artigo 187, que define o abuso segundo a seguinte dicção: "Também comete ato ilícito o titular de um direito que, ao exercê-lo, excede manifestamente os limites impostos pelo seu fim econômico ou social, pela boa-fé ou pelos bons costumes."

De se observar que ambos os dispositivos não contêm uma definição de ato ilícito, mas, antes, tão-somente prescrevem que as hipóteses ali identificadas constituem ilicitude $^{188}$. São, pois, exemplos de ilicitude.

A partir dessa sistemática, da disposição topográfica dos dispositivos e de sua redação, concluem os comentadores do Código Civil que o abuso de direito é uma modalidade do ato ilícito (gênero ${ }^{189}$ ), com características próprias e conteúdo especial ${ }^{190}$.

Os elementos que conferem essa especificidade em relação aos demais atos ilícitos - sem, contudo, negarem sua inclusão entre estes, o que inarredavelmente decorre de lei ${ }^{191}$-, são aquelas já referidas pelos que propalam sua autonomia. Sergio CAVAliER FILHo observa a circunstância de o abuso, diferentemente do que trata o art. 186 do Código Civil, não constituir ofensa frontal ao direito de outrem (mas, antes, o exercício anormal do direito) e amparar-se (formalmente ou aparentemente) em lei, embora ferindo seu espírito ${ }^{192}$, além de sua configuração prescindir, segundo entende, de ocorrência de dano ${ }^{193}$.

Humberto THEODORO JR., por outro lado, sustenta que, na qualidade de modalidade de ato ilícito ${ }^{194}$, o abuso de direito conserva as características e propriedades daquele. Trata-se, portanto, de uma posição ainda mais específica, entre aqueles que advogam a

\footnotetext{
${ }_{188}^{188}$ Eduardo JORDÃO, Repensando a Teoria do Abuso de Direito, Salvador, Juspodium, 2006, p. 124.

${ }^{189}$ Humberto HeOdORO JR., Comentários ao Novo Código Civil, v. 3, tomo 2, Rio de Janeiro, Forense, 2005, p. 122 .

${ }_{190}^{19}$ Sergio Cavalieri Filho, Programa de Responsabilidade Civil, São Paulo, Atlas, 2009, p. 153.

${ }^{191}$ Está escrito: "Também comete ato ilícito...".

${ }^{192}$ Programa de Responsabilidade Civil, São Paulo, Atlas, 2009, p. 153.

193 São suas palavras: "Outra diferença entre o ato ilícito previsto no artigo 186 e o do artigo 187 é que apenas o primeiro faz alusão ao dano. Isso importa dizer que a ilicitude configuradora do abuso do direito pode ocorrer sem que o comportamento do agente cause dano a outrem." In: Programa de Responsabilidade Civil, São Paulo, Atlas, 2009, p. 153.

${ }^{194}$ Comentários ao Novo Código Civil, v. 3, tomo 2, Rio de Janeiro, Forense, 2005, p. 118.
} 
natureza de ilicitude do abuso de direito. Esse entendimento, que assim o difere de outros doutrinadores, importa em conseqüências insignes para a concepção do instituto, como a circunstância de serem indispensáveis à sua configuração a geração de dano ${ }^{195}$ e a presença de dolo ou culpa do agente ${ }^{196}$, como insculpido pelo art. 186 do Código Civil. Como dito, essas exigências não encontram eco em grande parte da doutrina e o debate sobre o tema é particularmente caro à prática de abuso em caso de exercício de direito de voto em assembleias - o que será oportunamente discutido.

Sendo indiscutível a natureza ilícita do abuso de direito, parece-nos - em que pese a respeitável opinião de Humberto THEODORO JR. - que tanto a interpretação gramatical, quanto a sistemática esteiam o entendimento de Sergio CAVALIERI FILHO. Note-se que ambos os institutos encontram-se disciplinados sob mesmo Título III, do Livro III da Parte Geral, denominado "Dos Atos Ilícitos”. Assim, resta claro que o Código Civil concebe os "atos ilícitos" (que dão nome ao Título) como gênero, de que são espécies o ato ilícito stricto sensu (chamado também "não-abusivo", de que trata o art. 186) e o abuso de direito (art. 187).

Não fosse assim, razão não haveria para que o abuso fosse prescrito em dispositivo próprio, e não no seio do mesmo artigo 186. Em contrário se poderia alegar que o emprego do advérbio "também" pelo art. 187 denotaria a continuidade normativa do dispositivo anterior - resultante, talvez, de uma opção por artigos mais curtos e a preterição das técnicas de subdivisão de artigos. Todavia, a resposta está no fato de que o advérbio refere-se antes ao gênero, encimado no nomen iuris do Título III, que à espécie, mencionada no art. 186.

A comprovação disso está na redação do art. 927 ( "Aquele que, por ato ilícito (arts. 186 e 187), causar dano a outrem, fica obrigado a repará-lo", localizado no Livro das Obrigações, na Parte Especial do Código), certamente presidida por um propósito didático.

Ao cominar a obrigação de indenizar àquele que causa dano na prática de ato ilícito, o texto legal refere-se evidentemente ao gênero (não à espécie), pois que faz

\footnotetext{
${ }^{195}$ Ele afirma textualmente "Como o abuso de direito é uma modalidade de ato ilícito, é indispensável, para sua configuração, a ocorrência de um dano para o terceiro prejudicado. Sem prejuízo - que pode ser material ou moral - não há o que reparar e conseqüentemente não há ato ilícito em sentido estrito. Pode haver ilicitude, para outros fins, não, porém, para a ocorrência de responsabilidade civil, em função da qual se construiu a figura do ato ilícito stricto sensu." In: Comentários ao Novo Código Civil, v. 3, tomo 2, Rio de Janeiro, Forense, 2005, p. 122.

${ }^{196}$ Humberto THEODORO JR., Comentários ao Novo Código Civil, v. 3, tomo 2, Rio de Janeiro, Forense, 2005, p. 121.
} 
remissão expressa a ambos os artigos (186 e 187, entre parêntesis).

Ademais, o art. 927 do Código Civil expressamente condiciona (condicio iuris) a obrigação de indenizar à ocorrência de dano. Ora, o dano é da essência do ato ilícito não-abusivo (art. 186), de modo que, sem lesão, nem sequer existe ilicitude nesse caso. Não faria sentido a inclusão desse requisito no dispositivo. Destarte, a razão de ser dessa condicio iuris é restringir, no caso do abuso de direito (e não o ato ilícito em sentido estrito), o surgimento do dever de indenizar às hipóteses em que a conduta resulta em dano $^{197}$ - o que implica, a contrario sensu, a possibilidade de existir abuso sem dano, incompatível com tese defendida por Humberto THEODORO JR., de que o abuso seria modalidade do ato ilícito stricto sensu e que, assim, conservaria as características e propriedades deste. A interpretação do art. 927 impõe a conclusão de que uma e outra são institutos distintos, ainda que de um mesmo gênero - $\mathrm{o}$ ato ilícito em sentido amplo.

Sem prejuízo do posterior aprofundamento em todos os desdobramentos em que importa o entendimento defendido pelo mestre mineiro, o fato é que, como ele próprio sublinha, o Código Civil tomou posição clara e enquadrou o abuso de direito entre os atos ilícitos.

Isso implica, em suas palavras, duas conseqüências necessárias: os direitos não são absolutos e a ordem jurídica reprime o exercício destes quando extrapolam os limites impostos por sua relatividade ${ }^{198}$. De outra banda, é igualmente indiscutível que, na hipótese de ocorrência de dano gerado por abuso, o agente estará obrigado a reparar o prejudicado - por decorrência da sistemática do Código Civil (o que já bastaria) e, ainda, da remissão expressa do art. 927.

Essas premissas, com relação às quais é convergente a doutrina, delineiam porção significativa do instituto e de sua disciplina, que serão mais adiante exploradas.

\subsubsection{Abuso de direito como cláusula geral}

O art. 187 do Código Civil contém ainda outras características marcantes que têm levado a doutrina a enquadrar a norma nele contida entre as chamadas "cláusulas

\footnotetext{
${ }^{197}$ A restrição não faz sentido no caso do art. 186, porque o dano é elemento imprescindível à caracterização da ilicitude ali prevsita.

${ }^{198}$ Comentários ao Novo Código Civil, v. 3, tomo 2, Rio de Janeiro, Forense, 2005, p. 120.
} 
gerais"199 - técnica normativa consagrada nas últimas décadas do século passado e que visa, essencialmente, a atribuir mais flexibilidade e permeabilidade ao sistema.

Nessa ordem de idéias, mostra-se oportuna a menção, mesmo que rápida, à "realocação" por que o próprio Código Civil tem passado no sistema jurídico brasileiro.

As concepções doutrinárias mais recentes têm destacado crescentemente a relevância das normas constitucionais na disciplina do direito privado. A jurisprudência do Supremo Tribunal Federal e demais tribunais tem palmilhado o mesmo caminho. Isso decorre não apenas da ampliação da matéria formalmente inclusa na Carta Política - o que se tem verificado ao longo da história constitucional brasileira e comparada -, mas também de uma mudança de enfoque doutrinário que acompanhou esse alargamento ${ }^{200}$.

A Constituição passa, assim, a assumir a função de "eixo central do direito privado", não apenas porque disciplina temas de direito privado e é fonte de validade das normas infraconstitucionais, mas também porque a interpretação destas últimas deve ser feita à luz daquela ${ }^{201}$.

Nada obstante essa perda do protagonismo, o Código Civil mantém relevância pronunciada, ainda assim. Por sua extensão e profundidade, pela acuidade de sua elaboração, pela técnica refinada e por seu caráter unitário e sistemático ${ }^{202}$, ele constitui documento legislativo de substanciosa importância para o sistema como um todo e de capital relevância para os microssistemas que gravitam ao seu redor. Tem-se afirmado, por isso, que ele como que desempenha uma função intermediária entre a Constituição e esses microssistemas ${ }^{203}$.

\footnotetext{
${ }^{199}$ Nelson Nery JR. - Rosa Maria de Andrade Nery, Código Civil Comentado, São Paulo, RT, 2003, p. 138; Keila Pacheco FERreIRA, Abuso do direito nas relações obrigacionais, Belo Horizonte, Del Rey, 2007, pp. 121-138; Alexandre Guerra, Responsabilidade Civil por Abuso do Direito, São Paulo, Saraiva, 2011, pp. 146-156; Daniel M. Boulos, Abuso do Direito no Novo Código Civil, São Paulo, Método, 2006, pp. 150161.

${ }^{200}$ Tratando do fenômeno histórico de contínua inclusão na Constituição de temas atinentes à pessoa humana - que teve lugar especialmente após o final da II Guerra Mundial -, Alexandre GuERRA observa: "Com isso, muitas matérias relativas à pessoa humana ascenderam a nível constitucional, o que fez ser necessária uma ampla reforma da concepção do direito civil como até então compreendido pelos juristas (...). Passamos a entender que a Constituição Federal deve assumir o papel de eixo central do direito privado e, mesmo no contexto da legislação infraconstitucional, desempenha a Carta Política função de maior relevância, servindo como ponte de ligação e ponto de contato entre as diversas leis e microssistemas de normas que regulam a vida em sociedade.” In: Responsabilidade Civil por Abuso do Direito, São Paulo, Saraiva, 2011, p. 132 .

201 Alexandre GueRra, Responsabilidade Civil por Abuso do Direito, São Paulo, Saraiva, 2011, p. 131.

${ }^{202}$ Miguel ReAle, Visão Geral do Código Civil, in: Gisele de Melo Graga Tapai (coord.), Novo Código Civil brasileiro - Estudo Comparativo com o Código Civil de 1916, Constituição Federal, Legislação Codificada e Extravagante, São Paulo, RT, 2003, p. 10.

${ }^{203}$ Alexandre GUERRA, Responsabilidade Civil por Abuso do Direito, São Paulo, Saraiva, 2011, p. 134.
} 
Isso porque a tendência legislativa de criação de microssistemas também verificada nas últimas décadas - não prescinde de normas gerais, que amiúde encontram assento na sistemática dos textos codificados ${ }^{204}$.

Por isso mesmo, o código afasta-se cada vez mais da disciplina de matérias muito específicas e concretas - as quais progressivamente incumbem às leis esparsas e seus microssistemas -, para privilegiar uma disciplina básica, quanto à extensão, e mais abstrata, quanto à concretude, preservando seu caráter unitário e sistemático.

Nesse contexto é que se evidencia o recurso à técnica legislativa das cláusulas gerais, em cuja previsão o Código Civil de 2002, à semelhança do congênere português, foi pródigo ${ }^{205}$. Miguel REALE destaca a opção por essa técnica na elaboração do anteprojeto e esclarece que ela constitui expediente necessário "para [a] contínua atualização dos preceitos legais ${ }^{\text {,206. }}$.

Esse objetivo de perenidade normativa é alcançado pela amplitude semântica ou valorativa das cláusulas gerais, sensivelmente superior à da generalidade das demais normas (de conteúdo muito preciso e fechado ${ }^{207}$ ).

Não se enclausurando em fórmulas rígidas de sentido preciso ${ }^{208}$ (as quais, por isso mesmo, demandam reforma legislativa sempre que seu conteúdo normativo se tornar obsoleto ou descompassado com a realidade social ou axiológica em que se aplicam), as cláusulas gerais são propositadamente imprecisas e abertas. Admitem, por isso, uma variedade imensa de $\operatorname{conteúdos}^{209}$ e, para sua concreção, é indispensável a colheita pelo aplicador de valores na realidade social e nos princípios normativos de relevância hierarquicamente superior ${ }^{210}$.

\footnotetext{
${ }^{204}$ Alexandre GuerRA, Responsabilidade Civil por Abuso do Direito, São Paulo, Saraiva, 2011, p. 134.

205 Sobre essa opção legislativa, pronunciou-se Miguel REALE: "Não menos relevante é a resolução de lançar mão, sempre que necessário, de cláusulas gerais, como acontece nos casos em que se exige probidade,boa-fé ou correção (corretezza) por parte do titular do direito, ou quando é impossível determinar com precisão ao alcance da regra jurídica." Cf. Lições Preliminares de Direito, São Paulo, Saraiva, 1999, p. 45.

${ }^{206}$ Visão Geral do Código Civil, in: Gisele de Melo Graga Tapai (coord.), Novo Código Civil brasileiro Estudo Comparativo com o Código Civil de 1916, Constituição Federal, Legislação Codificada e Extravagante, São Paulo, RT, 2003, p. 13.

${ }^{207}$ Alexandre GUERRA, Responsabilidade Civil por Abuso do Direito, São Paulo, Saraiva, 2011, p. 146.

${ }^{208}$ Padrão de fórmulas que, na descrição de Judith MARTINS-CosTA, é "enucleado na definição, o mais perfeita possível, de certos pressupostos e na correlata indicação à punctual e pormenorizada de suas conseqüências". In: A Boa-Fé no Direito Privado Brasileiro - Sistema e Tópica no Processo Obrigacional, São Paulo, RT, 2000, p. 147.

209 Judith Martins-Costa, A Boa-Fé no Direito Privado Brasileiro - Sistema e Tópica no Processo Obrigacional, São Paulo, RT, 2000, p. 295.

${ }^{210}$ Alexandre GUERRA, Responsabilidade Civil por Abuso do Direito, São Paulo, Saraiva, 2011, p. 151. E afirma Miguel REALE: Como se vê, o que se objetiva é alcançar o Direito em sua concreção, ou seja, em
} 
Essa característica é que atribui perenidade às cláusulas gerais. A evolução social e as alterações axiológicas não requerem modificação de sua estrutura normativa, pois que elas já carregam no próprio seio o vínculo com essa (cambiante) realidade $^{211}$ - na qual, como dito, se buscam os elementos para o preenchimento de seu conteúdo (vago). Por isso, tem-se dito que as cláusulas gerais são porta de ingresso no sistema jurídico de valores que lhe são exteriores ${ }^{212}$.

E dentro exatamente dessa conceituação encontra-se, entre nós, a reprovação ao abuso de direito, veiculada pelo art. 187 do Código Civil. Trata-se inequivocamente de uma cláusula geral, não apenas pela amplitude sem par de sua hipótese de incidência (o direito de que se abusa), mas também pela generalidade de seus requisitos caracterizadores $^{213}$, adiante examinados.

\subsubsection{Os requisitos}

\subsubsection{O "direito" e a conduta comissiva ou omissiva}

Já foi aqui referido o entendimento doutrinário de que o abuso de direito não é, há muito, instituto adstrito ao Direito Civil ou mesmo ao direito privado. Trata-se, assim, de um princípio geral de aplicação alastrada aos mais extremos campos do direito e, também, às mais variadas posições jurídicas. Pois bem: a disciplina do art. 187 do Código Civil foi erigida em perfeita consonância com essa tese.

Significa isso que o dispositivo em referência estriba a natureza ilícita do exercício abusivo de qualquer posição jurídica - e não apenas do direito subjetivo, por exemplo - e em qualquer ramo do direito ${ }^{214}$, e não apenas daquelas situações disciplinadas pelo próprio Código Civil.

Inexiste, pois, situação jurídica que, a priori, escape à incidência da

razão dos elementos de fato e de valor que devem ser sermpre levados em conta na enunciação e na aplicação da norma." Cf. Visão Geral do Código Civil, in: Gisele de Melo Graga Tapai (coord.), Novo Código Civil brasileiro - Estudo Comparativo com o Código Civil de 1916, Constituição Federal, Legislação Codificada e Extravagante, São Paulo, RT, 2003, p. 16.

211 "A partir do momento em que ao juiz é dada a possibilidade de completar o significado da cláusula, esta se mantém incessantemente atualizada, pois os valores, usos e padrões de conduta aplicados para os eu preenchimento deverão estar objetivamente vigentes no sistema social em que se opera." Cf. Keila Pacheco FERREIRA, Abuso do direito nas relações obrigacionais, Belo Horizonte, Del Rey, 2007, p. 129.

${ }_{212}$ Alexandre GuerRA, Responsabilidade Civil por Abuso do Direito, São Paulo, Saraiva, 2011, p. 146.

${ }^{213}$ Miguel ReAle, Visão Geral do Código Civil, in: Gisele de Melo Graga Tapai (coord.), Novo Código Civil brasileiro - Estudo Comparativo com o Código Civil de 1916, Constituição Federal, Legislação Codificada e Extravagante, São Paulo, RT, 2003, p. 13.

${ }^{214}$ Sergio CAVAlieri FilHo, Programa de Responsabilidade Civil, São Paulo, Atlas, 2009, p. 153. 
norma em comento - ou, por outra, não se cogita de posições jurídicas de que se poderia licitamente abusar, subtraindo-se à aplicação da reprimenda veiculada pelo art. 187 do Código Civil.

Essa é a posição tomada por Daniel M. Boulos, para quem o dispositivo “dirige-se aos direitos subjetivos patrimoniais (direitos de crédito e direitos reais), aos denominados direitos-deveres (poderes-deveres) ou poderes-funcionais, às liberdades, aos ônus jurídicos, aos direitos potestativos, aos poderes às expectativas, isto é, diz respeito a qualquer situação ativa, ou permissão genérica de atuação." Idêntico entendimento manifestam Sergio CAVALIERI FILHO ${ }^{215}$ e Alexandre GUERRA ${ }^{216}$.

Nesse mesmo sentido, e atento à interpretação gramatical, anota Sergio CAVAliERi FiLHo que também a expressão titular de um “direito” - genericamente, sem nenhuma restrição explícita - confere ao dispositivo esse caráter imensamente vasto de sua hipótese de incidência ${ }^{217}$.

A própria localização sistemática do dispositivo na Parte $\mathrm{Geral}^{218}-\mathrm{e}$ não, por exemplo, no Livro dedicado ao Direito das Obrigações na Parte Especial -, é demonstração insofismável dessa amplitude ${ }^{219}$, que atinge os demais livros da parte especial $^{220}$ - o que é certo e indisputável - e ainda domínios estranhos ao próprio diploma codificado.

Essa sistemática implica uma generalidade ainda mais acentuada do que aquela empregada pelo congênere português, por exemplo. Embora o dispositivo deste diploma também esteja na Parte $\mathrm{Geral}^{221}$ (tal como no brasileiro), ele localiza-se no título destinado ao "exercício e tutela dos direitos" e não em partição específica para as ilicitudes - "Daí, inclusive, a razão pela qual o artigo 334 diz ser ilegítimo o exercício de forma abusiva e não, propriamente, ilícito. "222 A conceituação genérica do instituto como ato

\footnotetext{
${ }^{215}$ Programa de Responsabilidade Civil, São Paulo, Atlas, 2009, p. 153.

${ }^{216}$ Responsabilidade Civil por Abuso do Direito, São Paulo, Saraiva, 2011, pp. 144-145.

${ }^{217}$ Programa de Responsabilidade Civil, São Paulo, Atlas, 2009, p. 153.

218 Alexandre GuERRA, Responsabilidade Civil por Abuso do Direito, São Paulo, Saraiva, 2011, p. 143. O autor anota: "Assume relevância o fato de a norma que trata do abuso do direito no Código Reale constar na parte geral do diploma legislativo em foco, o que não ocorreu por mera casualidade, mas surtindo efeitos intensos, quer pela abrangência de sua redação, quer por seu âmbito de operação”.

219 Sobre tal posicionamento do dispositivo, comenta Daniel M. Boulos: "E a razão para tanto foi justamente a de possibilidade que os efeitos dela emanados atingissem indistintamente, cada uma das relações jurídicas que foram especialmente disciplinas na Parte Especial do Código." In: Abuso do Direito no Novo Código Civil, São Paulo, Método, 2006, p. 147.

${ }^{220}$ Alexandre GuERrA, Responsabilidade Civil por Abuso do Direito, São Paulo, Saraiva, 2011, p. 143.

${ }^{221}$ O diploma lusitano de 1966 adotou a estrutura germânica, como os brasileiros de 1916 e 2002.

222 Daniel M. Boulos, Abuso do Direito no Novo Código Civil, São Paulo, Método, 2006, p. 159.
} 
ilícito ${ }^{223}$ parece mais adequada à amplitude do suporte fático em que a norma incide.

Nessa ordem de idéias, destaque-se, ainda, e na esteira do observado no item anterior, que o Código Civil de 2002 tratou do abuso de direito entre os atos ilícitos e a estes, como o revogado diploma, dedicou título próprio, em que estabeleceu critérios gerais para sua qualificação. Todavia, inovando em relação à ordem anterior, tratou-os apartadamente da responsabilidade civil ${ }^{224}$ - que, como fonte de obrigação, foi introduzida no livro próprio da parte especial.

Essa opção, melhor que a do legislador de 1916, estrema com suficiente clareza a diferença entre a ilicitude e a responsabilidade civil, que constitui uma possível (ato ilícito indenizativo ${ }^{225}$ ), mas não necessária tampouco exclusiva, eficácia daquela primeira. O tratamento compartimentado e divorciado de atos ilícitos e dever de indenizar é sistematicamente mais favorável, que o outro modelo, ao caráter generalizante do abuso de direito - que, destarte, certamente encontra aplicação, como sobredito, nos mais variados campos do direito e posições jurídicas.

O art. 187 do Código Civil, portanto, estriba a ilicitude de todas condutas que, conquanto atinentes ao exercício dos mais variados direitos, incorram nos quadros abertos e vagos de sua hipótese de incidência - inclusive, como se verá, no exercício do direito de voto em decisões assembleares.

Incluem-se também não apenas as condutas comissivas - certamente as mais frequentes -, mas também as omissivas ("embora seja mais dificilmente configurável"226), contanto que violados qualquer dos parâmetros imperativos estipulados pelo dispositivo em análise.

\subsubsection{Elemento subjetivo e elemento objetivo}

Discute a doutrina se a disciplina do Código Civil de 2002 acerca do abuso de direito filiou-se à teoria subjetivista ou à teoria objetivista. Debate-se, em suma, se o elemento volitivo, mesmo que culposo, integra ou não o suporte fático da norma do

\footnotetext{
${ }^{223}$ Caio Mario da Silva PereIRA, Instituições de Direito Civil, v. 1, Rio de Janeiro, Forense, 2006, p. 675. ${ }^{224}$ Daniel M. Boulos, Abuso do Direito no Novo Código Civil, São Paulo, Método, 2006, p. 160.

${ }^{225}$ Marcos Bernardes de Mello, Teoria do Fato Jurídico - Plano da Existência, São Paulo, Saraiva, 2000, p. 222.

${ }^{226}$ José de Oliveira AsCensão, Direito Civil - Teoria Geral, v. 3, São Paulo, Saraiva, 2010, p. 225. O autor cita o caso do proprietário de imóvel que, surpreendido com fogo em seu prédio, não o apaga, para que se alastre aos terrenos vizinhos.
} 
art. 187.

Entre nós, filiam-se aos subjetivistas Rui STOCCO e Humberto THEODORO JR. Este último, em seus comentários ao Código Civil, após sustentar que a maioria dos estudiosos contemporâneos adota igual posição, afirma que "nosso direito positivo atual não dá ensejo a dúvidas" e teria perfilhado essa corrente doutrinária ${ }^{227}$.

Ele chega a esse entendimento a partir do pressuposto já anteriormente analisado (item 4.2, supra) de que o abuso de direito, previsto pelo art. 187 do Código Civil, é uma modalidade do ato ilícito disciplinado pelo dispositivo antecedente (art. 186) e de que, nessa condição, conserva todas as características e propriedades deste ${ }^{228}$. E conclui, assim, que a configuração do abuso depende do animus nocendi (a intenção de prejudicar) ou, ao menos, de culpa em sentido amplo ${ }^{229}$, que é requisito indispensável à hipótese do art. 186.

Acrescente-se o argumento de que, em matéria de responsabilidade civil, as hipóteses que prescindem de culpa são aquelas da parte final do parágrafo único do art. 927 do Código Civil ou, ainda, nos termos desse mesmo dispositivo, "nos casos especificados por lei”. Essa previsão expressa não constaria da letra do art. 187 e, por isso, o abuso não poderia ensejar responsabilidade objetiva ${ }^{230}$.

Nada obstante o entendimento por ele defendido, Humberto THEODOR JR. avalia que à luz do Código Civil restou de menos importância a disputa entre as duas correntes doutrinárias ${ }^{231}$. Antes do mais, porque, atesta, na prática, seria "rara a hipótese de exercício abusivo de direito sem a intenção do agente de causar o resultado nocivo

\footnotetext{
${ }^{227}$ Além da ocorrência do dano, no entender do autor, como já sublinhado. Cf. Comentários ao Novo Código Civil, v. 3, tomo 2, Rio de Janeiro, Forense, 2005, p. 118.

228 "Nosso direito positivo atual não dá ensejo a dúvidas: adotou claramente a orientação preconizada pela teoria subjetivista do abuso de direito. Primeiro definiu o ato ilícito absoluto, como fato humano integrado pelo elemento subjetivo (culpa) (art. 186). Em seguida, qualificou, de forma expressa, o exercício abusivo como um ato ilícito." In: Comentários ao Novo Código Civil, v. 3, tomo 2, Rio de Janeiro, Forense, 2005, p. 118. Com esse mesmo fundamento, inclusive, ele refuta a tese subjetivista ainda mais restrita de que a configuração do abuso de direito dependeria de dolo ou, no mínimo, de culpa grave, não bastando a culpa leve. $\mathrm{O}$ autor sublinha que a norma do art. 187 apenas qualifica o abuso como ato ilícito e descreve tão somente elementos objetivos (excesso manifesto dos limites do direito). Preleciona, assim: "Ora, se declaradamente o abuso é um ato ilícito e se, em sua descrição legal, não se aponta para um elemento subjetivo especial, este haverá de ser aquele que o próprio Código já definiu para o ato ilícito, em geral, no art. 286." E conclui: “Vale dizer, sendo o abuso de direito uma sorte de ato ilícito, seu elemento subjetivo é a culpa lato sensu (conduta voluntária intencional ou eivada de negligência ou imprudência). Não deve, data vênia, a doutrina acrescer à definição legal requisitos que o legislador podendo adotar, não quis fazê-lo." In: Comentários ao Novo Código Civil, v. 3, tomo 2, Rio de Janeiro, Forense, 2005, p. 127.

${ }^{229}$ Humberto HeOdoro Jr., Comentários ao Novo Código Civil, v. 3, tomo 2, Rio de Janeiro, Forense, 2005, p. 118

${ }^{230}$ Eduardo JORDÃo, Repensando a Teoria do Abuso de Direito, Salvador, Juspodium, 2006, p. 126

${ }^{231}$ Comentários ao Novo Código Civil, v. 3, tomo 2, Rio de Janeiro, Forense, 2005, pp. 119 e 128.
} 
para a vítima”: a conduta (que constitui abuso) é ato voluntário em portanto, intencional, de tal modo que, mesmo que o agente não queira o dano, quer, ao menos, o fato que enseja o dano ${ }^{232}$.

Ademais, completa o sempre mencionado autor, a norma do art. 187 impingiu ao titular de um direito o dever de conservar-se no campo da "normalidade" e, portanto, cominou-lhe uma prestação negativa consistente no dever de não desviar o exercício do direito para "objetivos ilícitos e indesejáveis, dentro do contexto social"233. Assim, se o agente excede a normalidade de seu direito, deixa de ter o cuidado devido que lhe é imposto por lei e incorre, pois, em culpa em sentido estrito, violando a obrigação negativa a que está sujeito.

Em suas palavras, "se o titular de um direito tem o dever de exercitá-lo dentro de certos limites, incorre pelo menos em culpa stricto sensu, quando deixa de adotar a conduta exigível, e, por isso, causa dano a outrem."234 Resume Humberto THEODORO JR. que o abuso de direito resulta sempre de um descompasso entre a atuação do titular do direito e a conduta a que legalmente ele está adstrito e, portanto, nesse caso, "fundando-se em infração a dever de conduta, sempre ocorrerá, na espécie, um evento culposo" ${ }^{, 235}$.

Nada obstante a posição do autor mineiro, a larga maioria dos doutrinadores e comentadores do código entende que o art. 187 do Código Civil contemplou a chamada teoria objetivista ${ }^{236}$.

Esse entendimento decorre da inexistência de expressa previsão pelo art. 187 do Código Civil. Não está apenas aí, no entanto, o elemento decisivo que conduz à

\footnotetext{
${ }^{232}$ São suas as palavras: "Para que se imagine o exercício de qualquer direito, não se pode prescindir da conduta do agente (ato voluntário). Se este pode não estar intencionalmente desejando prejudicar o ofendido, sem dúvida estará necessariamente querendo o fato no qual se traduz o exercício de seu direito e do qual, anomalamente, se origina o resultado danoso. Se não quer, portanto, o dano, quer o fato que o acarreta. Não tem, por isso, maior repercussão prática as divergências entre as correntes subjetivistas $e$ objetivistas, em matéria de responsabilidade civil pelo exercício abusivo de direito." In: Comentários ao Novo Código Civil, v. 3, tomo 2, Rio de Janeiro, Forense, 2005, p. 128, p. 198.

${ }^{233}$ Comentários ao Novo Código Civil, v. 3, tomo 2, Rio de Janeiro, Forense, 2005, p. 113.

${ }^{234}$ Comentários ao Novo Código Civil, v. 3, tomo 2, Rio de Janeiro, Forense, 2005, p. 128.

${ }^{235}$ Comentários ao Novo Código Civil, v. 3, tomo 2, Rio de Janeiro, Forense, 2005, p. 128.

${ }^{236}$ Citam-se Caio Mario da Silva PereIRA (Instituições de Direito Civil, v. 1, Rio de Janeiro, Forense, 2006, p. 675), Silvio de Salvo Venosa (Direito Civil - Parte Geral, São Paulo, Atlas, 2009, p. 510), Sergio CAVAlieri Filho (Programa de Responsabilidade Civil, São Paulo, Atlas, 2009, p. 152), Daniel M. Boulos (Abuso do Direito no Novo Código Civil, São Paulo, Método, 2006, p. 136), Milton Flávio de Almeida Camargo LAUTENSChläGer (Abuso do Direito, São Paulo, Atlas, 2007, p. 82), Eduardo JORDÃo (Repensando a Teoria do Abuso de Direito, Salvador, Juspodium, 2006, p. 126), Alexandre GuERRA (Responsabilidade Civil por Abuso do Direito, São Paulo, Saraiva, 2011, p. 318) e Keila Pacheco FerREIRA (Abuso do direito nas relações obrigacionais, Belo Horizonte, Del Rey, 2007, p. 144)
} 
preponderância da teoria objetivista. O próprio Humberto THEODORO JR. não discorda da inexigência pelo citado dispositivo dos elementos subjetivos. Ao contrário, ele a sublinha ${ }^{237}$. Todavia, como visto, o autor mineiro entende que o abuso seria modalidade do ato ilícito disciplinado pelo art. 186 e, portanto, reteria seus pressupostos e requisitos, entre os quais a culpa ou o dolo.

Essa opinião, contudo, é isolada. Os artigos 186 e 187 do Código Civil prevêem, como visto, duas espécies do gênero "ato ilícito". São dispositivos flagrantemente diversos ${ }^{238}$ e que não guardam relação de dependência entre si, senão, e tão-somente, de identidade de gênero. Um e outro constituem ilicitude, mas cada qual tem os próprios requisitos - que não se confundem nem se comunicam. As razões exegéticas que fundamentam essa conclusão já foram anteriormente declinadas (item 4.2, supra). Destaque-se, em acréscimo, que tal entendimento está em plena consonância com a posição já consolidada à luz do revogado Código Civil de 1916 (item 4, supra)

Importa, portanto, aqui, apenas sublinhar novamente a existência de duas espécies do mesmo gênero (ilicitude) e, destarte, destacar a distinção ontológica entre ilícito abusivo (art. 187) e o ilícito não abusivo (art. 186). Como categoria própria, este último exige imprescindivelmente para sua configuração o elemento subjetivo e a ocorrência de dano - requisitos estes que, diz a doutrina majoritária, não estão presentes no caso do abuso (art. 187).

Sergio CAVALIERI FILHO advoga que o Código Civil adotou a doutrina de SAILELLES e afirma categoricamente que a concepção do dispositivo é objetiva e, assim, "não é necessária a consciência de se excederem, com o seu exercício, os limites impostos pela boa-fé, pelos bons costumes ou pelo fim social ou econômico do direito",239.

Essa posição doutrinária está tão consolida que até os combatentes parecem dela aproximar-se intimamente. Curioso é especialmente o que ensina Humberto THEODORO JR.

Embora defenda fortemente a necessidade do elemento subjetivo, aduz uma consideração que o avizinha muito da corrente objetivista. Ao tratar especificamente de abuso de direito por violação da boa-fé, Humberto THEODORO JR. sustenta que o discriminem entre a conduta consoante esse ditame e aquela contrária a ele está no

${ }^{237}$ Comentários ao Novo Código Civil, v. 3, tomo 2, Rio de Janeiro, Forense, 2005, p. 127.

${ }^{238}$ Eduardo JORDÃo, Repensando a Teoria do Abuso de Direito, Salvador, Juspodium, 2006, p. 126

${ }^{239}$ Programa de Responsabilidade Civil, São Paulo, Atlas, 2009, p. 152. 
atendimento ou não a um padrão social de comportamento (objetivo, é de se concluir), e não à intenção do agente (que é subjetiva, por definição).

Com efeito, ele observa tratar-se esta da boa-fé objetiva (e não da subjetiva), isto é, o modelo de conduta social, o "standard jurídico", o "padrão objetivo de conduta, fundado na lealdade e transparência"240. Os contornos desse padrão, prossegue ele, devem ser perscrutados no "meio social em que o titular do direito atua", para, assim, identificar-se o comportamento ético e o não-ético e, então, constatar-se o atendimento ou não à boa-fé.

Nessa ordem de idéias, conclui o mesmo autor que "é, pois, no sentido ético, e não no psicológico (íntimo), que se avalia o comportamento para fins de aferir a prática do exercício abusivo de um direito subjetivo." E ainda: "Não é o estado anímico do agente que importa, mas o rumo dado exteriormente ao seu proceder (...) tem-se de determinar não a figuração que o agente teve de seu comportamento e de seu intento (isto é, se ele agiu 'de boa-fé' ou não), mas o que se tem de indagar é se ele atuou, in concreto, segundo a boa-fé."241 Ele acrescenta que nisto está a diferença entre um conceito "psicológico" e "ético" para a boa-fé e conclui que, para o art. 187 do Código Civil, o importante é este último, e não o primeiro.

Se bem que Humberto THEODORO JR. expressamente rejeite a tese dos objetivistas, as observações e conclusões por ele externadas parecem contrapor-se àquelas anteriormente feitas e acercar-se da escola por ele combatida.

Especificamente sobre a ordem jurídica brasileira, cumpre ainda mencionar a posição adotada a respeito do tema pelo Centro de Estudos Judiciários do Conselho da Justiça Federal em suas Jornadas de Direito Civil, realizadas com o objetivo de fixar entendimentos interpretativos sobre o Código Civil de 2002. O enunciado n. ${ }^{\text {o }} 37$ trata do abuso de direito e prevê: "A responsabilidade civil decorrente do abuso de direito independe de culpa, e fundamenta-se somente no critério objetivo-finalístico.” Mesmo se restringido à responsabilidade civil (que, conforme se verá adiante, é um efeito possível, mas não o único emanado dessa ilicitude), o enunciado é claro sobre a desnecessidade de elemento subjetivo para a caracterização da figura.

Por fim, e ainda sobre esse ponto, cabe uma afirmação adicional, que é evidente, mas que, de qualquer sorte, não parece ociosa. E, ainda, pode evitar uma errônea

\footnotetext{
${ }^{240}$ Comentários ao Novo Código Civil, v. 3, tomo 2, Rio de Janeiro, Forense, 2005, p. 124.

${ }^{241}$ Comentários ao Novo Código Civil, v. 3, tomo 2, Rio de Janeiro, Forense, 2005, pp. 124-125.
} 
conclusão a que uma interpretação muito rasa da opção legislativa (pela teoria objetivista) poderia conduzir.

A exclusão (ou melhor, a não inclusão) do elemento volitivo como requisito à configuração do ilícito abusivo no Código Civil não significa que o comportamento meramente emulativo não é abusivo e, portanto, estaria legitimado. Nada mais absurdo ${ }^{242}$.

A doutrina reconhece majoritariamente que a teoria objetivista representou historicamente uma evolução da subjetivista, primeva. E ela apenas teve lugar a partir da progressiva consolidação do instituto do abuso de direito na jurisprudência, na doutrina e nos ordenamentos jurídicos. Já por aí se vislumbra a altíssima improbabilidade de acerto da afirmação. A razão de ordem técnica da falsidade desse entendimento, contudo, está no fato de que o comportamento emunlativo - independente da má intenção do agente - não realiza objetivamente o interesse do titular do "direito" invocado, mas, antes, apenas nega os interesses alheios ${ }^{243}$. Isso implica a inegável violação dos imperativos de observância da boa-fée ${ }^{244} \mathrm{ou}$, em último caso, do próprio fím econômico da posição jurídica de que o agente é titular.

Portanto, a adoção da teoria objetivida não reduz o campo social (de realizações efetivas) de aplicação do instituto do abuso de direito (não minora o âmbito material de subsunção da norma veiculada pelo art. 187 do Código Civil, no caso brasileiro), mas, antes, amplia-o para atingir até mesmo aqueles comportamentos que, embora desnudados de má intenção ou culpa, violam os standards de regular exercício ${ }^{245}$.

\footnotetext{
${ }^{242}$ José de Oliveira ASCENSÃO, comentando o art. $334^{\circ}$ do Código Civil português (muitíssimo semelhante ao disposto no art. 187 do congênere brasileiro) ao tratar do ato emulativo e chicaneiro e sublinhar a necessidade de que ele seja "condenado", conclui o tópico com a seguinte observação: "O que impressiona é justamente que os desvio da função pessoal, que representam a origem do abuso do direito (na modalidade dos ato emulativos), não estão afinal, pelo menos à primeira vista, cobertos pela previsão do abuso do direito no art. 334!" Entretanto, ele, a seguir, diz: “Mas os atos chicaneiros e os atos emulativos não podem deixar de ser condenados. Vemos depois se temos de recorrer a outros princípios gerais da ordem jurídica, ou se é possível a aplicação direta do art. 334." (cf. Direito Civil - Teoria Geral, v. 3, São Paulo, Saraiva, 2010, p. 220.) E, páginas adiante, ao tratar da boa-fé, conclui seu raciocínio: "E no que respeita aos atos chicaneiros $e$ emulativos? A boa-fé ultrapassa muito o âmbito destes atos. Mas também os pode abranger; o ato emulativo tal como o chicaneiro é um ato desconforme à boa-fé, como padrão de correção na vida de relação." E mais: “A nossa conclusão é assim diferenciadora. O limite da boa-fé abrange certos tipos de atuações disfuncionais, consistente nomeadamente nos atos emulativos e chicaneiros.” (p. 224)

${ }^{243} \mathrm{O}$ que, obviamente, não pode ser considerado um interesse legítimo. Cf. Jorge Manuel CouTINHO DE ABreu, Do Abuso de Direito - Ensaio de um Critério em Direito Civil e nas Deliberações Sociais, Coimbra, Almedina, 2006, p. 44.

${ }^{244}$ Eis exatamente o mesmo entendimento a que chegou José Oliveira ASCENSÃO, no direito português, conforme observado há poucas notas de rodapé.

${ }^{245}$ Tanto é assim que o exercício do direito que não resulte em vantagem objetiva para seu titular e acarrete apenas prejuízo para terceiros é abusivo, mesmo que desprovido de dolo ou culpa. Cf. Jorge Manuel
} 


\subsubsection{A prescindibilidade do dano}

Intimamente ligada, por seus fundamentos interpretativos, ao ponto anterior está a prescindibilidade da ocorrência de dano para a configuração do abuso de direito $^{246}$.

As razões de ordem exegética, com efeito, são exatamente as mesmas ali expostas: o comando do art. 187 do Código Civil é independente do dispositivo antecedente (um e outro são espécies autônomas de um mesmo gênero) e, ao contrário deste, não prevê, como requisito, o resultado danoso ${ }^{247}$.

Dano, segundo o entendimento corrente, é a subtração ou diminuição de um bem jurídico ${ }^{248}$, quer se trate de bem de natureza patrimonial ${ }^{249}$, quer se trate - com a inclusão historicamente recente do chamado "dano moral" - de bem integrante da própria personalidade da vítima ${ }^{250}$, como o são a honra, a imagem, a liberdade etc.

Embora seja o dano elemento constitutivo do ilícito não-abusivo, não é o único e, portanto, sua ocorrência por si só não implica necessariamente a ilicitude da conduta que o causou. As posições jurídicas ativas acarretam a subordinação (jurídica) do interesse daquele que ocupa a respectiva posição passiva e seu exercício pode resultar em diminuição de um bem jurídico deste último sujeito.

É o exemplo recorrente do empresário que, estribado no princípio constitucional da livre iniciativa, começa uma empresa (atividade) em um mercado que não se encontra em crescimento: possivelmente seus concorrentes experimentaram diminuição de seu giro e, conseguintemente, do lucro. Como esse, há ainda o caso da execução de uma cambiária contra o devedor inadimplente, o protesto do título, entre

Coutinho de Abreu, Do Abuso de Direito - Ensaio de um Critério em Direito Civil e nas Deliberações Sociais, Coimbra, Almedina, 2006, pp. 44-45.

${ }_{246}$ No direito português dá-se o mesmo (a possibilidade de não ocorrer dano), embora naquele ordenamento jurídico o abuso de direito constitua "ilegitimidade", mas não necessariamente ilicitude. Cf. José de Oliveira ASCEnSÃo, Direito Civil - Teoria Geral, v. 3, São Paulo, Saraiva, 2010, p. 228.

${ }^{247}$ Sergio CaVAlieri Filho, Programa de Responsabilidade Civil, São Paulo, Atlas, 2009, p. 11: "Isso importa dizer que a ilicitude configuradora do abuso do direito pode ocorrer sem que o comportamento do agente cause dano a outrem.",

${ }_{248}^{4}$ Sergio CAVAliERI FILHO, Programa de Responsabilidade Civil, São Paulo, Atlas, 2009, p. 71.

${ }^{249}$ Nesse caso, trata-se de bem integrante do patrimônio da vítima e, portanto, é dotado de valor econômico e pode conseguintemente ser expresso em dinheiro.

${ }^{250}$ Um e outro integram a chamada esfera jurídica do sujeito, a qual é o complexo de relações jurídicas de que ele é titular (cf. Carlos Alberto da Mota PINTO, Teoria Geral do Direito Privado, Coimbra, Coimbra, 1991, p. 344). Parcela dessa esfera é chamada patrimônio e correspondente ao complexo de relações jurídicas (cf. José Manuel CARvalho SAntos, Código Civil Brasileiro Interpretado, v. 2, p. 59) dotadas de valor econômico e conseqüente expressão pecunniária. 
incontáveis outros. Nessas hipóteses, não existe contrariedade ao Direito, muito embora suceda, como visto, a diminuição do bem jurídico de titularidade do sujeito passivo.

Isso ocorre, como bem explica Caio Mario da Silva PEREIRA, "porque o dano pode ser o resultado inevitável do exercício do direito, a tal ponto que este se esvaziaria de conteúdo se a sua utilização tivesse de fazer-se dentro do critério da inocuidade"251. Trata-se precisamente de hipóteses de "exercício regular de um direito reconhecido" (CC: art. 188, I). Na inocorrência de abuso na conduta (art. 187) e também de culpa (art. 186), a decorrência do dano é lícita.

De toda sorte, e para o que importa ao presente item, se o dano, "ainda que exclusivamente moral", é requisito necessário à configuração do ilícito não-abusivo, não o é ao abuso de direito ${ }^{252}$. Trata-se de diferença marcante entre as duas espécies de ilicitude previstas pelo Título III do derradeiro livro da Parte Geral.

A doutrina é bastante convergente a esse respeito. No entanto, novamente diverge dela a voz de Humberto THEODORO JR., conforme anteriormente já referido. Segundo seu entendimento, sendo a figura disciplinada pelo art. 187 tão-somente uma modalidade da figura prevista pelo art. 186, conserva os requisitos desta e, por conseguinte, também a necessidade de ocorrência do dano: "sem o prejuízo - que pode ser material ou moral - não há o que reparar e, conseqüentemente, não há ato ilícito em sentido estrito. $" 253$

Todavia, a esse respeito, o vigente Código Civil adota a uma sistemática diversa daquela consagrada pelo diploma anterior. Enquanto este tratava do ilícito e do dever de indenizar reunidos em um único dispositivo (CC/16: art. 159, na Parte Geral), aquele disciplina divorciadamente o ato ilícito (que é objeto dos arts. 186 e 187 da Parte Geral) e a responsabilidade civil (de que cuidam os arts. 927 e ss., situados no livro de Direito das Obrigações).

Na sistemática atual, a ocorrência do dano é requisito para o surgimento do dever de prestar indenização (responsabilidade civil aquiliana: art. 927) e não para a configuração do ato ilícito abusivo (art. 187). É bem verdade que o mesmo não se dá quanto ao ilícito não-abusivo, como visto; mas, nesse caso, o dano é de sua natureza e, portanto, a inexistência da lesão implica também a inexistência do próprio ilícito - razão

\footnotetext{
${ }^{251}$ Instituições de Direito Civil, v. 1, Rio de Janeiro, Forense, 2006, p. 673.

${ }^{252}$ Sergio CaVAlieri Filho, Programa de Responsabilidade Civil, São Paulo, Atlas, 2009, p. 11.

${ }^{253}$ Comentários ao Novo Código Civil, v. 3, tomo 2, Rio de Janeiro, Forense, 2005, p. 122.
} 
por que nem sequer se pode cogitar de dever de indenizar.

Nessa ordem de idéias, a afirmação supra transcrita de Humberto THEODORO JR. parece inaplicável ao abuso de direito, conquanto verdadeira para o ilícito não-abusivo.

O curioso é que o próprio autor parece admitir isso, nada obstante sua posição inicialmente explicitada. Com efeito, após afirmar a imprescindibilidade do dano, ele assevera que "Pode haver ilicitude [sem dano], para outros fins, não porém, para a ocorrência de responsabilidade civil ${ }^{, 254}$. Ora, nesse ponto está justamente a convergência da doutrina.

Quando não sucede o dano, a conduta abusiva, embora ilícita, não enseja naturalmente o dever de indenizar - pela razão evidente de que não há o que repor. Nesse caso, não exsurge da conduta ilícita, portanto, a responsabilidade civil. Nem por isso, contudo, deixa de ser ilícita ou deixa de ser sancionada. A reparação é uma, e típica ${ }^{255}$, mas não a única, conseqüência possível ${ }^{256}$.

As sanções aos ilícitos abusivos são, com efeito, numerosas e variadas ${ }^{257}$. Integram o arcabouço repressor dos atos contrários ao direito e, tecnicamente, não são disciplinados em único dispositivo, mas, antes, encontram-se polvilhados por todo o sistema jurídico. Não perfazem, por isso, uma lista fechada ${ }^{258}$ e sua aplicação é causística. Exemplificativamente, a doutrina cita a cessação da prática, a perda de proteção legal ao ato $^{259}$, as invalidades ${ }^{260}$ (a anulabilidade ${ }^{261}$ ou a nulidade ${ }^{262}$ ), o desfazimento (a reposição

\footnotetext{
${ }^{254}$ Comentários ao Novo Código Civil, v. 3, tomo 2, Rio de Janeiro, Forense, 2005, p. 122.

${ }^{255}$ Está prevista pelo art. 927 do Código Civil. Cf. Daniel M. Boulos, Abuso do Direito no Novo Código Civil, São Paulo, Método, 2006, p. 193: "Analisando-se o Código Civil, infere-se que, tipicamente (ou seja, fazendo-se menção expressa ao artigo 187), pode ser mencionado [como conseqüência do abuso de direito], tão-somente, o artigo 927 do Código Civil..."

${ }_{256}^{25}$ Eduardo JoRDÃO, Repensando a Teoria do Abuso de Direito, Salvador, Juspodium, 2006, p. 125.

257 "É tão grande a extensão da previsão [dos efeitos concretos que resultam do exercício abusivo de direitos] que os efeitos são os mais variados. (...) Por isso dificilmente se consegue chegar a algo de unitário." In: José de Oliveira Ascensão, Direito Civil - Teoria Geral, v. 3, São Paulo, Saraiva, 2010, p. 227.

${ }^{258}$ José de Oliveira AsCensão, Direito Civil - Teoria Geral, v. 3, São Paulo, Saraiva, 2010, p. 227. Daniel M. Boulos relata um julgado do Supremo Tribunal de Justiça de Portugal, a respeito do art. 334 do Código Civil luso, em que se assenta que o dispositivo legal "não determina a conseqüencia do ato abusivo, limitando-se a estatuir a 'ilegitimidade', deixando para o juiz a tarefa de definir, em cada caso, a solução mais adequada." In: Abuso do Direito no Novo Código Civil, São Paulo, Método, 2006, p. 194, n. 123.

${ }^{259}$ José de Oliveira AsCENSÃo fala em "exceção de não cumprimento". In: Direito Civil - Teoria Geral, v. 3, São Paulo, Saraiva, 2010, p. 228.

${ }^{260}$ Humberto HEOdoro JR., Comentários ao Novo Código Civil, v. 3, tomo 2, Rio de Janeiro, Forense, 2005, p. 129. Observa o mesmo autor que essa hipótese é freqüente no direito processual, mesmo sem provocar o dever de indenizar (o que, portanto, contradiz o próprio entendimento defendido pelo autor).

${ }^{261}$ Alexandre Guerra, Responsabilidade Civil por Abuso do Direito, São Paulo, Saraiva, 2011, p. 286; Daniel M. Boulos, Abuso do Direito no Novo Código Civil, São Paulo, Método, 2006, p. 199.
} 
das partes ao estado anterior) independente de indenização ${ }^{263}$, a perda de direito $^{264}$. São sanções que, diz a doutrina, dependem da forma de que se reveste o ato abusivo no caso concreto $^{265}$ - as quais, inclusive, podem cumular-se entre si ou mesmo com o dever de indenizar, conforme haja ou não dano.

De qualquer modo, a natureza de uma categoria jurídica não é decorre de seus efeitos, mas dos elementos constitutivos de seu tipo (restrito ou aberto, como no caso). E é certo, como atesta a doutrina majoritária, que o resultado danoso da conduta não integra o suporte fático do ilícito abusivo.

\subsubsection{Do excesso manifesto}

A conduta abusiva pressupõe a existência de um "direito" - ou, mais precisamente, de uma posição jurídica subjetiva ativa, simples ou complexa, “funcionalizada" ou não. Tal conduta é ilícita, mas quem a pratica "invoca” em seu favor, e para praticá-la, essa posição jurídica de que é titular formal ou aparentemente ${ }^{266}$.

A ilicitude, portanto, não está no exercício dessa posição jurídica, de que o agente é titular, mas na circunstância de exceder "manifestamente" os limites desse direito - esta é a dicção legal.

Mais adiante se delineará o campo que, uma vez "manifestamente" excedido, acarreta a ilicitude da conduta. Trata-se de precisar os sentidos dos termos e expressões basilares do dispositivo do art. 187 do Código Civil ("fim econômico ou social", "boa-fé" e "bons costume”). Antes, contudo, é preciso pôr em relevo o excesso manifesto de que trata o Código Civil. Essa expressão não se encontra empregada gratuitamente ${ }^{267}$.

Exceder é ultrapassar, ir além, extrapolar, transpor, estender-se, alongar-

\footnotetext{
${ }^{262}$ Eduardo JORDÃo, Repensando a Teoria do Abuso de Direito, Salvador, Juspodium, 2006, p. 123; Jorge Manuel Coutinho De ABReu, Do Abuso de Direito - Ensaio de um Critério em Direito Civil e nas Deliberações Sociais, Coimbra, Almedina, 2006, p. 77; Daniel M. Boulos, Abuso do Direito no Novo Código Civil, São Paulo, Método, 2006, p. 198.

${ }^{263}$ Jorge Manuel Coutinho DE ABREu, Do Abuso de Direito - Ensaio de um Critério em Direito Civil e nas Deliberações Sociais, Coimbra, Almedina, 2006, p. 77; Daniel M. Boulos, Abuso do Direito no Novo Código Civil, São Paulo, Método, 2006, p. 197; Sergio CAVALIERI FILHO, Programa de Responsabilidade Civil, São Paulo, Atlas, 2009, p. 153.

${ }^{264}$ Eduardo JORDÃo, Repensando a Teoria do Abuso de Direito, Salvador, Juspodium, 2006, p. 123.

${ }^{265}$ Daniel M. Boulos, Abuso do Direito no Novo Código Civil, São Paulo, Método, 2006, p. 201.

${ }^{266}$ Daniel M. Boulos, Abuso do Direito no Novo Código Civil, São Paulo, Método, 2006, p. 162.

${ }^{267}$ Daniel M. Boulos, Abuso do Direito no Novo Código Civil, São Paulo, Método, 2006, p. 163.
} 
se, passar além de ${ }^{268}$. Ora, quem excede os limites basilares fixados pelo art. 187 do Código Civil (boa-fé, bons costumes, fim econômico e social) já se encontra nos domínios da ilicitude e não se estriba, já então, em direito. Sua conduta é ilícita: "no ato abusivo, não há qualquer direito sendo exercido" ${ }^{269}$. O emprego do verbo no artigo de lei ${ }^{270}$, portanto, é suficiente para a caracterização da antijuridicidade.

Contudo, optou-se na redação legislativa por agregar a ele um advérbio de modo, manifestamente - que equivale a claramente, notoriamente, patentemente, flagrantemente, inegavelmente, declaradamente, evidentemente etc. Denota, pois, segundo interpretação gramatical, uma maneira de exceder que torna esse excesso inequívoco, indiscutível, indisputável.

Ao debruçar-se sobre o termo, e estribado no princípio hermenêutico da inexistência de termos inúteis nos textos legais, sustenta Daniel M. Boulos que seu emprego tem dois efeitos normativos: evitar "interpretações meramente subjetivas" e constituir-se em "válvula de segurança", na separação entre o exercício lícito e o exercício ilícito. Por se tratar, explica ele, de intervenção do Estado na autonomia privada, a imposição dos limites veiculados pelo art. 187 do Código Civil não pode prestar-se à violação desse campo de liberdade, que segue sendo a regra e "deve preponderar na sociedade de qualquer país civilizado"271. Ao mesmo entendimento adere Alexandre GUERRA, que acrescenta que a conduta apenas atingirá a ilicitude se o excesso "se revestir de intensidade tal que torne inequívoca sua existência” ${ }^{\text {272 }}$.

De nossa parte, entendemos que o advérbio parece ter uma função hermenêutica, dirigida aos intérpretes do texto legal, para guiá-los na concreção dos termos abertos e vagos que se lhe seguem.

Não parece certo, com efeito, que sua inclusão encurte o âmbito de aplicação do dispositivo (se considerado hipoteticamente sem o advérbio), a significar $a$ contrario sensu que o excesso não clamoroso isentaria de ilegalidade a conduta. Está, como dito, no excesso, e não seu modo, a ilicitude do agir - mesmo porque os limites impostos pelo art. 187 do Código Civil decorrem, na verdade, do sistema e já assim se encontravam no ordenamento jurídico brasileiro antes mesmo da entrada em vigor do

${ }^{268}$ Caldas Aulete, Dicionário Contemporâneo da Língua Portuguesa, v. 2, Rio de Janeiro, Delta, 1985, p. 1496.

${ }^{269}$ Eduardo JORDÃo, Repensando a Teoria do Abuso de Direito, Salvador, Juspodium, 2006, p. 116.

${ }^{270}$ Exceder na terceira pessoa do singular do presente do indicado: "excede".

${ }^{271}$ Daniel M. Boulos, Abuso do Direito no Novo Código Civil, São Paulo, Método, 2006, p. 165.

${ }^{272}$ Responsabilidade Civil por Abuso do Direito, São Paulo, Saraiva, 2011, p. 161. 
vigente diploma.

Nessa ordem de idéias, o efeito do termo na conformação da norma é dirigir a concreção, pelo intérprete, das balizas que limitam o "exercício regular do direito". Seu emprego atribui ênfase ao caráter objetivo desse exercício hermenêutico. A significação dos termos vagos e abertos não deve, com efeito, ser buscada na opinião pessoal do intérprete ou nas circunstâncias pessoais dos sujeitos envolvidos, mas na realidade social e nos princípios normativos de relevância hierarquicamente superior - que são dados objetivos. Delineados no caso, com suficiente clareza, os conceitos a priori acinzentados desses termos vagos, qualquer ultrapassagem a seus limites - vale dizer, qualquer excesso - se evidenciará naturalmente.

Parece acertada, portanto, a afirmação de Daniel M. Bolous de que a inserção do "manifestamente" reflete a preocupação do legislador com as "interpretações meramente subjetivas do juiz ao apreciar o caso concreto" ${ }^{\text {273 }}$. E, em certo sentido, a conseqüência inarredável - também coincidente com o juízo do autor - é a redução da incerteza e da insegurança jurídicas.

De todo modo, parece-nos que a tônica do emprego do advérbio, conquanto gramaticalmente destinado a alterar o sentido do verbo, está menos no "exceder-se" que cos termos que se lhe seguem no texto legal em comento, cujo aclaramento permite delinear-se o "exercício regular de direito" e, portanto, evidenciar a conduta que o excede e constitui, por isso, abuso de direito.

Naturalmente, essa concreção e esse recurso à realidade social são expedientes imprescindíveis à aplicação da norma, pois que veiculadora, por opção legislativa, de uma cláusula geral - como já acima visto. A função normativa do advérbio, assim, é, reitere-se, de ênfase, de destaque. Evidencia o especial valor legislativo atribuído ao correto e objetivo delineamento dos termos vagos e abertos - objeto dos itens subseqüentes deste trabalho.

Conquanto na ordem da dicção legal, a boa-fé não ocupe a primeira posição entre as balizas que delineiam o abuso de direito, seu estudo em antecipação aos demais se justifica pela relevância que apresenta - havendo mesmo quem entenda que, nos sistema jurídicos que não contêm norma legal expressa a respeito do abuso de direito, é o

${ }^{273}$ Abuso do Direito no Novo Código Civil, São Paulo, Método, 2006, p. 164. 
princípio da boa-fé que dá suporte à vedação dessas práticas ${ }^{274}$ e que nele se estribaram as decisões judiciais francesas do século XIX, anteriores ao desenvolvimento da respectiva teoria e, naturalmente, da positivação da norma ${ }^{275}$.

Com efeito, a experiência estrangeira converge com esse entendimento. Em ordenamentos jurídicos não contemplados por norma legal expressa sobre a ilicitude abusiva, a jurisprudência aplica-o com suficiente tranqüilidade e o fundamento teórico é justamente a violação ao princípio da boa-fé.

Na França, por exemplo, a vedação à conduta abusiva é consagrada pela jurisprudência a partir da repressão, no âmbito geral do direito das obrigações, aos comportamentos desleais e a doutrina reconhece o "estreito liame" entre as noções de abuso de direito e boa-fé ${ }^{276}$. Também na Itália, o suporte legal das decisões judiciais repressoras do abuso de direito esteiam-se nos artigos $1.175^{277}$ e $1.375^{278}$ do Code Civile, que, respectivamente, referem-se à observância de "corretezza" no comportamento e à boa-fé ${ }^{279}$.

Assentado nos sempre citados princípios da eticidade, socialidade e operabilidade e no emprego sistemático de cláusulas gerais, a boa-fé foi expressamente reconhecida pelo Código Civil de 2002, entre outros dispositivos, nas disposições gerais sobre os contratos (art. 422 280 ) e, ainda, como elemento de caracterização do abuso de direito (art. 187). De que boa-fé, no entanto, se trata?

\footnotetext{
${ }^{274}$ Eduardo JORDÃo, Repensando a Teoria do Abuso de Direito, Salvador, Juspodium, 2006, p. 104: “Ou seja: à falta da consagração expressa do abuso de direito,este princípio cumpre-lhe o papel, o que demonstra a estreita relação entre ambos."

${ }^{275}$ Eduardo JORDÃO, Repensando a Teoria do Abuso de Direito, Salvador, Juspodium, 2006, p. 104/105: "Em outras palavras: aqueles atos abusivos levados a juízos entre o final do século XIX e início do século $X X$, que deram azo à criação da teoria do abuso de direito não deveriam ser reprimidos porque (i) embora conformes ao direito subjetivo, contrariavam o direito objetivo; nem porque (ii) causaram danos anormais ou violaram o direito de outrem, socialmente mais relevante; nem porque (iii) embora juridicamente lícitos, contrariavam a moral ou a (nova)consciência jurídica coletiva; nem porque (iv) contrariavam (ou descumpriam) a suposta função social inerente aos direitos; nem porque $(v)$ violavam limites internos (e posteriores à criação) do direito subjetivo; nem porque (vi) violavam o valor supostamente imanente a cada um dos direitos. Aqueles atos deveriam ser reprimidos simplesmente porque eram atos ilícitos, já que contrariavam uma específica norma de direito objetivo, o princípio da boa-fé." E mais adiante remata: " $O$ ato abusivo é 'apenas proibido', por não não encontrar guarida no ordenamento jurídico. Tampouco cabe falar em permissão em âmbito jurídico e proibição somente em esfera metajurídica. $O$ ato abusivo é juridicamente defeso, j'que sua realização configura violação de uma norma jurídica, o princípio da boafé." " (p. 108)

${ }^{276}$ Eduardo JORDÃo, Repensando a Teoria do Abuso de Direito, Salvador, Juspodium, 2006, p. 103.

277 “Art. 1175 Comportamento secondo correttezza

Il debitore e il creditore devono comportarsi secondo le regole della correttezza $(1337,1358)$."

278 "Art. 1375 Esecuzione di buona fede

Il contratto deve essere eseguito secondo buona fede (1337,1358,1366, 1460).,

${ }^{279}$ Eduardo JORDÃo, Repensando a Teoria do Abuso de Direito, Salvador, Juspodium, 2006, p. 103.

280 "Art. 422. Os contratantes são obrigados a guardar, assim na conclusão do contrato,c Omo na sua execução, os princípios da probidade e boa-fé.”
} 
A doutrina distingue dois sentidos diferentes para a expressão. No direito brasileiro, fala-se em boa-fé subjetiva e boa-fé objetiva ${ }^{281}$.

No primeiro caso, ela indica um estado de espírito em que o sujeito encontra-se convencido da licitude de certo comportamento ou ignora sua ilicitude. Tratase, como se vê, de uma atitude psicológica: age de boa-fé (subjetiva) quem se conduz imaginando que está se comportamento em conformidade com a licitude.

Esse estado psicológico pode apresentar relevância jurídica e, nesse caso, ou se atribui uma vantagem a quem se comporta de boa-fé ou é aplicada uma sanção àquele que age de má-fé, que é o seu oposto ${ }^{282}$. Casos há, ainda, nos ordenamentos jurídicos, em que mesmo a boa-fé não é premiada, porque o desconhecimento é culposo ${ }^{283}$, vale dizer, o agente devia conhecer o que ignora por negligência, imprudência ou imperícia.

Nessas hipóteses, como observa Jorge Manuel CoutinHo DE ABREU, “a boa-fé insere-se nas normas jurídicas como elemento constitutivo da sua previsão, da hipótese $^{, 284}$. É o caso do possuidor de um título de crédito que, emitido incompleto, haja sido preenchido sem sua ciência (donde a boa-fé) em desconformidade com os ajustes realizados: o descumprimento não lhe poderá ser oposto (CC: art. 891, parágrafo único; LUG: art. 10; Decreto n. ${ }^{\circ}$ 2.044/08: art. $3^{\circ}$; Lei n. ${ }^{\circ}$ 7.357/87: art. 16). Também o devedor de boa-fé, que ignora o trespasse de um estabelecimento empresarial, ainda quando objeto de publicidade e publicação ${ }^{285}$, pagará bem se o fizer o alienante, embora devesse fazê-lo ao adquirente (CC: art. 1.149).

Em todos esses casos fica claro designar-se pelo termo o estado de

\footnotetext{
${ }^{281}$ Essas denominações são criticadas por Jorge Manuel COUTINHO DE ABREU, que prefere boa-fé "estado" ou "situação" e boa-fé "princípio", respectivamente. No caso da chamada boa-fé objetiva, o autor observa que ela é verificada a partir da conduta dos sujeitos e, portanto, no seu entender, "têm de ser tomados em conta elementos subjetivos"; quanto à boa-fé subjetiva. Cf. Do Abuso de Direito - Ensaio de um Critério em Direito Civil e nas Deliberações Sociais, Coimbra, Almedina, 2006, pp. 56/57, n. 110. Para Fernando Augusto CunHA DE SÁ, que também é citado por Jorge Manuel CoutinHo DE ABREU, a terminologia tradicional lusa, que emprega "psicológico" e "ético" para se referir aos sentidos subjetivo e objetivo, respectivamente, não é igualmente adequada. Ele principalmente critica o fato de que o qualificativo "ético"subtrai, ou parece subtrair, o conceito ao campo da juridicidade, para remetê-lo a outro campo normativo distinto. Cf. Abuso de Direito, Lisboa, Ministério das Finanças, 1973, p. 171.

${ }^{282}$ José de Oliveira AsCEnSÃo, Direito Civil - Teoria Geral, v. 3, São Paulo, Saraiva, 2010, p. 147.

${ }^{283}$ José de Oliveira AsCEnSÃo, Direito Civil - Teoria Geral, v. 3, São Paulo, Saraiva, 2010, p. 148.

${ }^{284}$ Do Abuso de Direito - Ensaio de um Critério em Direito Civil e nas Deliberações Sociais, Coimbra, Almedina, 2006, p. 55.

285 "Art. 1.144. O contrato que tenha por objeto a alienação, o usufruto ou arrendamento do estabelecimento, só produzirá efeitos quanto a terceiros depois de averbado à margem da inscrição do empresário, ou da sociedade empresária, no Registro Público de Empresas Mercantis, e de publicado na imprensa oficial."
} 
espírito daquele que desconhece o vício, a ilicitude, e comporta-se convencido de que está agasalhado pela ordem jurídica. Não é nessa acepção, no entanto, que o termo se presta ao delineamento do abuso de direito ${ }^{286} \mathrm{e}$, portanto, não é esse o significado da expressão empregada pelo art. 187 do Código Civil ${ }^{287}$. Nesse caso, designa o texto legal a chamada boa-fé objetiva, que não é estado de espírito, mas princípio de direito.

Como princípio - normativo ou geral de direito ${ }^{288}-$, a boa fé impõe às pessoas que se comportem de maneira honesta, correta, leal, não frustrando a legítima confiança ou expectativa de terceiros ${ }^{289}$. Trata-se, portanto, de um padrão de comportamento (um modelo de conduta, um arquétipo, um standard), cuja observância é obrigatória.

É cogente, porque os princípios são espécie do gênero norma, ao lado das regras - a outra espécie - e são, por isso, dotados de conteúdo deôntico. Mas os princípios singularizam-se por seu elevado grau de generalidade, resultado da vagueza e indeterminação de seu suporte fático e de seu preceito ${ }^{290}$.

Eles têm natureza eminentemente finalística, porquanto fixam um valor $^{291}$ ou fim a ser perseguido por quem a eles se encontra submetido. Sua verificação no ordenamento jurídico e sua vigência independem de menção explícita de um dispositivo normativo, porquanto seu delineamento pode decorrer da relevância que um determinado valor apresenta no conjunto de dispositivos integrantes do sistema ${ }^{292}$.

Assim, observa Eduardo JORDÃO, no caso do princípio da boa-fé, seu acolhimento pelo ordenamento jurídico implica "haurir", no conjunto de seus dispositivos, "a valorização das condutas de boa-fé, em detrimento das condutas opostas" ${ }^{293}$. Em outras palavras, esse princípio encontra-se presente, ainda que implicitamente, se as regras integrantes do ordenamento jurídico, em seu conjunto, favorecem a conduta honesta,

\footnotetext{
${ }^{286}$ Jorge Manuel CoutinHo DE ABREu, Do Abuso de Direito - Ensaio de um Critério em Direito Civil e nas Deliberações Sociais, Coimbra, Almedina, 2006, p. 59; José de Oliveira AsCENSÃO, Direito Civil - Teoria Geral, v. 3, São Paulo, Saraiva, 2010, p. 224.

${ }^{287}$ Daniel M. Boulos, Abuso do Direito no Novo Código Civil, São Paulo, Método, 2006, p. 180; Alexandre Guerra, Responsabilidade Civil por Abuso do Direito, São Paulo, Saraiva, 2011, p. 171.

${ }^{288}$ Jorge Manuel Coutinho DE ABReu, Do Abuso de Direito - Ensaio de um Critério em Direito Civil e nas Deliberações Sociais, Coimbra, Almedina, 2006, p. 55.

289 Jorge Manuel Coutinho DE ABREu, Do Abuso de Direito - Ensaio de um Critério em Direito Civil e nas Deliberações Sociais, Coimbra, Almedina, 2006, p. 55.

${ }^{290}$ Keila Pacheco FERREIRA, Abuso do direito nas relações obrigacionais, Belo Horizonte, Del Rey, 2007, p. 134.

${ }^{291} \mathrm{O}$ valor, em si mesmo, não tem conteúdo deôntico, diferente das normas. Cf. Keila Pacheco FERREIRA, Abuso do direito nas relações obrigacionais, Belo Horizonte, Del Rey, 2007, p. 135.

${ }^{292}$ Eduardo JORDÃO, Repensando a Teoria do Abuso de Direito, Salvador, Juspodium, 2006, p. 105.

${ }^{293}$ Eduardo JORDÃo, Repensando a Teoria do Abuso de Direito, Salvador, Juspodium, 2006, p. 105.
} 
correta, leal e respeitadora das legítimas expectativas de terceiros e, ainda, se tais dispositivos coíbem a prática oposta, vale dizer, desonesta, incorreta, desleal e que frustra a legítima expectativa dos outros.

Dificilmente existirá ordenamento jurídico que não consagre ${ }^{294}$, mesmo que não explicitamente, o princípio da boa-fée ${ }^{295}$. De todo modo, entre nós, a questão apresenta menos relevância prática que teórica, pois que existem diversas e diversificadas (espalhadas) demonstrações explícitas de contemplação desse princípio pelo ordenamento jurídico pátrio $^{296}$. Ainda que mais não fosse, ao menos o art. 187 do Código Civil, que disciplina especificamente de abuso de direito, trata explicitamente boa-fé - aqui tomada, como se disse, em seu sentido objetivo, de princípio.

De qualquer maneira, essa afirmação (de que a boa-fé do art. 187 do Código Civil é a boa-fé objetiva), mesmo que somada à lição de que esta boa-fé consiste na exigência de comportamento honesto, correto, legal, é ainda insuficiente, como observa Jorge Manuel COUTINHO DE ABREU ${ }^{297}$. De fato, isto não basta para atribuir concreção à elevada generalidade dessa cláusula geral.

A doutrina, especialmente baseada na lição de Judith MARTINS-CosTA, imputa três funções a esse princípio ${ }^{298}$ : a hermenêutica-interpretativa (como, aliás, quanto aos contratos, estava já previsto pelo art. 130, n. 1, do revogado Código Comercial de $1850^{299}$ ), a de criação de deveres jurídicos e a de limitação ao exercício de direitos subjetivos $^{300}$ (ou qualquer outra posição jurídica). Esta última interessa particularmente ${ }^{301}$.

\footnotetext{
${ }^{294}$ São palavras de Eduardo JORDÃO: "Não se trata de hipótese teoricamente impossível, mas tampouco se trata de hipótese razoável. Abstraídas as ilações ad absurdum, dissemos e repetimos que nunca houve qualquer ordenamento que não acolhesse o princípio da boa-fé." Cf. Repensando a Teoria do Abuso de Direito, Salvador, Juspodium, 2006, p. 105.

${ }^{295}$ Eduardo JoRDÃo, Repensando a Teoria do Abuso de Direito, Salvador, Juspodium, 2006, p. 105.

296 Eduardo JORDÃo cita numerosos dispositivos, que explícita ou implicitamente veiculam o princípio da boa-fé: além do preâmbulo (em que pese o entendimento de que ele não tem caráter normativo), o art. $3^{\circ}$, inc. I, da Constituição da República e, ainda, no Código Civil, os artigos 110, 112, 129, 138, 147 e 148. Repensando a Teoria do Abuso de Direito, Salvador, Juspodium, 2006, p. 105.

${ }^{297}$ Do Abuso de Direito - Ensaio de um Critério em Direito Civil e nas Deliberações Sociais, Coimbra, Almedina, 2006, p. 59.

${ }^{298}$ Eduardo Luiz BUSSATTA fala em duas funções, no âmbito dos contratos: revelar o efetivo conteúdo da relação obrigacional (como cânone interpretativo e fonte de deveres laterais de conduta não disposto expressamente pelas partes nem previsto explicitamente pela lei) e a função "defensiva", consistente na imposição e limites ao exercício de direitos subjetivos. Apud Alexandre GuERRA, Responsabilidade Civil por Abuso do Direito, São Paulo, Saraiva, 2011, p. 173.

299 "Art. 131 - Sendo necessário interpretar as cláusulas do contrato, a interpretação, além das regras sobreditas, será regulada sobre as seguintes bases: 1 - a inteligência simples e adequada, que for mais conforme à boa fé, e ao verdadeiro espírito e natureza do contrato, deverá sempre prevalecer à rigorosa e restrita significação das palavras; (...)”

300 Judith Martins-Costa, A Boa-Fé no Direito Brasileiro - Sistema e Tópica no Processo Obrigacional, São Paulo, RT, 2000, pp. 427-428.
} 
Como já dito, a conduta abusiva (por exemplo, por exceder manifestamente os limites impostos pela boa-fé) é ilícita, porque não calcada em posição jurídica - direito subjetivo, em regra, embora não apenas. Ainda que formal ou aparentemente invocada, esta posição jurídica não dá suporte à conduta do agente, que, destarte, extrapola seus limites. Tais limites compreendem não apenas o conteúdo da própria posição jurídica, se simples, ou conjunto delas, se complexa (direito subjetivo, por exemplo), mas também pelos ditames que decorrem desse princípio da boa-fé. Dizer-se, pois, que a boa-fé limita o exercício do direito subjetivo, verbi gratia, é afirmar que limita o próprio direito - e nisto consiste a função em destaque do aludido princípio ${ }^{302}$.

Sucede, no entanto, que, por se tratar de uma cláusula geral, como visto, a limitação que a boa-fé impõe não se restringe a um diminuto âmbito de aplicação, mas perpassa todo o conjunto de posições jurídicas admitidas pelo sistema. E seu conteúdo é passível de concreção em cada caso - afirmação que, tão-somente, confirma, como sublinha Jorge Manuel COUTINHO DE ABREU, seu caráter indeterminado, de "norma em branco".

Bem por isso o mesmo autor põe em destaque um conjunto de casos que a doutrina e a jurisprudência consagraram como aplicação da boa-fé objetiva. São, como ele salienta, "hipóteses típicas", "figuras sintomáticas" caracterizadoras do indigitado princípio $^{303}$.

A primeira delas, comumente citada ${ }^{304}$, é a proibição de venire contra factum proprium, que veda, em atenção à boa-fé, uma "pretensão incompatível ou contraditória com a conduta anterior do pretendente" $" 305$. O modo como o agente comporta-

\footnotetext{
${ }^{301}$ Eduardo JoRDÃo, Repensando a Teoria do Abuso de Direito, Salvador, Juspodium, 2006, p. 106, n. 271.

${ }^{302}$ Por isso, parece inadequado falar-se que, no abuso de direito, a conduta inicia-se lícita e, então, torna-se ilícita. Nem lógica, nem temporalmente existe sucessão (causal ou temporal) entre a regra jurídica atributiva do direito (rectius, da posição jurídica) e o princípio que "limita" esse direito (como que retirando parcela da permissão ou do poder anteriormente concedido pelo direito). Um e outro integram a ordem jurídica e conformam (dão forma à) licitude (e, a contrario sensu, da ilicitude) da conduta. É, pois, no sentido de conformação, de dar forma, que se emprega o termo "limitação" como função do princípio da boa-fé. Com apoio em Eros Roberto GRAU, que sustenta ser o intérprete o produtor da norma, observa Eduardo JORDÃO: "Na produção normativa, o intérprete lerá os dispositivos normativos já com as restrições impostas pelos principios e pelas outras regras que depreenderá dos demais dispositivos." E concluí no sentido antes comentado: "É por esta razão que, possuindo o direito subjetivo um conteúdo normativo, dentre os atos por ele protegidos não se incluem aqueles que forem contrários ao princípio da boa-fé." Cf. Repensando a Teoria do Abuso de Direito, Salvador, Juspodium, 2006, p. 107.

${ }^{303}$ Do Abuso de Direito - Ensaio de um Critério em Direito Civil e nas Deliberações Sociais, Coimbra, Almedina, 2006, p. 59.

${ }^{304}$ Alexandre GUERRA, Responsabilidade Civil por Abuso do Direito, São Paulo, Saraiva, 2011, p. 172; Daniel M. Boulos, Abuso do Direito no Novo Código Civil, São Paulo, Método, 2006, p. 182.

${ }^{305}$ Do Abuso de Direito - Ensaio de um Critério em Direito Civil e nas Deliberações Sociais, Coimbra, Almedina, 2006, p. 59.
} 
se, ao exercer regularmente um direito, é juridicamente relevante, porque gera nos demais integrantes da relação jurídica ${ }^{306}$ uma legítima expectativa com relação à conduta dele no futuro.

É legítima essa conjectura formulada pelos demais, porque objetivamente baseada no proceder anterior do agente. É, como dito, o comportamento deste que incute nos demais a suposição de que ele se conduzirá de determinada maneira posteriormente. E porque legítima, essa expectativa é tutelada pelo direito - inclusa que está precisamente pelo princípio da boa-fé, que preceitua a vedação ao comportamento contraditório ou incompatível com a conduta anterior. Em caso de frustração dessa legítima expectativa, o agente viola o princípio da boa-fé e sua conduta qualifica-se por abusiva e, portanto, ilícita.

Já o parcialmente revogado Código Comercial estipulava, quanto à hermenêutica dos contratos, que o "fato dos contraentes posterior" à avença é a "melhor explicação da vontade" das partes ao celebrar o negócio ${ }^{307}$. No caso da boa-fé objetiva, o princípio não se limita a uma diretriz interpretativa, como se viu, mas impõe ao agente um comando para que não se conduza em contradição ou de maneira incompatível com o comportamento por ele próprio preteritamente adotado. Esse comportamento é o "factum proprium" de que trata o adágio latino ${ }^{308}$ e ao qual ele acha-se, por aplicação do princípio da boa-fé, obrigado a não contradizer - sob pena de infringir o comando e, conseguintemente, incorrer em abuso de direito e sujeitar-se aos efeitos dessa ilicitude.

Outra "figura sintomática" do princípio da boa-fé, muito próxima do anterior - ou talvez até mesmo por ela englobada -, porque também embasada na fundada expectativa da contraparte, é aquela que os alemães chamam de Verwirkung ${ }^{309}$. Nesse caso, o titular do direito não o exerce, total ou parcialmente, por muito tempo e infunde nas demais pessoas a legítima expectativa de que não tornaria a exercê-lo, "revelando-se, portanto, um posterior exercício manifestamente desleal e intolerável”310.

O adimplemento substancial é outra hipótese típica de aplicação do

\footnotetext{
${ }^{306}$ Especialmente nas relações jurídicas que se protraem no tempo, de trato sucessivo ou simplesmente com prestações diferidas.

307 “Art. 131 - Sendo necessário interpretar as cláusulas do contrato, a interpretação, além das regras sobreditas, será regulada sobre as seguintes bases: (...) 3 - o fato dos contraentes posterior ao contrato, que tiver relação com o objeto principal, será a melhor explicação da vontade que as partes tiverem no ato da celebração do mesmo contrato; (...)"

${ }^{308}$ Daniel M. Boulos, Abuso do Direito no Novo Código Civil, São Paulo, Método, 2006, p. 183.

${ }^{309}$ Jorge Manuel Coutinho DE ABREu, Do Abuso de Direito - Ensaio de um Critério em Direito Civil e nas Deliberações Sociais, Coimbra, Almedina, 2006, p. 59.

${ }^{310}$ Jorge Manuel Coutinho DE ABReu, Do Abuso de Direito - Ensaio de um Critério em Direito Civil e nas Deliberações Sociais, Coimbra, Almedina, 2006, p. 60.
} 
princípio da boa-fé. Nesse caso, em que pese o dever do sujeito passivo de cumprir exatamente a prestação avençada - em contraposição ao direito do credor de exigi-lo, em princípio, nesses termos ${ }^{311}$-, a boa-fé determina que o sujeito ativo não pode recusar a prestação se esta satisfaz seu interesse, mesmo que não coincida completamente com o ajustado $^{312}$. Entre nós, esse comando tem sido utilizado para evitar a resolução contratual (CC: art. 475), especialmente nos contratos longos de prestações diferidas, quando há descumprimento de apenas parte das obrigações ${ }^{313}$. Nesse caso, o princípio da boa-fé veda o surgimento do poder formativo à resolução contratual ${ }^{314}$.

O mesmo aplica-se, ainda, à argüição da exceção de contrato não cumprido (CC: art. 476), quando a parte em tese inadimplente cumpriu a parcela substancial da prestação, atendendo ao interesse do credor, deixando de adimplir parcela ínfima ou obrigação lateral. Tem lugar aqui a mesma ratio: o comando principiológico da boa-fé veda a invocação dessa exceção, afigurando-se abusiva a conduta diversa do credor, mesmo que formalmente o dispositivo legal aparentemente o $\operatorname{assista}^{315}$.

Cita ainda Jorge Manuel Coutinho DE ABReu, como hipótese típica de aplicação do princípio em referência, a vedação ao "abuso" de argüição de nulidade de negócios jurídicos por vícios de forma ${ }^{316}$. Quem cumpre ou assume o cumprimento de avença que sabe viciada por defeito formal não pode impugnar sua validade com fundamento nesse vício. Também esse parece uma aplicação da proibição de venire contra factum $_{\text {proprium }}^{317}$.

Também a inobservância dos bons costumes torna abusivo o exercício da posição jurídica. A doutrina aponta duas acepções para a expressão, ambas assaz fluidas ${ }^{318}$ : uma de natureza sociológica e outra idealista. No primeiro caso, os limites desse elemento

\footnotetext{
${ }^{311}$ Código Civil: "Art. 313. O credor não é obrigado a receber prestação diversa da que lhe é devida, ainda que mais valiosa."

312 Jorge Manuel Coutinho DE ABREu, Do Abuso de Direito - Ensaio de um Critério em Direito Civil e nas Deliberações Sociais, Coimbra, Almedina, 2006, p. 60.

${ }^{313}$ Judith Martins-Costa, A Boa-Fé no Direito Brasileiro - Sistema e Tópica no Processo Obrigacional, São Paulo, RT, 2000, p. 456; Daniel M. Boulos, Abuso do Direito no Novo Código Civil, São Paulo, Método, 2006, p. 182.

${ }^{314}$ Alexandre GUERRA, Responsabilidade Civil por Abuso do Direito, São Paulo, Saraiva, 2011, p. 174.

315 Jorge Manuel Coutinho DE ABReu, Do Abuso de Direito - Ensaio de um Critério em Direito Civil e nas Deliberações Sociais, Coimbra, Almedina, 2006, p. 60.

${ }^{316}$ Jorge Manuel Coutinho DE ABREu, Do Abuso de Direito - Ensaio de um Critério em Direito Civil e nas Deliberações Sociais, Coimbra, Almedina, 2006, p. 60.

${ }^{317}$ Cf. referência a Wiacker feita por Jorge Manuel CoutinHo DE ABREU. In: Do Abuso de Direito - Ensaio de um Critério em Direito Civil e nas Deliberações Sociais, Coimbra, Almedina, 2006, p. 60, n. 118.

318 Jorge Manuel Coutinho DE ABREu, Do Abuso de Direito - Ensaio de um Critério em Direito Civil e nas Deliberações Sociais, Coimbra, Almedina, 2006, p. 64.
} 
da cláusula geral são marcados pela "opinião social dominante" 319 , enquanto, neste último caso, a delimitação deita raízes em "ditames de ordem filosófica ou religiosa", coincidentes ou não com aquela primeira ${ }^{320}$.

Para fins de singularização do caráter abusivo da conduta, predomina doutrinariamente o primeiro entendimento ${ }^{321}$. Esteja claro, todavia, que, mesmo nesse caso, por bons costumes não são tomados os usos ou as práticas morais efetivamente realizadas - isto é, aquilo que se verifica no comportar-se dos homens (mores) -, mas as convicções morais que a sociedade entende devam ser observadas (bonus mores). É o "dever ser ético-social"322, é a "consciência ética dos cidadãos"323. Os bons costumes, portanto, são delineados pelas convicções morais da sociedade, e não pelas práticas sociais.

Não é demais acrescentar que a moral de que se está tratando não é aquela dita "subjetiva", proveniente do magistrado que eventualmente se depare com a aplicação desse dispositivo, mas, diversamente, é aquela que se colhe objetivamente na sociedade ${ }^{324}$.

Os bons costumes, portanto, são a porta pela qual os preceitos morais que são elementos alienígenas ao sistema, gerados fora deles - ingressam na ordem jurídica $^{325}$ e, por essa intromissão, vedem juridicamente a eles contrária. Não se confundem, como categorias, as regras morais e jurídicas, mas elas, nesse caso, comunicam-se entre si.

Não segue daí, no entanto, que exista uma relação funcional entre uma e outra - a observação é de José de Oliveira AsCEnsão. Assim, conquanto seja ilícita a conduta que infrinja os bons costumes, as posições jurídicas não são atribuídas para que o titular realize os bons costumes. Esses limites, portanto, afirma o mesmo autor, não dizem respeito à função, mas ao modo do exercício dessas posições, donde, completa ele, sua violação não implica comportamentos "disfuncionalizados", mas incorretos - o que, nessa ordem de ideias, denuncia a pouca unidade existente entre os elementos caracterizadores

\footnotetext{
${ }^{319}$ Jorge Manuel CoutinHo DE ABREU, Do Abuso de Direito - Ensaio de um Critério em Direito Civil e nas Deliberações Sociais, Coimbra, Almedina, 2006, p. 63.

${ }^{320}$ Jorge Manuel Coutinho DE ABReu, Do Abuso de Direito - Ensaio de um Critério em Direito Civil e nas Deliberações Sociais, Coimbra, Almedina, 2006, p. 63.

${ }^{321}$ Jorge Manuel Coutinho DE ABREu, Do Abuso de Direito - Ensaio de um Critério em Direito Civil e nas Deliberações Sociais, Coimbra, Almedina, 2006, p. 63.

322 José de Oliveira AsCEnsão, Direito Civil-Teoria Geral, v. 3, São Paulo, Saraiva, 2010, p. 223.

${ }_{223}$ Alexandre GuERrA, Responsabilidade Civil por Abuso do Direito, São Paulo, Saraiva, 2011, p. 181.

${ }^{324}$ Jorge Manuel Coutinho DE ABREu, Do Abuso de Direito - Ensaio de um Critério em Direito Civil e nas Deliberações Sociais, Coimbra, Almedina, 2006, p. 63

${ }^{325}$ José de Oliveira ASCEnSÃo, Direito Civil-Teoria Geral, v. 3, São Paulo, Saraiva, 2010, p. 223.
} 
do abuso de direito.

Como já se disse, e não poderia ser diferente (pois que inserta em uma cláusula geral), a noção de bons costumes é muito fluida, como os demais standards da figura abuso de direito. Mas, quanto a essa característica, a nota que se destaca é que seu grau de indeterminação é ainda mais elevado que aquele observado no caso da boa-fé razão por que, segundo afirma Jorge Manuel COUTINHO DE ABREU, ao contrário do que sucede neste último caso, não existem "figuras sintomáticas" de abuso de direito por violação dos bons costumes ${ }^{326}$.

Muitos autores sustentam como critério fundamental para a caracterização do abuso de direito o atendimento pelo titular da chamada "função social"327. Esse atendimento seria, assim, a diretriz segura para qualificação do exercício da posição jurídica como regular, se presente, ou abusiva, se ausente. Jorge Manuel COUTINHO DE ABREu indaga se a isso se reduziria a fórmula empregada pelo Código Civil português - e reiterada pelo brasileiro, embora com ordem inversa de seus adjetivos - "fim social ou econômico" ${ }^{328}$. E ainda pergunta se a "disjuntiva ou [que igualmente está no texto da lei pátria] quer dizer que o fim social se não confunde com o econômico „329.

Em comentário ao dispositivo brasileiro, Alexandre GUERRA trata-os separadamente. Aduz que por fim econômico entende-se "o proveito material ou a vantagem que o exercício do direito trará para seu titular, ou, ainda, a perda que suportará por não exercê-lo",330. Acrescenta: "No atual sistema, não mais se concebe o exercício de um direito que não vise a satisfazer interesse sério e legítimo" 331 . Com relação ao fim social, afirma tratar-se da aplicação do princípio da socialidade ( "a visão social do direito, como instrumento de construção de uma sociedade justa, livre, igualitária e solidária”) e, citando Santiago DANTAS, preleciona que o direito subjetivo não pode ser exercido contra "a finalidade social que a lei teve em mira, quando o

\footnotetext{
${ }^{326}$ Jorge Manuel COUTINHO DE ABREU afirma que esta ausência de figuras típicas é causa da indeterminação e "inconcreção" elevada da noção de bons costumes; parece-nos, contudo, ser exatamente o oposto. Do Abuso de Direito - Ensaio de um Critério em Direito Civil e nas Deliberações Sociais, Coimbra, Almedina, 2006 , p. 13.

327 Jorge Manuel Coutinho DE ABREu, Do Abuso de Direito - Ensaio de um Critério em Direito Civil e nas Deliberações Sociais, Coimbra, Almedina, 2006, p. 33.

${ }^{328}$ Do Abuso de Direito - Ensaio de um Critério em Direito Civil e nas Deliberações Sociais, Coimbra, Almedina, 2006, p. 67.

329 Do Abuso de Direito - Ensaio de um Critério em Direito Civil e nas Deliberações Sociais, Coimbra, Almedina, 2006, p. 67.

${ }_{330}$ Alexandre GUERRA, Responsabilidade Civil por Abuso do Direito, São Paulo, Saraiva, 2011, p. 182.

${ }^{331}$ Alexandre GuERrA, Responsabilidade Civil por Abuso do Direito, São Paulo, Saraiva, 2011, pp. 182-183.
} 
reconheceu e protegeu, ${ }^{, 332}$.

Ensina José de Oliveira ASCENSÃO que as situações jurídicas são figuras funcionais, porquanto criadas "para o desempenho de objetivos ou funções". E acrescenta que essa destinação funcional constitui mais uma categoria de limites dos "direitos", de tal modo que o exercício destes sem atendimento daquela constitui disfunção, que lhe acarreta a ilegitimidade - que, entre nós, melhor seria traduzida por ilicitude ${ }^{333}$.

\subsection{Efeitos jurídicos da prática de atos abusivos}

A pluralidade e diversidade de efeitos jurídicos do ato abusivo, bem como a possibilidade de sua fixação por ato judicial - e não, ex ante, pela própria norma jurídica -, põe às claras a natureza de "cláusula geral" do dispositivo do art. 187 do Código Civil. Suas características de indeterminação e vagueza não se circunscrevem à hipótese legal de incidência, mas alcançam também o conjunto dos efeitos jurídicos que decorre da realização fática e da respectiva subsunção. Bem por isso a técnica legislativa pátria optou por restringir o dispositivo em comento ao delineamento de sua hipótese e à produção do efeito jurídico mínimo, que é o estabelecimento da relação jurídica de ilicitude entre aquele que pratica o abuso e aquele que o sofre (se exercidos direitos nos termos vagos e indeterminados da hipótese prevista pelo art. 187 do Código Civil, o ato será imputado abusivo e, portanto, ilícito). Os demais efeitos que decorrem dessa situação jurídica não são previstos pela mesma norma, mas por outras normas integrantes do sistema jurídico (por exemplo, a regra do art. 927 do Código Civil, que prevê por efeito do ato abusivo a obrigação de o agente a indenizar os prejuízos por ele causados).

Não há, entretanto, perda de unidade normativa, porque, como salienta Eros Roberto GRAU, quando uma norma tem aplicação no caso concreto não é ela unicamente que se está a aplicar, mas todo o ordenamento jurídico - que é um sistema e não um aglomerado desconexo de individualidades deônticas. Não são raros os casos em que os efeitos jurídicos de um ato encontram-se polvilhados em numerosas e diversificada normas. Veja-se, por ilustração, a relação jurídica de paternidade, cujos efeitos encontramse previstos por dispositivos não apenas dispersos no próprio de Direito da Família, mas também em outros livros do Código Civil (v.g., art. 496 e art. 974) e em outras leis esparsas.

\footnotetext{
332 Alexandre GUERRA, Responsabilidade Civil por Abuso do Direito, São Paulo, Saraiva, 2011, p. 183.

${ }^{333}$ Direito Civil - Teoria Geral, v. 3, São Paulo, Saraiva, 2010, p. 218.
} 
A dificuldade que se apresenta ao tema dos efeitos jurídico do ato abusivo não decorre do tratamento legislativo disperso, mas da não determinação precisa, fechada, específica de todos e cada um desses efeitos. Sua delimitação, em última instância, será pronunciada por ato judicial e essa fixação dependerá de todas as circunstâncias fáticas envolvidas e, especialmente, do regramento jurídico dispensado ao “direito" (ou outra posição jurídica) abusado. Isso porque está inclusa na noção de cláusula geral não apenas os critérios que qualificam o abuso, mas também as consequências.

Basicamente, embora sem limitação - pois não é possível fazer uma lista exaustiva $^{334}$-, são tidas como consequências do ato abusivo sua invalidade, decorrente de seu caráter ilícito; a responsabilidade civil pelos danos causados, conforme previsto pelo art. 927; a reposição das partes ao estado anterior; a recusa a proteção legal do ato abusivo.

${ }^{334}$ Daniel Boulos, Abuso de Direito no Novo Código Civil, p. 194. 


\section{CAPÍTULO TERCEIRO - ABUSO DE VOTO NO DIREITO SOCIETÁRIO}

Conquanto a comunhão de interesses entre os credores no processo concursal não dê causa à geração de uma nova pessoa jurídica, a Lei n. ${ }^{0}$ 11.101/05 concebeu órgãos para terem parte no deslinde do processo (que é judicial, mas também econômico) de composição dos diversos interesses envolvidos. Entre eles, destaca-se, especialmente se comparada a vigente lei ao regime pretérito, a assembleia geral de credores, o locus em que têm assento os titulares dos créditos submetidos ao concurso e no qual tais credores podem exercer o direito político do voto, de que resultam as decisões colegiadas condutoras, em linhas gerais (atual ou potencialmente), dos destinos do processo concursal.

Por sua natureza colegiada, por sua superior posição hierárquica, por sua composição, que tende a ser numerosa ${ }^{335}$ e diversificada, e por suas atribuições, certamente as mais graves, a assembleia geral dos credores é o órgão mais complexo desse arranjo de interesses decorrente do concurso. Nada obstante, e essa observação não é inédita, a disciplina a ela dispensada pela Lei n. ${ }^{0} 11.101 / 05$ é demasiado tímida ${ }^{336}$. Por essa razão, e embora não seja a única possibilidade - nem unânime entre os juristas ${ }^{337}$-, a aplicação de suas normas e o estudo que a tenha por objeto não podem prescindir do recurso ao longevo depósito normativo, jurisprudencial e doutrinário formado a respeito das assembleias societárias, especialmente aquelas que têm lugar no complexo dos tipos de sociedades, as anônimas. Igual percurso palmilha-se quanto a outras assembleias em situação semelhante

\footnotetext{
335 Nada obsta, em tese, a existência do processo de recuperação envolvendo credores pouco numerosos ou até mesmo na ausência de pluralidade deles. Examinada a questão em matéria falimentar, a aplicação do regime concursal foi admitida pela jurisprudência (à luz do direito anterior: TJSP, $3^{\mathrm{a}}$ Câm. Dir. Priv., Ap. Cível 030.264-4/3, Rel. Des. Ênio Santarelli Zuliani, j. 14/4/1997; Ap. Cível 261.205-4/5, Rel. Des. Hamilton Elliot Akel, j. 1\%/4/2003) e pela doutrina (Rubens ReQuĩ̃o, Curso de Direito Falimentar, v. 1, São Paulo, Saraiva, 1998, pp. 41-43; Ecio PERIN JR., Curso de Direito Falimentar e Recuperação de Empresas, São Paulo, Método, 2006, pp. 172-174).

${ }^{336}$ Lamentada por Sheila Christina Neder CEREZETTI, A Recuperação Judicial de Sociedades por Ações - O Princípio da Preservação da Empresa na Lei de Recuperação e Falências, tese de doutorado, Faculdade de Direito da USP, São Paulo, mimeo, 2010, p. 236.

${ }^{337}$ Sheila Christina Neder CEREZETTI, por exemplo, entende que a omissão legislativa deve ser solucionada com o recurso às normas do Código Civil, "subsidiariamente aplicável à lei concursal". In: A Recuperação Judicial de Sociedades por Ações - O Princípio da Preservação da Empresa na Lei de Recuperação e Falências, tese de doutorado, Faculdade de Direito da USP, São Paulo, mimeo, 2010, p. 236.
} 
- de parca regulamentação legal -, como é o caso daquelas de condôminos em condomínios edilícios (CC: arts. 1.347 e 1.349 a 1.356, entre outros) e, mesmo, de debenturistas de companhias (LSA: art. 71, especialmente).

\subsection{A formação da vontade nas sociedades anônimas}

\subsubsection{A teoria orgânica}

Todas as pessoas jurídicas atuam por meio de órgãos ${ }^{338}$. Eles decorrem da divisão de trabalho e são estabelecidos com o objetivo de ordenar, facilitar e melhorar a consecução dos fins do organismo que integram. Constituem, portanto, instrumento para que a pessoa jurídica cumpra sua atividade (finalidade imediata) e persiga seu escopo-fim (finalidade mediata) 339 e 340 . Decorre daí que, quanto mais numerosos, variados, difíceis e complexos forem os fins perseguidos, tanto mais complexo deverá ser o organismo e, geralmente, mais numerosos e emaranhados os órgãos ${ }^{341}$.

Órgão, segundo preleciona Marcelo Vieira von ADAMEK a respeito de entes personificados, é “o centro de imputação de poderes funcionais exercidos, por um ou mais indivíduos que nele estejam investidos, para formar e manifestar a vontade

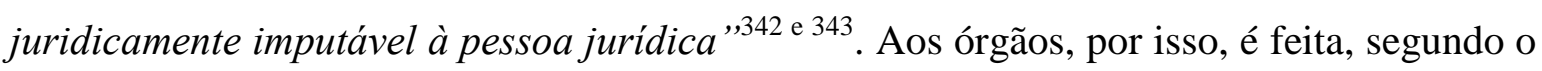

\footnotetext{
338 É a sintética afirmação de Giuseppe ROMANO-PAVONI: "una persona giuridica non può agire che attraverso organi.” In: Le deliberzioni delle assemblee dele società, Milão, Giuffrè, 1951, p. 49. No mesmo sentido: Luis Manuel RoJAS JR., El Derecho de Voto em la Sociedad Anónima, México, Editoral Jus, 1945, p. 37.

${ }^{339}$ Giuseppe Romano-PAVONI, Le deliberzioni delle assemblee dele società, Milão, Giuffrè, 1951, p. 49.

${ }^{340}$ Não é o caso de se estender a respeito do tema no presente trabalho. De todo modo, são oportunas as explicações de Eduardo de Melo Lucas CoElHo, a respeito das pessoas jurídicas, a teoria orgânica e a formação da deliberação social. Embora a criação da personalidade jurídica gere um novo centro de imputação de direitos de deveres, autônomo e apartado de seus associados, tal pessoa não dispõe de um mecanismo bio-psíquico tampouco consciência própria e vontade em sentido psicológico. Assim, em última instância, a técnica jurídica consiste em imputar à pessoa jurídica atos que, em verdade, são de pessoas naturais: "Por isso que a ordem jurídica procede, ai também, à compensação da falta segundo a mesma técnica, imputando ao ente actos volitivos de pessoas físicas tal como se fosse aquele, em lugar destas, o sujeito da vontade." Assim, acrescenta, "não se elimina (...) a incapacidade natural da pessoa colectiva”, mas “cria-se tão-só como que o sucedâneo normativo da respectiva capacidade". "Determinadas pessoas físicas, para o efeito tituladas pelo direito, e dotadas de específicos poderes, de uma competência, entram em cena, querendo e agindo, e as suas intervenções são tratadas, verificados aqueles e outros pressupostos, como actos do ente jurídico." Observe-se, como também sublinha o mesmo autor, que não é caso de representação; essas pessoas naturais, em verdade, "numa visão e designação que se diria antropomórfica", são órgãos da pessoa jurídica. In: A Formação das Deliberações Gerais - Assembleia Geral das Sociedades Anónimas, Coimbra, Coimbra Ed., 1994, pp. 69-72.

${ }^{341}$ Luis Manuel RoJAS JR., El Derecho de Voto em la Sociedad Anónima, México, Editoral Jus, 1945, p. 37.

${ }^{342}$ Marcelo Vieira von ADAMEK, Responsabilidade Civil dos Administradores de S/A e as Ações Correlatas, São Paulo, Saraiva, 2009, p. 11.

${ }^{343}$ Já Eduardo de Melo Lucas COELHO conceitua segundo duas acepções, que são "duas facedas da mesma realidade e não de realidades distintas": "Numa óptica propícia à máxima abstração do conteúdo conceitual, o órgão constitui um entreposto de competências estabelecidas em normas de organização do
} 
mesmo autor e na mesma obra, "a distribuição, especifica e ordenada, de diferentes funções, deveres, responsabilidades, direitos e prerrogativas", tanto "para a formação da vontade coletiva como para a sua ulterior exteriorização e execução, bem como para a fiscalização de seu cumprimento. "344 A atuação em concreto dos órgãos denomina-se função orgânica, de que são elementos os atos orgânicos ${ }^{345}$.

Para o desempenho de suas funções, os diversos e especializados órgãos não se justapõem no arranjo orgânico societário de maneira isolada, mas, antes, comunicam-se entre $\mathrm{si}^{346}$, segundo a complementaridade das respectivas atribuições e a ordem hierárquica $^{347} \mathrm{e}^{348}$, estatuída conforme a relevância, generalidade, abstração (ou concretude) das atribuições de cada qual ${ }^{349}$.

O órgão pode ser integrado por uma ou mais pessoas (chamadas titular ou membro), naturais ou jurídicas conforme o caso $^{350}$. Não se confunde com tais integrantes, no entanto ${ }^{351}$. Estes são apenas o instrumento necessário para que o órgão

ente, de origem legal e estatutária, ademais confiadas a certas pessoas físicas para, no domínio assim definido, através da correspondente actividade darem realização ao princípio organicista.” E completa: "Noutra acepção, o conceito aplica-se às próprias pessoas, justamente, chamadas ao cumprimento de tarefas da instituição órgão, mediante concretas acções humanas praticadas no exercício do complexo de poderes e deveres que para o efeito lhes são atribuídos.” In: A Formação das Deliberações Gerais Assembleia Geral das Sociedades Anónimas, Coimbra, Coimbra Ed., 1994, p. 72.

${ }^{344}$ Marcelo Vieira von ADAMEK, Responsabilidade Civil dos Administradores de S/A e as Ações Correlatas, São Paulo, Saraiva, 2009, p. 11.

345 Eduardo de Melo Lucas CoElho, A Formação das Deliberações Gerais - Assembleia Geral das Sociedades Anónimas, Coimbra, Coimbra Ed., 1994, pp. 72-73.

${ }^{346}$ É o caso do conselho de administração da sociedade anônima que fixa “a orientação geral dos negócios da companhia” (LSA: art. 142, inc. I), que deve ser executada pela diretoria.

347 "De fato, apesar de cada órgão possuir atribuições privativas - e, por consequência indelegáveis -, eles não se posicionam paralelamente em um mesmo nível, mas, ao reverso, estruturam-se de forma hierárquica." Cf. Marcelo Vieira von ADAMEK, Responsabilidade Civil dos Administradores de S/A e as Ações Correlatas, São Paulo, Saraiva, 2009, pp. 15-16.

${ }^{348} \mathrm{O}$ que se verifica, essencialmente, pela possibilidade de composição e destituição dos membros do órgão inferior pelo superior - LSA: art. 142, inc. II; art. 132, inc. III. No mesmo sentido: Marcelo Vieira von ADAMEK, Responsabilidade Civil dos Administradores de S/A e as Ações Correlatas, São Paulo, Saraiva, 2009, p. 16: para o autor, não há propriamente submissão de um órgão ao outro (já que existem atribuições específicas e indelegáveis), mas "há órgãos que se colocam em posição superior, pois regulam a eleição dos cargos de outros órgãos; e, nos limites da lei, tomam decisões que vão impor determinados comportamentos aos demais."

${ }^{349}$ Luis Manuel RoJAS JR., El Derecho de Voto em la Sociedad Anónima, México, Editoral Jus, 1945, p. 37.

${ }^{350}$ Assim, e.g., não se admitem pessoas naturais como membros da administração das companhias (LSA: art. 146), sociedade em comandita por ações (art. 146 LSA e art. 1.090 do CC c/c art. 146 da LSA) ou sociedades do Código Civil (CC: art. 997, inc. VI; arts. 1.039 c/c art. 1.042; art. 1.045, art. 1.046, parágrafo único; art. $1.060 \mathrm{e}$ art. $1.046 \mathrm{c} / \mathrm{c}$ art. 997, inc. VI, ou, na LSA, art. 146; nesse sentido, cf. por todos: Haroldo Malheiros Duclerc VerçosA, Curso de Direito Comercial, v. 2, São Paulo, Malheiros, 2006, p. 440; em contrário: José Edwaldo Tavares BorbA, Direito Societário, Rio de Janeiro, Renovar, 2010, p. 125).

351 Sobre assunto, preleciona Eduardo de Melo Lucas COELHO: "Neste caso, a realização do princípio orgânico em concreto, ou seja, a actuação do órgão no segundo sentido [as pessoas físicas chamadas ao cumprimento de tarefas da instituição, "mediante concretas acções humanas praticadas no exercício do complexo de poderes e deveres para o efeito lhes são atribuídos"'] constitui a denominada 'função orgânica' (organschaftliche Funktion), desentranhando-se esta em 'actos orgânicos' (organschaftliche Akte, Organaktionen), que são as acções singulares levadas a efeito no desempenho por aqueles titulares do órgão (Organwalter, Organmitglieder), a partir de sua posição orgânica (Organstellung) e no exercício de poder 
desempenhe suas atribuições. Órgão é o cargo ou centro de imputação ${ }^{352}$. Pela investidura, as pessoas tornam-se membros do órgão e, dessa maneira e enquanto mantiverem tal condição, podem exercer juridicamente as atribuições (funções, deveres, poderes, responsabilidades) enfeixadas nesse centro de imputação. Os integrantes são, pois, instrumento (o "suporte"353) do órgão - mas não ele próprio.

A modificação na composição do órgão, isto é, a alteração de seus membros, não prejudica a identidade deste, que está na combinação de suas atribuições, como visto, e não na individuação de seus titulares.

O órgão não é dotado de personalidade jurídica ${ }^{354}$ nem tem, por conseguinte, capacidade jurídica ou patrimônio. Não é sujeito de direito. É, como visto, parte (indissociável) de um organismo e todas as atribuições por ele exercidas são imputadas não a ele próprio, mas ao organismo.

Nesse ponto, no entanto, faz-se necessário esquadrinhar suficientemente as estreitas ligações entre personalidade jurídica e órgãos. Se é certo que aquela é conceito inarredavelmente ligado ao de órgãos, pois que, como acima afirmado, inexistem pessoas jurídicas que não contenham estes, não é igualmente verdadeiro que a existência de órgãos pressuponha imprescindivelmente também a existência de pessoa ${ }^{355}$.

Órgãos, nesse contexto, constituem-se instrumento, meio para o exercício de certas atribuições e o atendimento a determinados interesses. Não são, contudo, como sublinha Giuseppe ROMANO-PAVONI, um instrumento qualquer, predisposto pelo ordenamento jurídico para o atendimento a qualquer fim; assim se chama, completa ele, apenas aquele "mezzo personale per la soddistazione di interessi referentisi a dati

orgânico inerente (organschaftliche Macht).” In: Formação das Deliberações Gerais - Assembleia Geral das Sociedades Anónimas, Coimbra, Coimbra Ed., 1994, pp. 72-73.

${ }^{352}$ Claríssimas são as palavras de Marcelo Vieira von ADAMEK: "O órgão pode ser integrado por uma ou mais pessoas, físicas ou jurídicas, mas ele não é a pessoa investida no cargo, e sim, concretamente, o próprio cargo ou centro de imputação de poderes funcionais. (...) O seu titular não se confunde com o órgão em si; nem as modificações de seus membros, as mutações do substrato pessoal, modificam a configuração dos órgãos em si." In: Responsabilidade Civil dos Administradores de S/A e as Ações Correlatas, São Paulo, Saraiva, 2009, p. 12.

${ }_{353}$ Marcelo Vieira von ADAMEK , Responsabilidade Civil dos Administradores de S/A e as Ações Correlatas, São Paulo, Saraiva, 2009, p. 12.

${ }^{354}$ Marcelo Vieira von ADAMEK , Responsabilidade Civil dos Administradores de S/A e as Ações Correlatas, São Paulo, Saraiva, 2009, p. 13.

355 "Senza dubbio non è concepibile l'esistenza di persone giuridiche senza organi, ma non è altretantto vero l'inverso, non si può cioè affrermare com uguale assolutezza che ogni organo presuppone l'esistenza di una persona giuridica". Cf. Giuseppe ROMANO-PAVONI, Le deliberzioni delle assemblee dele società, Milão, Giuffrè, 1951, pp. 49-50. 
ripporti ${ }^{356}$.

A esse propósito, ensina Francesco CARnElutTI que a noção de órgão vincula-se à de interesse comum ou coletivo ${ }^{357}$, da qual é decorrência lógica ${ }^{358}$. Os titulares de interesses comuns enfeixam-se em grupos sociais (que, observamos nós, podem constituir pessoa jurídica, mas não necessariamente) e organizam-se para perseguirem a satisfação de tais interesses. A complexidade dessa organização varia, naturalmente, conforme a composição do grupo e a natureza do interesse envolvido. Desse ajuntamento pode decorrer a existência de órgão, que, no entendimento do mestre italiano, conforme explicado por Erasmo Valladão A. e N. FrANÇA, “é o indivíduo, ou indivíduos, enquanto agem para o desenvolvimento deste interesse coletivo, ou seja, enquanto agem para o cumpre uma função do grupo.” ${ }^{359}$ Daí a decorrência lógica: imputa-se a esse(s) indivíduo(s) (na verdade, como acima observado, não a eles mesmos, enquanto tais, mas como ocupantes investidos do cargo) certas atribuições de cujo exercício depende o atendimento ao objetivo coletivamente colimado.

A existência de órgão pressupõe, assim, um complexo sistemático de interesses, unificado em razão de fins específicos (unificação esta que pode, ou não, ensejar a formação de uma personalidade jurídica) e que congrega, para seu atendimento, um universo de atividades-meio, das quais uma parcela será imputada ao órgão. O órgão, portanto, é um expediente jurídico existente não apenas nas pessoas jurídicas, mas em outras coletividades não-personificadas ${ }^{360}$, aos quais se atribui o desempenho de certas atividades com vistas ao atendimento à finalidade mediata que precisamente fundamenta a formação e a manutenção da dita coletividade, personificada ou não.

Nessa ordem de ideias, não parece difícil aceitar a existência de órgãos também nos processos concursais, à semelhança do que sucede nas pessoas jurídicas entre as quais as sociedades e, entre estas, por sua vez, especialmente, as companhias, que

\footnotetext{
${ }^{356}$ Veja-se a afirmação do autor italiano: "organo significa solo mezzo, strumento prestabilito dal diritto per la soddisfazione di certi interessi, non nel senso che sai da chiamare organo quasiasi mezzo giuridico, mas solo Il mezzo personale per la soddisfazione di interessi riferentisi a dati ripporti." In: Le deliberzioni delle assemblee dele società, Milão, Dott. A. Giuffrè, 1951, p. 50.

${ }^{357}$ Sobre as noções de interesse, interesse coletivo e conflito de interesses, q.v. item subsequente, sobre "interesse social".

${ }^{358}$ Apud Erasmo Valladão A. e N. FrançA, Arts. 35 a 46, in SouZA JunIOR, Francisco Satiro - PITOMBO, Antônio Sérgio A. de Moraes (coord.), Comentários à Lei de Recuperação de Empresas e Falência, São Paulo, RT, 2007, p. 187.

${ }^{359}$ Erasmo Valladão A. e N. FrançA, Arts. 35 a 46, in SouZA JunIor, Francisco Satiro - PITOMBo, Antônio Sérgio A. de Moraes (coord.), Comentários à Lei de Recuperação de Empresas e Falência, São Paulo, RT, 2007, p. 187.

${ }^{360}$ Veja-se o caso das assembleias especiais de debenturistas previstas pela Lei n. ${ }^{\circ}$ 6.404/76 (art. 71 e art. 231)
} 
contêm o modelo mais complexo de arranjo orgânico.

\subsubsection{Dos diversos órgãos}

A previsão e a disciplina dos órgãos, nos diversos entes coletivos, são muito heterogêneas ${ }^{361}$. Mesmo considerada essa diversidade, há alguns critérios que permitem úteis classificações para a imersão nessa matéria.

Quanto às funções, são quatro as naturezas dos órgãos nas entidades coletivas. Os deliberativos são os órgãos supremos, aos quais geralmente incubem as principais e mais graves decisões a respeito do destino da coletividade, a nomeação e destituição dos membros dos órgãos subordinados, a tomada de conta desses órgãos, entre outras atribuições. Aos órgãos administrativos cabem a execução das decisões dos órgãos deliberativos e a gestão da atividade a que se dedica a coletividade e, ainda, a representação dessa coletividade. Há também os órgãos fiscalizadores, que, auxiliares aos deliberativos, têm por função precípua o exercício da função que lhe atribui nome com relação aos órgãos da administração especialmente, isto é, verificar o cumprimento por aqueles órgãos das diretrizes fixadas pelos órgãos deliberativos, das disposições estatutárias, legais etc. Por derradeiro, há os órgãos consultivos, também auxiliares, que se prestam à elaboração de estudos ou recomendações, normalmente sem força vinculativa dos demais órgãos.

Quanto ao número de membros, os órgãos podem ser singulares, quando composto de apenas um membro, ou plurais, se admitem dois ou mais membros. Estes últimos, por sua vez, quanto ao modo de funcionamento, podem ser sucessivos ou simultâneos, conforme respectivamente haja uma ordem de sucessão (e exclusão) entre os diversos titulares - de tal modo que atuação do sucessor dependa da ausência ou impedimento de seu antecessor - ou as atribuições são imputadas, ao mesmo tempo, a todos os titulares ${ }^{362}$.

Também essa última espécie comporta uma nova subdivisão, em três grupos. Os órgãos plurais simultâneos podem ser colegiais, conjuntos (ou coletivos) ou, ainda, de funcionamento disjunto (ou separado).

\footnotetext{
${ }^{361}$ Marcelo Vieira von ADAMEK, Responsabilidade Civil dos Administradores de S/A e as Ações Correlatas, São Paulo, Saraiva, 2009, p. 13.

${ }^{362}$ Marcelo Vieira von ADAMEK, Responsabilidade Civil dos Administradores de S/A e as Ações Correlatas, São Paulo, Saraiva, 2009, p. 13.
} 
Neste último caso, os poderes, imputados a todos os titulares, podem ser exercidos por cada um isoladamente, sem o necessário concurso de todos - salvo, observa Marcelo Vieira von ADAMEK "na medida em que algum deles tenha o direito de se opor a

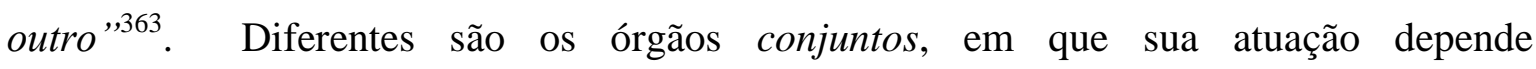
obrigatoriamente do concurso de certo número de membros. Em outras palavras, as atribuições do grupo não podem ser exercidas individualmente por cada um dos membros, mas apenas na hipótese de confluir a atuação de um determinado número deles. Por fím, os órgãos colegiais (ou colegiados) atuam mediante deliberação, isto é, o produto das manifestações de vontade de seus membros segundo um procedimento e uma apuração.

Ainda outra classificação assenta-se no critério da competência ${ }^{364} \mathrm{e}$, assim, extrema os órgãos em internos e representativos (ou, por oposição à primeira classe, externos). Estes últimos cuidam de manifestar a terceiros a vontade da coletividade e " $a$ praticar os atos jurídicos e materiais que afetam as relações das sociedades perante terceiros $^{\text {,365 }}$. São, pois, esses órgãos que vinculam à coletividade. Já os órgãos internos, como o próprio nome sugere, não se relacionam, em regra ${ }^{366}$, com terceiros, concernindo suas atribuições às questões interna corporis.

Classificam-se ainda os órgãos em permanentes ou episódicos, de acordo com seu funcionamento, na ordem, perene ou intermitente, e em obrigatórios ou facultativos, conforme sua previsão (no ato constitutivo) e composição (e não seu funcionamento, que é o critério para a classificação anterior) sejam cogentes ou não.

\subsubsection{Os órgãos deliberativos}

O órgão deliberativo por excelência das sociedades anônimas é a assembleia geral $^{367}$ (embora não seja o único ${ }^{368}$ ). Trata-se do órgão supremo da

\footnotetext{
${ }^{363}$ Responsabilidade Civil dos Administradores de S/A e as Ações Correlatas, São Paulo, Saraiva, 2009, p. 13.

${ }^{364}$ Marcelo Vieira von ADAMEK , Responsabilidade Civil dos Administradores de S/A e as Ações Correlatas, São Paulo, Saraiva, 2009, p. 14.

${ }_{365}$ Marcelo Vieira von ADAMEK , Responsabilidade Civil dos Administradores de S/A e as Ações Correlatas, São Paulo, Saraiva, 2009, p. 14.

${ }^{366}$ Uma exceção geralmente apresentada é a nomeação de administradores pelas assembleias gerais das sociedades anônimas, que produzem efeito perante terceiros embora seja ato do dito órgão interno.

${ }^{367} \mathrm{O}$ Decreto-Lei n. ${ }^{\circ} 2.627 / 40$, ao contrário do vigente diploma legal, definia a assembleia geral e o fazia como "a reunião dos acionistas, convocada e instalada na forma da lei e dos estatutuos a fim de deliberar sobre matéria de interesse social". Cf. Fran MARTINs, Comentários à Lei das Sociedades Anônimas, v. 1, Rio de Janeiro, Forense, 1977, p. 137.

368 "Nesse sentido, deliberação social não significa apenas a vontade dos acionistas emergentes da assembleia, órgão soberano do ente social. É que, nas sociedades, a assembleia não é o único órgão
} 
companhia $^{369}$ e 370 e sua existência é indispensável ${ }^{371}$. Nela têm assento os titulares de parcela de seu capital social e nela são debatidos (pelos integrantes) e deliberados (pelos titulares de direito de voto ${ }^{372}$ ) os mais variados assuntos de interesse da companhia, "inclusive os mais diminutos problemas administrativos"373. Não lhe cabe, contudo, nenhum ato executivo ${ }^{374} \mathrm{e}$, por sua posição hierárquica, tem reservadas para si certas matérias privativas (LSA: art. 122).

Trata-se de órgão plural do tipo colegial, que delibera por maioria dos presentes, em regra (LSA: art. 129), e por maioria do capital votante quanto a certas matérias (art. 136), observada ainda a possibilidade de o estatuto das companhias fechadas aumentar o quorum para matérias também por ele especificadas (art. 129, $\S 1^{\circ}$ ).

A assembleia pode reunir-se em caráter ordinário (AGO) ou extraordinário (AGE), de acordo com a matéria objeto da ordem do dia - sendo extraordinária a deliberação sobre qualquer tema não reservado à ordinária ${ }^{375}$ (LSA: art.

deliberante, posto que a outros se estende esse mesmo poder. É bem verdade que estão afetas ainda às assembleias as decisões principais da sociedade, as quais dizem respeito à sua estrutura jurídica, à disciplina de suas atividades, à organização de sua vida interna e à ordenação de suas relações com o exterior. Mas porque a urgência das decisões societárias seja incompatível com o ritual das assembleias é que se verificou uma hipertrofia dos órgãos da administração. Assim, não é apenas a assembleia o único órgão deliberativo da sociedade. Deliberam, também, o conselho de administração e, por vezes, até a diretoria." In: Priscila Corrêa da FonseCA, Suspensão de Deliberações Sociais, São Paulo, Saraiva, 1986, pp. 75-76.

José Edwaldo Tavares BorBA, Direito Societário, Rio de Janeiro, Renovar, 2010, p. 366. Essa supremacia não decorre de sua competência, cuja repartição é feita, em caráter não delegável, pela Lei, mas deriva essencialmente do poder de eleger e destituir os membros dos demais órgãos (conselho fiscal, conselho de administração e, na ausência deste, da diretoria).

${ }^{370}$ Muito oportuna é a observação de Fabio Konder COMPARATO a respeito da superioridade da assembleia geral, a quem imputa - por aplicação, em "sentido puramente abstrato", da diferença entre potestas e auctoritas estabelecida na experiência jurídica romana - o imperium (isto é, o poder supremo, originalmente derivado do poder militar), relegando a simples potestas aos demais órgãos legais e estatutários (cf. Fabio Konder Comparato - Calixto SAlomão Filho, O Poder de Controle na Sociedade Anônima, Rio de Janeiro, Forense, 2005, pp. 31-32). Para o autor, “O que foi dito, porém, não significa que a assembleia geral se confunda com a própria sociedade. Embora órgão máximo, ela não é o organismo, e aí vai uma das diferenças fundamentais entre o regime jurídico das anônimas e o das demais sociedades, nas quais falta essa estruturação orgânica." (p. 32)

${ }^{371}$ Alfredo Sérgio LAZZARESCHI NETO, Lei das Sociedades por Ações Anotada, São Paulo, Saraiva, 2006, p. 184, n. 1a.

${ }^{372}$ Nem todos os acionistas podem votar (não o podem os preferencialistas sem direito, ou com esse direito restrito, os morosos, se suspenso seu direito - art. 120).

${ }^{373}$ Fabio Ulhoa CoElHo, Curso de Direito Comercial - Direito de Empresa, v. 2, São Paulo, Saraiva, 2012 , p. 222. O autor registra que em outros países (Itália e EUA, por exemplo) não é assim, sendo defeso à assembleia geral deliberar sobre assuntos de atribuição dos órgãos de administração.

374 José Edwaldo Tavares BorBA, Direito Societário, Rio de Janeiro, Renovar, 2010, p. 366. Assim, em caso de deliberação de ato jurídico específico (por exemplo, a realização de uma avença), não lhe caberá executar a deliberação e contrair obrigação perante terceiros, mas tão-somente o autoriza (ou determina), o que será efetivado pela diretoria.

${ }^{375}$ As AGOs devem realizar-se dentro dos quatro meses subsequentes ao término do exercício social; suas matérias são recorrentes e, por isso, a realização do conclave mostrar-se necessária a cada ano (LSA: art. 132 - por exemplo: eleição dos membros dos órgãos da administração e do conselho físcal, se o caso; destinação do lucro líquido e distribuição de dividendo; tomar as contas dos administradores). 
131). Nada obsta, contudo, a deliberação conjunta de matérias de ambas as naturezas (art. 131, parágrafo único).

A Lei das Sociedades por Ações disciplina ainda, e minuciosamente, além das atribuições das assembleias gerais, todo o procedimento que se deve observar para se alcançar a deliberação. Assim, trata-se da competência para sua convocação (art. 123) e os meios para sua realização (art. 124), quóruns de instalação (art. 125 e 135) e de aprovação (art. 129 e art. 136), procedimento (art. 134), registro de presença (art. 127), composição da mesa (art. 128) e lavratura de ata (art. 130). Da regularidade cumulativa de todos esses procedimentos (o iter assemblear) depende a validade da deliberação a ser tomada. E a deliberação externa e materializa a vontade social, naquele caso concreto.

\subsubsection{O poder de controle}

Em matéria de formação da vontade social, imprescindível é a referência ao poder de controle - matéria que, por sua especificidade e relevância, foi disciplinada pela Lei n. ${ }^{\circ} 6.404 / 76$.

A assembleia geral é o locus em que por excelência o poder de controle manifesta-se. Controla a companhia quem detém a aptidão de comandá-la, elegendo seus administradores e determinando a condução de sua atividade ${ }^{376}$. A assembleia é o órgão ao qual compete compor o conselho de administração (ou a diretoria) e decidir, em última instância, todas as questões relevantes da companhia ${ }^{377}$. Controlador é, pois, quem domina a assembleia geral, embora naturalmente o exercício desse poder se desdobre na atuação que seus titulares, por si ou por terceiros, manifestam nos demais órgãos societários ${ }^{378}$.

Para o melhor entendimento do fenômeno do controle, é de muita utilidade a distinção referida por Fabio Konder COMPARATO, baseada na disciplina alemã dos grupos de empresa, entre os três níveis da estrutura de poder das companhias: o nível

\footnotetext{
${ }^{376}$ Para Modesto CARVALHOSA, o controle sociedade é o "poder de dirigir as atividades sociais", o "poder efetivo de direção dos negócios sociais". E adverte que a noção tem também um sentido material (substancial), e não apenas um formal. Cf. Comentários à Lei de Sociedades Anônimas, v. 2, São Paulo, Saraiva, 2009, p. 489.

377 "A definição de poder de dominação ou controle, na sociedade anônima - já o dissemos - é sempre feita em função da assembleia geral, pois é ela o órgão primário ou imediato da corporação, que investe todos os demais e constitui a última instância decisória." Cf. Fabio Konder COMPARATO - Calixto SALOMÃo FILHO, O Poder de Controle na Sociedade Anônima, Rio de Janeiro, Forense, 2005, p. 51.

${ }_{378}$ Após fazer referência ao fato de que o poder de controle manifesta-se nas assembleias, José Edwaldo Tavares BORBA observa que ele "continua a se exercer, de forma indireta, em face da dependência em que se colocam os administradores diante do titular do poder de controle." In: Direito Societário, Rio de Janeiro, Renovar, 2010, p. 348.
} 
da participação no capital social, o da direção e, ainda, o do controle ${ }^{379}$.

O poder de controle pode caracterizar-se por decorrência da participação no capital social, que assegura ao acionista (ou ao grupo de acionistas) a dominação nas decisões assembleares. Segundo a clássica distinção estabelecida por Adolf BERLE JR. e Gardner MEANS, em sua seminal obra ${ }^{380}$ baseada nos dados estatísticos americanos de 1929, o controle pode-se alcançar, nesse caso, mediante a titularidade da quase totalidade das ações (controle "totalitário", como em uma one-man company ou wholly owned subsidiary, entre nós disciplinada como subsidiária integral ${ }^{381}$ ), da maioria delas (controle majoritário) ou, ainda, de parcela inferior à metade (controle minoritário).

Esse escalonamento decrescente de participação no capital social, mantido o controle, evidencia o fenômeno - observado pela dupla de estudiosos americanos na realidade daquela época em seu país - de descolamento entre a propriedade $^{382}$ das ações e o controle das companhias: o alcance deste não está condicionado necessariamente à aquisição daquela ${ }^{383}$ ou, por outra, a participação no capital social não assegura, por si apenas, o controle.

O exercício do controle da companhia pelo sócio majoritário é já uma manifestação desse fenômeno, pois que, exercendo efetivamente a direção da companhia, o controlador age perante os demais sócios, titulares de parcela significativa do capital social, como se fora gestor de negócios - a quem, portanto, ele é devedor de contas. No

\footnotetext{
379 “É com base nessa tríplice distinção que o direito alemão concebeu a disciplina dos grupos de empresas (Konzern). Há, assim, de um lado o grupo de subordinação (Unterordnungskonzern), cuja característica fundamental é a unidade de controle e, de outro, o grupo econômico de coordenação ou igualitário (Gleichordnungskonzern), 'quando empresas juridicamente autônomas, muito embora sem relação de subordinação, são reunidas sob uma direção unitária' (Lei acionária de 1965, § 18, alínea 2). No grupo econômico de coordenação, a unidade é de direção e não de controle. (...) É por isso que, contrariamente a uma opinião assaz difundida, a melhor doutrina considera a unidade de direção o único critério geral de identificação de todos os grupos econômicos, e não a unidade de controle, que só ocorre no grupo econômico de subordinação, muito embora este seja, de fato, o mais importante." In: Fabio Konder Comparato - Calixto Salomão Filho, O Poder de Controle na Sociedade Anônima, Rio de Janeiro, Forense, 2005, pp. 42-43.

${ }^{380}$ Intitulada "Modern Corporation and Private Property". Para o trabalho, foi consultada a tradução para o vernáculo: Adolf Berle Jr. - Gardner MEAns, A Moderna Sociedade Anônima e a Propriedade Privada, trad. Dinah de Abreu Azevedo, São Paulo, Abril Cultura, 1984.

${ }^{381}$ LSA: arts. 251 e seguintes. Registre-se, ainda, a existência entre nós da empresa pública (Decreto-Lei n. ${ }^{\circ}$ 200/67), de titularidade exclusiva do poder público (e eventualmente de uma única pessoa jurídica de direito público, que é seu controlador) e da recém-criada EIRELI, a empresa individual de responsabilidade limitada, tipo de pessoa jurídica acrescida ao Código Civil de 2002 pela Lei n. ${ }^{\circ}$ 12.441/11, que equivale a uma sociedade limitada unipessoal (cf. Fabio Ulhoa Coelho, Curso de Direito Comercial - Direito de Empresa, v. 2, São Paulo, Saraiva, 2012, pp. 409-411), em que uma pessoa natural (cf. Instrução DNRC n. ${ }^{\circ}$ $117 / 11$, Anexo I, n. 1.2.6, al. a) pode deter a totalidade de suas quotas.

382 "Property". Entre nós, melhor seria falar em titularidade (e não em propriedade, de sentido bem mais estrito).

${ }^{383}$ Merece referência a observação de Fabio Konder COMPARATO de que as conclusões desse estudo, tido por precursor, foi precedido por estudo de Karl Marx. Cf. Fabio Konder COMPARATO - Calixto SALOMÃo FILHO, O Poder de Controle na Sociedade Anônima, Rio de Janeiro, Forense, 2005, p. 51, n. 1.
} 
entanto, o divórcio entre "propriedade" e gestão torna-se patentemente visível naquela realidade societária em que tem lugar o controle minoritário. Nesse caso, as deliberações sociais - e, conseguintemente, o exercício do controle - são determinadas por titulares de parcela do capital inferior (e, por ocorrer, muito inferior) à maioria do capital social.

Essa realidade decorreu, nos Estados Unidos, da progressiva atomização da participação acionária das companhias daquele país, acompanhada da quase inevitável inação (o chamado “absenteísmo",384), nas assembleias gerais, desses acionistas extremamente numerosos e, ao menos tempo, titulares individualmente de parcelas absolutamente ínfimas do capital social. Quanto ao regramento legal das assembleias de acionistas e suas deliberações, contribui decisivamente para esse resultado o acréscimo ao já consagrado princípio majoritário da aplicação disseminada (para a generalidade das matérias) de quóruns relativos - que têm por base a parcela do capital social presente à assembleia e não a totalidade do capital social. Essa disciplina jurídica aplicada àquela realidade econômica ${ }^{385}$ resultou na existência, verificada já no começo do século nos EUA, do chamado controle minoritário.

Os estudos de BERLE JR. e MEANS chegaram ainda a uma quarta espécie de controle ${ }^{386}$, chamado de gerencial (ou administrativo), em que se verifica a separação completa entre o controle e a titularidade das ações. Em outras palavras, o controlador não é acionista; seu poder tem arrimo nas prerrogativas administrativas e não na participação acionária $^{387}$.

Também essa espécie de controle apenas ocorre em um cenário de franca

\footnotetext{
${ }^{384}$ Caracterizado pela ausência dos acionistas às assembleias gerais, mas que, como fenômeno, abrange uma realidade ainda mais ampla, consistente na indiferença dos acionistas quanto aos negócios sociais reduzindo-se seu interesse na "remuneração" de seu capital investido (são os chamados acionistas rendeiros). ${ }^{385}$ Acrescente-se ainda a dificuldade de outros acionistas rivalizarem com os detentores do poder de controle nas assembleias. Por um lado, tendo em vista o alto valor das ações, seria muito dispendiosa a aquisição no free float de ações em número necessário para fazer frente aos controladores nas deliberações sociais; ademais, desenvolveram-se progressivamente mecanismos estatutários (as poison pills) para evitar essa aquisição "hostil". Por outro lado, os expedientes de representação (os pedidos de procuração: proxy machineryu e proxy fights) nem sempre resultam na rivalização dos controladores.

${ }^{386}$ Referem-se os estudiosos americanos ainda a uma quinta espécie de controle, que é aquele obtido por "expedientes jurídicos" - como estrutura piramidal de sociedades, emissão de ações sem direito de voto ou com direito restrito e o voting trust. Sucede que esses são, na realidade, mecanismos de se atingir o controle, que se enquadrada, mesmo nesses casos, em alguma das quatro espécies enunciadas. Nesse sentido: Fabio Konder Comparato - Calixto SAlomão Filho, O Poder de Controle na Sociedade Anônima, Rio de Janeiro, Forense, 2005, p. 64.

${ }^{387}$ Fabio Konder COMPARATO - Calixto SAlOMÃo FILHO, O Poder de Controle na Sociedade Anônima, Rio de Janeiro, Forense, 2005, p. 71: "É o controle interno totalmente desligado da titularidade das ações em que se divide o capital social. Dada a extrema dispersão acionária, os administradores assume o controle empresarial de facto, transformando-se num órgão social que se autoperpetua por cooptação."
} 
dispersão acionária ${ }^{388}$. Inexistindo acionistas ou grupo de acionistas que exercem o poder, os membros da administração ${ }^{389}$ logram obter procuração de acionistas ${ }^{390}$ para, ao representá-los nas assembleias, alcançar o controle da companhia - inclusive a manutenção dos administradores em seus postos ${ }^{391}$. Nesse caso, os efetivos controladores (os administradores) não detêm participação societária ${ }^{392}$.

Seja qual for o expediente jurídico empregado, deve ele permitir (ou não será idôneo à caracterização do controle) que o controlador dirija o complexo de bens companhia e, dessa maneira, oriente sua atividade empresarial ${ }^{393}$ - o que, em princípio, será alcançado no comando das deliberações assembleares, tenha ou não o controlador assento naquele órgão.

É de se notar que o controle, por si mesmo, manifesta-se como um poder $^{394,395 \text { e } 396}$. Trata-se, portanto, de uma realidade pertencente ao domínio dos fatos ${ }^{397}$.

\footnotetext{
${ }^{388}$ Fabio Konder Comparato faz referência ao caso da Pennsylvania Railroad Co., reportado por Adolf BERLE JR. e Gardner MEANS, na qual, no ano de 1929, os vinte maiores acionistas tinham, em conjunto, 2,7\% do capital social e o maior acionista individual, $0,34 \%$ da totalidade. $\mathrm{O}$ autor registra ainda uma nova pesquisa realizada com o mesmo critério em $1963 \mathrm{em}$ que se verificou que esse fenômeno (o controle gerencial) havia se acentuado significativamente. Cf. Fabio Konder COMPARATO - Calixto SALOMÃo FILHO, O Poder de Controle na Sociedade Anônima, Rio de Janeiro, Forense, 2005, pp. 71 e 72.

389 São os tecnocratas empresariais, que acabam por constituir um corpo relativamente estável no bojo das companhias.

390 São o proxy machinery e as proxy fights. Comenta Fabio Konder COMPARATO: “A perpetuação dos administradores no poder é obtida, sobretudo, com a utilização de complexos mecanismos de representação de acionistas em assembleia (proxy machinery), explorando-se ao máximo o absenteísmo do corpo acionário." In: Fabio Konder COMPARATO - Calixto SAlOMÃo FILHO, O Poder de Controle na Sociedade Anônima, Rio de Janeiro, Forense, 2005, p. 72.

${ }^{391}$ Em seu estudo sobre o capitalismo moderno, Georges RIPERT consigna: "A assembleia geral é chamada a eleger os administradores e os fiscais. A maior parte dos acionistas ignora os nomes dos que estão incumbidos de escolher. Os administradores designam eles próprios os candidatos aos lugares vagos. Mais comumente, os estatutos thes dão, em caso de vaga, o direito de recrutamento sob reserva da ratificação pela primeira assembleia. (...) Os acionistas resignam-se a nada compreender, a nada saber. Fiam-se nos administradores. $O$ regime democrático das sociedades acaba no triunfo de pequena minoria de capitalistas. Tal democracia termina em plutocracia." In: Aspectos Jurídicos do Capitalismo Moderno, São Paulo, Freitas Bastos, 1947, pp. 109-110.

${ }^{392}$ Sobre essa circunstância e o delineamento do controle, afirma Fabio Konder COMPARATO, conforme acima já transcrito, "a melhor doutrina considera a unidade de direção o único critério geral de identificação de todos os grupos econômicos" (Fabio Konder COMPARATO - Calixto SALOMÃo FILHO, $O$ Poder de Controle na Sociedade Anônima, Rio de Janeiro, Forense, 2005, p. 43). Nessa espécie de controle encontram-se aqueles grupos societários em que as companhias integrantes mantêm participações recíprocas e, ainda, as companhias controladas por fundações (p. 73).

393 Fabio Konder COMPARATO afirma que "o controle sobre a atividade empresarial implica, necessariamente, o controle dos bens empresariais e vice-versa". E, citando Claude CHAMPAUD, consigna que ele "afirmou, corretamente, que controlar uma empresa significa poder dispor dos bens que lhe são destinados, de tal sorte que o controlador se torna senhor de usa atividade econômica". In: Fabio Konder Comparato - Calixto Salomão Filho, O Poder de Controle na Sociedade Anônima, Rio de Janeiro, Forense, 2005, p. 126.

${ }^{394} \mathrm{Na}$ diferença estabelecida pela experiência jurídica romana entre potestas, imperium e auctoritas (referida por Fabio Konder Comparato em sua obra clássica, sempre citada), o poder de controle (um poder econômico, por natureza) é identificado como potestas sem auctoritas, porquanto predominam as circunstâncias de fato e não de direito. Cf. Guilherme Döring Cunha PEREIRA, Alienação do Poder de Controle Acionário, São Paulo, Saraiva, 1995, p. 9.
} 
Sua previsão legal, portanto, presta-se não à sua constituição (jurídica), mas à aplicação de normas que, de alguma maneira, conduza seu exercício ao atendimento a determinadas finalidades fixadas pela política legislativa.

A Lei n. ${ }^{\circ}$ 6.404/76, em caráter inaugural entre nós ${ }^{398}$, tratou do poder de controle $^{399}$ e 400 , caracterizando seu titular (art. 116 e art. $243, \S 2^{\circ}$ ) e os deveres e as responsabilidades a ele imputados (art. 116, parágrafo único, e art. 117).

Considera-se controlador a pessoa (natural ou jurídica) ou o grupo de pessoas (vinculados por acordo de votos - art. $118^{401}$ - ou sob controle comum) "titular de direitos de sócio que lhe assegurem, de modo permanente, a maioria dos votos nas deliberações da assembleia-geral e o poder de eleger a maioria dos administradores da companhia" e "usa efetivamente seu poder para dirigir as atividades sociais e orientar o funcionamento dos órgãos da companhia”.

Como disposto na lei, não é requerido que o controlador seja, necessariamente, acionista, contanto que, nada obstante não tenha ações, seja titular de

\footnotetext{
${ }^{395}$ Fabio Konder COMPARATO qualifica-o como poder originário (porque não deriva de nenhum outro nem se arrima em outro), uno (ou exclusivo, porque, pela própria natureza, não admite concorrente) e geral ( "porque se exerce em todos os campos e setores, sem encontrar nem admitir domínios reservados, por parte dos órgãos societário”). Cf. Fabio Konder COMPARATO - Calixto SAlOMÃo FILHO, O Poder de Controle na Sociedade Anônima, Rio de Janeiro, Forense, 2005, pp. 48-49.

${ }^{396}$ Rubens REQUIÃO sustenta que o controle, em si mesmo, tem natureza jurídica de bem imaterial. Cf. Curso de Direito Comercial, v. 2, São Paulo, Saraiva, 2009, p. 150.

397 Fabio Konder COMPARATO, citando artigo de Tullio ASCARELLI, afirma que, para o jurista italiano, "enquanto a participação de uma sociedade no capital de outra constitui uma relação jurídica típica, o controle não corresponde a uma situação jurídica determinada, mas a uma situação de fato, que pode derivar de várias relações jurídicas levando-se em consideração não só o tipo de relação, como também as modalidades de fato correspondentes à situação comparativa dos diferentes interessados na vida da sociedade." Não deriva daí, contudo, que juridicamente a noção seja irrelevante ou tenha ela importância exclusivamente econômica; ao contrário, na qualidade de situação fática, "pode constituir pressuposto de aplicação de determinadas normas”. In: Fabio Konder COMPARATO - Calixto SALOMÃo FILHO, O Poder de Controle na Sociedade Anônima, Rio de Janeiro, Forense, 2005, p. 47.

${ }^{398}$ O Decreto-Lei n. ${ }^{\circ} 2.627 / 40$ não tratou do controle; previa a figura do acionista majoritário, mas não criava responsabilidades para ele. Cf. Modesto CARVAlHOSA, Comentários à Lei de Sociedades por Ações, v. 2, São Paulo, Saraiva, 2009, p. 475.

399 Até então, incomum no direito comparado. Cf. Fran MARTins, Comentários à Lei das Sociedades Anônimas, v. 2, t. 1, Rio de Janeiro, Forense, 1984, p. 87.

400 Fabio Konder COMPARATO relata críticas à definição legal, que, "nessa fase do capitalismo pósindustrial", não só é "insuficiente, deixando de compreender todas as diferentes modalidades do fenômeno, como também rígido, conduzindo ao reconhecimento do controle onde ele efetivamente não se manifesta". A opinião dele, no entanto, é contrária a esse entendimento; não se trata, diz ele, de um conceito abstrato e universal, mas de um conceito operacional, "como instrumento prático de aplicação de um sistema normativo especifico”. Cf. Fabio Konder COMPARATO - Calixto SALOMÃo FILHO, O Poder de Controle na Sociedade Anônima, Rio de Janeiro, Forense, 2005, p. 80.

${ }^{401}$ Não se exige seja o acordo arquivado na sede da companhia (LSA: art. $118, \S 1^{\circ}$ ), exigência formal que tem seus propósitos e feitos, mas cuja ausência não pode elidir a caracterização do poder de controle e a imputação dos deveres e responsabilidade consentâneos. Cf. Guilher Döring Cunha PEREIRA, Alienação do Poder de Controle Acionário, São Paulo, Saraiva, 1995, p. 17.
} 
direito de voto ${ }^{402}$. Admite-se o controle conjunto, derivado de acordo de voto (art. 118) ou, ainda, de acionistas submetidos a um controle comum ${ }^{403}$. Estão igualmente contempladas as hipóteses de controle minoritário ${ }^{404}$ e mesmo de inexistência de controlador ${ }^{405}$ e 406.

Fabio Konder COMPARATO afirma que a exigência adicional de nomeação da maioria dos administradores tem inspiração no direito anglo-saxônico ${ }^{407}$, mas é, "à primeira vista”, carente de sentido ${ }^{408}$. Sobre o caráter permanente, adverte o mesmo autor que isso não necessariamente significa o prolongamento no tempo - já que o adquirente do poder de controle mantêm-no como tal enquanto dele não se desfaça, ainda que por um curto espaço de tempo (até que o aliene ${ }^{409}$. E, a respeito da necessidade de exercício efetivo, sustenta que apenas faz sentido para (como elemento integrante do conceito) o controle minoritário ${ }^{410}$.

$\mathrm{E}$, por fim, o mesmo autor resume: "Controle haverá toda vez que esse

\footnotetext{
${ }^{402}$ Por exemplo, no usufruto ou na alienação fiduciária em garantia.

${ }^{403}$ Observa Fabio Konder COMPARATO, a partir da análise conjunta do art. 116 e do art. 243 , $\S 2^{\circ}$, da Lei n. ${ }^{\circ}$ 6.404/76, que os termos "grupo de pessoas sob controle comum" (no art. 116) designam o controle último nas mãos de uma pessoa natural, já que a hipótese de controle piramidal por pessoa jurídica já é contemplado pelo art. 243, $\S 2^{\circ}$ : “Ou seja, na hipótese de incidência definida no art. 116, o controle é sempre direto e as sociedades sob controle comum são tidas, com conjunto, por controladoras. No art. 243 , $\$ 2^{\circ}$, despreza-se o escalão intermédio, buscando-se a sociedade controladora em último grau." In: Fabio Konder COMPARATO - Calixto SAlomão Filho, O Poder de Controle na Sociedade Anônima, Rio de Janeiro, Forense, 2005, p. 85.

${ }^{404}$ Fabio Konder COMPARATO - Calixto SALOMÃo FILHO, O Poder de Controle na Sociedade Anônima, Rio de Janeiro, Forense, 2005, p. 84.

${ }^{405}$ Fabio Konder COMPARATO - Calixto SAlomão Filho, O Poder de Controle na Sociedade Anônima, Rio de Janeiro, Forense, 2005, p. 84. O art. 122, parágrafo único, da Lei n. ${ }^{\circ} 6.404 / 76$ expressamente prevê a possibilidade de ele não existir (em caso de urgência, a confissão da falência ou o pedido de concordata rectius, o ajuizamento de recuperação judicial - será formulado "com a concordância do acionista controlador, se houver (...)".

${ }^{406}$ Por exemplo, o titular de direito de voto que cumule todos os requisitos do art. 116 da Lei n. ${ }^{\circ} 6.404 / 76$, salvo o previsto pela alínea "b", i.e., o exercício efetivo do poder (hipótese que Fabio Konder COMPARATO entende aplicável apenas ). Também o caso em que há apenas dois sócios com participações iguais e não submetidos a um controle comum ou acordo de votos.

${ }^{407} \mathrm{Na}$ Inglaterra, a lei determina a competência (residual) do board e, nos Estados Unidos, o órgão tem atribuições agigantadas, inclusive a determinar os dividendos a serem pagos. No Brasil, no entanto, os poderes do conselho de administração não lhe atribui o poder supremo da companhia - razão por que, entende, é discutível "que esse poder de eleger a maioria dos administradores coincida com a essência do poder de controle". Cf. Fabio Konder Comparato - Calixto SAlomão Filho, O Poder de Controle na Sociedade Anônima, Rio de Janeiro, Forense, 2005, p. 86.

${ }^{408}$ Segundo Fabio Konder COMPARATO, o que se teve em mente era a possibilidade de, mediante acordo de votos, o acionista majoritário conceder ao minoritário a maioria dos cargos da administração ou, ainda, a conferência de 'vantagens políticas' (representações nos órgãos da administração) a determinadas classes de acionistas. Cf. Fabio Konder Comparato - Calixto SAlomão Filho, o Poder de Controle na Sociedade Anônima, Rio de Janeiro, Forense, 2005, p. 86.

${ }^{409}$ Fabio Konder COMPARATO - Calixto SALOMÃo FILHO, O Poder de Controle na Sociedade Anônima, Rio de Janeiro, Forense, 2005, p. 86.

410 "O titular de direitos de sócio que lhe assegurariam a preponderância nas deliberações sociais, em razão da dispersão acionária, pode manter-se ausente das assembleias gerais, perdendo com isto, de fato, o comando da empresa. " Já no controle majoritário o desuso (ou mau uso) do poder não é elemento definidor desse status e ficará ele responsável, pois, mesmo nesse caso, o poder é exercido em seu nome ou por delegação sua.
} 
poder estiver em mãos de titulares de direitos próprios de acionistas, ou de administradores, pessoas físicas ou jurídicas, isoladamente ou em conjunto, de modo direto ou indireto." O elemento nuclear, conclui, é a o "poder de determinar as deliberações da assembleia geral" ${ }^{\text {"411 }}$. Cumpre ainda observar a aproximação defendida pelo jurista entre a figura do controlador e do empresário, subtraindo este à figura da pessoa jurídica $^{412}$.

Na disciplina dispensada pela Lei n. ${ }^{\circ}$ 6.404/76, o mesmo artigo que, em seu caput, delimita o poder de controle impõe, em seu parágrafo único, deveres a seu titular $^{413}$.

Pelas obrigações sociais o controlador não responde diferentemente dos demais participantes do capital social, minoritários ou sem direito de voto. Como qualquer outro acionista, ele responde limitadamente com o valor de suas ações, subscritas ou adquiridas (LSA: art. $1^{\circ}$, in fine $)^{414}$. Em outros termos, o exercício do controle não é causa de nenhuma especial responsabilidade nessa matéria ${ }^{415}$.

Não está, portanto, nesse campo o elemento diferencial do tratamento jurídico dispensado pelo legislador ao acionista controlador, se comparado àquele próprio dos demais sócios não integrantes do bloco de controle. O contraste entre esses regimes jurídicos está na imposição ao controlador do dever de empregar seu poder para perseguir certas finalidades. Igual determinação não é dirigida aos demais acionistas. Dessa imposição - ou, por outra, do descumprimento dessa imposição - ou, ainda, da prática de

\footnotetext{
${ }^{411}$ Fabio Konder COMPARATO - Calixto SALOMÃo FILHO, O Poder de Controle na Sociedade Anônima, Rio de Janeiro, Forense, 2005, p. 88.

${ }^{412}$ Escrevendo ainda antes da adoção da teoria da empresa pelo ordenamento jurídico brasileiro (art. 966 do Código Civil de 2002), e referindo-se, destarte, ao Codice Civile italiano de 1942, ele registra: " $A$ personalidade jurídica não pode transformar-se, sob pena de monstruoso antropomorfismo, de mero centro de imputação de interesses, em titular de atividades ou poderes, atributos esses privativos do homem. Dizer que é a própria companhia quem 'exerce profissionalmente uma atividade econômica organizada, com a finalidade de produção ou troca de bens ou serviços' (art. 2.082 do Código peninsular) é abusar da metáfora. É manter o velho capitalismo em seu tranquilo e experimentado anonimato". In: Fabio Konder Comparato - Calixto Salomão Filho, O Poder de Controle na Sociedade Anônima, Rio de Janeiro, Forense, 2005, p. 141.

${ }^{413}$ Sublinha Rubens REQUião que a identificação do controlador pela Lei n. ${ }^{\circ} 6.404 / 76$ destinou-se precisamente à fixação de suas obrigações e responsabilidades. Cf. Curso de Direito Comercial, v. 2, São Paulo, Saraiva, 2009, p. 151.

${ }^{414}$ Existem exceções, normalmente aplicáveis a determinados setores da economia - como é o caso das instituições financeiras, seguradoras, de previdência privada aberta e de capitalização, em que os controladores ficam solidariamente responsáveis aos administradores ou à própria companhia. Cf. Lei n. ${ }^{\circ}$ 2.321/87 (art. 15), Lei n. ${ }^{\circ} 9.447 / 97$ (art. $1^{\circ}$ ) e Lei n. ${ }^{\circ} 10.190 / 01$.

${ }^{415}$ Fabio Ulhoa Coelho, Curso de Direito Comercial - Direito de Empresa, v. 2, São Paulo, Saraiva, 2012, p. 312 .
} 
ilícitos, irregularidades ou fraudes pode surgir responsabilidade pessoal do controlador ${ }^{416}$; mas aquela não decorrerá tão-somente da condição de detentor do poder de controle.

O campo da liberdade de que dispõe o controlador para o exercício dos poderes fundados em suas ações encontra-se, por isso, amesquinhado. A imposição legal redu-lo, se comparado àquele âmbito franqueado aos acionistas minoritários.

Esse regramento está no contexto daquele fenômeno, analisado no capítulo precedente, da funcionalização do direito subjetivo. O tema, tomado aqui no âmbito das sociedades anônimas, é ainda mais complexo, porque envolve certos deveres impostos a todos os acionistas (LSA: art. 115) e a definição do interesse social - isto é, aquele interesse que deve ser perseguido pela companhia - é matéria controversa ${ }^{417}$. (O debate sobre o interesse social e o interesse dos sócios será mais aprofundadamente discutido logo adiante. De todo modo, cumpre mesmo a teoria institucionalista a respeito do interesse social que não exclui, por completo, a liberdade dos sócios para perseguirem os interesses próprios - contanto que não impeçam ou prejudiquem o atendimento àquele interesse objetivo e alheio aos sócios que é o interesse da companhia.)

De qualquer maneira, importa relembrar que o aludido fenômeno tem conferido certas modificações no conceito clássico de direito subjetivo, para impor a seu titular o emprego da posição jurídica subjetiva ativa e complexa não unicamente na satisfação do interesse próprio, mas também na persecução a outros interesses - que, não fosse a imposição legal, ele não perseguiria.

O termo funcionalização, como ficou anteriormente assentado, deriva da aproximação entre as duas figuras icônicas, como o são direito subjetivo e o poder-função (poder dever). Este último, reitera-se, é posição jurídica igualmente complexa; diferenciase, claramente, no entanto daquela outra, pois não pode ser exercida em favor de seu titular, mas, bem diversamente, deve voltar-se exclusivamente para a satisfação de interesses de terceiros - o que, inclusive, acarreta a impossibilidade de o titular dele dispor ou de deixar de utilizá-lo.

O direito subjetivo funcionalizado diferencia-se da concepção clássica de contornos típicos do liberalismo do século XIX - pela imposição legal, em seu plexo de posições jurídicas, de uma posição (simples) negativa consistente no dever do titular de

\footnotetext{
${ }^{416}$ Fabio Ulhoa CoElHo, Curso de Direito Comercial - Direito de Empresa, v. 2, São Paulo, Saraiva, 2012, p. 312.

${ }_{417}$ Q.v. item 3.2.2, infra.
} 
empregar aquela posição complexa no atendimento também de um interesse alheio ao titular - o que, nada obstante, não aniquila a proteção ao interesse do próprio titular, embora inevitavelmente a amesquinhe.

Trata-se, portanto, de expediente jurídico que atenua os contornos individualistas que presidiram o desenvolvimento dogmático clássico do direito subjetivo no penúltimo século, mas não desnatura, conforme já dito, o direito subjetivo, como categoria jurídica. E as razões que fundamentam esse movimento histórico é o atendimento pelo Estado de objetivos outros - que não serão alcançados mediante a atuação direta dele, mas pela imposição aos particulares de, no uso de seus direitos, também perseguirem tais interesses $^{418}$.

Por sua disciplina jurídica, o poder de controle toma, pois, a forma de direito subjetivo funcionalizado, na medida em que, por um lado, conserva para seu titular os poderes que são próprios dos acionistas (para, observado o disposto no art. 115, perseguir os próprios interesses) e, por outro, concomitantemente, impõe deveres a ele. Difere-se, assim, por exemplo, dos membros dos órgãos de administração, que exercem típico poder-dever, porquanto atuam exclusivamente no interesse da companhia. Fabio Konder COMPARATO, sustentando tratar-se de poder-dever, chega a afirmar que o controlador é, em verdade, um órgão (ou cargo) da companhia ${ }^{419}$.

Convém observar que alguns dos deveres impostos Lei de Sociedades por Ações ao controlador são, na verdade, destinados a regrar o comportamento da

\footnotetext{
${ }^{418}$ De um modo geral, esse expediente utilizado pelo legislador pode ser enquadrado, na classificação das formas de intervenção do Estado sistematizada por Eros Roberto GRAU, como intervenção sobre o domínio econômico por direção: "Quando o faz por direção, o Estado exerce pressão sobre a economia, estabelecendo mecanismos e normas de comportamento compulsório para os sujeitos da atividade econômica em sentido estrito." (Cf. A Ordem Econômica na Constituição de 1988, São Paulo, Malheiros, 2010, p. 147.) Nesse caso, o comportamento que deve ser observado pela companhia é imposto não a ela própria, mas ao seu controlador. Isso reflete, por um lado, a superação daquela ideia de que o regramento legal das sociedades é "neutro"; na verdade, ele presta-se ao atendimento de determinadas finalidades, como aquelas definidas pelo art. 116, parágrafo único, da Lei n. ${ }^{\circ}$ 6.404/76. Por outro lado, essa imposição ao controlador (que naturalmente é acompanhada de correspondentes sanções - art. 117, LSA) evidencia o movimento legislativo narrado por Fabio Konder COMPARATO: "A tradicional responsabilidade dos administradores sociais por atos culposos, devidamente provados, transformou-se em responsabilidade com culpa presumida, vindo, finalmente, dar lugar à responsabilidade também dos que exercem o controle. A antiga vinculação entre responsabilidade e poder de gestão transmudou-se numa relação entre responsabilidade e poder de controle." In: Fabio Konder COMPARATO - Calixto SAlOMÃo FILHO, O Poder de Controle na Sociedade Anônima, Rio de Janeiro, Forense, 2005, p. 435.

${ }^{419}$ Ele afiram que "Na economia da nova sociedade anônima", o controlador é tido por "seu mais recente órgão, ou, se preferir a explicação funcional do mecanismo societário, como titular de um novo cargo social. cargo, em sua mais vasta acepção jurídica, designa um centro de competência, envolvendo uma ou mais funções. " E completa que, em qualquer organização, um cargo é fundado em funções próprias e necessárias e, assim: "Ora, tais funções existem vinculadas à pessoa do controlador, pelo menos do acionista controlador." In: Fabio Konder COMPARATO - Calixto SALOMÃo FILHO, O Poder de Controle na Sociedade Anônima, Rio de Janeiro, Forense, 2005, pp. 141-142.
} 
companhia. O legislador adota uma técnica por meio da qual, objetivando o comportamento da companhia, determina sua persecução pelo controlador $^{420}$ - que, por ela, deve responder. O enunciado normativo do art. 116, parágrafo único, da Lei ${ }^{\circ}{ }^{\circ}$ 6.404/76, por exemplo, é bastante explícito ao determinar ao controlador que use o seu poder “com o fim de fazer a companhia realizar...”. Nota-se claramente a aquela aproximação afirmada por Fabio Konder COMPARATO entre o controlador e a figura do empresário - hoje reconhecida pelo Código Civil brasileiro (art. 966, caput) e, formalmente, imputada à sociedade empresária (cf. art. 982), embora, sustenta o autor ${ }^{421}$, devesse sê-lo ao sócio controlador, que efetivamente dirige as atividades, e não à pessoa jurídica como fazem o direito italiano e, agora, o brasileiro (e que, em seu sentir, constitui um antropomorfismo indesejável).

Nesse passo, determina a Lei n. ${ }^{\circ}$ 6.404/76 que o controlador deve conduzir a companhia de maneira que ela realize o seu objetivo social (isto é, prossiga suas atividades econômicas ${ }^{422}$ ) e, ainda, cumpra sua função social. Além disso, determina que o controlador deve "lealmente respeitar e atender" aos direitos e interesses dos demais acionistas, dos trabalhadores da companhia e da comunidade onde esta atua, com relação aos quais, impõe o mesmo dispositivo, ele (controlador) tem "tem deveres $e$ responsabilidades".

Tal compromisso que a lei cogentemente impõe entre o controlador e esses grupos sociais difusos que se relacionam com a companhia (LSA: art. 116, parágrafo único, $2^{\mathrm{a}}$ parte) evidencia, embora sem esgotá-lo, o conteúdo da própria função social da empresa, cujo cumprimento também é incumbência do titular do controle (art. 116, parágrafo único, $1^{\mathrm{a}}$ parte). $\mathrm{O}$ exercício do controle não pode ignorar esses interesses incidentes sobre a companhia. E mais do que simplesmente admitir sua legitimidade, a lei determina ao controlador que lhes atenda. Naturalmente, não desce o comando legal à minudência de especificar por que meios e em que aspectos esses direitos e interesses devam ser atendidos. Em suas decisões, contudo, o controlador deve conduzir a atividade da companhia de modo que contemple tais interessses.

Diferente é o dever impingido pelo art. 116-A do mesmo diploma legal, a

\footnotetext{
420 "Com efeito, é de todos sabido que as pessoas jurídicas imprimem em si o comportamento e a idoneidade de quem as controla”. In: Rubens REQUIÃo, Curso de Direito Comercial, v. 2, São Paulo, Saraiva, 2009, p. 151.

${ }_{421}^{4}$ Falando, embora, a propósito do Código italiano.

${ }^{422}$ Esse dever assume relevância no cenário do já referido debate travado entre contratualistas e institucionalistas. A lei impõe ao controlador seja garantidor de que a companhia se perpetuará pela exploração da atividade.
} 
ele acrescentado pela Lei n. ${ }^{\circ} 10.303 / 01$, e que, aplicável às companhias abertas, visa a atribuir mais transparência e confiabilidade ao mercado de capitais - perfilhando uma agenda de boas práticas de governança corporativa que ganhou relevo mundial a partir, principalmente, dos anos 1990.

Nesse mesmo sentido, o art. 117, caput, da Lei das Sociedades por Ações comina com o dever de reparar os danos causados ao controlador que cometa a ilicitude de abusar do direito que o controle lhe confere. Como observa Fabio Ulhoa CoELHo, o acionista controlador usufrui de uma condição privilegiada em relação aos demais; e não vai aí nenhuma irregularidade - muito ao contrário ${ }^{423}$.

Contudo, na hipótese em que esse direito é exercido abusivamente ${ }^{424}$, tem lugar uma ilicitude (uma contrariedade, portanto, ao direito), que reclama o dever de indenizar. Esse regramento já decorreria do que hoje dispõe o Código Civil (e o fazia, embora sem a mesma técnica e clareza, o diploma congênere revogado) a respeito de ato abusivo. Mas, ante a especificidade do micro-sitema regulado pela Lei n. ${ }^{\circ}$ 6.404/76, entendeu por bem o legislador disciplinar minuciosamente esse abuso e assim o fez não apenas ao prever o dever de indenizar (art. 117, caput), mas também ao especificar, embora não taxativamente ${ }^{425}$, as condutas que configuram abuso de direito $\left(\S 1^{\circ}\right)$.

O estudo sobre o abuso de direito nas assembleias de companhias é, contudo, objeto de tópico à frente.

\subsection{Do controle externo}

O controle externo é aquele que não provém da estrutura orgânica social: a orientação dos negócios da companhia (isto é, a direção sobre seus bens produtivos e sobre sua atividade econômica) não é levada a efeito pelo livre exercício de voto na assembleia geral $^{426}$, mas é faticamente determinada por uma atuação exógena - que, nada

\footnotetext{
${ }^{423}$ Curso de Direito Comercial - Direito de Empresa, v. 2, São Paulo, Saraiva, 2012, p. 313.

${ }^{424}$ Por ação ou omissão. Cf. Alfredo Sérgio LAZZARESCHI Neto, Lei das Sociedades por Ações Anotada, São Paulo, Saraiva, 2006, p. 161, n. 2c.

${ }^{425}$ Alfredo Sérgio LAZZARESCHI Neto, Lei das Sociedades por Ações Anotada, São Paulo, Saraiva, 2006, p. 161, n. 2 b.

${ }^{426}$ Não é que o voto não seja expediente necessário ao exercício desse controle; é que as diretrizes que balizam tal exercício não são voltadas ao atendimento do interesse dos acionistas, mas do terceiro detentor do controle. Cf. Modesto Carvalhosa, Comentários à Lei de Sociedades Anônimas, v. 2, São Paulo, Saraiva, 2009, p. 496.
} 
obstante, não suprime as instâncias societárias ${ }^{427}$. O poder é exercido $a b$ extra $^{428}$, e não $a b$ intus.

Também aqui se está diante de um poder fático ${ }^{429}$, embora seu exercício possa ser legitimado pela ordem jurídica ${ }^{430}$. Não foi o caso do Brasil, ao menos na Lei n. ${ }^{\circ}$ $6.404 / 76$, que não cuidou, em princípio, desse tema ${ }^{431}$.

A doutrina aponta alguns requisitos cumulativos para a configuração do controle externo, a saber: a) que o poder (a influência) seja de natureza econômica; b) que tal poder se estenda a toda a atividade desenvolvida pela empresa controlada; c) que a subordinação imposta seja permanente ou, ao menos, duradoura; d) seja impossível à controlada subtrair-se à subordinação, sem séria ameaça de sofrer prejuízo econômico grave $^{432}$.

Por sua natureza econômica, o controle externo é exercido por meio das relações de mercado, estabelecidas entre aquele que exerce o controle e aquele que é controlado (e normalmente formalizadas por contratos ${ }^{433}$ ou outros negócios jurídicos

${ }^{427}$ Guilherme Döring Cunha PEREIRA, Alienação do Poder de Controle Acionário, São Paulo, Saraiva, 1995, p. 14.

${ }^{428}$ Pode suceder a eventualidade de o controlador externo até ser acionista; contudo, o controle nesse caso não decorre do exercício do voto. Cf. Modesto CARVAlHOSA, Comentários à Lei de Sociedades Anônimas, v. 2, São Paulo, Saraiva, 2009, p. 496.

${ }^{429}$ São observações de Guilherme Döring Cunha PEREIRA: "O poder de controle não se possui em razão de uma especial legitimação jurídica, como ocorre, por exemplo, com o poder de pedir a divisão da coisa comum que a lei confere ao condômino. É um estado de fato que deve ser identificado para a imposição de exigências legais.” In: Alienação do Poder de Controle Acionário, São Paulo, Saraiva, 1995, p. 14.

${ }^{430}$ Fabio Konder COMPARATO cita um exemplo previsto pelo Código das Obrigações da Suíça. Quando uma pessoa jurídica de direito interno daquele país declara um interesse público numa determinada companhia, os estatutos podem atribuir a tal entidade, mesmo que não titular de capital social, o poder de indicar representantes para compor seus órgãos de administração e de fiscalização. Em que pese o caráter facultativo da previsão estatutária, uma vez efetivada, torna-se direito adquirido da entidade estatal e não pode ser suprimida sem sua aquiescência (o mencionado autor reporta decisão do Tribunal Federal suíço nesse sentido). Um exemplo semelhante pelo mesmo jurista citado é o art. 2.458 do Código Civil italiano, engendrado no período fascista, que assegura ao Estado, contanto que titular de parcela mínima de capital social, seja assegurado representante nos órgãos internos da companhia. Em qualquer dos casos, a assembleia perde a atribuição para nomeação e destituição dos integrantes representantes do Estado. No Brasil, a referência é à intervenção do Banco Central em instituições financeiras nos termos da Lei n. ${ }^{\circ}$ 6.024/74; In: Fabio Konder ComParato - Calixto SAlomão FilHo, O Poder de Controle na Sociedade Anônima, Rio de Janeiro, Forense, 2005, pp. 98-99 e 101.

${ }^{431}$ Modesto Carvalhosa, Comentários à Lei de Sociedades Anônimas, v. 2, São Paulo, Saraiva, 2009, p. 495. Nada obstante, Fabio Konder COMPARATO afirma que a lei não é completamente alheia ao controle externo e, no art. 249, parágrafo único, ao conferir à Comissão de Valores Mobiliários (CVM) atribuição para indicar as sociedades a serem abrangidas pela regra da consolidação das demonstrações financeiras, determinou sua extensão às sociedades que, conquanto não controladas ("entenda-se, 'não controladas acionariamente', segundo a norma do art. $243, \xi 2^{\circ}$ ") sejam financeira ou administrativamente dependentes da companhia. Cf. Fabio Konder ComPARATO - Calixto SALOMÃo FILHO, O Poder de Controle na Sociedade Anônima, Rio de Janeiro, Forense, 2005, pp. 83-84.

${ }^{432}$ Guilherme Döhring Cunha PEREIRA, Alienação do Poder de Controle Acionário, São Paulo, Saraiva, 1995, p. 14.

${ }^{433}$ Modesto Carvalhosa, Comentários à Lei de Sociedades Anônimas, v. 2, São Paulo, Saraiva, 2009, p. 496. 
equivalentes) e por meio das quais aquele primeiro impõe a este último um mal, ou lhe promete um bem, extremamente significativo do ponto de vista econômico - de tal sorte que ao destinatário do "assédio" apresenta-se muito mais conveniente submeter-se aos termos propostos pelo controlador que cessar a relação com ele ${ }^{434}$. Nada obstante apesar desse grave "constrangimento" econômico, é certo que o mal afligido ou a vantagem prometida não são injustos e, portanto, não podem ultrapassar, em princípio, as fronteiras da legalidade ${ }^{435}$.

Acrescente-se que a submissão imposta pelo controlador ao controlado não pode se restringir a algumas de suas atividades, mas deve estender-se a todas elas ${ }^{436}$ ou não se caracteriza o controle ${ }^{437}$. Por fim, deve ela perdurar no tempo - de maneira, portanto, duradoura, e não episódica.

Numerosos são os exemplos apresentados pela doutrina. Um típico é aquele em que o contrato de mútuo é garantido pela constituição de penhor sobre as ações integrantes do bloco de controle. O art. 113 da Lei n. ${ }^{\circ}$ 6.404/76 não suprime o direito de voto fundado nas ações apenhadas; contudo, autoriza que, por ajuste das partes, o acionista não vote sem o consentimento do credor pignoratício. Não se trata, no caso, de controle interno, porque o direito de voto não é subtraído ao acionista, mas seu exercício, por força do contrato celebrado com o credor, é vinculado aos interesses deste último.

Mesmo sem a constituição dessa garantia sobre as ações, é possível que os maiores credores da companhia exerçam, de fato, o controle dela ao condicionar, nas tratativas pré-contratuais, a renovação de empréstimos à adoção pela companhia devedora de determinadas medidas administrativas e políticas, à composição de órgãos

\footnotetext{
434 "A influência deve sempre resultar conveniente ao sujeito controlado, no sentido de que sujeitar-se a ela é melhor do que sofrer o mal do fim da relação (...)”. In: Guilherme Döhring Cunha PEREIRA, Alienação do Poder de Controle Acionário, São Paulo, Saraiva, 1995, p. 15.

${ }^{435}$ Reproduzem-se, em seguida, as palavras de Carlo PASTERIS transcritas (e traduzidas) por Guilherme Döhring Cunha PEREIRA: "porém no próprio estado de subordinação econômica, em confronto com o qual a ameaça do mal (que não pode de qualquer forma ser iniuria datum) é apenas um dos elementos constitutivos, e não já a única fonte; o dano que o sujeito controlador pode sofrer tem de fato caráter essencialmente econômico e deriva sempre do exercício por parte do sujeito controlador de um direito próprio, do qual podem derivar indubitavelmente relevantes consequências econômicas a favor ou em detrimento do sujeito dominado; tal poderia ser, por exemplo, a revogação de um particular contrato de comissão ou de agência." In: Alienação do Poder de Controle Acionário, São Paulo, Saraiva, 1995, p. 15.

436 "Mas se essa influência externa não chega a ser dominante, no sentido de se estender a toda a atividade empresarial da subordinada e ter permanência ou certa duração, não há como falar em controle." Cf. Guilherme Döring Cunha PEREIRA, Alienação do Poder de Controle Acionário, São Paulo, Saraiva, 1995, p. 15.

${ }^{437}$ Guilherme Döring Cunha PEREIRA transcreve trecho do livro de Carlo PASTERIS: "obviamente, é de se excluir-se uma forma parcial de controle limitada a uma só das várias atividades do sujeito”. E conclui: “ou este está sob controle ou não”. In: Alienação do Poder de Controle Acionário, São Paulo, Saraiva, 1995, p. 15.
} 
administrativos ${ }^{438}$ etc.

Aponta-se também a emissão de debêntures como fonte de exercício de controle externo. Contudo, anota Fabio Konder COMPARATO que, no Brasil, diferentemente do que sucede em outros países, esse controle externo decorre de um poder antes fático que de direito ${ }^{439}$. Deveras, conforme se verá mais adiante, em que pese o tratamento específico conferido pela Lei n. ${ }^{\circ}$ 6.404/76 a essa espécie de credores, as hipóteses de intervenção dos debenturistas na condução dos negócios sociais (notadamente mediante a aprovação ou rejeição de deliberação anteriormente tomada pelos acionistas quanto a determinadas matérias) são tímidas, se comparadas à legislação estrangeiras, e tópicas (específicas), não se generalizando a toda a condução das atividades sociais - como é próprio do poder de controle.

A sociedade em conta de participação, o contrato de concessão mercantil exclusiva $^{440}$, o contrato de franquia também são apontados como estruturas obrigacionais que permitem o exercício do controle externo - embora, como é evidente, a configuração efetivamente desse poder dependa da ocorrência conjunta de todos os requisitos apontados supra pela doutrina.

Cumpre registrar, por derradeiro, que o tema do controle externo é particularmente caro ao direito concursal. A progressiva deterioração da situação econômico-financeira do devedor faz deslocar o risco da atividade empresária (que, em princípio, é do empresário devedor ou dos sócios da sociedade empresária devedora) para

\footnotetext{
${ }^{438}$ É caso típico dos bancos de desenvolvimento e investimento, como BNDES e BNDESPar, lembra Modesto CARVAlHosa. In: Comentários à Lei de Sociedades Anônimas, v. 2, São Paulo, Saraiva, 2009, p. 496.

${ }^{439}$ Fabio Konder COMPARATO - Calixto SAlomão Filho, O Poder de Controle na Sociedade Anônima, Rio de Janeiro, Forense, 2005, p. 92 . O autor cita o caso da França, em que o Code de Commerce atribui ao representante dos debenturistas, por exemplo, o amplo acesso aos mesmos documentos franqueados aos acionistas nas assembleias gerais e uma série extensa de matérias objeto de deliberação dos acionistas não pode ser efetivada sem autorização da comunidade de titulares de debêntures; nem mesmo a emissão de novas debêntures pode ser levada a efeito sem a prévia consulta aos atuais debenturistas - que têm direito de preferência para subscrição, em caso de aprovação (pp. 92-93).

${ }^{440} \mathrm{O}$ mesmo e sempre citado Fabio Konder COMPARATO afirma que, sobretudo no mercado de produtos técnicos altamente especializados, o distribuidor amiúde vê-se diante do dilema de ou se tornar concessionário ou simplesmente cessar a atividade. Nesse contexto, não oferece resistência a celebrar contratos com cláusulas que efetivamente o obrigam a se submeter à direção determianda pelo concedente. Nesse contexto, o concedente logra impor "permanente fiscalização sobre as instalações materiais daquele [concessionário/distribuidor] e a qualificação profissional dos seus empregados"; também "o concessionário se obriga a utilizar os métodos de venda e de publicidade ditados pelo concedente, e a assegurar um serviço de reparação ou manutenção pós-venda". Em reforço desse controle, não é rara também a concessão de mútuo pelos concedentes aos concessionários - normalmente vinculando a investimento na própria atividade (reforma de suas instalações) -, a imposição de formas societárias específicas, a exigência de capital mínimo etc. "Tudo isso - conclui COMPARATO -, coberto pela sanção temível da retirada da concessão, costuma deixar os concessionários à inteira mercê dos concedentes." In: Fabio Konder COMPARATO - Calixto SAlOMÃo FilHo, O Poder de Controle na Sociedade Anônima, Rio de Janeiro, Forense, 2005, pp. 95-96.
} 
os seus credores - movimento que é acompanhado, em iguais sentido e proporção de um deslocamento também do poder de controle.

Com efeito, na ausência do estado de insolvabilidade ${ }^{441}$ - isto é, na situação ordinária, de equilíbrio econômico-financeiro - o sucesso ou insucesso da atividade explorada e de seus resultados financeiros é de interesse exclusivo dos titulares de capital investido, vale dizer, dos empresários e dos sócios de sociedades empresárias. A eles tocarão mais ou menos lucro; eles suportarão menos ou mais prejuízo, conforme o caso. A variabilidade dos resultados empresariais, nesse cenário, é em princípio irrelevante para o credor, cujo direito não se sujeita a ela e o qual se encontra devidamente resguardado pelo sistema jurídico, que assegura seu cumprimento, até mesmo compulsoriamente (excluída naturalmente a eventual inoperância ou ineficiência do sistema judiciário de execução forçada do crédito). Conforme já foi referido, e consoante será ainda explorado adiante quando se tratar dos sistemas de voto, nos arranjos empresariais existe uma relação direta entre o risco assumido e o direito político de condução (direção, controle) da atividade empresarial. Assim, no contexto em tela, os empresários ou sócios da sociedade assumem o risco e têm em suas mãos a condução do negócio; aos credores, contudo, não expostos ao risco, são alheios à sorte da empresa.

A situação modifica-se radicalmente, no entanto, se o devedor ingressa em crise e o estado de insolvabilidade apresenta-se concreto. Nesse caso, por insuficiência de ativo ou por falta de liquidez do devedor ${ }^{442}$, não apenas o empresário e os sócios da sociedade (que até então tinham a condução do negócio) podem deixar de auferir lucro e ainda não resgatarem o patrimônio investido (o que integra o risco próprio da atividade), mas também os credores (que até então não enfrentavam risco e também não dirigiam o negócio) ficam francamente expostos ao risco de não receberem seus respectivos créditos, voluntária ou mesmo compulsoriamente - nada obstante, por alheios à administração, não tenham concorrido com as decisões estratégicas sobre a direção dos negócios empresariais que conduziram àquela periclitante situação o arranjo empresarial e todos os que difusamente com ele se relacionaram.

\footnotetext{
${ }^{441}$ Adota-se a precisão terminológica de Fabio Konder COMPARATO (em que pese entendimento em contrário - cf. Rubens REQuĩ̃o, Curso de Direito Falimentar, v. 1, São Paulo, Saraiva, 1998, pp. 4-5): insolvência é o inadimplemento de uma obrigação (um fato, portanto), enquanto insolvabilidade é um estado econômicofinanceiro do devedor de inaptidão para o adimplemento das obrigações. "Assim, enquanto a insolvência é um fato que diz respeito a uma obrigação, a insolvabilidade é um estado que interessa à generalidade dos credores do devedor." In: O Seguro de Crédito, São Paulo, RT, 1968, pp. 46-47.

${ }^{442}$ Ao tratar do contrato de seguro de crédito, Fabio Konder COMPARATO consigna que a insolvabilidade do devedor, "notadamente no caso de déficit patrimonial”, constitui o risco central desse contrato. In: O Seguro de Crédito, São Paulo, RT, 1968, p. 52.
} 
A exposição ao risco torna os credores também legitimados a tomar parte na direção da atividade empresarial - e a vigente legislação concursal brasileira promove, com nuances, exatamente esse deslocamento do centro decisório. Por isso, a insolvabilidade é geralmente apontada como uma causa que conduz à imposição de um controle externo sobre o devedor em dificuldades. O próprio Fabio Konder COMPARATO expressamente o afirma: "Há, assim, em primeiro lugar, toda uma série de hipóteses em que o controle externo de uma situação de endividamento da sociedade. Em razão de seu direito de crédito, cuja execução forçada pode levar a companhia à falência, o credor passa, muitas vezes, a dominar a devedora comandando a sua exploração empresarial. "443

\subsubsection{Assembleias especiais}

Cumpre registrar, além das assembleias gerais ordinárias e extraordinárias, a existência de outras assembleias concernentes à sociedade anônima e previstas, no caso brasileiro, pela Lei n. ${ }^{\circ}$ 6.404/76. São as chamadas assembleias especiais.

É a assembleia de subscritores (ou de constituição, na dicção legal), que tem lugar na constituição da companhia por subscrição pública e que, uma vez já projetado o estatuto, confeccionado o prospecto e emitidas e subscritas as ações - tudo por obra de seus fundadores -, exercerá a função de aprovar o estatuto, efetivamente constituir a companhia e eleger os membros dos órgãos administrativos e fiscais (LSA: arts. 86 e 87).

Também se preveem assembleias especiais de acionistas (LSA: art. $4^{\circ}$-A; art. 16, inc. III; art. 16, parágrafo único; art. 18, parágrafo único; art. 136, § $1^{\circ}$, por exemplo), que envolvem determinada parcela dos titulares do capital social (os acionistas titulares de 10\%, no mínimo, das ações em circulação no mercado; a classe de acionistas que tem direito estatutário de eleição em separado de membros dos órgãos da administração; os acionistas atingidos por reforma estatutária que regule a diversidade de classes; os acionistas preferencialistas de certa classe a que tenha sido conferido, pelo estatuto social, o direito de vetar a reforma do próprio estatuto; acionistas preferenciais cujas preferências e características tenha sido alterada por deliberação da assembleia geral) e tem por atribuição deliberar sobre matérias específicas.

\footnotetext{
${ }^{443}$ Fabio Konder COMPARATO - Calixto SAlomão Filho, O Poder de Controle na Sociedade Anônima, Rio de Janeiro, Forense, 2005, pp. 90-91. Calixto SALOMÃo FILHO refere-se ainda à imposição pelos credores de estruturas de poder de controle gerencial ou administrativo, "com empresas ou administradores especializados na gerência de empresas em crise assumindo a diretoria e o controle interno da companhia por meio da atribuição a estes de ações preferenciais de classe especial” (p. 91).
} 


\subsubsection{Assembleia especial de debenturistas}

Ainda entre essas assembleias genericamente chamadas de especiais, há uma mais específica que chama particularmente a atenção. Isso, porque integrada por quem não é parte no capital social e, ainda assim, é chamada a deliberar não apenas sobre matéria do próprio interesse (LSA: art. 71, caput), o que em comunhões de interesse não causa absolutamente perplexidade, mas também para acatar ou rejeitar deliberação previamente tomada pelos acionistas quanto a tema interna corporis - a respeito do qual outros sujeitos assemelhados a esses (em situação análoga) não são consultados. Isto é: trata-se de uma assembleia de "intrusos" chamada legalmente a se imiscuir em atribuição originalmente conferida à assembleia geral de acionistas - precisamente porque relacionada estritamente à direção da companhia (LSA: art. 231). Refere-se, aqui, à assembleia de debenturistas.

As debêntures veiculam, em linhas gerais, "operações econômicas" de mútuo. São valores mobiliários que atribuem a seu titular um direito ao crédito contra a companhia emitente; conquanto os títulos de mesma emissão não percam sua individualidade (como valores mobiliários e fundamento para o exercício do respectivo direito - individual - de crédito), enfeixam-se em uma única escritura pública, que lhe são base e que estipulam os termos do negócio, como a remuneração do valor mutuado (taxa de juros, correção monetária), as garantias, o prazo de resgate, a conversibilidade ou não em ações, entre outras condições.

Normalmente as debêntures envolvem, em seu conjunto, valores vultosos e são emitidas para resgate a longo prazo (costuma funcionar como alternativa, pela captação direta da poupança popular no mercado de valores mobiliários, ao recurso ao sistema financeiro ou ao aumento de capital social ${ }^{444}$ ), a fim possibilitar investimentos (amiúde, de significativa monta) ou "reestruturar" dívidas pretéritas, embora, à evidência, nada obsta a estipulação de prazos curtos e o emprego para outra finalidade ${ }^{445}$.

\footnotetext{
${ }^{444}$ José Edwaldo Tavares BoRBA, Direito Societário, Rio de Janeiro, Renovar, 2010, p. 283.

445 "As debêntures prestam-se, normalmente, a propiciar à empresa emitente recursos de longo prazo, destinando-se, em regra, a financiar investimento fixo. São uma alternativa para o aumento de capital (...). mas não só os investimentos fixos poderão ser financiados por debêntures, servindo estas também para atender às necessidades de capital de giro da sociedade.” Cf. José Edwaldo Tavares BorBA, Direito Societário, Rio de Janeiro, Renovar, 2010, p. 283.
} 
Os titulares de debêntures são, pois, credores da companhia ${ }^{446}$; contudo, pela especificidade do título que lhes atribui o crédito $^{447}$, são destinatários de um regime jurídico próprio, especial em relação àquele conferido à generalidade dos credores. Nesse regramento, chama particularmente a atenção o caráter "institucional" que a lei dispensa à proteção aos interesses desses credores.

Reconhece-se claramente o estabelecimento de uma comunhão de interesses entre os debenturistas ${ }^{448}$ e a Lei n. ${ }^{\text {0 }}$ 6.404/76, assim, prevê não menos que dois órgãos (cada qual com atribuições próprias e distintas) destinados à proteção dos interesses deles. (Trata-se de um exemplo retumbante de que a existência de órgãos, como já afirmado, prescinde da criação de personalidade jurídica; conquanto, nesse caso, seja inegável sua relação - e até de dependência - com a companhia, tais órgãos não vinculam integrantes dessa pessoa jurídica, mas, bem ao contrário, credores inteiramente alheios a ela.)

Um desses órgãos é o agente fiduciário, pessoa natural ou instituição financeira autorizadas (LSA: art. 66, $\S 1^{\circ}$ ), nomeado pela companhia emitente na escritura pública de emissão dos títulos (LSA: art. 66, caput) e que tem por atribuição, em linhas muito gerais, a proteção dos “direitos e interesses dos debenturistas”, inclusive mediante a prestação de informações relevantes (elaboração de relatórios, notificação de eventual inadimplente da emitente etc. - LSA: art. $68, \S 1^{\circ}$ ) e, ainda, mediante declaração de vencimento antecipado dos títulos, a execução de garantias, o ajuizamento de pedido de falência e a representação dos debenturistas nos processos concursais etc. O outro órgão é a assembleia (especial) de debenturistas.

A lei reconhece algumas atribuições específicas desse órgão deliberativo.

Uma delas, de caráter genérico, respeita a "matéria de interesse da comunhão dos debenturistas" - o que pode, por exemplo, consistir na apreciação, pela

\footnotetext{
446 A relação fundamental da qual derivam as debêntures é um mútuo (cujas condições são fixadas pela escritura pública de emissão - LSA: art. 61), do qual cada título representa uma fração. Cf. José Edwaldo Tavares BorbA, Direito Societário, Rio de Janeiro, Renovar, 2010, pp. 281-282; Fabio Ulhoa CoELHO, Curso de Direito Comercial - Direito de Empresa, v. 2, São Paulo, Saraiva, 2012, p. 167.

${ }^{447}$ As debêntures normalmente servem aos empréstimos de longo prazo; muito se assemelham ao título de crédito abstrato (cf. Cf. José Edwaldo Tavares BoRBA, Direito Societário, Rio de Janeiro, Renovar, 2010, p. 282; Rubens Requião, Curso de Direito Comercial, v. 2, São Paulo, Saraiva, 2009, p. 111); podem ser conversíveis em ação (LSA: art. 57); seus limites de emissão e suas garantias são regrados pela lei (LSA: arts. 58 e 60) e, como valor mobiliário (Lei n. ${ }^{\circ}$ 6.385/76: art. $2^{\circ}$, inc. I), são ofertados no mercado, sob a fiscalização da Comissão de Valores Mobiliários - CVM (Lei n. ${ }^{\circ}$ 6.385/76: art. $8^{\circ}$ ); além disso, pode haver diversas emissões e, em cada qual, a estratificação em classes.

448 Anota José Edwaldo Tavares BORBA que, no regime legal anterior à LSA, "a comunhão de interesses entre debenturistas estava condicionada a uma especial convenção nesse sentido”, enquanto o vigente diploma tornou-a “compulsória”. Cf. Direito Societário, Rio de Janeiro, Renovar, 2010, p. 303.
} 
comunidade desses credores, de alteração proposta pela companhia nas condições originais de emissão dos títulos (prazo de resgate, taxa de juros remuneratórios etc.). A aplicação do princípio majoritário, com quórum de maioria dos títulos em circulação (LSA: art. 71, § $\left.5^{\circ}\right)$, a atribuição de um voto por debênture $\left(\S 6^{\circ}\right)$ e regras procedimentais ${ }^{449}$, reforça ainda mais esse caráter "institucional", pois que excepciona o princípio da autonomia da vontade ao vincular às deliberações assembleares mesmo os credores ausentes ou dissidentes.

Muito ligada à competência genérica das assembleias especiais de debenturistas prevista pelo art. 71 da Lei n. ${ }^{\circ}$ 6.404/76 é aquela prevista pelo art. $57, \S 2^{\circ}$, restritamente aplicável aos títulos conversíveis em ações. Enquanto perdurar o direito à conversão, ou a assembleia especial ou o agente fiduciário deverá aprovar a deliberação da assembleia geral de acionistas que altere o estatuto social para mudar o objeto social (art. $57, \S 2^{\circ}$, al. a) ou "criar ações preferenciais ou modificar as vantagens das existentes, em prejuízo das ações em que são conversíveis as debêntures” (al. b). O fundamento parece claro: sendo a conversão vantagem política para atrair debenturistas, qualquer alteração sensível diretamente em seus direitos (alínea $b$ ) ou radical na sociedade emitente (alínea $a$ ) deve submeter-se ao apreço da comunidade de credores diretamente atingidos.

A terceira atribuição refere-se à necessária aprovação das operações de cisão, fusão ou incorporação de companhia emissora de debêntures ainda não resgatadas (LSA: art. 231). Inexistindo deliberação ou sucedendo a desaprovação, mesmo que realizados esses atos societários eles serão ineficazes perante os debenturistas - salvo se dispensada o conclave especial nos termos do $\S 1^{\circ}$ do art. 231 da Lei n. ${ }^{\circ} 6.404 / 76$.

Note-se a singularidade da disciplina legal em comento: conquanto inexista problema de solvabilidade (o regramento não pressupõe existência de crise na empresa e, portanto, não se trata de norma concursal) e muito embora haja regras específicas a respeito da responsabilidade das companhias envolvidas nessas operações societárias, uma vez ultimadas estas (LSA: arts. 232 e 233), o legislador destacou esse delgado estrato de credores (os debenturistas) para, diferentemente de todos os demais, deliberar sobre a aprovação ou não da proposta - por sua vez já acatada, segundo o rito procedimental próprio, pelas respectivas assembleias gerais de acionistas envolvidas ${ }^{450}$.

\footnotetext{
${ }^{449}$ Regramento do iter assemblear, com regras de convocação (LSA: art. $71, \S 1^{\circ}$ ), instalação $\left(\S 3^{\circ}\right.$ ) e, supletivamente, aplicação de todas aquelas próprias das assembleias gerais de acionistas $\left(\S 2^{\circ}\right)$.

${ }_{450}$ Não cumpre aos debenturistas, naturalmente, deliberar sobre o ato societário, que é de competência das assembleias de acionistas, mas tão somente sobre sua eficácia perante essa comunidade de credores. Cf. . Alfredo Sérgio LazZareschi Neto, Lei das Sociedades por Ações Anotada, São Paulo, Saraiva, 2006, p. 461, n. 1a.
} 
Trata-se de uma situação excepcionalíssima, e que guarda certa semelhança com o que se verifica no âmbito recuperacional - em que os credores são chamados a decidir o destino da companhia. Não é, aqui nas debêntures, o caso necessariamente do exercício de um controle externo, pois que, como já referido, no mais das vezes, o poder desses credores é grave, é radical - não resta dúvida -, mas muito restrito em seu âmbito material, muito específico, pontual ${ }^{451}$. De todo modo, evidencia-se inequivocamente uma intervenção (e esse termo, ensina Eros Roberto GRAU, embora a propósito de outro assunto, denota a ação em área de outrem ${ }^{452}$ ) de credores (agentes alheios ao capital social) na direção dos negócios sociais, que excepciona a regra geral de que aos titulares do capital social toca a condução (o controle) da empresa - exceção que não é uma novidade (basta, por exemplo, relembrar a constatação já antiga do divórcio entre "propriedade" e, ainda, os casos de controle externo).

O fundamento dessa disciplina específica, que prevê aprovação dos debenturistas quanto a certas matérias, parece estar em um conjunto de características que é próprio dessa espécie de valor mobiliário. Algumas delas são essenciais e outras, acidentais (embora recorrentes) às debêntures - nenhuma talvez seja exclusiva dessa categoria jurídica. Mas elas, em conjunto, reclamam uma disciplina especial.

O perfil de longo prazo - típico dessa espécie de dívida ${ }^{453}$, embora não seja uma característica essencial - conduz a uma natural aproximação (um alinhamento) entre os interesses desses credores e os dos acionistas.

Quando a dívida é de curto prazo, a contraposição de interesses entre as partes manifesta-se rapidamente e de maneira muito saliente - mesmo que, do ponto de vista jurídico, ela não seja ainda tecnicamente exigível. Quanto menor o lapso temporal compreendido entre a concessão do crédito e seu vencimento, maior a previsibilidade do credor quanto ao efetivo adimplemento - pois que se reduz, em proporção, a probabilidade de a situação patrimonial considerada no instante da concessão alterar-se significativamente até o termo. Por isso, ao titular do crédito de curto prazo pouco importa

\footnotetext{
${ }^{451}$ Reitere-se que próprio professor Fabio Konder COMPARATO, após se referir às debêntures como meio de exercício de poder de controle externo, expressamente ressalva que "Entre nós, esse controle externo dos debenturistas sobre a companhia emitente correspondem a uma situação mais de fato que de direito." $\mathrm{E}$ sublinha a restrita matéria franqueada pela Lei das Sociedades por Ações à deliberação desse estrato de credores.

${ }^{452}$ A Ordem Econômica na Constituição de 1988, São Paulo, Malheiros, 2010, p. 72.

${ }^{453}$ De fato, não é uma característica essencial das debêntures, mas sua disciplina legal não deixa dúvidas de que ela é "desenhada" precipuamente para essa finalidade. Tanto isso é certo que não causa espécie a ninguém a previsão das chamadas "debêntures perpétuas" pelo art. 54, $\S 3^{\circ}$, da Lei n. ${ }^{\circ} 6.404 / 76$. Nesse caso, o alinhamento dos interesses dos acionistas e dos debenturistas impõe uma quase coincidência.
} 
a ulterior sobrevivência do devedor. Seu interesse, como seu crédito, é imediatista.

Diferente é a situação do credor de longo prazo, como sói ocorrer com as debêntures. Nesse caso, a considerável distância entre os instantes da concessão do crédito e de sua exigibilidade sujeita o devedor à ação das mais diversificadas, imprevisíveis e numerosas variáveis, que influem diretamente em sua situação econômico-financeira e tornam incontornável a preocupação do credor com a oportuna solvabilidade do devedor no (longínquo) momento em que seu crédito se vencer. Acrescente-se que, normalmente, embora não seja característica essencial, as emissões de debêntures envolvem quantias vultosas - tanto assim que a própria lei as restringe, impondo lhes limites (LSA: art. 60).

Mesmo as garantias que podem ser constituídas em favor das debêntures (notadamente a real e a flutuante) não são aptas a reduzir o risco a termos tão satisfatórios quanto a certeza da estabilidade econômico-financeira do devedor. Essas garantias, por privilegiadas que sejam, não asseguram juridicamente o adimplemento do crédito.

$\mathrm{Na}$ situação desfavorável extrema, em que se instaura o concurso liquidatório-solutório, a ordem de pagamentos, embora favorável a tais créditos se comparada à generalidade dos demais (quirografários), impõe, mesmo nesse caso, a preterição de seu adimplemento em relação às restituições em dinheiro (LREF: art. 149 c/c art. 86), aos créditos extraconcursais (LREF: art. 149 c/c art. 84) e, entre os concursais, aos trabalhistas, no caso da debênture com garantia real (LREF: art. 83, incs. I e II), e àqueles trabalhistas, com garantia real, tributários e com garantia especial, no caso da debênture com garantia flutuante (que é crédito com privilégio geral -art. 83, inc. I, II, III, IV e V, al. $c$, da LREF c/c art. 58, $\S 1^{\circ}$, da LSA).

À evidência, as operações societárias constituem eventos de invulgar relevância para o prosseguimento das atividades sociais e, claro, para a manutenção de sua solvabilidade e pagamento de seu passivo. (Não por acaso, já se disse, a Lei de Sociedades por Ações expressamente prevê normas a respeito da responsabilidade das companhias resultantes dessas operações pelo passivo anterior.)

Portanto, a maior garantia do debenturista segue sendo a manutenção da saúde econômico-financeira da companhia emitente, o que inarredavelmente acarreta a aproximação entre os interesses dos credores e do devedor.

Essa característica, contudo, não é bastante - o que se demonstra, antes de tudo, em razão de não ser ela essencial às debêntures (mas apenas eventual) e, depois, 
porque existem numerosos outros créditos de longo prazo (notadamente, certas linhas de crédito bancário) que, nada obstante, não contam com uma disciplina tão favorável (ou, pelo menos, tão "invasiva" nas entranhas sociais) quanto aquela prevista pelo art. 231 da Lei n. ${ }^{\circ} 6.404 / 76$.

Um reflexo desse alinhamento entre os interesses dos credores debenturistas e dos acionistas está na possibilidade, expressamente prevista e disciplinada pela Lei n. ${ }^{\circ} 6.404 / 76$, de conversibilidade dos títulos em ações ${ }^{454}$.

Nada impede, evidentemente, que, convergindo as partes, qualquer outra dívida da companhia seja extinta mediante dação em pagamento com a transferência ao credor de ações em valor equivalente às emitidas pela própria companhia (que também podem, por sua vez, resultar de um aumento de capital social lastreado nesse passivo a ser extinto). Aplicam-se, nessa hipótese, as disposições do Código Civil (arts. 356 a 359). No caso em referência, contudo, incidem as normas específicas da lei acionária, o que, por um lado, rebustece a certeza e a segurança jurídica envolvidas e, por outro, externa patentemente $^{455}$ o alinhamento potencial (cuja atualização será eventual) entre o debenturista e o interesse social: o titular da debênture não é acionista, mas a eventualidade de se tornar $^{456}$ é possível e disciplinada.

Portanto, também essa estrutura normativa favorece à intromissão dos debenturistas nas questões sociais previstas pelo art. 231 da Lei de Sociedades por Ações embora, por si, não a determine, já que a possibilidade é franqueada mesmo para os titulares de debêntures não conversíveis.

Outra razão - esta de ordem formal-jurídica - afigura-se plausível para justificar o tratamento legal próprio dispensado da Lei de Sociedades por Ações especificamente aos debenturistas. Muito embora, já se disse, os diversos títulos não percam sua individualidade, todos aqueles resultantes de uma mesma emissão lastreiam-se

\footnotetext{
${ }^{454}$ Ensina Luiz Gastão Pases de Barros LEÃES que as debêntures conversíveis em ação são títulos que, além de conferirem a seus titulares o direito de crédito (como sucede a qualquer debenturista), asseguram a eles também a eles o direito de as converter em ações do capital da companhia emissora e, assim, tornarem-se acionistas. Verificam-se, nesse caso, continua ele, negócios coligados, que se unem conquanto mantenham-se distintos. Acrescenta, ainda, que a "combinação desses diferentes esquemas negociais visa a dar mais atração a esses títulos, dando possibilidade, de um lado, aos debenturistas de se tornarem sócios da sociedade devedora (se a nova situação lhes convier), à vista dos resultados acusados pela mesma, e, de outro lado, à sociedade emissora de transformar capital de crédito em capital de risco." E conclui que "É esse o objetivo econômico complexo - o chamado equity kicker da prática norte-americana - que cria o liame de dependência entre os referidos negócios coligados." In: Debêntures Conversíveis em Ações, in Pareceres, v. 2, São Paulo, Singular, 2004, pp. 778-779.

${ }^{455}$ Numa relação que, em matéria de política legislativa, não se sabe se de causa ou de efeito.

${ }^{456}$ Que depende, naturalmente, da concorrência de um conjunto de eventos, como a previsão na escritura pública de emissão e o exercício da opção no termo fixado.
} 
na respectiva escritura ${ }^{457}$, que é condição de sua criação e que contém a disciplina própria que se aplicará a todas elas, uniformemente ou individualizada por classe (LSA: art. 53).

Assim, se as demais relações de crédito da companhia constituem-se difusamente, sem entrelaçamento causal e tampouco formal entre si - sem unidade, enfim -, os debenturistas encontram-se enfeixados por escritura de emissão e, ainda que conservando certa diferença nas estratificações em classes, aproximam-se muito mais daquilo que se poderia qualificar por interesses coletivos em sentido estrito (mesma relação jurídica base) ou, mesmo, individuais homogêneos (se fechado o foco de análise no âmbito de cada título). A homogeneidade decorrente dessa origem comum redunda em um paralelismo de interesses entre os debenturistas e é possível divisar um mecanismo orgânico e organizado de defesa "coletiva" de seus interesses.

A referência à disciplina societária dos debenturistas e de seu crédito merece destaque não apenas por esquadrinhar a relação de interesses diretamente envolvidos com as companhias, mas também porque, em certa medida - e não sem patentes imperfeições -, autoriza uma análise paralela, sempre sob a perspectiva da sociedade, com a disciplina dispensada aos credores na recuperação judicial.

As diferenças de toda ordem são radiculares e não permitem maior aproximação dos institutos, mas é possível verificar em ambos os casos uma tendência normativa de alinhar, tanto quanto possível, os interesses, em princípio contrapostos, entre os credores e o devedor e de franquear àqueles primeiros imiscuir-se nos assuntos interna corporis, para salvaguardar seu interesse egoístico na satisfação do crédito.

\subsubsection{Os órgãos administrativos}

A descrição das funções exercidas pelos órgãos de administração já teve lugar precedentemente. Importa aqui fazer referência à estrutura contemplada pela Lei n. ${ }^{\text {o }}$ 6.404/76 e ao desempenho, por ela, dessas funções.

A opção do legislador brasileiro pelo sistema dual (ou dualista), de

\footnotetext{
${ }^{457}$ Não é o caso de se aprofundar nos debates acerca da natureza jurídica das debêntures, mas não se pode deixar de pôr em relevo a vinculação intrínseca entre todos (e cada um dos) títulos e a escritura pública de emissão. Sobre esse assunto, escreveu Fran MARTINs: “A emissão de debêntures, no sentido de serem as mesas colocadas no mercado, tem a natureza de uma oferta pública, feita pela sociedade para o aperfeiçoamento de um contrato de mútuo. O empréstimo é um só, cada debênture ou título representando uma parcela do mesmo, tornando-se o debenturista, ao subscrever ou adquirir as debêntures, um credor da sociedade. ” In: Comentários à Lei das Sociedades Anônimas, v. 1, Rio de Janeiro, Forense, 1977, p. 314.
} 
tradição alemã, em detrimento daquele outro até então adotado, o monista, originado na França $^{458}$ - embora facultativo em alguns $\operatorname{casos}^{459}$-, oferece solução mais adequada e eficiente ao exercício das funções de administração, particularmente nas companhias mais complexas. Ela separa em órgãos diferentes as atribuições de gestão (execução e representação) e de supervisão e tomada de decisões estratégicas ${ }^{460}$.

Entre os órgãos deliberativo que reúne os acionistas (assembleia geral) e aquele que implementa a gestão (diretoria), antepõe-se um terceiro órgão (conselho de administração), intermediário ${ }^{461}$, que, bem menos complexo que as assembleias, mas também adstrito à persecução dos interesses dos sócios ${ }^{462}$ e 463 e sociais ${ }^{464}$, tem, por um lado, instrumentos aptos (eleição e destituição dos diretores, fiscalização da gestão e exame de documentos, livros contratos etc.) e, por outro, agilidade institucional ${ }^{465}$ suficiente para eleger os membros da diretoria, fixar as políticas e supervisionar sua implementação e o alcance de resultados ${ }^{466}$.

\footnotetext{
458 Breve descrição do regime da revogada Lei de Sociedades por Ações: “Anteriormente, seguíamos a orientação de que a sociedade anônima seria administrada por uma diretoria, com poderes não apenas para orientar os negócios sociais como para praticar os atos de gestão propriamente ditos, cabendo a cada diretor as atribuições que fossem conferidas pelos estatutos (Decreto-Lei $n .^{\circ}$ 2.627, art. 116). Funcionava, assim, a diretoria com o único órgão administrativo da sociedade, podendo as suas deliberações ser tomadas de forma colegiada mas cada diretor tendo atribuições próprias, fixadas no estatuto (Decreto-lei $n^{\circ}{ }^{o}$ 2.627, art. 116, § 1. ${ }^{\circ}$, e).” Cf. Fran MARTins, Comentários à Lei das Sociedades Anônimas, v. 1, Rio de Janeiro, Forense, 1977, pp. 268-269.

459 Apenas são obrigadas a ter conselho de administração as companhias abertas e as de capital autorizado (LSA: art. 138, $\S 2^{\circ}$ ) e, ainda, as sociedades de economia mista (art. 239).

${ }^{460}$ Marcelo Vieira von ADAMEK, Responsabilidade Civil dos Administradores de S/A e as Ações Correlatas, São Paulo, Saraiva, 2009, p. 18.

461 Adriano Castello BRANCO, O Conselho de Administração nas Sociedades Anônimas, Rio de Janeiro, Forense Universitária, 2004, p. 24

462 Os integrantes do conselho de administração devem refletir, tanto quanto possível, a variedade de perfis dos acionistas. Para tanto, a Lei n. ${ }^{\circ}$ 6.404/76 prevê algumas regras procedimentais de eleição de seus membros (como a adoção do voto múltiplo - art. 141) e garantia de membros representativos de minoritários de companhias abertas (art. 141, $\S 4^{\circ}$, inc. I), dos preferencialistas (art. 141, $\S 4^{\circ}$, inc. II) ou deles em conjunto $\left(\S 5^{\circ}\right)$.

${ }^{463}$ A Lei n. ${ }^{\circ} 10.303 / 01$ acrescentou o parágrafo único ao art. 140 da Lei n. ${ }^{\circ}$ 6.404/76, que permite a participação no conselho de um representante dos empregados, "escolhidos pelo voto destes, em eleição direta, organizada pela empresa, em conjunto com as entidades sindicais que os representem”. Além disso, a Lei n. ${ }^{\circ}$ 12.353/10 tornou obrigatória essa representação nas empresas públicas e sociedades de economias mistas federais. Trata-se de tendência originada na Alemanha (cf. Paulo Fernando Campos Salles de TOLEDO, Modificações Introduzidas na Lei das Sociedades por Ações quanto à Disciplina da Administração das Companhias, in Reforma da Lei das Sociedades Anônimas: Inovações e Questões Controvertidas da Lei $n^{\circ}$ 10.303, de 31.10.2001, coord. Jorge Lobo - Antonio Kandir, Rio de Janeiro, Forense, 2002, p. 431) e que procura "internalizar interesses aparentemente externos" e, nesse caso específico, visa a "propiciar para o empregado maio influência na gestão” (cf. Adriano Castello BRANCO, O Conselho de Administração nas Sociedades Anônimas, Rio de Janeiro, Forense Universitária, 2004, pp. 33 e 35).

${ }^{464}$ Já não se faz necessário seus membros sejam acionistas (LSA: art. 146, conforme redação conferida pela Lei n. ${ }^{\circ}$ 12.431/11), mas eles são eleitos e destituídos pela assembleia geral (art. 140).

${ }^{465}$ Composto por muito menos membros; suas convocações são substancialmente menos custosas, bem assim suas instalações etc.

${ }_{466}$ As atribuições do conselho de administração, destarte, afastam o acionista das decisões estratégicas e coloca os diretores na condição de executores das deliberações do conselho. Cf. Marcelo Vieira von
} 
O conselho de administração é órgão plural ${ }^{467}$ de funcionamento colegiado $^{468}$, deliberando, em regra, por maioria de $\operatorname{votos}^{469}$ (LSA: art. 140, inc. IV), adotado o sistema de voto por cabeça. Ele não tem poder de representação ${ }^{470}$ e seus membros, eleitos para o cumprimento de mandato ${ }^{471}$ pela assembleia de acionistas e também por ela e destituídos, não podem delegar suas atribuições a outrem ou fazerem-se substituir por procurador ${ }^{472}$.

Por sua deliberação majoritária e por sua composição determinada pela assembleia de acionistas, o conselho é considerado "instância societária de consolidação do poder do controlador", podendo seus membros ser parte em acordo de acionistas para vinculação de sua atuação no órgão da administração (LSA: art. 118, §§ $8^{\circ}$ e $9^{\text {o473}}$ ).

Já a diretoria é órgão obrigatório, incumbido da representação da companhia ("administração externa", também dita presentação, pois que a exteriorização da vontade social e o poder de vincular a sociedade decorrem de suas funções orgânicas, e não de negócio jurídico de mandato) e gestão (“administração interna”), consistente na condução dos negócios e execução de atos necessários ao exercício da atividade-objeto social.

Se bem que plural ${ }^{474}$ e de funcionamento simultâneo, não é, em princípio, órgão colegial, mas disjunto: cada diretor pode exercer autonomamente as atribuições do

ADAmeK, Responsabilidade Civil dos Administradores de S/A e as Ações Correlatas, São Paulo, Saraiva, 2009, p. 21.

${ }^{467}$ No mínimo três (LSA: art. 140, caput), sempre pessoas naturais, acionistas ou não (LSA: art. 146, conforme redação conferida pela Lei n. ${ }^{\circ} 12.431 / 11$ ), residentes ou não no país (art. 146 , $\S 2^{\circ}$ ), sendo o máximo fixado pelo estatuto (art. 140, inc. I).

${ }^{468}$ Essa característica já evidencia claramente a feição "normativa" (de fixação de orientação geral dos negócios) e não executiva do órgão. Cf. Adriano Castello BRANCO, O Conselho de Administração nas Sociedades Anônimas, Rio de Janeiro, Forense Universitária, 2004, p. 25. Registre-se, ainda sobre o caráter colegial do conselho de administração, a ausência de fixação pela lei de atribuições individuais (cf. Marcelo Vieira von ADAMEK, Responsabilidade Civil dos Administradores de S/A e as Ações Correlatas, São Paulo, Saraiva, 2009, p. 22).

${ }^{469}$ Isto é, maioria simples dos presentes, instalada a reunião validamente nos termos definidos pelo estatuto social (LSA: art. 140, inc. IV).

${ }^{470}$ Marcelo Vieira von ADAMEK, Responsabilidade Civil dos Administradores de S/A e as Ações Correlatas, São Paulo, Saraiva, 2009, p. 22.

${ }^{471}$ Nunca superior a três anos, permitida a reeleição (LSA: art. 140, inc. III).

472 Marcelo Vieira von ADAMEK, Responsabilidade Civil dos Administradores de S/A e as Ações Correlatas, São Paulo, Saraiva, 2009, p. 21.

${ }^{473}$ Em que pesem as críticas contrárias à opção feita pelo legislador, que reduz a independência do membro do conselho de administração - na contramão das "boas práticas" de governança corporativa. Cf. Paulo Fernando Campos Salles de TOLEDO, Modificações Introduzidas na Lei das Sociedades por Ações quanto à Disciplina da Administração das Companhias, in Reforma da Lei das Sociedades Anônimas: Inovações e Questões Controvertidas da Lei ${ }^{\circ}{ }^{\circ} 10.303$, de 31.10.2001, coord. Jorge Lobo - Antonio Kandir, Rio de Janeiro, Forense, 2002, p. 427: “Todos esses fatores, no entanto - sinais explícitos de modernidade - foram desconsiderados pelo legislador no ponto em que introduziu, no art. 118 da Lei de Sociedades por Ações, os $\S \S 8^{\circ}$ e 9."

474 No mínimo, haverá dois diretores (LSA: art. 143), sempre pessoas naturais. 
órgão (LSA: art. 144). Contudo, o estatuto ou o conselho de administração poderão restringir a matéria de competência específica de cada diretor (LSA: art. 144, $1^{\text {a }}$ parte, $a$ contrario sensu), bem como exigir que determinados atos sejam realizados exclusivamente por certo membro ou dependa da concorrência de um certo número de diretores ou especificamente de alguns deles (ato conjunto) ${ }^{475}$. Ainda é possível que certas decisões estatutariamente definidas sejam submetidas à deliberação colegiada do órgão, que, então, funcionará de maneira colegial ${ }^{476}$.

Também aos diretores é vedado fazerem-se substituir; contudo, a companhia pode, mediante, naturalmente, os membros da diretoria, constituir procuradores, definidos no instrumento os poderes e o prazo (salvo, se judicial - LSA: art. 144, parágrafo único).

Seus membros são eleitos e destituídos pelo conselho de administração ou, não existindo, pela assembleia de acionistas. Para preservar da distinção entre os órgãos administrativos, e como medida de implementação de boas práticas no governo da companhia, a Lei n. ${ }^{\circ}$ 6.404/76 veda que mais de um terço dos membros do conselho sejam concomitantemente integrantes da diretoria $\left(\operatorname{art} .143, \S 1^{\circ}\right)$.

Registre-se, por fim, a possibilidade de o estatuto criar outros órgãos de administração, aos quais, contudo, não será lícito delegar as atribuições privativas dos órgãos legais (LSA: arts. 122, 139 e 163, § $7^{\circ}$ ). Eles deverão ter apenas funções técnicas ou consultivas $^{477}$.

\subsubsection{Os órgãos de fiscalização}

O conselho fiscal é órgão de existência obrigatória (deve, pois, indeclinavelmente ser previsto e disciplinado pelo estatuto ${ }^{478}$ ), mas seu funcionamento pode ser permanente ou eventual, conforme a eleição para os membros do órgão deva

\footnotetext{
475 José Edwaldo Tavares BoRBA, Direito Societário, Rio de Janeiro, Renovar, 2010, p. 405.

476 Ou seja: embora em princípio, não seja órgão colegial, algumas "decisões” podem submeter-se a esse sistema. Nessa hipótese, o estatuto determinará os quóruns de instalação e de deliberação (cf. José Edwaldo Tavares BorbA, Direito Societário, Rio de Janeiro, Renovar, 2010, p. 405).

${ }^{477}$ Marcelo Vieira von ADAMEK, Responsabilidade Civil dos Administradores de S/A e as Ações Correlatas, São Paulo, Saraiva, 2009, p. 26.

${ }^{478}$ Fabio Ulhoa COELHO afirma que, por força do caráter obrigatório, a existência do conselho fiscal não está condicionada à previsão estatutária e, portanto, "o conselho fiscal existe, esmo que omisso o estatuto". In: Curso de Direito Comercial - Direito de Empresa, v. 2, São Paulo, Saraiva, 2012, p. 257.
} 
ocorrer sempre (intermitentemente) ou apenas quando solicitado pelos acionistas ${ }^{479}$. No primeiro caso, encontram-se as sociedades de economia mista (LSA: art. 240) e aquelas que têm previsão estatuária nesse sentido (art. 161).

Em sendo eventual, o pedido de funcionamento do conselho fiscal pode ser feito em qualquer assembleia geral de acionistas, mesmo que a matéria não figure da ordem do dia do instrumento convocatório (LSA: art. 161, $\S 3^{\circ}$ ). Isso reflete claramente a preocupação do legislador com a efetiva atuação desse órgão. Tal pedido pode ser formulado por acionistas representativos de dez por cento do capital votante ou de cinco por cento das ações sem direito de voto $\left(\S 2^{\circ}\right)$.

Seus membros são, conforme dispuser o estatuto, de três a cinco, sempre ocupados por pessoas naturais. A Lei n. ${ }^{\circ}$ 6.404/76 reserva a eleição de um membro aos preferencialistas sem direito de voto ou com esse direito restrito e a eleição de outro membro aos acionistas minoritários representativos de, no mínimo, dez por cento do capital votante (art. 161, $\S 4^{\circ}$ ).

O exercício da fiscalização pelo conselho tem uma função de assessoramento da assembleia geral, naquelas deliberações a respeito da regularidade da administração da companhia ${ }^{480}$. Seu parecer acerca dos atos submetidos à sua fiscalização não é vinculativo da assembleia, mas tem caráter estritamente opinativo ${ }^{481}$.

A par do conselho fiscal, previsto pela lei (e obrigatoriamente pelo estatuto), podem ser constituídos outros órgãos de fiscalização, como é o caso das auditoras independentes $^{482}$ - que são obrigatórias nas companhias abertas (LSA: art. 177).

(e deve sê-lo nas sociedades de economia mista - LSA: art. 240) ou eventual. Assim, os cargos do órgão devem ou podem ser ocupados.

\subsection{Interesse social}

Investigar o interesse social, como ensina Pier Giusto JEAGER, é

479 "Se os acionistas, porém, reputam desnecessário o funcionamento do órgão, como instrumento auxiliar na fiscalização dos administradores, eles simplesmente não elegem os conselheiros.” Cf. Fabio Ulhoa Coelho, Curso de Direito Comercial - Direito de Empresa, v. 2, São Paulo, Saraiva, 2012, pp. 257-258.

${ }^{480}$ Fabio Ulhoa Coelho, Curso de Direito Comercial-Direito de Empresa, v. 2, São Paulo, Saraiva, 2012, p. 257.

${ }_{481}$ José Edwaldo Tavares BoRBA, Direito Societário, Rio de Janeiro, Renovar, 2010, p. 425.

482 Após registrar o desprestígio histórico dos conselhos fiscais, ele observa um movimento paralelo de afirmação dessas auditorias independentes. Cf. José Edwaldo Tavares BoRBA, Direito Societário, Rio de Janeiro, Renovar, 2010, p. 429. 
perscrutar sobre o "problema fundamental" da sociedade por ações. Convém, contudo, e ainda estribado nos ensinamentos do autor italiano, esclarecer preliminarmente o exato sentido do primeiro elemento da expressão ${ }^{483}$.

\subsection{1. "Interesse"}

E, quanto à noção de interesse, a fonte em que se haure a lição é ainda hoje o perene magistério de Francesco CARNELUTTI. Ensina ele que interesse é a "relação existente entre um sujeito, que possui uma necessidade, e o bem apto a satisfazê-lo, determinada na previsão geral e abstrata de uma norma" ${ }^{\text {484 }}$. O interesse, portanto, é uma relação estabelecida entre um sujeito que tem uma determinada necessidade e um bem que é apto a atender a tal necessidade ${ }^{485}$ e 486 . Orlando de CARVALHO, em sentido próximo, define interesse como "o produto do confronto da necessidade com o bem jurídico (em sentido amplo, de coisa ou serviço), traduzindo-se em se julgar esse bem idóneo para para satisfazer aquela necessidade (...). O interesse é o condutor da acção, o catalizador, digamos assim, no meio a utilizar. "487 A relevância jurídica do interesse é tão manifesta que, não é ocioso relembrar, já houve quem nele visse a própria noção de direito subjetivo.

Em relação à noção de interesse, Pier Giusto JAEGER distingue dois termos avizinhados. Por escopo (scopo), refere-se ele à "soddifazione del bisogno, proprio del titolare dell 'interesse, che il bene (oggetto dell 'interesse stesso) è idoneo a realizzare”. A satisfação em si mesma não é objeto de proteção jurídica, afirma o autor, mas apenas os meios com os quais ela pode e deve ser perseguida. Já motivo, o segundo termo, estriba-se no conceito de valoração (valutazione), que é um juízo emitido pelo sujeito sobre uma situação concreta; quando essa valoração determina ou contribui para determinar a vontade do sujeito que vem a realizar uma determinada ação, ela é chamada motivo.

\footnotetext{
483 "Contribuisce non poço, a nostro avviso, ad aggravare le difficoltà del problema la mancanza di um'intesa preliminare circa il significato da attribuire alla nozione di interesse, che la maggioranza degli autori sempre dare per presupposta...”. In: Pier Giusto JEAGER, L’interesse social, Milão, Giuffré, 1972, p.3. ${ }^{484}$ Apud Erasmo Valladão A. e N. FrAnçA, Conflito de Interesses nas Assembleias de S.A., São Paulo, Malheiros, 1993, pp. 15-16. Exatamente a mesma definição é dada por Pier Giusto JEAGER: "Per interesse intendiamo la relazione tra um soggetto, cui fa capo um bisogno, e il bene idôneo a soddisfare tale bisogno, determinata nella previsione generale ed astratta di uma norma." In: L'interesse social, Milão, Giuffré, 1972 , p.3.

${ }^{485}$ Alfredo RocCo faz uma precisão ainda maior. Para este, utilidade é aptidão da coisa a satisfazer a necessidade de alguém (e é bem tudo aquilo que satisfaz a necessidade de alguém); trata-se, pois, de uma noção objetiva. Já interesse é o juízo emitido pelo sujeito de uma necessidade sobre a aptidão do bem para satisfazer tal necessidade. Apud Pier Giusto JAEGER, L'interesse sociale, Milão, Giuffré, 1972, p.3, n. 4.

${ }^{486}$ L'interesse sociale, Milão, Giuffré, 1972, pp. 4-5.

487 Apud Jorge Manuel Coutinho DE ABReu, Do Abuso de Direito - Ensaio sobre um Critério em Direito Civil e nas Deliberações Sociais, Coimbra, Almedina, 1999, p. 120, n. 271.
} 
Tendo em vista a multiplicidade de interesses e de sujeitos de direito convivendo em um mesmo ambiente jurídico, duas hipóteses apresentam-se possíveis: que uma mesma pessoa seja titular de mais de um interesse e que diversos sujeitos tenham o mesmo interesse.

Na primeira hipótese, os interesses podem manter entre si relações de indiferença ou de relevância e, neste último caso, as relações relevantes podem consistir em instrumentalidade ou em incompatibilidade, que é o próprio conflito (in casu, intrasubjetivo) de interesses.

Tais relações, por se referirem ao mesmo sujeito (são intrasubjetivas e, portanto, não alcança um terceiro), apresentam pouca relevância jurídica ${ }^{488}$ : seus efeitos restringem-se a esse sujeito e eventual contraste é resolvido no foro íntimo dele, “determinando a prevalenza di un motivo sull'altro" "489. Sua delimitação, contudo, é de franca utilidade para a compreensão das situações análogas em caso de relações intersubjetivas, em que a ordem jurídica é chamada a intervir.

Assim é que, quando a satisfação de uma necessidade não é prejudicada (não sofre interferência) pela satisfação de outra necessidade, então um interesse é indiferente ao outro. Se a satisfação de uma determinada necessidade é o que torna possível a satisfação de uma segunda necessidade, fica claro que entre os interesses há relação de instrumentalidade: o primeiro é instrumento para o alcance do segundo ${ }^{490}$. Os interesses são incompatíveis (fala-se, ainda, em interesses em conflito), por sua vez, quando a satisfação de uma necessidade do sujeito impede a satisfação de outra necessidade dessa mesma pessoa ${ }^{491}$.

Na segunda das hipóteses acima aventadas, diferentemente da primeira, as relações entre os interesses revelam importância jurídica - ressalvada a de indiferença, em que os interesses podem conviver paralelamente, sem mútua interferência ${ }^{492}-$, porquanto ultrapassam os limites da intrasujetividade para alcançar a intersubjetividade.

\footnotetext{
${ }^{488}$ Pier Giusto JAEGER, L'interesse sociale, Milão, Giuffré, 1972, p. 7.

${ }^{489}$ Pier Giusto JAEGER, L'interesse sociale, Milão, Giuffré, 1972, p. 8.

${ }^{490}$ Erasmo Valladão A. e N. FRANÇA cita exemplos dados por Francesco CARNELUTTI: "se um homem não comeu e, assim, não restaurou suas forças, não consegue construir sua casa”. Assim a satisfação do interesse sobre a comida é instrumento para a satisfação do interesse que recai sobre a construção: sem o primeiro, não se obtém o segundo. Outro exemplo: "para comer, o homem deve primeiro procurar o alimento e para construir a casa, deve procurar os materiais". Vislumbra-se, nesse caso, que o atendimento a uma necessidade depende da "conquista de posições sucessivas", o que permite falar-se em interesses mediatos e imediatos. In: Conflito de Interesses nas Assembleias de S.A., São Paulo, Malheiros, 1993, p. 17. ${ }^{491}$ Para todas essas distinções, veja-se: Pier Giusto JAEGER, L'interesse sociale, Milão, Giuffré, 1972, p. 7. 492 Erasmo Valladão A. e N. FrAnÇA, Conflito de Interesses nas Assembleias de S.A., São Paulo, Malheiros, 1993, p. 17.
} 
É possível, desse modo, que um determinado bem não seja apto a satisfazer a necessidade de mais de um sujeito ou, ao menos, não a satisfazer inteiramente. Nesse caso, sucede interferência entre os interesses relativos àquela necessidade. Trata-se aqui de conflito de interesses (ou incompatibilidade), que pode consistir em incompatibilidade absoluta, caso a satisfação da necessidade de um sujeito impeça a satisfação, mesmo que parcial, da do outro ou em incompatibilidade relativa, se a necessidade de um sujeito é atendida pelo menos parcialmente.

Ainda no campo da intersubjetividade dos interesses, destacam-se as relações de instrumentalidade, em que se dá algo diverso do verificado anteriormente: a identidade de interesses não determina o conflito entre eles, mas, ao contrário, acarreta colaboração entre seus titulares. Isso, porque, nesse caso, o bem torna-se apto a satisfazer a necessidade de todos, mas apenas na hipótese de haver colaboração entre os agentes. Ou por outra: essa mútua colaboração permite alcançar o bem, que satisfará a todos e que de outro modo (sem o concurso dos interessados) não seria obtido. Sobre o assunto, escreveu Francesco CARNELUTTI que “un bisogno dell'uno non può essere soddisfatto se non sia soddisfatto il bisogno dell'altro; allora, la probabibilità del soddisfacimento di um bisogno si determina insieme rispetto al'uno e rispetto all'altro ${ }^{~} 493$.

E conclui Pier Giusto JEAGER que a expressão interesse coletivo outro sentido não tem senão o de enunciar essa solidariedade de interesses ${ }^{494}$. Observa ele mesmo, em acréscimo, que o interesse coletivo não é uma soma de interesses individuais, pois que conceitos não são homogêneos. Interesse coletivo, entende ele, exprime relação entre interesses de diversos sujeitos, e não uma 'qualidade' do interesse. Contrapõe-se, assim, não a interesse individual, mas aos conceitos de conflito de interesses e de indiferença entre os interesses ${ }^{495}$.

Essa comunhão de interesses permite, segundo Francesco CARNELUTTI, como já anotado no princípio desse capítulo, a formação de qualquer grupo social (família, associações, sociedades empresariais, sindicatos e o próprio Estado) e também sua organização, da qual deriva a criação de órgãos ${ }^{496}$. É certo, desse modo, que todo fenômeno associativo deriva de um interesse coletivo, mas, dada sua variedade e o vasto espectro de maneiras pelas quais tais fenômenos se articulam, Pier Giusto JEAGER julga

\footnotetext{
${ }^{493}$ Apud Pier Giusto JAEGER, L’interesse sociale, Milão, Giuffré, 1972, pp. 8-9.

${ }^{494}$ L'interesse sociale, Milão, Giuffré, 1972, p. 9.

${ }^{495}$ L'interesse sociale, Milão, Giuffré, 1972, pp. 9-10.

${ }^{496}$ Erasmo Valladão A. e N. FrANÇA, Conflito de Interesses nas Assembleias de S.A., São Paulo, Malheiros, 1993, p. 18.
} 
necessária uma precisão ainda maior.

Escrevendo no início da década de 1970, ele reparte os interesses coletivos em interesses de grupo e interesses de série. A diferença não está na quantidade de titulares (sujeitos), mas na exata limitação ou não deles. Na primeira espécie (intereressi di gruppo) estão os interesses cujos titulares formam uma pluralidade fechada, determinada, finita, sejam eles em baixo número ou numerosos, mas sempre exatamente identificáveis. Já os interessi di serie compreendem um número não finito de interesses, incluindo-se entre os titulares todos aqueles que, a qualquer momento, tenha uma determinada relação. Destarte, enquanto a primeira espécie reúne apenas sujeitos contemporâneos entre si, a segunda "si proietta nel tempo, e abbraccia individui viventi in momenti diversi ${ }^{, 497}$.

Por força dessa diferença, cada espécie recebe uma disciplina jurídica própria. No interesse de grupo, que é mais facilmente identificável, o legislador pode deixar aos próprios titulares a satisfação desse interesse, uma vez que, para o alcance desse escopo, os integrantes promovem uma organização, da qual todos, direta ou indiretamente, participam. Nesse caso, a intervenção da ordem jurídica apenas se justifica quando surge conflito entre eles ou quando o interesse coletivo conflita-se com interesses de sujeitos estranhos ao grupo.

Muito diferente, ainda segundo a lição de JEAGER, é a tutela jurídica dispensada aos interessi di serie. Por sua generalidade, cada interesse dessa natureza interfere no interesse da coletividade dos cidadãos, o que reclama intervenção da ordem jurídica estatal e atuação de seus órgãos. Ademais, não fosse assim, esses interesses de série restariam sem tutela, dada a inação dos titulares, que não logram organizar-se para $\operatorname{tanto}^{498}$.

Essa temática encontrou eco entre nós, especialmente após a promulgação da Lei da Ação Civil Pública (Lei n. ${ }^{\circ}$ 7.347/85) e do Código de Defesa do Consumidor (Lei n. ${ }^{\circ}$ 8.078/90). Esses diplomas legais, em conjunto, dispensaram um tratamento sistemático aos "direitos" coletivos, que até então não encontravam respaldo no

\footnotetext{
${ }^{497}$ L'interesse sociale, Milão, Giuffré, 1972, p. 10. Cf. também Erasmo Valladão A. e N. FrANÇA, Conflito de Interesses nas Assembleias de S.A., São Paulo, Malheiros, 1993, p. 19, n. 12.

498 Pier Giusto JAEGER explica que essa inação decorre do fato de que, no momento da satisfação da necessidade, ou os titulares são desconhecidos ou simplesmente não existem (naquele momento). Cf: "Invece la valuazione e l'attuazione degli interessi di serie non può essere abbandonata senza cautele ai titolari di essi, perchè cosi rimarrebbero privi di tutela i soggetti i quali, o perchè sconosciuti nel momento in cui la valutazione viene compiuta, o perchè addirittura non esistenti, non potrebbero parteciparvi." In: L'interesse sociale, Milão, Giuffré, 1972, p. 11.
} 
ordenamento positivo brasileiro.

Por interesses coletivos, segundo a doutrina pátria, entendem-se aqueles de natureza transindividual (ou metaindividual ${ }^{499}$ ) e objeto indivisível ${ }^{500}$. Assim se qualifica o objeto (aspecto objetivo dos interesses coletivos), porque apenas nessa condição ele se encontra apto a satisfazer todas as necessidades que sobre ele recaem. Em outras palavras, sua divisibilidade implica a inexorável incapacidade de ele atender aos interesses a ele dirigidos. Na unicidade do objeto encontram unidade os interesses envolvidos.

Em seu aspecto subjetivo, os interesses coletivos têm natureza transindividual, porque estabelecem relação não entre o objeto e uma ou algumas pessoas determinadas, mas entre o objeto e um "número expressivo" delas ${ }^{501}$. Não são, portanto, um liame que tem em um dos polos uma determinada pessoa (ou algumas delas), mas um conjunto (determinado ou não) de pessoas efetiva ou potencialmente numerosas. Não há uma quantidade mínima, está claro - mesmo porque sua qualificação resulta da natureza de sua estrutura e não do número de titulares (que, embora alto em potência, pode ser baixo no caso concreto).

A vigente disciplina legal, em particular o art. 81 do $\mathrm{CDC}^{502}$, divide os interesses coletivos em três categorias, a saber, os interesses difusos, os coletivos em sentido estrito e, ainda, os individuais homogêneos.

As duas primeiras categorias diferenciam-se, entre si, em razão de os interesses difusos serem de titularidade de um conjunto indeterminado de pessoas que se ligam por circunstâncias de fato - e não por uma relação jurídica de base. Não há, por isso - no apurado sentido que ensina Pier Giusto JAEGER quanto aos interessi di serie -, como se precisar com exatidão que pessoas são os titulares. É o caso do interesse ao meio

\footnotetext{
${ }^{499}$ Roberto Senise LisBOA, Contratos Difusos e Coletivos, São Paulo, RT, 1997, p. 55. Fala-se ainda em supraindividual (cf. Fredie DiDIER JR. - Hermes ZANETTI JR., Curso de Processo Civil - Processo Coletivo, v. 4, Salvador, Juspodium, 2009, p. 74.)

${ }^{500}$ Roberto Senise LiSBOA, Contratos Difusos e Coletivos, São Paulo, RT, 1997, p. 58: "O interesse coletivo é de natureza transindividual e objeto indivisivel, verificando-se a titularidade coletiva do direito, por meio da comunhão, e do bem, através do condomínio."

${ }_{501}$ Roberto Senise LISBOA, Contratos Difusos e Coletivos, São Paulo, RT, 1997, p. 55.

502 "Art. 81. A defesa dos interesses e direitos dos consumidores e das vítimas poderá ser exercida em juízo individualmente, ou a título coletivo.

Parágrafo único. A defesa coletiva será exercida quando se tratar de:

I - interesses ou direitos difusos, assim entendidos, para efeitos deste código, os transindividuais, de natureza indivisível, de que sejam titulares pessoas indeterminadas e ligadas por circunstâncias de fato; II - interesses ou direitos coletivos, assim entendidos, para efeitos deste código, os transindividuais, de natureza indivisivel de que seja titular grupo, categoria ou classe de pessoas ligadas entre si ou com a parte contrária por uma relação jurídica base;

III - interesses ou direitos individuais homogêneos, assim entendidos os decorrentes de origem comum."
} 
ambiente equilibrado (assegurado pela Constituição da República: art. $225^{503}$ ), que, por disposição constitucional, é de titularidade de todos, nada obstante tais titulares não se encontrem vinculados por uma relação jurídica, mas por uma circunstância fática. Outro exemplo recorrente, no direito do consumidor, é o comando proibitivo de publicidade enganosa ou abusiva ${ }^{504}$.

Nesse exemplo ilustrativo, ensina Kazuo Watanabe que se podem vislumbrar claramente as duas notas características desse interesse. Com efeito, essa publicidade veiculada pelos meios comunicação pode atingir um número indeterminado de pessoas - potenciais consumidores, não são passíveis de se identificarem individualmente, que não se acham "vinculados entre si por qualquer relação-base „505, 506 e 507 . Outrossim a indivisibilidade do objeto resta evidenciada com singular clareza: "pois uma única ofensa é suficiente para a lesão de todos os consumidores, e igualmente a satisfação de um deles, peal retirada do produto do mercado, beneficia ao mesmo tempo todos eles. „508

Por essas características fundamentais, a tutela desse tipo de interesse deve ser levada a efeito, nas palavras de Kazuo WATANABE, "molecularmente", isto é, em benefício de todo o conjunto indeterminado de pessoas - e não de maneira atomizada,

\footnotetext{
503 “Art. 225. Todos têm direito ao meio ambiente ecologicamente equilibrado, bem de uso comum do povo e essencial à sadia qualidade de vida, impondo-se ao Poder Público e à coletividade o dever de defendê-lo e preservá- lo para as presentes e futuras gerações." Note-se que, no dispositivo constitucional, está clara aquela noção exposta por Pier Giusto JAEGER (op. cit., p. 10) de que interessi di serie protraem-se no tempo e abarcam indivíduos que vivem em momentos diversos. Seria, pois, um interesse não apenas intersujetivo (ou transindividual), mas também intergeracional.

${ }^{504}$ Fredie Didier JR. - Hermes ZanetTi JR., Curso de Processo Civil - Processo Coletivo, v. 4, Salvador, Juspodium, 2009, p. 74.

505 Comentários aos artigos 80 e 81, in AA.VV., Código de Defesa do Consumidor Comentado pelos Autores do Anteprojeto, Rio de Janeiro, Forense Universitária, 2007, p. 821.

${ }^{506} \mathrm{Na}$ verdade, é mais preciso afirmar-se que inexiste relação-base anterior à lesão, pois que a lesão faz nascer uma relação jurídica da qual os lesados, determináveis ou não, são titulares. O próprio Kazuo WATANABE, ao tratar dos interesses coletivos em sentido estrito (em que, ao contrário do que sucede nos difusos, existe uma relação jurídica-base), preleciona: "Essa relação jurídica-base [nos interesses coletivos stricto sensu] é a preexistente à lesão ou ameaça de lesão do interesse ou direito do grupo, categoria ou classe de pessoas. Não a relação jurídica nascida da própria lesão ou da ameaça de lesão." (Cf. Comentários aos artigos 80 e 81, in AA.VV., Código de Defesa do Consumidor Comentado pelos Autores do Anteprojeto, Rio de Janeiro, Forense Universitária, 2007, p. 822). E, voltando aos direitos difusos, cogitando da hipótese de efetiva lesão, o mesmo autor enuncia: "Esses mesmos fatos - publicidade enganosa e colocação no mercado e produtos com alto grau de nocividade ou periculosidade à saúde ou segurança dos consumidores - podem repercutir, em termos de lesão específica, na esfera jurídica de consumidores determinados. Nessa perspectiva, estaremos diante de ofensa a interesse ou direitos individuais. Se varais forem as vítimas, teremos então os chamados interesses ou direitos individuais homogêneos." (p. 821). E, portanto, já então haverá relação jurídica (comum aos atingidos).

507 Ainda sobre a relação-base, o mesmo autor observa: "É claro que, num plano mais geral do fenômeno jurídico em análise, é sempre possível encontrar-se um vínculo que une as pessoas, como a nacionalidade. Mas a relação jurídica base que nos interessa, na fixação dos conceitos em estudo, é aquela da qual é derivado o interesse tutelado, portanto itneresse que guarda relação mais imediata e próxima com a lesão ou ameaça de lesão." In: Comentários aos artigos 80 e 81, in AA.VV., Código de Defesa do Consumidor Comentado pelos Autores do Anteprojeto, Rio de Janeiro, Forense Universitária, 2007, p. 823.

${ }^{508}$ Comentários aos artigos 80 e 81, in AA.VV., Código de Defesa do Consumidor Comentado pelos Autores do Anteprojeto, Rio de Janeiro, Forense Universitária, 2007, p. 821.
} 
quanto a cada pessoa envolvida. Por isso, afirmamos nós, em geral essa proteção depende atuação dos órgãos estatais ou outros, de natureza coletiva, legitimados legalmente (CR: art. 23, incs. VI e VIII; art. 129, inc. III; CDC: art. 55).

Já os interesses coletivos em sentido estrito, que são igualmente transindividuais e indivisíveis. Pertencem, no entanto, não a um conjunto indeterminado de pessoas ligadas por circunstâncias fáticas, mas a um grupo, categoria ou classe de pessoas ligadas entre si por uma relação jurídica de base (primeira modalidade) ou, ainda, reunidas em razão de, também com fundamento em uma "relação jurídica de base", terem parte contrária comum (segunda modalidade). É possível, nesse caso, delimitar aqueles que integram tal grupo (categoria ou classe): embora tais pessoas possam ser indeterminadas, serão ao menos determináveis ${ }^{509}$.

A relação-base, observa-se, é preexistente a eventual lesão ou ameaça de lesão que reclame tutela jurídica. E, como anota Kazuo WatanABE, "Não se pode confundir essa relação jurídica base preexistente com a relação jurídica originária da lesão ou ameaça de lesão. "510 Tal relação, como visto, e conforme a modalidade do interesse coletivo stricto sensu, tanto pode agregar os titulares entre si como pode vinculálos a uma contraparte comum.

É essa relação-base comum o elemento característico do interesse, que lhe confere identidade e unidade - e não eventual "organização", que, quando ocorre, tem lugar apenas na primeira das duas modalidades ${ }^{511}$. É por essa relação-base que permite a determinação das pessoas titulares.

Por fim, há os interesses individuais homogêneos, uma novidade introduzida no ordenamento jurídico brasileiro pelo Código de Defesa do Consumidor ${ }^{512}$.

\footnotetext{
${ }^{509}$ Fredie Didier JR. - Hermes Zanetti JR., Curso de Processo Civil - Processo Coletivo, v. 4, Salvador, Juspodium, 2009, p. 74.

510 Comentários aos artigos 80 e 81, in AA.VV., Código de Defesa do Consumidor Comentado pelos Autores do Anteprojeto, Rio de Janeiro, Forense Universitária, 2007, p. 822.

511 Com efeito, ensina Kazuo Watanabe: 'Mesmo sem organização, os interesses ou direitos 'coletivos', pelo fato de serem de natureza indivisível, apresentam identidade tal que, independentemente de sua harmonização formal ou amalgamação pela reunião de seus titulares em torno de uma entidade representativa, passam a formar uma só unidade, tornando-se perfeitamente viável, e mesmo desejável, a sua proteção jurisdicional em forma molecular." In: Comentários aos artigos 80 e 81, in AA.VV., Código de Defesa do Consumidor Comentado pelos Autores do Anteprojeto, Rio de Janeiro, Forense Universitária, 2007 , p. 824.

512 Roberto Senise LiSBOA, Contratos Difusos e Coletivos, São Paulo, RT, 1997, p. 55. Kazuo WATANABE afirma tratar-se "praticamente" de uma novidade, anotando que a Lei n. ${ }^{\text {7 } 7.913, ~ d e ~ 7 / 7 / 1989, ~ " i n s t i t u i u ~ u m a ~}$ forma de class action para a tutela dos interesses dos investidores no mercado de valores mobiliários, mas conferiu apenas ao Ministério Público a legitimação para agir e deu um tratamento bastante diferente do adotado pelo Código." In: Comentários aos artigos 80 e 81, AA.VV., Código de Defesa do Consumidor Comentado pelos Autores do Anteprojeto, Rio de Janeiro, Forense Universitária, 2007, p. 826, n. 38.
} 
Fredie DIDIER JR. e Hermes ZANETTI JR. diferenciam-nos das duas espécies precedentes, afirmando serem, na verdade, direitos coletivamente $\operatorname{tratados}^{513}$ ou, ainda, direitos acidentalmente coletivos - por oposição aos outros dois, chamados essencialmente coletivos $^{514}$. Isso porque, diferentemente dos demais, esses interesses não são transindividuais (há numerosos interesses individuais paralelos, mas não um interesse de titularidade de conjunto numeroso, determinado ou não, de pessoas) de natureza indivisível.

Seus elementos característicos, nos termos do dispositivo legal, são a homogeneidade e a origem comum $^{515}$. Essa origem comum pode ser de direito ou de fato e não requer necessariamente unidade de tempo e factual ${ }^{516}$. Pode ela, ainda, ser próxima ou remota, embora, quanto mais distante, menos homogeneidade haverá ${ }^{517}$.

A homogeneidade, portanto, está estreitamente vinculada à origem comum e, anota Kazuo WATANABE, "talvez a própria redação do dispositivo legal induzisse a pensar, inicialmente, que a 'homogeneidade pela origem comum' seja um único requisito". Todavia, e como antes observado, se a origem, embora comum, for muito remota, é possível que, no extremo, os interesses individuais não guardem homogeneidade - especialmente se submetidos a causas próximas diversas.

Ainda dentro dessa abordagem geral acerca dos interesses, e antes, contudo, de adentrar propriamente no tema do interesse social, uma derradeira precisão terminológica faz-se oportuna, pois concerne ao interesse público.

Ele não se confunde com o interesse coletivo em sentido amplo, como acima explicitado. Historicamente, seu reconhecimento precedeu (e muito) o deste último, cuja origem, aliás, está exatamente, aponta a doutrina, na insatisfação da dicotomia entre

\footnotetext{
${ }^{513}$ Curso de Processo Civil-Processo Coletivo, v. 4, Salvador, Juspodium, 2009, p. 76.

${ }^{514}$ Curso de Processo Civil - Processo Coletivo, v. 4, Salvador, Juspodium, 2009, p. 73.

515 Kazuo Watanabe, Comentários aos artigos 80 e 81, AA.VV., Código de Defesa do Consumidor Comentado pelos Autores do Anteprojeto, Rio de Janeiro, Forense Universitária, 2007, p. 825.

516 Kazuo Watanabe, Comentários aos artigos 80 e 81, AA.VV., Código de Defesa do Consumidor Comentado pelos Autores do Anteprojeto, Rio de Janeiro, Forense Universitária, 2007, p. 825. O autor cita o caso de um produto nocivo vendido por longo tempo e em diversas regiões do país. No exemplo, cada um dos consumidores tem direito à indenização e, nada obstante os desencontros de época e lugar, esse direito tem "origem comum".

${ }^{517}$ A queda de um avião é uma causa próxima que reúne os interesses dos familiares e sucessores, o que torna bastante homogêneos os direitos individuais deles; no exemplo anterior do produto nocivo, esses interesses podem ser menos homogêneos, especialmente se agregadas causas próximas (como condições pessoais ou uso irregular) que podem potencializar os efeitos. Os exemplos são reportados por Kazuo WATANABE. In: Comentários aos artigos 80 e 81, AA.VV., Código de Defesa do Consumidor Comentado pelos Autores do Anteprojeto, Rio de Janeiro, Forense Universitária, 2007, p. 825.
} 
interesses privado e público ${ }^{518}$ para abranger as numerosas e diversificadas necessidades verificadas na sociedade moderna - certamente muito mais complexa que aquela que viu nascer a distinção entre público e privado ${ }^{519}$.

De fato, os interesses coletivos não se enquadram nem entre os privados, como é evidente, nem mesmo entre os públicos. Trata-se como que de uma categoria "intermediária" lhe seguiu - não prejudica a noção de interesse público, que subsiste. Este concerne, diferentemente do interesse coletivo, às necessidades gerais e impessoais de toda a população ${ }^{521}$ organizada politicamente. O interesse público é, assim, o interesse do bem geral $^{522}$.

São os chamados interesses públicos materiais aqueles que são de titularidade por toda a população, que dizem respeito às suas necessidades gerais e impessoais. Há ainda os interesses públicos formais, isto é, aqueles nomeadamente assim qualificados por disposição legal. Em qualquer dos casos, o Estado - o ente coletivo dotado de personalidade jurídica e derivado da organização política da sociedade - é geralmente aquele a quem incumbe a persecução do interesse, ainda que sua titularidade, a rigor, seja de toda a população indeterminadamente.

Os interesses públicos são heterogêneos entre si, porquanto as necessidades sobre as quais recaem são numerosas e diversificadas, bem como suas respectivas valorações. Com esse fundamento, a doutrina distingue os interesses públicos em duas amplas categorias, os interesses primários e os secundários. Aqueles dizem respeito à necessidade de toda a comunidade, enquanto estes referem-se às necessidades direta da administração pública ${ }^{523}$.

Em razão do elevado número, da heterogeneidade dos interesses públicos, eles podem estabelecer entre si relações de instrumentalidade ou mesmo de incompatibilidade, para usar as expressões de Francesco CARnElutTI e Pier Giusto

\footnotetext{
${ }^{518}$ Roberto Senise LISBOA, Contratos Difusos e Coletivos, São Paulo, RT, 1997, p. 51.

${ }^{519}$ A dicotomia entre público e privado deita raízes na Antiguidade greco-romana, a partir da distinção muito clara entre o ambiente doméstico (domus, oikia), estruturado a partir do pater familias, e o ambiente político (polis, civitas), de acesso restrito aos cidadãos (cives). A origem da consectária distinção entre direito público e privado, por sua vez, está na sempre citada afirmação de Ulpiano (Digesto 1.1.1.2): "Publicum jus est quod ad statum rei romanae spectat, privatum, quod ad singulorum utilitatem." Cf. Tercio Sampaio FERRAZ JR., Introdução ao Estudo do Direito - Técnica, Decisão, Dominação, São Paulo, Atlas, 1994, pp. 134-135.

${ }_{520}$ Roberto Senise LisBOA, Contratos Difusos e Coletivos, São Paulo, RT, 1997, p. 51.

${ }_{521}^{521}$ Roberto Senise LISBOA, Contratos Difusos e Coletivos, São Paulo, RT, 1997, p. 51.

${ }^{522}$ Hugo Nigro MAZZILLI apud Roberto Senise LisBOA, Contratos Difusos e Coletivos, São Paulo, RT, 1997, p. 53, n. 66 .

${ }_{523}$ Roberto Senise LisBOA, Contratos Difusos e Coletivos, São Paulo, RT, 1997, p. 53.
} 
JAEGER. Um interesse público secundário, por exemplo, pode ser instrumental à consecução de um interesse primário - como é o caso da construção de um fórum ou o provimento de cargos de juízes de Direito em relação à promoção da Justiça em uma determinada comarca. Em caso de incompatibilidade, mesmo que o Estado seja considerado o titular último do interesse público - ou, ao menos, o legitimado para sua persecução -, a resolução não fica circunscrita ao interior da pessoa (jurídica) e a ordem jurídica é chamada a intervir - hipótese em que para a persecução de cada interesse são legitimadas pessoas diferentes (como o caso de um conflito entre interesses de um Município e seu respectivo Estado) ou mesmo órgãos diferentes (e.g., o órgão municipal responsável pelo exercício do poder de polícia relativo a uso de elevadores aplica multa ao órgão estadual que opera, sem autorização, esses equipamentos).

Em casos nos quais pesem as diferenças de natureza, pode ocorrer, e não raro ocorre, de os interesses públicos e coletivos (especialmente, os difusos) coincidirem (e.g., interesse público na promoção de meio ambiente equilibrado muito provavelmente coincide com o interesse difuso de uma comunidade atingida pela poluição de um determinado curso d'água). Pode ocorrer, ainda, de eles estabelecerem entre si relações de instrumentalidade ou incompatibilidade (o interesse da administração pública na construção de hidrelétrica, para promoção do crescimento econômico e o interesse da população ribeirinha atingida pela represa da usina).

\subsubsection{O interesse "social"}

A investigação sobre o tema "interesse social" (leia-se: o interesse da sociedade ou, in casu, da sociedade anônima, da companhia) traduz-se no exame daqueles interesses que têm proteção legal - e que podem, por isso, ser perseguidos legitimamente pela companhia. Portanto, indagar-se sobre o interesse social é perscrutar sobre as finalidades que a ordem jurídica tolera ou impõe sejam objetivados pela sociedade - isto é, para que fim o instituto jurídico cognominado sociedade anônima (ou, genericamente, de qualquer outro tipo societário) pode ou deve ser dirigido.

Essa análise passa necessariamente pela investigação da natureza desse instituto jurídico ${ }^{524}$. Como tradução da reunião de esforços de seus acionistas, a companhia deve perseguir os interesses dos seus sócios ou ela tem um interesse próprio, independente

\footnotetext{
524 Julio BARRETO, O Conflito de Interesses entre a Companhia e seus Administradores, Rio de Janeiro, Renovar, 2009, p. 91.
} 
do dos sócios (e até contrário a eles)? Aprofundada a investigação do tema, verifica-se que em tordo desse ponto fulcral o debate se estabeleceu.

Duas são as correntes doutrinárias que polarizam o debate. Embora já não abarquem todas as teorias explicativas do tema, elas mostram-se ainda assim de muita utilidade, já pela simples polarização (que, na mais rasa das análises, permite minimamente ilustrar a complexidade das companhias ${ }^{525}$ ), já por clarear duas concepções extremas a respeito das finalidades últimas de um relevantíssimo instituto jurídico.

A referência é às teorias contratualistas e institucionalistas.

\subsubsection{As teorias institucionalistas}

As teorias institucionalistas têm sua raiz última alicerçada na análise de germânico Walther RATHENAU ${ }^{526}$ e 527 no primeiro quarto do século XX, no pós Primeira Guerra Mundial ${ }^{528}$. A partir da constatação das profundas transformações por que o instituto "sociedade anônima" havia passado em seu emprego econômico e social desde sua origem até então, ele reclamava uma mudança na concepção e aplicação jurídica desse expediente (chamou-a substituição de conteúdo ${ }^{529}$ ). Essa "visão" sobre o fenômeno ficou conhecida, por sua origem alemã, como teoria do Unternehemen an sich (isto é, da empresa em $s i^{530}$, e que Calixto SALOMÃO FILHO chama também de institucionalismo

\footnotetext{
525 São como dois "tipos ideais" weberianos.

${ }^{526}$ Pier Giusto JEAGER, L’interesse social, Milão, Giuffré, 1972, p.17. Sobre essa origem, JEAGER observa que, nada obstante tenha havido autores anteriores que colocaram em relevo alguns dos problemas posteriormente levantados por RATHENAU, nenhum outro logrou uma formulação tão vigorosa e fortemente polêmica, nem influenciou tanto a doutrina posterior quanto o referido alemão (pp. 17-18).

${ }_{527}$ Conhecido amplamente pela doutrina societária, a nota curiosa é que Walther Rathenau não era jurista, mas "homem de Estado" (tendo sido ministro das relações exteriores da Alemanha durante a República de Weimar, até 1922, quando, nesse cargo, foi assassinado), além de empresário, filósofo, sociólogo (Cf. Erasmo Valladão A. e N. FRANÇA, Conflito de Interesses nas Assembleias de S.A., São Paulo, Malheiros, 1993, p. 22) e economista (Cf. Calixto SAlomão FILHO, Interesse Social: A Nova Concepção, in Novo Direito Societário, São Paulo, Malheiros, 2011, p. 32).

528 Julio BARRETO anota que a publicação original teve lugar em 1917. Cf. O Conflito de Interesses entre a Companhia e seus Administradores, Rio de Janeiro, Renovar, 2009, p. 103.

${ }^{529}$ São suas palavras, traduzidas por Julio BARRETO: "Denominei em outros escritos como substituição de conteúdo (Substituition des Grundes) o fenômeno pelo qual todas as organizações humanas com o passar do tempo podem ser atingidas: a organização contém o seu nome características peculiares de sua realidade original, inobstnate suas condições, frequentemente seus objetivos e sua constituição interna tenham se modificado, semelhante ao que acontece a uma concha de marisco abandonada, na qual gerações de outros seres encontra morada." In: O Conflito de Interesses entre a Companhia e seus Administradores, Rio de Janeiro, Renovar, 2009, pp. 103-104, n. 201.

${ }^{530} \mathrm{O}$ autor não emprega o termo empresa em sentido técnico, mas para designar a grande sociedade anônima, e utiliza indistintamente Aktiengesellschaft (sociedade por ações) e Unternehmen (empresa). Cf. Calixto SAlomão FILHo, Interesse Social: A Nova Concepção, in Novo Direito Societário, São Paulo, Malheiros, 2011, pp. 32-33.
} 
publicista $^{531}$ ), que é a mais conhecida das teorias institucionalistas ${ }^{532}$ e que influenciou decisivamente a reforma societária daquele país promovida pela Lei de Ações (Aktiengesetz) de $1937^{533} \mathrm{e}^{534}$.

Em suas análises, o autor alemão referia-se, particularmente, àquelas companhias que hoje se chamariam macroempresas, cuja administração, verificou ele, havia se agigantado e ultrapassado a estrutura burocrática de muitos países. Constatou, mais, que, frente a esse fenômeno, a atuação do grande acionista perdeu significado ${ }^{535}$ e que as companhias já não agiam isoladamente, mas em concerto com outras junto das quais formavam o "hoje conhecido fenômeno do grupo",536. Também nelas centralizou-se a pesquisa e o desenvolvimento tecnológico.

Estribado na constatação dessas mudanças - que o Erasmo Valladão A. e N. FRANÇA sintetiza como decorrência da transmudação da empresa familiar para a grande empresa $^{537}$-, o autor alemão reclamava para as "macroempresas" uma visão publicística, inclusive com um modelo de governo semelhante à composição constitucional do Estado.

Em síntese apertada, Modesto CARvalhosa reporta que, na visão de RATHENAU, fim e objeto social se contrapõem na companhia e que este último deve

\footnotetext{
${ }_{531}$ Interesse Social: A Nova Concepção, in Novo Direito Societário, São Paulo, Malheiros, 2011, p. 32.

${ }^{532}$ Erasmo Valladão A. e N. FRANÇA, Conflito de Interesses nas Assembleias de S.A., São Paulo, Malheiros, 1993, p. 23.

${ }_{533}$ Pier Giusto JEAGER, L'interesse social, Milão, Giuffré, 1972, p.14.

${ }^{534}$ Discute-se (e a questão não é isenta de interesses para a abordagem do tema em referência), a propósito da influência de RATHENAU na lei acionária alemã (que teve lugar depois de sua morte e já sob o III Reich), as ligações talvez existentes entre suas ideias e as doutrinas totalitárias, que viriam a prevalecer pouco depois na Alemanha. De fato, como mais adiante se verá, a concepção do autor acerca da companhia torna-a um instrumento empregado prioritariamente para o atendimento da "economia nacional" (Nationalwirtschaft): ela é vista como engrenagem dessa economia coletiva. Pier Giusto JAEGER descreve assim essa característica: "La società, sola o legata ad altre in gruppi e Konzerne, è um ingranaggio di questa economia colletiva, che supera l'individualismo dell'aspirazione del singolo capitalista al lucro (Gewinnstreben, Ertragstreben), nel nome del generale interesse ad uma poruzione magiore e migliore." (Cf. L'interesse sociale, Milão, Giuffrè, 1972, pp. 21-22). A respeito dessa concepção e sua vinculação com o autoritarismo, Modesto CARVALHOSA afirma o seguinte: "A teoria desenvolvida pelo emrpesário Walter Rathenau é fruto da ideologia imperialista germânica, que também se manifestou na Primeira Guerra Mundial e sempre esteve ligada às doutrinas totalitárias ou autoritárias de que resultou o Führerprinzip da reforma legislativa de 1937." (Cf. Comentários à Lei de Sociedades por Ações, v. 2, São Paulo, Saraiva, 2009, p. 450). Erasmo Valladão A. e N. FRANÇA, por outro lado, sustenta que "não é inteiramente verdadeiro[a]" a existência de vinculação entre a teoria do citado autor alemão e a "filosofia do desastre" ou à ideologia que seria precursora do nazismo (Conflito de Interesses nas Assembleias de S.A., São Paulo, Malheiros, 1993, p. 23)

${ }_{535}$ Erasmo Valladão A. e N. FRANÇA acredita que, assim, Rathenau antecipou em vários anos as conclusões do estudo de Adolf Berle Jr. e Rudolf Means - The Modern Corporation and Private Property, publicado na década de 1940 com base em dados de 1929 -, sobre a separação entre propriedade e controle, nas companhias americanas. Cf. Conflito de Interesses nas Assembleias de S.A., São Paulo, Malheiros, 1993, p. 22 e p. 22 , n. 18.

${ }_{536}$ Erasmo Valladão A. e N. FRANÇA, Conflito de Interesses nas Assembleias de S.A., São Paulo, Malheiros, 1993, pp. 22-23.

${ }^{537}$ Erasmo Valladão A. e N. FrançA, Conflito de Interesses nas Assembleias de S.A., São Paulo, Malheiros, 1993, pp. 22-23.
} 
prevalecer, do que decorre a hegemonia dos órgãos da administração (que, observa Calixto SALOMÃo FILHO, é considerado um órgão neutro e, portanto, apto à persecução do interesse da companhia ${ }^{538}$ ) sobre a assembleia e o grupo controlador torna-se, assim, depositória e intérprete do interesse social ${ }^{539}$.

A sumarização da teoria da empresa em si é feita por Pier Giusto JEAGER, que arrola suas principais características.

A primeira delas é justamente a já referida visão "publicística" das questões atinentes à sociedade anônima. Por ser a forma típica da grande empresa, ela enfeixa interesses de diversos gêneros, entre os quais não apenas os dos acionistas, mas também aqueles dos trabalhadores e dependentes, dos consumidores e, acrescente-se, o interesse coletivo ao desenvolvimento nacional (Nationalwirtschaft: a companhia é, assim, uma "engrenagem" da economia coletiva, que supera o "individualismo" da aspiração do capitalista singular ao lucro, "em nome do interesse geral a uma produção maior e melhor" ${ }^{540}$ ).

Note-se, portanto, que a primeira característica evidencia que o interesse social, segundo essa teoria, não se cinge aos acionistas, mas se estende a outros centros de interesse direta (trabalhadores e consumidores) e indiretamente (os dependentes) relacionados à companhia e outro, ao menos aparentemente, ainda mais remoto, que é o interesse coletivo na economia nacional.

A segunda característica, muito estreitamente relacionada à precedente, consiste no reconhecimento de que a empresa tem um interesse próprio, que não é obtenção de lucros e sua repartição entre os acionistas, mas a produção (isto é, a oferta ao mercado da utilidade econômica em que resulta sua atividade-meio, ou seja, o seu objeto social) de modo mais eficiente - o que justifica o "autofinanciamento" dos resultados positivos, em detrimento da distribuição de dividendos.

Ou seja, na tensão insuperável entre a partilha do lucro e seu reinvestimento na empresa para manutenção ou expansão dos negócios, esta última opção é que atende às finalidades da companhia, segundo essa teoria. Em outras palavras, essa característica explicita o entendimento de que o interesse social é a execução do objeto

\footnotetext{
538 Calixto SAlomão FIlHo, Interesse Social: A Nova Concepção, in Novo Direito Societário, São Paulo, Malheiros, 2011, p. 33.

${ }^{539}$ Comentários à Lei de Sociedades por Ações, v. 2, São Paulo, Saraiva, 2009, p. 451.

${ }^{540}$ Tradução livre do trecho, já anteriormente citado no original, de Pier Giusto JAEGER, L'interesse sociale, Milão, Giuffrè, 1972, pp. 21-22.
} 
social da companhia e não a distribuição de resultado entre os integrantes de seu capital social. Ilustra muito bem essa característica a sempre referida companhia que navegada sobre o rio Reno: suas naus, nas palavras de seu administrador, existiam não para pagar dividendos a seus acionistas, mas para navegar sobre aquele rio ${ }^{541}$.

A solução da tensão acima referida, entre a distribuição do lucro e seu reinvestimento, demanda, para que se dê nos termos aqui considerados, um deslocamento do centro decisório dos acionistas para a administração. Como acima resumido por Modesto CARVAlhosa, a teoria de Unternehmen an sich concebe os órgãos de administração como mais talhados para a "correta" persecução do interesse social.

Nisto consiste a terceira característica e que se traduziu, na doutrina germânica, no chamado Führerprinzip, a qual se constitui na autonomia e independência da administração em relação à assembleia de sócios $^{542}$, degradada em sua importância ${ }^{543}$. Em sua aplicação à Lei Acionária alemã de 1937, fortemente influenciada, como visto, por essa teoria, tal característica encontrou aplicação em seu $\S 70$, que prescrevia que os membros do Vorstand (órgão de administração) deveriam dirigir os negócios sociais àquelas finalidades acima referidas, isto é, ao bem do estabelecimento, de seus empregados e no interesse comum da nação e do Reich $^{544}$ - o que atribuição uma função política aos administradores e simultaneamente reduziu marcantemente a soberania da assembleia geral $^{545}$.

Os acionistas, nesse contexto, são vistos como "egoístas" e, portanto, se deixados à própria sorte - instáveis como são tanto em sua composição quanto na formação de sua maioria -, conduzirão a companhia para o atendimento a tais interesses individualistas e não ao "verdadeiro" interesse social.

Destarte, como reporta Pier Giusto JAEGER, essa característica consiste na tendência de subtrair aos sócios (ao menos aos especuladores e rendeiros ${ }^{546}$ ) o controle da empresa, para confiá-lo à administração, mais estável - independente, tanto quanto

\footnotetext{
${ }_{541}^{541}$ Pier Giusto JAEGER, L'interesse sociale, Milão, Giuffrè, 1972, p. 19, n. 14.

${ }^{542}$ Erasmo Valladão A. e N. FRAnÇA, Conflito de Interesses nas Assembleias de S.A., São Paulo, Malheiros, 1993, pp. 25-26.

${ }^{543}$ Calixto Salomão Filho, Interesse Social: A Nova Concepção, in Novo Direito Societário, São Paulo, Malheiros, 2011, p. 33

${ }^{544}$ Erasmo Valladão A. e N. FrançA, Conflito de Interesses nas Assembleias de S.A., São Paulo, Malheiros, 1993, p. 25.

545 Modesto CarvalhoSa, Comentários à Lei de Sociedades por Ações, v. 2, São Paulo, Saraiva, 2009, p. 452.

${ }^{546}$ Erasmo Valladão A. e N. FranÇA, Conflito de Interesses nas Assembleias de S.A., São Paulo, Malheiros, 1993, p. 24.
} 
possível, das "maiorias mutáveis de acionistas também mutáveis"547. O mesmo autor observa, por fim, que essa terceira característica favorece a prática dos chamados votos plurais ou, ainda, aqueles reservados a um pequeno número de acionistas, normalmente ligados aos membros dos órgãos de administração ${ }^{548}$.

A quarta característica concerne ao condicionamento do exercício de todos os direitos dos acionistas ao atendimento ao interesse superior da empresa (em si), ao qual os acionistas têm dever de fidelidade. Explica Pier Giusto JAEGER que, em geral, os direitos em geral (informação, de impugnação às deliberações assembleares e, como já referido, aos lucros) ficam "reduzidos"

De um modo geral, como se vê, a teoria da empresa em si desloca decisivamente o interesse social da figura de seus acionistas para a própria companhia. Pressupõe, no, por assim dizer, âmbito exosocietário (exterior à sociedade), uma relação de quase servilidade desse corpo social em relação àquilo que denomina "economia nacional". Por força dessa pressuposição, os interesses dos sócios apenas têm lugar e podem ser legitimamente atendidos na medida em que coincidirem com aquele interesse exterior à companhia e que por ela (e seus acionistas) deve ser perseguido.

As principais críticas feitas à teoria de Unternehmen an sich são também explicadas, com especial clareza, por Pier Giusto JAEGER.

Em que pese o reconhecimento pela doutrina, diz ele, da importância social e econômica das grandes empresas organizadas sob a forma de sociedade anônima e, até mesmo, das aspirações dos trabalhadores a tomarem parte nas decisões societárias, sustentam os críticos que não se fazia necessária a inclusão de novos princípios no direito “acionário". A sede da solução do problema não estaria nesse campo do direito, mas em outras plagas, como o direito público e o direito do trabalho. Como instituto de direito privado, formado por sujeitos privados, não pode a companhia perseguir fins gerais

${ }_{547}$ L'interesse sociale, Milão, Giuffrè, 1972, p. 23.

${ }^{548} \mathrm{O}$ voto plural é entre nós vedado (LSA: art. $110, \S 2^{\circ}$ ). Consiste na possibilidade de conceder a uma parcel de ações votantes um voto de maior valor que o voto conferido a outra parcela de ações. Parte da doutrina, entende que essa vedação, no Brasil, foi parcialmente excepcionada pela previsão, introduzida na Lei n. $^{\circ}$ 6.404/76 pela Lei n. ${ }^{\circ}$ 10.303/01 (e anteriormente já prevista em leis esparsas), das chamadas golden shares (ou ações de classe especial), em companhias objeto de processo de desestatização, que atribuem a seu titular direito de veto (que, portanto, tem hegemonia sobre a totalidade dos demais acionistas). Veja-se, por todos, Alfredo Sérgio LazZARESCHI Neto, Lei das Sociedades por Ações Anotada, São Paulo, Saraiva, 2006, p. 144 , n. 3. Por oportuno, esclareça-se que o voto plural (que é mecanismo concentrado de poder) não se confunde com o múltiplo (que, ao revés, é mecanismo de resguardo dos minoritários), admitido no País nas assembleias gerais em certas hipóteses de eleição dos membros do conselho de administração, que atribui a cada ação tantos votos quantos sejam os membros do conselho e, além disso, admite ao acionista que cumule seus votos em um só candidato ou os distribua entre vários (LSA: art. 114).

${ }^{549}$ L'interesse sociale, Milão, Giuffrè, 1972, p. 23. 
abstratos, mas deve voltar-se para a consecução concreta de um ganho para aqueles diretamente envolvidos ${ }^{550}$.

Outra crítica, de ordem teórica, centra-se na dificuldade de reconhecer a empresa em si (e não os sócios) como titular de um interesse autônomo, independente dos sócios que a constituem. Pier Giusto JAEGER fala na impossibilidade de atribuir interesse a um "ente místico", desprovido não apenas de existência na realidade dos fatos, mas também de reconhecimento jurídico como sujeito de direito ${ }^{551}$. A empresa é instrumento de seus sócios; atribuir-se interesse a ela apenas se admite como forma elíptica para denotar, na verdade, o interesse dos sócios.

Nessa mesma ordem de ideias, ofende a lógica, dizem os críticos, a defesa de que a sociedade precisa ser "defendida" de seus acionistas - o que, de qualquer sorte, não tem respaldo nas ordens jurídicas ${ }^{552}$. Por outro lado, e ainda no plano teórico e dogmático, critica-se a falta de precisão conceitual quanto a "empresa",553 e, por conseguinte, também a indeterminação do que seria seu interesse ${ }^{554}$.

Além disso, se a empresa deve servir aos interesses coletivos da economia nacional, o controle deveria caber ao Estado e não aos órgãos de administração, composta por (capitalistas) privados.

Nesse mesmo sentido, atribuindo a estes poucos o controle da empresa, cristaliza-se uma estrutura desigual entre os acionistas que suprime o princípio democrático e legitima uma situação de fato verificada nessas companhias.

Fomenta-se, com efeito, a formação de "dinastias econômicas", que perenizam a concentração de riqueza em poucas mãos - o que, por si só, não corresponde verdadeiramente ao interesse público, mas bem o contrário ${ }^{555}$. Além disso, os órgãos de administração tornam-se os únicos depositários e intérpretes (autênticos) do interesse social - pressuposto que permite a eles legitimar todas as suas decisões (mesmo aquelas tomadas exclusivamente em proveito próprio) e praticamente aniquila a hipótese teórica de

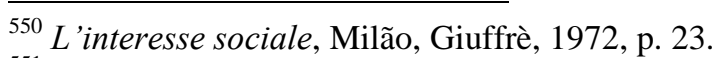

${ }^{551}$ L'interesse sociale, Milão, Giuffrè, 1972, p. 25.

${ }^{552}$ L'interesse sociale, Milão, Giuffrè, 1972, pp. 25-26.

553 Constatação já acima referida (cf. Calixto SALOMÃo FILHO, Interesse Social: A Nova Concepção, in Novo Direito Societário, São Paulo, Malheiros, 2011, pp. 32-33.)

${ }^{554}$ Erasmo Valladão A. e N. FRANÇA, Conflito de Interesses nas Assembleias de S.A., São Paulo, Malheiros, 1993, p. 25.

${ }^{555}$ L'interesse sociale, Milão, Giuffrè, 1972, p. 27.
} 
que eles possam cometer abusos desse poder ${ }^{556}$.

Nesse contexto, o principal prejudicado é o sócio minoritário. Embora detentor de parcela do capital social, fica reduzido, por um lado, à condição análoga à dos debenturistas, privado de tomar parte nas decisões e no destino da companhia; por outro, fica submetido a uma situação ainda mais grave que esses credores sociais, porque, além de tudo, é ainda devedor de uma "fidelidade à empresa",557.

Entre as teorias institucionalistas está ainda aquela chamada teoria da pessoa em si (Person an sich), também de origem alemã, baseada na concepção de Otto von GIERKE da "realidade" da pessoa jurídica ${ }^{558}$. Essa teoria procura demonstrar que a sociedade, porque dotada de personalidade jurídica, tem interesse próprio, distinto dos interesses de seus sócios ${ }^{559}$ e superior a eles ${ }^{560}$. O acionista é considerado um "órgão" do ente social ${ }^{561}$ e deve empregar seu voto no sentido do interesse da sociedade (ou interesses da coletividade), e não no próprio interesse ${ }^{562}$. Conforme afirma Modesto CARVALHOSA, os "arautos" da teoria, por estarem arraigados a essa valoração, admitem inclusive a possibilidade de controle judicial sobre o mérito das deliberações inoportunas objetivamente aos interesses da companhia ${ }^{563}$.

Ponderando-se sobre a vizinhança desta teoria à anterior - que as permite o enquadramento sob um mesmo gênero -, as diferenças são marcantes. Fundamentalmente a divergência está em que, enquanto nesta última o interesse social localiza-se $n a$ própria sociedade (em sua personalidade jurídica ${ }^{564}$ ), a primeira teoria concebe-o externo a ela. Portanto, a identificação do interesse da companhia com o

\footnotetext{
${ }^{556}$ L'interesse sociale, Milão, Giuffrè, 1972, p. 28.

${ }^{557}$ L'interesse sociale, Milão, Giuffrè, 1972, p. 28.

${ }^{558}$ Erasmo Valladão A. e N. FRANÇA, Conflito de Interesses nas Assembleias de S.A., São Paulo, Malheiros, 1993, pp. 26-27.

${ }^{559}$ Em referência ao pensamento de GIERKE, observa Julio BARRETO que, para o citado autor, “o egoísmo dos homens haveria de ser limitado pelo organismo das associações humanas, nas quais as pessoas, enquanto membros, subordinar-se-iam à personalidade mais elevada da entidade coletiva.” In: , O Conflito de Interesses entre a Companhia e seus Administradores, Rio de Janeiro, Renovar, 2009, p. 101.

${ }^{560}$ Pier Giusto JAEGER, L'interesse sociale, Milão, Giuffrè, 1972, p. 31.

561 Modesto Carvalhosa, Comentários à Lei de Sociedades por Ações, v. 2, São Paulo, Saraiva, 2009, p. 451.

${ }_{562}$ Renato Ventura RIBEIRO, Direito de Voto nas Sociedades Anônimas, São Paulo, Quartier Latin, 2009, p. 110.

${ }^{563}$ Comentários à Lei de Sociedades por Ações, v. 2, São Paulo, Saraiva, 2009, p. 451. No mesmo sentido: Pier Giusto JAEGER, L'interesse sociale, Milão, Giuffré, 1972, pp. 33-34: "La tesi esposta per ultima [teoria de person an sich] pone ristretti limiti al potere della maggioranza, permettendo al giudice di valutare $i$ motivi ispiratori e persino la convenienza obbiettiva per la società delle deliberazioni assembleari e di dichiarare invalide quelle che risultino per essa inopportune (...)".

564 "Il concetto di impresa, pertanto, si riduce ad esprimere lo scopo dell'Aktiengeselschaf, ovvero l'attività economica assunta come oggetto sociale, e no qualcosa di esterno e sovrapposto alla società (...)”. In: Pier Giusto JAEGER, L’interesse sociale, Milão, Giuffré, 1972, p. 33.
} 
interesse público, que é próprio da teoria de Unternehmen an sich, não tem lugar na teoria da pessoa em si.

Por conseguinte, o predomínio da administração e do poder da maioria na condução dos negócios sociais, presentes no institucionalismo publicista, não cabe na teoria da pessoa em si, que, muito ao contrário, protege os direitos da minoria ${ }^{565}$. O direito de voto, no contexto desta última teoria, deve ser exercido em direção a esse interesse endossocietário, e não exterior à sociedade ${ }^{566}$. Por isso, aponta Pier Giusto JAEGER, na hipótese grupo de sociedades, a teoria radicada em GIERKE não permite ao voto ser em uma delas proferido em favor de outra integrante do mesmo grupo, pois que esta outra é estranha à primeira ${ }^{567}$.

Ainda no campo das institucionalistas pós Primeira Guerra Mundial, merecem rápida menção as teorias da instituição e de HAUSSMANN. Quanta a esta última, sem se deter aprofundadamente sobre a noção jurídica de empresa - que é definida como organismo vivo ${ }^{568}$ - e negando que ela própria seja titular de interesse, o autor sustenta ser ela produto da confluência de diversos sujeitos titulares de um interesse comum ${ }^{569}$. Não se limitam tais titulares aos sócios, mas são incluídos também os membros dos órgãos da administração, os credores, trabalhadores e seus dependentes ${ }^{570}$. Acentua-se o objetivo de lucro (ganho) desses interessados (Erasmo Valladão A. e N. FRANÇA cita a cogestão nas companhias alemãs, promovida pela então futura lei acionária, de 1965, como aplicação desse entendimento ${ }^{571}$ ) e, como a teoria de GIERKE, nega-se visivelmente relevância do interesse público na disciplina das sociedades ${ }^{572}$.

A teoria da instituição, de que são referência Maurice HAURIOU e SANTI RomANo na França e na Itália, respectivamente, foi elaborada no âmbito do direito público

\footnotetext{
${ }^{565}$ Erasmo Valladão A. e N. FRANÇA, Conflito de Interesses nas Assembleias de S.A., São Paulo, Malheiros, 1993, p. 27; Pier Giusto JAEGER, L’interesse sociale, Milão, Giuffré, 1972, p. 33.

${ }^{566}$ Pier Giusto JAEGER, L'interesse sociale, Milão, Giuffré, 1972, p. 33.

${ }^{567}$ Pier Giusto JAEGER, L'interesse sociale, Milão, Giuffré, 1972, p. 33.

${ }^{568}$ Pier Giusto JAEGER, L 'interesse sociale, Milão, Giuffré, 1972, p. 35.

${ }^{569}$ Pier Giusto JAEGER, L'interesse sociale, Milão, Giuffré, 1972, p. 35.

${ }^{570}$ Erasmo Valladão A. e N. FRANÇA, Conflito de Interesses nas Assembleias de S.A., São Paulo, Malheiros, 1993, p. 28; Pier Giusto JAEGER, L’interesse sociale, Milão, Giuffré, 1972, p. 35.

571 "Na verdade, a experiência germânica da cogestão (Mitbestimmung), iniciada nos anos imediatamente posteriores à Segunda Guerra e albergada no § 96 da Lei Acionária de 1965, parece apontar exatamente nessa direção. Independentemente de serem ou não acionistas da sociedade, os trabalhadores têm assento no conselho de administração de várias companhias para defender os seus interesses, que não se confundem com os interesses dos sócios (daí o caráter institucionalista da teoria ora examinada." In: Conflito de Interesses nas Assembleias de S.A., São Paulo, Malheiros, 1993, p. 29.

${ }^{572}$ Pier Giusto JAEGER, L'interesse sociale, Milão, Giuffré, 1972, p. 35.
} 
e, depois, foi então transposta para o direito privado ${ }^{573}$.

Funda-se ela na noção de instituição (que lhe dá nome), centrada, por sua vez, em três características: a realização da ideia de um grupo social; a existência de um poder organizado colocado a serviço da persecução dessa ideia; e manifestação de comunhão do grupo em que a ideia se realiza 574 e 575.

A instituição, dessa maneira, atribui perenidade àquele corpo social ${ }^{576}$. E o interesse social, nesse caso, não resulta simplesmente da justaposição dos interesses de seus integrantes, mas constitui um interesse superior, da própria instituição - algo próximo da teoria da empresa em si $^{577}$. Sobrepõe-se o interesse da realização plena da ideia de obra aos interesses de seus integrantes ${ }^{578}$.

Entre a lei acionária alemã de 1937 e a de 1965, reporta Calixto SAlOMÃo FILHO uma "rica construção doutrinária" naquele país - provocada notadamente pela promulgação nesse ínterim de diplomas legais que contemplaram a participação dos empregados no conselho de administração das companhias ${ }^{579}$.

\footnotetext{
${ }^{573}$ Erasmo Valladão A. e N. FRAnÇA, Conflito de Interesses nas Assembleias de S.A., São Paulo, Malheiros, 1993, p. 29.

574 Julio BARReto, O Conflito de Interesses entre a Companhia e seus Administradores, Rio de Janeiro, Renovar, 2009, p. 102.

575 Transcreve Erasmo Valladão A. e N. FRANÇA a seguinte definição de instituição de Maurice HAURIOU: "Uma organização social, estável em relação à ordem geral das coisas, cuja permanência é assegurada por um equilíbrio de forcas ou por uma separação de poderes, e que constitui, por si mesma, um estado de direito." In: Conflito de Interesses nas Assembleias de S.A., São Paulo, Malheiros, 1993, pp. 29-30. SANTI ROMANO afirma: "Per instituzione noi intendiamo ogni ente o corpo sociale. 1). L'ente di cui parliamo deve avere un'esistenza obbiettiva e concreta, e, per quanto immateriale, la sua individualità dev'essere esteriore e visibile: appunto per rendere meglio questo suo carattere, l'abbiamo anche detto un 'corpo' sociale. (...) 2). Diciamo inoltre che l'istituzione è un ente o corpo sociale, nel senso che essa à manifestazione della natura sociale e3 no puramente individuale dell'uomo. (...) 3). L'istituzione è un ente chiuso, che può venire in considerazione in sè e per se, appunto perchè ha una propria individualità. (...) 4). L'instituzione è un'unità ferma o permanentemente, che cioè non perde la sua identità, almeno sempre e necessariamente, pel mutarsi dei singoli suoi elementi, delle persone che ne fanno parte, del suo patrimonio, dei suoi mezzi, dei suoi dei suoi interessi, dei suoi fini, dei suoi uffici, dei suoi amministratori, dei suoi destinatari, delle sue norme, e cosi via. (...)”. In: L'ordinamento giuridico - Studi sul conccetto, Le fonti e i caratteri del diritto Parte prima, Pisa, Cav. Mariotti, 1917, pp. 35, 36, 37 e 38.

${ }^{576}$ Afirma Julio BARRETO que "A ideia de obra, assim, na qualidade de algo inconscientemente aceito por todos teria força para condicionar a manifestação da vontade consciente de seus integrantes”. In: O Conflito de Interesses entre a Companhia e seus Administradores, Rio de Janeiro, Renovar, 2009, p. 102.

${ }^{577}$ Erasmo Valladão A. e N. FrançA, Conflito de Interesses nas Assembleias de S.A., São Paulo, Malheiros, 1993 , p. 32.

578 Julio BARRETO, O Conflito de Interesses entre a Companhia e seus Administradores, Rio de Janeiro, Renovar, 2009, p. 102.

${ }^{579}$ Leis essas que podem ser consideradas "uma continuação natural da doutrina do Unternehmen an sich, afirma Calixto SALOMÃo FILHO. E acrescenta: "Com efeito, até o advento de tais leis, tanto do ponto de vista jurídico quanto do político-econômico, observava-se e criticava-se a falta de uma aplicação efetiva dos princípios institucionalistas na lei de 1937. No plano jurídico, acusava-se a doutrina do Unternhemen an sich de não ser coerente com as premissas por ela mesmo afirmadas, que postulam o reconhecimento, na disciplina das sociedades por ações das diversas categorias de interesse dos trabalhadores, dos sócios e da coletividade confiando a tutela de todos esses interesses ao Vorstand, órgão não apto, pela sua vinculação
} 
Essas modificações, cujas razões políticas são apontadas pela doutrina ${ }^{580}$, representaram, entende o mesmo autor, "a afirmação definitiva do institucionalismo na Alemanha" - todavia, não mais segundo aquele exacerbado perfil publicístico de RATHENAU e, sim, na confluência (e reconhecimento) dos interesses dos diversos grupos de sócios $e$, ainda, dos trabalhadores.

Essa "confluência" traduz-se na identificação do interesse social com o interesse à preservação (e perpetuação) da empresa, que é comum a todos esses envolvidos. Isso não implica a eliminação dos embates entre os diversos interesses desses personagens, mas "fixa os parâmetros para a discussão sobre o tipo de organização mais apta a garantir tal interesse $" 581$ e introduz tais conflitos no interior dos órgãos societários, os quais, mediante mecanismos de debates e deliberações, devem, em princípio, resolver tais conflitos.

\subsubsection{Teorias contratualistas}

Essas outras teorias negam que o interesse social seja superior ao interesse dos sócios - o que as diferencia das precedentes, institucionalistas. Estribam-se na concepção fundamental de que as companhias têm natureza jurídica de contrato. Tratase, portanto, de união voluntária de interesses e, assim, o interesse da sociedade não pode representar outros senão os interesses comuns de seus contratantes, isto é, de seus acionistas - que prevalecem sobre os interesses extrassociais ${ }^{582}$ e 583 .

ao grupo de controle, a levar a efeito essa complicada tarefa com a necessária imparcialidade". In Interesse Social: A Nova Concepção, in Novo Direito Societário, São Paulo, Malheiros, 2011, pp. 34-35.

${ }_{580}$ Calixto SALOMÃo FILHO sublinha a "particular situação da Alemanha no segundo pós-guerra" e cita a necessidade das nações ocupantes do território germânico (e também pelos sindicatos) de enfraquecer os "centros de poder" na indústria alemã e a afirmação de uma "economia democrática" desejada pela República de Weimar e frustrada pelo ulterior nacional-socialismo. Cf. Interesse Social: A Nova Concepção, in Novo Direito Societário, São Paulo, Malheiros, 2011, pp. 35-36.

${ }^{581}$ Calixto SAlomão Filho, A Nova Concepção, in Novo Direito Societário, São Paulo, Malheiros, 2011, p. 37.

${ }_{582}$ Renato Ventura RibeIRo, Direito de Voto nas Sociedades Anônimas, São Paulo, Quartier Latin, 2009, p. 113.

${ }^{583} \mathrm{O}$ desaparecimento da distinção entre interesse social e interesse de sócio nas sociedades unipessoais é fortemente criticada pelo professor Calixto SALOMÃo FILHO. Enquanto em uma concepção institucionalista, essa hipótese implica a redução do interesse do sócio ao interesse da sociedade, exatamente o oposto é o que se verifica in casu: redução do interesse da sociedade ao interesse do sócio. Inexiste, por consequência, conflito de interesses (no sentido supra examinado) e o sócio utiliza-se da sociedade como coisa própria. Contrabalança-se essa concepção individualista com a previsão, em alguns ordenamentos (como o italiano), de responsabilidade ilimitada do sócio pelas dívidas sociais. Em todo caso, e as críticas seguem feitas pelo mesmo autor, esse contrapeso é imperfeito, uma vez que as regras sobre responsabilidade ilimitada do sócio 
Em que pese essa nota característica, as diversas teorias reunidas sob essa rubrica guardam diferenças marcantes ${ }^{584}$, notadamente quanto à delimitação conceitual de "interesse comum",585.

Algumas teorias contratualistas limitam-se ao interesse dos sócios na qualidade de sócios (uti socii), excluindo, portanto, aqueles outros que tenham raiz em causas alheias à sociedade: embora "comuns" ao sócios, não integram o interesse social. Outras o identificam na deliberação, pela maioria, na assembleia geral - podendo, nesse caso, reconhecer interesses alheios à sociedade ${ }^{586}$. Divergências existem ainda quanto à restrição do interesse social àquele comum dos sócios atuais, enquanto outras, procurando explicar a perenidade da companhia, incluam os interesses dos sócios futuros.

É que, embora essa expressão, como anota Pier Giusto JAEGER, introduza um critério distintivo no universo praticamente ilimitado dos interesses de que os sócios podem ser titulares, ela não restringe os interesse dos sócios àqueles típicos e específicos deles enquanto tais (uti socii). Em outras palavras, a expressão, por sua generalidade, pode comportar um conjunto de interesses que, conquanto comuns aos sócios, têm origem alheia à sociedade. Cita-se o exemplo da companhia familiar no qual os acionistas têm interesse comum não enquanto membros da sociedade, mas como integrantes da família ${ }^{587}$ - o que, dizemos nós, pode resultar em interesses bem diferentes do que eles manifestariam, não fossem parentes.

Por isso, parcela da doutrina acrescenta à expressão uma qualificação que delimita o interesse social e o restringe ao interesse comum dos sócios manifestado por estes na qualidade de sócios - enquanto sócios, ut socii ${ }^{588 \text { e } 589}$. A esse interesse típico e específico reduz-se o interesse social e, destarte, são considerados extrassociais (que, ergo, não integram o interesse social) todos os demais interesses dos sócios, tanto aqueles

prestam-se à proteção dos credores, ao passo que aquelas atinentes ao conflito de interesse servem à tutela de interesse interno. Cf.: Calixto SAlOMÃo FILHO, A Nova Concepção, in Novo Direito Societário, São Paulo, Malheiros, 2011, p. 37.

${ }_{584}$ Jorge Manuel Coutinho DE ABReu, Do Abuso de Direito - Ensaio de um Critério em Direito Civil e nas Deliberações Sociais, Coimbra, Almedina, 1999, p. 113.

${ }_{585}^{585}$ Pier Giusto JEAGER, L'interesse social, Milão, Giuffré, 1972, p. 86.

${ }^{586}$ Renato Ventura RIBEIRO, Direito de Voto nas Sociedades Anônimas, São Paulo, Quartier Latin, 2009, p. 113.

${ }_{587}^{58}$ Pier Giusto JEAGER, L'interesse social, Milão, Giuffré, 1972, p. 87.

${ }^{588}$ Pier Giusto JEAGER: . "L'interesse sociale secondo questa definizione, sarebbe quindi um interesse típico, necessariamente comune a tutti $i$ soci, perchè referibile non tanto alle persone fisiche di essi, quanto alla loro posizione giuridica all'interno della società, e, aggiungiamo, di quella determinata società." In L'interesse social, Milão, Giuffré, 1972, p. 88.

${ }_{589}$ A esse entendimento filia-se Jorge Manuel COUTINHO DE ABREU: "Já dissemos que o interesse da sociedade (ou social) é um interesse dos sócios enquanto tais." In: Do Abuso de Direito - Ensaio sobre um Critério em Direito Civil e nas Deliberações Sociais, Coimbra, Almedina, 1999, p. 117. 
individuais, quanto aqueles coletivos alheios à sociedade. Em abreviadas palavras, o interesse social é o interesse dos sócios, depurado de qualquer interesse extrassocial ${ }^{590}$.

Mesmo esse entendimento, contudo, não bastou, consoante observa o mesmo Pier Giusto JAEGER, para extirpar divergências doutrinárias entre os contratualistas a respeito do interesse social.

Uma preocupação manifestada pelos estudiosos e que respeita à perenidade da companhia (à sua existência através do tempo) refere-se à inclusão no "conjunto" não apenas do interesse atual dos sócios, mas também de seu interesse a "longo termo" ${ }^{591}$ e, ainda, do interesse dos próprios sócios futuros ${ }^{592}$. Trata-se, entende essa doutrina, de decorrência incontornável da concepção de que se partiu: coincidindo o interesse social com o interesse típico dos sócios, não é possível distinguir o interesse daqueles membros reunidos em um determinado momento do interesse daqueles outros que integrarão esse grupo no futuro ${ }^{593}$.

Dessa maneira, o amálgama que permite a reunião intertemporal desses membros é justamente o objetivo comum de tornar a empresa eficiente e idônea a produzir o máximo de lucros possível ${ }^{594}$. Essa meta torna-se imprescindível à preservação da empresa através do tempo ${ }^{595}$.

Critica-se esse entendimento por ele assemelhar-se muito ao das teorias institucionalistas. Concebido nos termos acima delineados, o interesse social assume, com efeito, um caráter típico, substancialmente imutável ao longo da vida da sociedade - algo muito próximo do institucionalismo. A diferença cinge-se à imputação aos sócios ou à

\footnotetext{
590 Citação de Pier Giusto JAEGER, fazendo referência à teoria: o interesse social é "l'interesse dei soci depurato da ogni interesse extrasociale”. In: L'interesse social, Milão, Giuffré, 1972, p. 93.

${ }^{591}$ Pier Giusto JEAGER, L'interesse social, Milão, Giuffré, 1972, p. 88.

${ }^{592}$ Calixto Salomão Filho, Interesse Social: A Nova Concepção, in Novo Direito Societário, São Paulo, Malheiros, 2011, p. 29.

${ }^{593}$ Erasmo Valladão A. e N. FrançA, Conflito de Interesses nas Assembleias de S.A., São Paulo, Malheiros, 1993, p. 38.

${ }^{594}$ Esclarecedoras são as palavras de Jorge Manuel COUTINHO DE ABREU. Ele observa que os sócios são portadores de interesses contraditórios, tanto na gênese da sociedade (por exemplo, na avaliação das entradas de cada qual), quanto no curso de sua vida. "Evidentemente, não é nestas contradições que se situa o interesse social." Por isso, o interesse social deve ser comum a todos os sócios e consiste, precisamente, no lucro. Verbis: "E existe, de facto, essa comunidade - todo e qualquer sócio pretende obter o máximo lucro através da actividade da empresa social. O fim lucrativo é mesmo um elemento essencial do contrato de sociedade. Mas realce-se, o interesse colectivo só é qualificado como interesse social na medida em que se prende com a causa comum do contrato - o lucro. Qualquer outro interesse colectivo ou comum de que sejam titulares os sócios já não merece tal qualificação." São interesses extrassociais. Cf. Do Abuso de Direito - Ensaio sobre um Critério em Direito Civil e nas Deliberações Sociais, Coimbra, Almedina, 1999, pp. 118-119.

595 Calixto Salomão Filho, Interesse Social: A Nova Concepção, in Novo Direito Societário, São Paulo, Malheiros, 2011, p. 29.
} 
pessoa jurídica - o que importa pouco, dizem os críticos ${ }^{596} \mathrm{e}^{597}$.

Ademais, esse entendimento acentua a relevância do escopo-meio da empresa (realização do objeto social, que torna possível a maior eficiência e o melhor funcionamento da companhia e, portanto, sua perenidade) em detrimento de seu escopofim (obtenção de lucro social e sua distribuição entre os titulares de capital social), cuja persecução não pode tornar inviável a continuidade da atividade (sob pena de impedir a distribuição de lucros no futuro aos sócios atuais e aos sócios futuros). Tudo isso avizinha bastante a presente teoria daquelas anteriormente referidas.

Outra vertente dos contratualistas, todavia, procurando evidenciar sua diferença com relação às teorias institucionalistas, sustenta que o interesse social resulta exclusivamente dos sócios atuais, e não também dos futuros e eventuais. Assim, o interesse social consiste no objetivo de maximizar os lucros sociais - o que, ainda que não confessadamente, resulta no atendimento também aos interesses dos sócios futuros. Por isso, Pier Giusto JAEGER assevera não ser fácil distingui-la da teoria logo acima referida salvo quanto, naturalmente, à afirmada exclusão dos sócios futuros e eventuais.

O mesmo estudo de Pier Giusto JAEGER relata ainda a existência de uma terceira vertente que não enfatiza apenas o objetivo instrumental (escopo-meio) da companhia, em detrimento dos interesses no escopo-final dos acionistas, mas considera também estes últimos no conceito de interesse social - que, ademais, não é concebido como um dado imutável, identificável com o objeto social, mas variável com o mudar das

\footnotetext{
${ }^{596}$ Pier Giusto JEAGER, L'interesse social, Milão, Giuffré, 1972, p. 89. Sobre essa aproximação, obtempera, no entanto, Erasmo Valladão A. e N. FRANÇA: "Ora, por essa forma, não se diferencia o interesse coletivo dos sócios do interesse da empresa, chegando-se à teoria do Unternehmen na sich (muito embora empresa, aqui, seja entendida como a atividade consistente no objeto da sociedade e não uma entidade distinta, sobreposta a esta). " In: Conflito de Interesses nas Assembleias de S.A., São Paulo, Malheiros, 1993, p. 39.

${ }^{597}$ Jorge Manuel CoutiNHO DE ABREU constata a existência dessa crítica. Pergunta ele: "o interesse social é algo predeterminado e invariável e único? Quando, por exemplo, um sector dos sócios vota pelo autofinanciamento e outro pela distribuição de todos os lucros, há interesses sociais distintos?" E ainda questiona se algum dos grupos poderia invocar o "interesse social". A resposta, diz ele, está em que a crítica identifica o interesse com a causa ou fim do contrato social - o que é um erro. "Na verdade, o interesse é a relação entre uma pessoal, que tem uma necessidade, e o bem que essa pessoa julga apto para satisfazer tal necessidade. (...) Ora, no interesse social teremos uma relação etnre uma necessidade - que é sempre a obtenção do maior lucro por parte de todos os sócios: é da própria essência do contrato de sociedade - e um bem - que é determinado em cada deliberação (no caso que serviu de paradigma, o autofianciamento ou a distribuição de todos os lucros). Logo, só um dos polos da relação (a necessidade) é imutável, constante. $O$ outro (o bem jurídico) não, é susceptível de variações, pois variadas podem ser as situações com que se depara a sociedade." Assim, nesse confronto, cabe à maioria decidir: "é ela que vai determinar qual o bem, qual o meio mais apto a conseguir o máximo lucro." Contudo, adverte ele, a maioria não é a titular do interesse social: "Cabe-lhe decidir no quadro do interesse da sociedade - tendo o fim lucrativo comum como 'estrela polar'. Se assim não suceder, tem de aceitara-se a impugnabilidade.” E conclui, conceituando-o como: "a relação entre a necessidade de todo o sócio enquanto tal na consecução do maior lucro e o meio julgado apto a satisfazê-la." In: Do Abuso de Direito - Ensaio sobre um Critério em Direito Civil e nas Deliberações Sociais, Coimbra, Almedina, 1999, pp. 119-121.
} 
necessidades dos sócios (uti socii) ao longo do tempo ${ }^{598}$.

A vertente em seguida referida pelo mesmo autor concebe o interesse social como um conceito relativo, que não resulta simplesmente da somatória dos interesses individuais dos sócios. Constitui o interesse comum deles em sentido objetivo: é verificado por uma valoração objetiva dos interesses particulares dos sócios em um determinado momento ${ }^{599}$.

Uma derradeira corrente rejeita a definição de interesse social como interesse típico do sócio e concebe-o como resultado de qualquer relação de solidariedade entre os interesses individuais dos sócios. A consequência relevante desse entendimento é a impossibilidade de os sócios deliberarem contra o interesse social - hipótese, por outro lado, admitida por aqueles que o concebem como resultado de interesse típico de sócios ${ }^{600}$. Também essa vertente derradeira identifica lesão ao interesse social sempre que violado o interesse de um grupo minoritário de sócios, enquanto as teorias que sustentam a "tipicidade" do interesse social admitem o atendimento a este mesmo sob violação do interesse de determinados sócios.

Para o próprio Pier Giusto JAEGER, a sociedade é concebida como um contrato de execução continuada e o interesse social correspondente ao interesse do grupo de sócios atuais. Na formulação original de sua tese, esse interesse poderia, portanto, ser revisto constantemente e até mesmo eventualmente desconsiderado, se proveniente de deliberação unânime $e^{601}$.

As teorias contratualistas mais modernas rejeitam a ideia de que o interesse da sociedade, particularmente a anônima aberta, limita-se ao grupo de sócios atuais. O próprio JAEGER, quarenta anos depois de sua tese, escreveu um artigo em que identificou o interesse social na obtenção de shareholder value, ou seja, no alcance do maior valor de mercado possível das ações - o que resultaria na justaposição ideal entre

\footnotetext{
598 "Questi scrittori, se non rinunciano alla conttrapposizione fra interesse sociale e interessi extrasociali, cercano di renderne i termini più elastici: l'interesse sociale non si configura più, secondo quanto invece avviene nelle opinioni riferite in precedenza, come um dato immutabile, commisurato alla realizzazione dell'oggetto sociale, ma come un termine variabile con il mutare dei bisogni dei soci (sia pure uti socii) nei diversi momenti della vita della società.” Pier Giusto JEAGER, L'interesse social, Milão, Giuffré, 1972, p. 93. ${ }^{599}$ Pier Giusto JEAGER, L'interesse social, Milão, Giuffré, 1972, p. 94. Refere-se ele à teoria de Mengoni e, em seguida, transcreve trecho do magistério deste autor: "Ma resta pur vero che sono proprio questi interessi concreti il punto di partenza della determinazione dell'interesse sociale, che è perciò un concetto essenzialmente relativo, in quato risulta da una valutazione oggettiva degli interessi particulari di cui sono portatori, in un determinato momento, coloro che partecipano alla società.,

${ }^{600}$ Erasmo Valladão A. e N. FranÇA, Conflito de Interesses nas Assembleias de S.A., São Paulo, Malheiros, 1993, p. 41.

${ }^{601}$ Calixto SAlomão Filho, Interesse Social: A Nova Concepção, in Novo Direito Societário, São Paulo, Malheiros, 2011, p. 29.
} 
escopo-meio e escopo-fim.

\subsubsection{Teorias modernas}

A abertura do direito societário à mútua influência com outros ramos do direito (interdisciplinaridade), em especial o concorrencial, propiciou, explica Calixto SALOMÃo FILHO, o desenvolvimento de novos conhecimentos ${ }^{602}$. Tem tomado a atenção dos estudiosos, particularmente, os efeitos econômicos das regras societárias - estudo a que se tem atribuído o nome de análise econômica do direito ${ }^{603}$.

A empresa, vista sob essa perspectiva, é conceituada como um feixe de contratos (nexus of contracts ${ }^{604}$ ). Ou, por outra, “a firma é vista como um único agente subscritor de um grupo de contratos, que começa pelos contratos com os sócios e vai desde contratos com fornecedores e clientes até contratos com trabalhadores e contratos de empréstimo necessários para suprir as necessidades de fundos da empresa" ${ }^{\text {,605. }}$.

Dessa maneira, o fundamento da empresa está na redução dos custos de transação (ou custos de negociação, em linguagem jurídica) e para esse objetivo devem convergir as leis societárias ${ }^{606}$. Nesse contexto o controle interno da empresa

602 Calixto SAlomão FILHo, Interesse Social: A Nova Concepção, in Novo Direito Societário, São Paulo, Malheiros, 2011, p. 40: "Pode-se dizer que hoje está ultrapassada essa fase intimista do direito societário. Por fase intimista se quer significar o período em que o direito societário se sente autossuficiente para analisar e regular as questões de organização da vida empresarial. Se há algum marco da nova fase do direito societário é exatamente sua abertura para a interdisciplinariedade. Não só dentro da ciência do direito como fora dela. É a fase, por exemplo, de discussão das relações entre direito societário e direito concorrencial. É a fase também das discussões sobre os efeitos econômicos das regras societárias."

603 Sobre o risco dessa essa "análise" determinar o sentido das regras jurídicas, em detrimento de considerações valorativas ou distributivas do direito, adverte Calixto SALOMÃo FILHO que "É, portanto, necessário restringir a análise econômica do direito a um instrumento exclusivamente analítico, sem atribuir-lhe qualquer caráter valorativo. Então, sim, a teoria tem verdadeira utilidade, inclusive no campo societário, como se verá." Cf.: Interesse Social: A Nova Concepção, in Novo Direito Societário, São Paulo, Malheiros, 2011, p. 42.

${ }^{604}$ Esse entendimento jurídico-econômico, relata Rodrigo Ferraz Pimenta da CunHA, surge na década de 1970, a partir do desenvolvimento dos estudos realizados por Ronald Coase nos anos 1930. De acordo com ele, a teoria do nexus of contracts "Baseia-se em concepção essencialmente econômico-contratualista, segundo a qual as relações internas e externas da companhias seriam simplesmente um aglomerado de contratos (um feixe de contratos), postos em ordem em vista do benefício econômico que trariam para as partes envolvidas." E acrescenta: "Segundo essa corrente, as companhias só existiriam como roupagem jurídica para minimizar os custos das operações econômicas entre acionistas, administradores e terceiros em geral." In: Estrutura de Interesses nas Sociedades Anônimas - Hierarquia e Conflitos, São Paulo, Quartier Latin, 2007, p. 94.

${ }^{605}$ Calixto SAlomão FIlHo, Interesse Social: A Nova Concepção, in Novo Direito Societário, São Paulo, Malheiros, 2011, p. 43.

606 "A disponibilização de uma estrutura previamente construída e experimentada diminuiria o custo e os riscos da contratação, caso ela tivesse de ser feita a cada constituição. (...) A concepção de personalidade só teria função por minimizar o valor dessas relações econômicas (agency costs) que, de outra forma, seriam realizadas separadamente.” In: Rodrigo Ferraz Pimenta da CUNHA, Estrutura de Interesses nas Sociedades Anônimas - Hierarquia e Conflitos, São Paulo, Quartier Latin, 2007, p. 95. 
(independente do tipo societário) é atribuído àquele grupo de pessoas "com as quais transacionar no mercado é excessivamente oneroso para a própria empresa ou para esse grupo de pessoas ${ }^{, 607}$.

Observa a esse propósito Calixto SALOMÃo FILHO que tal teoria acarreta a equivalência substancial entre controle interno e controle externo ${ }^{608}$ e, como consequência, a empresa já não pode ser vista como resultado dos interesses dos sócios (teorias contratualistas) nem como entidade destinada à autopreservação (teorias institucionalistas), mas como "uma organização capaz de estruturar da forma mais eficiente - e aqui a eficiência é a distributiva e não a alocativa - as relações jurídicas que envolvem a sociedade. "609

Outra teoria moderna, particularmente cara à fundamentação teórica das sociedades unipessoais, é aquela que concebe a sociedade como um contrato organização. A base dela está na diferença estabelecida entre contratos associativos e contratos de permuta. O discriminem não está na existência ou não de uma finalidade comum, como ensinou Tullio AsCARELLI a respeito dos contratos plurilaterais ${ }^{610}$, mas, sim, na circunstância de que os vínculos de permuta destinam-se à atribuição de direito subjetivo às partes ${ }^{611}$, ao passo que os contratos associativos prestam-se à criação de uma estrutura organizativa $^{612}$. Enquanto essa distinção estriba-se em um critério funcional (conforme o

\footnotetext{
${ }^{607}$ Calixto SAlomão FILHo, Interesse Social: A Nova Concepção, in Novo Direito Societário, São Paulo, Malheiros, 2011, p. 43.

${ }^{608}$ Ambos os controles, explica ele, podem ser úteis para os interesses da empresa. O controle externo tem lugar nas hipóteses em que os sócios são tão heterogêneos que tornam altos os custos de transação (no caso, os custos quanto à tomada das decisões) e sujeitam a empresa à operação ineficiente ou, no extremo, à paralisação. Já quanto o custo de transação é maior nas relações estabelecidas com um grupo externo, o controle interno é o mais útil. Cf. Interesse Social: A Nova Concepção, in Novo Direito Societário, São Paulo, Malheiros, 2011, pp. 43-44.

${ }^{609}$ Calixto SAlOMÃo FILHO, Interesse Social: A Nova Concepção, in Novo Direito Societário, São Paulo, Malheiros, 2011, p. 44. E acrescenta o autor: "É nessa definição em termos econômicos de seu objeto, que a liberta das trações do liberalismo exacerbado do século XIX que a sociedade pode melhor cumprir a sua função social."

${ }^{610}$ Em seu clássico estudo sobre contratos plurilaterais, o autor italiano distingue-o dos simplesmente de permuta por (a) possibilitar a participação de mais de duas partes e (b) "pelo fato de que, quanto a todas essas partes, decorrem do contrato, quer obrigações, de um lado, quer direitos, de outro." In: O Contrato Plurilateral, in Problema das Sociedades Anônimas e Direito Comparado, São Paulo, Saraiva, p. 275.

${ }^{611}$ Com arrimo em Paolo Ferro-Luzzi, Márcio Ferro CATAPANI reume: "Os contratos de escambo têm como efeito jurídico a criação, modificação ou extinção de relações jurídicas, constituindo uma outra forma de se ver o direito subjetivo, mais adequada ao campo obrigacional. No entanto, o tradicional esquema fattispecielefeito jurídico não é adequado para a explicação dos contratos, sendo mais operacional a utilização do esquema imputação/qualificação. Por essa lógica, o que realmente caracteriza um contrato de escambo (e seu protótipo, que é a compra e venda) é que o valor do fato juridicamente relevante se concretiza em uma pluralidade de imputações que têm por objeto qualificações heterogêneas e destacadas (como, v.g., a propriedade e o crédito)." In: Os Contratos Associativos, in Direito Societário Contemporâneo I, Erasmo Valladão A. e N. França (coord.), São Paulo, Quartier Latin, 2009, p. 94.

${ }^{612}$ Calixto Salomão FIlHo, Interesse Social: A Nova Concepção, in Novo Direito Societário, São Paulo, Malheiros, 2011, p. 44.
} 
valor prevalente do ato ${ }^{613}$ ), a de ASCARELLI é estrita e propositadamente formal ${ }^{614}$.

Sobre a nota característica dos contratos organizacionais, isto é, a própria organização, explica em outra obra o mesmo Calixto SALOMÃo FILHO, que "significa a coordenação da influência (jurídica) recíproca entre atos" 615 e 616 . Por isso, acrescenta Márcio Ferro CATAPAnI, a disciplina jurídica quanto ao objetivo desse tipo de contrato "aplica-se primordialmente sobre a atividade e, secundariamente, sobre as contribuições dos membros ",617.

Trata-se de uma teoria jurídica, e não econômica; objetiva não obter a eficiência econômica, mas alcançar o melhor ordenamento dos interesses envolvidos na sociedade e a solução dos eventuais conflitos verificados entre eles ${ }^{618}$. Nessa ordem de ideias, o interesse social está na "estruturação e organização mais apta a solucionar os conflitos entre esse feixe de contratos e relações jurídicas" ${ }^{\prime 619}$. Volta-se, portanto, para a "estabilização da estrutura organizativa econômica"620 e, por conseguinte, para a consideração tanto do interesse ao lucro empresarial (que certamente motivou seu criador), quanto do interesse à autopreservação ${ }^{621}$ - sem, no entanto, identificar-se com um ou com

${ }^{613}$ Márcio Ferro CATAPANI, Os Contratos Associativos, in Direito Societário Contemporâneo I, Erasmo Valladão A. e N. França (coord.), São Paulo, Quartier Latin, 2009, p. 93.

${ }^{614}$ Observou ele a respeito: "Leva-se, assim em conta, o aspecto estrutural e não aquele econômico (ou funcional). (...) OSTI (...) acha preferível classifica os contratos conforme os característicos econômicos deles (...). Parece-me, no entanto, preferível o sistema tradicional de assentar as classificações jurídicas, antes de mais anda, sobre critérios formais; proporcionam eles uma certeza jurídica que, ao contrario, não pode ser própria a critérios econômicos." In: O Contrato Plurilateral, in Problemas das Sociedades Anônimas e Direito Comparado, São Paulo, Saraiva, 1945, p. 275, n. 2.

${ }_{615}$ Calixto SAlOMÃo FILHO, A Sociedade Unipessoal, São Paulo, Malheiros, 1995, p. 58.

616 "Portanto, adotada a teoria do contrato organização, é no valor organização e não mais na coincidência de interesses de uma pluralidade de partes ou em um interesse específico à autopreservação que se passa a identificar o elemento diferencial do contrato social." In: Calixto SALOMÃo FILHO, Interesse Social: A Nova Concepção, in Novo Direito Societário, São Paulo, Malheiros, 2011, p. 45.

617 Os Contratos Associativos, in Direito Societário Contemporâneo I, Erasmo Valladão A. e N. França (coord.), São Paulo, Quartier Latin, 2009, p. 95. Ainda estribado em Ferro-Luzzi, acrescenta o autor que a relação entre o contrato associativo e a atividade deve ser vista sob dois pontos de vista. Por um, o contrato é fundamento (a base) da atividade; por outro, a atividade é o necessário desenvolvimento daquele contrato (que sobre esta projeta-se).

618 Observa Calixto SALOMÃo FILHO que nem todos os interesses que envolvam a sociedade são "internados" e, portanto, ela não oferece solução para todos eles: "A teoria organicista não impõe a internalização de interesses. Ao erigir a sociedade como instrumento de resolução de conflitos sugere que este ente seja capaz. de tanto. (...) É inegável, por outro lado, que existem interesses que não podem ser resolvidos internamente. Em muitos casos é até positivo para estes interesses que a mediação entre eles e o interesse social se faça por regulação estatal.” In: Interesse Social: A Nova Concepção, in Novo Direito Societário, São Paulo, Malheiros, 2011, p. 46.

${ }^{619}$ Calixto SAlOMÃo FIlHo, Interesse Social: A Nova Concepção, in Novo Direito Societário, São Paulo, Malheiros, 2011, p. 45.

${ }^{620}$ Calixto SAlOMÃo FILHo, A Sociedade Unipessoal, São Paulo, Malheiros, 1995, p. 60.

621 "Portanto, é inafastável considerar o interesse da organização assim criada como composto pelo itneresse ao lucro empresarial de seu criador e também pelo interesse na autopreservação (Erhaltungsinteresse)”. In: Calixto SAlOMÃo FILHO, A Sociedade Unipessoal, São Paulo, Malheiros, 1995, p. 60 . 
outro $^{622}$.

\subsubsection{Interesse social na Lei n. $^{\circ}$ 6.404/76}

Destaca Erasmo Valladão A. e N. FRANÇA que apenas a vigente Lei de Sociedades por Ações veio a regular de maneira mais completa e abrangente o tema no País ${ }^{623}$. Atento aos reclamos por uma visão "institucional" da sociedade anônima, o legislador reviu a disciplina dispensada pelo Decreto-Lei $n .^{\circ} 2.627 / 40$, procurando um alinhamento estável entre os interesses da empresa, do acionista, do gestor e, ainda, do credor $^{624}$. Entre uma solução privatista pura e uma publicista radical, a vigente lei optou por uma posição conciliatória, estabelecendo um regime dual.

Dual, porque previu um regramento para os acionistas em geral e outro para o controlador. Quanto àqueles, o art. 115, caput, determina-lhes que exerçam o voto "no interesse da companhia”; quanto a este, o art. 116, parágrafo único, impinge o dever de "usar o poder com o fim de fazer a companhia realizar o seu objetivo e cumprir sua função social" e, ainda, imputa-lhe os "deveres e responsabilidades para com os demais acionistas da empresa, os que nela trabalham e para com a comunidade em que atua, cujos direitos e interesses deve lealmente respeitar e atender." Assim, ao acionista em geral compete exercer o voto no interesse comum dos sócios, uti socii, e ao controlador cabe a tutela dos interesses intra e extraempresariais, nos termos do dispositivo legal citado $^{625}$.

Com supedâneo em Luiz Gastão Paes de Barros LEÃES, Erasmo Valladão A. e N. FRANÇA distingue-se assim o interesse social stricto sensu do interesse social lato sensu.

Aquele é o previsto pelo art. 115 da Lei n. ${ }^{\circ} 6.404 / 76$ e é interpretado como o interesse comum dos sócios uti singuli e, ainda, no entender do mesmo FRANÇA, o "eventual interesse comum que não diga respeito à sua condição de sócios" (como no

\footnotetext{
622 "Identificando-se o interesse social ao interesse à melhor organização possível do feixe de relações envolvidas pela sociedade, esse jamais poderá ser identificado com o interesse à maximização dos lucros ou com o interesse à preservação da empresa." In: Calixto SALOMÃo FILHO, Interesse Social: A Nova Concepção, in Novo Direito Societário, São Paulo, Malheiros, 2011, p. 45.

${ }^{623}$ No mesmo sentido: Modesto CARvahoSA, Comentários à Lei de Sociedades por Ações, v. 2, São Paulo, Saraiva, 2009, pp. 446-447.

${ }^{624}$ Erasmo Valladão A. e N. FRANÇA, Conflito de Interesses nas Assembleias de S.A., São Paulo, Malheiros, 1993, pp. 54-55.

${ }^{625}$ Conflito de Interesses nas Assembleias de S.A., São Paulo, Malheiros, 1993, p. 56.
} 
caso da companhia familiar) ${ }^{626}$.

Isso, porque, sendo comunhão voluntária, a companhia constitui uma comunhão de escopo ${ }^{627}$, muito embora seja possível a ocorrência de conflito entre os interesses envolvidos, notadamente entre os interesses individuais e o comum a todos. $\mathrm{O}$ que mantém os sócios unidos é justamente o escopo social ou "qualquer interesse que se insira no esquema causal do contrato de sociedade", vale dizer, o escopo-meio (a atividade empresarial) e o escopo-fim (a produção e a distribuição de resultados) ${ }^{628}$.

Em resumo, como sustenta Fabio Konder Comparato, "quando a lei usa a expressão 'interesse da companhia', está referindo-se ao interesse do acionista enquanto tal, ao modelo jurídico de acionista, abstratamente considerado; e não a determinado indivíduo que figura concretamente como acionista de determinada companhia. $", 629$

\subsection{As deliberações sociais}

Esclarecido o conteúdo do interesse social e, ainda, revisitadas as diversas teorias que procuram explicar a natureza da sociedade anônima e o sentido que o interesse social deve ter, convém tratar agora propriamente das deliberações sociais, que constituem o evento jurídico produtor, em concreto, da vontade social ${ }^{630}$.

O processo jurídico por meio do qual essa vontade toma corpo tem por princípio o voto - instituto por que tal estudo inicia-se.

${ }^{626}$ Conflito de Interesses nas Assembleias de S.A., São Paulo, Malheiros, 1993, p. 58.

${ }^{627}$ Erasmo Valladão A. e N. FrANÇA, Conflito de Interesses nas Assembleias de S.A., São Paulo, Malheiros, 1993, pp. 58-59: "Ora, a comunhão de escopo, lembra Ascarelli, se coordena com um interesse comum a todos os participantes, de maneira que nos confrontos de cada um dos participantes pode-se distinguir um interesse extra-social e um interesse que, embora próprio de cada um, é comum a todos."

${ }^{628}$ Erasmo Valladão A. e N. FrAnÇA, Conflito de Interesses nas Assembleias de S.A., São Paulo, Malheiros, 1993, pp. 59-60.

${ }^{629}$ Controle conjunto, abuso no exercício do voto acionário e alienação indireta de controle empresarial, in Direito Empresarial, São Paulo, Saraiva, 1990, p. 88. Em sentido semelhante, Erasmo Valladão A. e N. FRANÇA resume: "Pode-se concluir, assim,m que o interesse da companhia (ou interesse social stricto sensu), na Lei 6.404, constitui um conceito típico e específico, consistente no interesse comum dos sócios à realização do sescopo social, abrangendo, portanto, qualquer interesse que diga respeito à causa do contrato de sociedade, seja o interesse à melhor eficiência da empresa, seja à maximização dos dividendos. Em face desse conceito, portanto, qualquer outro interesse comum ou individual dos sócios pode ser classificado como extra-social." In: Conflito de Interesses nas Assembleias de S.A., São Paulo, Malheiros, 1993, pp. 62-63.

${ }^{630}$ Plínio Paulo BIng, Direito Assemblear nas Sociedades Mercantis e Civis, Porto Alegre, Sergio Antonio Fabris Editor, 2007, p. 14. 


\subsubsection{O voto}

$\mathrm{O}$ ato mediante o qual quem é dotado do devido poder concorre para a formação da vontade social é o voto ${ }^{631}$. A deliberação é um ato colegial de formação da vontade social $^{632}$ e, por essa sua natureza, resulta da combinação das manifestações individuais integrantes do órgão ${ }^{633}$ e ${ }^{634}$. Essas expressões individuais veiculam-se precisamente pelo exercício do voto.

Para José Edwaldo Taveres BORBA, "voto é uma manifestação individual

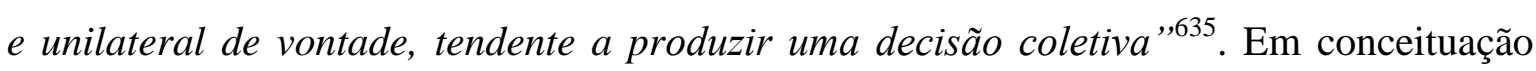
um pouco mais ampla, Fabio Ulhoa COELHO preleciona que voto é "a manifestação de sua vontade ou entendimento, em assembleia, na fase de tomada de decisão relativa a cada ponto da pauta da sessão "636.

Giuseppe SENA, por seu turno, e estribado em Francesco Carnelutti, afirma que "Il voto può essere in limine definito come una dichiarazione cioè com in contegno espressivo dell'agente', un 'contegno diretto ad esprimerne il pensiero ${ }^{,, 637}$ ou ainda, e mais precisamente, "una dichiarazione con la quale il soggetto esprime una intenzione (o volontà), diretta ad un determinato fine il quale consiste nello svolgimento di un interesse ${ }^{, 638}$. Eduardo de Melo Lucas COELHO, escrevendo sobre a formação das deliberações sociais, preleciona ser o voto "a forma pela qual o membro da assembleia da sociedade, titular desse direito, exprime, nesta fase, a sua posição pessoal acerca da proposta. "639 Marcelo Lamy REGO destaca: “o direito de voto é o direito do acionista de manifestar sua vontade na Assembleia Geral, a favor ou contra a aprovação de proposta

\footnotetext{
${ }^{631}$ Giuseppe Romano-Pavoni, Le deliberzioni delle assemblee dele società, Milão, Giuffrè, 1951, p. 87. Como uma "prima definizione", afirma Giuseppe SENA que o termo voto é normalmente utilizado para indicar "uma dichiarazione concorrente con altre analoghe (cioè com altri voti) in uma combinazione di atti giuridici detta deliberazione.” In: Il voto nella assemblea della società per azioni, Milão, Giuffrè, 1958, p. 2. ${ }^{632}$ Tullio AsCARELl, Vícios das Deliberações Assembleares - Direitos Individuais dos Acionistas Prescrição, in Problema das Sociedades Anônimas e Direito Comparado, São Paulo, Saraiva, p. 399.

633 Eduardo de Melo Lucas CoElHo, A Formação das Deliberações Gerais - Assembleia Geral das Sociedades Anónimas, Coimbra, Coimbra Ed., 1994, p. 67.

${ }^{634}$ Embora empregado na forma plural, pois que a pluralidade integrantes é indubitavelmente o que sucede no mais das vezes, é possível que o órgão colegiado seja composto, apesar do nome, por um único membro como sucede na companhia subsidiária integral (LSA: arts. 251 a 253). Cf. Calixto SALOMÃo FILHO, $A$ sociedade unipessoal, São Paulo, Malheiros, 1992, pp. 223-224.

${ }^{635}$ Direito Societário, Rio de Janeiro, Renovar, 2010, p. 339.

${ }^{636}$ Curso de Direito Comercial - Direito de Empresa, São Paulo, Saraiva, 2012, p. 340.

${ }^{637}$ Il voto nella assemblea della società per azioni, Milão, Giuffrè, 1958, p. 12.

${ }^{638}$ Il voto nella assemblea della società per azioni, Milão, Giuffrè, 1958, p. 18.

${ }^{639}$ A Formação das Deliberações Gerais - Assembleia Geral das Sociedades Anónimas, Coimbra, Coimbra Ed., 1994, p. 148.
} 
de deliberação, e de ter seu voto computado na formação da vontade social. "640

Em obra monográfica sobre o tema no âmbito das companhias, Renato Ventura RIBEIRO define o voto como "direito do acionista ou de pessoa legalmente legitimada, de caráter político, exercido conforme as orientações legais e estatutárias, expresso por meio da manifestação de vontade e destinado à formação da deliberação coletiva". E complementa o autor: "Representa a aceitação ou rejeição, pelo acionista, da proposta apresentada em assembleias ${ }^{, 641 .}$

Em sua extensa conceituação ${ }^{642}$, o autor perpassa aspectos numerosos, que serão objeto dos itens subsequentes. De se sublinharem, desde logo, contudo, algumas características importantes por ele apresentadas.

Resta evidenciado o caráter político do direito ${ }^{643}$, pois que, como ensina Luis Manuel ROJAS JR., atribui ao titular a "facultad de coadyuvar con su decisión particular en la asamblea, para determinar la dirección de los negocios y el destino de la propiedad social”,644. Isto é, o voto é o expediente jurídico mediante o qual o seu titular pode tomar parte nas deliberações e, assim, influir na formação da vontade social e na direção dos negócios sociais.

Entre outras classificações, a doutrina tradicionalmente divide os direitos

\footnotetext{
${ }^{640}$ Pedido de Procuração para Votar, Direito Societário - Desafios Atuais, Rodrigo R. Monteiro de Castro Leandro Santos de Aragão (coord.), São Paulo, Quartier Latin, 2009, p. 316.

${ }^{641}$ Direito de Voto nas Sociedades Anônimas, São Paulo, Quartier Latin, 2009, p. 157.

${ }^{642} \mathrm{Na}$ doutrina, encontram-se outros conceitos. Para José Edwaldo Tavares BORBA, "O voto é uma manifestação individual de e unilateral de vontade, tendente a produzir uma decisão coletiva." In: Direito Societário, Rio de Janeiro, Renovar, 2010, p. 339.

${ }^{643}$ Plínio Paulo BING (Direito Assemblear nas Sociedades Mercantis e Civis, Porto Alegre, Sergio Antonio Fabris Editor, 2007) credita ao Poder Legislativo a "fonte" das assembleias modernas (p. 10). Todavia, sublinha as diferenças entre "assembleias públicas" e as "assembleias privadas" - de ente público e de pessoas jurídicas de direito privado, respectivamente, explica ele (p. 13). E anota que a analogia, nessa área, é "aplicada com cuidado e reservas" (p. 11). O paralelismo é também citado por José Edwaldo Tavares BORBA: "Desde a Grécia antiga, quando se instaurou o estado democrático, a prática do voto passou a representar um instrumento efetivo de manifestação coletiva organizada. As sociedades comerciais, especialmente a sociedade anônima, acolheram a prática do voto como um meio de consultar o quadro de sócios, definindo a vontade socail." Cf. Direito Societário, Rio de Janeiro, Renovar, 2009, p. 340. Por outro lado, são muito oportunas as observações de Modesto CARVALHOSA a respeito da influência que a maturação democrática e os movimentos da sociedade civil organizada têm exercido no "ressurgimento" das assembleias gerais de acionistas. Após fazer referência a seu ocaso (resultado do crescente absenteísmo, particularmente na realidade societária americana), afirma que a formação de grupos civis "de pressão" (por exemplo, contra os abusos do poder estatal e econômico, na defesa dos direitos trabalhistas e do consumidor, na preservação do meio ambiente, no zelo com os interesses das comunidades locais) tem tornado, notadamente nos Estados Unidos, "um fórum institucional de discussão e deliberação da maior importância, inclusive política, no sentido da preservação do sistema capitalista”. E conclui: "Na luta pela maximização do lucro, o sistema de livre empresa tem encontrado na assembleia geral um instrumento a serviço dos interesses da sociedade civil’. In: Comentários à Lei de Sociedades por Ações, v. 2, São Paulo, Saraiva, 2009 , p. 390.

${ }^{644}$ El Derecho de Voto en la Sociedad Anónima, México, Jus, 1945, pp. 60-61.
} 
dos acionistas em políticos e patrimoniais. Concernem estes últimos naqueles de conteúdo econômico, que atribuem aos titulares, acrescenta o autor anteriormente citado, "La participación en los resultados patrimoniales que se obtengan”; são "concedidos en interés particular y exclusivo del socio y que este ejerce frente a la sociedad”, pois que decorrentes da condição do sócio de "credor" da sociedade ${ }^{645}$. Assim, são direitos patrimoniais o direito a participar dos lucros sociais, à participação no acervo, em caso de liquidação, e ao reembolso, em caso de exercício da retirada.

Já os direitos políticos ${ }^{646}$, como o voto, conferem ao titular, em linhas gerais, o poder de tomar parte na direção da companhia. Assim, concorrem para a formação da vontade social (v.g.:alteração de estatuto social - LSA: art. 122, inc. I), para condução dos negócios (eleição e destituição dos membros da administração - LSA: art. 122 , inc. II) e sua fiscalização ${ }^{647}$ (apreciação das contas prestadas pelos administradores LSA: art. 122, inc. III), etc. Em suma, é político o direito de voto, porque possibilita que se participe da decisão colegiada (observado o princípio majoritário ${ }^{648}$, que, no mais das vezes, preside as deliberações sociais) sobre a condução da companhia e de suas atividades.

E o exercício desse poder de decidir sobre os destinos do ente social passa necessariamente pela manifestação levada a efeito pelo titular, por ocasião do conclave. Giuseppe SENA ensina que "Il voto può essere in limine definito come una dichiarazione cioè come 'un contegno espressivo dell'agente', um 'contegno diretto ad esprimerne il pensiero ", 649 . O exercício desse "poder" reveste-se, por isso, da natureza de ato jurídico unilateral, pois é emanado da declaração exclusivamente do titular da posição jurídica.

\footnotetext{
${ }^{645}$ El Derecho de Voto en la Sociedad Anónima, México, Jus, 1945, p. 35. A noção de "credor" da companhia não é exatamente precisa, pois que a constituição e a exigibilidade do direito ao dividendo é condicionada e o direito ao acervo apenas se torna exigível no recesso ou na dissolução.

${ }^{646}$ Outras denominações: derecho de consecución, de cooperación social, de coadministración (cf. Luis Manuel Rojas JR., El Derecho de Voto en la Sociedad Anónima, México, Jus, 1945, p. 35) ou, simplesmente, de administração (cf. Renato Ventura RibeIRO, Direito de Voto nas Sociedades Anônimas, São Paulo, Quartier Latin, 2009, p. 158).

${ }^{647}$ Com efeito, de nada adiantaria tomar parte nas decisões assembleares, se não fosse franqueado ao sócio a fiscalização (inclusive do cumprimento das ditas decisões).

${ }^{648}$ Ensina Antonio Pavone LA RosA: "Il principio maggioritario implica che sia da considerare come decisione più conforme all'interesse comune quella della maggioranza dei soci, la quale, in quanto ha nella società un interesse economico prevalente, deve poter imporre la propria volontà nella determinazione delle misure più idonee al conseguimento dello scopo comune." In: Diritto di voto e diritto di annullamento delle deliberazioni assembleari, in Rivista trimestrale di diritto e procedura civile, ano VII (1953), Milão, Giuffrè, pp. 923-924.

${ }^{649}$ Il voto nella assemblea della società per azioni - Parte generale, Milão, Giuffrè, 1958, p. 12.
} 
Discute a doutrina se essa declaração é de vontade ou de verdade ${ }^{650} \mathrm{ou}$, ainda, de uma $e$ outra simultaneamente. Como adiante se verá, na realidade, a sede da matéria objeto desse debate não está na natureza do voto, em si, mas no objeto sobre o qual ele recai ${ }^{651}$. Como exemplifica Modesto CARvalhosA, o voto será declaração de verdade na aprovação das contas apresentadas pela administração (LSA: art. 132) ou na ratificação do dividendo obrigatório declarados pelos órgãos administrativos (LSA: art. 202) e, por outro lado, será declaração de vontade nas deliberações sobre o aumento de capital social, eleição e destituição de administradores etc ${ }^{652}$.

Questão mais sensível diz respeito à delimitação da obrigatoriedade de o voto ser "exercido conforme as orientações legais e estatutárias". Por sua complexidade, esse tema será explorado no item subsequente. Importa perscrutar se tais "orientações" (o termo causa certa espécie: seriam normas cogentes ou enunciariam princípios?) concernem apenas à formulação procedimental (que constitui, naturalmente, elemento para verificação da validade como ato jurídico da manifestação do sócio) ou se, diversamente, adentrariam ao próprio "mérito" do voto, para vincular seu exercício a uma determinada finalidade prescrita pela lei ou pelo estatuto social. Certamente, a resposta a essa questão será de muita utilidade para a investigação de questão análoga no âmbito das deliberações das assembleias gerais de credores, nos processos concursais.

$\mathrm{Na}$ verdade, o que o trecho em destaque espelha na conceituação retro indicada é o debate sobre a natureza do voto. Discute-se se seria típico direito subjetivo ou poder-funcional, isto é, se o seu exercício é inteiramente livre, a juízo de seu titular, para o atendimento aos próprios interesses, ou se essa liberdade está tolhida por uma finalidade que compulsoriamente o titular deve perseguir. Da resolução desse debate dependem questões outras bastante salientes, como a obrigatoriedade ou não do exercício do voto e, principalmente, sua vinculação ou não a um determinado objetivo - o que pode implicar, por exemplo, a possibilidade de exame da legalidade do "mérito" da decisão.

Independente da natureza de posição jurídica subjetiva complexa que assume o "direito" de voto, é certo que ele contém em suas posições elementares ao menos o poder formador, que decorre de uma norma secundária e sua eficácia consiste na alteração da esfera jurídica da companhia, e não em uma prestação.

\footnotetext{
${ }^{650}$ Giuseppe SENA, Il voto nella assemblea della società per azioni, Milão, Giuffrè, 1958, p. 19.

${ }^{651}$ Explica Modesto CARVALHOSA: "Evidentemente que a natureza de declaração de vontade ou de verdade depende do objeto do voto. ” In: Comentários à Lei de Sociedades por Ações, v. 2, São Paulo, Saraiva, 2009, p. 390.

${ }^{652}$ Comentários à Lei de Sociedades por Ações, v. 2, São Paulo, Saraiva, 2009, p. 390.
} 
Outro dado relevantíssimo do voto é seu caráter irrenunciável. O efetivo exercício ou não do direito de voto é, como se sabe, faculdade do acionista (ressalvado o caso de acordo - LSA: art. 118); integra o âmbito de liberdade de que ele dispõe no governo de suas ações na estrutura orgânica da sociedade. Essa possibilidade é permite a formação de um grupo de acionistas muito referido em matéria de "controle difuso" que são os absenteístas.

Contudo, não é dado, mesmo àqueles que inarredavelmente abstêm-se de comparecer ou, comparecendo, deixam de votar, renunciar ao direito de voto que decorre das ações de sua titularidade. O voto é, além disso, inderrogável, porquanto, explica Modesto CARvalhosa, não pode ser subtraído a determinado acionista por decisão da maioria. Concebe-se a existência de espécie ou classe ação que não atribua tal direito, mas de um determinado acionista ${ }^{653}$.

\subsubsection{Voto: direito subjetivo ou poder funcional}

Como "direito" político, o exercício do voto nas companhias tem por eficácia a interferência (decisiva ou não) de seu titular na condução da sociedade e de seus negócios. O exame de sua natureza, para verificação de seu enquadramento na categoria de direito subjetivo ou de poder funcional - conforme examinado no Capítulo 2 deste trabalho -, depende da prévia referência ao que, nas sociedades companhias, é o interesse social - já que para o atendimento a este (penda ele para qualquer dos extremos que tomam as preocupações doutrinárias: os sócios ou a empresa em si) deve voltar-se a direção dos destinos da sociedade.

Em sua obra monográfica sobre conflito de interesses nas companhias, Erasmo Valladão A. e N. FRANÇA, após esquadrinhar as diversas teorias institucionalistas e contratualistas sobre o interesse social ${ }^{654}$, faz referência precisamente à relação existente entre o conceito adotado de interesse social (conforme a perspectiva adotada) e as deliberações sociais, no que, entende ele, está centrada a questão da natureza do voto ${ }^{655}$. Dessa maneira, a investigação deste último tema nas companhias não pode se desvincular da análise mais abrangente a respeito da própria finalidade das sociedades, feita no item

${ }^{653}$ Comentários à Lei de Sociedades por Ações, v. 2, São Paulo, Saraiva, 2009, p. 387.

${ }^{654}$ Q.v. abordagem do tema acima.

${ }^{655}$ Conflito de Interesses nas Assembleias de S.A., São Paulo, Malheiros, 1993, p. 43. 
precedente $^{656}$. Também Pier Giusto JAEGER externa a relação existente entre a concepção acerca do interesse social e sobre o voto ${ }^{657}$.

\subsection{Direito subjetivo}

De fato, os doutrinadores contratualistas sustentam, como visto, que o interesse social não se encontra fora do agrupamento societário, mas está em seu interior, coincidente com o interesse dos acionistas. Nesse caso, portanto, não existe o dever de o sócio exercer o voto no sentido de atender a um interesse pré-determinado e estranho à companhia.

$\mathrm{O}$ acionista não se encontra, por isso, adstrito a perseguir um "interesse social" determinado, uma vez que este é resultado justamente dos interesses dos sócios. E, no caso de certas vertentes contratualistas, que entendem ser o interesse social um conceito relativo e variável - proveniente de uma valoração objetiva dos interesses dos sócios em concreto $^{658}$-, o interesse social é justamente decorrência da manifestação do voto dos $\operatorname{acionistas}^{659}$.

Destarte, segundo as teorias contratualistas, o voto constitui meio para a tutela dos interesses individuais e egoísticos do acionista ${ }^{660}$. Há até mesmo quem admita inclusive a persecução, pelo voto, de interesse extra social, "desde que, com isso, não se

\footnotetext{
${ }^{656}$ Pier Giusto JEAGER relata que, para a doutrina, na definição de interesse social a doutrina entreve o "problema fundamental" da sociedade por ações: presta-se não apenas à identificação de seu papel no sistema jurídico, mas também e, diz ele, principalmente, "come strumento per l'interpretazione del diritto positivo" (cf. L'interesse social, Milão, Giuffré, 1972, p.1). Observa Calixto SALOMÃo FILHO que "Em uma ciência valorativa e finalista como é o direito, debater os fundamentos é discutir sua função e objetivo." (Interesse Social: A Nova Concepção, in Novo Direito Societário, São Paulo, Malheiros, 2011, p. 27) A natureza do voto está diretamente relacionada, como se afirmou acima, aos próprios fundamentos das sociedades anônimas e, por extensão, do direito societário - razão por que são oportunas também as seguintes afirmações do mesmo autor: "Analisar os fundamentos do direito societário é analisar a função das sociedades. Ora, a mera menção à função societária traz à mente os clássicos ensinamentos contratualista e institucionalista a respeito da razão de ser das sociedades comerciais.” (p. 27).

${ }^{657}$ L'interesse sociale, Milão, Giuffrè, 1972, pp. 100 e 101, nn. 25 e 29.

${ }^{658}$ Como a teoria de Mengoni. Q.v. item precedente deste trabalho e, ainda, Pier Giusto JAEGER, L 'interesse sociale, Milão, Giuffrè, 1972, p. 94.

${ }^{659}$ Erasmo Valladão A. e N. FRANÇA, Conflito de Interesses nas Assembleias de S.A., São Paulo, Malheiros, 1993, p. 44. O autor ainda observa: "Tal posicionamento, como parece claro, decorre do próprio conceito que os mencionados autores fazem do interesse social. Se, como visto, para Mengoni, por exemplo, o interesse social é um conceito essencialmente relativo, resultando da objetiva avaliação dos interesses particulares de que são portadores, em determinado momento, aqueles quer participam da sociedade, é óbvio que essa indeterminação do conceito faz com que seja impossível, a priori, estabelecer-se uma obrigação de perseguir o interesse social." (pp. 44-45, n. 80)

${ }_{660}$ Renado Ventura RiBeIRo, Direito de Voto nas Sociedades Anônimas, São Paulo, Quartier Latin, 2009, p. 169; Erasmo Valladão A. e N. FranÇA, Conflito de Interesses nas Assembleias de S.A., São Paulo, Malheiros, 1993, p. 45.
} 
coloque em contrates com o interesse comum de todos "661. Sobre o assunto, observa Renado Ventura RIBEIRO que, se não existissem tais limites, não haveria conflito de interesses e o voto se destinaria efetivamente apenas à defesa de fins egoísticos. E completa: "Por outro lado, se todos os sócios concordarem com um fim extra-social e o voto for apenas direito individual, não há possibilidade de conflito de interesses."

Os doutrinadores, como Pier Giusto JAEGER, que entendem defeso o exercício do direito em atendimento a interesse externo à companhia advogam que a vedação decorre de um princípio geral, consistente no dever de dar cumprimento ao contrato social segundo os imperativos da boa-fé - e não de perseguir um interesse determinado $^{662}$.

Mesmo nessa concepção contratualista, existem certos limites ao exercício do voto ${ }^{663}$. Além da impossibilidade de emprego do voto em contraste com o interesse comum de todos, não pode ele direcionar-se exclusivamente para prejudicar os demais sócios - que pode, precisamente, constituir abuso de direito ${ }^{664}$.

Reforçam o entendimento de que o voto é um direito subjetivo o fato de seu exercício ser facultativo, e não obrigatório (o que é incompatível com o poder funcional, como restou assentado no Capítulo 2 deste trabalho), e, ainda, sua valoração econômica, própria dos direitos subjetivos (patrimoniais) ${ }^{665}$. Também não incorre em responsabilidade, em caso de exercício regular (não abusivo).

Em contrário, anota Renato Ventura RIBEIRO que obrigatoriedade de voto não é regra, mas existe - como é o caso, no direito brasileiro, do acordo de acionista de

\footnotetext{
${ }^{661}$ Erasmo Valladão A. e N. FRANÇA, Conflito de Interesses nas Assembleias de S.A., São Paulo, Malheiros, 1993, p. 44. In: Direito de Voto nas Sociedades Anônimas, São Paulo, Quartier Latin, 2009, p. 171.

${ }_{622}$ "Si deve riconoscere quindi che l'obbligo del socio in conflitto d'interessi con la società di non perseguire il proprio interesse extrasociale, mettendo in pericolo la società stessa, è espressione di un principio generale. Solo che tale principio non può consistere, come vuole la prima tendenza dottrinale criticata, nell'obbligo degli azionisti di agire per la realizzazione di un determinato interesse; bensì in quello di dare esecuzione al contratto di società secondo buona fede, nei limiti del principio di collaborazione." In: L'interesse sociale, Milão, Giuffrè, 1972, p. 219.

${ }^{663}$ Do contrário, nem haveria a possibilidade de conflito de interesses e, então, o voto seria puramente meio de defesa de interesses egoísticos. Cf. Renado Ventura RIBEIRo, Direito de Voto nas Sociedades Anônimas, São Paulo, Quartier Latin, 2009, p. 171.

${ }^{664}$ Nota Erasmo Valladão A. e N. FRANÇA que, nesses casos, por coerência à natureza atribuída pelos doutrinadores dessa corrente ao direito de voto, não recorrem eles à figura do "excesso de poder", mas a típicas figuras do direito privado, como o são a violação do princípio da boa-fé na execução do contrato, o motivo ilícito e, ainda, o ato emulativo e o abuso de direito. In: Conflito de Interesses nas Assembleias de S.A., São Paulo, Malheiros, 1993, p. 45.

${ }^{665} \mathrm{O}$ argumento é referido por Renato Ventura RIBEIRO, baseado em Patrick Ledoux: "Argumenta-se ainda que o direito de voto tem um valor e a ideia de valor é indissociável da noção de direito subjetivo." In: Direito de Voto nas Sociedades Anônimas, São Paulo, Quartier Latin, 2009, p. 170.
} 
voto em bloco ${ }^{666}$ - LSA: art. $118, \S \S 3^{\circ}$ e $9^{\circ}$. Ademais, e ainda à luz da legislação nacional, conquanto não compulsório, o voto, se exercido, deve sê-lo tendo em mira o "interesse da companhia" (LSA: art. 115, caput). Quanto à ausência de responsabilidade, em caso de voto não abusivo, observa o mesmo autor que "convém lembrar que os administradores não são responsáveis pelos atos regulares de gestão (art. 158), embora exerçam atribuições definidas em lei como função (art. 154)"; destarte, conclui ele, "a ausência de responsabilidade não implica a inexistência de poder ou função ${ }^{\text {"667 }}$. E sobre o uso do voto como meio de tutela dos direitos dos sócios, pondera-se a existência de outros instrumentos ${ }^{668}$.

As teorias, normalmente de matiz contratualista, que concebem o voto como direito subjetivo comportam, ainda, uma subdivisão entre direito subjetivo puro e coletivo $^{669 \text { e } 670 .}$

Quanto à primeira concepção, encontra-se ela já delineada nos termos supra consignados. Respeitado o interesse comum, o acionista pode exercer o voto na defesa dos próprios interesses individuais. Segundo esse entendimento, havendo consenso entre os sócios, seria possível inclusive a persecução de interesses extra sociais, isto é, o emprego do voto para perseguirem interesses estranho à sociedade ${ }^{671}$.

O conflito de interesses apenas tem lugar na hipótese de o voto individual contrariar o interesse comum. Invoca-se ainda, como hipóteses de exercício ilegítimo do voto, figuras como o abuso de direito, o dever (e sua violação) de boa-fé e colaboração e, ademais, com supedâneo na doutrina germânica, o dever (e sua infringência) de fidelidade (Treuepflicht $)^{672}$.

\footnotetext{
${ }^{666}$ Nesse caso - de acordo de voto em bloco -, observa Modesto CARVALHOSA que o direito é exercido "com o encargo ou ônus de integrar o conjunto dos demais votos contratualmente vinculados". E completa: "Trata-se assim de um direito-função - o exercício conjunto do controle e não de um direito-prerrogativa, já que será de qualquer forma exercido pela comunhão de controle, mesmo se contrário à vontade de seu titular ( $\S \S 8^{\circ}$ e $9^{\circ}$ do art. 118). ” In: Comentários à Lei de Sociedades por Ações, v. 2, São Paulo, Saraiva, 2009, pp. 388-389.

${ }^{667}$ Direito de Voto nas Sociedades Anônimas, São Paulo, Quartier Latin, 2009, pp. 170-171.

${ }^{668}$ Renado Ventura RIBEIRO, Direito de Voto nas Sociedades Anônimas, São Paulo, Quartier Latin, 2009, p. 171.

${ }_{669}$ Renado Ventura RibeIRo, Direito de Voto nas Sociedades Anônimas, São Paulo, Quartier Latin, 2009, p. 171.

${ }^{670}$ Giuseppe SENA concebe o voto como direito coletivo em uma posição intermediária, entre as duas teses (direito subjetivo e poder funcional), porque se presta à persecução do interesse solidário àquele de outros sujeitos, porque "svolga l'interesse proprio ed anche gli interessi (solidali al suo) degli altri soggetti". Cf. Il voto nella assemblea della società per azioni, Milão, Giuffrè, 1958, pp. 43-44, n. 87.

${ }^{671}$ Renado Ventura RiBeIro, Direito de Voto nas Sociedades Anônimas, São Paulo, Quartier Latin, 2009, pp. 171-172.

${ }^{672}$ Renado Ventura RiBeIRo, Direito de Voto nas Sociedades Anônimas, São Paulo, Quartier Latin, 2009, pp. 172-173.
} 
Já os partidários do direito subjetivo coletivo sustentam que o voto não deve ser exercido na persecução exclusiva do interesse próprio, mas também daquele dos demais sócios: "O voto é um direito subjetivo coletivo com a finalidade de tutelar o interesse coletivo dos sócios e não o interesse individual de cada um "673. Trata-se, como observa Giuseppe SENA, um de seus defensores, de uma decorrência da concepção contratualista da sociedade - uma comunhão voluntária de interesses, que encontra identificação do escopo social com o desenvolvimento do interesse comum dos sócios ${ }^{674}$.

Em suas observações a respeito do tema, o citado doutrinador italiano afirma que o voto é conferido ao sócio para a persecução de seu interesse, e não de um interesse superior estranho a ele, nem de um "interesse social" entendido como abstração e objetivação do interesse comum a todos os sócios, unificado e imputado à pessoa jurídica. Não existe, portanto, o dever do titular do voto de exercê-lo em favor de um terceiro. Com esse fundamento, ele rejeita a ideia de que o voto pudesse representar o exercício de um

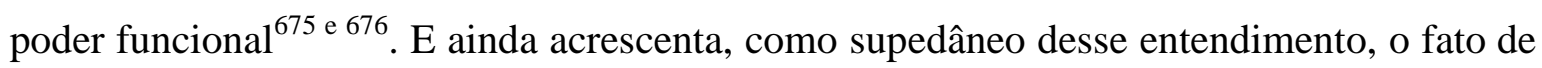
que o titular pode dele dispor de maneira livre ou simplesmente abster-se de exercê-lo ${ }^{677} \mathrm{e}$ ${ }^{678}$, sem se expor à pena de responsabilidade. Mesmo os limites impostos pela disciplina do conflito de interesse são sempre negativos (proíbem o exercício) e jamais positivos (não obrigam certo comportamento) ${ }^{679}$.

${ }^{673}$ Renado Ventura RiBeIRo, Direito de Voto nas Sociedades Anônimas, São Paulo, Quartier Latin, 2009, p. 173.

${ }^{674}$ Il voto nella assemblea della società per azioni, Milão, Giuffrè, 1958, pp. 157-158. Afirma ele: "È questo il risultato, in relazione al problema della definizione del potere esercitato col voto, di quella impostazione di tutta la problematica delle società che trae origine dal prevalere della teoria contrattualistica sulla c.d. teoria institucionalista (...)".

${ }^{675}$ Tudo isso, afirma ele, decorre da natureza contratual do ato constitutivo da sociedade: "infatti lo scopo perseguito dai soci è certamento egoistico e ciascun socio partecipa alla società esclusivamente nel proprio itneresse." In: Il voto nella assemblea della società per azioni, Milão, Giuffrè, 1958, p. 150.

${ }^{676}$ Com efeito, a nota característica do poder funcional está na vinculação de seu exercício à persecução de um interesse alheio a seu titular. A matéria foi objeto de estudo no Capítulo 2 desse trabalho e ali (item 2.2.2) foi afirmado: "Também este [o poder funcional] se compõe de posições jurídicas simples ativas, embora não apenas. Nisso, aliás, reside a distinção entre eles. Diferentemente do direito subjetivo, seu exercício não se destina à satisfação do interesse do próprio titular, mas de terceiros - a quem, por força de norma, tal poder deve favorecer. A estes, portanto, e não ao titular, é atribuível o que resulta de 'vantajoso' nesse exercício, $e$ do modo como exigido pela função do direito".

677 Também essa característica do poder funcional foi objeto de estudo no Capítulo 2, em que também se consignou: "E, porque conferido para persecução de interesse alheio, o titular do poder funcional, ao contrário de quem tem direito subjetivo, não é dotado de liberdade para exercer o poder ou não. Ele tem o dever de fazê-lo."

${ }^{678} \mathrm{Na}$ realidade, ao se afirmar que se pode "dispor" do voto, quer-se significar que integra a liberdade do titular exercê-lo ou não. Todavia, o direito ao voto é irrenunciável e inderrogável. Preleciona Modesto CARVALHOSA: "Embora direito relativo o voto é irrenunciável por parte do acionista cujas ações possuam legal ou estatutariamente tal prerrogativa. Além disso, é inderrogável o direito de voto por parte da maioria. ” In: Comentários à Lei de Sociedades por Ações, v. 2, São Paulo, Saraiva, 2009, p. 387.

${ }^{679}$ Esse caráter facultativo (que decorre da ausência de deveres positivos imputados aos sócios), explica Giuseppe SENA, é confirmado pela falta de normas que imponham aos sócios responsabilidade por não votar, ao contrário do que sucede com os administradores - que são obrigado a agir no interesse de terceiros 
Obtempera Giuseppe SENA, contudo, que, no exercício do voto para a tutela do próprio interesse, o sócio concorre com os demais, mediante o expediente da deliberação, para a direção da sociedade. Por força do princípio majoritário, que é próprio dessa técnica jurídica, o sócio dispõe potencialmente não apenas do próprio interesse, mas também do de seus pares - na medida em que seu voto, sozinho ou aglomerado a outros, forma a maioria e conseguintemente vincula todos os sócios, inclusive os ausentes e os divergentes ${ }^{680}$.

Assim, SENA caracteriza o voto como "quase" um tertium genus, intermediário entre o direito subjetivo e o poder funcional - já que é empregado na persecução ao próprio interesse do titular, mas também potencialmente dispõe sobre o interesse alheio. Essa posição intermediária, continua ele, "consiste nell'atribuire il potere ad uno fra più soggetti cui fanno capo gli interessi dei quali si dispone, e viene indicata come diritto soggettivo collettivo. "681

Ressalta ele ademais, em reforço à tese desse caráter intermediário, a circunstância de que o sujeito a quem é atribuído o voto não é um "terceiro" em relação ao titular do interesse - o que, reitere-se, repele a tese de poder funcional -, mas também não há coincidência entre um e outro, porque o titular do voto é apenas um entre os demais sujeitos titulares do interesse perseguido - o que torna imprópria a também a tese do direito subjetivo ${ }^{682}$.

De maneira análoga, visto o mesmo fenômeno sob a ótica do interesse objetivado pelos titulares do voto, completa Giuseppe SENA, também persiste o caráter intermediário. Se esse interesse correspondesse ao interesse de um terceiro estranho (hipótese em que o o voto seria um poder funcional), seria concebível que todos votantes agissem em busca de um interesse idêntico, o que, no entanto, não sucede. Por outro lado, se o votante perseguisse apenas o próprio interesse individual (estar-se-ia diante de um direito subjetivo), certamente os interesses se colocariam em posição de conflito.

(hipótese de poder funcional). Cf. . Il voto nella assemblea della società per azioni, Milão, Giuffrè, 1958, p. 151.

${ }^{680}$ Il voto nella assemblea della società per azioni, Milão, Giuffrè, 1958, p. 151. E sintetiza: “La rilevanza di ciò è evidente quando si consideri che il socio viene così ad influire, non solo sullo svolgimento di un proprio interesse, ma anche (almeno potencialmente) sullo svolgimento di interesse altrui." (pp. 151-152)

${ }^{681}$ Il voto nella assemblea della società per azioni, Milão, Giuffrè, 1958, p. 152. Assertivamente escreve: "In tale categoria, a mio avviso, deve essere classificato il voto del socio nell 'assemblea."

${ }^{682}$ São esclarecedoras suas observações, referindo-se ao titular do voto (acionista): "soggetto che non è un terzo rispetto al titolare dell'interesse, ma non è nepputre esclusivamente il titolare, perchè è uno fra i più soggetti cui fanno capo gli interessi in questione." In: Il voto nella assemblea della società per azioni, Milão, Giuffrè, 1958, p. 152. 
Assumindo essa posição intermediária, no entanto, é certo que, se, por um lado, deve-se excluir a possibilidade de persecução a interesse idêntico, deve-se, por outro, igualmente rejeitar o desenvolvimento de interesse em conflito. E, assim, os sócios devem perseguir interesses solidários ${ }^{683}$. Em conclusão, resume: "Il voto verrebbe così definito come l'esercizio di un diritto soggettivo collettivo, diretto, attraverso la deliberazione dell'assemblea (che è combinazione del tipo atto colletivo), allo svolgimento di un interessse individuale del socio, interesse che si pone tuttavia in posizione di solidarietà nel rapporto con analoghi interessi degli altri soci. ",684

A tese, em que pese desenvolvida com concatenação, merece uma crítica. Não está claro se o a noção de interesse comum, que a permeia por completo, refere-se a todos os sócios ou se apenas aos que compõem a maioria deliberante. Observa Renato Ventura RIBEIRO que, "se não servir para tutelar todos, fica fragilizada a ideia de direito subjetivo"; por outro lado, se destinada à tutela de todos, não se explicam as deliberações não consensuais, isto é, tomadas por quorum inferior à unanimidade - salvo se, observa o mesmo autor, "se admitir que há mais de um interesse comum dos sócios" "685.

\subsection{Poder funcional}

Outra corrente doutrinária sustenta tratar-se o voto em assembleia de acionistas de poder funcional, poder-dever ${ }^{686}$. Ao exercê-lo, portanto, não é facultado a seu titular ter em conta o atendimento ao próprio interesse, mas, antes, e exclusivamente, a um interesse que lhe é alheio. Esse interesse estranho ao titular é o interesse social, e para sua persecução é que o voto é, de acordo com esse entendimento, conferido ao acionista ${ }^{687}$.

Observa Renato Ventura RIBEIRO, a respeito dessa corrente, que, apesar de o voto constituir um direito (rectius: uma posição jurídica subjetiva complexa, com elementares ativas), "não há plena liberdade de votar, pois o voto deve ser exercido em

\footnotetext{
${ }^{683}$ Diz ele "essi debbono svolgere solamente interessi solidali”. In: Il voto nella assemblea della società per azioni, Milão, Giuffrè, 1958, p. 153.

${ }^{684}$ Giuseppe SENA, Il voto nella assemblea della società per azioni, Milão, Giuffrè, 1958, p. 153.

${ }^{685}$ Direito de Voto nas Sociedades Anônimas, São Paulo, Quartier Latin, 2009, p. 173.

${ }^{686}$ Importa esclarecer que o debate travado em torno da natureza do voto e, em especial, acerca da tese em tela não compreende o poder de controle, que, no Brasil, é reconhecido como uma categoria própria, dotada naturalmente de regramento específico. Em sua obra monográfica, Renato Ventura RIBEIRO expressamente faz a ressalva e volta suas preocupações particularmente para o voto não decorrente do bloco de controle. Cf. Renato Ventura RIBEIRO, DIREITO de Voto nas Sociedades Anônimas, São Paulo, Quartier Latin, 2009, p. 176.

${ }^{687}$ Erasmo Valladão A. e N. FRANÇA, Conflito de Interesses nas Assembleias de S.A., São Paulo, Malheiros, 1993 , p. 43.
} 
prol do interesse social”. Ele mesmo relata que já se chegou a falar em voto como "função social", "por se entender ser o voto um poder jurídico (Kannrecht) capaz de influir na esfera alheia", 688 .

Consigna Erasmo Valladão A. e N. FRANÇA que o poder (poder-dever), como categoria jurídica, é outorgado a alguém para que ele persiga uma finalidade determinada, que justificou sua previsão legal e sua atribuição a esse titular. Assim, ao se enquadrar o voto nessa categoria, continua o autor, "é evidente" que ele "não pode ser livre no seu exercício, mas deve dirigir-se precipuamente àquela finalidade determinada pela lei ${ }^{, 689}$.

Por força dessa concepção acerca do voto, que o identifica com o poder função, essa posição doutrinária admite - e reclama - com tranquilidade a aplicação ao direito societário de institutos típicos de direito público ${ }^{690}$.

Nesse contexto, o preciso delineamento do interesse social torna-se relevantíssimo, porque o voto - que, reitere-se, não é direito, mas poder funcional e, portanto, não deve ser empregado em persecução ao interesse próprio do titular - deve ser exercido com vistas a seu atendimento e a inobservância desse dever importa em vício, que macula sua validade. Em outras palavras, como sucede em qualquer poder dever, será viciado o voto exercido pelo titular em contrariedade ao interesse que lhe é imposto perseguir - pouco importa se voltado à satisfação do próprio titular ou, ainda, de interesse de terceiros ${ }^{691}$.

Em análise da Lei n. ${ }^{\circ}$ 6.404/76, e após referir-se à disposição do art. 115 ( "O acionista deve exercer o direito a voto no interesse da companhia..."), Fabio Konder COMPARATO sublinha a existência de "interesses que devem ser atendidos no exercício dos poderes que a lei atribui aos acionistas, sejam eles controladores ou não”. E conclui: “a não-realização intencional desses interesses, legalmente impostos, configura um abuso ou

\footnotetext{
${ }^{688}$ Direito de Voto nas Sociedades Anônimas, São Paulo, Quartier Latin, 2009, p. 174.

${ }^{689}$ Conflito de Interesses nas Assembleias de S.A., São Paulo, Malheiros, 1993, p. 43.

${ }^{690}$ Pier Giusto JAEGER, L'interesse sociale, Milão, Giuffrè, 1972, pp. 100 e 101, nn. 25 e 29; Renato Ventura RIBEIRo, Direito de Voto nas Sociedades Anônimas, São Paulo, Quartier Latin, 2009, p. 174; Erasmo Valladão A. e N. FRANÇA, Conflito de Interesses nas Assembleias de S.A., São Paulo, Malheiros, 1993, p. 44 (com referência ao mesmo JAEGER).

${ }^{691}$ Renato Ventura RIBEIRO explicita: "Tendo-se o voto como direito-função, cumpre discutir se o voto contrário ao interesse social é nulo ou anulável e a atuação na defesa de interesse extra-social é nulo ou anulável e a atuação na defesa de interesse extra-social caracteriza desvio ou excesso de poder." In: Direito de Voto nas Sociedades Anônimas, São Paulo, Quartier Latin, 2009, p. 175.
} 
desvio de poder, juridicamente sancionável ${ }^{, 692}$.

As críticas a essa teoria são diversas. Como sublinhado no subitem precedente, o caráter facultativo do voto é fortíssimo empecilho à procedência da tese ${ }^{693}$. Não é ocioso relembrar que o poder função (como o são o poder familiar e os cargos públicos), porque destinado à proteção de interesse de terceiros, é de exercício obrigatório - o que o diferencia do direito subjetivo.

Também não podem ser ignoradas, como estorvo à tese, a dificuldade de precisar os limites do interesse social - que, segundo esse entendimento, é o padrão para verificação da regularidade do voto - e a possibilidade de divergência entre os votos, que contraria a ideia em referência (se os sócios devessem atender a um único interesse, a convergência seria de regra) ${ }^{694}$. Nessa mesma ordem de ideias, a tese não explica a deliberação que decide pela dissolução da sociedade ${ }^{695}$.

Além disso, como justificar a aplicação do princípio da proporcionalidade? A proporção entre o peso do voto e a participação no capital social parece não fazer sentido, se o exercício do voto limita-se ao cumprimento de um ofício e não à persecução do próprio interesse ${ }^{696}$. Por outro lado, se prevalecesse a tese, a deliberação violadora do interesse social poderia ser impugnada mesmo por aquele acionista que tivesse votado no sentido prevalecente ${ }^{697}$.

\subsection{Outras teorias}

A doutrina relata outras teorias que procuram definir a natureza jurídica

\footnotetext{
${ }^{692}$ Controle conjunto, abuso no exercício do voto acionário e alienação indireta de controle empresarial, in Direito Empresarial, São Paulo, Saraiva, 1990, p. 86. Ele ressalva, todavia, a diferença dos interesses que devem ser perseguidos pelos titulares do poder de controle e pelos demais acionistas. "É que uns são autênticos empresários, ao passo que os outros não passam de sócios capitalistas." Sem perscrutar a respeito da natureza do voto, Alfredo Sérgio LAZZARESCHI NETO anota, sinteticamente: "O acionista não tem o dever de comparecer às assembleias gerais e exercer o direito de voto; se o acionista comparece, é livre para abster-se de votar; mas, se vota, deve exercer esse direito no interesse da companhia." In: Lei das Sociedades por Ações Anotada, São Paulo, Saraiva, 2006, p. 143, n. 1 b.

${ }^{693}$ Que, no caso do Brasil, ao menos, como visto, apenas é excepcionado em caso de acordo de acionistas - o qual, naturalmente, decorre sempre da livre vontade de seu signatário (LSA: art. 118).

${ }^{694}$ Renato Ventura RIBEIRO, DIREITO de Voto nas Sociedades Anônimas, São Paulo, Quartier Latin, 2009, p. 174.

${ }^{695}$ Embora Renato Ventura RIBEIRO divise a possibilidade, “se sua existência [i.e., da sociedade] for prejudicial [ao interesse social?]”. Cf. Direito de Voto nas Sociedades Anônimas, São Paulo, Quartier Latin, 2009 , p. 176.

696 A crítica, feita por Renato Ventura RIBEIRO, é imputada a Patrick Ledoux. Cf. : Direito de Voto nas Sociedades Anônimas, São Paulo, Quartier Latin, 2009, p. 176.

${ }^{697}$ Renato Ventura RIBEIRO, DIREITO de Voto nas Sociedades Anônimas, São Paulo, Quartier Latin, 2009, p. 175 .
} 
do voto nas assembleias de acionistas da companhia. Renato Ventura RIBEIRO menciona a teoria que, ante as teorias extremadas, concebe o voto como uma categoria mista, entre o poder funcional e o direito subjetivo. Em uma tentativa de conciliação das duas posições, anteriormente examinadas, essa tese atribui ao voto o dever de defesa do patrimônio e dos interesses dos acionistas e, ainda, como procedimento de gestão da sociedade. $\mathrm{O}$ mesmo autor critica essa vertente não apenas pela natural dificuldade de conceber-se um instituto "misto", mas também pela embaraçosa situação de se definir, nesse caso, qual interesse (social ou individual) deve prevalecer ${ }^{698}$.

A natureza de direito individual é imputada ao voto por outra teoria que, salvo quanto à possibilidade de o titular de voto perseguir outras finalidades que não suas egoísticas, é muito próxima do direito subjetivo ${ }^{699}$. Para tal vertente, o interesse social tem o efeito exclusivo de atribuir limites ao exercício do direito de voto. Mas o titular não tem o dever de persegui-lo e, observadas as restrições por ele impostas, o voto pode ser empregado livremente para o atendimento de qualquer outro interesse, mesmo, como já sublinhado, outro que não o estritamente egoístico.

Uma derradeira tese convém ser mencionada. Defende ela o caráter obrigatório do voto e, portanto, atribui a ele a natureza jurídica de dever legal ${ }^{700}$. Por sua

${ }^{698}$ Renato Ventura RIBEIRO, DIREITO de Voto nas Sociedades Anônimas, São Paulo, Quartier Latin, 2009, p. 176. Menciona o autor ser base para essa tese Jean-Marc Hauptmann.

${ }^{699}$ Renato Ventura RIBEIRO, DIREITO de Voto nas Sociedades Anônimas, São Paulo, Quartier Latin, 2009, p. 177.

${ }^{700}$ Registre-se a tese defendida por Renato Ventura RIBEIRO, que entende dever ser obrigatório o exercício do voto. Observa inicialmente o autor que, apesar do caráter, em princípio, facultativo do voto (que decorreria da liberdade de votar), a companhia tem interesse nele e o seu não exercício (proveniente da ausência do acionista ou da abstenção daquele que comparece) pode ensejar consequências - donde a conclusão pela obrigatoriedade, que pode se fundamentar, segundo o autor, tanto na teoria contratualista, quanto na institucionalista. Esta última acarreta a atribuição ao voto da natureza de poder funcional e, nessa qualidade, o titular, que deve perseguir o interesse fixado pela lei, não pode subtrair-se ao cumprimento desse mister. No caso da ordem jurídica brasileira, o fundamento seria o sempre citado art. 115 da Lei n. ${ }^{\circ}$ 6.404/76 (que impõe ao acionista o dever de exercer o direito de voto no interesse da companhia), a partir de uma "análise estritamente funcional": a ausência ou a abstenção do acionista, nas assembleias, desatende ao interesse social e, portanto, viola a norma em comento. Já nos limites da teoria contratualista, esse comportamento violaria o dever de colaboração (ou de fidelidade, na tradição germânica), a boa-fé (invoca a aplicação do disposto no art. 422 do Código Civil) e a affectio societatis (embora considere ser "questionável" sua presença nas companhias). O autor obtempera que "embora discutivel a existência de um dever de cooperação nas sociedades anônimas, pode estar presente nas sociedades anônimas intuito personae”; quanto às companhias intuito pecuniae, salienta que os acionistas devem contribuir para a formação da vontade social (para se alcançar o interesse social, já que a completa ausência do acionista impede o cumprimento do fim social); menciona o abuso de minoria (particularmente, sua ausência nas deliberações que dependem de maioria qualificada: "isso porque o direito de obstrução tem limites" e "o abuso de direito é ato ilícito"). De lege ferenda, defende a inclusão dessa obrigatoriedade na ordenação jurídica nacional e afirma que esse entendimento está em consonância com a concepção institucionalista da Lei de Sociedades por Ações de 1976; sustenta também a necessidade de imposição de sanções ( "A sanção deve ser o não recebimento dos dividendos e juros sobre o capital próprio, relativo às ações cujo direito de voto não fora exercido naquele exercício social.”). Cf. Direito de Voto nas Sociedades Anônimas, São Paulo, Quartier Latin, 2009, pp. 177-183. 
fundamentação e contornos, todavia, presta-se mais à propositura de uma modificação na estrutura legal existente do que propriamente a uma análise da realidade existente no Brasil e no direito comparado.

\subsubsection{Declaração unilateral}

A deliberação, como já referido, é um ato colegial, que se imputa à sociedade. É o resultado, nas palavras de Giuseppe SENA, de uma combinação de atos jurídicos $^{701}$ - os quais, por sua vez, não são imputados à sociedade, mas aos sócios ${ }^{702}$. Tais atos são os votos.

Já se examinou, ademais, embora não em caráter conclusivo, as teorias existentes a respeito da natureza jurídica da possibilidade conferida ao acionista de tomar parte nas deliberações da sociedade. Importa, agora, no esquadro da teoria dos atos jurídicos, localizar aquele em que se enquadra o voto.

Para tanto, contudo, faz-se imprescindível pôr em revista a estrutura jurídica das deliberações societárias.

\subsection{O voto e a formação da vontade unitária coletiva}

Sobre o tema, já foi referido que, diferentemente do sucedido nas pessoas naturais, a formação da vontade na pessoa jurídica não é produto de um móvel biopsíquico, mas, antes, constitui um ato jurídico (promovido, em última instância, por pessoas naturais), decorrente da justaposição (e interação) de outros atos jurídicos. Para sua realização, concorre a atuação dos órgãos da pessoa jurídica.

Observa Eduardo de Melo Lucas CoElHo que, até por “conexão” com os elementos da atuação da pessoa natural (a vontade natural e a concretização em ato), a "função orgânica" deve ser analisada também em dois momentos distintos e constitutivos fundamentais: a formação da vontade (função de formação da vontade ${ }^{703}$ ) e a conversão

\footnotetext{
${ }^{701}$ Il voto nella assemblea della società per azioni, Milão, Giuffrè, 1958, p. 11.

702 Erasmo Valladão A. e N. FRANÇA, Invalidade das Deliberações de Assembleia das S/A, São Paulo, Saraiva, 1999, p.45.

${ }^{703}$ Ou willensbildende Funktion.
} 
desta num comportamento exterior (função de execução da vontade $\left.{ }^{704}\right)^{705}$.

Quanto à primeira função, pode suceder de o órgão dela incumbido ser singular, e, nesse caso ${ }^{706}$, uma única pessoa natural será destinatária exclusiva de toda a atribuição orgânica, ou ser plural e, então, aos diversos integrantes tocará a atribuição. Na primeira hipótese, a formação da vontade da pessoa jurídica depende de uma decisão $($ Entschlu $\beta)$ e, na segunda, sendo o órgão de funcionamento colegial $^{707}$, depende de uma deliberação $(\text { Beschlu } \beta)^{708}$. O produto da atuação desses órgãos (o resultado da elaboração volitiva) deve ser, em qualquer das hipóteses, unitário e qualitativamente idêntico, inobstante a diferença de modalidade formal ${ }^{709}$.

O traço característico, no caso do órgão singular, está em que o processo de formação da vontade da pessoa jurídica coincide pari passu com a formação da vontade do indivíduo (ocupante do cargo), cuja singularidade natural assegura um resultado único $^{710}$. No caso do órgão (plural) colegial, a formação da vontade "emerge" da "pluralidade de posições e vontades singulares naturais, sob o signo da inerente variabilidade "711. A unidade a que devem convergir tais vontades individuais não resultará de um movimento psicológico nem mesmo sociológico dos integrantes do órgão, mas, antes, de um conjunto de regras jurídicas ${ }^{712}$ e 713 - razão por que se afirma que tal unidade

${ }^{704}$ Ou ausführende Funktion.

${ }^{705}$ A Formação das Deliberações Gerais - Assembleia Geral das Sociedades Anónimas, Coimbra, Coimbra Ed., 1994, pp. 73-74.

${ }^{706}$ Assemelhada situação verificar-se-á nas hipóteses em que o órgão plural for de funcionamento disjunto (ou separado).

${ }^{707}$ Como anteriormente examinado, o órgão plural simultâneo (em que todos os membros são destinatários de atribuições) pode funcionar de maneira conjunta ou disjunta (conforme se faça ou não necessário o concurso de certo número de seus membros) ou, ainda, colegial ("quando os titulares do órgão plural atuam em grupo, mediante deliberação tomada em reunião, atendido certo procedimento jurídico." - cf. Marcelo Vieira von ADAMEK, Responsabilidade Civil dos Administradores de S/A e as Ações Correlatas, São Paulo, Saraiva, 2009, p. 13).

708 Eduardo de Melo Lucas CoElHo, A Formação das Deliberações Gerais - Assembleia Geral das Sociedades Anónimas, Coimbra, Coimbra Ed., 1994, pp. 75-76.

709 "Trata-se, como quer que seja, de modalidades formalmente distintas mas qualitativamente idêntica,s expressão de uma função orgânica que não sofre alteração de substância pela circunstância técnica acidental de o indivíduo ceder o passo, na sua consecução, à pluralidade de pessoas; expedientes capazes, por isso, de produzir os mesmos efeitos na esfera jurídica do ente e de constituírem idêntico fundamento para a sua actuação concreta no mundo externo." In: Eduardo de Melo Lucas CoELHO, A Formação das Deliberações Gerais - Assembleia Geral das Sociedades Anónimas, Coimbra, Coimbra Ed., 1994, p. 76.

${ }^{710}$ Ressalvados, obviamente, os meandros psicológicos da formação interna da vontade - que quase nunca têm relevância jurídica.

711 Eduardo de Melo Lucas CoELho, A Formação das Deliberações Gerais - Assembleia Geral das Sociedades Anónimas, Coimbra, Coimbra Ed., 1994, p. 76.

712 Deveras, sem a observância das regras jurídicas (de competência e procedimento, em essência), as manifestações do colegiado reduzem-se a mera "opinião coletiva"; o pretenso "escrutínio" não passa de uma "pesquisa de opinião".

713 "Como melhor veremos adiante, da pluralidade de vontades singulares naturais extrai-se, segundo regras jurídicas determinadas, uma decisão qualitativamente unitária, isto é, uma decisão que aceita ou recusa certa proposta, e a ordem jurídica valora e qualifica esse acto orgânico com unidade, como posição 
assume sempre natureza normativa.

Essas regras jurídicas concernem, especificamente, à previsão do órgão competente para o desempenho dessas funções deliberativas, à delimitação de suas atribuições e, ainda, ao procedimento ${ }^{714}$ de aferição das vontades individuais dos legitimados a se manifestarem e formação da "vontade unitária".

Esse procedimento, denominado pelos italianos de "método assemblear", e que, em conjunto com as normas de atribuição (competência), constitui condição de validade das deliberações, destina-se a estruturar a sucessão de eventos e fases que resultará na proclamação do resultado, que veicula precisamente a vontade unitária do conjunto de acionistas ${ }^{715}$.

Em linhas muito gerais, esse procedimento estrutura-se segundo a seguinte ordem de acontecimentos: uma vez composta a mesa diretora, verificada a presença do quorum necessário de acionistas (quórum de instalação) e instalada a assembleia, é feita a apresentação da proposta objeto da deliberação (cuja matéria, como regra, deve ter constado da "ordem do dia",716, isto é, a relação de temas ${ }^{717}$ passíveis de deliberação na assembleia e que deve integrar o instrumento convocatório do conclave ${ }^{718}$ ), a que se seguem o estabelecimento dos debates (o contraditório ${ }^{719}$ ), a manifestação dos votos e, por fim, a apuração e proclamação do respectivo resultado, conforme o quórum necessário (quorum de deliberação).

do colectivo na matéria, atribuindo-lhe o mesmo significado para a actuação do ente jurídico que o acto determinante do órgão singular." In: Eduardo de Melo Lucas COELHO, A Formação das Deliberações Gerais - Assembleia Geral das Sociedades Anónimas, Coimbra, Coimbra Ed., 1994, p. 79.

714 Giuseppe SENA, Il voto nella assemblea della società per azioni, Milão, Giuffrè, 1958, p. 48; Erasmo Valladão A. e N. FrANÇA, Invalidade das Deliberações de Assembleia das S/A, São Paulo, Saraiva, 1999, p.37.

${ }^{715}$ Erasmo Valladão A. e N. FRANÇA, Invalidade das Deliberações de Assembleia das S/A, São Paulo, Saraiva, 1999, p.37.

716 "A indicação da ordem do dia tem por finalidade cientificar os acionistas sobre as matérias a serem discutidas e deliberadas, bem como possibilitar-lhes a devida obtenção de informações a fim de que possam decidir sobre seu voto de forma consciente" - o que naturalmente veda formas genéricas ("outros assuntos de interesse da companhia"). Cf. Alfredo Sérgio LAZZARESCHI NeTO, Lei das Sociedades por Ações Anotada, São Paulo, Saraiva, 2006, p. 124, n. 1h. Em certos casos, e também para fornecer subsídios (nesses casos, imprescindíveis) para os debates e o voto, é necessária, além de a matéria integrar a ordem do dia, a apresentação prévia de determinados documentos a seu respeito (caso da tomada de contas dos administradores - LSA: art. 132, I, c/c art. 133). Em outros casos, em virtude da relevância e da emergência da matéria, é dispensada sua figuração no instrumento convocatório (como o requerimento para instalação do conselho fiscal e eleição de seus membros - LSA: art. $161, \S 3^{\circ}$ ).

717 As matérias referidas na ordem do dia não se confundem com a proposta. Aquelas já são uma certa delimitação do amplo campo de possibilidades da pessoa jurídica, mas

${ }_{718}$ A seleção dessas matérias compete, naturalmente, àquele legitimado para efetivar a convocação (LSA: art. 123).

${ }^{719}$ Erasmo Valladão A. e N. FRANÇA, Invalidade das Deliberações de Assembleia das S/A, São Paulo, Saraiva, 1999, p.37. 
A necessidade de estabelecimento do contraditório ${ }^{720}$ nas assembleias de acionistas - ao qual se fez referência -, expõe a relevância da "confrontação de interesses" que deve ter lugar nesses conclaves. Como observa Modesto CARVALHOSA, as assembleias não são uma simples consulta, como poderia ocorrer com o voto por correspondência ${ }^{721}$. Portanto, a respectiva deliberação deve ser antecedida de debates, que têm precisamente o propósito de preparar o voto ${ }^{722}$ e formar a opinião individual dos acionistas acerca da proposta. Os debates, assim, não apenas se originam na proposta, mas podem resultar em sua modificação ou sua substituição ${ }^{723}$ - que, ao depois, será submetida ao escrutínio.

Essa função formadora do convencimento dos acionistas e seu potencial alterador da proposta evidenciam a influência nada desprezível que a ação individual do acionista tem na formação da vontade coletiva ${ }^{724}$ - o que, por si só, é razão bastante para fundamentar o prestígio dos debates assembleares na legislação societária.

Convém, ademais, relembrar que participantes e o de votantes na assembleia integram universos que, embora concêntricos, não são sempre coincidentes aliás, geralmente não o são: a exclusão ${ }^{725}$ ou suspensão ${ }^{726}$ do direito de voto amesquinham este último grupo, se comparado ao outro ${ }^{727}$. E, dessa maneira, os direitos políticos de

\footnotetext{
${ }^{720}$ Eduardo de Melo Lucas COELHO, com supedâneo na doutrina alemã, não fala em contraditório, mas em "princípio dialético". Todavia, ele parece restringir o alcance da expressão (veja-se: "toda a votação pressupõe um objecto, sobre o qual actuam duas forças em direcções diferentes: os votos contra e os votos a favor". Cf. A Formação das Deliberações Gerais - Assembleia Geral das Sociedades Anónimas, Coimbra, Coimbra Ed., 1994, p. 81, n. 85; também quando afirma que a assembleia "é projectada na proposta", para possibilitar "o voto e a deliberação em forma dialéctica" - p. 97). Uma expressão ou outra poderiam ser empregadas aqui indistintamente, mas não apenas para significar a contrariedade (potencial) dos votos (como faz o autor português), mas o desenvolvimento dos debates que o precedem - e que, no sentido aqui desejado, guarda semelhança com a dialética aristotélica, como "arte da discussão da exercitação da lógica" (cf. Nicola ABbaGnANo, Dicionário de Filosofia, trad. Alfredo Bosi e Ivone Castilho Benedetti, São Paulo, Martins Fontes, 2000, v. Dialética, p. 271). Todavia, tendo em vista a restrição semântica de COELHO, optou-se por empregar o termo contraditório - de resto, muito desenvolvido, em sentido muito próximo ao aqui desejado, pela doutrina processual quanto à garantia constitucional processual que lhe toma o nome.

${ }_{721}$ Comentários à Lei de Sociedades por Ações, v. 2, São Paulo, Saraiva, 2009, p. 607.

722 "No direito de voto estão compreendidos todos os direitos e requisitos inerentes à formação de opinião $e$ condições de ato de votar, como ingresso, presença e participação na assembleia geral, direito de palavra, proposição, protesto, pedido de informaç̃̃es à mesa ou à diretoria, apresentação de questões de ordem, expressão de voto, verbal ou por escrito, tudo podendo ser realizado diretamente ou por procurador constituido.” In: Renato Ventura RIBEIRo, Direito de Voto nas Sociedades Anônimas, São Paulo, Quartier Latin, 2009, p. 163.

${ }_{723}$ Eduardo de Melo Lucas CoElho, A Formação das Deliberações Gerais - Assembleia Geral das Sociedades Anónimas, Coimbra, Coimbra Ed., 1994, pp. 145-146.

${ }_{724}$ Eduardo de Melo Lucas COELHO, A Formação das Deliberações Gerais - Assembleia Geral das Sociedades Anónimas, Coimbra, Coimbra Ed., 1994, p. 146.

${ }^{725}$ LSA: art. $115, \S 1^{\circ}$, art. $134, \S 1^{\circ}$ e art. 134.

${ }^{726}$ LSA: art. 120.

727 "O que, todavia, merece saliência é que participantes na discussão e votantes não são uma e mesma categoria, podendo o direito de intervir na discussão competir, designadamente, a sócios excluídos da votação." In: Eduardo de Melo Lucas CoELHO, A Formação das Deliberações Gerais - Assembleia Geral das Sociedades Anónimas, Coimbra, Coimbra Ed., 1994, p. 146.
} 
presença e $\operatorname{voz}^{728}$ (que apenas têm lugar na ocorrência de debates) remanescem para os integrantes exclusivos daquele primeira categoria ${ }^{729}$ como o único meio disponível, na assembleia, para tomarem parte no conclave e influenciarem a formação da vontade social (conquanto sem voto).

Por tudo isso, os debates são previstos e favorecidos pela legislação societária e seu alcance dá-se pelo estabelecimento de discussão entre os participantes (votantes ou não) das matérias apresentadas, com o pedido de esclarecimentos ${ }^{730}$, o lançamento de argumentos e contra-argumentos ("permuta de argumentos favoráveis e contrários "731) e o exercício da persuasão ${ }^{732}$ : "Diferentemente, portanto, do voto por consulta, que isola os acionistas, a deliberação em assembleia geral os reúne para formar a vontade coletiva." 733

O avanço tecnológico, particularmente em matéria de telecomunicações e telemática (internet), tornou inevitável a pressão pelo emprego de novos meios na realização de assembleias e na manifestação válida da vontade pelos sócios. Disso não têm se descurado a doutrina, a legislação e a regulamentação estatal aplicável ${ }^{734}$. Existem,

\footnotetext{
${ }^{728}$ Ou direito de palavra. O revogado Decreto-Lei n. ${ }^{\circ} 2.627 / 45$ (a antiga Lei de Sociedades por Ações) expressamente previa a possibilidade de acionistas sem direito de voto comparecer às assembleias gerais e discutir matérias submetidas à deliberação (art. 90, parágrafo único).

729729 "Todos os acionistas, independentemente da espécie ou classe de ações que possuem, têm o direito de participar da assembleia geral, manifestando-se na primeira fase de cada ponto, por meio de pedidos de esclarecimentos, argumentos ou outras falas." In: Fabio Ulhoa CoElHo, Curso de Direito Comercial Direito de Empresa, v. 2, São Paulo, Saraiva, 2012, p. 340.

${ }^{730}$ Fabio Ulhoa CoElho, Curso de Direito Comercial - Direito de Empresa, v. 2, São Paulo, Saraiva, 2012, p. 340 .

731 Eduardo de Melo Lucas Coelho, A Formação das Deliberações Gerais - Assembleia Geral das Sociedades Anónimas, Coimbra, Coimbra Ed., 1994, p. 146.

${ }^{732}$ Apenas para ilustrar a força persuasiva dos debates entre acionistas (que têm crescido em relevância, em especial por decorrência do chamado "ativismo minoritário"), podem-se citar certos acontecimentos societários experimentados por companhias abertas no Brasil e exterior, como os casos Oi (empresa de telefônica, resultante de numerosas operações societárias, em especial incorporação, em que o debate sobre o valor das do reembolso pago a acionistas retirantes ganhou o noticiário da imprensa nacional) e $L A E P$ (titular, no Brasil, da produção de lácteos "Parmalat" e cujos minoritários se "entrincheiraram" em um site na internet chamado ADVFN para postular o atendimento a determinados direitos de que se entendiam titulares). Destaca-se, ainda, o caso Yahoo!, ocorrido nos Estados Unidos: entre os anos 2005 e 2007, suas ações foram "ofuscadas" pelo despenho do concorrente Google e o presidente da companhia, Terry Semei, "era criticado por não conseguir manter a participação de mercado e por ter perdido oportunidade de negócios importantes, como a compra do You Tube”; então, um acionista, Erik Jackson, usou seu blog na internet e, ainda, vídeos no You Tube para pedir apoio dos demais acionistas para um conjunto de propostas denominado "Plano B para o Yahoo!" Também foram redigidos textos em um tipo de site (os “colaborativos", chamados “wiki”). Sobre os casos, cf. Luciana TAROCIE, Minoritários na Web, in Revista Capital Aberto, ano 9, n. 103, março de 2012, pp. 36-39, pp. 36-39. Esses fatos, além de evidenciar o poder catalizador e agregador da internet para reunião e atuação de grupos sociais organizados (que não é objeto de preocupação aqui), põe em destaque o poder dos minoritários influenciar, e até decisivamente, as deliberações a partir unicamente da persuasão.

${ }^{733}$ Não por outra razão mesmo ao preferencialista sem direito de voto é conferido o direito de presença e voz na assembleia geral de acionistas das companhias.

734 Escrevendo na década de 1990 em Portugal, Eduardo de Melo Lucas CoELHo ensina que os debates usualmente ocorrem "em reunião directa e pessoal dos participantes num certo tempo e lugar" e as
} 
ademais, informações de que a utilização desses expedientes tem grassado na prática societária, mundial e brasileira. A aplicação desses meios, contudo, afora o atendimento a outros requisitos e preocupações ${ }^{735}$, não pode impedir a ocorrência de debates ${ }^{736}$ nem ao menos prejudicar a unidade temporal que amalgama as diversas manifestações na formação de um ato único (unidade do ato), localizado temporalmente entre a enunciação da proposta e a tomada dos votos ${ }^{737}$. Em outros termos, é preciso assegurar que as interações se deem na mesma ocasião, dentro do lapso limitado por esses dois eventos.

Verifica-se, portanto, que a proposta é o centro em torno do qual giram

manifestações são veiculadas oralmente; mas advertia já aquela época, e à luz da legislação daquele país, a desnecessidade (legal) de processamento dos debates naqueles termos - cf. A Formação das Deliberações Gerais - Assembleia Geral das Sociedades Anónimas, Coimbra, Coimbra Ed., 1994, p. 146. Não considerando ainda a utilização da técnica telemática, Plínio Paulo BING admite o debate em "discussão oral ou escrita" (Cf. Direito Assemblear nas Sociedades Mercantis e Civis, Porto Alegre, Sergio Antonio Fabris Editor, 2007, p. 49). Hodiernamente, conhece-se a possibilidade de realização de assembleias virtuais (exclusivamente em ambiente telemático) e on line (de configuração mista, com a realização em local geográfico - dito presencial -, mas admitida a participação por meio eletrônico - sobre o assunto, cf. Renato Ventura RiBeIRo, Aplicação de Novas Tecnologias nas Assembleias Gerais de Sociedades Anônimas, in: Direito Societário - Desafios Atuais, Rodrigo R. Monteiro de Castro - Leandro Santos de Aragão (coord.), São Paulo, Quartier Latin, 2009, pp. 289-291). De todo modo, presencial ou não, de maneira oral ou escrita, com emprego ou não de algum meio tecnológico (de telecomunicações, informática etc.), em qualquer dos casos é imprescindível a unidade de tempo que amalgame as manifestações opinativas, para que constituam efetiva "preparação" para o voto, no lapso que medeia a enunciação da proposta e o exercício do voto. Assegurar a participação do acionista nesses debates tem sido uma preocupação na implantação desses meios tecnológicos na realização das assembleias gerais de acionistas. Quanto aos limites técnicos da telemática, reporta Renato Ventura RIBEIRO que: "Nas assembleias parcialmente virtuais, pode haver o acompanhamento virtual. Mas nem sempre o acompanhamento pode significar direito de participação. No plano material, pode haver ou não possibilidade de intervenção à distância, como, por exemplo, o uso da palavra." (In: Aplicação de Novas Tecnologias nas Assembleias Gerais de Sociedades Anônimas, Direito Societário - Desafios Atuais, Rodrigo R. Monteiro de Castro - Leandro Santos de Aragão (coord.), São Paulo, Quartier Latin, 2009, p. 291).

735 Preocupações, por exemplo, quanto à integridade da manifestação do voto e a autenticidade de seu prolator; quanto ao atendimento a certas formalidades legais (assinatura no livro - físico - de "presença", conceito, que, por sua vez, merece revisão); e quanto à privacidade dos debates, à exclusão de terceiros estranhos à assembleia e à vedação de tornar públicas as informações sensíveis da companhia.

${ }^{736}$ Existem, no entanto, entendimentos divergentes. A doutrina registra a tendência de enfraquecimento das assembleias, em consequência do absenteísmo e da utilização de acordos de acionistas ("que tornam a assembleia geral num mero centro formalizador de deliberações já tomadas e a admissão de tomada de decisões sem a sua realização" - Cf. Renato Ventura RIBEIRO, Direito de Voto nas Sociedades Anônimas, São Paulo, Quartier Latin, 2009, p. 209), e o descrédito na influência efetiva dos debates na formação do convencimento dos acionistas (é o chamado voto pré-concebido).

${ }^{737}$ Eduardo de Melo Lucas COELHO compara os debates às tratativas que antecedem a celebração de um contrato. Escreve ele: "Também na discussão se ponderam e controvertem as diferentes possibilidade de uma certa regulação de interesses jurídico-privados, longe ainda da conformação que uma futura actuação orgânica, por enquanto meramente projectada, assumirá no final. Longe, por outras palavras, de uma estável vinculação formal dos participantes e determinada regulação material, que só com a votação se verificará." In: A Formação das Deliberações Gerais - Assembleia Geral das Sociedades Anónimas, Coimbra, Coimbra Ed., 1994, p. 147. Ao ensejo da comparação estabelecida pelo autor luso, pode-se, a propósito do emprego de meios tecnológicos nas assembleias, acrescentar, ao que já ficou assentado em nota de rodapé precedente, que, ao contrário das tratativas pré-contratuais, os debates assembleares não podem ser estabelecidos "entre ausentes" (CC: art. 428, inc. II a IV), mas apenas "entre presentes" (CC: art. 428, inc. I), isto é, com simultaneidade das declarações de parte a parte - mesmo que tal simultaneidade torne-se viável, na ausência de identidade geográfica, em razão do emprego de aparato tecnológico. 
os acontecimentos que se sucedem na assembleia ${ }^{738}$ e 739 : encerrados os debates, que a têm por tema, os sócios manifestam-se sobre ela, pelo voto, e a deliberação, por fim, não é nada além do que seu acatamento ou sua rejeição - trata-se da identidade estrutural entre proposta e deliberação. Ela desempenha, portanto, uma evidente função técnicoorganizativa $^{740}$ dos trabalhos assembleares.

É preciso sublinhar essa constatação, porque é essa técnica assemblear que preside a condução de seus trabalhos - que conforma o voto e, portanto, delimita seus efeitos e permite seu enquadramento na categoria jurídica entre aquelas doutrinariamente apontadas para os atos jurídicos em sentido amplo.

Antes da proposta, como afirma Eduardo de Melo Lucas CoELHo, existe apenas "um simples quadro de possibilidades eventualmente susceptíveis de atingirem o objetivo previsto”. Desse amplo, complexo e desordenado conjunto de possíveis soluções, recorta-se "um conteúdo material relativamente restrito e excludente dos demais",741, que é precisamente a proposta.

Apresentada a proposta, por quem é legítimo (direito de iniciativa ${ }^{742}$ ),

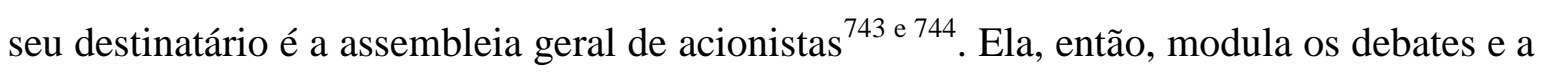
manifestação do voto, uma vez que a deliberação sempre consistirá exclusivamente na

\footnotetext{
${ }^{738}$ Não se pode descurar, reitere-se, que a proposta deve referir-se à matéria previamente inclusa na ordem do dia integrante do instrumento convocatório.

${ }_{739}$ Afirma Eduardo de Melo Lucas COELHO que a deliberação é impensável sem a proposta e, assim como esta última não teria significado se não correspondesse a uma deliberação específica. Cf. A Formação das Deliberações Gerais - Assembleia Geral das Sociedades Anónimas, Coimbra, Coimbra Ed., 1994, p. 98.

${ }_{740}$ Nesse sentido, define com invulgar felicidade Eduardo de Melo Lucas CoELHO: "A proposta, recorde-se, surge como expediente técnico-organizatório destinado a possibilitar o exercício da função orgânica "de formação da vontade, necessariamente estimulada esta pela inter-acção de acontecimentos exteriores e de exigências do fim societário, e por teste, e pela competência do órgão, adrede condicionada." In: A Formação das Deliberações Gerais - Assembleia Geral das Sociedades Anónimas, Coimbra, Coimbra Ed., 1994, p. 105.

${ }^{741}$ A Formação das Deliberações Gerais - Assembleia Geral das Sociedades Anónimas, Coimbra, Coimbra Ed., 1994, pp. 97-98.

${ }_{742}$ Em princípio, no caso, os acionistas. Cf. Eduardo de Melo Lucas CoELHo, A Formação das Deliberações Gerais - Assembleia Geral das Sociedades Anónimas, Coimbra, Coimbra Ed., 1994, pp. 107-109.

${ }^{743} \mathrm{~A}$ incumbência de enunciar a proposta feita por quem tem o direito de iniciativa é da mesa diretora da assembleia, que preside seus trabalhos. Esse poder de direção atribui à mesa o poder de fazer um controle inicial da proposta, para determinar ou não sua submissão ao escrutínio (por exemplo, por encontrar-se ela incluída ou não na matéria integrante ordem do dia). Em caso de dúvida ou controvérsia, essa questão de ordem deve ser submetida à própria assembleia. Cf. Eduardo de Melo Lucas CoELHO, A Formação das Deliberações Gerais - Assembleia Geral das Sociedades Anónimas, Coimbra, Coimbra Ed., 1994, p. 145.

${ }_{744}$ Ao órgão colegial "está submetida a formação da vontade da pessoa jurídica, a ele é apresentado o projeto de solução da questão problemática que estimula o exercício da função orgânica para sobre o mesmo deliberar." Cf. Eduardo de Melo Lucas CoELHO, A Formação das Deliberações Gerais - Assembleia Geral das Sociedades Anónimas, Coimbra, Coimbra Ed., 1994, p. 107. Nota: fiéis à classificação e à nomenclatura enunciadas no princípio desse capítulo, preferimos o emprego da expressão órgão colegial para significar o que o autor português designa por órgão coletivo, que nos termos suso delineados tem sentido próprio (mesmo que órgão plural conjunto, isto é, cuja manifestação depende da concorrência de todos, e não menos que todos, os seus integrantes).
} 
opção por uma das duas alternativas: ou a aprovação ou a rejeição da aludida proposta. Outro conteúdo não pode ter a manifestação do voto - exceção feita à abstenção. Sucede que ela ou não produz efeitos ou seus efeitos se equivalem aos do voto contra. Não produz efeitos quando o quórum de aprovação é relativo aos presentes e, por lei, é excluída das contas. É o caso da regra geral da Lei n. ${ }^{o}$ 6.404/76: art. 129. Se, contudo, o quórum de aprovação considera o capital social votante (e.g., art. 136 da LSA), a ausência do acionista à assembleia e seu comparecimento para abster-se ou votar contrariamente têm o mesmo efeito $^{745}$.

Observe-se que, guardada a conexão com a ordem do dia, a proposta pode ser alterada ou substituída na própria assembleia, pelos mesmos legitimados a apresentá-la originalmente. Isso não altera, contudo, essa sistemática deliberativa, que igualmente consistirá, necessária e unicamente, em acatar ou desaprovar a nova ou modificada proposta ${ }^{746}$.

Ao se afirmar, como feito acima, que a proposta modula os debates e os votos, põe-se em evidência a gravíssima influência que tem a vontade individual de seu autor no produto deliberativo a que se chegará.

A proposta, com efeito, é já a redução a uma única solução de um amplíssimo universo de outras tantas, como se disse acima. O órgão colegial não concorre (não intervém) para essa restrição - que provém exclusivamente de seu autor -, mas a ela ele ficará adstrito: o processo deliberativo não escolherá uma entre várias soluções possíveis, mas se cingirá "a dar uma resposta nos termos da limitada alternativa aludida ${ }^{, 747}$. Já se afirmou acima que essa limitação é obtemperada pela possibilidade de oferecimento pelos legitimados de modificação ou substituição dessa proposta original; mas também se consignou que esse movimento não altera a sistemática deliberativa e, portanto, os debates e a votação restarão, de qualquer sorte, estreitados a esses novos limites.

\footnotetext{
${ }_{745}$ Quem se abstém, expressa ou tacitamente, afirma Eduardo de Melo Lucas COELHO, não emite voto algum. Não significa, contudo, que seja desprovida de efeitos jurídicos. O mesmo autor arrola alguns: "os votantes que se abstêm concorreram com a sua presença para a válida constituição do colégio; pelo facto da abstenção é-lhes facultada a impugnação da deliberação (...); a abstenção tem, em princípio, que abranger todos os votos de que disponha um mesmo acionista, sob pena de violação do princípio da unidade do voto." In: A Formação das Deliberações Gerais - Assembleia Geral das Sociedades Anónimas, Coimbra, Coimbra Ed., 1994, pp. 152 e 153.

${ }_{746}$ Sobre o assunto, cf. Eduardo de Melo Lucas COELHO, A Formação das Deliberações Gerais - Assembleia Geral das Sociedades Anónimas, Coimbra, Coimbra Ed., 1994, p. 98.

${ }^{747}$ Eduardo de Melo Lucas Coelho, A Formação das Deliberações Gerais - Assembleia Geral das Sociedades Anónimas, Coimbra, Coimbra Ed., 1994, p. 111.
} 
Dessa maneira, a proposta não se limita a uma técnica-organizativa da deliberação, mas, como sublinha Eduardo de Melo Lucas COELHo "vai ao ponto de antecipar em grau não despiciendo a deliberação final, apresentado-se, na realidade dos factos, portadora de um coeficiente decisório. "748 Em certo sentido, a proposta é já uma antecipação da deliberação.

Deveras, resulte o conclave em acatamento ou rejeição da proposta, não será possível à deliberação chegar a um sentido diferente daquele alcançado pela proposta $^{749}$. O sentido da deliberação será sempre coincidente com aquele enunciado pela proposição, quer pela recusa da solução ou medida apresentada, se rejeitada, quer por sua adoção (e implementação), se aprovada. Em outras palavras, “o conteúdo e o sentido dos votos e da emergente deliberação aferem-se, pois, exclusivamente pelo conteúdo e sentido da proposta em que se fundam. ,750

Dessa maneira, a proposta contém a carga dispositiva (o comando, o regramento) e o voto limita-se à adesão ou, ao contrário, à sua rejeição - o que redundará, pela deliberação, em sua aprovação ou não.

Uma ideia inicial, construída a partir desse iter procedimental assemblear, poderia conduzir à conclusão de que a proposta constitui uma declaração negocial, com relação à qual o voto seria a aceitação. $\mathrm{O}$ entendimento, contudo, sofre algumas objeções e parcela da doutrina prefere lhe atribuir a natureza de simples "projeto de deliberação", que representa, destarte, a eleição "provisória" de uma entre numerosas soluções possíveis voltadas para o cumprimento dos escopos da sociedade ${ }^{751}$. Diz-se provisória, porque o caráter definitivo será atribuído à solução pela deliberação.

\footnotetext{
${ }^{748}$ Eduardo de Melo Lucas CoELHo, A Formação das Deliberações Gerais - Assembleia Geral das Sociedades Anónimas, Coimbra, Coimbra Ed., 1994, p. 111.

${ }_{749}$ Por muito oportuno, sejam transcritos os trechos a respeito desse ponto da obra de Eduardo de Melo Lucas COELHO: "Só podendo estar em causa uma aprovação ou uma recusa, é óbvio que qualquer desvio ao conteúdo da proposta, enquanto tal, apenas prevalecerá se a proposta for substituída ou vier a ser recusada e apresentada outra que contemple o aspecto divergente. Em qualquer dos casos, não é concebível que, votada determinada proposta, possa a deliberação valer com um sentido diferente. A proposta pode, evidentemente, resultar não aprovada, com o significado próprio equivalente à mera recusa da solução ou medida nela contida, ou ser, ao invés, aprovada, implicando a adopção dessa medida ou solução. Impensável é poder originar uma deliberação de sentido não coincidente." In: A Formação das Deliberações Gerais - Assembleia Geral das Sociedades Anónimas, Coimbra, Coimbra Ed., 1994, pp. 112113.

${ }^{750}$ Eduardo de Melo Lucas CoElHo, A Formação das Deliberações Gerais - Assembleia Geral das Sociedades Anónimas, Coimbra, Coimbra Ed., 1994, p. 113.

${ }^{751}$ São palavras de Eduardo de Melo Lucas COELHO: "A sua natureza é a de um simples projeto de deliberação, representando a eleição provisória, em conveniente enunciação, de uma entre múltiplas linhas de solução imagináveis na execução do fito social, que será juridicamente corporizada na deliberação." In: A Formação das Deliberações Gerais - Assembleia Geral das Sociedades Anónimas, Coimbra, Coimbra Ed., 1994, p. 144.
} 
Nessa hipótese, a proposta (que é um projeto) apenas integrará a manifestação dos sócios que mediante o voto a acatarem ou, dito de outra forma, o voto a absorverá o conteúdo da proposta.

Precisamente por isso, e em que pese seu destacado papel na deliberação (portadora de um coeficiente decisório), não é ela elemento autônomo. Na verdade, sua enunciação - que funciona como técnica-organizativa para o deslinde procedimental da assembleia - constitui uma antecipação (fática ${ }^{752}$ ) do conteúdo que, ao depois, integrará os votos individuais dos sócios. Essa antecipação presta-se tão-somente a lhe possibilitar o exercício da sempre referida função técnico-organizativa. E, uma vez acatada pelo voto, a proposta passa a integrar a manifestação do sócio; é por ela absorvida e, assim, esvai-se.

A proposta constitui, destarte, a antecipação do conteúdo que será absorvido pelo voto e o integrará.

Mas que forma jurídica toma o voto como ato humano que se destina a produzir efeitos?

Uma parcela da doutrina alemã mais antiga divergia da qualificação do voto como declaração de vontade, ao fundamento de que ele se fundiria aos demais na deliberação (que é a consumação da formação da vontade coletiva) e, assim, seria por esta absorvido. Perderia, com isso, talvez retroativamente, sua autonomia ${ }^{753}$.

Sucede que a autonomia do voto subsiste mesmo na superveniência da

\footnotetext{
${ }^{752}$ Precisamente porque fática (destinada a exercer essa função técnica-organizativa do iter assemblear) e não autônoma (será absorvida pelo voto), sustenta parte da doutrina alemã não ser a proposta suscetível de qualificação jurídica no enquadramento do negócio jurídico (Cf. Eduardo de Melo Lucas CoELHO, A Formação das Deliberações Gerais - Assembleia Geral das Sociedades Anónimas, Coimbra, Coimbra Ed., 1994, p. 144). E, considerando o complexo processo de formação da vontade da pessoa jurídica, essa circunstância não causa perplexidade, uma vez que os atos intermediários não importam por si, mas pelo fim (e no fim) a que se voltam - o que é magistralmente ensinado por Eduardo de Melo Lucas CoELHO no seguinte trecho: "Isto em assonância, de resto, com a tónica processual do fenômeno da formação da vontade colectiva, entendido como acto de fattispecie complexa, ordenação lógica de antecedentes e consequentes em vista de certo escopo terminal, onde os actos interlocutórios não têm de valer por si autonomamente, mas só no encadeamento recíproco de cuja harmônica sequencia depende a boa consecução do resultado final." (p. 145) Nessa mesma ordem de ideias, observa o mesmo autor, que não causa estranhamento o fato de eventuais anomalias da proposta (salvo, dizemos nós, naquilo que, no desempenho de sua função organizativa, possa prejudicar o iter assemblear) careçam de relevância própria e figurem como vícios da deliberação (em que, ao cabo do escrutínio, integrada ao voto, a proposta "consomese" por fim - cf. p. 145).

753 Eduardo de Melo Lucas Coelho, A Formação das Deliberações Gerais - Assembleia Geral das Sociedades Anónimas, Coimbra, Coimbra Ed., 1994, p. 160: "E como a vontade colectiva não pode desagregar-se nas suas componentes uma vez exteriorizada mediante a proclamação da deliberação, o fenómeno volitivo interno-individual do votante perde autonomia e significado próprio."
} 
deliberação ${ }^{754}$. A deliberação e o voto em algo se assemelham aos contratos e às tratativas pré-contratuais ${ }^{755}$, e é certo quanto a estas que a ulterior formação da avença não impede a anulação das declarações negociais que a formaram - o que comprova insofismavelmente a autonomia das ditas declarações ${ }^{756}$. Em semelhante sentido, a anulação da deliberação por vício dos votos determinantes na votação ${ }^{757}$ evidencia a autonomia jurídica das manifestações individuais ${ }^{758}$. A deliberação ulterior, portanto, não acarreta a "fusão" dos votos e a conseguinte perda de sua autonomia.

Esteja claro que o caráter unitário da deliberação, resultado da votação, decorre tão somente da apuração aritmética dos votos devidamente valorados. São as (complexas) normas atinentes aos quoruns deliberativos que, uma vez incidindo sobre o resultado da votação, faz nascer a deliberação ${ }^{759}$. Os votos são, pois, seu substrato fático. Essa descrição é o quanto basta para explicar a deliberação, não se fazendo necessário o recurso à figura da "fusão" desses votos, cujo resultado seria a deliberação ${ }^{760}$.

Superada essa questão, subsiste ainda a indagação sobre a natureza do voto. E, para tanto, imprescindível se faz esquadrinhar os efeitos produzidos pelo voto.

Conforme esquematiza Eduardo de Melo Lucas COELHO, uma primeira corrente entende que o efeito do voto é exatamente a disciplina material da deliberação, que se alcança mediante a aglutinação de votos singulares. Para outros, o efeito seria a vinculação do respectivo votante no sentido daquela manifestação, "analogamente à proposta contratual que, sem determinar ainda os efeitos do contrato, obriga já o seu proponente nessa direcção”. Não produziria, portanto, o efeito material a que visa a

\footnotetext{
754 “Contesta-se, porém, que o voto perca por isso, quiçá retrospectivamente, a sua independência com o surgimento da deliberação, e, muito mais, que já a preponderante expectativa desta implicasse a redução do voto, desde a origem, à condição de mero elemento não autónomo na resolução do colectivo. "Cf. Eduardo de Melo Lucas Coelho, A Formação das Deliberações Gerais - Assembleia Geral das Sociedades Anónimas, Coimbra, Coimbra Ed., 1994, p. 155.

755 Eduardo de Melo Lucas COELHO, A Formação das Deliberações Gerais - Assembleia Geral das Sociedades Anónimas, Coimbra, Coimbra Ed., 1994, p. 147.

${ }^{756}$ Eduardo de Melo Lucas CoElHo, A Formação das Deliberações Gerais - Assembleia Geral das Sociedades Anónimas, Coimbra, Coimbra Ed., 1994, p. 161.

${ }^{757}$ Erasmo Valladão A. e N. FrançA, Invalidade das Deliberações de Assembleia das S/A, São Paulo, Saraiva, 1999, pp. 113-114.

${ }_{758}$ Citando Mathias BOHN, conclui Eduardo de Melo Lucas CoELHO: "Não pode, portanto, 'falar-se de uma fusão indiferenciada dos votos na deliberação, prevalecendo a opinião de que os mesmos permanecem autónomos'.” In: A Formação das Deliberações Gerais - Assembleia Geral das Sociedades Anónimas, Coimbra, Coimbra Ed., 1994, p. 161.

${ }^{759}$ Sobre a deliberação, Priscila Corrêa da FONSECA afirma: "Não há dúvida, por conseguinte - malgrado a controvérsia vigorante na doutrina - que a deliberação social é negócio jurídico unilateral, o qual, como cediço, embora constituído pela declaração de vontade de uma só parte, forma-se por várias pessoas, partilhando a natureza do ato colegial." In: Suspensão de Deliberaçães Sociais, São Paulo, Saraiva, 1986, p. 74.

${ }^{760}$ Eduardo de Melo Lucas CoElHo, A Formação das Deliberações Gerais - Assembleia Geral das Sociedades Anónimas, Coimbra, Coimbra Ed., 1994, p. 156.
} 
deliberação - que apenas seria desencadeado pela efetiva deliberação.Uma terceira corrente, por fim, sustenta que o efeito próprio do voto é o de guindar, ou não, a proposta em uma deliberação, ou não ${ }^{761}$.

Nenhuma dessas posições isoladamente, contudo, parecem abarcar de maneira satisfatória os efeitos do voto.

$\mathrm{Na}$ realidade, pela própria natureza da decisão colegiada, o voto individualmente considerado não tem o efeito de determiná-la, mas tão-somente de contribuir com seu resultado: “o acionista não pode senão pretender 'influir' nesta harmonia com o sentido da declaração" ${ }^{~ 762}$. Deveras, o acionista profere o voto pela aprovação ou pela rejeição da proposta com o fim de esse voto, em cooperação com outros exercidos no mesmo sentido, influir na decisão - que, nada obstante, apenas será tomada, se atendido aritmeticamente o quórum necessário, isto é, se reunidos em um mesmo grupo votos suficientes para tanto.

O voto é, destarte, apenas um elemento que concorre para a formação do ato orgânico. Trata-se tão-somente de uma potencialidade na consecução da decisão: "daí, precisamente, que o efeito do voto singular na esfera jurídica da sociedade não exceda o peso de uma simples influência mediata ${ }^{, 763 .}$.

Quanto à natureza jurídica, a doutrina no sentido de que o voto é uma declaração unilateral de vontade ${ }^{764} \mathrm{e}^{765}$, qual uma proposta negocial. No escrutínio, o voto vincula seu titular àquela manifestação favorável ou contrária à proposta (deliberativa) apresentada na assembleia. A declaração cinge-se, tecnicamente, a essa adesão ou não à proposta, mas, como já visto, na medida em que adere ou não, ele toma para si e absorve o conteúdo daquela proposta assemblear. Esta é, como visto, o "projeto

\footnotetext{
${ }^{761}$ A Formação das Deliberações Gerais - Assembleia Geral das Sociedades Anónimas, Coimbra, Coimbra Ed., 1994, p. 157.

${ }^{762}$ Eduardo de Melo Lucas Coelho, A Formação das Deliberações Gerais - Assembleia Geral das Sociedades Anónimas, Coimbra, Coimbra Ed., 1994, p. 158.

763 Eduardo de Melo Lucas COELHO, A Formação das Deliberações Gerais - Assembleia Geral das Sociedades Anónimas, Coimbra, Coimbra Ed., 1994, p. 159. Cf. também p. 163.

764 "A declaração de voto é, na realidade, incluida, na generalidade dos casos, na categoria das declarações de vontade em sentido técnico.” In: Eduardo de Melo Lucas COELHO, A Formação das Deliberações Gerais - Assembleia Geral das Sociedades Anónimas, Coimbra, Coimbra Ed., 1994, p. 161. Em outro trecho, e a outro propósito, mas cuidando do tema "declaração", esclarece o mesmo autor: "A forma representantiva socialmente reconhecível mediante a qual se exprime a vontade com vista à produção de certo efeito jurídico (...) é, em regra, a 'declaração' dessa vontade. O declarante dá a conhecer, a conhecer, normalmente a declaratário certo, eventualmente ao público, que o efeito jurídico deve ter lugar de acordo com a sua vontade, concorrendo esta para o realizar segundo os ditames da ordem jurídica.” (p. 123)

${ }^{765}$ No mesmo sentido: "Il voto è solo una dichiarazione di una parte in un contratto, però, oltre ad essere elemento di un elemento di un atto, cioè della volontà della deliberazione. " Giuseppe ROMANO-PAVONI , Le deliberzioni delle assemblee dele società, Milão, Giuffrè, 1951, p. 93.
} 
de deliberação" (isto é, a solução, escolhida entre outras tantas imagináveis, da questão apresentada, para realização do objeto social) que passa a integrar (e, como tal, esvai-se, desfaz-se) o conteúdo do voto singular.

Trata-se de declaração de vontade, porque, ao contrário do que sucede aos atos jurídicos em sentido estrito ${ }^{766}$, o regramento de seus efeitos está compreendido na manifestação da vontade, não decorrendo de lei. Esse "regramento" é talhado pela proposta $^{767} \mathrm{e}^{768}$, como visto, mas é o voto singular ${ }^{769}$ que, adotando-o, manifesta-o como efeitos queridos. Como tal, fica o voto contendo requisitos de existência, validade e eficácia e de seu exercício pode o titular abusar, o que será objeto de exame adiante.

Acrescente-se tratar-se de declaração unilateral receptícia, porquanto é dirigida a uma pessoa determinada, a quem é comunicada, e sua eficácia resta condicionada à efetiva comunicação deste destinatário ${ }^{770}$.

Discute-se a quem essa declaração é dirigida, se à própria sociedade, se ao presidente da assembleia. Esta última opção parece a mais adequada. A circunstância de os votos serem materialmente dirigidos a ele é já indício bastante: ele enuncia a proposta, que é dirigida à coletividade dos membros do órgão, e ele deve receber a adesão ou não dos votos singulares à proposta submetida à apreciação, bem como, apurado o valor aritmético das manifestações, proclamar o resultado ${ }^{771}$. Para a sociedade, tem relevância apenas a deliberação proclamada (sendo os fatos precedentes apenas fases de sua formação), que a ela se imputa, sendo, segundo alguns, difícil admitir que ela mesma intervenha no processo

\footnotetext{
${ }^{766}$ Conceitua Marcos Bernardes de MELLo: "o fato jurídico que tem por elemento nuclear do suporte fático manifestação ou declaração unilateral de vontade cujos efeitos jurídicos são prefixados pelas normas jurídicas e invariáveis, não cabendo às pessoas qualquer poder de escolha da categoria jurídica ou de estruturação do conteúdo das relações jurídicas respectivas." In: Teoria do Fato Jurídico - Plano da Existência, São Paulo, Saraiva, 2000, p. 141.

${ }^{767}$ Que é potência, no sentido aristotélico.

768 "O voto encontra-se limitado nas suas virtualidades enunciativas, em derradeiro termo, pelo conteúdo da proposta. Trata-se, como vimos, de exigência disciplinar técnico-organizatória relacionada com o funcionamento da assembleia no exercício da função deliberativa, em virtude da qual se exprime o voto numa concordância (voto a favor) ou discordância (voto contra)." In: Eduardo de Melo Lucas COELHO, A Formação das Deliberações Gerais - Assembleia Geral das Sociedades Anónimas, Coimbra, Coimbra Ed., 1994, p. 171.

${ }_{769}^{7}$ Que é ato, no sentido aristotélico - ato não de deliberar, mas compor, integrar a deliberação.

770 Orlando GoMEs, Introdução ao Direito Civil, Rio de Janeiro, Forense, 1999, p. 283. Difere-se, portanto, das declarações unilaterais não receptícias (das quais o exemplo, sempre citado, é o testamento), cuja eficácia independe de sua recepção por quem quer que seja.

${ }^{771}$ Embora sublinhando o caráter "duvidoso" da opção, Eduardo de Melo Lucas CoELHO aponta-a como a que melhor, "no confronto com as outras teses em presença", por harmonizar-se "porventura melhor, como se disse acima, com a função do voto - substrato numérico a partir do qual se abstrai racionalmente a deliberação - e com o seu efeito - a contribuição do vontade em solidariedade orgânica com outros votantes, para a formação da deliberação - função e efeito que se cumprem no instante do apuramento e valoração dos votos a cargo do presidente e da mesa." In: A Formação das Deliberações Gerais Assembleia Geral das Sociedades Anónimas, Coimbra, Coimbra Ed., 1994, p. 168.
} 
de formação da própria vontade (tendo em vista, justamente, a carência natural de uma estrutura psíquica, a qual justamente fundamenta que a ordem jurídica lhe organize um processo jurídico substitutivo) ${ }^{772}$.

\subsection{Declaração de verdade ou de vontade}

Ainda da natureza jurídico do voto, merece referência o tema, objeto debate na doutrina, atinente ao conteúdo da declaração, se de verdade ou de vontade ou, ainda, declaração de vontade $e$ verdade ou vontade $o u$ verdade.

O exame do tema consiste, preleciona Renato Ventura RIBEIRO, em investigar se a declaração de voto é "imperativa, representando a vontade do emissor", ou "informativa, dando ciência de um fato como verdade",773. A importância do tema está nos efeitos jurídicos de uma e outra ${ }^{774}$. Em matéria de negociação entre acionistas acerca do exercício do voto, a distinção é critério para enquadramento da conduta entre as práticas lícitas ou ilícitas: é fato típico insculpido no art. $177, \S 2^{\circ}$, do Código Penal criminalizar apenas a negociação atinente à declaração de verdade ${ }^{775}$.

Para aqueles que sustentam tratar-se de declaração de verdade (ou de conhecimento $^{776}$ ), o voto não expressa uma vontade, mas uma "opinião" ou conhecimento acerca da matéria objeto da proposta em deliberação; ele exterioriza um entendimento

\footnotetext{
772 "Parece, pois, que se levantam impedimentos estruturais e funcionais, e não só conceituais, de tomo à aludida concepção da sociedade como destinatária do voto.” Eduardo de Melo Lucas CoELHO, A Formação das Deliberações Gerais - Assembleia Geral das Sociedades Anónimas, Coimbra, Coimbra Ed., 1994, p. 169.

${ }^{773}$ Direito de Voto nas Sociedades Anônimas, São Paulo, Quartier Latin, 2009, p. 197.

${ }^{774}$ Para Giuseppe SENA, a importância da distinção está nos efeitos jurídicos que dele decorrem: a declaração de vontade produz efeitos jurídicos conforme o conteúdo da própria declaração (a vontade declarada conforma os efeitos que ela irá produzir), enquanto a declaração de verdade não produzirá efeitos quanto aos fatos submetidos à deliberação. Com efeito, respondendo à indagação sobre qual o particular efeito jurídico de se determinar a natureza jurídica da declaração, o autor italiano esclarece que o efeito é conforme o conteúdo da declaração (cf. Il voto nella assemblea della società per azioni, Milão, Giuffrè, 1958, p. 30). Assim, completa, "una dichiarazione può essere definita come dichiarazione di volontà solo in quanto sia costitutiva degli effetti conformi al contenuto della dichiarazione, mentre sarà una mera dichiarazione di verità se non avrà alcuna effricacia rispetto agli effetti derivanti dal fatto rappresentato." (p. 30) Mais adiante, acrescenta a diferenciação entre as duas categorias (o que justifica a importância do tema): "la dichiarazzione di volontà si differenzia dalle altre dichiarazioni per la produzione di effetti giuridici conformi al contenuto della dichiarazione stessa, od in altre parole, per la rilevanza che ha in essa, rispetto agli effetti, la volontà del dichiarante." (p. 38). Nada obstante, é preciso estar claro que, como manifestação de vontade ante os fatos ou propostas apresentadas, o voto não é um negócio jurídico, mas um ato jurídico em sentido estrito (Renato Ventura RIBEIRo, Direito de Voto nas Sociedades Anônimas, São Paulo, Quartier Latin, 2009, p. 199) e, portanto, não é dado ao declarante determinar os efeitos jurídicos do ato por ele realizado.

${ }^{775}$ É o que consigna Fabio Ulhoa CoElHo. Cf. Curso de Direito Comercial - Direito de Empresa, v. 2, São Paulo, Saraiva, 2012, p. 341.

${ }^{776}$ Giuseppe SENA, Il voto nella assemblea della società per azioni, Milão, Giuffrè, 1958, p. 39.
} 
quanto à correspondência da matéria à realidade examinada ${ }^{777}$.

Para outra corrente, o voto é o exercício de um poder jurídico e consiste, assim, na declaração de vontade ${ }^{778}$, com o propósito específico de ver aprovada a opinião pelo acionista manifestada na deliberação ${ }^{779}$.

Destaca-se ainda opinião diversa que sustenta ser o voto uma declaração concomitantemente de verdade e de vontade: o acionista exprime uma opinião (uma verdade) e esta é a base da sua declaração de vontade ${ }^{780}$. Por fim, há de se mencionar o entendimento majoritário de que o voto será declaração de vontade ou de verdade conforme o objeto sobre o qual recair a deliberação.

\subsection{Formas de emissão}

O voto é, como visto, declaração unilateral receptícia de vontade. Pressupõe, portanto, um processo de comunicação ${ }^{781}$. Indaga-se nesse passo se existe forma vinculada ou vedada para a sua manifestação (CC: art. 104, inc. III). A vigente Lei n. ${ }^{\circ} 6.404 / 76$ é omissas a esse respeito e, assim, resta franqueado ao estatuto dispor sobre o tema $^{782}$.

A doutrina nacional exige seja o voto manifestado expressamente, vedada a forma implícita ou tácita; no entanto, admite-se a votação por aclamação (em que a concordância com a proposta é manifestada pela inércia dos votantes ${ }^{783}$ ), além daquela

\footnotetext{
${ }^{777}$ Fabio Ulhoa CoElho, Curso de Direito Comercial - Direito de Empresa, v. 2, São Paulo, Saraiva, 2012, p. 340 .

778 Giuseppe SENA, Il voto nella assemblea della società per azioni, Milão, Giuffrè, 1958, p. 38. E ele esclarece: "E ciò, a mio parere, non può essere negato che il voto esprima una intenzione (o volontà) diretta ad un determinato fine consistente nello svolgimento di un interesse (del votante o di un terzo), che contenga insomma gli elementi costitutivi dell'atto giuridico." Giuseppe ROMANO-PAVONI é da mesmo entendimento: "A mio avviso, il voto è una manifestazione di volontà". In: Le deliberzioni delle assemblee dele società, Milão, Giuffrè, 1951, p. 88.

${ }^{779}$ Renato Ventura RIBEIRO, DIREITo de Voto nas Sociedades Anônimas, São Paulo, Quartier Latin, 2009, p. 198. Acresce o autor o seguinte comentário: "Mesmo que a deliberação tenha um conteúdo de declaração de conhecimento ou de verdade [como, dizemos nós, é a apreciação das contas das administração], o voto exprime a vontade de declarar tal conhecimento ou verdade." In: Giuseppe ROMANO-PAVONI, Le deliberzioni delle assemblee dele società, Milão, Giuffrè, 1951, p. 88.

780 "Per il Messineo, nel voto si riscontrerebbe tanto una dichiarazione di opinione, che una dichiarazione di volontà: il votante esprimerebbero un'opinione e questa starebbe a base della sua dichiarazione di volontà." ${ }^{781}$ Orlando GoMES, Introdução ao Direito Civil, Rio de Janeiro, Forense, 2000, p. 283.

${ }^{782}$ Renato Ventura RIBEIRO, Direito de Voto nas Sociedades Anônimas, São Paulo, Quartier Latin, 2009, p. 200.

${ }^{783}$ Renato Ventura RIBEIRO, Direito de Voto nas Sociedades Anônimas, São Paulo, Quartier Latin, 2009, p. 207. Votação por aclamação é aquela em que a manifestação da concordância com a proposta dá-se não por um ato positivo (o levantamento de mãos, por exemplo), mas pela inércia dos votantes - os quais, assim, uma vez enunciada a proposta, devem permanecer como estão ou, em caso de discordância, manifestar-se de outro
} 
em que a concordância é evidenciada por um ato positivo de fácil cognição (pelo levantamento das mãos, por exemplo ${ }^{784}$ ). Outra opção é o voto por escrito.

A respeito do emprego de meios tecnológicos, notadamente de telecomunicações e de telemática, ou, ainda, da utilização da via epistolar, considerações já foram feitas acima sobre a preservação de debates efetivos, em que as manifestações se interajam de imediato, haja a reunião presencial ou não dos integrantes. Quanto estritamente à manifestação do voto, contudo, as restrições à diversificação dos meios técnicos de expressão são menores.

Existem, com efeito, países que admitem a votação por correspondência e a Diretiva 2007/36/CE (da Comissão Europeia) permite-o por carta postal, $e$-mail ou outro meio eletrônico ${ }^{785}$. No Brasil, contudo, a doutrina rejeita a hipótese $\mathrm{e}^{786}$ e 787 e a Lei n. ${ }^{\circ}$ 6.404/76 exige a comprovação da presença com a assinatura no livro de presença (art. 127).

\subsection{Voto aberto ou secreto}

Conforme haja identificação ou não do autor do voto diz-se que ele é aberto ou secreto. A doutrina aconselha o emprego dessa última modalidade em algumas deliberações em que se faz necessário assegurar mais fortemente a completa liberdade do votante, como é o caso daquela que tem por objeto a expulsão de sócio ${ }^{788}$. Todavia, apresenta inconvenientes gravíssimos, senão inconciliáveis, com relação ao ato colegial que é a deliberação.

O voto secreto não implica a impossibilidade absoluta de identificação

modo. (Normalmente, na votação por aclamação, o presente enunciada a proposta e abre a votação nos termos seguintes, ou por equivalentes: “Aqueles que forem a favor da proposta permaneçam como estão”.)

${ }^{784}$ Método completamente inadequado aos sistemas de voto por capital; mesmo no sistema por cabeça, permanecem inconvenientes, como a não identificação dos votantes (quando tal verificação é importante para controlar impedimento ou conflito de interesse).

${ }^{785}$ Renato Ventura RIBEIRO, Direito de Voto nas Sociedades Anônimas, São Paulo, Quartier Latin, 2009, p. 208.

${ }^{786}$ Como já acima referido, Modesto CARVAlHOSA considera essa forma de manifestação mera "consulta". Cf. Comentários à Lei de Sociedades por Ações, v. 2, São Paulo, Saraiva, 2009, p. 607.

${ }^{787}$ Renato Ventura RIBEIRO credita essa desconfiança com relação ao voto por correspondência ao fato de a questão ter sido analisada à luz da correspondência tradicional (por correios) e não com os mecanismos eletrônicos dos correntes dias (e-mail, por exemplo). In: Direito de Voto nas Sociedades Anônimas, São Paulo, Quartier Latin, 2009, p. 211.

${ }^{788}$ Renato Ventura RibeIRO, Direito de Voto nas Sociedades Anônimas, São Paulo, Quartier Latin, 2009, p. 201. Sobre exclusão de sócio especificamente nas sociedades anônimas, cf. Renato Ventura RIBEIRO, Expulsão de Sócios nas Sociedades Anônimas, São Paulo, Quartier Latin, 2005 (que não integra a bibliografia do presente trabalho). 
dos votantes. Por elementos externos, é possível indiretamente chegar-se à autoria das manifestações de vontade. É o caso, por exemplo, da votação por unanimidade e ou, ainda, aquela em que é aprovada a proposta, por maioria, e a parcela do capital social vencida é inferior participação de um acionista (ele certamente, portanto, votou no sentido da deliberação ${ }^{789}$ ). Não é o que de ordinário ocorre, no entanto.

A não identificação do votante impede sua vinculação aos respectivos votos e, dessa maneira, a verificação a posteriori (por exemplo, por decisão judicial) de eventual vício do voto ${ }^{790}$ não permitirá o dimensionamento de sua invalidade na formação da deliberação - isto é, não será possível verificar ${ }^{791}$ se os votos inválidos terão sido determinantes para o resultado proclamado, hipótese em que, e apenas nela, acarretaria também a invalidade desta ${ }^{792}$. Resta prejudicado igualmente o exercício do direito de recesso, bem como a imputação de responsabilidade pelo voto ao acionista, cuja manifestação permanece ignorada. Os acordos de voto se tornariam pouco efetivos, ante a impossibilidade de verificação de seu cumprimento ${ }^{793}$.

Bem diferente é o voto aberto, cuja explícita vinculação com seu autor permite que, com precisão, o controle posterior de sua validade delimite os efeitos (ou falta deles) de seu vício. Todos os inconvenientes do anonimato ficam superados, como a verificação da dissidência, a imputação de responsabilidade pelo voto etc. Por tudo isso, em regra, é o que deve ocorrer nas assembleias societárias.

\subsection{Representação}

O voto deve ser exercido pelo próprio acionista ou por seu representante. No primeiro caso, deve fazer prova de sua condição nos termos do art. 126 da Lei n. ${ }^{\circ}$ $6.404 / 76$.

\footnotetext{
789 O exemplo de Renato Ventura RIBEIRO: "Se um acionista detém trinta por cento dos votos e a deliberação foi tomada com mais de setenta por cento dos votos, é possível saber qual o sentido de seu voto. ” In: Direito de Voto nas Sociedades Anônimas, São Paulo, Quartier Latin, 2009, p. 201.

${ }^{790}$ Falta de capacidade ou legitimação do votante; apuração de conflito de interesse, proibição ou abuso de voto; etc.

${ }_{791}^{79}$ Salvo por aqueles meios indiretos, anteriormente mencionados.

792 "Os vícios do voto, como se disse, só são relevantes para o efeito de invalidar a assembleia ou suas deliberações se, sem os votos viciados, não se tiver configurado a maior necessária (...) para a regular formação daqueles atos. ” In: Erasmo Valladão A. e N. FRANÇA, Invalidade das Deliberações de Assembleia das S/A, São Paulo, Saraiva, 1999, pp. 113-114.

${ }^{793}$ Há ainda outros inconvenientes, como a impossibilidade de o acionista outorgante de mandato verificar o cumprimento ou não de sua vontade pelo mandatário. Sobre tais críticas, cf. Renato Ventura RIBEIRO, Direito de Voto nas Sociedades Anônimas, São Paulo, Quartier Latin, 2009, pp. 201-204.
} 
O voto tem caráter irrenunciável ${ }^{794}$. Uma vez, contudo, que é direito disponível, inexiste impedimento a que seu exercício (ou abstenção dele) seja objeto de negócio envolvendo seu titular (ressalvada a hipótese em que o voto constitui declaração de verdade e o ajuste a esse respeito pode constituir crime ${ }^{795}-\mathrm{CP}$ : art. $177, \S 2^{\circ}$ ).

O acordo de acionistas pode ter por fim exatamente regrar o exercício do voto pelos convenentes $^{796}$, inclusive para a formação do bloco de controle (LSA: art. 116, caput, e art. 118, caput). São os chamados "acordos de voto" (por oposição aos acordos de bloqueio, destinados a restringir a circulação das ações, criar preferências e opções de compra etc.), os quais foram ainda mais prestigiados com as alterações introduzidas na Lei n. ${ }^{\circ} 6.404 / 76$ pela Lei n. ${ }^{\circ} 10.303 / 01$, que criou mecanismos de efetivação desses acordos ${ }^{797}$.

Quanto à representação do acionista, além daquela promovida pelos chamados "representantes legais" das pessoas jurídicas, a Lei n. ${ }^{\circ}$ 6.404/76 prevê a possibilidade de outorga de mandato. Mas, nesse caso, restringe o prazo máximo de sua vigência um ano em regra (art. 126, $\S 1^{\circ}$ ), salvo se ação integrar acordo de acionista hipótese em que este prazo poderá ser superior (art. 118, § $7^{\circ}$ ). A lei impõe, ainda, restrições àqueles que podem figurar como procurador: apenas têm legitimidade outros acionistas, administradores da companhia, advogados e, exclusivamente em caso de sociedade anônima aberta, também instituições financeiras e, sendo acionista um fundo de investimento, seu respectivo administrador (art. 126, $\S 1^{\circ}$ ).

Os poderes outorgados devem sempre ser especiais ${ }^{798}$ e, naturalmente, o

\footnotetext{
${ }^{794}$ Modesto Carvalhosa, Comentários à Lei de Sociedades por Ações, v. 2, São Paulo, Saraiva, 2009, p. 387.

${ }^{795}$ Fabio Ulhoa CoElHo, Curso de Direito Comercial - Direito de Empresa, v. 2, São Paulo, Saraiva, 2012 , p. 341.

${ }^{796}$ Modesto CARvalhosa sustenta tratar-se esse caso de uma hipótese de cessão de voto, vedada pelo parcialmente revogado Decreto-Lei n. ${ }^{\circ} 2.627 / 40$ (o voto era incindível da titularidade da ação), foi admitida pela lei acionária de 1976, em sua redação original, e ainda de maneira ainda mais aprofundada após as reformas introduzidas na Lei de S.A. pela já referida Lei n. ${ }^{\circ} 10.303 / 01$. De todo modo, o autor estabelece uma diferença entre cessão e tráfico de voto, nos termos adiante transcritos, considerando apenas essa última uma ilicitude, criminalmente tipificada inclusive (CP: art. 177, § $2^{\circ}$ ). São suas palavras: "Pela cessão de votos, mediante uma convenção ou vantagem, direta ou indireta, o acionista cede à comunhão de controle ou a terceiros o exercício dessa prerrogativa, mantendo as demais inerentes à ação (art. 118). Já pelo tráfico de votos, o próprio acionista vota na assembleia geral, mediante vantagem direta ou indiretamente recebida, para atender a interesses de outros acionistas, dos administradores ou dos controladores. Trata-se de um ilícito condenado pelas legislações dos diversos países e também pela doutrina e pela jurisprudência." In: Comentários à Lei de Sociedades por Ações, v. 2, São Paulo, Saraiva, 2009, p. 700.

${ }^{797}$ Alterações, nesse sentido, promovido pela Lei n. ${ }^{\circ} 10.303 / 01$ na Lei de Sociedades por Ações: a vedação à denúncia do acordo celebrado por prazo determinado (art. $118, \S 6^{\circ}$ ), a não computação do voto proferido pelo acionista em contraste com o acordo de acionista arquivado na sede da companhia (art. 118, $\S 8^{\circ}$ ), o direito de os convenentes votarem pelo acionista integrante do acordo que falte às deliberações ou, comparecendo, abstenha-se (art. 118, $\S 9^{\circ}$ ).

${ }^{798}$ Modesto Carvalhosa, Comentários à Lei de Sociedades por Ações, v. 2, São Paulo, Saraiva, 2009, p. 700.
} 
mandante pode fixar-lhe restrições materiais. Inexiste exigência de forma específica para a procuração, razão por que o instrumento privado é o bastante ${ }^{799}$.

O tema merece referência não apenas por seu regramento dogmático, mas também pela possibilidade que ele veicula de exercício de poder na companhia. Embora o assunto seja de menos visibilidade no Brasil - ao contrário do que sucede, por exemplo, nos Estados Unidos -, é comum nos mercados em que a pulverização do capital social das companhias abertas é mais frequente.

Nesses casos, a representação é empregada antes em benefício do procurador que do mandante $e^{800}$ : ao confluir em si poderes de representação de acionistas titulares de parcelas significativas do capital social, o procurador pode influenciar as deliberações sociais, eventualmente até de maneira decisiva e, no limite, conquistar o poder de controle. Trata-se de expediente muito utilizado para o alcance do chamado já estudado controle gerencial, em que uma "casta" de administradores da companhia consegue manter-se no poder societário mediante a "colheita" de procurações (mediante o pedido de procuração, ou proxy solicitation ${ }^{801}$ ) suficientes para lhes assegurar a eleição para os cargos da administração (fala-se em proxy machinery ${ }^{802}$ ). Embora, como dito, seja incomum essa espécie de controle interno no País, a Lei n. ${ }^{\circ} 6.404 / 76$, contrariando o regime jurídico anterior, permitiu a outorga de procuração por acionistas aos administradores para fins de representação nas assembleias gerais.

Mas essa possibilidade de representação pode também ser empregada para o exercício de "ativismo" pelos minoritários ${ }^{803}$. Reunidos mediante um procurador único, podem eles estabelecer políticas uniformes de votação nas deliberações e atuação nos debates societários de modo organizado - de tal sorte que logrem obter representatividade que, de outro modo, não alcançariam.

Em atenção também a essa hipótese, a Lei n. ${ }^{\circ}$ 6.404/76 prevê o pedido de procuração mediante o envio de correspondência (art. 126, $\S 2^{\circ}$ ) e, também, a possibilidade

\footnotetext{
${ }^{799}$ Modesto Carvalhosa, Comentários à Lei de Sociedades por Ações, v. 2, São Paulo, Saraiva, 2009, p. 700. Embora o voto possa ser verbal (o que autorizaria o mandato verbal - CC: art. 657), a exigência de instrumento está atrelado à necessidade de habilitação do procurador perante a mesa da assembleia. A firma reconhecida do outorgante é exigível, nos termos do art. 654, § $2^{\circ}$, do Código Civil.

${ }^{800}$ Renato Ventura RIBEIRO, Direito de Voto nas Sociedades Anônimas, São Paulo, Quartier Latin, 2009, p. 330 .

${ }^{801}$ Marcelo Lamy Rego, Pedido de Procuração para Votar, Direito Societário - Desafios Atuais, Rodrigo R. Monteiro de Castro - Leandro Santos de Aragão (coord.), São Paulo, Quartier Latin, 2009, p. 326.

${ }^{802}$ Renato Ventura RIBEIRO, Direito de Voto nas Sociedades Anônimas, São Paulo, Quartier Latin, 2009, p. 331.

${ }^{803}$ Hipóteses que também podem ser incluídas nas proxy fights. Cf. Renato Ventura RIBEIRO, DIREITO de Voto nas Sociedades Anônimas, São Paulo, Quartier Latin, 2009, pp. 330-331.
} 
de acionistas representativos de parcela do capital (0,5\%, no mínimo) requererem os endereços dos acionistas $\left(\operatorname{art} .126, \S 3^{\circ}\right)^{804}$.

Por derradeiro, cumpre observar a existência de dispositivos na Lei de Sociedades por Ações que disciplinam o exercício do voto em hipóteses específicas, como são os casos de copropriedade de ações, constituição de usufruto, penhor, caução sobre elas, ou, ainda, de sua alienação fiduciária em garantia e o fideicomisso ${ }^{805}$.

\subsubsection{Sistemas de voto}

\subsection{Valor do voto}

Para a tomada da decisão, nos processos de deliberação das assembleias societárias, a manifestação de cada sócio pode ou não ter valoração diferente entre si. Basicamente são dois os critérios adotados pela legislação societária nacional e comparada.

O primeiro deles é o chamado voto por pessoa ou por cabeça - chamado ainda viril ou igualitário ${ }^{806}$. Nesse caso, inexiste desigualdade entre os sócios (one man, one vote) e o voto manifestado por cada um deles tem exatamente o mesmo valor.

Esse sistema encontra paralelo nas democracias políticas modernas, mas não é de aplicação frequente na legislação societária ${ }^{807}$. Ele impõe um indesejável descolamento entre o capital investido (a que direta e proporcionalmente está atrelado o risco assumido) e o poder de gestão da sociedade, o que desincentiva fortemente o investimento $^{808}$ e força a igualdade política entre acionistas de perfis, aptidões e propósitos

\footnotetext{
${ }^{804}$ Sobre as finalidades desse regramento, cf. Renato Ventura RIBEIRO, DIREITO de Voto nas Sociedades Anônimas, São Paulo, Quartier Latin, 2009, p. 331.

${ }^{805}$ Não é o caso de tratar do assunto aqui, além da ligeira referência. Sobre o assunto, cf. Renato Ventura RIBEIRO, DIREITO de Voto nas Sociedades Anônimas, São Paulo, Quartier Latin, 2009, pp. 281-322.

${ }^{806}$ Renato Ventura RIBEIRO, DIREITO de Voto nas Sociedades Anônimas, São Paulo, Quartier Latin, 2009, p. 187.

${ }^{807}$ Após fazer referência à comparação entre a assembleia geral de acionistas e a organização democrática dos Estados ocidentais (o parlamento), Fabio Ulhoa COELHO di-la "anacrônica", porque, enquanto no direito societário a organização do poder "funda-se na medida da contribuição de cada acionista para a formação do capital social, ou seja, é parâmetro da força econômica dos partícipes do órgão", a democracia contemporânea "repele, com veemência, qualquer fórmula censitária de organização do poder politico". Assim, conclui ele que a referência aos órgãos do estado democrático não é "nada útil à compreensão do direito societário”. Cf. Curso de Direito Comercial - Direito de Empresa, v. 2, São Paulo, Saraiva, 2012, p. 223.

${ }^{808}$ Renato Ventura RIBEIRO, DIREITO de Voto nas Sociedades Anônimas, São Paulo, Quartier Latin, 2009, p. 188. Giuseppe ROMANO-PAVONI adverte que, embora a discussão tenha vulto no âmbito das assembleias gerais de acionistas das sociedades anônimas, "l'argomento si presta ad uma trattazione generale, essendo Il fenômeno uguale, anche se diverse possono essere Le modalità com cui si presenta, Nei diversi tipi di società”. Cf. Le deliberzioni delle assemblee dele società, Milão, Giuffrè, 1951, p. 87.
} 
bem distintos como normalmente o são os majoritários e os minoritários.

Quando previsto pelo direito positivo, esse sistema, se aplicado, é mais adequado às sociedades personalíssimas, normalmente prestadoras de serviços intelectuais ou artísticos, em que as características pessoas dos sócios (seus atributos intelectuais ou artísticos) são economicamente mais relevantes para a organização produtiva do que o capital investido - e conseguintemente o desligamento entre este último e o poder político tem bem menos repercussão. Seu contraste com a "lógica" das sociedades de capitas, contudo, torna-o altamente improvável entre elas, mesmo em tese; em companhias abertas é sem cabimento.

Há registros de emprego episódico desse sistema no direito comparado ${ }^{809}$ e, entre nós, ele encontra aplicação unicamente nas cooperativas ${ }^{810}$ - tipo societário em que a partilha do resultado não guarda relação com as quotas de cada cooperado, mas com as operações por ele efetuadas (CC: art. 1.094, inc. VII) - e como critério subsidiário para desempate nas deliberações em sociedades simples (CC: art.1.010, $§ 2^{2^{811}}$ ). Além disso, os conselhos de administração das companhias, que não são órgãos de acionistas, mas integrantes da administração, deliberam por esse sistema.

Outro sistema existente é de muito mais vasto emprego. Nele, o voto, para fins de deliberação, não é exatamente o mesmo para todos os sócios independente da porção do capital social de que são titulares. Ao contrário, o valor de cada voto é

${ }^{809}$ Renato Ventura RIBEIRO preleciona que esse sistema foi adotado pelo Código Comercial francês de 1808 desde sua promulgação até 1867; em Portugal, tem emprego nas sociedades civis e nas sociedades em nome coletivo e, quanto aos sócios de capital, nas sociedades de capital e indústria. Cf. Direito de Voto nas Sociedades Anônimas, São Paulo, Quartier Latin, 2009, p. 187.

${ }^{810}$ É o que preveem o art. 1.094, inc. VI, do Código Civil e o art. $4^{\circ}$, inc. V, da Lei n. ${ }^{\circ} 5.764 / 71$ (exceto as cooperativas centrais, federações e confederações de cooperativas, se não exercem atividade de crédito, caso em que podem optar por voto proporcional às quotas), independente do número de quotas do cooperado e tenha a cooperativa capital social ou não (único caso de dispensa de capital social entre os tipos societários brasileiros).

${ }^{811}$ Convém observar que esse critério é de aplicação raríssima, mesmo nesse caso. As hipóteses de "empate" em deliberação (assim aqui em âmbito societário, como em qualquer outro tipo de assembleias, como a de credores) são, com efeito, de escassez extrema. Não é possível sua ocorrência, por exemplo, quando a deliberação versa sobre uma única proposta: nesse caso, a aprovação dela depende, no mais raso dos quóruns, do voto afirmativo de sócios representativos da maioria do capital social que se faz presente. Se proferirem voto nesse sentido sócios titulares de apenas metade do capital social, por exemplo, optando a outra metade por rejeitar a proposta, esta restará desaprovada, uma vez que não atingiu o quórum de aprovação (metade é menos que a maioria), permanecendo as coisas como estão; e não terá ocorrido empate, portanto. O empate apenas terá lugar quando a deliberação versar simultaneamente sobre mais de uma proposta (isto é, quando versar sobre opções possíveis; exemplo: eleição de membro de órgão, quando há dois ou mais candidatos), sendo absolutamente excludentes entre si (nada impede que, pela diferença de extensão ou compreensão, não sejam completamente excludentes - cf. Eduardo de Melo Lucas COELHO, A Formação das Deliberações Gerais - Assembleia Geral das Sociedades Anónimas, Coimbra, Coimbra Ed., 1994, p. 98), e cada uma delas contar com o voto afirmativo de sócios que representem exatamente a mesma proporção do capital social. Unicamente em casos como esses é que, nas sociedades do Código Civil, far-se-á necessário o recurso ao sobredito critério de desempate (a deliberação optará pela hipótese que contar com o maior número de sócios), que, bem se vê, é de notável raridade. 
ponderado segundo a proporção de capital social que detém o seu titular. Assim, tanto mais vale o voto do sócio quanto maior é seu quinhão no capital sociedade.

Atende, pois, ao princípio da proporcionalidade ${ }^{812}$ : diferentemente do sistema precedentemente examinado, este provoca uma identidade entre o capital investido (e, ergo, o risco assumido ${ }^{813}$ e ${ }^{814}$ ) e o poder político de influência nos destinos da sociedade $^{815}$. Não por outro motivo é de emprego quase unânime em todos os ordenamentos jurídicos ${ }^{816}$ e, de modo geral, para todos os tipos societários. Fala-se em sistema de voto por ação ou, ainda, princípio real ou do valor do capital $^{817}$.

Algumas observações a esse respeito fazem-se necessárias.

A proporção é estabelecida, como visto, entre o valor do voto do acionista e a parcela do capital social da sociedade por ele detida. No caso da sociedade anônima brasileira, a Lei n. ${ }^{\circ}$ 6.404/76 impõe a igualdade das ações (que são a porção

812 Modesto Carvalhosa, Comentários à Lei de Sociedades por Ações, v. 2, São Paulo, Saraiva, 2009, p. 391. O mesmo autor, em outro trecho, afirma que o voto, embora direito pessoal, origina-se da parcela de patrimônio detida pelo acionista no capital. E completa: "A propriedade da ação implica o direito irrenunciável ao voto respectivo, por isso que os votos se contam em função da parcela do capital possuído $e$ não das pessoas que detêm as respectivas ações, sem embargo, é óbvio do aspecto da legitimidade." (p. 388) ${ }^{813}$ Note-se que, como regra, no Brasil, tendo em vista a omissão da Lei n. ${ }^{\circ}$ 6.404/76, não prejudica o voto a pendência de integralização da respectiva ação, salvo se diversamente disciplinado pelo estatuto social (Modesto Carvalhosa, Comentários à Lei de Sociedades por Ações, v. 2, São Paulo, Saraiva, 2009, p. 391; Renato Ventura RIBEIRO, DIREITo de Voto nas Sociedades Anônimas, São Paulo, Quartier Latin, 2009, p. 253: “se as ações podem ser negociadas após integralizados trinta por cento do preço de aquisição, deve poder ter direito de voto”); mesmo a mora não implica automaticamente a suspensão desse direito (LSA: art. 120; a realidade é diferente em outros países, como Portugal, Itália, França, Espanha e Argentina - cf. Eduardo de Melo Lucas CoElho, A Formação das Deliberações Gerais - Assembleia Geral das Sociedades Anónimas, Coimbra, Coimbra Ed., 1994, p. 59; Renato Ventura RIBEIRO, DIREITO de Voto nas Sociedades Anônimas, São Paulo, Quartier Latin, 2009, p. 253). O fundamento está na existência do crédito (exigível, mesmo que não satisfeito ainda) da companhia em relação ao acionista, o qual, inclusive, autoriza-a à tomada de medidas específicas (notadamente aquelas dos arts. 107e 120 da Lei n. ${ }^{\circ}$ 6.404/76); ademais, é inegável o interesse do subscritor da ações nos negócios da companhia (Renato Ventura RIBEIRO, DIREITO de Voto nas Sociedades Anônimas, São Paulo, Quartier Latin, 2009, p. 190). Existem críticas à disciplina brasileira que se fundamentam no fato de essa regra prever veladamente uma hipótese de voto plural, não admitido pela mesma lei (Modesto CARvalhosA, Comentários à Lei de Sociedades por Ações, v. 2, São Paulo, Saraiva, 2009, pp. 393 e 403). Em que pese a disposição da lei nacional, registre-se a existência no direito comparado sistemas diferentes: na Suíça, o voto é proibido com estribo em ações não integralizadas (Código das Obrigações: art. 694) e, na Alemanha, a regra é a mesma, conquanto se permita derrogação por disposição estatutária (AktG § 134, 4). Cf. Direito de Voto nas Sociedades Anônimas, São Paulo, Quartier Latin, 2009 , p. 190. Ainda sobre o assunto, convém observar que a ação de fruição também não impede o voto, se ele lhe era atribuído antes da amortização. (Modesto CARVAlHOSA, Comentários à Lei de Sociedades por Ações, v. 2, São Paulo, Saraiva, 2009, p. 394)

${ }^{814}$ Essa relação de identidade plena entre o poder de voto e o risco assumido é alcançada na disciplina das assembleias (especiais) de debenturistas, em que cada debênture atribui a seu titular um voto (LSA: art. 71, § $\left.6^{\circ}\right)$.

${ }_{815}$ "Decir que el voto es proporcional, nos está indicado que su valor se determina por el monto de la inversión del accionista en la empresa y por consiguiente por el mayor o menor número de sus acciones." In: Luis Manuel RoJAs JR., El Derecho de Voto em la Sociedad Anónima, México, Editoral Jus, 1945, p. 123. ${ }_{816}$ Trata-se de um "principio unánimemente aceptado por las legislaciones de todos los pueblos cultos". Cf. Luis Manuel RoJAS JR., El Derecho de Voto em la Sociedad Anónima, México, Editoral Jus, 1945, p. 123.

${ }^{817}$ Renato Ventura RIBEIRO, DIREITO de Voto nas Sociedades Anônimas, São Paulo, Quartier Latin, 2009, p. 189. 
indivisível do capital social -LSA: art. 28), tenham valor nominal (LSA: art. 11, $\S 2^{\text {o818}}$ ) ou não ${ }^{819}$. Portanto, cada uma das ações será representativa exatamente da mesma fração do capital social, o que permite concluir que o valor proporcional do voto do acionista nas deliberações sociais guardará relação direta e necessária com o número de ações de que ele é titular ${ }^{820}$. Em outras palavras, cada ação com direito a voto atribui ao titular um voto e, ergo, o acionista terá tantos votos quantas ações forem de sua titularidade ${ }^{821}$.

Todavia - e ainda quanto a esse assunto, embora não seja o caso das companhias -, não é ocioso mencionar-se a existência de tipos societários que admitem frações desiguais de capital social. É a hipótese, no Brasil, das sociedades limitadas, quanto às quotas - parcelas indivisíveis (CC: art. 1.056) em que se reparte seu capital social (CC: art. 1.055, $1^{\mathrm{a}}$ parte) e que podem, prescreve o Código Civil, ser iguais ou desiguais (art. 1.055, $2^{\mathrm{a}}$ parte), tocando uma ou várias a cada sócio (art. 1.055, in fine). A par do sistema de pluralidade de quotas (ou de quotas múltiplas ${ }^{822}$ ), muito mais vantajoso $^{823}$, o diploma legal admitiu o modelo de quota única inicial ${ }^{824} \mathrm{e}$, assim, na hipótese de existência de quotas desiguais ${ }^{825}$, o voto dos quotistas guardará proporção com a respectiva participação no capital social e não com o número de quotas.

Uma segunda observação diz respeito à derrogação parcial do princípio da proporcionalidade por decorrência das ações sem valor nominal. Mesmo nessa hipótese, como visto, o valor de cada voto é igual entre si e conserva-se assim, nos termos acima delineados, a proporção entre o valor do voto e o número de ações. Não segue, contudo, que a contribuição por cada ação tenha sido igual e, na hipótese de desigualdade, ter-se-á verificado um descolamento entre o capital empregado e o poder político atribuído. Essa

\footnotetext{
${ }^{818}$ O texto legal é inequívoco: " $\$ 2^{\circ}$. O valor nominal será o mesmo para todas as ações da companhia."

${ }^{819}$ Ensina José Edwaldo Tavares BORBA que "correspondendo o capital social a um determinado número de ações, cada ação representa uma fração desse capital"; como esse capital é expresso em pecúnia, o valor ideal de cada ação "não é [outro] senão o quociente da divisão do montante do capital pela quantidade de ações” (cf. Direito Societário, Rio de Janeiro, Renovar, 2010, p. 232). Donde se conclui, afirmamos nós, ser cada ação representativa da mesma parcela do capital social; trata-se, em outras palavras, da mesma fração.

820 "É princípio geral o de que, na falta de diferente cláusula contratual, a cada acção corresponde um voto." In: Eduardo de Melo Lucas COELHo, A Formação das Deliberações Gerais - Assembleia Geral das Sociedades Anónimas, Coimbra, Coimbra Ed., 1994, p. 58.

${ }^{821}$ Naturalmente, nas legislações que permitem ações de valor nominal diferentes (Alemanha e Suíça, por exemplo: AktG § 134 e Código das Obrigações, art. 692), o cômputo da votação observará essa medida de proporção e não se dará por unidade de ação. Cf. Renato Ventura RIBEIRO que In: Direito de Voto nas Sociedades Anônimas, São Paulo, Quartier Latin, 2009, p. 190.

${ }^{822}$ José Waldecy LuCENA, Das Sociedades Limitadas, Rio de Janeiro, Renovar, 2005, p. 313.

${ }^{823}$ Trata-se, conforme lição de José Waldecy LUCENA, que se apoia em Egberto Lacerda Teixeira, de sistema muito mais vantajoso, pois facilita as transferências (cessões) de quotas e a divisibilidade do capital social, reduzindo as hipóteses de "co-propriedade" (co- titularidade) de quotas, e facilita, ainda, a contagem dos votos nas assembleias. In: Das Sociedades Limitadas, Rio de Janeiro, Renovar, 2005, p. 313.

${ }^{824}$ José Waldecy LuCENA, Das Sociedades Limitadas, Rio de Janeiro, Renovar, 2005, p. 313.

${ }^{825}$ Muito pouco frequente na prática societária.
} 
possibilidade decorre da previsão legal que admite, para cada emissão de ações sem valor nominal, a fixação de um preço de emissão (LSA: art. 14), coincidente ou não com o das emissões anteriores ${ }^{826}$.

Outra observação refere-se à possibilidade de a participação no capital social não atribuir ao titular o direito político do voto. A regra one share one vote ${ }^{827}$, embora seja rigorosamente observada em outros tipos societários e seja recomendada, quanto às companhias abertas, pelas boas práticas de "governança corporativa" geralmente aceitas, não é aplicada em toda hipótese nas sociedades anônimas brasileiras. Como se sabe, a Lei n. ${ }^{\circ}$ 6.404/76 autoriza que o estatuto social subtraia ou restrinja o direito de voto dos titulares de ações preferenciais $\left(\right.$ art. 111) ${ }^{828}$, contanto que, nesse caso, tais ações não ultrapassem metade de todas as ações emitidas (art. 15, $\S 2^{\text {o829 }}$ ).

Dessa maneira, o direito de voto, direito essencial do sócio em outras sociedades, não o é nas sociedades anônimas, observados os limites legais. Portanto, a relação de proporção entre voto e participação societária, supra analisada, não está presente nesse caso e, ergo, não é uma verdade verificável em toda sociedade ${ }^{830 \text { e } 831}$.

Por fim, merecem menção certos expedientes jurídicos que, procurando atender a determinados interesses e finalidades, provocam de algum modo propositada desproporção entre o poder de voto e a participação societária.

Um desses expedientes que contrastam claramente o princípio da

\footnotetext{
${ }^{826}$ Modesto CARVAlHOSA ilustra a hipótese com clareza cristalina: “Em consequência, a participação do acionista, no capital da companhia, medir-se-á em razão do número de ações de que é titular proporcionalmente ao número total de ações emitidas. Se, v.g., numa emissão do capital, a subscrição foi de $R \$ 50,00$ (cinquenta reais) por ação e, no aumento subsequente, a subscrição foi de $R \$ 150,00$ (cento e cinquenta reais), em ambos os casos, contar-se-ão o mesmo número de ações, independentemente, portanto, da diferença de contribuição do acionista ao capital, numa e noutra oportunidade." In: Comentários à Lei de Sociedades por Ações, v. 2, São Paulo, Saraiva, 2009, p. 392. Ainda a respeito, observa o mesmo autor que o capital social (de que as ações são fração) não reflete necessariamente o valor de todas as entradas (o capital efetivamente empregado pelos acionistas), já que parcela do preço de emissão das ações sem valor nominal e o ágio das ações emitidas com valor nominal devem integrar a conta das "reservas de capital" (art. $\left.182, \S 1^{\circ}, a\right)$, que não obrigatoriamente se converterão em capital social (art. 200).

${ }^{827}$ Expressamente prevista, quanto às ações ordinárias, pela lei brasileira (Lei n. ${ }^{\circ}$ 6.404/76: art. 110).

${ }^{828}$ A norma tem caráter autorizativo e, naturalmente, na ausência de expressa previsão no estatuto social, as ações preferenciais atribuem direito de voto. Cf. José Edwaldo Tavares BorBA, Direito Societário, Rio de Janeiro, Renovar, 2010, p. 341.

${ }^{829}$ Conforme redação atribuída pela Lei n. ${ }^{\circ} 10.303 / 01$.

${ }^{830}$ Em comentário ao princípio da proporção, observa Modesto CARVALHOSA: “A derrogação gradativa do princípio dá-se, em primeiro lugar, pela faculdade de emissão de ações preferenciais sem direito de voto ou com voto limitado. (...) É, com efeito, a existência de ações preferenciais uma efetiva ruptura do princípio da proporcionalidade entre capital e voto, e que tornou possível o exercício do controle da companhia por uma minoria de acionistas.” In: Cf. Comentários à Lei de Sociedades por Ações, v. 2, São Paulo, Saraiva, 2009, p. 391.

${ }^{831}$ De se citar, ainda, a vedação de voto às ações ao portador, cuja emissão foi proibida pela Lei n. ${ }^{\circ}$ 8.021/90. Sobre a derrogação do princípio da proporcionalidade por essa regra, veja-se Modesto CARVALHOSA, Comentários à Lei de Sociedades por Ações, v. 2, São Paulo, Saraiva, 2009, p. 392.
} 
proporcionalidade é o voto plural, vedado, no entanto, pela legislação societária pátria (LSA: art. $101, \S 2^{\circ}$ ). Não é dado, assim, ao estatuto atribuir a determinadas ações privilegiadas mais de um voto ${ }^{832}$. Uma exceção, de aplicação restritíssima no Brasil, são as chamadas golden shares, ações preferenciais de classe especial previstas pelo art. $17, \S 7^{\circ}$, da Lei n. ${ }^{\circ} 6.404 / 76^{833}$ e que têm lugar apenas nas companhias objeto de desestatização ${ }^{834}$. O ente desestatizante poderá criá-las e apenas ele poderá detê-las e elas poderão conferir poderes especiais, "inclusive o poder de veto às deliberações da assembleia-geral nas matérias que especificar”. Assim, embora titular de uma única ação, pode o ente desestatizante determinar o veto de deliberação tomada pela totalidade dos demais acionistas.

A lei brasileira prevê ainda a possibilidade - não isenta de controvérsias $^{835}$ - de limitação do número de votos por acionistas (LSA: art. $110, \S 1^{\text {o836}}$ ). Não pode o estatuto impor um número mínimo de ações de que cada acionista deve ser titular para poder exercer seu direito de voto $^{837}$. Assim, o que preceitua a lei é a possibilidade de criação convencional de um teto máximo de votos por acionista, “ou seja, nenhum acionista poderá ter, individualmente, mais do que, por exemplo, mil votos

\footnotetext{
${ }^{832}$ Muito atrelada às teorias institucionalistas na Alemanha no pós-Primeira Guerra Mundial, essa técnica visava a manter o controle nacional das companhias. A proibição no Brasil fundamenta-se justamente na desproporção entre ação e capital que ela implica ( "o voto assegura o direito de voto na sociedade por acionistas independentemente do valor que tenham contribuído para a formação do capital social”) e no favorecimento que acarreta à concentração "da vontade social em mãos de um único ou de um pequeno grupo de acionistas". Cf. Modesto CARVAlhoSA, Comentários à Lei de Sociedades por Ações, v. 2, São Paulo, Saraiva, 2009, p. 402.

${ }^{833}$ Também a Lei 9.491/97 prevê a possibilidade: “Art. $8^{\circ}$ Sempre que houver razões que justifiquem, a União deterá, direta ou indiretamente, ação de classe especial do capital social da empresa ou instituição financeira objeto da desestatização, que lhe confira poderes especiais em determinadas matérias, as quais deverão ser caracterizadas nos seus estatutos sociais."

834 "Em consequência, o voto plural será ilegal, à exceção do regime de golden share, na restrita forma e efeitos constantes do $\S 7^{\circ}$ do art. 17." In: Modesto CARVAlHoSA, Comentários à Lei de Sociedades por Ações, v. 2, São Paulo, Saraiva, 2009, p. 402. Não é demasiado sublinhar que não se confunde com o voto plural o voto múltiplo, admitido pela Lei n. ${ }^{\circ}$ 6.404/76. Trata-se, neste caso, de um sistema de votação destinado à proteção das minorias acionárias, por favorecer que elejam representantes no conselho de administração. Se previamente solicitado, pode-se atribuir a cada ação, na deliberação da assembleia geral para eleição dos membros do aludido órgão, tantos votos quantos cargos existam, facultando-se aos acionistas cumular todos os votos em um único candidato ou distribuí-los como desejar (art. 141).

${ }^{835}$ Modesto Carvalhosa, Comentários à Lei de Sociedades por Ações, v. 2, São Paulo, Saraiva, 2009, p. 401.

${ }^{836}$ No direito comparado, preveem-no as leis da Alemanha (AktG, § 134, 1), Espanha (art. 105, 2), França (art. 177), Itália, Portugal (CSC: art. $\left.384^{\circ}, 2\right)$.

${ }^{837}$ Alfredo Sérgio LAZZARESCHI NeTO, Lei das Sociedades por Ações Anotada, São Paulo, Saraiva, 2006, p. 144, n. 2b. Fundamenta Modesto CARVAlhosa: "Desde logo deve-se entender que o preceito não pode prejudicar o direito dos acionistas minoritários." Acrescenta: “” A lei expressamente estabelece que a cada ação ordinária corresponde um voto nas deliberações da assembleia geral, o que não poderá ser suprimido pelo estatuo, já que se trata de norma de ordem pública." In: Comentários à Lei de Sociedades por Ações, v. 2, São Paulo, Saraiva, 2009, p. 401.

${ }^{838}$ José Edwaldo Tavares BorbA, Direito Societário, Rio de Janeiro, Renovar, 2010, p. 340. O mesmo exemplo é mencionado por Alfredo Sérgio LAZZARESCHI NeTO. Cf. Lei das Sociedades por Ações Anotada, São Paulo, Saraiva, 2006, pp. 143-144, n. 2a
} 
Outro exemplo vislumbrado por Modesto CARVALHOSA prevê a atribuição de um voto para cada ação até o limite de cem ações e, a partir de então, cada ação corresponde a um único voto $^{839}$.

O fundamento da norma é a proteção da minoria e a "minimização do poder de controle da companhia pelos detentores de grandes lotes de ações" ${ }^{„ 840}$. Se previsto pelo estatuto social, deve, ademais, ser aplicado a todos os acionistas, sem discriminação ${ }^{841}$.

Há registros, no entanto, de que essa possibilidade não tem sido empregada na prática societária ${ }^{842}$. Primeiro, porque a contrariedade ao princípio da proporcionalidade é, em geral, indesejável e, dificilmente, o poder econômico se submeteria voluntariamente a ela, ainda quando objetive atrair capitais não integrantes do bloco de controle. Para esse fim, e sem risco de alterar a composição de uma estrutura societária, há regras protetivas mais específicas que têm sido mais frequentemente utilizadas - como a reserva estatutária ou mediante acordo de acionistas de cargos no conselho de administração e até na diretoria ou, ainda, a fixação de dividendos mínimos e/ou fixos etc. Outra razão apontada para o insucesso dessa previsão legal é a suposta facilidade para ser burlada, quando estatutariamente prevista $^{843}$.

Bem se vê, portanto, que, na legislação acionária brasileira, em que pese a vinculação em princípio existente entre capital investido e poder político dentro da companhia, existem regras (ações sem direito de voto; ações sem valor nominal com preço de emissão diferentes; golden shares, etc.), que excepcionam ou mitigam essa correlação.

A doutrina destaca, ainda, a possibilidade de adoção mista dos dois sistemas, por cabeça e por ação. Registra-se, por exemplo, a possibilidade de discriminação por matérias, tocando a deliberação de algumas delas ao sistema por cabeça e de outras ao

\footnotetext{
${ }^{839}$ Comentários à Lei de Sociedades por Ações, v. 2, São Paulo, Saraiva, 2009, p. 401. Dessa forma, ilustra ele, "se o acionista tiver 99 ações, serão 99 os votos. Se tiver 53 ações, serão 53 os votos. Se possuir 150 ações, serão 105 os votos. Se tiver 147 ações, também serão 105 os votos."

${ }^{840}$ Modesto Carvalhosa, Comentários à Lei de Sociedades por Ações, v. 2, São Paulo, Saraiva, 2009, p. 402.

${ }^{841}$ Modesto Carvalhosa, Comentários à Lei de Sociedades por Ações, v. 2, São Paulo, Saraiva, 2009, p. 402.

${ }^{842}$ José Edwaldo Tavares BoRBA, Direito Societário, Rio de Janeiro, Renovar, 2010, p. 340

${ }^{843}$ São palavras de José Edwaldo Tavares BORBA: "Essa faculdade não tem sido utilizada na prática estatutária, em face, certamente, da facilidade com que o preceito seria fraudado. O acionista, diante de uma decisão importante, transferiria lotes de ações para terceiros, 'testas-de-ferro', que exerceriam o voto no seu interesse.” In: Direito Societário, Rio de Janeiro, Renovar, 2010, p. 340
} 
sistema por ações ${ }^{844}$. Renato Ventura RIBEIRO arrola entre os sistemas mistos as deliberações que admitem o voto plural (ou duplo), não admitida no Brasil, ou, ainda, a limitação máxima de votos por acionista, prevista pela Lei n. ${ }^{\circ} 6.404 / 76^{845}$.

\subsection{Princípio da unidade do voto}

O voto consiste, em linhas gerais, na aprovação ou rejeição da proposta, como visto. O critério de ponderação do voto, para formação da deliberação, é variável, embora preponderantemente, em âmbito societário, observe-se a proporção ao capital social - mais ainda àquele exclusivamente "votante". O ponto aqui é indagar-se se, sendo titular de mais um de um voto, independente do critério de ponderação, o acionista poderia votar com parcela deles em um sentido e outra parcela, em outro.

E a resposta é negativa. Como regra, vigora o princípio da unidade ${ }^{846}$, que veda o exercício de votos divergentes, isto é, a possibilidade de emissão de votos distintos ${ }^{847}$ pelo mesmo acionista ${ }^{848}$. Embora a ação seja o título que dá sustento ao direito de voto (tanto é assim que, pelo princípio da indivisibilidade, o voto da ação sob condomínio é único ${ }^{849}$ ), este é de titularidade do acionista e seu exercício, por conseguinte, deve observar a congruência com o titular.

Sendo o voto, como visto, uma declaração unilateral de vontade, não se afigura possível que o mesmo declarante manifeste-se em sentidos divergentes ${ }^{850}$. Admitirse o contrário seria violar o princípio que veda venire contra factum proprium. Seja qual for o fator de ponderação do voto (por exemplo, o número de ações - como sói ocorrer nas

\footnotetext{
844 “Algumas legislações trazem a obrigatoriedade do voto por cabeça na constituição das companhias." Cf. Renato Ventura RIBEIRO, Direito de Voto nas Sociedades Anônimas, São Paulo, Quartier Latin, 2009, p. 193.

${ }^{845}$ Direito de Voto nas Sociedades Anônimas, São Paulo, Quartier Latin, 2009, p. 193. E ainda: "O limite máximo do número de votos por acionista pode ser tido como meio termo entre a atribuição de um voto por ação e o voto 'por cabeça', no qual cada acionista tem direito a um voto, independente de participação social." (p. 222)

${ }^{846}$ Eduardo de Melo Lucas CoElHo, A Formação das Deliberações Gerais - Assembleia Geral das Sociedades Anónimas, Coimbra, Coimbra Ed., 1994, p. 153.

${ }^{847}$ Ressalvada a hipótese de apreciação pela assembleia de propostas múltiplas e não excludentes entre si, votos divergentes são sempre contraditórios entre si.

${ }^{848}$ Renato Ventura RIBEIRO, Direito de Voto nas Sociedades Anônimas, São Paulo, Quartier Latin, 2009, p. 273.

${ }^{849}$ LSA: art. 28, parágrafo único. Cf. também: Modesto CARvalHosA, Comentários à Lei de Sociedades por Ações, v. 2, São Paulo, Saraiva, 2009, p. 395.

${ }^{850}$ Tratando de condomínio não de ação, mas de lote de ação, manifesta-se Modesto CARVALHOSA no sentido da indivisibilidade do voto, se o representante dos condôminos for comum: "pois o representante deve refletir de forma coerente a vontade dos condôminos, votando univocamente com todas as ações do condomínio." In: Comentários à Lei de Sociedades por Ações, v. 2, São Paulo, Saraiva, 2009, p. 395.
} 
deliberações assembleares societárias e deve ocorrer, no caso das companhias), a declaração do sócio é única e una - é apenas uma só ${ }^{851}$.

Nada obstante o princípio da unidade, Renato Ventura RIBEIRO ${ }^{852}$, que defende a possibilidade, em tese, de votos divergentes, na omissão da lei ${ }^{853}$, sustenta que a Lei n. ${ }^{\circ}$ 6.404/76 "indiretamente" admitiu a possibilidade em caso de acordo de acionista. Um acionista não integrante da convenção pode, por sucessão, receber ações decorrentes do falecimento de um signatário do acordo (celebrado com cláusula que obriga os sucessores). Nessa hipótese, entende o autor que é admissível o voto divergente, já que o disposto no $§ 10$ do art. 118 da Lei de Sociedades por Ações não abrangeria esse caso ${ }^{854}$.

Uma exceção é o chamado voto múltiplo, expressamente admitido pela Lei n. ${ }^{\circ}$ 6.404/76 (art. 141). Nas deliberações para eleição dos membros do conselho de administração da companhia, é possível que, em vez de se deliberar a nomeação, uma a uma, de cada um dos cargos do órgão, seja realizado escrutínio único e sejam atribuídos a cada ação tantos votos quantos cargos existam. E mais: faculta-se ao acionistas dirigir todos seus votos a um único candidato ou "distribui-los entre vários" (art. 141, caput, in fine). Ora, nesta última hipótese será possível ao votante exercer votos divergentes -

\footnotetext{
${ }^{851}$ É o mesmo fundamento que veda, no direito brasileiro, o exercício do recesso parcial (decorrência do que dispõe o art. 137, $\S 1^{\circ}$, da LSA). Modesto CARVALHOSA chega a afirmar que a hipótese contrária constituiria abuso de direito. Cf. Comentários à Lei de Sociedades Anônimas, v. 2, São Paulo, Saraiva, 2009, p. 907. Renato Ventura RIBEIRO anota, contudo, que, na Itália, recente reforma legislativa autorizou o exercício parcial da retirada - dispositivo que milita em favor da possibilidade de exercício de votos divergentes. Cf. Direito de Voto nas Sociedades Anônimas, São Paulo, Quartier Latin, 2009, p. 277.

${ }^{852}$ Tratando da modificação estabelecida ao longo dos tempos que admitiu tais exceções, lembra Renato Ventura RIBEIRO: "No passado foi dito que ninguém pode proibir um acionista de se expor ao ridículo, votando em mais de um sentido, com votos contraditórios, bem como tachada tal atitude de comportamento não sério." In: Direito de Voto nas Sociedades Anônimas, São Paulo, Quartier Latin, 2009, p. 273.

853 " $\mathrm{Na}$ ausência de disposição legal, como o voto é atribuído pela ação, quer ao acionista ou a outro legitimado, deve ser possivel a um acionista emitir votos em sentidos diversos." In: Direito de Voto nas Sociedades Anônimas, São Paulo, Quartier Latin, 2009, p. 277. Em favor de seu entendimento, sustenta que votos divergentes não eliminam a obrigatoriedade de exercício desse direito político em favor do interesse social e que, tendo em vista as múltiplas maneiras de se atender a ele, as opções destinatárias do voto seriam "indiferentes" e, portanto, a escolha por qualquer delas ou por ambas teria o mesmo efeito jurídico: "Como há diversas formas de se alcançar o escopo legal, votos divergentes, inclusive em sentidos opostos, podem estar consoante o interesse social" (p. 277). O autor ilustra a tese com o seguinte exemplo: "Na assembleia geral discutem-se as diversas propostas para aumento da produção, entre as quais a construção de nova unidade fabril ou a aquisição de empresa. Ambas as alternativas permitem alcançar o interesse social. Ainda que haja dúvidas sobre qual a melhor delas" (pp. 277-278). Ele ainda advoga que o acionista de votos divergentes apenas pode impugnar a deliberação para a qual haja concorrido com menos de metade de suas ações (majoritariamente, portanto, foi contra a proposta aprovada) e que o recesso seja parcial, para abranger apenas as ações com supedâneo nas quais absteve-se ou divergiu da deliberação tomada (p. 279).

${ }^{854} \mathrm{~A}$ esse dispositivo, contudo, estaria adstrito o acionista que, após vincular-se a um acordo, adquirisse por ato intervivos novas ações - que restariam, por acréscimo, também submetidas aos termos do pacto parassocial. In: Renato Ventura RIBEIRO, Direito de Voto nas Sociedades Anônimas, São Paulo, Quartier Latin, 2009, p. 275.
} 
embora não contraditórios ${ }^{855}$. De toda sorte, reitera-se o caráter excepcional dessa medida e, ainda mais, os propósitos protetivos de minoria que a justificam.

\subsubsection{Votação, apuração e proclamação}

Já ficou assentado que a deliberação é ato colegial. Esse ato não é espécie de fato jurídico (trata-se de ato jurídico em sentido amplo, que tanto pode consistir em negócio jurídico, quanto em jurídico em sentido estrito), mas modo de formação da manifestação de vontade. Tem lugar nos casos em que há pluripessoalidade, como no exemplo em que os condôminos de um imóvel revogam a proposta de arrendamento feita a alguém $^{856}$. Em uma definição, ato colegial "ato coletivo, colegial, é o ato que em sua formação há pluralidade de vontades que se fundem numa só ",857.

Há quem estabeleça distinção conceitual entre ato coletivo e colegial. Precisa é aquela feita por SANTORO-PASSARELLI e referida por Erasmo Valladão A. e N. FRANÇA: em ambos os casos, vontades distintas e singulares conformam outra vontade; contudo, enquanto nesta última espécie a vontade formada é imputada a um sujeito diverso (como é o caso das sociedades: a vontade formada na deliberação pelos sócios é imputada à pessoa jurídica), na primeira é imputada aos próprios agentes das vontades singulares (é a deliberação de condôminos, a estes imputada) ${ }^{858}$.

Sobre o exato sentido do verbo "fundir" empregado nessa definição já se pronunciou anteriormente. A formação do ato colegial não aniquila os atos singulares que

\footnotetext{
${ }^{855}$ De fato, nesse caso, as propostas não são excludentes entre si, já que os membros do conselho não são eleitos em "chapas", mas individualmente, e os votos são distribuídos, no máximo, em tantos candidatos quantas vagas houver (hipótese em que o voto, embora múltiplo, não se diferencia do outro sistema e não tem utilidade alguma) ou em menos candidatos que vaga (o que usualmente ocorre para proteção das minorias). Diferente seria a hipótese (meramente teórica, ad argumentandum) em que houvesse mais votos que vagas.

${ }^{856} \mathrm{O}$ exemplo é de Marcos Bernardes de Mello. In: Teoria do Fato Jurídico - Plano da Existência, São Paulo, Saraiva, 2000, p. 176.

${ }^{857}$ Marcos Bernardes de Mello. In: Teoria do Fato Jurídico - Plano da Existência, São Paulo, Saraiva, 2000, p. 176.

${ }^{858}$ Erasmo Valladão A. e N. FrAnÇA, Invalidade das Deliberações de Assembleia das S/A, São Paulo, Saraiva, 1999, p.42, n. 46. Em sentido semelhante, Fabio Konder COMPARATO, também citado pelo mesmo autor, afirma que os atos coletivos distinguem-se dos colegiais porque suas "várias manifestações de vontade não se fundem em ato de uma só pessoa (jurídica, bem se vê), como ocorre nas deliberações de assembleias de condomínios." Quanto àqueles outros o exemplo são também as deliberações das assembleias de acionistas, identificadas como "atos ou negócios jurídicos que se formam pela idêntica manifestação de vontade de vários sujeitos, constituindo o órgão de uma pessoa jurídica.” In: Da Imprescritibilidade da Ação Direta de Nulidade de Norma Estatutária, in Novos Ensaios e Pareceres de Direito Empresarial, Rio de Janeiro, Forense, 1981, pp. 216-217.
} 
o integram ${ }^{859}$. A preservação de sua autonomia (ontológica) é que permite a verificação ou não de seus vícios e o conseguinte juízo sobre sua validade ou não, separadamente do ato colegial que ele integra. Esta "fusão" indica assim, mais propriamente, o enfeixamento dos votos proferidos em um mesmo sentido. Se reunidos em "necessária cooperação" e perfazendo eles quantitativamente os requisitos aritméticos necessários, esses votos formam uma "posição qualitativamente unitária em forma de deliberação "860.

Dessa maneira, enquanto o voto é ato do acionista a ele imputável e que, em conjunto e combinado com outros votos, pode perfazer uma deliberação, esta é um ato unilateral da companhia a ela unicamente imputável. Para aí se chega por via da votação.

Votação é o escrutínio, é a globalidade que envolve a emissão dos votos (emissão eficaz, leia-se, recebida por seu destinatário) de todos os votantes ${ }^{861}$. No iter assemblear, segue-se aos debates e precede a apuração.

Esta última consiste no agrupamento dos votos emitidos acerca da proposta em duas secções, a dos favoráveis e a dos contrários, e, ao depois, na aferição dos requisitos legais e estatutários para se chegar ao posicionamento que logrou êxito (aprovação da proposta ou sua rejeição). Recorre-se, para tanto, ao princípio de votação, que é a "regra valorativa de carácter geral estabelecida na normação organizatória, pela qual se afere se determinada relação de voto - relação quantitativa - representa aceitação ou recusa da proposta ${ }^{\text {,862. }}$.

A esse propósito, já se feriu o tema atinente ao sistema de voto, por cabeça ou ponderado, quase sempre em razão da representatividade do capital social detido. Dessa maneira, na apuração, os votos serão contabilizado segundo o número de votantes (votação por cabeça, bastante pouco usual em matéria societária) ou segundo uma ponderação aplicada a cada votante - correspondente à sua participação no capital social, em regra como dito. Referência foi feita, ademais, à impossibilidade de o votante apresentar manifestação divergente, devendo seu voto ser sempre manifestado em um

\footnotetext{
${ }^{859}$ Priscila Corrêa da FONSECA observa: "No ato coletivo, por seu turno, há também um concurso de diversas vontades (de conteúdo e finalidades idênticas), sem contudo se fundirem, permanecendo juridicamente autônomas. ”In: Suspensão de Deliberações Sociais, São Paulo, Saraiva, 1986, p. 73.

${ }^{860}$ Eduardo de Melo Lucas CoElho, A Formação das Deliberações Gerais - Assembleia Geral das Sociedades Anónimas, Coimbra, Coimbra Ed., 1994, p. 158.

861 Eduardo de Melo Lucas COELho, A Formação das Deliberações Gerais - Assembleia Geral das Sociedades Anónimas, Coimbra, Coimbra Ed., 1994, p. 147. Pode-se ainda empregar o mesmo termo para significar, mais estreitamente, "a declaração de voto exprimindo a posição individual de cada um dos votantes acerca da proposta” (pp. 147-148).

${ }^{862}$ Eduardo de Melo Lucas COELHO, A Formação das Deliberações Gerais - Assembleia Geral das Sociedades Anónimas, Coimbra, Coimbra Ed., 1994, pp. 178-179.
} 
único sentido.

Importa, pois, nesse passo, mencionar as regras atinentes ao quórum de aprovação - que decorrem, na verdade, da aplicação do princípio majoritário, de emprego alastrado nos diversos ordenamentos jurídicos ${ }^{863}$. O princípio da unanimidade $^{864}$, com efeito, é de raríssima ocorrência: é improvável de fato que qualquer estrutura societária subsista à rigidez absoluta do consenso - quase nunca atingível. A veracidade da afirmação, com efeito, é evidente e, para sua verificação, não se faz necessário nem sequer ultrapassar os domínios das "máximas da experiência". É notável, por conseguinte, a escassez de matérias deliberativas que demandam tal quórum ${ }^{865}$.

Portanto, o princípio majoritário impõe-se primariamente por uma necessidade premente e instransponível: ou bem se quebra a regra do consenso ou a companhia queda inviável.

Fundamentos teóricos, contudo, existem. Um deles estriba-se na natureza da deliberação, já examinada: tratando-se ela de ato colegial (produto da combinação das declarações unilaterais dos votos singulares), é imputável à companhia, e não à maioria de votantes vencedora, e, portanto, àquela, e não a esta, a minoria se sujeita ${ }^{866}$. Nesse sentido, parece ser o entendimento de Giuseppe SENA que, citando Venditti, ressalta a função da organização colegiada ("strumento perchè venga ad esistenza un atto dotato di unitaria rilevanza giuridica e generale efficacia nei confonti di tutti $i$ partecipi del gruppo in quanto costituiti dalla legge in collegio") e, em seguida, consiga "il principio maggioritario come un criterio di organizzazione del collegio al quale sarà riferita

\footnotetext{
863 “É, pois, o princípio maioritário que domina, nos termos expostos, a formação das deliberações sociais nas sociedades anónimas.” In: Eduardo de Melo Lucas CoELHO, A Formação das Deliberações Gerais Assembleia Geral das Sociedades Anónimas, Coimbra, Coimbra Ed., 1994, p. 187.

${ }^{864}$ Eduardo de Melo Lucas COELho, A Formação das Deliberações Gerais - Assembleia Geral das Sociedades Anónimas, Coimbra, Coimbra Ed., 1994, p. 184. O autor destaca sua aplicação nas sociedades civis alemãs (BGB: $\S 709, \mathrm{I})$, bem como a proteção que esse princípio assegura às minorias.

${ }^{865}$ No caso da Lei n. ${ }^{\circ}$ 6.404/76, as hipóteses são bem raras: art. 229, § $5^{\circ}$ (em caso de cisão, se as ações integralizadas com patrimônio da companhia cindida forem atribuídas aos acionistas em desproporção); art. 221 (em caso de transformação, salvo se previsto no estatuto social); art. 87, § $2^{\circ}$, in fine (alteração do projeto de estatuto na assembleia de constituição de companhia constituída por subscrição pública). O Decreto-Lei n. ${ }^{\circ}$ 2.627/40: art. 72 (mudança de nacionalidade da companhia brasileira).

${ }^{866}$ Marcelo Vieira von ADAMEK, Abuso de Minoria em Direito Societário - Abuso das Posições Subjetivas Minoritárias, tese de doutorado, Faculdade de Direito da USP, São Paulo, mimeo, 2010, pp. 30-31. O autor cita ainda três explicações reportadas por Hebert Wiedemann (no seu livro Gesellschaftsrecht): "A primeira, que remonta a Grotius, é de ordem quantitativa: pars major, pars sana. A segunda, elaborada por Locke e Rousseau, é de ordem normativa e, por essa visão, a minoria teria dado uma autorização contratual para que a maioria tome as decisões. Por fim, a terceira, que já traz em si os contornos para a proteção à minoria, preconiza que, se se der poder apenas à maioria, ela irá oprimir a maioria e se forem dados poderes à minoria, razão pela qual poderes devem ser concedidos a ambos, ideia-força essa expressa na frase de Alexander Hamilton, transcrita na abertura do trabalho." A frase é: "Men love power (...). Give all power to the many, they will oppress the few. Give all power to the few, they will oppress the many. Both therefore ought to have power, that each may defend itself against the other." (cf. pp. 3 e 32)
} 
unitariamente la deliberazione,867. Outro fundamento, referido por Fabio Konder Comparato, arrimado em Hans KELSEN, é a ideia de que "o ordenamento social deve estar de acordo com o maior número possível de sujeitos, e em desacordo com o menor número possível",868.

O princípio majoritário implica, necessariamente, a imposição de um sacrifício à minoria vencida. Por isso, e na busca por um equilíbrio, sua adoção é geralmente acompanhada de algum expediente que franqueie à parcela insatisfeita o desfazimento de seu laço com a sociedade. Esse mecanismo de saída normalmente consiste em diminuta ou inexistente barreira à alienação da ação a terceiros (LSA: art. 36) ou em francas hipóteses de exercício da retirada (LSA: art. 137 et passim) ou, ainda, uma composição dessas duas "válvulas de escape" ${ }^{869}$. Sem prejuízo destas, o legislador ainda prevê outros mecanismos de proteção à minoria que decide permanecer vinculada à organização societária ${ }^{870}$.

Entre os mecanismos de tutela da minoria está a diferenciação dos quóruns de aprovação, conforme a matéria sobre o que versa a proposta. Com efeito, a legislação usualmente prevê quóruns mais elevados, quando a matéria é nuclear ao arranjo societária, quando é mais sensível aos minoritários ou quando, por qualquer outra razão, faz-se necessária uma composição de interesses mais homogênea.

Essa variação pode resultar não apenas em escalonamento crescente da parcela aritmeticamente necessária à aprovação das matérias mais sensíveis, mas também, e no mesmo sentido, em ampliação crescente da base sobre a qual esse número relativo (fração, percentagem) incide. Assim, por exemplo, na técnica da Lei n. ${ }^{\circ}$ 6.404/76, a generalidade das matérias demanda o voto afirmativo da maioria dos presentes (art. $129^{871}$ ), uma vez instalada validamente a assembleia (em primeira ou segunda convocação

\footnotetext{
${ }^{867}$ In: Il voto nella assemblea della società per azioni, Milão, Giuffrè, 1958, p. 106.

${ }^{868}$ Fabio Konder COMPARATO - Calixto SAlOMÃo FILHO, O Poder de Controle na Sociedade Anônima, Rio de Janeiro, Forense, 2005, p. 61.

${ }^{869}$ Usualmente a legislação prevê uma justaposição desses dois mecanismos. Nas sociedades de capital, normalmente se privilegia a livre circulação de ações, em detrimento das hipóteses de recesso; nas sociedades de pessoas, ao reverso, o recesso é direito de aplicação ampla e a circulação das quotas amiúde tem graves restrições. Nas limitadas, diferentemente das sociedades anônimas, a alienação de quotas a terceiros pode ser obstada pela manifestação de sócio representativo de mais de $25 \%$ do capital social (CC: art. 1.057, in fine); por outro lado, em matéria de recesso, as hipóteses são abertas no art. 1.077 e, especialmente, no art. 1.029, ambos do Código Civil (em que pese a polêmica a respeito da aplicação deste último).

${ }^{870}$ Porque, como lembra Marcelo Vieira von ADAMEK, "o regular funcionamento de uma coletividade não pode ser pautado pela regra infatilóide segundo a qual 'os incomodados que se retirem"”. In: Abuso de Minoria em Direito Societário - Abuso das Posições Subjetivas Minoritárias, tese de doutorado, Faculdade de Direito da USP, São Paulo, mimeo, 2010, p. 35.

${ }^{871}$ A nomenclatura utilizada na Lei n. ${ }^{\circ}$ 6.404/76 guarda diferença em relação àquela adotada pelo texto constitucional de 1988, quanto ao processo legislativo no Congresso Nacional. Nos termos da lei, "maioria
} 
- art. 125). Nos casos específicos do art. 136, de matérias mais graves, no entanto, o quórum é ligeiramente menor (basta a metade), mas a base sobre a qual incide é maior: não compreende apenas os presentes, senão de todos aqueles que têm direito de voto. Ainda nessa matéria, merece registro a possibilidade admitida pelo próprio artigo 136 da Lei das Sociedades por Ações de os estatutos das companhias fechadas preverem, quanto àquelas matérias, quóruns ainda mais elevados.

Fato é que, atendido o quórum adequado, conforme previsto pela lei e/ou pelo estatuto, são assim apurados os votos e, então, proclamado o resultado da deliberação - quer haja a aprovação da proposta (deliberação positiva), quer suceda sua rejeição (deliberação negativa $)^{872}$. A deliberação assim aperfeiçoa-se.

No regime da Lei n. ${ }^{\circ}$ 6.404/76, em que pese a ausência de regramento acerca da proclamação do resultado, é necessária a lavratura da ata ${ }^{873}$, instrumento escrito que deve reportar os acontecimentos que tiveram lugar na sessão deliberativa.

Sua feitura justifica-se como mecanismo que permite o controle da legalidade e legitimidade de suas instalação e deliberações. "Constitui, pois, a ata instrumento de certeza jurídica, na medida em que registra as deliberações e a vontade social, permitindo assim que seja ela oponível aos demais órgãos sociais e, por meio destes, ao colégio acionário e, após publicada, a todos os acionistas e terceiros. ",874

\subsubsection{Vícios de voto}

\subsection{Invalidade de assembleia, deliberação e voto}

Antes de ferir o tema em referência, é preciso esclarecer a distinção de três realidades conexas, passível cada qual de vícios próprios, que podem ou não comprometer os demais institutos relacionados. Consoante já examinado, não se

absoluta" não significa a maioria dos votantes existentes (presentes ou não), mas maioria dos presentes. É nesse sentido que a expressão é empregada no art. 129. Incidindo sobre todo o capital votante, o art. 136 faz expressa menção a essa base, mais extensa ( “...metade, no mínimo, das ações com direito a voto...”).

${ }_{872}$ Eduardo de Melo Lucas CoElHo, A Formação das Deliberações Gerais - Assembleia Geral das Sociedades Anónimas, Coimbra, Coimbra Ed., 1994, p. 191.

${ }^{873}$ Conceitua-a Modesto CARVAlHOSA: "o resumo das formalidades e das deliberações que houve na assembleia geral, constituindo o documento comprobatório dos atos jurídicos levados a efeito durante os trabalhos". In: Comentários à Lei de Sociedades Anônimas, v. 2, São Paulo, Saraiva, 2009, p. 764.

${ }^{874}$ Modesto Carvalhosa, Comentários à Lei de Sociedades Anônimas, v. 2, São Paulo, Saraiva, 2009, p. 764. 
confundem assembleia, deliberação ${ }^{875}$ e voto.

Ficou afirmado que o voto é declaração unilateral receptícia de vontade. Sujeitando-se, portanto, aos vícios que são próprios dos atos jurídicos ${ }^{876}$. Assim, podem padecer de erro, dolo, fraude, simulação ou, ainda, de incapacidade de seus titulares ou de violação a determinados dispositivos legais (LSA: art. 115, § $1^{\circ}$; art. 134, § $1^{\circ}$, art. 228, $\S$ $\left.2^{\mathrm{o}}\right)^{877}$

A invalidade do voto não implica necessariamente a da deliberação ${ }^{878}, \mathrm{o}$ ato colegial resultante da combinação desses votos e que acata ou rejeita a proposta apresentada. Usualmente, a deliberação é inválida quando seus termos violam a normas legais cogentes ou o estatuto, ainda que o conclave tenha se realizado regularmente ${ }^{879}$. No primeiro caso, as deliberações são nulas ou anuláveis, conforme o caso, mesmo que com o voto afirmativo da unanimidade ${ }^{880}$. Se, por outro lado, a infração é do próprio estatuto, a

${ }^{875}$ O tema já foi objeto de exame acima (item 3.3),

${ }^{876}$ Eduardo de Melo Lucas CoELHo, A Formação das Deliberações Gerais - Assembleia Geral das Sociedades Anónimas, Coimbra, Coimbra Ed., 1994, p. 191.

${ }^{877}$ Erasmo Valladão A. e N. FrAnÇA, Invalidade das Deliberações de Assembleia das S/A, São Paulo, Saraiva, 1999, p.45.

878 Tullio AsCARel, Vícios das Deliberações Assembleais - Direitos Individuais dos Acionistas Prescrição, in Problemas das Sociedades Anônimas e Direito Comparado, São Paulo, Saraiva, 1945, p. 399: "Já por isso é óbvia a distinção entre os vícios que dizem respeito à deliberação e aqueles que dizem respeito ao voto."

${ }^{879}$ Erasmo Valladão A. e N. FrAnÇA, Invalidade das Deliberações de Assembleia das S/A, São Paulo, Saraiva, 1999, p.85

${ }^{880}$ Erasmo Valladão A. e N. FRANÇA exemplifica alterações estatutárias violadoras da lei: "Se, por exemplo, resolverem modificar o estatuto para (a) estabelecer um prazo menor que o legalmente previsto para as convocações (\$ $1^{o}$, do art. 124); (b) restringir o ingresso dos acionistas sem direito de voto no conclave (parágrafo único, do art. 125); (c) permitir o voto plural para determinada classe de ações $\left(\$ 2^{\circ}\right.$, do art. 110); (d) permitir o voto por correspondência independentemente da realização de assembleia (art. 110, caput); (e) estabelecer quorum de instalação ou deliberação inferior ao legal (arts. 125, 129 e 136, ressalvado o disposto no $\S 2^{\circ}$ ), e assim por diante." (p. 98) E o mesmo autor ainda sintetiza: "Todos esses casos referem-se, precipuamente, ao procedimento assemblear, mas o vício que os contamina não está no conclave em si, que pode, inclusive, ter sido regularmente convocado e instalado, e sim no conteúdo das deliberações tomadas." Afirma, mais, que a invalidade, in casu, é absoluta (nulidade), porquanto as disposições estatutárias têm caráter permanente (a impugnação delas importa não apenas aos presentes acionistas, mas também aos futuros) e devem observar o princípio lex superior derrogat inferiori ("Estando as regras estatutárias em desacordo com as regras legais , devem prevalecer, naturalmente, estas últimas" p. 98). Outros exemplos concretos são citados pelo mesmo autor: "Se, por exemplo, numa determianda assembleia for desrespeitado o direito de preferência (rectius, opção) do acionista (art. 109, IV), o ato será anulável, mas se, através de uma deliberação, ainda que unânime, forem reformados os estatutos para excluir tal direito, o ato será absolutamente nulo. Da mesma forma, o desrespeito, numa hipótese concreta, ao direito de o acionista minoritário, que tenha um décimo do capital social com direito a voto, requerer a adoção do processo do voto múltiplo (art. 141) implica anulabilidade do ato; a reforma estatutária que postergue tal direito será nula." (pp. 103-104) São casos ainda de nulidade: "a deliberação que atentar contra a ordem pública ou os bons costumes, por impossibilidade ou ilicitude do objeto (art. 145, II, do Código Civil [corresponde ao art. 166, II, do vigente diploma]). Entre vários exemplos arrolados por Donati, acham-se o das deliberações que visem a obrigar os administradores da companhia: (a) constituir penhor de bens com pacto comissório (art. 765 do Código Civil [corresponde ao art. 1.428 do Código Civil]), (b) a concluir contratos objetivando a herança de pessoa viva (v.g., de instituição de herança de pessoa viva a favor da sociedade, contrariando o art. 1.089 do Código Civil); (c) a cometer crimes (usura, contrabando, concorrência desleal, falsificação de documentos, corrupção, crimes de colarinho branco, etc.), ou atos 
deliberação é apenas anulável, pois que os interesses atingidos cingem-se aos próprios acionistas $^{881}$.

Pode suceder, no entanto, de a invalidade dos votos macular também a deliberação. Mas, para isso, é necessário que tais votos tenham sido determinantes para o resultado; ou seja, se eles não forem suficientes para alterar o resultado, a deliberação será válida apesar da invalidade de alguns de seus votos ${ }^{882}$.

Pode ocorrer, ainda, de a invalidade recair sobre a própria assembleia, hipótese em que, por consequência, todas as deliberações nela tomadas serão igualmente inválidas $^{883}$.

Convém esclarecer, na esteira da lição de Erasmo Valladão A. e N. FRANÇA, que a disciplina das invalidades das assembleias gerais de sociedades anônimas é peculiar: enquanto aquelas absolutas (os casos de nulidade) são regidas pelo Código Civil, as invalidades relativas (anulabilidades) têm regime próprio.

Este regime é especial (previsto pela Lei n. ${ }^{\circ}$ 6.404/76, lex specialis), se comparado àquele geral disciplinado pelo Código Civil, e seus prazos decadenciais são mais curtos. Essas características se impõem em razão da necessária estabilidade de suas deliberações, que é sensivelmente mais acentuada nas assembleias que em outros atos jurídicos. Isso porque os efeitos da insegurança jurídica são particularmente deletérios no caso delas $^{884}$.

Deveras, se é certo que a preocupação com a estabilidade das relações jurídicas tem lugar também entre os demais atos jurídicos, as assembleias - sobretudo em companhias abertas - apresentam a peculiaridade de produzirem efeito sobre um universo

imorais ou fraudulentos de maneira geral (prática de atos emulativos, simulação, fraude contra credores etc.).” (pp. 106-107) Também são nulas as deliberações que infrinjam normas legais voltadas à proteção de interesses de terceiros (como as que visam a assegurar a integridade do capital social - cf. pp. 107-108), as que objetivam assegurar das demonstrações financeiras, as que contrariem o interesse público (por exemplo, coma violação do disposto no art. 222 da Constituição da República, que limita a participação estrangeira no capital social de "empresas jornalísticas e de radiodifusão sonora e de som e imagens") etc.

${ }^{881}$ Esses acionistas, completa Erasmo Valladão A. e N. FRANÇA, "podem livremente renunciar à aplicação das regras estatutárias, normas meramente internas da corporação, nos casos concretos, inexistindo, outrossim, interesses outros (de 'futuros acionistas', relativos a direitos irrenunciáveis e inderrogáveis, etc.) que justifiquem a sanção de nulidade de tais atos. O compo da nulidade absoluta das deliberações, portanto, restringe-se a sanção de nulidade de tais atos. " In: Invalidade das Deliberações de Assembleia das S/A, São Paulo, Saraiva, 1999, p.105.

${ }^{882}$ Renato Ventura RIBEIRO, Direito de Voto nas Sociedades Anônimas, São Paulo, Quartier Latin, 2009, p. 261.

${ }^{883}$ Erasmo Valladão A. e N. FrAnÇA, Invalidade das Deliberações de Assembleia das S/A, São Paulo, Saraiva, 1999, p.85.

${ }^{884}$ Erasmo Valladão A. e N. FrANÇA, Invalidade das Deliberações de Assembleia das S/A, São Paulo, Saraiva, 1999, p. 69. 
de pessoas normalmente muito mais amplo do que aquele sujeito aos efeitos da generalidade dos demais atos jurídicos. O problema toma contornos ainda mais graves, porque a incerteza acerca das assembleias prejudica a própria gestão da companhia - o que potencializa notavelmente seus efeitos negativos ${ }^{885}$. Por tudo isso, faz-se necessária a restrição temporal da possibilidade de impugnação das assembleias. Esgotado, in albis, o prazo decadencial (dois anos, conforme LSA: art. 286), convalidada restará a assembleia viciada $^{886}$.

Disciplinados pela Lei n. ${ }^{\circ}$ 6.404/76, os casos de anulabilidade de assembleia geral são previstos pelo art. 286 e decorrem da inobservância das normas de convocação ou instalação previstas pela lei (LSA: arts. 123 a 128) ou pelo estatuto social (que pode conter disposições complementares: LSA, art. 123, caput). Por consequência, anulada a assembleia, anuladas restarão as deliberações nela tomadas.

Já as nulidades das assembleias seguem as regras do Código Civil, que poderão ser alegadas a qualquer tempo por qualquer interessado ou pelo Ministério Público $\left(\mathrm{CC}:\right.$ art. 168) ${ }^{887}$.

\subsection{Invalidade de voto}

Os vícios de voto podem constituir anulabilidades ou nulidades (espécies de invalidades) ou ineficácia do voto ${ }^{888}$. Renato Ventura RIBEIRO menciona ainda a inexistência $^{889}$.

\footnotetext{
885 "O interesse na estabilidade das deliberações, de resto, não se deve apenas à circunstância de tais atos poderem atingir um círculo muito vasto de pessoas e, sobretudo nas companhias abertas, a todo tempo mutável, mas, especialmente, aos danos que poderiam advir à própria gestão da empresa social, se sujeitos à impugnação em prazo muito dilatado.” In: Erasmo Valladão A. e N. FRANÇA, Invalidade das Deliberações de Assembleia das S/A, São Paulo, Saraiva, 1999, p.70.

${ }^{886}$ Erasmo Valladão A. e N. FRANÇA arrola exemplificativamente as seguintes hipóteses: "(a) inobservância da ordem do dia (art. 124, caput); (b) recusa de participação ao acionista (ou seu representante, cf. $\$ \S 1^{o} e$ $4^{o}$, do art. 126) na assembleia (seja ingresso na própria reunião, seja de participação na discussão dos assuntos tratados, seja na votação desses assuntos quando o acionista também tiver direito de voto excetuadas as hipóteses expressas de proibição de voto arroladas nos $\$ \S 1^{o s}$ dos arts. 115 e 134 , e do $\S 2^{\circ}$ do art. 228, e de suspensão desses direito, prevista no art. 120); (c) inexistência do quorum legal ou estatutário das deliberações (arts. 129 e 136); (d) falta de lavratura de ata (art. 130); (e) ausência de publicação prévia dos documentos da administração (art. 133, ressalvada a hipótese do art. 294, II); (f) inobservância do procedimento e demais formalidades estabelecidas no art. 134, caput, e seus $\$ \S 1^{\circ}$ e $2^{\circ}$." In: Invalidade das Deliberações de Assembleia das S/A, São Paulo, Saraiva, 1999, pp. 91-96.

${ }^{887}$ Erasmo Valladão A. e N. FrançA, Invalidade das Deliberações de Assembleia das S/A, São Paulo, Saraiva, 1999, p. 75.

${ }^{888}$ Erasmo Valladão A. e N. FrançA, Invalidade das Deliberações de Assembleia das S/A, São Paulo, Saraiva, 1999, p. 114.

${ }_{889}$ Direito de Voto nas Sociedades Anônimas, São Paulo, Quartier Latin, 2009, p. 263.
} 
O art. 286 da Lei n. ${ }^{\circ}$ 6.404/76 refere-se a erro, dolo, fraude ou simulação. Omite-se, no entanto, a respeito da coação, já prevista pelo Código Civil de 1916, e tampouco cuida de estado de perigo e lesão, vícios que apenas vieram a ser previstos pelo vigente diploma legal civil.

Nada obstante a lacuna, o entendimento doutrinário é de que, em tese, esses vícios também maculam o voto. É que, quanto à sua configuração, eles são disciplinados pela lex generalis e, portanto, a omissão pela lex specialis não lhes prejudica teoricamente o reconhecimento ${ }^{890}$.

Quanto concretamente à simulação, seu emprego é comum em transferências de ação, para que o adquirente vote pelo alienante, que está impedido de fazê-lo. É o caso do administrador da companhia que, sendo também acionista, é impedido de deliberar na assembleia que julga suas contas (LSA: art. $115, \S 1^{\circ}$, e art. $\left.134, \S 1^{\circ}\right)^{891}$. Também se cita o exemplo do acionista que simula a transferência da ação para evitar, em deliberação, a regra que limita o número de votos (LSA: art. 110, $\left.§ 1^{\circ}\right)^{892}$.

É anulável o voto proferido com erro, se este é substancial. Erros que não firam a essência da decisão ou a vontade do votante não são, com efeito, substanciais e não ensejam, pois, a anulação do voto ${ }^{893}$. Diferente é o caso em que o acionista baseia sua manifestação em informações econômico-financeiras falsas da companhia (balanço irregular, v.g. ${ }^{894}$ ). O direito de informação tem por uma de suas funções justamente o auxílio ao exercício do voto ${ }^{895}$. Sobre a fraude, o entendimento de Erasmo Valladão A. e N. FRANÇA é de que a referência legal diz respeito à fraude à lei, hipótese em que o voto será nulo. Não se trata de fraude contra credores, porque esta apenas teria lugar nos atos da

\footnotetext{
${ }^{890}$ A questão foi examinada, quanto à coação e na vigência do hoje revogado Código Civil, por Trajano Miranda VALVERDE e sua conclusão alinha-se com o entendimento acima esposado: "se um dia for possível provar que os acionistas, individualmente, que formaram a maioria, foram vítimas da coação de outros acionistas ou de terceiros, a possibilidade de se anular a deliberação é indiscutível, já que entre os vícios da vontade se inclui a coação”. Apud: Erasmo Valladão A. e N. FRANÇA, Invalidade das Deliberações de Assembleia das S/A, São Paulo, Saraiva, 1999, p. 115.

891 Tullio Ascarelli, Vícios das Deliberações Assembleares - Direitos Individuais dos Acionistas Prescrição, in Problema das Sociedades Anônimas e Direito Comparado, São Paulo, Saraiva, pp. 412-413, n. 45; Erasmo Valladão A. e N. FrAnçA, Invalidade das Deliberações de Assembleia das S/A, São Paulo, Saraiva, 1999, p. 115; Renato Ventura RIBEIRO, Direito de Voto nas Sociedades Anônimas, São Paulo, Quartier Latin, 2009, p. 264.

${ }^{892}$ Erasmo Valladão A. e N. FRANÇA, Invalidade das Deliberações de Assembleia das S/A, São Paulo, Saraiva, 1999, p. 115, n. 123.

${ }^{893}$ Renato Ventura RIBEIRO, Direito de Voto nas Sociedades Anônimas, São Paulo, Quartier Latin, 2009, p. 265.

${ }^{894}$ Erasmo Valladão A. e N. FRANÇA, Invalidade das Deliberações de Assembleia das S/A, São Paulo, Saraiva, 1999, p. 115.

${ }^{895}$ Renato Ventura RIBEIRO, Direito de Voto nas Sociedades Anônimas, São Paulo, Quartier Latin, 2009, p. 265.
} 
própria sociedade - e não em sua deliberação. Mesmo que esta autorizasse tal prática, apenas as medidas tomadas pela administração caracterizaria o vício ${ }^{896}$.

Ainda outra hipótese de invalidade diz respeito à incapacidade, relativa ou absoluta, do votante, o que também é regido pela lei civil (CC: arts. $3^{\circ}$ e $4^{\circ} \mathrm{c} / \mathrm{c}$ art. 166 , inc. I, e art. $171, \mathrm{I})^{897}$.

Por fim, merece destaque duas outras hipóteses de invalidade que particularmente importam ao tema dessa tese, que são, precisamente, o voto proferido em violação das proibições de voto (LSA: art. $115, \S 1^{\circ}$; art. $134, \S 1^{\circ}$; e art. $228, \S 2^{\circ}$ ) e de voto abusivo, em conflito com o interesse da companhia (LSA: art. 115, caput, e $\S 1^{\circ}$, in fine $)^{898}$.

Conforme já se afirmou, a eventual invalidade do voto não implica, necessariamente, a da deliberação por ele integrada. Essa "contaminação" apenas tem lugar quando os votos inválidos, tendo sido lançados no sentido da deliberação, forem suficientes para alterar o resultado final, caso desconsiderados. É a chamada "prova de resistência". A deliberação não será inválida se, subtraídos os votos maculados, o quórum de aprovação for, ainda assim, atingido. A deliberação conterá votos inválidos, mas, nesse caso, ela mesma será válida.

Importa referir que, por "serem distintos e terem consequências diversas os vícios do voto e os das deliberações " ${ }^{~} 999$, o interesse na invalidação ou na declaração de nulidade dos votos maculados pode eventualmente subsistir mesmo nas circunstância acima mencionadas, isto é, ainda que a deliberação conserve-se válida, apesar de conter votos inválidos. $\mathrm{O}$ acionista que tenha votado com vício de consentimento, por exemplo, pode querer isentar-se de responsabilidade por aquele voto ou exercer o direito de retirada $^{900}$.

\footnotetext{
${ }^{896}$ Erasmo Valladão A. e N. FRANÇA, Invalidade das Deliberações de Assembleia das S/A, São Paulo, Saraiva, 1999, p. 116.

${ }^{897}$ Renato Ventura RIBEIRO ainda faz referência à falta de legitimação ou defeito de representação, convencional ou legal. In: Direito de Voto nas Sociedades Anônimas, São Paulo, Quartier Latin, 2009, p. 263.

${ }^{898}$ Erasmo Valladão A. e N. FrAnçA, Invalidade das Deliberações de Assembleia das S/A, São Paulo, Saraiva, 1999, p. 117.

${ }^{899}$ Renato Ventura RiBeIro, Direito de Voto nas Sociedades Anônimas, São Paulo, Quartier Latin, 2009, p. 262. Conclui: "Portanto, os vícios de voto devem sempre ser apurados, independentemente de alterarem ou não o resultado da deliberação."

${ }^{900}$ Renato Ventura RIBEIRO, Direito de Voto nas Sociedades Anônimas, São Paulo, Quartier Latin, 2009, p. 262.
} 


\subsubsection{Voto abusivo e voto em conflito de interesses: precedentes}

Na evolução histórica do regramento legal das sociedades anônimas, a regra, em matéria de exercício de voto, tem sido, segundo nos lembra Renato Ventura RIBEIRO, sua liberdade. Nada obstante, ao longo do século XX, desenvolveu-se também quanto ao voto o instituto do abuso de direito ${ }^{901}$. Conforme analisado no capítulo anterior, o abuso de direito, surgido no âmbito estrito do direito subjetivo em matéria de direito civil, espraiou-se no curso daquele século a diversos outros campos do direito.

Entre os domínios em que o abuso encontrou aplicação estão justamente os votos e as deliberações assembleares societárias. Como relata o mesmo supra citado autor, a partir da ampla liberdade que vigorou nessa matéria em um período inicial, a própria evolução econômica e social conduziu à necessidade do estabelecimento de determinadas restrições, para mitigar ou evitar alguns abusos que se verificaram. Em paralelo, evoluiu no âmbito do direito civil a teria do abuso de direito, que, ao depois, como dito, expandiu-se além daqueles limites iniciais ${ }^{902}$.

A vedação ao abuso do exercício do voto nas assembleias societárias refletiu a preocupação do legislador não apenas com a proteção dos acionistas de modo geral, mas também da própria empresa, dos acionistas minoritários e, ainda, particularmente no caso das abertas, do público investidor ${ }^{903}$. Deve ainda ser feita referência ao desenvolvimento do próprio direito societário e das teorias acerca do interesse social e da necessidade de o voto alinhar-se aos interesses da companhia ${ }^{904}$.

Nessa matéria, a evolução da legislação brasileira ${ }^{905}$, que culminou com a Lei n. ${ }^{\circ}$ 6.404/76, caminhou em sentido muito próximo daquela que teve lugar na Itália e na Alemanha ao longo do século $\mathrm{XX}^{906}$.

A Lei Acionária alemã de 1965 manteve as linhas gerais do diploma

\footnotetext{
${ }^{901}$ Direito de Voto nas Sociedades Anônimas, São Paulo, Quartier Latin, 2009, p. 355.

902 Direito de Voto nas Sociedades Anônimas, São Paulo, Quartier Latin, 2009, p. 355.

${ }^{903}$ Renato Ventura RIBEIRO, Direito de Voto nas Sociedades Anônimas, São Paulo, Quartier Latin, 2009, p. 355.

${ }^{904}$ Renato Ventura RibeIRo, Direito de Voto nas Sociedades Anônimas, São Paulo, Quartier Latin, 2009, p. 355.

${ }^{905}$ Narra Erasmo Valladão A. e N. FRANÇA, com apoio em Waldirio BULGARELLI, que, somente a partir do momento em que foi assegurada a franca criação de sociedades anônimas no Brasil (o que se deu com a Lei n. 3.150 , regulamentada pelo Decreto n. ${ }^{\circ} 8.821$, ambos de 4/11/1882) e que, portanto, elas foram subtraídas à tutela administrativa do Estado, é que o legislador começou a tratar de regras sobre conflito de interesses entre sócios nas assembleias, para evitar abusos. In: Conflito de Interesses nas Assembleias de S.A., São Paulo, Malheiros, 1993, p. 69.

${ }^{906}$ Erasmo Valladão A. e N. FrAnÇA, Conflito de Interesses nas Assembleias de S.A., São Paulo, Malheiros, 1993, pp. 81-82.
} 
legal precedente, de 1937 - que, segundo Jorge Manuel CoutinHo DE ABREU, foi o primeiro diploma legal a reconhecer expressamente o abuso de direito nas legislações societárias $^{907}$, muito embora os códigos comerciais italiano e germânico já previssem hipóteses de divieto del voto ${ }^{908}$. Repetiu, assim, o sistema dualista, que prevê hipóteses de proibição de voto e outras de conflito substancial de interesses.

No primeiro caso, a norma pró́be o exercício do direito de voto, se verificada sua hipótese de incidência - que normalmente concerne a uma contradição, em tese, de interesses ${ }^{909}$. O controle do voto é realizado ex ante, não se fazendo necessário um exame das circunstâncias concretas e do conteúdo da manifestação do acionista. Em havendo a violação da interdição legal, o voto será nulo e, se decisivo para a deliberação, esta será anulada.

Assim, a Lei Acionária veda ao acionista o exercício do voto na assembleia que deliberar sobre a aprovação das contas prestadas por ele próprio (em sendo ele administrador), sobre exoneração de obrigações suas para com a companhia e, ainda, sobre exercício de direitos que esta tenha em relação a ele ${ }^{910}$.

Idêntica disciplina era já prevista pelo Código Comercial germânico (HGB), que, à referida lista, acrescentava ainda a hipótese de deliberação a respeito de qualquer negócio jurídico celebrado entre a companhia e o acionista. Essa sistemática de proibição formal, no entanto, mostrou-se insuficiente. Por um lado, elas não alcançavam uma série numerosa de conflitos substanciais de interesses não abarcados pelos estritos termos da previsão legal. Por outro, concluiu-se que a consequência jurídica da norma proibitiva (a nulidade do voto) era demasiado rigorosa em certos casos, como a vedação incondicional a todo e qualquer negócio entre acionista e a companhia. Por isso, relata Erasmo Valladão A. e N. FRANÇA, que mesmo antes da lei societária de 1937 a doutrina germânica já procurava uma “cláusula geral” mai genérica e flexível.

\footnotetext{
907 Do Abuso de Direito - Ensaio sobre um Critério em Direito Civil e nas Deliberações Sociais, Coimbra, Almedina, 1999, p. 123.

908 "Nel codice di commercio erano stabilite talune ipotesi, nelle quali il sócio non era legittimato al voto in assemblea: precisamente, per $i$ soci amministratori, vigeva il divieto di voto nelle deliberazioni di approvazione dei bilanci e in quelle riguardanti la loro responsabilità (art. 161). Nel codice di commercio tedesco (\$ 252), con una disciplina più ampia, era vietato il voto al socio nelle deliberazioni concernenti il proprio esonero da responsabilità, la liberazione da un'obbligazione, la conclusione di un negozio ovvero l'inizio o la transazione di una lite con la società." In: Agostino GAMBINO, La disciplina del conflito di interessi del socio, in Rivista del diritto commerciale, ano LXVIII (1969), $1^{\mathrm{a}}$ parte, pp. 377-378.

${ }^{909} \mathrm{E}$ que, em última instância, estriba-se no princípio nemo judex in causa propria. Cf. Agostino GAMBINO, La disciplina del conflito di interessi del socio, in Rivista del diritto commerciale, ano LXVIII (1969), $1^{\text {a }}$ parte, p. 378.

${ }^{910}$ Erasmo Valladão A. e N. FrAnÇA, Conflito de Interesses nas Assembleias de S.A., São Paulo, Malheiros, 1993, pp. 76-77.
} 
Assim foi que a lei de 1937, inovando em relação ao HGB, manteve, por um lado, as hipóteses de vedações formais ao exercício de voto - subtraído, contudo, o caso da celebração de negócios entre acionista e companhia - e, por outro, previu a possibilidade de anulação de deliberações "quando um accionista tenha procurado com o exercício do direito de voto obter para si ou um terceiro vantagens especiais em prejuízo da sociedade ou dos outros accionistas, sendo essas deliberações aptas a servir tal fim. "911

Essa segunda sistemática consiste em um controle ex post: a vedação não decorre da ocupação pelo acionista de uma determinada posição frente à companhia, mas demanda uma análise do mérito (de conteúdo) do voto proferido para verificar a incompatibilidade, in concreto, entre ele e o interesse da companhia. Apenas em caso de juízo positivo da questão (i.e., unicamente se forem incompatíveis o voto e o interesse da companhia) é que será anulado o voto e, a depender da influência na deliberação, também terá vez a anulação desta.

A Lei Acionária de 1967 reiterou essa mesma disciplina. Contudo, acrescentou uma hipótese que excepciona a vedação substancial; nesse caso, destarte, não terá lugar a anulação do voto, muito embora ele tenha sido proferido com o objetivo de obter para si ou para outrem vantagem indevida ou de prejudicar a companhia ou seus sócios. Trata-se da hipótese em que as deliberações concedem à companhia e aos demais acionistas uma “compensação adequada" ao prejuízo provocado, isto é, que "reponha o equilíbrio econômico" 912 .

Também na Itália verificou-se algo semelhante. O Código Comercial proibia aos acionistas administradores o voto (divieto di voto) nas deliberações de aprovação do balanço e naquelas relativas à própria responsabilidade perante a companhia $^{913}$. A inobservância implicava a nulidade do voto. O mesmo diploma previa ainda o conflito de interesse, cuja consequência era a responsabilidade por perdas e danos - e não nulidade ou anulação do voto ${ }^{914}$.

Por fim, o Codice Civile de 1942 cuidou do tema no art. 2.373.

\footnotetext{
911 Jorge Manuel Coutinho DE ABReu, Do Abuso de Direito - Ensaio sobre um Critério em Direito Civil e nas Deliberações Sociais, Coimbra, Almedina, 1999, p. 123.

912 Jorge Manuel Coutinho DE ABREU, Do Abuso de Direito - Ensaio sobre um Critério em Direito Civil e nas Deliberações Sociais, Coimbra, Almedina, 1999, pp. 123 e 125.

${ }_{913}$ Erasmo Valladão A. e N. FrAnÇA, Conflito de Interesses nas Assembleias de S.A., São Paulo, Malheiros, 1993, p. 78.

914 Agostino Gambino, La disciplina del conflito di interessi del socio, in Rivista del diritto commerciale, ano LXVIII (1969), $1^{\text {a }}$ parte, p. 379.
} 
Disciplinou-o em duas categorias, como na Alemanha, prevendo um conflito formal e um conflito material de voto. Neste último caso, existe uma proibição de voto, mas em caráter acautelatório: o comando normativo determina que o acionista em certas situações -nas deliberações com relação às quais tenha conflito de interesse, por interesse próprio ou de terceiros - abstenha-se de voto $^{915}$; mas, caso não o faça, o voto proferido ensejará a anulação da respectiva deliberação se ele tiver sido decisivo e se ele puder causar dano à sociedade. O resultado da conduta, portanto, tem de ser avaliado para se verificar sua anulação ou não.

Outro é o tratamento previsto para o divieto di voto em sentido próprio: nesse caso (a proibição de os administradores, sendo acionistas, votarem em deliberações relativas à sua responsabilidade), em sendo proferido o voto, ele será nulo ${ }^{916}$.

Também a Lei n. ${ }^{\circ}$ 6.404/76 disciplinou a matéria segundo essa sistemática: previu hipóteses de exercício abusivo de voto, em caso de conflito material, e aquelas de conflito formal.

\subsubsection{Voto abusivo na Lei . $^{0} 6.404 / 76$}

A Lei n. $^{\circ}$ 6.404/76 ampliou e generalizou a matéria de conflito formal e substancial de interesses entre acionistas e a companhia e explicitou a figura do abuso de direito $^{917}$, engendrando um regramento específico se comprado àquele de caráter geral disciplinado pelo art. 186 do Código Civil. As inovações promovidas pela lei visaram a estremar o voto abusivo ou conflitante, "de maneira a fazer prevalecer, sempre, o interesse comum dos sócios naquelas deliberações ",918.

A respeito do abuso de voto, convém sublinhar que, antes que o tema se desenvolvesse especificamente em matéria societária, toda a discussão jurisprudencial e doutrinária bem assim o regramento do instituto em sua abordagem geral - estribado, no caso brasileiro, naquele dispositivo do Código Civil de 1916 que trata, a contrariu senso, da matéria: art. 160, inc. I - serviram de substrato e padrão normativo para as decisões

\footnotetext{
${ }^{915}$ Modesto CARvalhosa, Comentários à Lei de Sociedades Anônimas, v. 2, São Paulo, Saraiva, 2009, p. 448.

916 "Verifica-se, pois, que a lei italiana, à semelhança da alemã, adotou um regime dicotômico, distinguindo os casos de divieto di voto e conflito de interesses." In: Erasmo Valladão A. e N. FrANÇA, Conflito de Interesses nas Assembleias de S.A., São Paulo, Malheiros, 1993, p. 81.

917 Modesto CARvalhosa, Comentários à Lei de Sociedades Anônimas, v. 2, São Paulo, Saraiva, 2009, p. 447.

918 Erasmo Valladão A. e N. FRANÇA, Conflito de Interesses nas Assembleias de S.A., São Paulo, Malheiros, 1993, p. 83.
} 
judiciais a respeito do voto e deliberações em assembleias de sociedades ${ }^{919}$.

O dispositivo da Lei n. ${ }^{\circ}$ 6.404/76 que trata essencialmente do tema encontra-se assim redigido: "Art. 115. O acionista deve exercer o direito a voto no interesse da companhia; considerar-se-á abusivo o voto exercido com o fim de causar dano à companhia ou a outros acionistas, ou de obter, para si ou para outrem, vantagem a que não faz jus e de que resulte, ou possa resultar, prejuízo para a companhia ou para outros acionistas $" 920$.

Erige-se, assim, um regime específico de abuso de direito.

O dispositivo em comento explicita, por um lado, o fim econômico ou social imposto ao exercício do direito de voto, o que evidencia claramente a funcionalização dessa posição jurídica - ou seja, o direito político de voto é conferido ao acionista para que ele o empregue no interesse da companhia ${ }^{921}$. Por outro lado, como sublinha Erasmo Valladão A. e N. FRANÇA, "mesclando elementos do direito brasileiro anterior com os do direito alemão e italiano (e até, em um tópico específico, do direito norte-americano...)", delineia o próprio abuso, mediante uma "regra genérica e flexível, que possibilita aplicação abrangente pelo intérprete, ${ }^{\text {,922 }}$.

A utilidade técnica do expediente empregado pelo legislador de 1976 é evidente. Em contraste com o altíssimo grau de generalidade do art. 186 do Código Civil não por acaso localizado na Parte Geral daquele diploma legal e destinado, por sua natureza, à aplicação aos mais diversos e diversificados ramos do direito -, estabelece claramente o fim econômico e social da posição jurídica em referência (em que pese o forte, já citado, debate acerca do que seria o interesse da companhia), o que nem sempre se encontra expresso nas demais normas jurídicas, e, em acréscimo, cria parâmetros para a caracterização do exercício abusivo.

Mitiga-se, por esse meio, as dificuldades de concreção da norma prevista

\footnotetext{
${ }^{919}$ Modesto Carvalhosa, Comentários à Lei de Sociedades Anônimas, v. 2, São Paulo, Saraiva, 2009, pp. 461-462.

${ }^{920}$ Conforme redação atribuída pela Lei n. ${ }^{\circ}$ 10.303/01. A original, com a diferença de uma preposição, era a seguinte: "Art. 115. O acionista deve exercer o direito de voto no interesse da companhia; considerar-se-á abusivo o voto exercido com o fim de causar dano à companhia ou a outros acionistas, ou de obter, para si ou para outrem, vantagem a que não faz jus e de que resulte, ou possa resultar, prejuízo para a companhia ou para outros acionistas."

921 Não se pode descurar, segundo entendemos, que a atribuição de uma finalidade específica a um direito subjetivo não aniquila o âmbito de liberdade de que dispõe o titular da posição jurídica para a persecução do próprio interesse. A funcionalização condiciona o exercício do direito subjetivo, como exposto no Capítulo 2 , mas não o desnatura, não o transmuda em poder funcional.

${ }_{922}$ Conflito de Interesses nas Assembleias de S.A., São Paulo, Malheiros, 1993, p. 83.
} 
pelo Código Civil, que se estriba em expressões assaz genéricas como o "seu fim econômico ou social" e "excede manifestamente". O fim está determinado e a delimitação do "excesso manifesto" tem por parâmetros claros os termos do texto normativo. Certamente, a técnica empregada no art. 115 - que apenas tem cabimento em um regramento específico, como é este da Lei n. ${ }^{\circ}$ 6.404/76 - não exonera de dificuldades a interpretação; mas é igualmente certo que a facilita sobremodo, se comparada àquela que tem lugar no caso do Código.

Ainda a respeito das diferenças que o regime específico da Lei de Sociedades por Ações guarda em relação àquele do Código Civil, convém observar o abuso de voto de que trata o art. 115 não podendo se caracterizar por conduta omissiva.

O voto é ato positivo - ainda quando seja uma abstenção - e, portanto, dele apenas pode-se abusar comissivamente, ao exercê-lo contrariamente ao interesse da companhia $^{923}$. Não existe o dever de votar, já se disse (relembre-se não se dirigir o comando normativo ao titular do poder de controle, mas aos acionistas em geral); o comportamento compulsório determinado pela norma legal em comento ("O acionista deve...") não está em "exercer o direito a voto”, mas em, ao exercê-lo, fazê-lo em proveito do "interesse da companhia". O não exercício do voto não é, pois, abusivo nos termos da Lei n. ${ }^{\circ}$ 6.404/76. Nada obstante, observa Renato Ventura RIBEIRO que a não subsunção do comportamento omissivo à norma mencionada não obsta a configuração de abuso de direito nos termos do art. 186 do Código Civil.

Por fim, é oportuno observar que, assim como a invalidade do voto não determinada a da deliberação, o exercício abusivo daquele não acarreta obrigatoriamente a deliberação abusiva.

Entende Jorge Manuel CoUTINHO DE ABREU ser desnecessário debruçarse sobre o voto abusivo, restringindo suas preocupações ao abuso da deliberação. Isso porque, sustenta, é amiúde difícil "autonomizar" o voto e analisá-lo individualmente no conjunto de votos que compõem a maioria ("Todos apontam numa mesma direcção, todos conduzem ao mesmo resultado deliberativo. Um ou alguns estão inquinados por intenções extra-sociais e outros não. Como discriminá-los? Pode não ser fácil...”). E, continua, mesmo que se logre alcançar tal intento, a anulação da deliberação é sempre possível, se

\footnotetext{
923 Em sua tese sobre abuso de minoria, Marcelo Vieira von ADAMEK arrola na modalidade de abusos positivos (comissivos) o exercício pelos minoritários do direito de voto. Cf. Abuso de minoria em Direito Societário - Abuso das Posições Subjetivas Minoritárias, tese de doutorado, Faculdade de Direito da USP, São Paulo, mimeo, 2010, pp. 155 e ss., item 5.2.1.
} 
comprovado que tais votos foram insuficientes para o desfecho ${ }^{924}$.

Embora, de fato, seja de difícil constatação abuso de voto não prevalente, a possibilidade em tese existe e a regra do art. 115 da Lei n. ${ }^{\circ}$ 6.404/76 não contém restrição. Do contrário, em termos práticos, apenas os controladores ou, pelo menos, a maioria eventual poderia incorrer em abuso de voto, o que tornaria despicienda a norma em comento dirigida - como adiante se verá - à generalidade dos acionistas, e não apenas àqueles primeiros. Acrescente-se que a sanção prevista pela norma recai sobre o comportamento no exercício do direito de voto e não sobre o exercício do poder de controle ou de maioria ${ }^{925}$ - mesmo porque não apenas o interesse social, referido pelo art. 115, mas também o dever societário de lealdade constitui, como lembra Marcelo Vieira von ADAMEK, limite ao exercício do voto ${ }^{926}$. Renato Ventura RIBEIRO, por isso, afirma que as normas sobre abuso de direito não se prestam à proteção aos minoritários, como muitos creem, mas à tutela da própria sociedade ${ }^{927}$.

Ademais, o interesse na identificação do voto abusivo, embora contrário à deliberação tomada, persiste para fins de responsabilidade civil. Assim, cogita-se de abuso em voto não prevalente de acionista que vise a induzir a compra de suas ações pela companhia ou pelo grupo majoritário controlador $^{928}$ ou, ainda, para prejudicar, com o dissenso ostensivo, o bom nome da companhia ou causar dissídio entre os acionsitas ${ }^{929}$.

Mais comum é a hipótese em que o abuso de minoria tem lugar no evento "assembleia", embora não necessariamente mediante o voto. Assim, por exemplo, no gozo do direito de voz, o acionista, eventualmente ligado a algum concorrente, por argui abusivamente alguma inverdade contra os membros da administração ou ainda, por emulação, difamar algum acionista - o que, em qualquer dos casos, pode prejudicar a companhia e sua imagem (sublinhe-se que tudo isso pode encontrar-se registrado na ata,

\footnotetext{
${ }^{924}$ Do Abuso de Direito - Ensaio sobre um Critério em Direito Civil e nas Deliberações Sociais, Coimbra, Almedina, 1999, pp. 125-126.

${ }_{925}$ Modesto Carvalhosa, Comentários à Lei de Sociedades Anônimas, v. 2, São Paulo, Saraiva, 2009, p. 464.

${ }^{926}$ Abuso de minoria em Direito Societário - Abuso das Posições Subjetivas Minoritárias, tese de doutorado, Faculdade de Direito da USP, São Paulo, mimeo, 2010, p. 156: "No direito brasileiro, o poder de voto encontra no interesse social e no dever societário de lealdade os limites e, quando os mesmos são transpostos, tem-se a figura do voto conflitante em sentido amplo que, como adiante se demonstrará (...), é inválido e expõe o sócio a responder por perdas e danos.".

927 "Até porque em tais casos as regras são aplicáveis a todos os acionistas, sejam majoritários ou minoritários, posi pode haver tanto abuso quanto conflito de interesses por parte da maioria como da minoria.” In: Direito de Voto nas Sociedades Anônimas, São Paulo, Quartier Latin, 2009, p. 356.

${ }_{928}$ Modesto Carvalhosa, Comentários à Lei de Sociedades Anônimas, v. 2, São Paulo, Saraiva, 2009, p. 464.

${ }^{929}$ Modesto Carvalhosa, Comentários à Lei de Sociedades Anônimas, v. 2, São Paulo, Saraiva, 2009, p. 463.
} 
pública). Pode ainda apresentar objeção ou proposição para o efeito exclusivo de manipular a cotação das ações no mercado ${ }^{930}$. Não é disso, no entanto, que trata o art. 115 da Lei n. ${ }^{\circ}$ 6.404/76, muito embora esses exemplos possam qualificar-se como abuso de direito $^{931}$.

\subsection{Dispositivo aplicável à generalidade dos acionistas}

Avançando na análise do aludido dispositivo, seu comando normativo dirige-se à generalidade dos acionistas. Portanto, de maneira indistinta, integre ou não o acionista o bloco de controle, fica o votante adstrito à vedação prevista pelo art. 115 .

Isso não impede, no entanto, que o legislador preveja, como de fato previu (art. 116, parágrafo único, e art. 117, caput e $\S 1^{\circ}$ ), normas específicas (e mais rígidas $^{932}$ ) para o exercício do poder de controle - cuja seio é exatamente a assembleia geral e a manifestação do voto. Registram-se, ainda na doutrina, preocupações específicas com o abuso de maioria e de minoria ${ }^{933}$, independente da hipótese prevista pelo art. 115 da Lei n. ${ }^{\circ} 6.404 / 76$.

\subsection{Condutas abusivas}

Quanto à configuração do abuso, nesse regramento específico da Lei n. ${ }^{\circ}$

\footnotetext{
${ }^{930}$ Modesto Carvalhosa, Comentários à Lei de Sociedades Anônimas, v. 2, São Paulo, Saraiva, 2009, pp. 463-464.

931 Hipóteses de voto abusivo dos minoritários, embora prevalente, são citadas por Marcelo Vieira von ADAMEK: deliberação tomada pelo voto "surpresa" da minoria (em caso de absenteísmo episódica da maioria), veto pela minoria (quando assegurado o direito estatutariamente, por exemplo para determinadas classes de preferencialista, em especial quanto a alteração do estatuto social), abuso na rejeição de contas de demonstrações financeiras (quando a maioria é também ocupante dos cargos de administração), abuso na instalação e no funcionamento do conselho fiscal, abuso na escolha de membros para órgãos sociais. Cf. Abuso de minoria em Direito Societário - Abuso das Posições Subjetivas Minoritárias, tese de doutorado, Faculdade de Direito da USP, São Paulo, mimeo, 2010, pp. 156-173.

932 "É óbvio, nessas circunstâncias, que esse voto se submete a um juízo muito mais severo do que o exercido em relação aos não-controladores, devendo-se perquirir a natureza egoística ou altruística da finalidade visada pelo votante." Cf. Fabio Konder COMPARATO, Controle conjunto, abuso no exercício do voto acionário e alienação indireta de controle empresarial, in Direito Empresarial, São Paulo, Saraiva, 1990, p. 93.

${ }^{933}$ Renato Ventura RIBEIRo, Direito de Voto nas Sociedades Anônimas, São Paulo, Quartier Latin, 2009, p. 355. Marcelo Vieira von ADAMEK destaca a pouca preocupação da doutrina e da jurisprudência com o abuso de minoria. Cf. Abuso de minoria em Direito Societário - Abuso das Posições Subjetivas Minoritárias, tese de doutorado, Faculdade de Direito da USP, São Paulo, mimeo, 2010, p. 116. Registre-se, com supedâneo no mesmo autor, que o chamado abuso de minoria não se limita ao abuso de voto, mas caracteriza-se no emprego de outros expedientes, como o manejo de medidas judiciais (strike suits), o exercício de determinados direitos societários (poder de retirada, convocação de assembleia geral, requisição de informações sociais), a provocação de distúrbios nas sessões assembleares etc.
} 
6.404/76, a norma em comento, se bem que filiada à Lei Acionária alemã de 1965, avança ao vedar não apenas o voto tendente à obtenção pelo votante para si ou para outrem de vantagem indevida, como faz aquele diploma estrangeiro, mas também a prática simplesmente emulativa, em que o exercício do direito político é dirigido exclusivamente a causar prejuízo a companhia ou aos acionistas ${ }^{934}$.

Assim, são considerados abusivos os votos que tenham por finalidade (a) obter, para si ou mesmo para terceiros, vantagem a que não faz jus $e$ que efetiva ou potencialmente cause prejuízo à companhia ou aos demais acionistas ou (b) causar dano à companhia ou a outros acionistas (voto ad aemulationem).

\subsection{Elemento objetivo e elemento subjetivo}

De início, verifica-se que o texto normativo leva em conta a finalidade do exercício do voto ( "com o fim de"). Evidencia-se assim o elemento subjetivo da conduta, i.e., a intenção do votante em sua manifestação assemblear. Este tema é destacado por Modesto CARvalhosA ${ }^{935}$ e por Erasmo Valladão A. e N. FrançA ${ }^{936}$; José Edwaldo Tavares BORBA sustenta a imprescindibilidade do dolo para caracterização do dano ${ }^{937}$, bem assim Renato Ventura RIBEIRO, que vai além e, considerando os exatos contornos da finalidade enunciada pelo art. 115 da Lei n. ${ }^{\circ}$ 6.404/76, explicita tratar-se de dolo específico $^{938}$.

Essa disciplina diverge daquela prevista pelo Código Civil, que, como pôde ser examinado (item 5.4.2 do Capítulo 2), dispensa o elemento subjetivo como requisito de caracterização do abuso de direito, segundo sustenta a doutrina majoritária. Assim, a intenção de abusar do direito é irrelevante, bastando que, segundo uma análise estritamente objetiva, a conduta do agente exceda de maneira manifesta os limites impostos pelo fim econômico ou social, pela boa-fé ou pelos bons costumes.

Nada obstante o entendimento inicialmente esposado, Modesto CARAVALHOSA sustenta que a intenção de lesar a companhia ou os demais acionistas não deve "ser subjetivamente perquirida". Segundo ele entende, os limites entre o dolo e o

\footnotetext{
${ }^{934}$ Erasmo Valladão A. e N. FRANÇA, Conflito de Interesses nas Assembleias de S.A., São Paulo, Malheiros, 1993, p. 83.

${ }^{935}$ Comentários à Lei de Sociedades Anônimas, v. 2, São Paulo, Saraiva, 2009, p. 461: “A lei leva em conta a finalidade, ou seja, a intenção do acionista no exercício do direito de voto."

${ }^{936}$ Conflito de Interesses nas Assembleias de S.A., São Paulo, Malheiros, 1993, p. 83.

${ }^{937}$ Direito Societário, Rio de Janeiro, Renovar, 2010, p. 343.

${ }^{938}$ Direito de Voto nas Sociedades Anônimas, São Paulo, Quartier Latin, 2009, p. 356.
} 
erro não são facilmente identificados e, assim, fundada o abuso nessa má intenção, o acionista acusado sempre invocaria em sua defesa o erro, subtraindo-se ao comando legal. Demais, observa que a jurisprudência tem admitido o abuso mesmo sem prova da intenção fraudulenta e conclui que "o exame objetivo do ato de votar contrariamente ao interesse social é, pois, suficiente à configuração de um ilícito no exercício da prerrogativa" ${ }^{939}$.

Em sentido semelhante, Erasmo Valladão A. e N. FRANÇA, após fazer referência à "finalidade" do voto, afirma, contudo, o seguinte: "Em todos os casos, pois, em que houver desvio de finalidade do voto, ou seja, quando o acionista votar de modo contrário ao interesse da companhia, que não é senão, como se viu, o interesse comum dos sócios uti socii, aliado ao prejuízo atual ou potencial para aquela ou para outros acionistas, dá-se o abuso do direito (ou se preferir, do poder) de voto. "940 $\mathrm{O}$ autor, citando Silvio RoDRIGUES, ainda faz referência, em alusão ao abuso de direito (em geral), à corrente doutrinária objetivista, que entende configurado o ilícito "quando o titular do direito utiliza em desacordo com a finalidade social para a qual o direito foi concebido $^{\text {"941 }}$, independentemente do dolo ou da culpa - ao contrário do que sustenta a teoria subjetivista.

Também Jorge Manuel CoUTINHO DE ABREU questiona, à luz do direito português, a necessidade do dolo para a configuração do abuso de voto ${ }^{942}$. Todavia, ele sustenta que o dolo faz-se necessário nas deliberações meramente emulativas, isto é, "aquelas pelas quais um ou mais sócios causam intencionalmente um dano à minoria”; nesse caso, contudo, é prescindível que os votantes aufiram benefícios ${ }^{943}$.

\subsection{Vantagem indevida e prejuízo real ou potencial}

Caracteriza-se o voto abusivo se dirigido a assegurar uma vantagem indevida, de que pode ser beneficiário nãoapenas o próprio votante, também um terceiro (outro acionista, por exemplo ${ }^{944}$ ). Essa vantagem pode naturalmente ser econômica

\footnotetext{
${ }_{939}$ Modesto CARvalhosa, Comentários à Lei de Sociedades Anônimas, v. 2, São Paulo, Saraiva, 2009, p. 462.

${ }^{940}$ Conflito de Interesses nas Assembleias de S.A., São Paulo, Malheiros, 1993, p. 84.

${ }^{941}$ Conflito de Interesses nas Assembleias de S.A., São Paulo, Malheiros, 1993, p. 84, n. 187.

${ }_{942}$ Do Abuso de Direito - Ensaio sobre um Critério em Direito Civil e nas Deliberações Sociais, Coimbra, Almedina, 1999, p. 125.

${ }_{943}$ Do Abuso de Direito - Ensaio sobre um Critério em Direito Civil e nas Deliberações Sociais, Coimbra, Almedina, 1999, p. 125.

${ }^{944}$ Que pode ser, por exemplo, uma interposta pessoa do controlador - cita Erasmo Valladão A. e N. FRANÇA com supedâneo em Mauro PENTEADO. Cf. Conflito de Interesses nas Assembleias de S.A., São Paulo, Malheiros, 1993, p. 85.
} 
(patrimonial), mas não apenas; pode ela ser também política (eleição de membros dos demais órgãos, obtenção de uma alteração estatutária etc. ${ }^{945}$ ). O abuso resta caracterizado em qualquer dos $\operatorname{casos}^{946}$.

É necessário, no entanto, que essa vantagem patrimonial ou política seja indevida.

No direito alemão, lembra Fabio Konder COMPARATO, a Lei Acionária emprega a expressão "vantagens especiais ou particulares" (besondere Vorteile) ${ }^{947}$. Assim, e naqueles termos, o abuso está, segundo afirma Jorge Manuel CoUTINHO DE ABREU, na vantagem que "não caiba a todos os sócios que se encontram perante a sociedade na mesma situação" e que, dessa maneira, resultam na violação do "princípio de igual tratamento" deles ${ }^{948}$.

O conteúdo da norma brasileira é bem próximo desse ${ }^{949}$. É indevida a vantagem que implica a quebra do princípio da igualdade entre os acionistas, por não ser atribuída a todos aqueles que se encontram na mesma situação jurídica perante a companhia, mas a apenas alguns deles em particular ${ }^{950}$. Nessa discrepância imotivada reside o elemento caracterizador da vantagem a que o beneficiário, nos termos da lei, "não faz jus".

${ }^{945}$ Cita Modesto CARVAlHosa: "Também as vantagens politicas com que se obtém o controle mediante a utilização abusiva das formas legais (art. 118), como, v.g., a acessão de ações d eoutra companhia pela constituição de subsidiária integral (art. 252), constituem fraude aos demais acionistas, sejam minoritários, sejam controladores." In: Comentários à Lei de Sociedades Anônimas, v. 2, São Paulo, Saraiva, 2009, p. 461.

${ }^{946}$ Não parece ser essa a orientação no direito italiano. Cf. Agostino GAMBINO, La disciplina del conflito di interessi del socio, in Rivista del diritto commerciale, ano LXVIII (1969), $1^{\text {a }}$ parte, p. 410.

${ }_{947}$ Controle conjunto, abuso no exercício do voto acionário e alienação indireta de controle empresarial, in Direito Empresarial, São Paulo, Saraiva, 1990, p. 90.

${ }^{948}$ Do Abuso de Direito - Ensaio sobre um Critério em Direito Civil e nas Deliberaçães Sociais, Coimbra, Almedina, 1999, p. 124.

${ }^{949} \mathrm{Na}$ verdade, essa é uma ideia que perpassa, de um modo geral, os diversos ordenamentos. Em breve análise do abuso de voto em diversos países, Aldo FerRARI observa que, além do direito italiano, o mesmo dá-se na França, em que tem relevância a figura do abus de droit, consistente, nesse caso, "nella disparità di tratamento ovvero in uma rupture d'égalité entre actionaires che comporta 'un vantaggio personale per alcuni azionisti a scapito di altri'”. Mesmo no sistema anglo-saxão, observa, em que "suo tradizionale pragmatismo" confere ao sócio liberdade para perseguir os próprios interesses por meio do direito do voto, "il perseguimento dell'interesse personale da parte dei soci incontra un limite invalicabile laddove l'eventuale vantaggio personale sia consequito dai soci di maggioranza in danno della società o dei soci di minoranza". In: L'abuso del diritto nelle società, Milão, Giuffrè, 1998, pp. 29-31.

$950 \mathrm{O}$ mesmo Fabio Konder COMPARATO resume a vantagem indevida como "uma violação ao princípio da igualdade relativa que consubstancia a justiça distributiva como assinalamos". In: Controle conjunto, abuso no exercício do voto acionário e alienação indireta de controle empresarial, in Direito Empresarial, São Paulo, Saraiva, 1990, p. 90. E mais adiante exemplifica: "Assim é que o acionista controlador pode auferir, como resultado da deliberação impugnada, benefícios econômicos diversos da simples distribuição de dividendos ou bonificações em dinheiro. Ora, embora seja o controlador, ele não deixa de ser acionista, não podendo portanto pretender, nessa qualidade, vantagens diversas das que competem, por lei, aos demais acionistas." 
Mas não basta a vantagem indevida; é necessário também o prejuízo à companhia ou aos demais acionistas. Aliás, e ainda a propósito do direito alemão, Jorge Manuel CoUTINHO DE ABREU observa que, nada obstante a conjunção dos requisitos, a tônica para a caracterização do abuso está antes no prejuízo causado que na vantagem auferida. Segundo ele, basta a configuração do desfavorecimento político ou patrimonial dos sócios, não sendo mais "correcto, a fim de definir o abuso nas deliberações sociais, estabelecer que sempre terá de haver uma vantagem especial, de que derive um prejuizo. "951

No direito italiano, ao comparar a disciplina do art. 2373 do Codice Civile de 1942 ao sistema precedente do Code commerciale, Agostino GAMBINO observa algo semelhante. Refere-se ele ao caso em que o voto é proferido para assegurar um interesse específico ou um lucro particular, não destinado ao bem comum, e, apesar disso, releva-se vantajpa também para a sociedade e, portanto, “conforme al concreto interesse patrimoniale del gruppo”. Sendo determinante para a deliberação, esse voto seria nulo à luz do direito anterior, mas não do vigente - que justamente acatou a necessidade de à vantagem especial somar-se o requisito do dano social ${ }^{952}$.

Em certa medida, para reforço do entendimento de COUTINHO DE ABREU, é oportuna a referência à previsão da Lei Acionária alemã de 1967 de que a anulação da deliberação tomada por voto prevalecente e determinante proferido em conflito de interesse, por baseada no desiderato de obtenção de vantagem especial pelo votante, pode ser afastada quando é oferecida aos demais acionistas uma "compensação adequada ao seu prejuízo" 953 . Se a medida compensatória aniquila o prejuízo e elide a anulação, então parece certo que o elemento mais relevante do abuso (senão determinante) não é a vantagem especial objetiva, mas o prejuízo incontornável causado.

No Brasil, talvez a questão perca um pouco de sua relevância. Em que pese ser muito próxima do direito alemão, como visto, a lei brasileira, ao contrário deste, prevê a modalidade de abuso meramente emulativo e, nesse caso, o ilícito resta configurado ainda quando efetivamente o voto não resulte em vantagem para alguém, contanto que tenha se dirigido a provocar prejuízo à companhia ou aos demais sócios. Está claro, pois, que o elemento mais importante é a imposição de prejuízo - que sempre deve

${ }^{951}$ Do Abuso de Direito - Ensaio sobre um Critério em Direito Civil e nas Deliberações Sociais, Coimbra, Almedina, 1999, p. 126.

${ }_{952}$ Agostino GAMBINO, La disciplina del conflito di interessi del socio, in Rivista del diritto commerciale, ano LXVIII (1969), $1^{\text {a }}$ parte, p. 410.

${ }_{953}$ Jorge Manuel CoUTINHO DE ABREu, Do Abuso de Direito - Ensaio sobre um Critério em Direito Civil e nas Deliberações Sociais, Coimbra, Almedina, 1999, p. 126. 
estar presente - e não a obtenção intencional da vantagem - irrelevante no caso da emulação ${ }^{954}$.

Quanto especificamente à modalidade de abuso em comento (não emulativo), resta saber se, no Brasil, ele se configura na ausência de prejuízo à companhia ou aos demais acionistas, presente a vantagem especial ao votante. E a resposta parece ser negativa, ante a presença da conjunção aditiva "e" do texto legal do art. 115 da Lei n. ${ }^{\circ}$ $6.404 / 76$.

No entanto, para a correta avaliação da afirmação acima, é imprescindível compreender-se, com estribo na lição de Modesto CARVALHOSA, que o "prejuízo" de que trata a lei pode consiste na imposição tanto de danos emergentes - i.e., a perda imediata ou futura -, quanto de lucros cessantes, "quando [a companhia ou a coletividade os demais sócios] deixa de obter uma vantagem lícita; ou, então, quando do voto lhe advém um resultado menor do que seria obtido se outra fossa a manifestação decisória do acionista "955. Portanto, se a vantagem é alcançada ao custo da não realização de um lucro maior da companhia (sem, no entanto, impor uma perda, ou seja, a companhia não perde, mas deixa de ganhar), por exemplo - a qual se lograria, se o voto tivesse sido proferido em sentido diverso -, abusiva será a manifestação política do acionista.

Ainda quanto ao prejuízo caracterizador do abuso, o comando legal exige seja ele efetivo ou potencial ("resulte, ou possa resultar, prejuizo"). O evento danoso não necessariamente terá lugar em um curto espaço de tempo a partir da deliberação. Assim, é preciso considerar, na configuração do abuso, o grau de previsibilidade de que estava o votante imbuído no momento de sua manifestação assemblear. Por outro lado, no exame da questão, não pode, por hipótese, um magistrado chamado a pronunciar-se aguardar a efetivação do dano para julgar a licitude ou não do voto proferido. Acrescente-se que também a superveniência de um fato imprevisível que obste o prejuízo não elidirá o caráter abusivo do voto ${ }^{956}$. Por tudo isso, a caracterização do abuso não está na imposição causal do dano pela deliberação, mas na possibilidade de que essa relação de causa-efeito exista.

\footnotetext{
${ }^{954}$ Fabio Konder COMPARATO explica que, enquanto no abuso emulativo, a tônica está na imposição de prejuízo, naquele não emulativo ela está na obtenção da vantagem indevida, assumindo o votante o risco do prejuízo que se vai impor. Cf. Controle conjunto, abuso no exercício do voto acionário e alienação indireta de controle empresarial, in Direito Empresarial, São Paulo, Saraiva, 1990, pp. 90-91.

${ }_{955}$ Comentários à Lei de Sociedades Anônimas, v. 2, São Paulo, Saraiva, 2009, p. 461.

956 "Sarà così irrilevante, ai fini dell'esito dell'impugnativa, che eventi imprevedibili successivi alla deliberazione, interrompendo il nesso causale tra questa e il danno, impediscano il concreto verificarsi del pregiudizio in conseguenza della realizzazione dell'operazione.” In: Agostino GAMBINO, La disciplina del conflito di interessi del socio, in Rivista del diritto commerciale, ano LXVIII (1969), $1^{\text {a }}$ parte, p. 411.
} 
O texto de lei menciona prejuízo "para a companhia ou para outros acionistas". Contudo, é certo que o prejuízo imposto à sociedade redunda necessariamente em efeitos de igual sentido em desfavor de seus membros ${ }^{957}$. A conjunção enuncia uma alternativa falsa ${ }^{958}$. Por outro lado, pode suceder que o os efeitos lesivos atinjam apenas alguns dos acionistas ${ }^{959}$.

\subsection{Abuso de voto emulativo}

Por derradeiro, é caso de mencionar o voto emulativo, já acima examinado (item precedente), que é considerado abusivo. Nessa hipótese, dispensa-se a ocorrência da vantagem, limitando-se a conduta a impor deliberadamente um prejuízo à companhia ou aos sócios.

\footnotetext{
${ }^{957}$ Jorge Manuel Coutinho DE ABREu, Do Abuso de Direito - Ensaio sobre um Critério em Direito Civil e nas Deliberações Sociais, Coimbra, Almedina, 1999, p. 126.

${ }^{958}$ Fabio Konder COMPARATO, Controle conjunto, abuso no exercício do voto acionário e alienação indireta de controle empresarial, in Direito Empresarial, São Paulo, Saraiva, 1990, p. 90.

959 Jorge Manuel CoutinHo DE ABREu, Do Abuso de Direito - Ensaio sobre um Critério em Direito Civil e nas Deliberações Sociais, Coimbra, Almedina, 1999, p. 126: "Na verdade, se pode falar-se de prejuízo da sociedade, tem de reconhecer-se que essa dano atinge sempre os sócios enquanto tais (...). E se pode também dizer-se que, num ou noutro caso, o prejuízo de alguns sócios não corresponde a qualquer prejuízo da sociedade, isso é irrelevante para o abuso de direito nas deliberações."
} 


\section{CAPÍTULO QUARTO - ABUSO DE VOTO NA RECUPERAÇÃO JUDICIAL}

\subsection{Recuperação judicial e as negociações estruturadas}

\subsubsection{O procedimento como mecanismo de estruturação das negociações}

Muito embora, em matéria de solução não liquidatória da crise da empresa, a disciplina da Lei n. ${ }^{\circ} 11.101 / 05^{960}$, divorciando-se do regime anterior, tenha se estribado em um mecanismo que subtrai ao Estado o poder de decidir sobre a alternativa à falência (sua possibilidade, os meios de satisfação dos interesses envolvidos e superação da crise do devedor) e o atribui aos próprios credores ${ }^{961}$, ela não prescindiu da jurisdição e do processo judicial.

Mesmo na recuperação dita extrajudicial - em que também a atuação do Estado não pode ser dispensada ${ }^{962}$-, mas fundamentalmente na judicial, a Lei de Recuperação de Empresas e Falências previu a intervenção do Judiciário, o acompanhamento pelo Ministério Público ${ }^{963}$, um conjunto de órgãos - em especial o administrador judicial -, e um processo judicial devidamente estruturado e disciplinado,

\footnotetext{
${ }^{960}$ São desse diploma legal os dispositivos citados no presente capítulo, salvo se indicado diversamente ou se o contrário decorrer do contexto.

${ }^{961}$ Sobre a solução não liquidatória disciplinada pela Lei n. ${ }^{\circ}$ 11.101/05, afirmam Marcos de Barros LiSBOA:

“O novo modelo de recuperação segue orientação oposta [àquela adotada pelo Decreto-Lei n. ${ }^{\text {7 }}$ 7.661/45]. $O$ entendimento de que cada empresa e cada setor possui particularidades e características próprias orientou a opção de atribuir ao devedor a responsabilidade de apresentar uma proposta de renegociação de dividas aso credores, de forma a constituir um plano de recuperação para aempresa." Cf. A Racionalidade Econômica da Nova Lei de Falências e de Recuperação de Empresas, in Luiz Fernando Valente de PAIVA (coord.), Direito Falimentar e a Nova Lei de Falências e Recuperação de Empresas, São Paulo, Quartier Latin, 2005, p. 48.

${ }^{962}$ De fato, como se viu, a despeito do nome, a recuperação extrajudicial demanda a propositura de uma ação, que não apenas pode ser meramente homologatória, mas também impositiva (art. 163).

${ }_{963} \mathrm{Em}$ que pese o veto ao art. $4^{\circ}$, as hipóteses de atuação do parquet são relativamente extensas na LREF. Cf. Newton DE LuCCA, Comentários, in Osmar Brina CORRÊA-LIMA - Sérgio Mourão CoRRÊA-LiMA (coord.), Comentários à Nova Lei de Falência e Recuperação de Empresas, Rio de Janeiro, Forense, 2009, p. 72. Sobre a participação do Ministério Público nos processos concursais, preleciona Sergio CAMPINHO: "Como se pode constatar, em síntese, o Ministério Público não é parte nos processos de falência ou de recuperação, mas, parafraseando Rubens Requião, possui um direito de intervenção e controle cuja finalidade apresenta duplo aspecto: assegurar a repressão aos crimes que venham a emergir da falência ou da recuperação $e$ defender, através de sua ação disciplinar, o interesse público e o crédito comercial." Cf. Falência e Recuperação de Empresa - O Novo Regime da Insolvência Empresarial, Rio de Janeiro, Renovar, 2009, p. 52.
} 
informado por todos os princípios e garantias constitucionais ${ }^{964}$. Recorrendo o devedor ao regime jurídico que lhe dispensa a LREF, ele não pode se afastar dessa necessária intervenção do Estado e a ela também se submetem todos os integrantes do concurso.

Não é um caminho incontornável, no entanto. Existem mecanismos preventivos da falência que têm origem estritamente econômica e cuja negociação passa ao largo da intervenção obrigatória do Estado. Não são abrangidos pelo direito concursal ${ }^{965}$. Jorge Lово cita numerosos exemplos, que vão desde mergers and aquisitions - em linhas gerais, a aquisição de controle societário e "operações" societárias de cisão, fusão e incorporação - até o recurso às linhas estatais de crédito específicas para empresas em crise $^{966}$, passando por parcerias (joint ventures) e, como não poderia deixar de ser, citamos nós, a renegociação de dívidas e contratos tratada e celebrada diretamente entre as partes envolvidas.

Todas essas soluções, naturalmente, são reguladas em seus aspectos materiais pelo ordenamento jurídico. E a "chancela" judicial, se desejada pelas partes, pode ser alcançada livremente quanto aos acordos celebrados entre credores e devedor. A hipótese não apenas é prevista pela legislação estritamente processual (CPC: 475-N, inc. III, e Lei n. ${ }^{\circ}$ 9.099/95: art. $74^{967}$ ), mas também é expressamente ressalvada pela Lei n. ${ }^{\text {o }}$ 11.101/05, que afastou a ilicitude (LREF: art. $167^{968}$ ) da anteriormente chamada, e com

964 “O processo é um método de trabalho referente ao exercício da jurisdição pelo juiz e dos poderes inerentes a ação e defesa, pelos sujeitos envolvidos no conflito, como escreve Cândido Rangel Dinamarco. Esse método é definido pelos princípios e pelo direito positivo, no caso as regras de direito processual civil, dos quais resulta um modelo imposto aos litigantes de modo a serem observadas e estarem presentes as diretrizes determinadas pela Constituição da República e definidas por lei.” In: Paulo Sérgio RESTIFFE, Recuperação de Empresas, São Paulo, Manole, 2008, p. 51.

965 Adota-se, aqui, a terminologia "direito concursal" como equivalente (mais sintético) à expressão "direito da empresa em crise", para significar o ramo concernente ao concurso de credores, quer em um sistema procedimental unificado ou quer em um sistema dualista para indicar as soluções liquidatória-solutória $e$ reorganizacional. Nelson ABRÃO define procedimentos concursais, como "as várias formas de processo, administrativo ou judicial, aplicáveis na regulação jurídica da situação de crise econômica de um devedor, empresário ou não, conforme o sistema legal que os adota." Cf. Curso de Direito Falimentar, São Paulo, LEUD, 1997, p. 19.

${ }^{966}$ Da Recuperação da Empresa no Direito Comparado, Rio de Janeiro, Lumen Juris, 1993, pp. 40-42. O autor cita exemplos de instituições financeiras e de fomento às empresas em crise que concedem crédito ou, ainda, outros mecanismos - que, sustenta ele, têm sido mais exitosos: "O mais eficaz meio extrajudicial de reorganização e recuperação da empresa tem sido, todavia, o realizado por órgãos públicos, criados para adquirir o controle da empresa, saneá-la e finalmente revender as ações ao investidor no mercado".

${ }_{967}$ Mesmo quando regida apenas pela Lei n. ${ }^{\circ}$ 9.099/95 (antes da alteração promovida no Código de Processo Civil pela Lei n. ${ }^{\circ}$ 11.232/05), a homologação judicial não estava sujeita aos limites de alçada previstos por aquela lei. Em qualquer dos casos, se o acordo tem lugar em demanda já ajuizada relativa ao crédito, a homologação pode exacerbar os limites objetivos da lide - o que, agora, está expresso no CPC, art. 475-N, inc. III.

${ }^{968}$ Muitos autores sustentam que a previsão legal é inútil, ante o princípio da legalidade (CR: art. $5^{\circ}$, inc. II); por todos, veja-se Fabio Ulhoa CoELHO, Comentários à Lei de Falências e de Recuperação Empresas, São Paulo, Saraiva, 2011, p. 525, e Paulo Penalva SANTOS, Comentários, in Osmar Brina CORRÊA-LIMA - Sérgio Mourão CORRÊA-LIMA (coord.), Comentários à Nova Lei de Falência e Recuperação de Empresas, Rio de Janeiro, Forense, 2009, p. 1119. No entanto, tendo em vista o regime anterior estritamente restritivo, a 
evidente tonalidade pejorativa, "concordata branca", então prescrita como causa de falência (LF: art. $2^{\circ}$, inc. III).

Socorrendo-se, porém, da Lei n. ${ }^{\circ} 11.101 / 05$, o devedor deverá, e os credores serão por consequência obrigados, a se submeter ao procedimento judicial por ela previsto.

Esse procedimento é estruturado para favorecer a efetiva negociação entre as partes envolvidas. Se o devedor em crise resolve socorrer-se da LREF, é presumível que as opções extrajudiciais falharam. Os agentes econômicos não recorreriam à recuperação judicial se alcançassem o resultado por meios menos custosos, como os acordos privados e, até mesmo, a recuperação extrajudicial. Também os requisitos e as condições da ação, em larga medida, prestam-se a evitar a provocação e a movimentação desnecessárias do Poder Judiciário. De toda sorte, submetida a questão à recuperação judicial, ela se processará perante o Judiciário e será estabelecido um conjunto de medidas processuais e não processuais voltadas para efetivar a negociação entre as partes. Aos credores por ela atingidos, não será mais possível exercer seu direito de crédito senão no bojo do instituto.

Sem ferir o controverso tema da preponderância material ou processual dos institutos versados pelas leis concursais, o instituto recuperação judicial realiza-se no bojo de um processo judicial. Existe efetivamente um litígio - uma pretensão do devedor resistida pela comunidade de credores ${ }^{969}$ - e sua composição é o destino para o qual se voltam os atos que compõem, coordenadamente, esse processo ${ }^{970}$.

Diferente, no entanto, da generalidade dos demais processos judiciais

previsão não parece de todo despicienda. Por todos, veja-se: Rachel SZTAJN, Comentários, in Paulo Fernando Campos Salles TOELEDO - Carlos Henrique ABRÃo (Coords.), Comentários à Lei de Recuperação de Empresas e Falência, São Paulo, Saraiva, 2010, pp. 550-551.

969 Humberto THEODORO JR.: "Para que haja, outrossim, a lide ou litígio é necessário que ocorra "um conflito de interesses qualificado por uma pretensão resistida', conforme a clássica lição de Carnelutti. ” In: Curso de Direito Processual Civil, v. 1, Rio de Janeiro, Forense, 2001, p. 30.

${ }^{970}$ Sobre o assunto, Paulo Sergio RESTIFFE preleciona: "As normas processuais civis da recuperação judicial de empresas - assim denominadas aqui as regras relativas à marcha processual da ação de recuperação de judicial de empresas -, a seu turno, igualmente buscam a composição de um litígio - o litígio de recuperação judicial -, lide que precisa ser composta, de forma vinculativa, por um órgão jurisdicional do Estado, imparcial e equidistante das partes em conflito, que necessita ser provocado para da a devida solução, fazendo-o mediante um conjunto de atos a esse fim destinado.” In: Recuperação de Empresas, São Paulo, Manole, 2008, p. 51. Mais adiante o mesmo autor define: "A legislação definiu e estabeleceu o processo de recuperação judicial de empresas como um método de trabalho que conjuga, de um lado, o procedimento, mediante atos interligados e coordenados, como seu lado exterior e visível, e, de outro, como seu lado interior ou interno, o estabelecimento de uma relação jurídica, na qual se desenvolve o exercício da jurisdição pelo juiz e os poderes inerentes à ação e defesa pelos sujeitos envolvidos na pretensão, tudo constituid e destinado para alcançar, no fim, este objetivo: o provimento jurisdicional.” (p. 52) 
contenciosos, a recuperação judicial contém a particularidade de que a decisão não decorrerá da imposição de vontade do juiz, em substituição forçada à vontade das partes. Bem ao contrário, resultará necessariamente da composição das partes a partir do acatamento (homologado ao depois pelo magistrado - art. 58) ou não (caso em que haverá a convolação: art. 73, inc. I e III) da proposta (o plano de recuperação) apresentada, quer seja aquela original, de iniciativa do devedor (art. 53), quer seja uma alternativa proveniente dos próprios credores (LREF: art. 56, $\S 3^{0^{971}}$ ).

A regulação legal das tratativas entre devedor e credores é chamada pelos americanos de structured bargaining ${ }^{972}$, negociações estruturadas. Elas são, como se vê, no caso brasileiro, estabelecidas no bojo de um processo judicial, que congrega não apenas expedientes estritamente processuais, embora geralmente também com efeitos materiais (como a preclusão - de que se lança mão, por exemplo, para a aprovação tácita do plano: art. $58,1^{\mathrm{a}}$ parte), mas também com a atuação de órgãos e deliberação - embora não necessariamente - pelo método assemblear (art. 56). Tudo é disposto no sentido de favorecer as negociações entre as partes e chegar-se a uma deliberação, que prestigie ou não a proposta apresentada.

É possível, portanto, desde logo afirmar-se que uma das finalidades da recuperação judicial - instrumental, é certo - é viabilizar tais negociações entre as partes. De fato, ponderam Marcos de Barros LisBoA et all. que "em linha com o modelo extrajudicial, a principal característica da recuperação judicial é o incentivo à negociação entre o devedor e seus credores, aliado à criação de instrumentos de coordenação" $" 973$.

Em um ambiente institucional com regras claras - minorando o risco de comportamentos oportunistas e desleais ${ }^{974}$-, sob a condução da Justiça, a supervisão do Ministério Público e do administrador judicial e ainda com concorrência de dois outros órgãos - embora facultativos: a assembleia geral de credores e o comitê de credores -, essas negociações são francamente favorecidas.

\footnotetext{
${ }^{971}$ Que, aprovada pelos credores, deverá passar pelo crivo do devedor para ser homologada pelo Juízo (art. ). 972 Eduardo Secchi Munhoz, Comentários, in Francisco Satiro SouzA Junior - Antônio Sérgio A. de Moraes Piтомво (coord.), Comentários à Lei de Recuperação de Empresas e Falência, São Paulo, RT, 2007, p. 287.

${ }^{973}$ A Racionalidade Econômica da Nova Lei de Falências e de Recuperação de Empresas, in Luiz Fernando Valente de PAIVA (coord.), Direito Falimentar e a Nova Lei de Falências e Recuperação de Empresas, São Paulo, Quartier Latin, 2005, p. 46.

${ }_{974}$ Marcos de Barros LisBOA et all., A Racionalidade Econômica da Nova Lei de Falências e de Recuperação de Empresas, in Luiz Fernando Valente de PAIVA (coord.), Direito Falimentar e a Nova Lei de Falências e Recuperação de Empresas, São Paulo, Quartier Latin, 2005, p. 46.
} 
Também são propícias às tratativas entre as partes a estrutura processual que se impõe, a qual, por efeito do impulso oficial e da preclusão, tendem a se suceder progressivamente, eliminando a possibilidade de regressão e tornando inexorável a superveniência de uma decisão - seja qual for seu conteúdo.

Assim, por exemplo, quanto ao devedor, uma vez deferido o processamento da recuperação - requerido, diga-se, por ele -, não lhe é mais dado desistir do processo sem a concordância dos credores ou deixar de apresentar uma proposta (o plano de recuperação), sob pena de falência. Também os credores, se atingidos pela recuperação judicial, já não poderão exercer seu crédito segundo as condições originais, mas apenas na medida e nas condições em que o resultado do processo recuperacional ${ }^{975}$ lhe proporcionar - conforme o plano aprovado ou de acordo com as disposições legais na liquidação falimentar, observadas as forças da massa. Intimados do plano, não podem os credores abster-se de manifestar ou o transcurso in albis do prazo legal implicará a aprovação da proposta do devedor. Enfim, a ordenação processual da recuperação força uma negociação entre as partes envolvidas e a conduz necessariamente a uma decisão final.

Mas não se limitam ao ambiente institucional e aos expedientes processuais as disposições da Lei n. ${ }^{0}$ 11.101/05 destinadas a "estruturar" as tratativas negociais entre devedor e credores. Introduziu-se na recuperação judicial um mecanismo de produção de deliberações típico de sociedades: a assembleia geral, que, aqui, é de credores. Embora ela não seja obrigatoriamente convocada, mesmo para tratar do plano de recuperação apresentado, é forçoso concluir que, na larguíssima maioria dos casos, a ela caberá decidir sobre a aprovação do plano de recuperação (em seus termos originais ou com modificações, que, de toda maneira, deverão passar pelo crivo do devedor).

Trata-se, como nas sociedades anônimas, de um órgão deliberativo e superior dos credores, ao qual a lei confere uma série de relevantíssimas atribuições para o deslinde da recuperação judicial. Importa referir que é nesse locus, atendendo ao método assemblear, segundo, portanto, um procedimento e nos limites de sua atribuição, que os credores têm assento (direito de presença), debatem o plano (direito de voz) e exercem o direito político de voto, para manifestar concordância com o plano (a proposta em

\footnotetext{
975 Aderimos aqui ao uso do adjetivo que compõe o título da obra coordenada por Newton DE LUCCA e Alessandra de Azevedo Domingues (Direito Recuperacional - Aspectos Teóricos e Práticos, São Paulo, Quartier Latin, 2009), também empregado na revista especializada organizada por Cristhiano IMHOF e a Min. Nancy ANDRIGHI (Revista de Direito Empresarial Recuperacional) e que se vem alastrando na jurisprudência, notadamente na paulista. Apesar de não constar do Vocabulário Ortográfico da Língua Portuguesa (VOLP), da Academia Brasileira de Letras (ABL), a inovação justifica-se pela força sintética do adjetivo, em relação à locução adjetiva (de recuperação), e pela variabilidade vocabular que possibilita.
} 
deliberação) ou rejeição dele $\mathrm{e}^{976}$.

Uma vez instaurado o concurso recuperacional, o exercício do crédito pelos credores apenas poderá ocorrer se e nos termos em que permitir a Lei n. ${ }^{\circ}$ 11.101/05 e, instalada a assembleia geral, a manifestação de vontade do credor apenas pode se dar no bojo desse órgão deliberativo. Ainda palmilhando o paralelo do instituto com as assembleias gerais de acionistas, nas companhias, precedentemente estudadas, é mister acentuar a força vinculativa das deliberações do órgão, que atinge não apenas os votantes presentes e convergentes com o resultado proclamado, mas também os ausentes, aqueles que se abstiveram e, mesmo, os divergentes.

A assembleia geral de credores, como a congênere nas companhias, é o órgão em que, pela confluência das vontades individuais dos credores, obedecido o método assemblear, é produzida juridicamente a vontade da comunhão de credores - como o interesse social, nas sociedades. Será por isso necessário perscrutar no âmbito do direito concursal, como foi feito no Capítulo 3 a respeito do interesse social ${ }^{977}$, sobre que interesses manifestados pela assembleia geral de credores têm proteção legal.

Ainda sobre a estrutura orgânica conferida pela Lei n. ${ }^{\circ}$ 11.101/05 à recuperação judicial, convém observar que, por sua complexidade e dos interesses envolvidos, é previsto também o comitê de credores, ao qual, embora seja ele facultativo, é atribuído um conjunto de funções importantes na defesa dos interesses dos credores.

Mediante, portanto, todos esses expedientes conferidos pela Lei n. ${ }^{\text {o }}$ 11.101/05, a recuperação judicial destina-se, instrumentalmente, a provocar as negociações estruturadas e, assim, chegar-se ao atendimento dos princípios insculpidos no art. 47 da Lei n. ${ }^{\circ} 11.101 / 05$, cujo exame se fará mais adiante.

\subsubsection{A natureza jurídica do instituto}

Questão relevante diz respeito à natureza jurídica do instituto da recuperação judicial. Sua importância evidencia-se por pelo menos duas características

\footnotetext{
${ }^{976}$ Sobre ela, afirmam Marcos de Barros LisBOA et all.: "constitui o fórum para as discussões dos interesses dos credores nos processos de recuperação judicial e falência." E com o comitê de credores constitui "dos instrumentos que buscam disciplinar e coordenar a forma de relacionamento entre o devedor e os seus credores não apenas nos procedimentos de recuperação, mas também na falência." Cf. A Racionalidade Econômica da Nova Lei de Falências e de Recuperação de Empresas, in Luiz Fernando Valente de PAIVA (coord.), Direito Falimentar e a Nova Lei de Falências e Recuperação de Empresas, São Paulo, Quartier Latin, 2005, pp. 46-47.

977 Q.v. item 3.2.2, no Capítulo 3.
} 
notáveis, que fazem destoar seu regime jurídico do regramento geral. São elas a sujeição compulsória dos credores atingidos ${ }^{978}$ à recuperação judicial (art. 49) e, por decorrência, a sujeição de seus créditos (que, na verdade, são novados) aos termos do plano de recuperação aprovado e homologado (arts. 58 e 59). Ou seja: em que pesem o caráter voluntário dos contratos e obrigações em geral (CR: art. 5, inc. II; CC: art. 421) e, ainda, sua força obrigatória - uma vez celebrados ou contraídas: art. 394 do CC -, o credor não pode oferecer resistência nem à sua inclusão no processo de recuperação judicial ${ }^{979}$, nem, ao final, aos efeitos da novação resultantes do plano aprovado e homologado.

Em outras palavras, a decisão unilateral de o devedor de propor a medida judicial - presentes, naturalmente, os requisitos que autorizam o deferimento pelo juízo - e a deliberação válida de aprovação do plano de recuperação pela assembleia de credores homologada - alteram a esfera jurídica do credor sem que ele possa oferecer nenhuma resistência ${ }^{980}$. Ele encontra-se em uma típica sujeição ${ }^{981}$, tocando o correspondente poder formador ao devedor e ao colégio formado pelos credores (a assembleia geral de credores), respectivamente.

Assim é que, sem a concorrência de sua vontade, o credor é introduzido (compulsoriamente, portanto) em uma comunhão de interesses. Tal comunhão decorre da concorrência dos credores pelo patrimônio do devedor, que, encontrando-se em crise, não está apto a adimplir todos os seus compromissos e, não logrando chegar a bom termo nas negociações extrajudiciais com as partes interessadas, socorre-se da recuperação judicial.

\footnotetext{
978 Existem créditos constituídos antes do ajuizamento da recuperação judicial que estão excluídos da dela: art. $5^{\circ}$, incs. I e II; art. $6^{\circ}, \S 7^{\circ}$, c/ art. 52, inc. III, (e CTN: art. 187); art. 49, $\S 3^{\circ}$; art. 49 , $\S 4^{\circ}$ c/c art. 86, inc. II. Cf. Mario Sergio Milani, Lei de Recuperação Judicial, Extrajudicial e Falência Comentada, São Paulo, Malheiros, 2011, pp. 211-212.

${ }^{979}$ A publicação do edital a que se refere o art. da Lei n. ${ }^{\circ}$ 11.101/05 determinada pela decisão de processamento da recuperação judicial é o ato formal (e processual, no caso) que torna compulsórias a submissão dos credores ao instituto e sua inclusão no processo judicial (qual fosse uma citação válida).

${ }_{980}$ Questão semelhante foi examinada pela doutrina societária no desenvolvimento do princípio majoritário. Com efeito, conforme estudado a respeito da natureza das companhias e das sociedades em geral (Capítulo 3, supra), as primeiras teorias, que imputavam natureza contratual às sociedades comerciais, tinham dificuldade na aceitação de que o desenvolvimento da relação entre os sócios - o que incluía as deliberações acerca do exercício de atividades sociais - e, ainda mais, a própria alteração do ato constitutivo se sustentasse em decisões não unânimes. De todo modo, a imposição inexorável da prática societária conduziu a doutrina à aceitação do princípio majoritário. O exame de questão semelhante, no âmbito concursal, todavia, tomou contornos significativamente diversos. Isso essencialmente porque, ao contrário do que sucede no arranjo societário com relação a seus sócios - que têm parte no órgão deliberativo -, o concurso de credores não é determinado pela vontade destes (a quem incumbirá a decisão sobre a aprovação ou não do plano de reorganização), mas exclusivamente do credor - que, por sua vez, fundamenta-se em razões de ordem fática muitas vezes completamente ignoradas pela comunidade de credores (que não sabe nem suspeita da falta de sustentação econômica ou financeira do devedor). E nada obstante a ausência de sua vontade em integrar um concurso, o credor vê-se coagido a compor essa comunhão e, assim, poder tomar parte nas deliberações e, inarredavelmente, submeter-se à decisão proclamada conforme os critérios e quóruns legais.

${ }_{981}$ Q.v. item 2.2.1.1, supra, no Capítulo 2. Excepciona, pois, o princípio da incolumidade das esferas jurídicas.
} 
Desde então, os interesses dos credores já não são tutelados individualmente, senão coletivamente $^{982}$. Entre os credores, cujo créditos possivelmente nada têm em comum senão o devedor, surge um interesse comum - que será melhor analisado mais adiante consistente, em linhas gerais, na obtenção mediante o plano de recuperação de um sacrifício menor de seus créditos do que aquele que lhes seria imposto pela solução liquidatória (falência).

Pela existência desse interesse comum, a comunhão de credores assemelha-se às sociedades ou, ainda, à comunhão de debenturistas de uma companhia. Mas delas diferencia-se em razão de não ser voluntária ${ }^{983}$ e decorrer exclusivamente do exercício pelo devedor comum do poder de ajuizar uma ação de recuperação judicial.

É preciso, destarte, delinear a natureza desse instituto, que compulsoriamente congrega em um interesse comum os diversos credores e, no bojo de um processo judicial, impõe ao final a alteração das condições originais de cada um dos créditos constituídos.

No exame dessa árida questão - ainda agravada pelas diversas feições que a solução não liquidatória da empresa em crise adotou ao longo do tempo e nos diversos ordenamentos jurídicos - numerosas teorias desenvolveram-se. São três as principais correntes em que se reúnem essas teorias, a saber: as contratuais, as processuais e a da obrigação legal - às quais Daniel Roque Vítolo, com base nas lições de Alfredo RocCO, ainda a da concordata como contrato.

As teorias contratuais, como é claro, concebem o acordo entre devedor em crise e credores simplesmente como um contrato. O problema que se evidencia de pronto está justamente na compatibilidade dessa tese com a possibilidade de imposição do acordo aos credores dissidentes e ausentes à deliberação ${ }^{984}$. Para solução desse dilema, surgiram várias teorias filiadas a essa corrente.

\footnotetext{
982 Explica Daniel Roque Vítolo que as ações individuais de credores têm por pressuposto o simples descumprimento das obrigações do devedor, que é por essas medidas judiciais constrangido "a cumplir com la obligación de la cual resulta titular". Todavia, "en aquellos casos en que el deudor se encuentra en una imposibilidad de hacer frente al conjunto de sus obligaciones, y su estado de impotencia patrimonial se revela con carácter general, la ley prevé un proceso que involucra todo su patrimonio y todos sus acreedores". Trata-se de um proceso de caráter coletivo: "tanto el proceso del concurso preventivo propiamente dicho [preventivo da falência], como el procedimiento de quiebra abierto a instancias de un acreedor - o del propio deudor -, importan una acción colectiva, y no tienen como presupuesto el mero incumplimiento de alguna obligación, sino un estado generalizado de insolvencia del deudor (...)." Cf. Elementos del derecho concursal, Buenos Aires, Ad Hoc, 2008, pp. 34-35

${ }_{983}$ Erasmo Valladão A. e N. FrANÇA, Comentários, in Francisco Satiro de SoUZA Junior - Antônio Sérgio A. de Moraes PItombo (coord.), Comentários à Lei de Recuperação de Empresas e Falência, São Paulo, RT, 2007, p. 187, n. 129.

${ }_{984}$ Rubens REQUião, Curso de Direito Falimentar, v. 2, São Paulo, Saraiva, 1995, p. 12.
} 
A primeira delas, a chamada teoria da vontade forçada, para não negar formalmente a natureza contratual do acordo celebrado entre devedor e credores,cria uma regra "interpretativa" segundo a qual a minoria fica obrigada pela vontade da maioria: a vontade daquela primeira parcela de credores fica suprida pela decisão desta última ${ }^{985}$. A crítica inarredável à teoria está na incompatibilidade entre a noção de contrato - que pressupõe classicamente a liberdade contratual - e a de "vontade forçada". Rigorosamente, não há aí "vontade" no sentido próprio do termo ${ }^{986}$. Alfredo RoCCO, contrariando essas críticas, acusa-as de insuficiente, porque a teoria em referência não sustenta a existência de contrato entre a minoria vencida e o devedor, mas afirma que a "concordata" é um contrato (envolvendo credores e devedor) e que, uma vez estipulado pela maioria, vincula também a minoria, que fica assim obrigada a observá-lo. Assim, a crítica à teoria, conclui Rocco, necessita comprovar não apenas que não há contrato sem vontade, mas também que não se pode estar ligado a um contrato (e submetido a ele) sem vontade ou contra a própria vontade $^{987}$.

A teoria da vontade presumida é a segunda das teorias contratuais, que, diz Daniel Roque VíTOLO, guarda relação com o sistema de "junta de credores" (assembleia de credores), os quais votam e deliberam. Os presentes às assembleias de credores votam em nome dos ausentes, que tacitamente aquiescem com a decisão tomada pela maioria ${ }^{988}$. Mesmo essa teoria não explica suficientemente a justificativa para reverter a vontade daqueles credores que votam contrários ao acordo proposto pelo devedor e aprovado pela maioria ${ }^{989}$. Por fim, a teoria da representação legal da minoria, segundo a qual a maioria dos titulares de crédito aceita a proposta do devedor não apenas em nome próprio, mas, com fundamento em uma "representação legal", em nome dos demais credores dissidentes e ausentes ${ }^{990}$. Para Rubens REQUIÃO, contudo, essa explicação

\footnotetext{
${ }^{985}$ Daniel Roque Vítolo informa que essa teoria foi criada por Christian Friederich KocH em comentário à legislação prussiana de 1855 e, ainda, por J. PARDESSUS com relação ao Código Comercial francês de 1808. Teria sido ainda seguida por Arnesber von ARNDTS e por WINDSCHEID. Cf. Acuerdos preventivos abusivos o en fraude a la ley, Buenos Aires, Rubinzal-Culzoni, 2009, pp. 114-115.

${ }^{986}$ Os críticos, anota Daniel Roque VítoLO, foram principalmente Augusto Sigmund SCHULTZE e LÖHR. Cf. Acuerdos preventivos abusivos o en fraude a la ley, Buenos Aires, Rubinzal-Culzoni, 2009, p. 115.

${ }^{987}$ Apud Daniel Roque Vítolo, Acuerdos preventivos abusivos o en fraude a la ley, Buenos Aires, RubinzalCulzoni, 2009, p. 115.

988 Daniel Roque Vítolo, Acuerdos preventivos abusivos o en fraude a la ley, Buenos Aires, RubinzalCulzoni, 2009, pp. 115-116.

${ }_{989}$ Rubens ReQUĩ̃̃, Curso de Direito Falimentar, v. 2, São Paulo, Saraiva, 1995, p. 13.

${ }^{990}$ Daniel Roque VíTOLO objeta que "Tampoco esta posición pudo superar la explicación referida respecto de los disidentes ni el origen o fuente de un mandato - legal o no - para que los disidentes - en épocas de juntas - pudieran ver desplazada su voluntad hacia los otros acreedores." Cf. Acuerdos preventivos abusivos o en fraude a la ley, Buenos Aires, Rubinzal-Culzoni, 2009, p. 116.
} 
desnatura a conteúdo contratual da teoria que procura fundamentar ${ }^{991}$.

Em divergência com teorias contratualistas, surgiram as processualistas, que, tendo em vista a circunstância de as soluções não liquidatórias da crise serem processadas judicialmente e dependerem de decisão jurisdicional, sustentam que o instituto tem essa natureza - processual $^{992}$.

Quanto a essas teorias, a primeira delas é atribuída a POTHIER, para quem a obrigatoriedade do acordo aos credores dissidentes e ausentes teria sua origem na respectiva sentença judicial homologatória. Embora não seja ela diretamente constitutiva dessa obrigatoriedade, ela tem o efeito de "substituir" a vontade da minoria ${ }^{993}$. Próxima a essa teoria, a de BRAVARD-VEYRÈRES sustenta que o acordo tem natureza convencional e judicial, de tal modo que a maioria expressa sua vontade e a da minoria é suprida pelo ato judicial de homologação - de modo que a vontade do juiz integraria o acordo para formar a obrigatoriedade a todos os credores ${ }^{994}$. Pela imposição da vontade judicial, não se trataria propriamente de um contrato 995.

Ainda na vertente processual, a de SCHULTZE sustenta que o acordo entre devedor e credores não seria propriamente contrato ou convenção, mas se trataria da própria sentença dita homologatória. Sua força obrigatória não decorreria, assim, da decisão da maioria, mas do poder do juiz fundado, por sua vez, na ordem jurídica. Dessa maneira, por força de lei, caberia ao juiz, na homologação, julgar conforme a decisão da maioria (de outro modo, não seria homologação), mas a obrigatoriedade não decorreria da precedente deliberação da maioria dos credores presentes ${ }^{996}$, mas da decisão judicial a respeito dela. Essa teoria foi criticada por tal entendimento contradizer a ideia de homologação: "el juez no crea el Derecho sino que el Derecho preexiste a su pronunciamiento" "997. A atribuição do magistrado limita-se a ratificar o acordado pela maioria, segundo o quórum legal e se atendidos os demais requisitos formais.

A ideia de "contrato processual" é desenvolvida pela teoria mista de

\footnotetext{
${ }^{991}$ Rubens REQUĩ̃o, Curso de Direito Falimentar, v. 2, São Paulo, Saraiva, 1995, p. 13.

992 Rubens ReQuĩ̃o, Curso de Direito Falimentar, v. 2, São Paulo, Saraiva, 1995, p. 13.

993 "La fuerza obligatoria del concordato se basaría exclusivamente en la sentencia del juez que lo homologa." Cf. Daniel Roque Vítolo, Acuerdos preventivos abusivos o en fraude a la ley, Buenos Aires, Rubinzal-Culzoni, 2009, p. 116. Se bem que a própria noção de "homologação" restaria prejudicada.

994 Daniel Roque Vítolo, Acuerdos preventivos abusivos o en fraude a la ley, Buenos Aires, RubinzalCulzoni, 2009, p. 117.

${ }_{995}$ Rubens ReQuĩ̃o, Curso de Direito Falimentar, v. 2, São Paulo, Saraiva, 1995, p. 13.

996 Daniel Roque Vítolo, Acuerdos preventivos abusivos o en fraude a la ley, Buenos Aires, RubinzalCulzoni, 2009, pp. 116-117.

${ }_{997}$ Daniel Roque Vítolo, Acuerdos preventivos abusivos o en fraude a la ley, Buenos Aires, RubinzalCulzoni, 2009, p. 117.
} 
KOHLER. Reconhece ele tratar-se o acordo de um contrato - de que são partes o devedor e os credores individualmente considerados -, mas de natureza processual, ao qual a lei atribui efeito de remissão. Assim se estrutura para lograr alcançar, de modo mais rápido e eficaz possível, os fins do processo coletivo, "que son de orden social y que tienen por objeto principal disminuir el daño producido por la insolvencia del deudor y soportarlo equitativamente entre todos los acreedores" "998. A desnecessidade de deliberação unânime é justificada pelo fato de o procedimento ser único, bem como ser também único o direito estabelecido entre o devedor e os credores. E, assim, igualmente único deve ser o "contrato" que põe termo ao processo e estabelece a relação creditícia ${ }^{999}$. Alfredo Rocco, contudo, critica a tese de KOHLER por entender que ela não supera o problema de a minoria ser vinculada pela maioria. Em se tratando de relações jurídicas processuais unitárias, elas não podem ser constituídas ou desconstituídas sem consenso entre todos os integrantes - o que não é o caso em análise (em que tem aplicação o princípio majoritário); por outro lado, se a relação processual é divisível, ela só produz efeitos entre seus participantes - o que também não se aplica ${ }^{1000}$.

Há, por fim, a teoria da obrigação legal. Ante a impossibilidade de fundamentar o fenômeno na figura do contrato, alguns teóricos defenderam ser a lei a fonte da sujeição dos credores não aderentes: é ela que determina a submissão destes - que compõem a minoria - à vontade da maioria, que celebra o ajuste com o devedor ${ }^{1001}$. Essa teoria é criticar por manter uma dupla explicação para o mesmo fenômeno, estribando na lei apenas os efeitos referentes aos não aderentes ${ }^{1002}$. Rubens REQUIÃo ainda enquadra nessa corrente a tese de que a solução não liquidatória é, na verdade, um benefício legal outorgado pelo Estado. Não há propriamente deliberação - com aceitação ou rejeição da proposta -, mas exigência de maioria é apenas a hipótese legal de incidência da norma ${ }^{1003}$.

\footnotetext{
998 Daniel Roque Vítolo, Acuerdos preventivos abusivos o en fraude a la ley, Buenos Aires, RubinzalCulzoni, 2009, p. 118.

${ }^{999}$ Sustenta Daniel Roque VíTolo que também essa teoria é incapaz de explicar a imposição do acordo aos credores ausentes e vencidos. Cf. Acuerdos preventivos abusivos o en fraude a la ley, Buenos Aires, Rubinzal-Culzoni, 2009, p. 118.

${ }^{1000}$ Rubens REQUĩ̃o, Curso de Direito Falimentar, v. 2, São Paulo, Saraiva, 1995, p. 13.

${ }^{1001}$ Rubens ReQUião, Curso de Direito Falimentar, v. 2, São Paulo, Saraiva, 1995, p. 15.

1002 Daniel Roque Vítolo, Acuerdos preventivos abusivos o en fraude a la ley, Buenos Aires, RubinzalCulzoni, 2009, p. 119: essa teoria "diferencia dos situaciones: entre el deudor concursado y los acreedores que dieron su conformidad o votaron favorablemente el acuerdo existiría un negocio jurídico bilateral - in contrato -, mientras que entre dicho deudor y quienes votaron en contra del acuerdo o se abstuvieron de hacerlo lo que tendría lugar es el acaecimiento de un hecho jurídico, al cual la ley le atribuye las mismas consecuencias, quedando obligada la minoría."

${ }^{1003}$ Rubens ReQUĩ̃o, Curso de Direito Falimentar, v. 2, São Paulo, Saraiva, 1995, p. 15.
} 
No Brasil, nos regimes que precederam o Decreto-Lei n. ${ }^{\circ} 7.661 / 45$, preponderou o sistema contratual ${ }^{1004}$. Cabia, pois, aos credores com exclusividade conceder ou recursar a concordata. Eles eram tidos pela lei como "melhores juizes de seus interesses” 1005 e, destarte, não intervinha o Judiciário no mérito da decisão concessiva ou de rejeição da medida.

Assim era, por exemplo, o Código Comercial de 1850, cujo art. 847 expressamente prescrevia que "para ser válida a concordata, exige-se que seja concedida por um número tal de credores que represente pelo menos a maioria destes em número, $e$ dois terços do valor de todos os créditos sujeitos aos efeitos da concordata”. Também a moratória prevista pelo art. 900 requeria a aprovação dos credores nos mesmos termos ${ }^{1006}$.

Essa sistemática foi mantida pelos diplomas legais posteriores, desde o Decreto n. ${ }^{\circ}$ 917/1890 ${ }^{1007}$, passando pela Lei n. ${ }^{\circ}$ 2.024/1908, até o Decreto n. ${ }^{\circ}$ 5.647/1929, que previa, para concessão da concordata preventiva ou suspensiva, a aprovação da maioria dos credores ${ }^{1008}$.

A Lei de Falências de 1945, contudo, modificou sobremodo aquela sistemática e, a despeito do emprego do termo "concordata", não mais admitiu a possibilidade de acordo entre devedor e credores. Revestiu o instituo de um caráter notadamente processual $^{1009}$ e conferiu apenas ao juiz o poder de conceder ou não a concordata, a despeito da vontade dos credores (quirografários ${ }^{1010}$ ), favorável ou contrária, sobre ela. Assim, deduzido o pedido pelo devedor, o juiz "dele toma conhecimento $e$

\footnotetext{
${ }^{1004}$ Sergio CAMPINHO, Falência e Recuperação de Empresa - O Novo Regime da Insolvência Empresarial, Rio de Janeiro, Forense, 2009, pp. 123-124. O autor, com apoio em J. X. Carvalho de Mendonça afirma que o "contrato" celebrado entre as partes era excepcional, porquanto, por um lado, encontrando-se em estado de insolvabilidade, o devedor está inábil para celebrar contratos, salvo com os credores; por outro lado, o contrato é "original" por excepcionar a regra da liberdade de contratar (quanto aos minoritários, vencidos, que se vinculam mesmo assim).

${ }_{1005}$ Rubens REQUĩ̃o, Curso de Direito Falimentar, v. 2, São Paulo, Saraiva, 1995, p. 15.

1006 “Art. 900. Reunidos os credores no dia assinado, que não será nem menos de dez nem mais de vinte do em que a ordem do Tribunal tiver sido apresentada ao Juiz, e lida a informação dos credores sindicantes, que lha deverão remeter com antecipação, serão os mesmos credores e o impetrante ouvidos verbalmente por si ou seus procuradores: e reduzidas a termo a contestação e a resposta, tudo em ato sucessivo, o Juiz devolverá todos os papéis com o seu parecer ao Tribunal. O Tribunal, ouvido o Fiscal, concederá ou negará a moratória como julgar acertado; podendo, antes da decisão final, mandar proceder a qualquer exame ou diligência que entender necessária para mais cabal conhecimento do verdadeiro estado do negócio; sendo necessário para a concessão que nela convenha a maioria dos credores em número, e que ao mesmo tempo represente dois terços da totalidade das dividas dos credores sujeitos aos efeitos da moratória."

1007 Muito elogiado, diga-se, pela "abundância" dos meios preventivos da falência. Cf. Darcy BESSONE, Instituições de Direito Falimentar, São Paulo, Saraiva, 1995, p. 14.

${ }^{1008}$ Rubens REQUĩ̃o, Curso de Direito Falimentar, v. 2, São Paulo, Saraiva, 1995, p. 16.

1009 Trajano Miranda Valverde, Comentários à Lei de Falências, v. 2, Rio de Janeiro, Forense, 2001, p. 237; Walter T. Álvares, Curso de Direito Falimentar, Belo Horizonte, Sugestões Literárias, 1982, p. 453.

${ }^{1010}$ Apenas eles se submetiam, na vigência do revogado Decreto-Lei n. ${ }^{\circ}$ 7.661/45, à concordata: art. 156, $\S$ $1^{\circ}$.
} 
decide da sua procedência ou improcedência, segundo as regras prescritas na lei”, queiram ou não os credores ${ }^{1011}$. A concessão da concordata dependia, pois, tão somente do atendimento aos requisitos legais (LF: art. $158 \mathrm{c} / \mathrm{c}$ art. 140) ${ }^{1012}$.

Nesse contexto, evidentemente, não tem lugar a feição contratual. São palavras de Trajano Miranda VALVERDE: “A configuração nitidamente processual que a lei vigente imprimiu ao instituto da concordata, quer preventiva, quer suspensiva da falência, não permite mais se duvide de sua feição característica - um favor, que o Estado, através do Poder Judiciário, concede ao devedor comerciante, infeliz e de boa-fé.",1013 Assim, sintetiza Rubens REQUIÃO: "Na ordem processual, a concordata preventiva configura uma demanda. Uma ação que o devedor ou falido promove contra os seus credores, os quais configuram uma só parte e que agem como litisconsorte. "1014

A Lei n. ${ }^{\circ} 11.101 / 05$, modificando o sistema do Decreto-Lei n. ${ }^{\circ}$ 7.661/45, restabeleceu - em consonância com as mais modernas legislações no mundo - a tradição anterior de atribuir aos credores o poder de decidir sobre a solução não liquidatória da crise do devedor (art. 45 e art. 58, $1^{\circ}$ ). Nada obstante, manteve a necessidade de recurso ao Poder Judiciário e à homologação do plano aprovado (art. 58).

Sergio CAMPINHO atribui à recuperação judicial a natureza contrato judicial, com feição novativa. Resulta da manifestação de vontade do devedor, pelo plano apresentado $^{1015}$, e dos credores, pelo órgão deliberante (a assembleia geral de credores). Sustenta ele que sua submissão ao processo judicial não a desnatura. Isso, porque a sentença homologatória não promove nenhuma alteração no conteúdo das disposições do plano de recuperação estabelecidas entre as partes. O processamento compulsório pelo Poder Judiciário contribui para reduzir reventais erros, permitir aos credores a oportunidade de verificarem eventual prejuízo a seus interesses e, ainda, dotar o acordo de força executiva. Mas não altera a natureza contratual do instituto, limitando-se o magistrado a verificar as disposições legais aplicáveis sobre o plano ${ }^{1016}$. Já Vera Helena de

\footnotetext{
${ }_{1011}$ Comentários à Lei de Falências, v. 2, Rio de Janeiro, Forense, 2001, p. 238.

1012 A tal ponto era irrelevante a vontade dos credores, que, não estando presentes os requisitos, o juiz não deveria conceder o benefício "ainda que seja de conveniência para os credores a concordata preventiva". Cf. Trajano Miranda VAlverde, Comentários à Lei de Falências, v. 2, Rio de Janeiro, Forense, 2001, p. 288.

${ }^{1013}$ Trajano Miranda VALVERde, Comentários à Lei de Falências, v. 3, Rio de Janeiro, Forense, 2001, p. 288.

${ }^{1014}$ Curso de Direito Falimentar, v. 2, São Paulo, Saraiva, 1995, p. 16.

${ }^{1015} \mathrm{E}$, eventualmente, na concordância com as alterações promovida pelos credores no plano - LREF: art. 56, $\S 3^{\circ}$.

${ }^{1016}$ Falência e Recuperação de Empresa - O Novo Regime da Insolvência Empresarial, Rio de Janeiro, Renovar, 2009, pp. 11-13 e 125.
} 
Mello FrANCO e Rachel SzTAJN defendem que o plano de recuperação é um negócio de cooperação celebrado entre devedor e credores, que muito se assemelha a um contrato plurilateral. Sua homologação visa a assegurar seu cumprimento, reduzindo os custos de transação ${ }^{1017}$.

Jorge LOBO atribui à recuperação a natureza jurídica de ato complexo, porquanto compreende um ato coletivo processual, um favor legal e uma obrigação ex lege. $\mathrm{O}$ ato coletivo é o acordo celebrado entre as partes, que resulta da vontade do devedor manifestada na petição inicial (e, poder-se-ia acrescentar, também mediante o plano de recuperação) e da vontade dos credores manifestada tácita (preclusão da oportunidade de objetar o plano apresentado: art. 58 c/c art. 55) ou expressamente (deliberação tomada em assembleia geral de credores). Essas vontades, complementa o autor, fundem-se, formando uma vontade unitária.

O chamado favor legal está na garantia assegurada pela LREF ao devedor, se atendidos os devidos requisitos, de suspensão das ações e execuções contra ele no período de cento e oitenta dias (art. $6^{\circ}$, caput e $\S 4^{\circ}$ ), de, nos termos do art. 47, sanear o estado de crise econômico-financeira, manter os empregos dos trabalhadores, respeitar os interesses dos credores e de, ao final, "reabilitar-se" (art. 63). E a obrigação ex lege da recuperação judicial está na novação das obrigações abrangidas pelo plano que decorre da sentença homologatória do plano prolatada pelo juízo (art. 59).

Ainda completa Jorge LoBO que a recuperação judicial é um instituto de Direito Econômico, pois que "não se pauta pela ideia de Justiça, mas de eficácia técnica numa zona intermediária entre o Direito Privado e o Direito Público”1018. Essa eficácia técnica, no caso, dirige-se para a "criar condições e impor medidas que propiciem às empresas em estado de crise econômica se reestruturarem, ainda que com o sacrifício de seus credores $" 1019$.

Deveras, a recuperação judicial, por sua complexidade, encontra-se mesmo localizada em zona intermediária entre o direito privado e o direito público - os quais a regem confluentemente.

Não se pode absolutamente desconsiderar a natureza processual da

\footnotetext{
${ }_{1017}$ Falência e Recuperação da Empresa em Crise, Rio de Janeiro, Elselvier, 2008, p. 234.

1018 Comentários, in Paulo Fernando Campos Salles TOLEDO - Carlos Henrique ABRÃo (coord.), Comentários à Lei de Recuperação de Empresas e Falência, São Paulo, Saraiva, 2010, pp. 172-173.

1019 Comentários, in Paulo Fernando Campos Salles TOLEDO - Carlos Henrique ABRÃo (coord.), Comentários à Lei de Recuperação de Empresas e Falência, São Paulo, Saraiva, 2010, p. 176.
} 
recuperação judicial. A instauração do processo, por suas características intrínsecas, não apenas força o estabelecimento de negociações estruturadas entre as partes envolvidas, mas ainda permite que essas tratativas - já por si presumivelmente "tensas" e eventualmente hostis, pois que assentadas em ambiente e sobretudo em circunstâncias extraordinárias e estranhas aos agentes econômicos - sejam supervisionadas pelo Poder Judiciário - para evitar abusos e condutas desleais ${ }^{1020}$-, com o auxílio do administrador judicial (auxiliar da Justiça, isento em relação aos interesses envolvidos e com marcante função fiscalizatória) e do Ministério Público.

Além disso, a homologação do acordo celebrado entre as partes produz o efeito de novar ex lege as obrigações por ele abrangidas ${ }^{1021}$ e, ademais, gera um título executivo - o que, em conjunto, confere certeza e segurança quanto ao cumprimento de suas disposições ${ }^{1022}$. Acrescente-se que a atuação do Poder Judiciário é necessária para a efetivação do favor legal, em que também consiste a recuperação judicial - por exemplo, no que se refere ao stay period previsto pelo art. $6^{\circ}$ da Lei n. ${ }^{\circ} 11.101 / 05$ e na vedação, por igual prazo, à venda ou à retirada do estabelecimento do devedor de bens de capital que, embora de propriedade aos credores, sejam essenciais à atividade (art. $49, \S 3^{\circ}$, in fine).

Por outro lado, o ressaltado caráter contratual está evidente. A deliberação da assembleia geral que aprova o plano (ou, sucedaneamente, a aprovação tácita) constitui um ato coletivo (processual, como dito) dos credores (no preciso sentido que foi objeto de exame no Capítulo 3, quando se tratou de deliberação assemblear ${ }^{1023}$ ). Essa manifestação coletiva de vontade, contudo, produz em conjunto com o plano apresentado pelo devedor (que, eventualmente, manifesta concordância com alteração promovida pelos credores na versão original do plano) um acordo, que é então homologado.

Contudo, esse acordo, em si mesmo, não parece ser, entendemos nós, um ato coletivo. Isso, porque, mesmo considerando a carga principiológica do art. 47 da Lei n. ${ }^{\circ}$ 11.101/05 e a consequente funcionalização do direito de voto dos credores (na assembleia geral), não existe perfeito alinhamento de interesses entre credores e devedor, mas preponderantemente contraposição - e o acordo (isto é, o plano aprovado) é, nas palavras de Tullio AsCARELl, “justamente o instrumento jurídico da solução dessa

\footnotetext{
${ }^{1020}$ Como sustenta Sergio CAMPINHO.

1021 Trata-se da obrigação ex lege de que trata Jorge LOBO.

1022 Conforme ressaltaram Vera Helena de Melo FRANCO e Rachel SzTAJN.

${ }^{1023}$ Item 3.3.1, supra.
} 
contraposição",1024.

É também dever do credor, na persecução de seu direito de crédito - de que o direito político de voto é desdobramento, uma vez instaurado o concurso recuperacional e provocada a assembleia -, observar as demais finalidades da recuperação judicial previstas pelo art. 47 da LREF. Contudo, a adição de um dever (leia-se, de uma posição jurídica subjetiva simples passiva) ao complexo direito subjetivo não o desnatura. Credor e devedores no bojo da recuperação judicial não estão nas mesmas condições em que se encontram os sócios discordantes em uma assembleia societária - nem estão como credores dissonantes em uma assembleia geral de credores. Falta-lhes o interesse comum em que se amalgamam os sócios de uma sociedade e mesmo os credores em concurso recuperacional. Por isso, é difícil estender a noção de ato coletivo - como se caracteriza a deliberação dos credores - também ao "acordo" (o plano aprovado) entre credor e devedores.

Mas esse acordo aproxima-se de um contrato - embora fortemente regrado pelas disposições processuais aplicáveis - de que são partes o credor e a comunhão de credores - os credores monoliticamente considerados, que se manifestam unitariamente ou pela ausência de objeção ao plano no prazo legal (aprovação tácita) ou pela deliberação da AGC (aprovação expressa). A vinculação dos credores ausentes e discordantes é questão atinente ao ato coletivo da deliberação, que funde as manifestações de vontade em uma só, e não ao acordo (bilateral) celebrado entre a comunhão de credores e o devedor em recuperação.

Assim, parece-nos que a recuperação judicial é um ato complexo que congrega um negócio jurídico (contrato) processual, um favor legal e uma obrigação ex lege, constituindo instituto de direito econômico.

\subsection{O "interesse" recuperacional}

O abuso de voto caracteriza-se pelo exercício desse direito político em desacordo com as finalidades que a lei lhe impõe ao assegurá-lo a seu titular. Assim, em última instância, o debate sobre o tema deve versar sobre o delineamento das finalidades econômicas e sociais que a ordem jurídica impõe a esse "direito". E essa investigação não

${ }_{1024}$ O Contrato Plurilateral, in Problema das Sociedades Anônimas e Direito Comparado, São Paulo, Saraiva, p. 276. 
prescinde de um exame mais amplo, acerca das "funções" e finalidades do próprio direito concursal ou, mais especificamente, da recuperação judicial.

O tema é muito complexo, mas sua análise torna-se imprescindível para se lançarem luzes sobre os padrões que permitem esquadrinhas o exercício regular e o exercício abusivo do voto pelo credor na recuperação judicial. É preciso, pois, investigarse o "interesse da recuperação" - o interesse recuperacional, por analogia ao interesse social, nas sociedades. Assim, como, nas companhias, a análise das finalidades do voto pelo acionista passa pelo prévio exame do interesse social, a verificação do abuso ou não do direito de voto na recuperação judicial requer a investigação do interesse na recuperação.

\subsubsection{As finalidades da recuperação judicial}

Entre os institutos previstos pela lei para a empresa em crise, a recuperação judicial (bem assim a extrajudicial) é aquele destinado à empresa viável, cuja crise é, portanto, reversível ${ }^{1025}$. Diversamente, a falência destina-se àquele empresário cuja empresa é inviável e a crise é, portanto, irreversível, não restando alternativa senão a liquidação.

A disciplina da recuperação judicial pela Lei . $^{\circ}$ 11.101/05 avança muito em relação à concordata, alternativa à falência prevista pelo Decreto-Lei n. ${ }^{\text {o }}$ 7.661/45. Trata-se de uma completa mudança de princípios, objetivos e meios.

Assim, por exemplo, a decisão sobre a concessão da medida já não cabe ao juízo, mas aos credores, os principais interessados. Por decorrência, essa concessão não está mais sujeita a critérios puramente formais e sem relação direta com a viabilidade da empresa, como sucedia na revogada Lei de Falências. Estribados nos documentos que o devedor deve lhes fornecer (além do próprio plano de recuperação, demonstrações financeiras, relação de credores, certidões, extratos e, ainda, demonstração da viabilidade do aludido plano e laudo econômico-financeiro e de avaliação dos bens e ativos do devedor - arts. 51 e 53), os credores têm condições - ou pelo menos as disposições legais visam a isso - de realizar um juízo sobre a viabilidade do plano apresentado e, portanto, decidir segundo a possibilidade efetiva de reerguimento da empresa e adimplemento do passivo

1025 Paulo Fernando Campos Salles de Toledo, Recuperação Judicial, a Principal Inovação da Lei de Recuperação de Empresas e Falências, in Revista do Advogado AASP, n. 83, ano XXV, setembro de 2005, p. 102. 
nas condições indicadas.

Ainda com relação a esse propósito de reerguimento, o plano pode atingir a generalidade dos débitos - apenas com as exceções expressamente previstas pela Lei $n$. ${ }^{\circ}$ 11.101/05 - e não apenas os quirografários, a que se restringia a antiga concordata. Além disso, os meios de recuperação não são fixados taxativamente pela própria lei; além daquele extenso rol previsto pelo art. 50, é lícito às partes elegerem os que entender necessários e suficientes à superação da crise. Também a disciplina de alguns desses meios é bastante favorável à recuperação, como é o caso da ausência de sucessão, nas dívidas do alienante, dos adquirentes de estabelecimentos vendidos judicialmente em processo de recuperação (art. 60, parágrafo único, c/c art. 141).

Uma vez aprovado o plano, o credores têm a oportunidade de acompanhar sua execução - não apenas pelo órgão superior da comunhão de credores (i.e., a assembleia geral de credores), mas também pela constituição de um órgão bem mais dinâmico, o comitê de credores. Como se vê, há toda uma estrutura institucional e orgânica a serviço da recuperação judicial, de seus credores e do devedor.

Todos esses avanços, exemplificativamente citados, e todos os mais que da lei constam, todavia, devem ser analisados à luz do que dispõe o art. 47, "pedra de toque do novo sistema" ${ }^{\text {,1026. }}$.

Conforme anota Fátima Nancy ANDRIGHI, a Lei n. ${ }^{\circ} 11.101 / 05$ adota também a técnica legislativa dos princípios, espécies de normas que se diferenciam das regras 1027 e 1028 , e, assim, o sistema falimentar passa a ser "fundado em normas de cunho geral que informam os valores buscados pelo legislador”.

Esses princípios, completa a mesma autora, positivam certos valores a serem protegidos pela ordem jurídica e conferem unidade ao sistema normativo. Desse

\footnotetext{
1026 Sheila Christina Neder CEREZETTI, A Recuperação Judicial de Sociedades por Ações - O Princípio da Preservação da Empresa na Lei de Recuperação e Falências, tese de doutorado, Faculdade de Direito da USP, São Paulo, mimeo, 2010, p. 159.

${ }^{1027}$ Comentários, in Osmar Brina CORRÊA-LIMA - Sérgio Mourão CORRÊA-LIMA (coord.), Comentários à Nova Lei de Falência e Recuperação de Empresas, Rio de Janeiro, Forense, 2009, p. 490.

${ }^{1028}$ Do tema já se tratou, em certa medida, no Capítulo 2. Em todo caso, transcrevemos a seguir os conceitos propostos por Humberto ÁvilA para cada uma dessas espécies de normas. Quanto às regras, diz ele: "são normas imediatamente descritivas, primariamente retrospectivas e com pretensão de decidibilidade $e$ abrangência, para cuja aplicação se exige a avaliação da correspondência, sempre centrada na finalidade que lhes dá suporte ou nos princípios que lhes são axiologicamente sobrejacentes, entre a construção conceitual da descrição normativa e a construção conceitual dos fatos." Já os princípios são "normas imediatamente finalísticas, primariamente prospectivas e com pretensão de complementariedade e de parcialidade, para cuja aplicação se demanda uma avaliação da correlação entre o estado de coisas a ser promovido e os efeitos decorrentes da conduta havida como necessária à sua promoção." Cf. Teoria dos Princípios - Da Definição à Aplicação dos Princípios Jurídicos, São Paulo, Malheiros, 2011, PP. 78-79.
} 
modo, se uma regra puder ser cumprida de mais de uma maneira, deverá ser adotado o comportamento que mais se coaduna com o princípio jurídico aplicável; igualmente, se duas normas estão em aparente contradição, deve ser privilegiada aquela que está mais conforme o princípio $^{1029}$.

Esses princípios, explica Eros Roberto GRAU, podem ser explícitos ou implícitos, conforme sejam recolhidos diretamente do texto legal (ou constitucional) ou defluam do sistema, como resultado da análise de diversos preceitos normativos ${ }^{1030}$. De todo o microssistema da Lei n. ${ }^{0} 11.101 / 05$ decorrem princípios aplicáveis à recuperação judicial, mas o art. 47 é o cerne principiológico explícito desse instituto específico.

Os princípios que constam do referido dispositivo enunciam os objetivos do instituto. Prescrevem, por isso, as finalidades que devem ser perseguidas pelos participantes mediante o processo de recuperação judicial. A disciplina do instituto pela Lei n. ${ }^{\circ} 11.101 / 05$ foi disposta de modo que favoreça o atendimento a tais finalidades e naturalmente a interpretação dos dispositivos legais deve ser feita à luz do que dispõe o art. 47.

Observa Paulo Fernando Campos Salles de Toledo que esses princípios são divididos em duas categorias conforme o grau de premência ordenado pelo legislador ${ }^{1031}$. Objetiva-se, antes de tudo, a superação da crise econômico-financeira $d o$ devedor (art. 47, 1ª parte) e, com isso ( “a fim de permitir...”), uma vez mantida em operação a empresa (a atividade), o atendimento às demais finalidades próximas e mediatas (art. $47,2^{\mathrm{a}}$ parte).

Em outras palavras, preliminarmente, deve-se perseguir " a superação $d a$ situação da crise econômico-financeira do devedor" e, uma vez alcançada, serão atingidos os demais objetivos próximos e mediatos ${ }^{1032}$ ("manutenção da fonte produtora, do emprego dos trabalhadores e dos interesses dos credores, promovendo, assim, a

\footnotetext{
${ }^{1029}$ Comentários, in Osmar Brina CORRÊA-LIMA - Sérgio Mourão CORRÊA-LIMA (coord.), Comentários à Nova Lei de Falência e Recuperação de Empresas, Rio de Janeiro, Forense, 2009, p. 490.

${ }^{1030}$ Ele ainda inclui os chamados princípios gerais de direito, coletados do "direito pressuposto". Cf. A Ordem Econômica na Constituição de 1988, São Paulo, Malheiros, 2010, p. 155.

${ }^{1031}$ O legislador "procura, pelo instituto da recuperação judicial, atingir finalidades a médio prazo e mediatas. O artigo 47 da LRE as enumera todas, cabendo ao intérprete enunciá-las”. Destarte, quer, em um primeiro momento, "estancar a hemorragia para, mais adiante, vencida a moléstia, permitir que o paciente volte à vida normal.” Cf. Recuperação judicial, a principal inovação da Lei de Recuperação e Empresas LRE, in Revista do Advogado AASP, v. 83, setembro de 2005, p. 102.

${ }^{1032}$ Também Jorge LOBO faz essa distinção: “A recuperação tem por finalidades imediatas a preservação dos negócios sociais, a continuidade do emprego e a satisfação dos direitos e interesses dos credores, e por finalidades mediatas, estimular a atividade empresarial, o trabalho humano e a economia crediticia." Cf. Comentários, in Paulo Fernando Campos Salles TOLEDO - Carlos Henrique ABRÃo (Coords.), Comentários à Lei de Recuperação de Empresas e Falência, São Paulo, Saraiva, 2010, p. 180.
} 
preservação da empresa, sua função social e o estímulo à atividade econômica”).

Esse escalonamento veicula ainda uma distinção importante, para a qual se quer dar destaque. É que o primeiro desses objetivos está diretamente ligado à figura do devedor ( "a superação da situação da crise econômico-financeira do devedor"), enquanto os demais objetivos (para o alcance dos quais o primeiro instrumentalmente se volta) não decorrem necessariamente do devedor, mas da manutenção da atividade econômica empresária. Essa constatação é importante, porque revela, a um só tempo, uma diferença de essência entre a falência e a recuperação judicial - que estava presente mesmo no regime anterior -, e uma identidade parcial que não existia sob a vigência do Decreto-Lei n. ${ }^{\circ} 7.661 / 45$ e que foi introduzido pelo regramento vigente.

\subsubsection{Objetivo instrumental: a recuperação do devedor}

Diferentemente do que sucede na quebra, na recuperação judicial não há desapossamento. Ao contrário, salvo as hipóteses excepcionais de afastamento do devedor (art. 64) ou de previsão no próprio plano, é ele quem se mantém à testa do negócio e sob cujos ombros repousa o dever (e a confiança dos credores) de reerguimento da empresa. Não se verifica aqui uma separação entre a sorte do negócio e a sorte do empresário tão evidente como na falência - embora a possibilidade de afastamento do devedor faça supor a supremacia da tutela da atividade ${ }^{1033}$. O legislador, em 2005 , formulou uma solução que objetiva a salvaguarda da empresa (da atividade, exercia por meio do estabelecimento) mediante a recuperação do devedor.

Já na falência, essa hipótese não tem lugar. É de sua essência o afastamento do devedor. A exploração da empresa por ele mostra-se inviável e não existe a expectativa legal de reerguimento do sujeito empresário. Isso está expresso já no dispositivo inaugural do capítulo que trata da falência, o art. 75 - dispositivo legal que, por seu conteúdo, exerce mutatis mutandis, para o sistema estritamente falimentar da Lei n. ${ }^{\circ}$ 11.101/05, a mesma função principiológica que o art. 47, para o regramento recuperacional.

1033 Nesse sentido é o entendimento de Ricardo NEGRÃO, que arrola entre os princípios norteadores da recuperação judicial: “(a) supremacia da recuperação da empresa (aspecto funcional) sobre o interesse do sujeito da atividade (aspecto subjetivo), promovendo, se necessário, o afastamento do empresário e de seus administradores e possibilitando uma gestão técnica profissional (por exemplo: arts. 50, III, IV, V, XIV, e 64-65)". Cf. Recuperação Judicial, in Paulo Penalva SANTOS, A Nova Lei de Falências e de Recuperação de Empresas - Lei $n^{o}$ 11.101/05, Rio de Janeiro, Forense, 2007, p. 141. 
O cotejo, portanto, dos dois aludidos dispositivos põe a nu a diferença de essência entre os dois institutos, a qual justifica, na estrutura da LREF, a manutenção de um sistema procedimental dualista: enquanto o devedor, na recuperação judicial, permanece à frente do negócio, ele é afastado na falência. No primeiro caso, existe a legítima expectativa de que a recuperação do devedor assegurará o emprego econômica e socialmente útil daquele arranjo produtivo envolvido; na quebra, não se cogita dessa possibilidade e, portanto, o falido é afastado das atividades e desapossado da massa falida objetiva. E, quanto a isso, repita-se, não há novidade: o mesmo já sucedia na concordata e na antiga falência; sob o regime do Decreto-Lei n. ${ }^{\circ}$ 7.661/45, o falido era também afastado e desapossado e o concordatário, ao contrário, permanecia na exploração da atividade, sob supervisão do comissário.

\subsubsection{Objetivos próximos e mediatos: os credores e a função social}

A novidade está, no entanto, na identidade de objetivos que se verifica na falência e na recuperação judicial, conforme disciplinadas pela Lei n. ${ }^{\circ}$ 11.101/05. A segunda parte do sempre referido art. 47, ainda que mais extensa em suas disposições textuais, evidencia uma identidade normativa com os objetivos da solução liquidatória prevista pelo art. 75 da mesma lei.

Na redação do art. 47 da LREF, excluídos os “interesses dos credores”, todos os demais objetivos previstos na segunda parte do dispositivo referem-se a interesses difusos. Assim, a manutenção da "fonte produtora" e o "estímulo à atividade econômica" não se destinam a atender ao interesse individual de alguém ou algum grupo vinculado ao devedor ou à empresa, mas visam a preservar a empresa - o que é explicitado no próprio texto legal - e, portanto, conservar a utilidade econômica e social daquele arranjo produtivo em benefício difuso de toda a economia.

Com efeito, preservada a empresa na recuperação judicial (mantida, portanto, a exploração da atividade, mediante o complexo de bens organizado, pelo mesmo titular), ela segue fornecendo ao mercado serviços e produtos ("fonte produtora"), o que favorece a concorrência no mercado e conseguintemente o consumidor ${ }^{1034}$, gera riquezas e

\footnotetext{
${ }^{1034}$ Há mais oferta de utilidades econômicas, o que, segundo os postulados da economia de mercado, pressiona o preço para baixo e a qualidade para cima.
} 
tributos. Por isso mesmo, estimula a atividade econômica ${ }^{1035}$ como um todo, tendo em vista o "efeito multiplicador" da manutenção do agente econômico no mercado ${ }^{1036}$ e atende, por consequência, aos interesses da comunidade em geral e da Fazenda Pública ${ }^{1037}$.

Note-se que mesmo a referência à "manutenção do emprego dos trabalhadores" não diz respeito apenas ao atendimento aos interesses daqueles que especificamente mantêm relação de emprego ou mesmo de trabalho com o devedor ${ }^{1038}$ (mesmo porque a aprovação do plano pode implicar o fechamento circunstancial de vagas), tampouco é atinente à satisfação de eventual crédito trabalhista (pois que, nessa condição, o trabalhador é considerado credor). Trata-se de oferecimento de postos de trabalho ao mercado em geral.

Tudo isso está a significar, no esteio de expressão empregada pelo próprio texto legal do art. 47 da LREF, que os objetivos da recuperação judicial direcionam-se a assegurar - a par de satisfazer os credores constituídos até a propositura da ação e submetidos à recuperação - o cumprimento da função social da empresa. (Mesmo o atendimento aos créditos sujeitos ao concurso resulta no exercício da função social da empresa, na medida em prestigia o sistema de crédito público - que é uma finalidade do direito concursal como um todo ${ }^{1039}$ - e estimula a continuidade da atividade econômica de seus credores.)

Expressado de outro modo, o comando normativo principiológico insculpido no art. 47 da Lei n. ${ }^{\circ} 11.101 / 05$ prescreve como finalidade da recuperação

\footnotetext{
${ }^{1035}$ Em certa medida, dos próprios empreendedores, que, na avaliação dos riscos envolvidos no exercício de sua atividade, considera a possibilidade de, experimentando insucesso, socorrer-se desse expediente.

${ }^{1036}$ Tratando do estímulo à atividade econômica, Rachel SzTAJN faz um comentário útil também à função da preservação da atividade no âmbito concorrencial: "está implícito o reconhecimento de qua empresa é uma das fontes geradoras de bem-estar social e que, na cadeia produtiva, o desaparecimento de qualquer dos elos pode afetar a oferta de bens e serviços, assim como a de empregos, por conta do efeito multiplicador da economia." Cf. Comentários, in Francisco Satiro de SouZA JR. - Antônio Sérgio A. de Moraes PIтOMBo (coord.), Comentários à Lei de Recuperação de Empresas e Falência, São Paulo, RT, 2007, p. 223.

${ }^{1037}$ Mauro Rodrigues PenTEADO, Comentários, in Francisco Satiro de SouZA JR. - Antônio Sérgio A. de Moraes PIтомво (coord.), Comentários à Lei de Recuperação de Empresas e Falência, São Paulo, RT, 2007, p. 74.

${ }_{1038}$ Embora também os abranja; por isso, Jorge LOBO arrola esta finalidade recuperação judicial entre as imediatas. Cf. Comentários, in Paulo Fernando Campos Salles TOLEDO - Carlos Henrique ABRÃO (Coords.), Comentários à Lei de Recuperação de Empresas e Falência, São Paulo, Saraiva, 2010, p. 180. Paulo Fernando Campos Salles TOLEDO observa a manutenção dos empregos é um objetivo imediato (sobre ela afirmou: "É claro que essas finalidades são atingidas de imediato, ao menos temporariamente, com o prosseguimento das atividades da empresa"), mas também mediato ("Mas o legislador quer mais (...). Assim, em primeiro lugar, procura-se manter a fonte produtora. Se a empresa, pois, recuperada, volta a atuar competitivamente no mercado, estarão igualmente mantidos os empregos de seus trabalhadores. "). Cf. Recuperação judicial, a principal inovação da Lei de Recuperação e Empresas - LRE, in Revista do Advogado AASP, v. 83, setembro de 2005, p. 102.

${ }^{1039}$ Nicola JAEGER, Il falimento e Le altre forme di tutela giurisdizionale, Milão, Francesco Vallardi, 1964, p. 65.
} 
judicial a superação da crise econômico-financeira do devedor para que os credores sejam pagos na forma acordada $e$ o exercício da atividade empresária cumpra sua função social. O complexo organizado de bens, colocado a serviço da execução da atividade empresária, cumpre sua função social, pois que gera os efeitos difusos positivos previstos pelo próprio art. 47: geração de empregos, oferecimento de utilidades ao mercado, recolhimento de tributos, estímulo à atividade econômica etc.

Dessa maneira, a norma contida no art. 47 da Lei $n .^{\circ} 11.101 / 05$ atribui concretude às normas constitucionais que preceituam a função social da empresa (dos bens de produção ${ }^{1040}-\mathrm{CR}$ : art. $5^{\circ}$, inc. XXIII; art. 170, inc. III) e favorecem ainda o atendimento a fundamentos da República ${ }^{1041}$ (dignidade da pessoa humana, valores sociais do trabalho e da livre iniciativa - CR: art. $1^{\circ}$, incs. III e IV) e outros princípios da ordem econômica (livre concorrência ${ }^{1042}$ e busca do pleno emprego CR: art. 170, incs. IV e VII).

O mesmo comando normativo decorre do que dispõe o art. 75 da LREF a respeito da falência. O tema será abordado mais adiante. Ao contrário do que sucedia na vigência do Decreto-Lei n. ${ }^{\circ}$ 7.661/45, a falência já não mais se presta exclusivamente ao atendimento dos interesses dos credores. A Lei impôs que também nela, na medida do possível, seja atendida a função social do complexo organizado de bens, agora reunido na massa falida objetiva.

Prescreve o aludido dispositivo que o instituto da falência, ao afastar o devedor da condução dos negócios, visa "a preservar e otimizar a utilização produtiva dos bens, ativos e recursos produtivos, inclusive os intangíveis, da empresa”. Ora, a utilização produtiva do complexo de bens, que não apenas deve ser preservada, mas também otimizada (elevada ao nível ótimo possível), implica seu aproveitamento nos mesmos termos que aqueles previstos pelo art. 47, $2^{\mathrm{a}}$ parte, da Lei n. ${ }^{\mathrm{o}}$ 11.101/05. Essa finalidade, que não existia no regime pretérito, alterou a feição da falência para que também ela produza, na medida do possível, efeitos difusos positivos para a generalidade da economia, mantendo-o como fonte produtora de serviços e bens - a qual, destarte, mantém e gera

\footnotetext{
${ }^{1040}$ Fabio Konder COMPARTO, Função social da propriedade dos bens de produção, in Direito Empresarial, São Paulo, Saraiva, 1990, p. 37.

${ }^{1041}$ Para Jorge LOBO são princípios em que a recuperação judicial se baseia: “a) conservação e função social da empresa; $b$ ) dignidade da pessoa humana e valorização do trabalho; c) segurança jurídica e efetividade do direito, conforme se depreende do art. 47." Cf. Comentários, in Paulo Fernando Campos Salles TOLEDOCarlos Henrique ABRÃo (Coords.), Comentários à Lei de Recuperação de Empresas e Falência, São Paulo, Saraiva, 2010, p. 180.

${ }^{1042}$ Conservada a "fonte produtora", preservado está no mercado um agente econômico que pressiona a concorrência - valor que a Constituição não apenas assegura (CR: art. 173, § 4º), mas fomenta (CR: art. 170, inc. IV).
} 
empregos, estimula a atividade econômica, gera tributos, preserva a empresa (a atividade). Cumpre, enfim, sua função social.

Assim na recuperação judicial, como na falência o cumprimento da função social constitui, portanto, uma finalidade comum. A a diferença marcante, já se disse, está em que naquele primeiro caso não há o afastamento do devedor (art. 47, $1^{\text {a }}$ parte) e neste último ele é obrigatório (art. 75, $1^{\mathrm{a}}$ parte). Havendo uma identidade de objetivos próximos e mediatos, a diferença essencial parece estar no instrumento para a consecução dessas finalidades: enquanto na recuperação judicial, a manutenção do empresário à frente do negócio (em regra) é o meio legal para alcançar o cumprimento dessa função, na falência o seu afastamento é instrumentalmente imprescindível.

\subsubsection{Os interesses difusos}

Existe um conjunto indeterminado de pessoas que sofrem influência do sucesso ou insucesso da recuperação de uma empresa em crise. São eles os beneficiários do cumprimento da almejada função social pelo complexo de bens organizado submetido à legislação concursal. Eles têm, por isso, evidente interesse econômico na recuperação como tinham, aliás, na concordata sob a vigência do direito anterior. Diferentemente, no entanto, do que sucedia no regime do Decreto-Lei n. ${ }^{\circ} 7.661 / 45$, esse interesse passa a ter relevância jurídica com a sistemática adotada pela Lei n. ${ }^{\circ} 11.101 / 05$.

Se é certo que, mesmo no vigente regramento legal, esses beneficiários da preservação da empresa não têm parte no processo judicial, nem assento nas instâncias decisórias, é igualmente induvidoso, por outro lado, que eles são destinatários de tutela jurídica - embora em intensidade e qualidade naturalmente diversa daquela dispensada àqueles que tem interesse jurídico direto na recuperação.

Aliás, a relevância desse público difuso é tamanha, que a recente preocupação do legislador com ele é apontado como um dos fundamentos para a implementação, a partir do último quarto do século $\mathrm{XX}$ nos ordenamentos jurídicos ocidentais de um modo geral, de profundas alterações nas legislações concursais ${ }^{1043}$. De fato, anota Sheila Christina Neder CEREzETTI, "a ampliação da dimensão e da complexidade das estruturas empresariais passaram a exigir a consideração de novas

${ }^{1043}$ Sheila Christina Neder CerezetTI, A Recuperação Judicial de Sociedades por Ações - O Princípio da Preservação da Empresa na Lei de Recuperação e Falências, tese de doutorado, Faculdade de Direito da USP, São Paulo, mimeo, 2010, p. 181. 
funções a serem exercidas pelas normas que pretendem reger a crise ${ }^{\text {1044 }}$. Entre essas "novas funções" está justamente o reconhecimento e uma maior proteção àqueles que se beneficiam, difusamente, da preservação da empresa.

Não é que já não se reconheçam os efeitos benéficos, do ponto de vista concorrencial e do mercado consumidor, da eliminação de agentes econômicos ineficientes. É próprio, e desejável, em um sistema econômico de mercado ${ }^{1045}$, que a livre concorrência premie os agentes econômicos mais eficientes - aptos a fornecer ao mercado produtos e serviços melhores a preços mais reduzidos ${ }^{1046}$, que redunda em maior grau de riqueza para a sociedade em geral ${ }^{1047}$ - e puna os ineficientes, eliminando-os do mercado o que juridicamente pode se processar (embora não necessariamente ${ }^{1048}$ ) pela legislação concursal e, eventualmente, pela via liquidatória-solutória ${ }^{1049}$.

Exatamente por isso, durante muito tempo se creu que o atendimento aos interesses dos credores pela legislação concursal representaria também a satisfação do interesse geral da coletividade. Explica Sheila Christina Neder CEREzETTI que, de fato, " $a$ crença nos benefícios decorrentes da eliminação de empresas insolventes, da qual decorreria devolução ao mercado e recursos produtivos a serem adequadamente utilizados, foi, sob o idela do liberalismo econômico, aproximado ao interesse público" ${ }^{, 1050}$.

O que se percebeu, no entanto, é a ineficiência resultante da dissipação da "energia cinética" (leia-se: proveito econômico e social) produzida por um complexo organizado de bens que vem a não mais ser explorado economicamente em razão de uma legislação concursal que não privilegie o seu (re)aproveitamento útil no próprio mercado. Constatou-se que, nos processos concursais - falimentares ou reorganizacional -, a "devolução" ao mercado dos recursos produtivos com o objetivo de serem

\footnotetext{
1044 Sheila Christina Neder CEREZETTI, A Recuperação Judicial de Sociedades por Ações - O Princípio da Preservação da Empresa na Lei de Recuperação e Falências, tese de doutorado, Faculdade de Direito da USP, São Paulo, mimeo, 2010, p. 180.

${ }^{1045}$ Fabio NuSDEO, Curso de Economia - Introdução ao Direito Econômico, São Paulo, RT, 1997, pp. 131140.

${ }^{1046} \mathrm{O}$ que se alcança com evolução tecnológica, investimento em pesquisa e desenvolvimento,

1047 Embora, em princípio, esse sistema "apenas" privilegie a produção global de riquezas (eficiência alocativa), sem se ocupar de sua distribuição em níveis e segundo padrões considerados socialmente desejados (eficiência distributiva).

$1048 \mathrm{O}$ agente econômico pode simplesmente decidir pela liquidação voluntária e extrajudicial.

1049 "Nem toda falência é um mal", afirma Fabio Ulho COELHO. "Algumas empresas, porque são tecnologicamente atrasadas, descapitalizadas ou possuem organização administrativa precária, devem mesmo ser encerradas." Cf. Curso de Direito Comercial - Direito de Empresa, São Paulo, Saraiva, 2012, pp. 251-252.

${ }^{050}$ Sheila Christina Neder CEREZETTI, A Recuperação Judicial de Sociedades por Ações - O Princípio da Preservação da Empresa na Lei de Recuperação e Falências, tese de doutorado, Faculdade de Direito da USP, São Paulo, mimeo, 2010, p. 181.
} 
"adequadamente utilizados", como cita Sheila Christina Neder CEREZETTI, não era eficiente. E isso se dava justamente porque a legislação não tinha em conta os benefícios difusos que a manutenção daquele arranjo produtivo assegurava.

O resultado, como dito, era a dissipação desse arranjo, com a inutilização ou subutilização dos bens de produção remanescentes e, em consequência, a perda de postos de trabalho, perda de arrecadação tributária, diminuição de oferta de bens e serviços, desestímulo à atividade econômica etc. Podem-se ainda citar os efeitos sistêmicos que a crise da empresa pode gerar, "contaminando" outros agentes do mercado com consequências gravísismas.

Assim, a evolução legislativa em matéria concursal que se seguiu a essa constatação procurou, por um lado, desenvolver técnicas que permitissem ao agente econômico em crise, mediante certos benefícios legais pontuais e transitórios, permanecer à frente do negócio - que, portanto, não se encerraria - e, com os resultados (ou outro mecanismo compensatório), adimplir as obrigações com seus credores. Por outro lado, em caso de liquidação inevitável, a legislação passou a privilegiar mecanismos de otimização do emprego do ativo envolvido.

Dessa maneira, e em qualquer dos casos, propicia-se a eliminação ou mitigação dos efeitos nefandos acima relatados da liquidação pura e simples dos ativos produtivos das empresas em crise. É exatamente essa a função social que a moderna legislação concursal procura atribuir à empresa em crise. É dela que trata a Lei n. ${ }^{\circ}$ 11.10/05 nas finalidades que confere à recuperação judicial (art. 47, $2^{a}$ parte) e à falência (art. 75). Dela é beneficiária toda a comunidade difusa que se relaciona direta ou indiretamente com aquele arranjo produtivo, isto é, não apenas credores, acionistas, mas também trabalhadores, fornecedores, consumidores, comunidades, Fazenda Pública, entes governamentais etc.

Conquanto esses beneficiários não tenham parte no processo concursal e nas instâncias decisórias previstas pela Lei n. ${ }^{\circ}$ 11.101/05, como dito, a promoção da função social da empresa em crise foi erigida a princípio tanto da recuperação judicial como da falência. Esse princípio, portanto, conforma ambos os institutos, que não podem, destarte, se voltar para a infringência a tal finalidade - sob pena de configuração de abuso de direito, nos termos analisados no Capítulo 2.

Com efeito, uma das modalidades de prática dessa ilicitude consiste precisamente na violação dos fins econômicos e sociais do "direito" (CC: art. 187). Os 
citados institutos concursais encontram-se adstritos à persecução dessa finalidade e seu descumprimento pode constituir ato abusivo.

\subsection{3. $O$ interesse dos credores}

Em que pesem as alterações por que passaram as legislações concursais e, talvez, bem a propósito delas -, o interesse dos credores não perdeu prestígio no regramento concursal. Bem ao contrário, a análise que se faz é de que essas alterações procuraram conciliar (o que não significa convergir) os interesses dos credores aos do devedor e, ainda, àqueles de terceiros, obtendo um resultado positivo para todos os envolvidos.

E razões, para isso, não faltam. Primeiro, porque assegurar o crédito é função premente de todo procedimento concursal, mesmo reorganizacional ${ }^{1051}$. Essa é, aliás, uma imposição do sistema de direito. Como observa Lorenzo StANGHELLINI, nenhum ordenamento jurídico moderno pode tolerar, sem reação, que as obrigações não sejam cumpridas ${ }^{1052}$. Do contrário, alastra-se a completa desconfiança entre os agentes do mercado e resta inviabilizada a pratica de qualquer atividade econômica. Com efeito, o crédito é essencial ao tráfico mercantil e sua concessão depende da avaliação pelo capitalista dos riscos envolvidos. Um sistema jurídico que descure da tutela do crédito torna impraticável a circulação do crédito ${ }^{1053}$. Por isso, o sistema concursal deve estruturase de modo que tutela o crédito e, portanto, do credor.

Por outro lado, já foi consignado, quando do exame, no capítulo precedente, do controle externo nas companhias, que a crescente deterioração da situação econômico-financeira do devedor faz deslocar o risco da atividade empresária (que, em princípio, é do empresário devedor ou dos sócios da sociedade empresária devedora) para os seus credores. Quando não há o estado de insolvabilidade, a sorte da atividade

\footnotetext{
${ }^{1051}$ Nicola JAEGER, Il falimento e Le altre forme di tutela giurisdizionale, Milão, Francesco Vallardi, 1964, p. 65.

1052 "Nessu ordinamento giuridico moderno può tollerare, senza reagire, che le obbligazioni non vengano adempiute, pena l'inevitabile cessazione dell'attività economica o la sostituzione della forza pubblica con una 'forza' privata capace di assicurate il generale rispeto degli impegni assunti." Cf. Le crisi di impresa fra diritto ed economia - Le procedure di insolvenza, Bolonha, Il Mulino, 2007, p. 15.

${ }_{1053}$ Daniel Roque Vítolo explica com singular clareza: "el desenvolvimiento de la actividad económica y del tráfico mercantil se encuentra altamente ligado al desarrollo del crédito, el cual, para condiciones más favorables de operatividad, recurre a la evaluación del riesgo y a su calificación." Dessa maneira, quem os outorga procura fundamentalmente conhecer "cuáles son los mecanismos de recuperación y cuáles son lãs posibilidades ciertas de percepción de dicho crédito." Cf. Elementos del derecho concursal, Buenos Aires, Ad Hoc, 2008, pp. 34-35.
} 
explorada e de seus resultados financeiros é de interesse exclusivo dos titulares de capital investido - dos empresários ou dos acionistas da companhia (ou, ainda, sócios da sociedade ou membro da EIRELI). Eles auferirão mais ou menos lucro; suportarão menos ou mais prejuízo, conforme o caso.

Ao credor, a variabilidade dos resultados empresariais é irrelevante, em princípio, nesse contexto. A exigibilidade de seu crédito independente dessa flutuação. Conforme já ficou assentado no Capítulo 3, nas estruturas societárias existe uma relação direta entre o risco assumido e o direito político de condução (direção, controle) da atividade empresarial. Destarte, os empresários ou sócios assumem o risco empresarial e têm em seu poder a condução do negócio. Já os credores não integram essa condução, mas também não estão em princípio sujeitos ao risco.

A situação, no entanto, é outra, se se o devedor ingressa em crise e o estado de insolvabilidade apresenta-se concreto. Nesse caso, o devedor não reúne condições de adimplir seu passivo e, portanto, seu insucesso não acarretará apenas a perda do que ele (ou seus sócios, se sociedade) investiu na atividade econômica ou deixou de ganhar, mas se estenderá também aos credores, que, muito embora não dirijam a atividade - tampouco deveriam sofrer os efeitos do risco -, terão seus créditos frustrados.

Ora, essa exposição dos credores ao risco torna-os forçosamente legitimados a também tomarem parte na direção da atividade empresarial. Verifica-se, destarte, pari passu com a assunção desse risco, um deslocamento do centro decisório, que faticamente, no princípio, e de direito, se instaurado o concurso, passa a sofrer a forte influência (e, em alguns casos, o controle) dos credores. Por isso, como se viu no Capítulo 2, a insolvabilidade é geralmente apontada como uma causa que conduz à imposição de um controle externo sobre o devedor em dificuldades.

Com a instauração do concurso, esse deslocamento efetiva-se de direito e, sob a vigência da Lei n. ${ }^{\circ} 11.101 / 05$, sua participação toma contornos institucionais, pois que são criados órgãos para a efetiva participação política dos credores, quer na condução do negócio, no caso de solução não liquidatória, quer na condução da liquidação, se a hipótese é de quebra. Os credores que, até então, mantêm relação jurídica individual (cada qual) com o devedor, veem-se compelidos a integrar uma comunhão de interesses, no bojo da qual, sob a cadência de um processo judicial, encontram-se aqueles órgãos referidos.

O principal deles é a assembleia geral de credores, que, quanto à comunhão, é o órgão superior. Nele o direito político de dirigir as negociações com o 
devedor - sobre a condução dos negócios deste doravante e, ainda, sobre as condições de pagamento do respectivo passivo - é exercido. Entre a indeterminada e difusa comunidade de pessoas sujeitas à influência direta e indireta da empresa em crise referidas no item precedente, apenas os credores têm assento nesse foro, em que, pelo voto, poderão perseguir o crédito - mas, como se verá, deverá observar as demais finalidades do instituto.

\subsubsection{Instauração do concurso: vontade exclusiva do devedor}

Como se disse, os credores formam uma comunhão de interesses. Haverão de, como os sócios reunidos em assembleia, manifestarem-se vontade única. Pronunciar-se-ão monoliticamente, uma vez ultimada a formação da vontade coletiva pelo método assemblear, a respeito do plano de recuperação apresentado pelo devedor, por exemplo (e sobre qualquer outro assunto de competência da assembleia geral de credores). Convém, contudo, esclarecer que, em que pesem as semelhanças existentes entre a comunhão de interesses nos processos recuperacionais e nas companhias, há uma diferença marcante.

As companhias são constituídas por efeito direto da comunhão de interesse dos fundadores e assim prosseguem por desejo de seus acionistas. Em outras palavras, a sociedade constitui-se e mantém-se porque, estribados na liberdade de associação $^{1054}$, os sócios assim a querem. Trata-se, portanto, de uma comunhão voluntária de interesses, conforme esclarece, em esquemática referência, Tullio ASCARELLI ${ }^{1055}$.

Já o concurso de credores na recuperação judicial é formado pela vontade exclusiva do credor, à qual, como se viu, os credores não podem oferecer resistência. A decisão judicial que defere o processamento da recuperação judicial instaura o concurso que altera a esfera jurídica de todos os credores atingidos sem que estes possam evitá-lo. A suspensão de suas eventuais ações e execuções que sucede a decisão de processamento; a impossibilidade de exercer o crédito fora do processo concursal; a necessidade de reconhecimento de seu crédito pelo juízo concursal para que ele possa ser exercido (verificação e habilitação). Enfim, há uma enormidade de efeitos extensos e graves que a instauração do concurso impõe aos credores e dos quais eles simplesmente não podem

\footnotetext{
${ }^{1054}$ A liberdade constitucional de associação (CR: art. 5º incs. XVII a XXI), que se aplica também às sociedades empresárias, consiste na liberdade de constituir, ingressar e retirar-se do ente associativo (observadas, naturalmente, as normas infraconstitucionais que regulam esses entes).

1055 Tullio ASCARELLI, Interesse sociale e interesse comune nel voto, in Rivista trimestrale di diritto e procedura civile, ano V (1951), Milão, Giuffrè, pp. 1163-1165.
} 
subtrair-se.

Eles encontram-se, com efeito, em posição de sujeição e, portanto, não podem evitar o concurso, seu regramento legal e o processo judicial, ao qual são formalmente integrados com a publicação do edital a que alude o art. $52, \S 1^{\circ}$, da Lei $n .^{\circ}$ $11.101 / 05^{1056}$.

O correspondente poder formador a essa sujeição integra o instituto da recuperação judicial previsto pela Lei n. ${ }^{\circ}$ 11.101/05 e é atribuído com exclusividade ao devedor que se encontra em crise e julga-se em condições de superá-la. Presentes os requisitos legais, o deferimento da medida pelo Judiciário impõe-se e o concurso está instaurado. Não há, portanto, vontade dos credores na composição dessa comunhão ${ }^{1057}$.

No caso das companhias, contudo, como dito, a concorrência de todos, e não menos que todos, os fundadores (subscritores) é imprescindível. Mesmo aqueles que contestam as teorias contratualistas são uníssonos em admitir que, quanto ao "espírito criador" da entidade, os sócios encontram-se em plena consonância - as divergências entre acionistas surgem temporal e logicamente após a constituição da companhia. Tanto isso é verdade que, na constituição por subscrição pública, a assembleia de subscritores não pode alterar o projeto de estatuto senão com a concordância da unanimidade dos presentes (LSA: art. 87, $\S 2^{\circ}$ ).

Enquanto nas companhias, a comunhão de interesses é evidente e as divergências é que precisam ser perscrutadas, no caso da recuperação dá-se precisamente o oposto entre os credores: a divergência é a regra e a visualização do interesse comum é que demanda um esforço hercúleo. Ainda apenas a título de ilustração, basta uma leitura ligeira dos comentadores e estudiosos a respeito do tema, para se verificar a ginástica de linguagem a que têm de recorrer para delimitar e fundamentar esse interesse comum. Não é, por óbvio, que não exista; mas, se comparado às divergências que têm lugar nas companhias, a diferença é abissal.

\subsubsection{2. $O$ interesse comum dos credores}

\footnotetext{
${ }^{1056}$ E do qual apenas serão excluídos se o respectivo crédito não for contemplado no plano apresentado pelo devedor.

1057 Apenas mediatamente seria possível verificar vontade deles na composição da coletividade de credores na recuperação (ou a massa falida subjetiva): ao concederem preteritamente crédito ao agora devedor, assumiram o risco de, eventualmente, reunirem-se em concurso.
} 
A comunhão de credores pressupõe a existência de um interesse comum de seus membros, já foi dito. No caso da Lei n. ${ }^{0} 11.101 / 05$, a disciplina "institucional" do instituto da recuperação judicial previu a existência de órgãos, notadamente a assembleia geral de credors, o órgão superior. Assembleia é, por excelência, uma reunião de pessoas titulares desse interesse em comum, para, segundo o método que lhe é próprio, debater e deliberar sobre assuntos determinados ${ }^{1058}$.

No caso da recuperação judicial e da assembleia geral de credores, a dificuldade verificada é justamente a identificação do "interesse comum" de seus memb ros. Com efeito, diferentemente do que sucede nas sociedades e mesmo nos condomínios edilícios, na assembleia geral de credores, os integrantes encontram-se reunidos, como visto, por razão completamente alheia à sua vontade - o deferimento pelo juiz da recuperação judicial, requerida não por eles, mas pelo devedor ${ }^{1059}$.

Ademais, seja pela origem do título (vale dizer, do direito de crédito) que lhes confere participação na assembleia, seja por seus interesses ${ }^{1060}$, essa comunidade mostra-se significativamente mais heterogênea do que aquela verificada nas assembleias de acionistas.

Dessa maneira, embora as lições doutrinárias acerca do interesse social nas sociedades - em particular, nas companhias - apresentem utilidade - o que justificou seu exame no Capítulo 3, precedente - para o desenvolvimento teórico das relações entre credores nos processos concursais ${ }^{1061}$, as diferenças, entre as hipóteses, não podem ser desconsideradas.

A respeito do tema, Erasmo Valladão A. e N. FRANÇA reconhece: "Não é fácil, entretanto, conceituar o que seja o interesse comum dos credores ${ }^{, 1062}$.

Ao tratar da natureza da coletividade de credores na falência - extensível

\footnotetext{
1058 Jairo SADDI, O Comitê e a Assembleia de Credores na Nova Lei Falimentar, in PAIVA, Luiz Fernando Valente de, Direito Falimentar e a Nova Lei de Falências e Recuperação de Empresas, São Paulo, Quartier Latin, 2005, p. 202.

${ }_{1059}$ Ou o decreto de quebra, no caso da falência.

1060 Ainda que tenham direitos de mesma natureza, credores distintos podem manifestar interesses diversos. Dois credores com garantia real, por exemplo, podem manifestar interesses substancialmente diversos. Imaginem-se um banco credor de mútuo e um fornecedor, ambos garantidos com hipoteca; este último poderá ter interesse na continuidade da atividade do devedor (que seguirá comprando seus produtos), enquanto o primeiro poderá preferir a liquidação imediata.

${ }^{1061}$ Veja-se Calixo SALOMÃo FILHO, Recuperação de Empresas e Interesse Social, in Francisco Satiro de SouzA JR. - Antônio Sérgio A. de Moraes Pitombo (coord.), Comentários à Lei de Recuperação de Empresas e Falência, pp. 43-53.

${ }^{1062}$ Comentários, in Francisco Satiro SouzA Junior - Antônio Sérgio A. de Moraes Pitombo (coord.), Comentários à Lei de Recuperação de Empresas e Falência, São Paulo, RT, 2007, p. 192.
} 
à recuperação judicial -, ele refuta individualmente diversas teorias existentes na doutrina: não reconhece natureza de associação (pois que ausente o elemento volitivo e presente o intuito econômico), nem de sociedade (também por carecer de voluntariedade); não é o caso universalidade de direito (pois que composta de pessoas!), nem de comunhão sobre os bens do devedor (pois que, na quebra, o falido, embora desapossado, mantém a propriedade dos bens até ulterior alienação ${ }^{1063}-\mathrm{e}$, acrescentamos nós, a fortiori se rejeita tal tese na recuperação judicial, em que, ordinariamente, o devedor mantém também a posse dos bens).

Destarte, embora fazendo referência à crítica de Trajano Miranda VALVERDE (para quem os credores agem no próprio interesse, contrariando o dos demais concorrentes - o que afastaria a idéia de 'comunhão' ${ }^{1064}$ ), conclui tratar-se de comunhão de interesses. Verbis: "É certo, porém, que, a par dos interesses individuais, pode haver também, tanto na recuperação, como na falência, interesses coletivos ou comuns dos credores (...). é lícito falar, assim, em uma comunhão de interesses entre os credores. „1065

Ainda assim, Erasmo Valladão A. e N. FrANÇA observa que, diferentemente do que ocorre em outros casos de comunhão de interesse - como é o caso dos debenturistas, na Lei . 6.404/76, que dispõe inclusive de um representante único, o agente fiduciário -, no caso dos credores, está ausente a estabilidade ${ }^{1066}$. E acrescenta que "tal interesse constituiria no interesse que tem cada credor em, ao menos a médio prazo, minimizar os seus prejuizos, mediante a ampliação das disponibilidade da massa.,"1067

Charles Jordan TABB afirma que a reorganization apenas tem sentido se conferir aos credores um “'going concern' premium” (um 'prêmio' pela continuidade da atividade), se comparado ao valor da liquidação dos ativos do devedor em crise ${ }^{1068}$. Nesse caso, ela pode ser uma boa opção para o devedor, que mantém seus bens e sua atividade, e para os credores, que se encontrarão em situação mais favorável do que se encontrariam na hipótese de quebra e liquidação de ativos, para os empregados, que mantêm seus trabalhos,

${ }^{1063}$ Paulo Fernando Campos Salles de Toledo, Da Personificação da Massa Falida, in Revista de Direito Mercantil, Industrial, Econômico e Financeiro, v. 78, p. 45.

${ }^{1064}$ Cf. Trajano de Miranda VAlverde, Comentários à Lei de Falências, v. 2, Rio de Janeiro, Forense, 2001 , p. 186, n. 804.

${ }^{1065}$ Comentários, in Francisco Satiro Souza Junior - Antônio Sérgio A. de Moraes Pitombo (coord.), Comentários à Lei de Recuperação de Empresas e Falência, São Paulo, RT, 2007, p. 187, n. 129.

${ }^{1066}$ Idem.

1067 Comentários, in Francisco Satiro SouZA JunioR - Antônio Sérgio A. de Moraes PITOMBo (coord.), Comentários à Lei de Recuperação de Empresas e Falência, São Paulo, RT, 2007, p. 192.

${ }^{1068}$ The Law of Bankruptcy, Nova Iorque, Foundation, 1997, p. 758. Observa, entretanto, que, em certos casos, é possível a obtenção os mesmos benefícios de uma reorganização no curso da liquidação. Refere-se à venda na falência dos ativos em bloco, hipótese em que "the debtor's assets possibly could be sold intact to a third party purchaser for a price that reflects the going concern value of the asse package.” (pp. 758-759) 
para os fornecedores, que mantêm um cliente.

Desse modo, acrescenta o mesmo TABB, as deliberações entre os credores dizem respeito à divisão desse "prêmio" entre eles: "Much of the negotiations that occur in chpater 11 are over how to allocate this premium between various stakeholders ${ }^{, 1069}$.

Essa circunstância é igualmente observada por Fabio Ulhoa CoELHO. De acordo com ele, nos processos concursais, os credores possuem interesses convergentes e divergentes. No caso da recuperação judicial, sustenta que cada classe deve arcar com parcela do "prejuízo" que lhes é imposto forçosamente, para que o devedor encontre meios de se recuperar. E afirma: "Em que medida se pode distribuir com justiça o prejuizo entre as classes é assunto em que os credores certamente divergem. Todos os credores têm interesse em que o devedor se recupere e pague suas dívidas, mas cada um quer empurrar para os demais a conta da recuperação judicial. "1070

\subsubsection{O interesse do devedor}

Naturalmente, encontra-se previsto e disciplinado o interesse do devedor na recuperação judicial. Encontrando-se em crise econômico-financeira e julgando-se apto a revertê-la (pois, do contrário, o pedido de autofalência é obrigatório: art. 105 da LREF), pode o devedor, atendidos os requisitos legais (arts. 48 e 51), propor a ação de recuperação judicial, por meio do qual da qual poderá gozar de certos benefícios legais (o stay period, por exemplo); exercer a atividade empresarial, sem dela se afastar; entabular a negociações estruturadas com seus credores (tratativas que presumivelmente não lograram êxito nas vias extrajudiciais) e, então, ter aprovado e homologado um acordo com seus credores que lhe permita superar a crise e evitar a falência. Em linhas gerais, nisso consiste o interesse do devedor.

E esse interesse está contemplado em uma série de dispositivos legais. A começar pela legitimidade exclusiva para o manejo da ação judicial: apenas o devedor pode propor sua recuperação judicial. E, se atendidos os requisitos formais e objetivos, o deferimento é de rigor e, destarte, instaurado estará o concurso de credores. Trata-se, como

1069 The Law of Bankruptcy, Nova Iorque, Foundation, 1997, p. 758. Em seguida acrescenta: “As noted above, the basic premise underlying a reorganization is that the oigng concern value of the usiness exceeds the liquidation value, and reorganizig allows financially interested partis to caputre that going concern premium."

${ }^{1070}$ Comentários à Nova Lei de Falências e de Recuperação de Empresas, p. 86. 
reiteradas vezes afirmado, de um poder formador - exercido judicialmente, é verdade -, ao qual se sujeitam os credores.

Como sublinhado, existe uma aproximação acentuada entre os institutos da falência e da recuperação judicial, tendo em vista a identidade de objetivos quanto à preservação da empresa e ao cumprimento de sua função social. Mas as distinção está na contemplação pela via recuperacional do interesse do devedor em manter-se à testa do negócio, evitando seu afastamento - que é obrigatório na falência. Nesta, aliás, e embora também haja tutela de seus interesses, o afastamento (desapossamento e interdição) do devedor é providência necessária (é condição) para a preservação, na medida do possível, da função social da empresa. Na recuperação judicial, a realidade é bem outra.

Em que pese a repercussão que o exercício do poder de ajuizamento da ação provoca nas esferas jurídicas de seus credores, uma vez deferida a medida judicial, o devedor transfere para seus credores e integralmente o poder de decidir sobre o deslinde das negociações para evitar a falência. Com efeito, deferido processamento da recuperação judicial, o devedor já não pode desistir da medida (salvo com a concordância dos credores - art. 52, $\S 4^{\circ}$, c/c art. 35, inc. I, al. $d$ ) e, em caso de rejeição do plano apresentado, a falência é incontornável (art. 56, $\S 4^{\circ}$ ). Mesmo depois de aprovado e homologado o plano, é possível, durante o período de supervisão (art. 61), a convolação da recuperação em falência, não apenas com supedâneo em descumprimento do acordo (art. 61, § $1^{\circ}$ ), mas também por simples decisão da assembleia de credores (art. 73, inc. I, c/c art. 42).

Portanto, o interesse do devedor é bastante prestigiado pela disciplina da recuperação judicial. Nada obstante, uma vez provocado a instauração do concurso, o ele passa a depender da resolução dos credores.

\subsection{A falência como meio de preservação da empresa}

Como visto, uma vez instaurado o processo concursal de recuperação, o voto exercido na assembleia geral que delibera sobre o plano atribui aos credores a possibilidade legal de optarem (mediante, do ponto de vista técnico, a adesão ou não ao plano apresentado) pela manutenção da via eleita pelo devedor (a aprovação do plano, com sua consequente homologação e a continuidade da recuperação judicial) ou pela mudança de direção e a decretação da falência e o afastamento do devedor. Em qualquer dos casos, indiferentemente, a Lei n. $^{\circ} 11.101 / 05$ prescreve instrumentos legais para o aproveitamento 
útil do arranjo produtivo e, portanto, para o cumprimento de sua função social - em plena consonância com os princípios enunciados pela própria lei e em cumprimento ao comando constitucional (CR: art. $5^{\circ}$, inc. XXIII, e art. 170, inc. III).

A opção pela falência, com efeito, não resulta, absolutamente, em subtrair ao arranjo produtivo a possibilidade de cumprimento de sua função social. Entendimento contrário resultava da disciplina dispensada à falência pelo Decreto-Lei n. ${ }^{\circ}$ 7.661/45. Diversamente, contudo, as modificações introduzidas nesse instituto pela Lei n. ${ }^{\circ}$ 11.101/05, e que serão adiante examinadas, visaram precisamente a possibilidade e a favorecer (fomentar) a preservação e otimização da utilidade produtiva dos bens envolvidos.

Ora, se o fundamento para que se considere abusivo o voto do credor optante pela falência é a violação do fim econômico e social desse direito político, em razão da negativa de atribuição de função social ao arranjo produtivo, essa afirmação verifica-se falsa. Exatamente porque, no sistema dualista brasileiro, a opção pela via falimentar não resulta na negativa de atribuição de função social ao arranjo produtivo.

\subsubsection{A "nova" falência}

Conforme já se pôde afirmar, a reforma implementada pela Lei $n .^{\circ}$ 11.101/05 no sistema concursal brasileiro não se limitou à completa, e quase unanimemente elogiada, modificação na solução organizacional da crise da empresa, em que a vetusta concordata cedeu lugar à recuperação de empresas. Ela abarcou ainda, e também de maneira radical, a disciplina da falência - cuja atual conformação guarda profunda diferença com relação ao modelo adotado pelo Decreto-Lei n. ${ }^{0}$ 7.661/45.

A análise comparativa da matéria estritamente falimentar em cada um dos diplomas legais evidencia a enorme preocupação do legislador de 2005 - que absolutamente não se notava na lei revogada - com a manutenção da utilidade econômica e social do arranjo produtivo do devedor, mesmo após a decretação da quebra.

Isso está a apontar uma mudança de orientação a respeito ao instituto, como anteriormente disciplinado pela revogada Lei de Falências. Não se abandonou, como não poderia deixar de ser, a finalidade executória - que lhe é da essência -, voltada à satisfação dos créditos envolvidos. Mas, mediante a introdução de um conjunto significativo e coordenado de alterações profundas, de natureza pricipiológica $e$ 
procedimental, o legislador procurou atribuir uma nova finalidade ao instituto.

Paralelamente ao atendimento aos interesses (egoísticos) dos credores, na medida das forças da massa falida, o legislador determinou medidas voltadas para assegurar o cumprimento da função social do arranjo produtivo a ela submetido. Essas medidas conferem à falência uma sistemática tão contrastante com aquela prevista pelo Decreto-Lei n. $7.661 / 45$ e, por outro lado, aproximam-na em suas finalidades tão intimamente da recuperação de empresas (veja-se, v.g., a confluência principiológica dos artigos 47 e 75 da LREF), que não seria exagero afirmar-se que a Lei n. ${ }^{\circ} 11.101 / 05$, a par da criação do regime recuperacional, engendrou uma "nova" falência - em plena consonância com as modernas concepções em direito falimentar ${ }^{1071}$.

Essa modificação radical no instituto da falência é constatada pela generalidade dos comentadores da Lei n. $^{\circ} 11.101 / 05$.

Essa preocupação da vigente lei com a função social da empresa é destacada por Paulo Fernando Campos Salles de Toledo, para quem a falência por ela prevista não é "a nossa velha conhecida, mas uma falência renovada", que tem também por objetivo, nos termos do texto legal, "preservar e otimizar a utilização produtiva dos bens, ativos e recursos produtivos, inclusive os intangíveis. "1072 Fabio Ulhoa COELHO também registra as "significativas alterações" na disciplina da matéria, que objetiva desde a otimização do recursos até “certa contribuição à luta pela manutenção da estabilidade da moeda nacional”"1073, e Carlos Klein ZANINI destaca que a falência, na nova lei, passou por uma "mudança de paradigma" e não é mais vista como fim em si mesmo, mas como meio a serviço da preservação da empresa ${ }^{1074}$.

Esclarecedoras são ainda as palavras de Adriana Valéria Pugliesi GARDINO, em dissertação de mestrado sobre a evolução da disciplina legal da empresa em crise no Brasil. Ao tratar especificamente da falência na Lei n. ${ }^{\circ}$ 11.101/05, a autora afirma que "esta [a falência] se apresenta com uma nova feição, com objetivos distintos daqueles previstos no ordenamento jurídico precedente." E, em seguida, completa: "Muitas das

\footnotetext{
${ }^{1071}$ Roberto García MARTínEZ afirma que a preservação da empresa é vista como uma solução de fundo, não simplesmente como um meio de alcançar uma melhor liquidação da massa falida, mas como solução da crise econômica e de preservação da empresa em crise, apartando-a da figura e da sorte do empresário. Cf. Derecho Concursal, Buenos Aires, Abeledo-Perrot, 1997, p. 36.

${ }^{1072}$ Cf. Comentários, in Paulo Fernando Campos Salles de TOledo - Carlos Henrique ABRÃo (coord.), Comentários à Lei de Recuperação de Empresas e Falências, São Paulo, Saraiva, 2010, p. 50.

${ }^{1073}$ Falências: Principais Alterações, in Falências: Principais Alterações, in Revista do Advogado AASP, v. 83 , setembro de 2005, p. 51.

${ }^{1074}$ Comentários, in Francisco Satiro SouzA Junior - Antônio Sérgio A. de Moraes Pitombo (coord.), Comentários à Lei de Recuperação de Empresas e Falência, São Paulo, RT, 2007, pp. 337-338.
} 
alterações e invocações havidas no âmbito da falência revelam que o legislador priorizou a preservação da atividade produtiva tanto quanto possível, mesmo na falência. "1075.

Por sua vez, Fátima Nancy ANDRIGHI explicita o entendimento de uma transformação radical no instituto: afirma estarem superadas as visões clássicas da falência e que tônica do instituto passa a ser, com a nova lei, “a intervenção na administração de uma organização que, em crise, não consegue mais harmonizar os interesse de todos aqueles que com ela se relacionam” e, dessa maneira, prioriza-se a manutenção dessa organização empresarial, "mesmo no caso de falência, para buscar nova harmonia em seu seio ${ }^{, 1076}$.

Dessa maneira, resta claro que as alterações implantadas pela Lei n. $^{\circ}$ 11.101/05 no instituto da falência, se comparado ao regime anterior, não foram pontuais, mas radicais e modificaram-lhe a própria "feição" com o propósito manifesto de assegurar a manutenção do arranjo produtivo, apesar do desapossamento - ou, melhor seria dizer, mediante ele, já que, como observa Claros Klein ZANINI, esse expediente que afasta o devedor da gestão da empresa é “meio necessário para preservação da empresa” ${ }^{1077}$ (ao contrário do que, como regra, sucede na recuperação judicial - art. 64).

Essa transformação na falência é, repita-se, sistemática. Deflui, pois, de

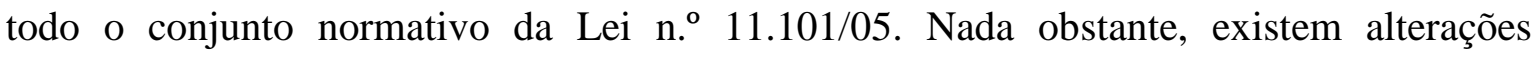
normativas determinantes para esse resultado. Elas é que são postas em exame a seguir.

\subsubsection{Os princípios enunciados pelo art. 75 da Lei n. $^{\circ} 11.101 / 05$}

A Lei n. ${ }^{\circ} 11.101 / 05$ contém princípios decorrentes de todo o sistema, mas, assim como o art. 47 em relação à recuperação judicial, o art. 75 contém o cerne principiológico explícito aplicável à falência.

\footnotetext{
1075 Cf. A Evolução do Tratamento Jurídico da Empresa em Crise no Direito Brasileiro, dissertação de mestrado, Faculdade de Direito da USP, São Paulo, mimeo, 2006, pp. 193-194. E, após citar as diversas alterações legislativas que dão suporte àquela afirmação, a autora conclui: “Assim, partindo-se da letra do artigo 75 da lei em vigor, arriscamos afirmar - e sem qualquer pretensão de esgotar o tema - que a falência consiste no estado insuperável de crise econômico-financeira da empresa e do empresário, que, reconhecida por decisão judicial, afasta o devedor de suas atividades (evitando que a sua presença implique perturbação do equilíbrio da ordem econômica), o que deve ser feito, entretanto, mediante a adoção de medidas que visem a preservar a utilização produtiva dos bens, ativos e recursos produtivos da empresa, inclusive os de natureza intangível e, mediante instauração do concurso de credores, efetuar o pagamento dos credores, de acordo com a ordem de classificação legal.” (p. 198)

${ }^{1076}$ Comentários, in Osmar Brina CORRÊA-LIMA - Sérgio Mourão CORRÊA-LIMA (coord.), Comentários à Nova Lei de Falência e Recuperação de Empresas, Rio de Janeiro, Forense, 2009, p. 492.

1077 Comentários, in Francisco Satiro SouZA JunioR - Antônio Sérgio A. de Moraes Pitombo (coord.), Comentários à Lei de Recuperação de Empresas e Falência, São Paulo, RT, 2007, p. 338.
} 
Ele delineia, por isso, os traços característicos desse instituto, que tanto o fazem destoar daquele modelo regrado pelo Decreto-Lei n. ${ }^{o}$ 7.661/45. São três os princípios por ele enunciados.

De acordo com o dispositivo, a falência (1) implica o "afastamento do devedor de suas atividades" na falência e (2) tem por objetivo "otimizar a utilização produtiva dos bens, ativos e recursos produtivos, inclusive os intangíveis da empresa". Em acréscimo, o parágrafo único ao mesmo artigo determina (3) o atendimento pela falência aos "princípios da celeridade e economia processual", o que pode ser considerado outro objetivo do instituto, embora instrumental (objetivo-meio).

Quanto ao afastamento do devedor de suas atividades, não há inovação se comparado ao direito anterior. Essa característica é elementar à falência ${ }^{1078}$, e, nada obstante a aproximação íntima promovida pela vigente LREF entre a liquidação (falência) e a reorganização (recuperação), foi mantida. Trata-se, aliás, de um dos pilares do sistema dualista da insolvência, que foi reeditado pela Lei n. ${ }^{\circ} 11.101 / 05$.

Assim na recuperação judicial como na falência, por decorrência do desequilíbrio verificado entre os interesses incidentes sobre a empresa, a instauração do concurso franqueia aos terceiros interessados meios de intervir na gestão empresarial. Por efeito, portanto, de qualquer um dos dois institutos, "interesses de terceiros são internalizados e esses passam a ter voz ativa na condução da empresa" "1079. A intervenção, contudo, não se efetiva da mesma maneira em qualquer dos casos, mas, bem ao contrário, dá-se em muito maior grau na hipótese de decretação de falência.

Decretada a quebra, o exercício da atividade (mediante aquele complexo de bens) pelo devedor é considerado irremediavelmente inviável pela lei: a crise, o para o sujeito empresário, é irreversível. Seu afastamento é, destarte, inexorável: já porque ele não reúne condições (isenção, credibilidade etc.) para presidir o processo liquidatório, que deve visar diretamente ao interesse dos credores, já porque, dado o grau incontornável da crise, não existe expectativa legítima de que ele possa atribuir finalidade produtiva àquele empresa. Faz-se imprescindível, assim, divorciar a sorte da empresa da sorte do

\footnotetext{
1078 Marcelo Andrade FERES, Comentários, in Osmar Brina CORRÊA-LIMA - Sérgio Mourão CORRÊA-LIMA (coord.), Comentários à Nova Lei de Falência e Recuperação de Empresas, Rio de Janeiro, Forense, 2009, p. 774.

${ }^{1079}$ Fátima Nancy ANDRIGHI, Comentários, in Osmar Brina CoRRÊA-LIMA - Sérgio Mourão CORRÊA-LIMA (coord.), Comentários à Nova Lei de Falência e Recuperação de Empresas, Rio de Janeiro, Forense, 2009, p. 493.
} 
empresário $^{1080}$.

Assim, na falência, a intervenção operada pela ordem jurídica é de tal ordem que o afastamento do devedor é inarredável. O controle sobre os bens é deslocado para uma estrutura completamente alheia à estrutura interna do devedor - que se trate de empresário (individual), EIRELI ou sociedade empresária.

Esse afastamento previsto pelo art. 75 da LREF é alcançado pelas normas dos artigos 102 e 103, que, respectivamente, (i) inabilitam o empresário para o exercício de qualquer atividade empresária (inclusive, claro, aquela que vinha exercendo) e (ii), pelo desapossamento, fazem-no perder o poder de gestão e disposição de bens, muito embora mantenha a propriedade - se bem que "esvaziada" ${ }^{1081}$. Desde então, empresário, sócios e administradores nada mais podem fazer (gestão, disposição, representação, inclusive processual, salvo se para defesa dos interesses pessoais - art. 76, parágrafo único), senão o que a Lei n. ${ }^{\circ} 11.101 / 05$ expressamente autoriza (como o poder de fiscalizar a falência, o acertamento do passivo - arts. $8^{\circ}, 103$ etc.), sendo nulos todos os atos realizados em desrespeito a essa prescrição ${ }^{1082}$. Mesmo que admitida a continuação provisória da atividade, ela não será conduzida pelo falido.

O segundo princípio enunciado pelo art. 75 da Lei n. ${ }^{\circ} 11.101 / 05$, que inova em relação ao direito precedente, concerne à preservação da empresa e otimização de seus ativos mesmo no curso da falência. Como se viu, a lei revogada não tinha esse propósito explícito, tampouco previa regras que o favorecessem, limitando-se a disciplina da falência aos expedientes estritamente necessários à satisfação dos créditos, nos limites da força da massa.

O vigente diploma legal, contudo, dando cumprimento ao comando constitucional da função social da propriedade (CR: art. 5º inc. XXIII, e art. 170, inc. III), adota posição diversa, e, a par da necessária exclusão do agente irrecuperável do mercado, dirige a falência também para a preservação da empresa e conservação de sua utilidade

1080 Essa separação, aliás, foi erigida pelo Senador Ramez Tebet (PMDB-MS), relator do projeto na Comissão de Assuntos Econômicos do Senado Federal, a princípio a ser adotado na lei. Cf. Paulo Fernando Campos Salles de Toledo, A Preservação da Empresa, Mesmo na Falência, in DE LUCCA, Newton DOMINGUES, Alessandra de Azevedo (coord.), Direito Recuperacional, São Paulo, Quartier Latin, 2009, p. 528. Cf. também Roberto García MARTíneZ, Derecho Concursal, Buenos Aires, Abeledo-Perrot, 1997, p. 36. ${ }^{1081}$ Paulo Fernando Campos Salles de Toledo, O Conceito de Propriedade e os Bens do Falido, in Revista dos Tribunais, v. 678, abril de 1992, pp. 57-64. Disponível em <http://www.revistadostribunais.com.br/>. Consultado em 15/2/2012, às 15 h50.

${ }^{1082}$ Fátima Nancy ANDRIGHI, Comentários, in Osmar Brina CORRÊA-LIMA - Sérgio Mourão CoRRÊA-LIMA (coord.), Comentários à Nova Lei de Falência e Recuperação de Empresas, Rio de Janeiro, Forense, 2009, p. 494. 
econômica. Trata-se, como visto acima, da distinção mais significativa entre as duas leis em matéria de falência ${ }^{1083}$ : sua finalidade legalmente definida extrapola os limites dos restritos interesses dos credores ${ }^{1084}$ - sem naturalmente desconsiderá-los ou prejudicá-los; aliás, muito ao contrário, uma vez que a preservação da utilidade econômica do ativo do devedor resulta em sua valorização, benéfica evidentemente à massa falida subjetiva.

Veja-se que ao erigir tal comando a princípio também da falência, o legislador equipara quanto a esse aspecto os dois institutos disciplinados pela Lei n. ${ }^{\circ}$ 11.101/05, o liquidatório e o recuperacional. Um e outro guardam diferenças, é certo tanto assim que a lei não supera o sistema dualista -, mas, sendo a preservação da empresa objetivo precípuo da recuperação judicial, a disciplina do art. 75 representa uma aproximação muito intensa entre os institutos. Referindo-se a este e ao artigo 47, Fátima Nancy ANDRIGHI afirma que os dois princípios "poderiam ser resumidos em um único e maior princípios de todo o direito empresarial: a conservação da empresa. "1085

As normas da Lei n. ${ }^{\circ}$ 11.101/05 destinadas à preservação da empresa na falência, não se limitam ao princípio insculpido no art. 75, mas se espraiam a certas regras que lhe dão concreção, tais como a continuação da atividade e a lacração apenas facultativa do estabelecimento; o momento de realização do ativo; a ordem de preferência de alienação do ativo; e a inexistência de sucessão do adquirente do estabelecimento nas dívidas da massa falida. Essas medidas serão objeto de exame a seguir.

Quanto, por fim, ao princípio da celeridade e a economia processual previstas pelo parágrafo único do art. 75 da LREF, convém assentar que não é despicienda $^{1086}$.

\footnotetext{
1083 Sergio CAMPINHO, em abono desse entendimento, afirma textualmente: "o escopo central da falência consiste na liquidação judicial do patrimônio do empresário insolvente visando à preservação do valor do ativo e utilização produtiva dos bens, inclusive intangíveis que integram o estabelecimento (artigo 75)”. Cf. Falência e Recuperação de Empresa - O Novo Regime da Insolvência Empresarial, Rio de Janeiro, Renovar, 2009, p. 426.

${ }^{1084}$ Em plena consonância com o moderno direito concursal: "Ya no se trata de liquidar para repartir, sino de conservar para salvar. "Cf. Roberto García MARTíneZ, Derecho Concursal, Buenos Aires, AbeledoPerrot, 1997, p. 36. De Adriana V. Pugliesi GARDINO são as seguintes palavras: "Parte-se, assim, do princípio de que a insolvência do devedor surte efeitos que transcendem aos interesses individuais entre o empresário e os seus credores, e por esta razão o instituto da falência não pode tratar exclusivamente da liquidação da empresa, mas, ao contrário deve encontrar meios de tutelar também a manutenção da atividade produtiva, dos postos de trabalho e da preservação da concorrência saudável ao mercado." Cf. Evolução do Tratamento Jurídico da Empresa em Crise no Direito Brasileiro, dissertação de mestrado, Faculdade de Direito da USP, São Paulo, mimeo, 2006, p. 42.

1085 Comentários, in Osmar Brina CorRÊA-LiMA - Sérgio Mourão CoRRÊA-LIMA (coord.), Comentários à Nova Lei de Falência e Recuperação de Empresas, Rio de Janeiro, Forense, 2009, p. 491.

${ }^{1086}$ Critica-se a previsão dessa norma no capítulo destinado à falência, quando, na verdade, deveria abarcar também a recuperação judicial. Cf. Carlos Klein ZANINI, Comentários, in SOUZA JUNIOR, Francisco Satiro
} 
Embora, como pondera Adriana V. Pugliesi GARDINO, a previsão legal possa parecer "utópica", "especialmente diante de uma circunstância que, a priori, independe integralmente da vontade da lei”, trata-se também de uma norma-princípio, de aplicação, portanto, cogente e que tem função interpretativa, servindo como referencial hermenêutico para aplicação da lei no caso concreto pelo juízo competente ${ }^{1087}$.

Os efeitos do atendimento a tais princípios não se circunscrevem ao processo em si mesmo ${ }^{1088}$, mas, ao presidir a tomada de decisões do magistrado e, ainda, ao espraiar-se também à atuação dos demais órgãos (Ministério Público, por exemplo), especialmente o administrador judicial, deve redundar em rapidez e economia (leia-se: eficiência) na realização do ativo, na administração dos recursos, no pagamento do passivo etc. Contribui, portanto, para uma minoração dos efeitos deletérios que a demora no processo e na efetivação do processo liquidatório causam aos interesses envolvidos.

São notórios, deveras, os efeitos perniciosos da cessação da atividade e de sua perduração no tempo sobre a massa falida objetiva. Esses malefícios, aliás, atingem não apenas os credores, diretamente envolvidos, mas todos os que com a empresa se relacionam e a economia de maneira geral. E, de um modo geral, as perdas assim geradas são graves e irrecuperáveis - ou de muito custosa recuperação.

A interrupção da atividade empresária implica não apenas a perda do going concern value - aquele valor agregado ao complexo organizado de bens em virtude de sua exploração econômica ${ }^{1089}$-, mas também a desvalorização do estabelecimento resultante da desagregação de seus elementos por sua não utilização. Especialmente certos intangíveis, como a marca, o valor do ponto comercial, o know how, desvanecem-se irreversivelmente nesses casos. A frustração dos contratos e relações empresariais também

de - PITOMBO, Antonio Sérgio A. de Moraes (coordenadores), Comentários à Lei de Recuperação de Empresas e Falência. Lei 11.101/2005, São Paulo, RT, 2007, p. 338.

${ }^{1087}$ Evolução do Tratamento Jurídico da Empresa em Crise no Direito Brasileiro, dissertação de mestrado, Faculdade de Direito da USP, São Paulo, mimeo, 2006, p. 94. Assim, em termos processuais, a aplicação desse princípio pode redundar em menor formalismo, em aplicação das nulidades processuais apenas em caso de efetivo prejuízo, subordinação da instrução probatória à efetiva necessidade etc. Cf. Comentários, in SOUZA JUNIOR, Francisco Satiro de - PITOMBO, Antonio Sérgio A. de Moraes (coordenadores), Comentários à Lei de Recuperação de Empresas e Falência. Lei 11.101/2005, São Paulo, RT, 2007, p. 339.

${ }^{1088}$ Em sentido contrário: Carlos Klein ZANINI, Comentários, in Francisco Satiro SoUZA JUNIOR - Antônio Sérgio A. de Moraes Pitombo (coord.), Comentários à Lei de Recuperação de Empresas e Falência, São Paulo, RT, 2007, p. 338.

${ }^{1089}$ Em matéria de avaliação de empresa (rectius, de seu estabelecimento, i.e., o complexo de bens organizados para o exercício da atividade empresarial - CC: art. 1.142), o going concern value difere-se do valor de liquidação, porque compreende este (que corresponde ao valor dos ativos) e, ainda, a valoração econômica decorrente da aptidão do estabelecimento para gerar lucros. Assim, normalmente aquele é maior que o valor de liquidação. A cessação da atividade, contudo, faz dissipar esse plus. 
ocasionam a perda do aviamento ${ }^{1090}$. Igualmente, estagnação dos ativos pode acarretar de maneira incontornável seu sucateamento. O resultado é assim, a um só tempo, a deterioração do valor de alienação desse arranjo produtivo, em prejuízo dos credores, e a perda da aptidão produtiva do complexo organizado de bens - em detrimento de toda a sociedade.

Dessa maneira, a presteza jurisdicional na falência determinada pelo art. 75 da Lei n. ${ }^{\circ}$ 11.101/05 pode contornar esse duplo inconveniente. Evitada a cessação da atividade ou, ao menos, mitigado o período em que assim se mantém, a preservação e otimização da utilidade produtiva do arranjo produtivo resta favorecida e, portanto, por um lado, facilita-lhe a alienação e evita a perda de valor e, por outro, é propícia à manutenção de sua função social - em benefício dos credores e também de toda a economia, pois é, explorado por outro agente econômico, aquele complexo de bens pode seguir seu curso, ofertando bens e serviços ao mercado, oferecendo postos de emprego, recolhendo tributos etc.

As características marcantes da falência na vigente lei, contudo, não se limitam à carga principiológica do art. 75, mas projeta-se também na disciplina de outros aspectos - disciplina esta que justamente objetiva atribuir concreção a esses princípios enunciados pelo referido dispositivo legal.

\subsubsection{Continuação provisória da atividade}

A continuidade provisória da atividade da massa falida não é inovação da vigente lei. Já o Decreto-Lei n. ${ }^{\circ} 7.661 / 45$ previa-a - e com disciplina, diga-se, mais minuciosa que aquela dispensada pela Lei n. ${ }^{\circ} 11.101 / 05$. Esta limita-se ao que dispõem o art. 99, incs. VI e XI, e art. 150. Aqueles primeiros determinam que, na sentença de quebra, o magistrado pronuncie-se sobre a continuação provisória da atividade e, em caso autorização, faça a correspondente ressalva na proibição à prática de atos de disposição dos bens do falido; já aquele derradeiro dispositivo cinge-se a prescrever que as despesas atinentes a ela serão pagas pelo administrador judicial com os recursos disponíveis.

Em que pese a timidez da disciplina, as diferenças que guarda com relação à revogada lei, embora pontuais, atribuem-lhe uma feição diversa, mais

${ }^{1090}$ Sergio CAMPINHO, Falência e Recuperação de Empresa - O Novo Regime da Insolvência Empresarial, Rio de Janeiro, Renovar, 2009, p. 300. 
consentânea dos propósitos enunciados pelo art. 75 da LREF.

No regime do Decreto-Lei n. ${ }^{\circ}$ 7.661/45, a continuação do negócio apenas tinha lugar se requerida pelo falido (art. 74). Já a Trajano Miranda VALVERDE causava espécie a disposição, pois que, destinada a acautelar a massa falida de maiores prejuízos decorrentes da paralisação do estabelecimento, a medida interessava tanto ao falido quanto, e principalmente, aos credores - o que, defendia o autor, deveria estender a legitimidade para o pedido também ao administrador da falência, i.e., o síndico ${ }^{1091}$.

A disciplina da matéria naquela lei tinha por principal propósito resguardar o falido para hipótese de ulterior impetração de concordata suspensiva - que, sem solução de continuidade no negócio, mostrar-se-ia mais viável ${ }^{1092}$. Esse objetivo deflui claramente do dispositivo que determinava a "cassação" automática da autorização judicial com a fluência in albis do prazo para o manejo do pedido da concordata (LF: art. $74, \S 7^{\circ}$, c/c art. 178). Em caso, todavia, de deferimento da continuação - que, além dessa hipótese acima referida (LF: art. $74, \S 7^{\circ}$ ), poderia ser a qualquer tempo cassado, conforme art. $74, \S$ $6^{\circ}$, da LF -, e tendo em vista o desapossamento do devedor, a gestão do negócio ficava a cargo de um gerente nomeado pelo juiz (LF: art. 74, caput) e remunerado e fiscalizado pelo síndico (LF: art. $74, \S 2^{\circ}$ ).

Já a Lei n. ${ }^{\circ}$ 11.101/05 contém disciplina diversa. A continuação da atividade pela massa falida não está mais condicionada à provocação do devedor, especialmente porque a razão que fundamentava sua legitimidade exclusiva no regime anterior (a possibilidade de futuro pedido de concordata suspensiva) não encontra paralelo na atual lei, ante a impossibilidade de suspensão da falência.

Assim, sem prejuízo de requerimento formulado por qualquer interessado (tendo em vista a inexistência de expressa limitação da legitimidade, são legitimados a fazer o pedido qualquer um que tenha legítimo interesse, inclusive o próprio devedor ${ }^{1093}$ ) em outro momento - não há preclusão ${ }^{1094}$-, o juiz pode agir de ofício ${ }^{1095}$ e é seu dever

\footnotetext{
${ }_{1091}$ Comentários à Lei de Falências, v. 2, Rio de Janeiro, Forense, 2001, p. 26.

1092 "Conservada a empresa através da continuação do negócio na falência, abre-se o caminho para várias soluções jurídicas tendentes a assegurar sua sobrevivência após o procedimento concursal. A primeira delas é a concordata suspensiva que, colocada na lei como termo final ao exercício empresário na falência (art. $74, \S 7^{\circ}$ ), parece, à primeira vista, erigir-se em sua condicionante e única finalidade.” Cf. Nelson ABRÃO, A Continuação do Negócio na Falência. São Paulo, Leud, 1998, p. 160.

1093 Em que pese a impossibilidade de reversão do desapossamento. Cf. Adalberto Simão FILHO, Comentários, in Comentários à Nova Lei de Recuperação de Empresas e de Falências, coord. Newton DE LUCCA - Adalberto SiMÃo FILHO, São Paulo, Quartier Latin, 2005, p. 445.

${ }^{1094}$ Sergio CAmPINHO, Falência e Recuperação de Empresa - O Novo Regime da Insolvência Empresarial, Rio de Janeiro, Renovar, 2009, p. 300.
} 
pronunciar-se a respeito da continuação da atividade e da lacração do estabelecimento já na sentença de quebra (art. 99, inc. XI).

As duas alternativas não são, contudo, necessariamente excludentes ${ }^{1096}$, e Sergio CAMPINHO chega a sugerir que o juiz primeiro determine a lacração e, só ao depois, inteirado dos fatos e até provocado pelo interessado, decida sobre a continuação ${ }^{1097}$. Para o exame da questão, o juiz deve pautar-se, além dos riscos envolvidos ${ }^{1098}$, na necessidade e razoabilidade da tomada da medida para o atendimento a suas finalidades ${ }^{1099}$.

Duas são as finalidades da continuação provisória da atividade empresarial em caso de falência e, na Lei n. ${ }^{\circ}$ 11.101/05, ambas parecem ter sido contempladas.

A primeira delas diz respeito à alienação dos ativos. A continuação da atividade não é meio de realização do ativo fixo do falido. Por isso, aliás, a diz-se dela "provisória": não constituindo meio de realização do ativo, apenas poderá permanecer até que suceda a alienação do complexo de bens ou, antes disso, a juízo do magistrado ${ }^{1100}$.

Nada obstante não seja meio de alienação do ativo fixo, ela presta-se à alienação de parcela dos bens integrantes da massa falida ${ }^{1101}$ e pode, destarte, favorecer o emprego ótimo desses bens e resultar em sua maior valorização - o que justifica o deferimento da medida. Assim, o estoque de matéria prima de uma indústria falida, por exemplo, pode eventualmente ser de melhor proveito para os credores (e da economia como um todo) se, em lugar de ser alienado in natura a algum outro industrial, por

\footnotetext{
1095 Sergio CAMPINHO, Falência e Recuperação de Empresa - O Novo Regime da Insolvência Empresarial, Rio de Janeiro, Renovar, 2009, p. 299.

${ }^{1096}$ Fabio Ulhoa COELHO, Comentários à Lei de Falências e de Recuperação Empresas, São Paulo, Saraiva, 2011, p. 373. É possível, por exemplo, que, inexistindo razões para a continuação da atividade, também seja indeferida a lacração.

1097 Sergio CAMPINHO, Falência e Recuperação de Empresa - O Novo Regime da Insolvência Empresarial, Rio de Janeiro, Renovar, 2009, p. 300.

1098 Afinal, a continuação não pode implicar a geração de novos custos que pressionem ainda mais o já minguado ativo integrante da massa falida.

1099 Adalberto SIMÃo FILHO, Comentários, in Comentários à Nova Lei de Recuperação de Empresas e de Falências, coord. Newton DE LUCCA - Adalberto SIMÃo FILHO, São Paulo, Quartier Latin, 2005, p. 445.

${ }^{1100}$ São observações de Paulo Fernando Campos Salles de TOLEDO: "Note-se, no entanto, que o próprio adjetivo empregado delimita o âmbito dessa continuidade, que será sempre provisória. Será, pois, levada a efeito enquanto não tiver início a realização do ativo, fase que, no atual sistema, deverá ocorrer 'logo após a arrecadação dos bens'." Cf. A Preservação da Empresa, Mesmo na Falência, in DE LUCCA, Newton DOMINGUES, Alessandra de Azevedo (coord.), Direito Recuperacional, São Paulo, Quartier Latin, 2009, p. 527. Também se manifesta Adalberto SIMÃo FILHO: "Será provisória a continuação deste negócio, porque funcionará nestes moldes até a alienação sua nas formas previstas em lei ou até quando o juiz assim decida, caso não se tenha condições econômico-financeiras de se prosseguir no negócio até a sua alienação." Cf. Comentários, in Comentários à Nova Lei de Recuperação de Empresas e de Falências, coord. Newton DE LUCCA - Adalberto SIMÃo FILHO, São Paulo, Quartier Latin, 2005, p. 445.

1101 É o que Nelson ABRÃO chama de "atividade processual de administração forçada com escopo liquidatório”. Cf. A Continuação do Negócio na Falência. São Paulo, Leud, 1998, p. 82.
} 
hipótese, for manufaturado e, então, o produto resultante for vendido ao mercado consumidor - presumivelmente com maior valor agregado ${ }^{1102}$. A ultimação dessa providência demanda a continuação provisória da atividade da empresa, cujo deferimento, nesse caso, não terá por fundamento a conservação do going concern value do ativo fixo, mas o aproveitamento ótimo da matéria prima arrecada pelo administrador judicial.

Não é essa, no entanto, a única finalidade do instituto ${ }^{1103}$ nem a principal. E, portanto, não é apenas nela que deve se estribar o juízo do magistrado acerca da continuidade da exploração produtiva do arranjo empresarial.

A tônica da continuação da atividade está centrada na valorização ou, ao menos, na minoração da perda de utilidade econômica e do valor do complexo produtivo de bens. Mantidos os estabelecimentos em atividade, conserva-se seu aviamento e, por consequência, favorece sua venda como tal, em detrimento da alienação isolada dos $\operatorname{ativos}^{1104}$.

Essa medida judicial, não é demais sublinhar, resulta em benefício da coletividade, que poderá contar com o emprego produtivo daquele arranjo empresarial primeiro no bojo da massa falida e, depois, e sem solução de continuidade, sob titularidade e exploração do adquirente -, e dos credores, que, além de auferirem o eventual resultado positivo (lucro) da atividade enquanto perdurar, obterão maior valor na realização ao final do ativo.

A continuação da atividade, portanto, não se presta exclusivamente à satisfação dos créditos concursais - embora francamente a favoreça -, mas também se destina a assegurar ou tornar propício o cumprimento da função social do complexo de bens arrecadados na falência. Muitos comentadores da Lei n. ${ }^{\circ} 11.101 / 05$ ressaltam essa finalidade, que tomou contornos vivos na vigente disciplina. Assim, Fátima Nancy ANDRIGHI sublinha que esse regime jurídico "faz sobressair o caráter social de proteção

\footnotetext{
${ }^{1102}$ Assim, por ilustração, imagine-se um estoque de matéria prima avaliado em $\mathrm{R} \$ 100$ mil que, empregado no processo industrial a um custo de produção total de $\mathrm{R} \$ 30$ mil, pode resultar em produtos que totalizem R \$200 mil. Nesse caso, a opção pela continuidade provisória terá alcançado um "ganho" de R $\$ 80$ mil em proveito dos credores que de outro modo não se atingiria.

${ }^{103}$ Opinião diversa tem Carlos Henrique ABRÃO, para quem “a continuação provisória é sempre com o intuito de realizar o ativo da empresa, e na percepção do administrador judicial. A continuação é provisória das atividades, e não do negócio”. Cf. Comentários, in Paulo Fernando Campos Salles TOLEDO -Carlos Henrique ABRÃo (Coords.), Comentários à Lei de Recuperação de Empresas e Falência, São Paulo, Saraiva, 2010, p. 372.

1104 Com a continuação da atividade, afirma Sergio CAMPINHO, "se alcançará o desiderato de uma proficiente liquidação do ativo, nela compreendida a alienação da própria empresa ou de suas filiais produtivas, vistas, num ou noutro caso, como unidades de produção viáveis ou que se podem viabilizar pelos recurso e ações do novo titular." Cf. Falência e Recuperação de Empresa - O Novo Regime da Insolvência Empresarial, Rio de Janeiro, Renovar, 2009, p. 300.
} 
aos direitos trabalhistas, notadamente quando o fechamento da empresa possa acarretar danos incomensuráveis aos empregados dela dependentes”. De semelhante modo, Fabio Ulhoa COELHO sustenta ser favorável à continuação da atividade a circunstância de o seu encerramento poder agravar "não só o prejuízo dos credores", mas também "produzir efeitos deletérios à economia regional, local ou nacional",1105.

Em favor do atendimento à função social da empresa pela continuação da atividade milita a regra que não apenas, em contraste com o Decreto-Lei n. ${ }^{\circ}$ 7.661/45, suprime a restrição à legitimidade para a requerer (e, portanto, os credores de um modo geral o podem fazer e, especialmente, o comitê de credores e o próprio administrador judicial), mas ainda admite, no decreto de quebra ou depois dele, seu deferimento de ofício pelo magistrado.

Apesar da disciplina da matéria pela Lei n. ${ }^{\circ}$ 11.101/05 ser francamente favorável à persecução da função social da empresa, uma crítica possível refere-se à timidez da regulação.

A mudança de finalidade atribuída pela lei à falência tem na continuação da atividade uma das mais representativas alterações voltadas para esse objetivo e, no entanto, não houve regulação sobre matérias relevantes - principalmente com relação ao risco envolvido e à manutenção de independência de seus resultados em relação às obrigações a serem atendidas na própria falência. Em matéria de continuação da atividade, Lorenzo STANGHELLINI manifesta extrema preocupação com os riscos envolvidos. Entende ele que, tendo em vista os evidentes riscos da atividade - que pode gerar menos receitas que despesas -, a medida apenas se justifica na presença de alguém disposto a assumir o risco $^{1106}$. De fato, a inquietação justifica-se, especialmente, ante a falta de disciplina mais minudente pela Lei n. ${ }^{\circ}$ 11.101/05. Em que pese esse aspecto crítico, todavia, a continuação não resta inviabilizada em razão dele e é relevante instrumento para a manutenção do valor e da utilidade econômica do arranjo produtivo.

\subsubsection{Realização do ativo logo após a arrecadação}

\footnotetext{
${ }^{1105}$ Fabio Ulhoa CoElHo, Comentários à Lei de Falências e de Recuperação Empresas, São Paulo, Saraiva, 2011 , p. 374.

1106 Le crisi di impresa fra diritto ed economia - Le procedure di insolvenza, Bolonha, Il Mulino, 2007, p. 187: "La continuazione dell'impresa in crisi , con il connesso rischio che l'attivo venga assorbito dalle spese prededucibili (...), è infatti limitato al caso in cui vi sia qualcuno disposto a rendersi acquirente dell'azienda."
} 
Outro aspecto importante diz respeito ao momento da marcha processual em que a alienação dos ativos tem lugar - que, na vigente lei, é antecipado em relação àquele em que o mesmo evento ocorria no Decreto-Lei n. ${ }^{\circ}$ 7.661/45.

Não se refere aqui à venda antecipada dos bens de que trata o art. 113 da LREF, atinente àqueles ativos perecíveis, deterioráveis, sujeitos a considerável desvalorização ou que sejam de conservação arriscada. Esse dispositivo encontra paralelo na revogada LF (art. 73) e poucas novidades apresenta em relação ao regime anterior - se bem que, mesmo tímidas, essas alterações têm por efeito também a manutenção da utilidade produtiva e ótima da massa falida objetiva.

De fato, os comandos normativos de ambas as leis não contêm diferenças, segundo nos parece. Mas, ainda assim, pode-se perceber na redação do art. 113 da Lei n. ${ }^{\circ}$ 11.101/05 uma preocupação explícita com os valores do art. 75 que não se vê no Decreto-Lei n. ${ }^{\circ}$ 7.661/45. Enquanto esta limita textualmente sua previsão aos bens "de fácil deterioração ou que se não possam guardar sem risco ou grande despesa”, a Lei n. ${ }^{\circ}$ 11.101/05 mantém esta última hipótese ("conservação arriscada ou dispendiosa") e, quanto à primeira, expressa-a não apenas ao repetir o termo deterioração (dos bens), que denota, de início, uma ideia de degradação física (embora, claro, a interpretação da Lei de Falências tenha sido bem mais extensa ${ }^{1107} \mathrm{e}^{1108}$ ), mas também pela referência a perecimento (de, parece-nos, âmbito normativo mais amplo ${ }^{1109}$ ) e à sujeição à "considerável desvalorização" - que é uma "deterioração" econômica, mesmo que não física, de frequentíssima ocorrência nos dias correntes, particularmente naqueles bens sujeitos à franca e rápida obsolescência, como é o caso dos equipamentos de informática, dos bens ligados à moda etc. ${ }^{1110}$

1107 Trajano de Miranda VAlverde, Comentários à Lei de Falências, v. 2, Rio de Janeiro, Forense, 2001, p. 24. Nota de J. A. Penalva SAntos e Paulo Penalva SANTOS: “A regra do art. 73 deve ser interpretada de forma mais abrangente, pois, em se tratando de determinados equipamentos que sofrem desgaste acelerado $e$ que se tornam obsoletos rapidamente, aguardar até a fase da liquidação para vendê-los pode na realidade representar um prejuízo para a massa, e também para o falido, maior do que se a venda fosse antecipada."

${ }^{1108}$ Razão por que, reiteramos, a alteração de texto é aqui mencionada mais para evidenciar uma mudança de concepção do legislador (que se reflete na escolha dos termos empregados no texto de lei) do que propriamente uma alteração do comando normativo - que, rigorosamente, não houve; assim antes como agora a norma tem a mesma extensão.

${ }^{1109}$ E que, no texto legal, precede os demais termos - talvez exatamente por denotar uma ideia mais abstrata, de que "deterioração" e "desvalorização" são aplicações mais concretas.

1110 Não se pode olvidar que o valor dos bens decorre de sua utilidade econômica (i.e., da aptidão para satisfação de uma necessidade socialmente manifestada; não deriva, portanto, do trabalho empregado em sua produção - cf. Fabio NuSDEO, Curso de Economia - Introdução ao Direito Econômico, São Paulo, RT, 1997, pp. 60-68). Bens obsoletos não são úteis, ao menos não para as finalidades para as quais foram criados, restando, se muito, o aproveitamento do material utilizado. Veja-se por exemplo a sapataria, objeto de falência, cujo estoque seja formado por sapatos, tênis e sandálias fora de moda. Esses bens, do ponto de vista econômico, não são úteis e não têm, por conseguinte, valor de mercado. 
Portanto, a mencionada mudança de redação, se não altera o sentido normativo, atribui ao menos à alienação antecipada de bens uma "coloração" mais viva e harmônica com a sistemática da Lei n. ${ }^{o} 11.101 / 05^{1111}$.

De todo modo, em matéria de realização de ativo em falência, não é essa disposição da vigente lei aquela mais e melhor privilegia o atendimento à função social da empresa, nem aquela que mais se contrasta com o regramento da lei anterior. Na verdade, é mais representativa dessa modificação e diferente do direito revogado a disposição referente ao momento em que tem lugar a alienação de bens ${ }^{1112}$ - tema hoje regido pelos arts. 139 e seguintes da Lei n. ${ }^{\circ} 11.101 / 05$.

A vigente disciplina dessa matéria não apenas simplificou e tornou mais ágil o processo falimentar, mas principalmente favoreceu o aproveitamento econômico dos bens integrantes do patrimônio do falido. Isso, porque ela permitiu a pronta realização do ativo, tão logo arrecadados e avaliados os bens (art. 113), o que evita ou, pelo menos, mitiga os efeitos deletérios que a cessação da atividade e sua perduração no tempo podem provocar no valor econômico da universalidade de bens e mesmo de cada um de seus elementos individualmente considerados ${ }^{1113}$.

Na vigência do Decreto-Lei n. ${ }^{\circ} 7.661 / 45$, o início do procedimento de alienação do ativo era condicionado, cumulativamente (art. 114), à prévia formação do

\footnotetext{
${ }^{1111}$ Outro aspecto - que, de toda sorte, será ao depois melhor explorada - merece referência. Diz respeito à concordata suspensiva, hipótese que não encontra paralelo na LREF (não é possível o ajuizamento da recuperação judicial após a decretação da quebra - art. 48, inc. I, LREF). Na vigência do Decreto-Lei n. ${ }^{\circ}$ 7.661/45, a impetração dessa medida prejudicava a liquidação dos bens (LF: art. 114), que, além de tudo, ainda estava condicionada à prévia (e demorada) formação do quadro geral de credores (LF: art. $114 \mathrm{c} / \mathrm{c}$ art. 63, inc. XIX). Não impedia, porém, é claro, a alienação antecipada (que, exatamente por isso, era dita "antecipada" e as hipóteses legais justificam a possibilidade jurídica de disposição pela Justiça de bem ainda integrante do patrimônio do falido potencialmente concordatário). Nada obstante, o fato é que o art. 73 do Decreto-Lei n. ${ }^{\circ} 7.661 / 45$ constituía uma exceção ao regime geral de realização do ativo (art. 114). Isso somado à possibilidade de futura impetração de concordata suspensiva certamente implicava uma interpretação restritiva do art. 73 e, por conseguinte, também uma aplicação judicial tímida. Removido esse óbice, ante a vedação de recuperação judicial no curso da falência na vigência da Lei n. ${ }^{\circ} 11.101 / 05$, quer-nos parecer que resta favorecida e prestigiada a regra do vigente art. 113, que, como visto, é igualmente meio de cumprimento pela falência da função social da empresa.

1112 "A lei atual modificou profundamente a matéria." Cf. Euler da Cunha PeIXOTO, Comentários, in Osmar Brina CORRÊA-LIMA - Sérgio Mourão CORRÊA-Lima (coord.), Comentários à Nova Lei de Falência e Recuperação de Empresas, Rio de Janeiro, Forense, 2009, p. 964.

${ }_{1113}$ "A medida impede a perda econômica que decorre da deterioração e obsolescência dos ativos, além de atuar como excelente meio de preservação do valor dos intangíveis, tais como a marca, a clientela e a própria organização do sistema de produção. Cumpre destacar, por outro lado, que pela primeira vez uma legislação concusal brasileira enfrenta a questão do valor dos bens intangíveis da falida, tais como nome, ponto comercial, marcas, clientela, know-how, entre outros, os quais se perdiam com a extinção da empresa que resultava da falência." Cf. Adriana V. Pugliesi GARDINO, A Evolução do Tratamento Jurídico da Empresa em Crise no Direito Brasileiro, dissertação de mestrado, Faculdade de Direito da USP, São Paulo, mimeo, 2006, p. 195.
} 
quadro geral de credores ${ }^{114}$ (art. $114 \mathrm{c} / \mathrm{c}$ art. 63, inc. XIX) $e$ à não impetração pelo falido da concordata suspensiva (ou, em caso de propositura, seu indeferimento pelo juiz: art. 114 c/c art. art. 178).

Ora, esse duplo condicionamento retardava exacerbadamente a realização do ativo, o que, em especial na hipótese de cessação da atividade - que apenas podia ser revertido mediante provocação do falido: art. 73 da LF -, prejudicava decisivamente o aproveitamento útil daquele arranjo produtivo. Nada mais indesejável.

A Lei n. ${ }^{\circ} 11.101 / 05$ contornou esse inconveniente e o art. 139 prescreveu

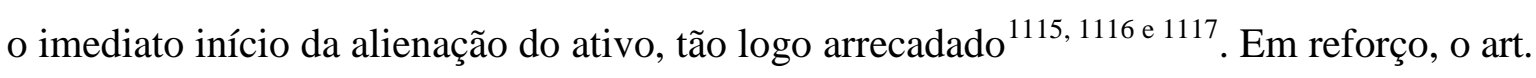
$140, \S 2^{\circ}$, expressamente determinou que "a realização do ativo terá início independentemente da formação do quadro-geral de credores".

Não subsiste, assim, a exigência de prévia formação do quadro geral de credores. Essa necessidade fundamentava-se, no Decreto-Lei n. ${ }^{\circ}$ 7.661/45, na bipartição do processo de falência em fases claramente separadas ${ }^{1118}$ e sucessivas. A segunda delas, que consistia propriamente na execução coletiva, com a realização do ativo e pagamento aos credores, deveria ser precedida da ultimação da primeira, que compreendia o conhecimento judicial da extensão do ativo (arrecadação e avaliação) e do passivo (verificação e habilitação de crédito) ${ }^{1119}$. (Exatamente entre uma fase e outra, era facultado ao devedor a impetração da concordata suspensiva - LF: art. 114 c/c art. 178.)

\footnotetext{
1114 Deseja-se, assim, que anteriormente à realização do ativo para pagamento do passivo (fase de execução coletiva), a "fase de conhecimento" já se encontrasse completa, com a exata delimitação da massa falida objetiva (arrecadação e avaliação do ativo) e da massa falida subjetiva (o passivo). Cf. Fabio Ulhoa Coelho, Falências: Principais Alterações, in Falências: Principais Alterações, in Revista do Advogado AASP, v. 83, setembro de 2005, p. 51; Rachel SzTAJN, Comentários, in Paulo Fernando Campos Salles ToLEDO - Carlos Henrique ABRÃo (Coords.), Comentários à Lei de Recuperação de Empresas e Falência, São Paulo, Saraiva, 2010, p. 493.

1115 Exatamente em razão desse regramento, Euler da Cunha PEIXOTO entendeu ter-se tornado "esdrúxula" a previsão supra referida de alienação "antecipada" do ativo prevista pelo art. 73: "no procedimento estabelecido pela Lei $n^{\circ}$ 11.101/2005, ela nunca será antecipada, mas, no máximo, preferencial, ou seja, o momento de sua realização é o apropriado, não caracterizando exceção, sendo esses bens vendidos antes dos outros em atendimento a condições especiais. " Cf. Comentários, in Osmar Brina CORRÊA-LIMA - Sérgio Mourão CORRÊA-LIMA (coord.), Comentários à Nova Lei de Falência e Recuperação de Empresas, Rio de Janeiro, Forense, 2009, p. 964.

${ }^{1116}$ A arrecadação encerra-se com a juntada do respectivo auto, do qual consta o inventário dos bens e sua avaliação (LREF: art. 110).

${ }^{1117}$ Naturalmente, como afirma Rachel SzTAJN, “o termo inicial [da realização do ativo] depende de outros fatores, entre eles, a prévia avaliação dos bens, a decisão quanto a vender a empresa, estabelecimentos, ou ainda, considerar a conveniência de alienar os ativos separadamente”. Cf. Comentários, in Paulo Fernando Campos Salles TOLEdo - Carlos Henrique TOLEdo (Coords.), Comentários à Lei de Recuperação de Empresas e Falência, São Paulo, Saraiva, 2010, p. 493.

1118 José da Silva PACHECO, Processo de recuperação Judicial, Extrajudicial e Falência, Rio de Janeiro, Forense, 2009, p. 397.

1119 Sergio CAMPINHO fala em "período de informação" e "período de liquidação". Cf. Falência $e$ Recuperação de Empresa - O Novo Regime da Insolvência Empresarial, Rio de Janeiro, Renovar, 2009, p. 425.
} 
Como esse acertamento do passivo soia demorar muito ${ }^{1120}$, o resultado era o já mencionado retardamento da realização do ativo, com todos os prejuízos consectários. Na Lei n. ${ }^{\circ} 11.101 / 05$, as "fases" da antiga Lei de Falências já não são autonomamente identificadas ${ }^{1121}$ e a verificação e habilitação de crédito (acertamento do passivo) correm paralelamente ao curso da falência ${ }^{122}$, sem prejudicar o deslinde deste, portanto.

Em que pese a ausência do quadro geral de credores - e, portanto, da delimitação definitiva dos credores -, registre-se a possibilidade de funcionamento do comitê de credores ${ }^{1123}$ (eleito pela assembleia ${ }^{1124}$ a partir do decreto de quebra ou mantido, após a convolação, com a composição formada durante a antecedente recuperação judicial: art. 99, inc. XII), para acompanhamento e fiscalização de todo o procedimento de realização do ativo (art. 27, inc. I, al. $a, b$ e $c$ ), salvaguardando, em acréscimo à atuação do Ministério Público, os interesses da comunidade de credores nos procedimentos de realização do ativo ${ }^{1125}$.

Além do paralelismo entre os cursos do processo da falência e da verificação e habilitação de crédito, que superou a prejudicialidade do segundo ao primeiro prevista pelo art. 114 do Decreto-Lei n. ${ }^{\circ} 7.661 / 45$, a realização do ativo logo após sua arrecadação harmoniza-se, na Lei n. ${ }^{\circ}$ 11.101/05, com a vedação da propositura de recuperação judicial "suspensiva" da falência - diferentemente do que sucedia na revogada lei.

Deveras, a recuperação judicial deve ser ajuizada antes da propositura da ação de falência por um credor ou, se já aforada, até no máximo o prazo de contestação (art. 95) e, em qualquer dos casos, é necessário o atendimento ao requisito do art. 48, inc. I,

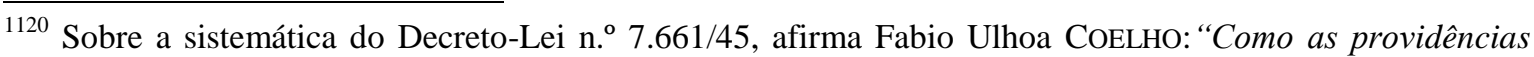
para tanto [delimitação do passivo], normalmente retardavam mais do que o desejável, o resultado era a deterioração dos bens arrecadados, com prejuizos imensos para toda a comunidade de credores." Cf. Comentários à Lei de Falências e de Recuperação Empresas, São Paulo, Saraiva, 2011, p. 478.

${ }_{1121}$ Sergio CAMPINHO, Falência e Recuperação de Empresa - O Novo Regime da Insolvência Empresarial, Rio de Janeiro, Renovar, 2009, p. 426.

1122 . Euler da Cunha PeIXOTO, Comentários, in Osmar Brina CORRÊA-LiMA - Sérgio Mourão CoRRÊA-LiMA (coord.), Comentários à Nova Lei de Falência e Recuperação de Empresas, Rio de Janeiro, Forense, 2009, p. 964

${ }^{1123}$ No caso da alienação antecipada, o próprio art. 113 da LREF determina a oitiva do comitê de credores de o magistrado proferir a decisão.

${ }^{1124} \mathrm{O}$ art. 39 da LREF prescreve quem é legítimo para compor o órgão deliberativo, na ausência do quadro geral de credores. Este é publicado, em edital, pelo administrador judicial; contudo, antes dele, há dois outros editais contendo a identificação dos créditos e dos credores. Essas relações de credores são veiculadas por ocasião do decreto de quebra (art. 99, inc. III, ou art. 105, inc. II) e ao término da fase extrajudicial (ou administrativa) da verificação de créditos (art. $7^{\circ}, \S 2^{\circ}$ ).

${ }^{1125} \mathrm{O}$ Decreto-Lei n. ${ }^{\circ} 7.661 / 45$ não previa a existência desse órgão e, talvez, em certa medida, isso justificasse a necessidade de prévia delimitação definitiva dos credores.
} 
da Lei de Recuperação de Empresas e Falências (não ser falido ou, se já o foi, ter sido declaradas extintas, por sentença transitada em julgado, as responsabilidades apuradas no feito).

No sistema do Decreto-Lei n. ${ }^{\circ} 7.661 / 45$, fazia sentido o condicionamento da alienação dos bens à não propositura pelo devedor da ação de concordata suspensiva, ou ao seu indeferimento. A disposição desses bens pelo síndico impediria, obviamente, que o desapossamento, determinado pela sentença de quebra (LF: art. 40), fosse revertido com a concessão do "favor legal” (LF: art. 183) e, por consequência, tornaria impossível o exercício da atividade pelo concordatário.

Ora, na Lei n. ${ }^{\circ} 11.101 / 05$, a questão não se coloca, uma vez que, como visto, não mais se prevê a possibilidade de suspensão da falência: após o decreto, ela não mais se reverte, senão por meio recursal ${ }^{1126}$. Assim, o retardamento na alienação do ativo nenhum benefício gera e quase sempre expõe o arranjo produtivo ao altíssimo risco de se deteriorar. A alienação do ativo tão logo encerrada a arrecadação, conforme previsto pela vigente lei, vem dar concreção ao disposto no art. 75 do mesmo diploma legal e, portanto a favorecer a preservação utilidade econômica e social do arranjo produtivo.

\subsubsection{A ordem de preferência na alienação dos ativos}

Outra medida que visa a preservar e otimizar a utilização produtiva dos bens, ativos e recursos produtivos da empresa na falência, atribuindo concretude ao princípio veiculado pelo art. 75 da Lei n. ${ }^{o} 11.101 / 05^{1127}$, é a ordem de preferência de alienação do ativo. Ela está prevista pelo art. 140 e foi estabelecida segundo um critério que prestigia a manutenção da atividade econômica.

Algo semelhante já existia no Decreto-Lei n. ${ }^{\circ} 7.661 / 45$ (art. 116), mas ainda muito incipiente ${ }^{1128}$. A norma era demasiado simples e somada à impossibilidade de alienação antes da formação do quadro geral de credores, a previsão era pouco efetiva. Com efeito, a ordem do art. 140 da LREF apenas faz sentido à luz da possibilidade de

\footnotetext{
${ }^{1126}$ Sergio CAMPINHO observa: "A razão dessa modificação de procedimentos se justifica, basicamente, em dois fatores: primeiro, na estrutura processual que não mais contempla a suspensão da falência. Uma vez decretada, seguirá seu curso contínuo, até a total venda dos bens arrecadados e o pagamento, na medida das forças da massa objetiva, dos credores do devedor." Cf. Falência e Recuperação de Empresa - O Novo Regime da Insolvência Empresarial, Rio de Janeiro, Renovar, 2009, p. 426.

1127. Rachel SzTAJn, Comentários, in Paulo Fernando Campos Salles Toledo - Carlos Henrique ABRÃo (Coords.), Comentários à Lei de Recuperação de Empresas e Falência, São Paulo, Saraiva, 2010, p. 494.

${ }^{1128}$ Fabio Ulhoa CoElHo, Comentários à Lei de Falências e de Recuperação de Empresas, São Paulo, Saraiva, 20111, p. 480.
} 
realização do ativo em curto espaço de tempo - logo após a arrecadação, como prevê o art. 139.

O rol previsto pelo aludido dispositivo e organizado segundo o grau de preferência estabelece nas duas primeiras hipóteses a alienação da "empresa". O termo não está aí empregado no sentido estrito que lhe é próprio - de atividade empresária ${ }^{129}$-, mas significa in casu o complexo de estabelecimentos ${ }^{1130}$ de que o falido é titular. Em que pese a ligeira atecnia ${ }^{1131}$, a escolha da palavra denota a preocupação do legislador com a mantença da complementariedade econômica dos bens individualmente considerados - o que apenas se logra com a preservação da unidade econômica (e jurídica) do estabelecimento. Mantendo-se a dinâmica do funcionamento dos estabelecimentos, evita-se a perda do aviamento que lhes qualifica - o que inarredavelmente não seria possível na hipótese de alienação dos bens (singulares) integrantes de cada um desses bens coletivos.

No caso do art. 140, inc. I, da LREF, a preferência é pela alienação em conjunto de todos os estabelecimentos integrantes da massa falida; o inc. II, que tem lugar apenas na impossibilidade justificada ${ }^{1132}$ de atendimento ao inciso precedente, prevê a venda de cada estabelecimento individualmente ("filiais ou unidades produtivas"). Em qualquer dos casos, resta favorecido o aproveitamento produtivo e econômico (que se reflete no valor de alienação) do aviamento que deflui da universalidade de fato. Conforme afirma Fabio Ulhoa COELHO, "o mercado valoriza, na verdade, o potencial de geração de riqueza que a empresa oferece" e os bens organizados em estabelecimento normalmente tem maior aptidão para tanto ${ }^{1133}$.

Restando inconveniente ou não logrando êxito a alienação de todos os estabelecimentos ou de cada um deles individualmente, o art. 140 da Lei n. ${ }^{\circ}$ 11.101/05 ainda prevê a venda de bens "em bloco" (inc. III). Não explicita a lei qual seria o elemento

\footnotetext{
1129 “Note-se que há imprecisão terminológica que é causa de estranheza: a palavra 'empresa', empregada no sentido de complexo de estabelecimentos e como objeto de direito." Cf. Rachel SzTAJN, Comentários, in Paulo Fernando Campos Salles TOLEDO - Carlos Henrique ABRÃO (Coords.), Comentários à Lei de Recuperação de Empresas e Falência, São Paulo, Saraiva, 2010, p. 495.

1130 "Assim, a conclusão inevitável é que a expressão 'alienação da empresa' deve ser entendida como correspondendo à alienação de todos os estabelecimentos, das várias unidades que são tomadas como unidade, um bloco monolítico de bens organizados para o exercício da atividade emeprsária e convém manter unificado." Cf. Rachel SzTAJN, Comentários, in Paulo Fernando Campos Salles TOLEDO - Carlos Henrique ABRÃo (Coords.), Comentários à Lei de Recuperação de Empresas e Falência, São Paulo, Saraiva, 2010, p. 495.

1131 Ricardo BERNADEI critica-a, por não observa a terminologia do Código Civil. Cf. Comentários, in Francisco Satiro SouZA Junior - Antônio Sérgio A. de Moraes PITOMBo (coord.), Comentários à Lei de Recuperação de Empresas e Falência, São Paulo, RT, 2007, p. 478.

1132 Rachel SzTAJn, Comentários, in Paulo Fernando Campos Salles TOLEDO - Carlos Henrique ABRãO (Coords.), Comentários à Lei de Recuperação de Empresas e Falência, São Paulo, Saraiva, 2010, p. 494.

${ }^{1133}$ Comentários à Lei de Falências e de Recuperação de Empresas, São Paulo, Saraiva, 20111, pp. 480-481.
} 
de homogeneidade que agregaria esse bloco (por valor, por emprego produtivo etc.) ou se ele seria escolhido esmo. De toda sorte, sendo certo que essa opção prefere à alienação de bens individualmente considerados (opção do inc. IV), sua adoção deve fundamentar-se presumivelmente em uma valorização superior àquela que teria vez se fosse escolhida derradeira possibilidade (inc. IV). Em outras palavras, é preciso que o valor global do bens vendidos em bloco seja superior à soma

A opção por qualquer das hipóteses toca ao administrador judicial, a quem a lei expressamente conferiu essa atribuição de "praticar os atos necessários à realização do ativo" (art. 22, inc. III, al. i). Note-se que o art. 140 contém um rol preferencial, mas não obrigatório. É certo que o critério que preside a ordenação desse rol não pode ser sem mais desconsiderado ${ }^{1134}$, mas a observância da preferência apenas tem lugar se promove efetivamente os valores do art. 75 .

Exatamente por isso, a opção feita pelo administrador deve ser - embora a lei não o preveja expressamente - fundamentada ${ }^{1135}$. E nada impede que haja mescla das diversas formas de alienação, se for conveniente à realização do ativo ou se for oportuno (art. 140, $\S 1^{\circ}$ ). O ideal seria que a lei expressamente exigisse a apresentação pelo administrador judicial de um "plano de liquidação". Embora não o faça, Sergio CAMPINHO afirma que cabe ao administrador "formatar um plano adequado de vendas dos bens", sempre visando a obter a forma mais eficiente ${ }^{1136}$.

Para esse fim, será oportuno o emprego da avaliação dos bens, que integra o auto de arrecadação e que, nos termos do art. 108 da LREF, deve ser feita "separadamente ou em bloco".

\subsubsection{Inexistência de sucessão do adquirente do estabelecimento}

Por fim, uma medida de extrema importância para a preservação da

\footnotetext{
${ }^{1134}$ Sustenta, oportunamente, Rachel SZTAJN que essa ordem "reduz o poder discricionário do administrador judicial", diferentemente do que sucedia na revogada lei. Cf. Comentários, in Paulo Fernando Campos Salles TOLEDO - Carlos Henrique ABRÃO (Coords.), Comentários à Lei de Recuperação de Empresas e Falência, São Paulo, Saraiva, 2010, p. 494. Note-se que o caput do artigo determina a observância da preferência ("séra realizada de uma das seguintes formas", devendo ser "observada a seguinte ordem de preferência"). Ademais, ao tratar da possibilidade de emprego de mais de uma forma, o $\S 1^{\circ}$ ao mesmo artigo condiciona-o à conveniência à realização do ativo ou em "razão de oportunidade". Ora, a aferição do atendimento ao dispositivo apenas é possível em justificativa apresentada pelo administrador judicial.

${ }_{1135}$ Comentários, in Paulo Fernando Campos Salles TOLEDO - Carlos Henrique ABRão (Coords.), Comentários à Lei de Recuperação de Empresas e Falência, São Paulo, Saraiva, 2010, p. 494.

${ }^{1136}$ Falência e Recuperação de Empresa - O Novo Regime da Insolvência Empresarial, Rio de Janeiro, Renovar, 2009, p. 427.
} 
função social da empresa na falência. Trata-se de norma claramente favorável à maximização do valor da massa falida objetiva e que, ao tornar atraente economicamente a outros agentes econômicos a aquisição de estabelecimento do falido, favorece a continuidade da atividade e, portanto, ao atendimento a sua função social. É um exemplo claro de confluência dos interesses difusos na permanência e otimização da utilidade econômica e social dos bens de produção e dos interesses dos credores na satisfação de seus créditos - por decorrência da valorização da massa falida objetiva.

Trata-se da disciplina da responsabilidade do adquirente do estabelecimento nas hipóteses dos incs. I e II do art. 140 da Lei de Recuperação de Empresas e Falências. Nesses casos, para que o potencial adquirente de estabelecimento integrante da massa falida objetiva oferte valor alto ao ativo, evita-se a assunção por ele dos débitos vinculados ao fundo de empresa a ser cedido ${ }^{1137}$. Em outras palavras, excepciona-se a regra do art. 1.146 do Código Civil.

De fato, dispõe o artigo 141, II, da LREF que, em havendo "alienação" de estabelecimento (de todos, se o caso, ou de cada um individualmente), este estará "livre de qualquer ônus e não haverá sucessão do devedor, inclusive as de natureza tributária, as derivadas da legislação do trabalho e as decorrentes de acidente de trabalho".

Assim, apesar do disposto no art. 1.146 do Código Civil e no art. 10 da Consolidação das Leis do Trabalho, a cessão onerosa do fundo de empresa não implicará a sucessão do adquirente nas dívidas do falido referentes à universalidade de fato objeto da transferência. Por esse passivo responderá exclusivamente a massa falida, nos termos da Lei n. ${ }^{\circ} 11.101 / 05$ e segundo a ordem de preferência prevista pelo artigo 83.

Quanto aos débitos tributários, a inexistência de sucessão está fulcrada no disposto no artigo 133, $\S 1^{\circ}$, do Código Tributário Nacional, com redação dada pela Lei Complementar n. 118/05 ${ }^{1138}$. Para evitar fraudes, no entanto, a regra que prevê a inexistência de sucessão contém exceções. Assim, existirá sucessão do adquirente do estabelecimento nas hipóteses do artigo 141, § $1^{\circ}$, da LREF e, ainda, quanto ao passivo tributário, nos casos (idênticos) do artigo 133, $\S 2^{\circ}$, do CTN.

1137 Ricardo Bernard, Comentários, in Francisco Satiro SouZA JR. - Antonio Sérgio A. de Moraes PITOMBO, Comentários à Lei de Recuperação de Empresas e Falência, p. 477.

${ }_{1138}$ Manoel Justino BeZERRA FILHO, Nova Lei de Recuperação e Falências Comentada, São Paulo, RT, 2005, p. 318. Conforme já se disse, a matéria requer, por força da Constituição da República, lei complementar. 


\section{4. Órgãos na recuperação judicial}

Órgão, reitere-se a lição de Marcelo Vieira von ADAMEK a respeito de que órgão é "o centro de imputação de poderes funcionais exercidos, por um ou mais indivíduos que nele estejam investidos, para formar e manifestar a vontade juridicamente imputável à pessoa jurídica" ${ }^{, 1139}$.

Embora a consideração ali se refira a entes personalizados, já ficou assentado $^{1140}$ que órgão não é de existência exclusiva no bojo de pessoas jurídicas. Ao contrário, essa noção está ligada à de interesse comum ou coletivo, da qual, já se disse, é decorrência lógica. Enfeixados em grupos sociais, os titulares de interesses comuns organizam-se para perseguir tais interesses e, a depender da complexidade dessa organização, podem criar órgãos para auxiliarem nessa persecução. Por isso, não causa espécie que existam órgãos também nos processos concursais, à semelhança do que sucede nas pessoas jurídicas.

Cabe ainda observar que, quanto mais numerosos, variados, difíceis e complexos forem os fins perseguidos pela coletividade, tanto mais complexa deverá ser a organização dessa comunhão de credores e, portanto, mais numerosos serão os órgãos. No caso da Lei n. ${ }^{\circ}$ 11.101/05, além de outros órgãos (administrador judicial, Ministério Público e o próprio juízo), há a previsão de dois diretamente relacionados aos credores: a assembleia geral e o comitê de credores. Nenhum deles é de funcionamento obrigatório, mas sua previsão legal resulta do relativamente elevado grau de complexidade dessa estrutura.

A previsão desses órgãos espelha a adoção pela Lei n. ${ }^{\circ} 11.101 / 05$ do chamado princípio da autonomia dos credores $^{1141}$. Segundo essa concepção, cabe aos credores, principais envolvidos na crise econômico-financeira da empresa, decidir sobre as mais relevantes questões suscitadas nos respectivos processos judiciais, especialmente sobre a aprovação ou rejeição do plano apresentado pelo devedor. Divorcia-se, portanto, como já se estudou, completamente a atual sistemática daquela prevista pelo Decreto-Lei

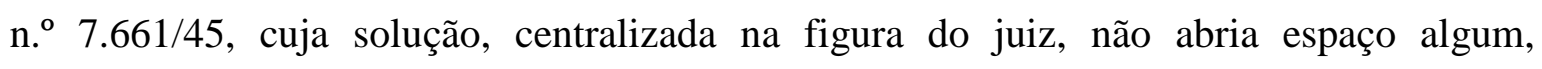
especificamente na concordata, à atuação dos credores. Registre-se, contudo, que a revogada lei previa o instituto, para atuar no âmbito da falência - razão por que ele não é

\footnotetext{
${ }^{1139}$ Marcelo Vieira von ADAMEK, Responsabilidade Civil dos Administradores de S/A e as Ações Correlatas, São Paulo, Saraiva, 2009, p. 11.

${ }_{1140}$ Item 3.1.1, Capítulo 3, supra.

${ }^{1141}$ Erasmo Valladão A. e N. FrAnÇA, Arts. 35 a 46 in SouZA Junior, Francisco Satiro - Pitombo, Antônio Sérgio A. de Moraes (coord.), Comentários à Lei de Recuperação de Empresas e Falência, p. 186.
} 
propriamente uma novidade da Lei n. ${ }^{\circ}$ 11.101/05.

Na vigente lei, os credores não são mais apenas destinatários dos efeitos do processo concursal - como sucedia na concordata -, mas, bem ao contrário, são parte a que, sob a cadência do processo judicial, cabe decidir, como dito, sobre as mais altas questões relativas ao concurso e, em especial, à aprovação ou rejeição do plano.

Essa concepção resulta de uma "desjudicialização" dos processos concursais - em particular, da recuperação judicial ${ }^{1142}$. Embora também na falência seja possível a atuação da assembleia, suas atribuições naquele instituto, pela própria natureza da liquidação judicial forçada, são muitíssimo mais reduzidas - sendo a principal delas deliberar sobre meio alternativo de realização do ativo. Na recuperação ao contrário, ela exerce certo protagonismo.

Nessa mesma ordem de ideias, a previsão de órgãos pela Lei n. ${ }^{\circ}$ 11.101/05 é reflexo de uma certa “institucionalização" que dispensou o legislador à comunhão de credores. Não é toda comunhão de interesses que conduz à criação de órgãos. Sua previsão pela Lei n. ${ }^{\circ}$ 11.101/05 reflete, portanto, uma concepção da recuperação como assemelhada a uma instituição.

As instituições, isso já foi objeto de análise no capítulo precedente, é centrada, em três características: a realização da ideia de um grupo social; a existência de um poder organizado colocado a serviço da persecução dessa ideia; e manifestação de comunhão do grupo em que a ideia se realiza. Além disso, a perduração no tempo é próprio dessa estrutura ${ }^{1143}$. É bem verdade que a recuperação judicial não tende a um alongamento no tempo; na verdade, há severa restrição no tempo - o período de supervisão não

1142 O Decreto-Lei n. 7.661, de 21.6.1945, também previa a 'assembleia de credores' (arts. 122 e 123); entretanto, o conclave apenas tinha lugar na falência (e não no processo de concordata) e suas funções e regras procedimentais eram bastante minguadas, se comparadas à disciplina da legislação anterior (para Trajano de Miranda VALVERDE, o Decreto-Lei 'nulificou-a': cf. Comentários à Lei de Falências, v. 2, Rio de Janeiro, Forense, 2001, p. 184) e da Lei n. ${ }^{\circ}$ 11.101/05. Convocada pelo juiz a pedido de credores representativos de um quarto do passivo habilitado, sua atribuição limitava-se à deliberação sobre o modo de realização do ativo (art. 122, função, por sinal, preservada pelos arts. 46 e 145 da vigente lei).

${ }^{1143}$ Reitere-se o que já foi transcrito de SANTI ROMANO: "Per instituzione noi intendiamo ogni ente o corpo sociale. 1). L'ente di cui parliamo deve avere un'esistenza obbiettiva e concreta, e, per quanto immateriale, la sua individualità dev'essere esteriore e visibile: appunto per rendere meglio questo suo carattere, l'abbiamo anche detto un 'corpo' sociale. (...) 2). Diciamo inoltre che l'istituzione è un ente o corpo sociale, nel senso che essa à manifestazione della natura sociale e3 no puramente individuale dell'uomo. (...) 3). L'istituzione è un ente chiuso, che può venire in considerazione in sè e per se, appunto perchè ha una propria individualità. (... 4). L'instituzione è un'unità ferma o permanentemente, che ciò̀ non perde la sua identità, almeno sempre e necessariamente, pel mutarsi dei singoli suoi elementi, delle persone che ne fanno parte, del suo patrimonio, dei suoi mezzi, dei suoi dei suoi interessi, dei suoi fini, dei suoi uffici, dei suoi amministratori, dei suoi destinatari, delle sue norme, e cosi via. (...)”. In: L'ordinamento giuridico - Studi sul conccetto, Le fonti e i caratteri del diritto - Parte prima, Pisa, Cav. Mariotti, 1917, pp. 35, 36, 37 e 38. 
extrapola, nos termos da lei, dois anos. Nada obstante, dada a complexidade dessa comunhão de credores, o legislador revestiu-a com uma disciplina que se aproxima de uma instituição.

\subsection{O administrador judicial}

Notável alteração do regime jurídico instituído pela Lei n. ${ }^{\circ} 11.101$, de 9/2/2005 $5^{1144}$, se comparado ao revogado, é a disciplina da figura do administrador judicial $^{1145}$. Como se sabe, unificaram-se sob um só órgão as atribuições anteriormente imputadas ao síndico, na falência, e ao comissário, na concordata. Embora mantidas as linhas gerais do regramento anterior, as normais atuais apresentam modificações importantes.

Como sustenta com propriedade Paulo Fernando Campos Salles de TOLEDO, as diferenças entre as figuras do Decreto-Lei n. ${ }^{\circ} 7.661 / 45^{1146}$ e o administrador judicial "não são apenas de rótulo, mas principalmente de funções". E não apenas. Também aspectos institucionais - atinentes, por exemplo, aos requisitos e critérios para nomeação - foram alterados, igualmente de maneira notável e em harmonia com os propósitos da profunda reforma promovida no sistema concursal brasileiro pelo vigente diploma.

Nesse contexto, destina-se o presente trabalho a examinar se e em que medida o administrador judicial, pelos critérios e forma de nomeação, destituição e substituição e por suas atribuições, atende ao interesse dos credores, quer na falência, quer na recuperação judicial. Dito de outro modo, a que interesses deve o administrador judicial servir e qual o papel reservado aos credores no desempenho, por aqueles, de suas atribuições? Nisto consiste o objeto deste trabalho.

\subsubsection{Breve histórico}

A Parte Terceira do Código Comercial ${ }^{1147}$, de 1850 , que disciplinou as

\footnotetext{
${ }^{1144}$ A ela referem-se os artigos citados no trabalho quando não especificado outro diploma legal. A vigente lei é referida como "Lei de Recuperação de Empresas e Falências" ou, simplesmente, "LREF".

${ }^{1145}$ Fábio Ulhoa COELHO, Falência-Principais Alterações, in Revista do Advogado da AASP, v. 83, p. 53.

1146 È referido como "Lei de Falências" ou, simplesmente, "LF".

${ }^{1147}$ Lei n. 556, de 25/6/1850.
} 
quebras por quatro décadas ${ }^{1148}$, disciplina o processo em duas fases. Uma vez decretada a falência, o Tribunal do Comércio ${ }^{1149}$ deveria nomear, na própria sentença, um ou mais credores que servissem de curadores fiscais provisórios ou, não existindo, alguém que tivesse a capacidade necessária (art. 809). A eles cumpria efetivar a instrução do processo, em que eram arrecadados e inventariados os bens do falido ${ }^{1150}$; Encerrada essa fase, os credores eram, então, convocados para deliberar sobre a nomeação de administradores, entre cujas funções estavam a realização do ativo e o pagamento do passivo da massa ${ }^{1151}$ (art. 842).

O Decreto 917, de 1890, “que passou definitivamente a matéria concursal para leis extravagantes" ${ }^{1152}$, embora tenha alterado profundamente a estrutura legislativa de então ${ }^{1153}$, manteve, em linhas gerais, o mesmo sistema de administradores.

Os síndicos provisórios, nova nomenclatura para os antigos curadores fiscais provisórios, eram, como estes, nomeados pelo Juízo entre os credores e, apenas na falta destes, poderiam ser terceiros. Inovação do diploma foi a instituição da figura do curador fiscal de massas falidas $^{1154}$, responsável por opinar na hipótese de divergência entre os referidos síndicos provisórios. Tal como no Código Comercial, também aos credores cabia a eleição dos síndicos definitivos (não mais chamados administradores ${ }^{1155}$ ), para ultimar as providências liquidatárias.

Segundo Nelson ABRÃO ${ }^{1156}$, a Lei 859, de 1902, foi o mais desastroso diploma no tocante à escolha do administrador concursal: foram instituídos os síndicos oficiais, nomeados pelo Juízo entre os arrolados em uma relação oficial da Juntas Comerciais. Sua atuação limitava-se, como nos diplomas anteriores, à primeira parte do procedimento. Os síndicos definitivos, eleitos pelos credores, atuavam na fase liquidatória e solutória. Segundo o autor, a má aplicação do diploma, gerou a promoção a síndicos oficiais de comerciantes inidôneos e incapazes.

$\overline{1148}$ Trajano de Miranda VALVERDE, Comentários à Lei de Falências, v. 1, Rio de Janeiro, Forense, 2001, p. 7.

${ }_{1149}$ Órgão jurisdicional formado por um "Presidente letrado, seis Deputados comerciantes, servindo um de Secretário, e três Suplentes também comerciantes; e terá por adjunto um Fiscal, que será sempre um Desembargador com exercício efetivo na Relação Rio de Janeiro” (art. $2^{\circ}$ do Título Único do Código Comercial).

${ }^{1150}$ Dizia o Código que se deveria "pôr os selos em todos os bens, livros e documentos do falido que forem susceptíveis de os receber" (art. 811). Tais selos deveriam, ao depois, ser rompidos pelo curador fiscal, na medida em que inventariava tais bens.

${ }^{1151}$ Nelson ABRÃO, O Síndico na Falência, São Paulo, LEUD, 1999, p. 102.

1152 Nelson ABRÃO, O Síndico na Falência, p. 102.

${ }_{1153}$ Trajano de Miranda VALVERDE, Comentários à Lei de Falências, v. 1, p. 9.

1154 Trajano de Miranda VALVERDE, Comentários à Lei de Falências, v. 1, p. 9.

1155 Idem.

${ }^{1156}$ Idem. 
A Lei n. ${ }^{\circ}$ 2.024, de 1908, permitia a nomeação, pelo juiz, por ocasião da sentença, de mais de um síndico - até o limite de três, conforme a importância da massa $^{1157}$. Tais indicados seriam pessoas idôneas, escolhidas também entre os principais credores, e sua missão durava até a realização da assembleia de credores, onde deveria ser apresentado plano de recuperação pelo falido. Não apresentada a proposta, ou recusada, o síndico era substituído por um liquidatário, eleito pelos credores e que realizaria o ativo e pagaria o passivo $^{1158}$.

O Decreto 5.746, de 1929, reduziu o número de síndico a um - também escolhido pelo Juízo e também entre os credores. Apenas na escusa do indicado é que seria possível a nomeação de terceiros.

Até esse momento, como se vê, embora os administradores responsáveis pela primeira fase dos processos falimentares (os quais, primeiro chamados curadores e, depois, síndicos provisórios, tinham por atribuição basicamente a arrecadação, o inventário e a guarda dos bens integrantes da massa falida) fossem nomeados pelo Juízo, e não pelos credores, estes últimos dispunham de bastante poder na condução do processo - o que nunca deixou de ser criticado por Trajano Miranda VALVERDE, para quem “A autonomia excessiva de que continuavam a gozar os credores, no estado jurídico da falência ou da concordata, com muitos dirietos e nenhuma obrigação, era, para nós, a causa primordial dos males de que se queixava o comercio" ${ }^{\prime 1159}$.

De fato, apenas eles poderiam ser nomeados, em princípio, síndicos e a eles cabia a nomeação do administrador responsável pelas fases subseqüentes do processo, que compreendiam a realização do ativo e a partilha do passivo.

Incumbido pela redação do anteprojeto da nova lei de falências, no ano de $1939^{1160}$, VALVERDE alterou a orientação que se vinha seguindo até então a respeito do síndico. Embora tenha mantido, como restou aprovado no Decreto-Lei n. ${ }^{\circ}$ 7.661/45, a nomeação do síndico e do comissário entre os credores, essa atribuição fica a cargo exclusivo do Juízo - não cabendo aos credores a eleição de um substituto, para a fase liquidatória: foi proscrita a figura do liquidatário.

\footnotetext{
${ }^{1157}$ Idem. Também Ricardo NEGRÃO, Manual de Direito Comercial e de Empresa, v. 3, São Paulo, Saraiva, 2008,p. 73..

${ }_{1158}$ Nelson ABRÃO, O Síndico na Falência, p. 103.

${ }^{1159}$ Comentários à Lei de Falências, v. 1, p. 10.

${ }^{1160} \mathrm{O}$ anteprojeto de 1939, encomendado pelo então ministro da Justiça, Francisco Campos, foi a base para o anteprojeto posterior, publicado em 1943 e da lavra de uma comissão de notáveis juristas, o qual, por sua vez, deu origem ao Decreto-Lei n. ${ }^{\circ}$ 7.661/45.
} 


\subsubsection{A Lei n. $^{\circ}$ 11.101/05: principais novidades}

$\mathrm{Na}$ disciplina da administração da falência e da recuperação judicial, que tomou o lugar da antiga concordata, o legislador da LREF alterou alguns aspectos. $\mathrm{O}$ primeiro deles é a unificação, em uma figura, das atribuições antes exercidas pelo síndico, naquele primeiro procedimento, e pelo comissário, no antes chamado "favor legal".

O mais notável, no entanto, parece ser a profissionalização do cargo, que não será mais ocupado pelo credor - embora não haja impedimento expresso a que um credor seja administrador judicial, não subsiste a necessidade de que seja -, mas por um profissional que atenda, preferencialmente, a certos requisitos - ou seja pessoa jurídica especializada.

\subsubsection{Natureza jurídica}

Durante um tempo discutiu-se se o síndico, no exercício de seu mister, exercia representação. Especialmente naqueles diplomas legais em que o administrador era nomeado pelos credores, trata-se naturalmente de alguém de 'confiança'. A relação, como é claro, guardava semelhança com a representação de natureza contratual, o mandato.

Com o desapossamento do falido, o síndico ocupava-lhe o posto, gerindo e administrando os bens e atuando ativa e passivamente na defesa do patrimônio - o que confirmava essa tese.

Todavia, esse entendimento perdeu força com o tempo. Rubens REQUIÃO, invocando o mestre J.X. CARVALHO DE MENDONÇA, sustenta que, como a massa falida não é pessoa jurídica, deve-se afastar a "cômoda e fácil explicação" de que o síndico é seu representante legal. Também não é mandatário nem representante do falido, nem dos credores - porquanto pode (e deve) o síndico atuar, sempre que o caso, contra o interesse de qualquer um deles. Trata-se, portanto, segundo entende, de um órgão da massa dos credores e assim deve ser tratado ${ }^{1161}$.

Antes dele, Trajano Miranda VALVERDE sustentara o mesmo:

${ }^{1161}$ Curso de Direito Falimentar, v. 1, São Paulo: Saraiva, 1998 
"O administrador não representa nem o devedor, nem a massa de credores, nem a massa falida, que não constitui pessoa jurídica. Não há representação voluntária, e a representação legal é inconcebível, porque o administrador não tutela o interesses egoístico deste ou daquele, mas age no interesse objetivo da justiça, eventualmente, contra o interesse pessoal do falido ou contra o interesse dos credores. $O$ síndico é o órgão ou agente auxiliar da justiça, criado a bem do interesse público" ${ }^{1162}$.

Para Haroldo Duclerc Malheiros VERÇOSA, se isso era verdade à luz do Decreto-Lei n. ${ }^{\circ}$ 7.661/45, com mais razão deve ser assim compreendido na atual lei - em que o interesse público é mais evidenciado ${ }^{1163}$. Trata-se de função judiciária.

Isso porque, diferentementemente do que sucedia sob a vigência da Lei de Falências, a atual Lei n. ${ }^{\circ} 11.101 / 05$

\subsubsection{Nomeação do administrador judicial: profissionalização}

Certamente, a inovação mais notável da Lei n. ${ }^{\circ} 11.101 / 05$, quanto ao administrador judicial, é o delineamento profissional que decorre de sua disciplina.

Tal como ocorria no Decreto-Lei 7.661/45, quanto ao síndico (LF: art. 14, parágrafo único, $\mathrm{IV}^{1164}$ ) e ao comissário (LF: art. 161, $\S 1^{\circ}$, IV), na vigente lei a nomeação do administrador judicial é feita pelo Juízo, ou na decisão de processamento da recuperação judicial (art. 52, I) ou na sentença de quebra (art. 99, IX), conforme o caso.

Mesmo na hipótese de substituição ou destituição do administrador judicial, a nomeação do substituto $\left(\S 3^{\circ} \mathrm{c} / \mathrm{c} \S 2^{\circ}\right.$ do art. 30) ou do novo administrador (art. $31, \S 1^{\circ}$ ) caberá ao magistrado.

Relembre-se, como ressaltado em aula anterior, o veto do Presidente da República às alíneas $c$ e $a$ dos incisos I e II, respectivamente, do art. 34 do projeto de lei encaminhado pelo Congresso Nacional. Tais dispositivos previam a atribuição da assembleia geral de credores para substituição e indicação do substituto.

\footnotetext{
1162 Curso, v. 1, p.445.

1163 Haroldo Malheiro Dulclerc VERÇOSA, Comentários, in SOUZA JUNIOR, Francisco Satiro de PITOMBO, Antônio Sérgio A. de Moraes (coord.), Comentários à Lei de Recuperação de Empresas e Falências - Lei 11.101/2005 - Artigo por Artigo, São Paulo, Malheiros, 2007, P. 165.

${ }^{1164}$ São da Lei n. ${ }^{\circ} 11.101 / 05$ ("LREF") os dispositivos de lei desacompanhados de especial referência; "LF" indica o Decreto-Lei n. ${ }^{\circ} 7.661 / 45$.
} 


\subsubsection{Critério para nomeação}

O critério adotado pela Lei 11.101/05 difere significativamente do direito anterior.

Sob a vigência da LF, síndico (art. 60) e comissário (art. 161, § 1º, IV, c/c art. 60) eram escolhidos "entre os maiores credores"; apenas em caso de três recusas sucessivas, o magistrado poderia nomear livremente pessoa estranha à coletividade de credores, contanto que "idônea e de boa fama, de preferência comerciante" (art. 60, § 2, in fine).

O critério da LF, ensina a doutrina, não se revelou muito feliz ${ }^{1165}$ : a simples titularidade de crédito, por óbvio, não torna o credor apto ao exercício dessa complexa e singular função ${ }^{1166}$ e a premissa de que os maiores credores, por terem interesse numa "rápida e eficiente execução concursal" (no caso da falência), assegurariam tais atributos ao processo falimentar mostrou-se falsa ${ }^{1167}$. Assim, mesmo sob a vigência do Decreto-Lei n. ${ }^{\circ} 7.661 / 45$, a jurisprudência já havia afastado a necessidade de tripla recusa de credores antes da nomeação pelo magistrado de alguém de sua confiança $^{1168}$.

Na Lei n. ${ }^{\circ}$ 11.101/05, os critérios para nomeação do administrador judicial são definidos pelo art. 21. A exigência de que seja credor já não subsiste. A escolha do magistrado é, assim, livre, contanto que atendidos os critérios legais. Não existe, pois, uma relação oficial e necessária para nomeação - ao contrário de outros ordenamentos.

O administrador judicial poderá ser pessoa natural ou jurídica. Em qualquer dos casos, o perfil delineado pela Lei n. ${ }^{\circ}$ 11.101/05 para o administrador judicial evidencia a necessidade de profissionalização ${ }^{1169}$ e competência técnica ${ }^{1170}$. Assim, se

\footnotetext{
${ }^{1165}$ Paulo Fernando Campos Salles deTOLEDO, Comentários, in TOLEDO, Paulo Fernando Campos Salles de - ABRÃ̃, Carlos Henrique (coord.), Comentários à Lei de Recuperação de Empresas e Falências, São Paulo, Saraiva, 2005, p. 47.

1166 Idem.

1167 Fabio Ulhoa COELHO, Falências: Principais Alterações, in Associação dos Advogados de São Paulo AASP, Revista da AASP, n. 83, ano XXV, setembro de 2005.

${ }_{1168}$ Fabio Ulhoa COELHO, Falências: Principais Alterações, in Associação dos Advogados de São Paulo AASP. No mesmo sentido: Alfredo Luiz KUGELMAS - Gustavo Henrique Sauer de Arruda PINTO, Administrador Judicial na Recuperação Judicial - Aspectos Práticos, in DE LUCCA, Newton DOMINGUES, Alessandra de Azevedo, Direito Recuperacional - Aspectos Teóricos e Práticos, São Paulo, Quartier Latin, 2009, pp. 197-233

${ }_{1169}$ A qual, entende Fabio Ulhoa COELHO, é a solução para o problema verificado na aplicação do diploma revogado. Cf. Falências: Principais Alterações.

${ }_{1170}$ Ricardo NEGRÃO, Manual de Direito Comercial e de Empresa, v. 3, São Paulo, Saraiva, 2008,p. 81.
} 
natural, prescreve a norma, a pessoa nomeada deverá ser "profissional” e, se jurídica, "especializada".

Quanto às pessoas naturais, a lei prescreve que o nomeado seja "preferencialmente advogado, economista, administrador de empresas ou contador".

O advérbio empregado não deixa dúvida sobre a natureza exemplificativa do rol. Desse modo, poderá ser escolhido quem tenha outra formação acadêmica ${ }^{1171}$ ou mesmo não tenha curso superior ${ }^{1172}$.

Essa relação legal figura como mera "diretriz orientadora"1173. Não denota ordem de prioridade entre as profissões dela integrantes, tampouco exige que apenas seja nomeado profissional estranho a ela quando não for possível a escolha de algum daqueles profissionais na comarca do processo concursal ${ }^{1174}$. Também não externa preferência das pessoas naturais sobre as jurídicas, ao contrário do que uma leitura desatenta levaria a crer ${ }^{1175}$.

Dessa maneira, a "diretriz orientadora" do art. 21, por arrolar "profissionais de áreas afins da recuperação judicial ou falência" "1176, indica que o caráter profissional - e, portanto, a aptidão técnica - do administrador judicial deve muito mais guardar relação com a administração de empresas em crise e com o processo concursal do que propriamente com a formação acadêmica mencionada ${ }^{1177}$. Esse entendimento, ademais, mostra-se harmônico com o trecho do dispositivo que exige seja especializada a pessoa jurídica nomeada administradora judicial.

Além de profissional, a Lei exige que seja idôneo. Não repetiu a norma

\footnotetext{
${ }^{1171}$ Para Paulo Fernando Campos Salles deTOLEDO, Comentários, p. 47.

1172 Para Paulo Fernando Campos Salles deTOLEDO, Comentários, p. 49.

1173 Haroldo Malheiro Dulclerc VERÇOSA, Comentários, in SOUZA JUNIOR, Francisco Satiro de PITOMBO, Antônio Sérgio A. de Moraes (coord.), Comentários à Lei de Recuperação de Empresas e Falências - Lei 11.101/2005 - Artigo por Artigo, São Paulo, Malheiros, 2007, P. 165.

1174 Haroldo Malheiro Dulclerc VERÇOSA, Comentários, in SOUZA JUNIOR, Francisco Satiro de PITOMBO, Antônio Sérgio A. de Moraes (coord.), Comentários à Lei de Recuperação de Empresas e Falências - Lei 11.101/2005 - Artigo por Artigo, São Paulo, Malheiros, 2007, P. 165.

1175 Haroldo Malheiro Dulclerc VERÇOSA, Comentários, in SOUZA JUNIOR, Francisco Satiro de PITOMBO, Antônio Sérgio A. de Moraes (coord.), Comentários à Lei de Recuperação de Empresas e Falências - Lei 11.101/2005 - Artigo por Artigo, São Paulo, Malheiros, 2007, P. 165.

${ }^{1176}$ Paulo Fernando Campos Salles deTOLEDO, Comentários, p. 47. O autor ainda critica o rol, entendendo que dele deveria constar também o engenheiro (p. 48).

1177 Esse entendimento é muito bem ilustrado por Haroldo M. D. VERÇOSA no seguinte trecho de seus comentários: "Mas, se o juiz tem a liberdade mencionada, sabe ele que um advogado especializado em direito de família; um economista acostumado a tratar tão-somente de complexas questões orçamentárias; um administrador de empresas que cuide de uma galeria de arte; ou um contador que somente faça imposto de renda de pessoa física, todos eles estarão mal preparados para cuidar da recuperação de uma empresa ou do andamento de uma falência, sendo preferível fazer recair a escolha sobre outras pessoas providas de um nivel razoável de conhecimento e bom senso." Cf. Comentários, p. 165.
} 
vigente a literalidade do dispositivo equivalente da Lei de Falências, que requeria "idoneidade moral e financeira" (art. 60, caput, in fine).

Nada obstante, a doutrina é pacífica quanto à extensão da idoneidade de que trata o art. 21 da LREF ao âmbito moral - tendo em vista que é função de confiança e que envolve a administração de bens e interesses múltiplos - e ao financeiro - o que se pode deduzir, no vigente texto de lei, da disciplina acerca da responsabilidade civil do administrador judicial $^{1178}$.

O administrador judicial pode ser ainda pessoa jurídica, como visto. Não inova a LREF em relação à LF, que já admitia essa possibilidade (LF: art. 60, § $5^{\circ}$ ).

Nesse caso, prescreve a Lei, deve ela ser especializada. Não se exige que seja sociedade - não parecendo absurdo que a função seja exercida por uma fundação ou mesmo uma associação, contanto que atendido o requisito de especialização do escopo ${ }^{1179}$.

A esse propósito, entende a doutrina que tal especialização deve estar refletida nos atos constitutivos da pessoa jurídica, arrolada expressamente entre seus fins $^{1180}$ e, no caso de sociedades, no objeto social ${ }^{1181}$. Assim, Ricardo NEGRÃO entende que devem ser pessoas jurídicas prestadoras de serviço de auditoria ou contabilidade ${ }^{1182}$. Sérgio CAMPINHO menciona "realização de auditorias, administração de terceiros e consultorias econômica e financeira",1183.

Ainda a esse respeito, entende Haroldo M. D. VERÇOSA que a pessoa

\footnotetext{
1178 Paulo Fernando Campos Salles deTOLEDO, Comentários, p. 47; Sergio CAMPINHO, Falência e Recuperação de Empresa: O Novo Regime da Insolvência Empresarial, Rio de Janeiro, Renovar, 2009, p. 59; Alfredo Luiz KUGELMAS - Gustavo Henrique Sauer de Arruda PINTO, Administrador Judicial na Recuperação Judicial - Aspectos Práticos, p. 199. Mauro Rodrigues PENTEADO, Comentários, in CORREAA-LIMA, Osmar Brina - CORRÊA-LIMA, Sérgio Mourão (coord.), Comentários à Nova Lei de Falências e Recuperação de Empresas, Rio de Janeiro, Forense, 2009.

1179 Não encontramos, na doutrina, nenhuma especial preocupação com essa distinção - embora haja o emprego do termo "sociedades" no lugar da expressão pessoas jurídicas. Todavia, a interpretação sistemática e gramatical conduz-nos à conclusão externada. No art. 21, o termo "profissional" refere-se às pessoas naturais e, mesmo que assim não fosse, o objetivo lucrativo, que é próprio da profissionalidade, não é o discriminem da sociedade em relação às outras pessoas jurídicas de direito privado, mas sim a possibilidade, exclusiva daquela primeira, de distribuir o lucro eventualmente obtido entre seus membros (CC: art. 53; art. 981, in fine; art. 997, VII, entre outros). Ademais, a expressão "pessoa jurídica" tem sentido próprio no direito privado e, ante a ausência de restrição expressa, não parece se sustentar entendimento em contrário. Acrescente-se que o elemento especialmente valorizado pelo legislador é a especialização e não a natureza da pessoa jurídica. Discutível, no entanto, é a possibilidade de nomeação de pessoa jurídica de direito público, como uma hipotética autarquia eventualmente constituída pelo Poder Público especialmente para esse fim.

${ }^{1180}$ Terminologia do art. 46, inc. I, do Código Civil empregada para pessoas jurídicas de direito privado.

${ }^{1181}$ Haroldo Malheiro Dulclerc VERÇOSA, Comentários, p. 166.

${ }_{1182}$ Manual de Direito Comercial e de Empresa, v. 3, São Paulo, Saraiva, 2008,p. 81.

${ }^{1183}$ Sergio CAMPINHO, Falência e Recuperação de Empresa: O Novo Regime da Insolvência Empresarial, Rio de Janeiro, Renovar, 2009, p. 59.
} 
jurídica deve contar com "profissionais representantes das múltiplas funções”" (tais como advogados, contadores, economistas, auditores e engenheiros). Critica, por isso, no caso de profissionais liberais, a proibição da legislação brasileira de constituição de sociedades "multiprofissionais"1184.

Por fim, mencione-se que, diferentemente da LF, a Lei 11.101/05 não exige expressamente que o administrador judicial seja residente e domiciliado ou sediado no foro em que tem curso o processo concursal. Todavia, sustenta Ricardo NEGRÃO a preferência por administradores da própria comarca ou de proximidade ${ }^{1185}$ - o que, de resto, entendemos nós, decorre dos princípios de economia e celeridade processual (LREF: art. 75, parágrafo único, e art. 189; CF: art. $5^{\circ}$, LXXVIII).

\subsubsection{Impedimentos para exercício da função}

A LREF prescreve ainda casos de impedimento para exercício da função de administrador judicial (e, também, para integrar o Comitê de Credores). São hipóteses de duas naturezas.

As hipóteses de que trata o art. $30, \S 1^{\circ}$, baseia-se em conflitos (formal) de interesse. São impedidos de exercer a administração judicial quem tiver parentesco consangüíneo ou por afinidade até o terceiro grau com o devedor, se empresário individual, ou com administradores, controladores ou representantes legais da sociedade empresária devedora. Também é impedido quem é amigo ou inimigo dessas figuras ou, ainda, seja delas dependente.

Sendo pessoa jurídica o administrador judicial, os impedimentos aplicam-se, por simetria da norma do $\S 1^{\circ}$ do art. 30, aos "administradores, controladores ou representantes legais" da entidade nomeada e, ainda, do profissional de que trata o art. 21, parágrafo único ${ }^{1186}$.

A interpretação do texto legal conduz ao entendimento de que o impedimento deveria ser verificado exclusivamente no momento da decretação da quebra ou do deferimento do processamento da recuperação judicial - e não em período anterior a qualquer dessas ocorrências (12 meses, por exemplo), como entende Paulo F. C. S. de

\footnotetext{
${ }_{1184}^{1185}$ Haroldo Malheiro Dulclerc VERÇOSA, Comentários, p. 166.

${ }^{1185}$ Manual de Direito Comercial e de Empresa, v. 3, p. 81.

1186 Nesse sentido: Sergio CAMPINHO, Falência e Recuperação de Empresa: O Novo Regime da Insolvência Empresarial, p. 61.
} 
TOLEDO, seria melhor ${ }^{1187}$.

Além dessas hipóteses prevista pela LREF, há casos em que o conflito material de interesse. $\mathrm{O}$ art. 66 do Decreto-Lei 7.661/45 expressamente previa a destituição do síndico no caso "de ter interesses contrários aos da massa”, o que não foi repetido pelo legislador de 2005 - sem prejuízo, no entanto, para sua aplicação, mesmo hoje. É o que entende Ricardo NEGRÃO ${ }^{1188}$.

Além dos impedimentos decorrentes de conflito de interesse, há aqueles, de natureza diversa, que decorrem de atos ou fatos que desabonam a pessoa para o exercício da administração judicial.

São aqueles que, no próprio cargo de administrador judicial ou de membro do Comitê de Credores, tenham, nos cinco anos anteriores, sido destituído (exoneração de natureza punitiva para a hipótese de prática de atos graves contrários à Lei ou aos interesses da comunidade de credores ou do devedor), deixado de prestar contas nos prazos legais ou, ainda que prestadas, tenham elas sido rejeitadas.

O lustro previsto para limitar, no tempo, tais impedimentos é novidade da atual 1 ei ${ }^{1189}$.

Questão intertemporal que merece relevância refere-se à aplicação ou não

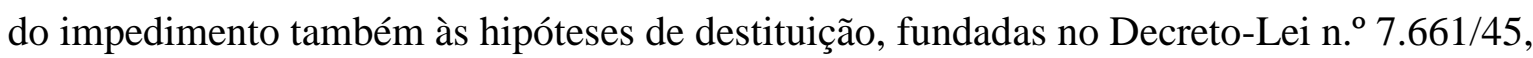
de síndicos e comissários. A doutrina apresenta resposta afirmativa, porque as hipóteses são equivalentes em ambos os diplomas; porque os processos em curso, quando da entrada em vigor da nova lei, seguem disciplinados pelo direito anterior (LREF: art. 192) e, ainda, em razão de aplicação por analogia da norma (Ubi eadem ratio, ibi eadem dispositio $)^{1190}$.

\subsubsection{Investidura}

\footnotetext{
1187 Comentários, p. 78. Esse é o prazo utilizado, por exemplo, pela Lei n. 6.024/74 para fins de indisponibilidade dos bens dos administradores de instituição financeira, em caso liquidação, intervenção extrajudicial ou falência.

1188 "O profissional que a exerce está impedido d, no mesmo processo ou não, atuar em posição processual contrária à da massa, porque a partir de seu compromisso não pode ter interesses contrários a ela, como preceituava a lei anterior (Decreto-Lei $n^{\circ}{ }^{\circ} 7.661 / 45$, art. 66). Não pode, por exemplo, ser advogado de credor em ação contra a massa e tampouco exercer a função de defensor - dativo ou contratado - de pessoa que for é em denúncia por crime falimentar”. Cf. Manual de Direito Comercial e de Empresa, v. 3, São Paulo, Saraiva, 2008,p. 86..

${ }^{1189}$ Paulo Fernando Campos Salles de TOLEDO, Comentários, p. 77.

${ }^{1190}$ Idem. Também:
} 
Nomeado o administrador judicial, é ele investido no cargo mediante termo de nomeação lavrado na sede do juízo (art. 33). Por esse termo, por um lado, ele se compromete a "bem e fielmente desempenhar o cargo" e, por outro, assume as responsabilidades daí decorrentes.

O prazo de que dispõe o administrador judicial é de 48 horas a contar de sua intimação pessoal da nomeação judicial. Não tomando posse dentro do prazo, o magistrado deverá nomear outra pessoa $\left(\operatorname{art.} 34^{1191}\right)$.

Sendo pessoa jurídica o administrador judicial nomeado, além de sua investidura, mediante a representação prevista em seus atos constitutivos, deve ser declinado o nome de um "profissional responsável” (art. 21, parágrafo único), que, embora a lei não seja explícita, certamente precisa também firmar o termo.

Esse profissional, pessoa natural, poderá integrar o quadro societário ou a administração da pessoa jurídica ou não: poderá ser empregado ou profissional liberal ${ }^{1192}$. Tal como já previa a LF revogada, sua substituição, no curso do processo, dependerá de provimento judicial.

Apesar do adjetivado responsável, esse profissional não é destinatário de nenhuma especial norma de responsabilidade civil. O art. 32 não faz essa discriminação. Desse modo, a identificação desse profissional tem função de criar uma "identidade física"1193 daquele responsável (leia-se: titular das atribuições) pela condução dos trabalhos. Evita-se, desse modo, substituições freqüentes e, com isso, as perdas decorrentes de eventuais soluções de continuidade.

\subsubsection{Substituição e destituição do administrador judicial}

O administrador judicial perderá o cargo em caso de substituição ou de destituição - hipóteses inconfundíveis. Uma e outra estão a cargo do juiz (art. $30, \S 2^{\circ}$, e art. 31).

A substituição aplica-se às hipóteses em que a nomeação do administrador judicial (ou do membro do Comitê de Credores) deu-se com inobservância dos impedimentos de que trata o art. 30. Nesse caso, o devedor, qualquer credor ou o

\footnotetext{
${ }^{1191}$ Hipótese em que não há nem destituição nem substituição, já que o cargo não foi ocupado.

${ }^{1192}$ Haroldo Malheiro Dulclerc VERÇOSA, Comentários, p. 166.

${ }^{1193}$ Haroldo Malheiro Dulclerc VERÇOSA, Comentários, p. 166
} 
Ministério Público podem requerer a substituição ao magistrado (art. 30, § 2º ), que deverá decidir em 24 horas $\left(\S 3^{\circ}\right)$.

Não existe prazo para a formulação do requerimento (ao contrário da reclamação, da LF, que deveria ser feita em 48 horas depois a publicação da nomeação) nem se prevê instauração de incidente processual, devendo os atos judiciais se processarem nos próprios autos da falência ou recuperação judicial.

Nada obstante a previsão de prazo para a decisão do magistrado, entende Haroldo M. D. VERÇOSA que também nesse caso deve ser franqueado ao administrador judicial o direito ao contraditório, com fundamento no art. $5^{\circ}$, inc. LV, da Constituição ${ }^{1194}$.

Contra a decisão cabe, naturalmente, agravo de instrumento. O problema é que o prazo concedido pelo Código de Processo Civil (10 dias) parece pouco harmônico com o prazo, em horas, fixado pela LREF para decisão do Juízo universal. Discute-se se provimento do recurso interposto pelo administrador judicial implicaria sua recondução ao cargo ou se limitaria à fixação em favor do agravante de indenização, com fundamento no art. 186 do Código Civil, a ser paga por quem deu causa à substituição injusta.

Nada obstante a previsão legal de provocação dos referidos legitimados para substituição do administrador judicial, entende Sergio CAMPINHO que é possível a substituição de ofício pelo magistrado ${ }^{1195}$, tendo a natureza de ordem pública das normas que regem a nomeação desse auxiliar da Justiça.

O mesmo autor entende que os atos praticados pelo administrador judicial impedido até sua substituição presumem-se válidos e eficazes, devendo ser anulados apenas aqueles que tiverem causado prejuízo às partes ${ }^{1196}$.

Ante a ausência de caráter punitivo, entende Fabio Ulhoa COELHO que também constituem hipóteses de substituição: (a) a renúncia fundamentada, ato voluntário (art. 22, III, $r$, e art. 24, $\S 3^{\circ}$ ); (b) a morte e, ainda, (c) a falência do administrador judicial $^{1197}$. Também a hipótese de não assinatura do termo de compromisso dentro do

\footnotetext{
1194 Haroldo Malheiro Dulclerc VERÇOSA, Comentários, p. 166

1195 Sergio CAMPINHO, Falência e Recuperação de Empresa: O Novo Regime da Insolvência Empresarial, p. 61 .

${ }_{1196}$ Sergio CAMPINHO, Falência e Recuperação de Empresa: O Novo Regime da Insolvência Empresarial, p. 61.

${ }^{1197}$ Fabio Ulhoa COELHO, Comentários à Nova Lei de Falências e de recuperação de Empresas - Lei $n$. 11.101, de 9-2-2005, São Paulo, Saraiva, 2005, p. 80.
} 
prazo legal seria de substituição (Ricardo NEGRÃO ${ }^{1198}$ ).

Acima relembramos o veto presidencial aos dispositivos que, no projeto de lei aprovado no Congresso Nacional, autorizam a assembleia geral de credores a substituir o administrador judicial e a nomeação de seu substituto.

Já a destituição decorre da prática de ato reprovável pelo administrador judicial, depois de investido. As hipóteses são aquelas do art. 31 e, ainda, do art. 23 da Lei n. $.^{\circ} 11.101 / 05:$ ( $a$ ) não apresentação das contas ou dos relatórios previstos na LREF dentro dos prazos estabelecidos nem em cinco dias depois de intimado pessoalmente a fazê-lo; $(b)$ desobediência aos preceitos da lei; $(c)$ descumprimento de deveres legais; $(d)$ omissão, negligência ou prática de ato lesivo às atividades do devedor ou de terceiros.

Os efeitos daí decorrentes são $(a)$ a perda do direito à remuneração, se decorrente de desídia, culpa, dolo ou descumprimento das obrigações, e, como visto, $(b)$ a impossibilidade, nos cinco anos subseqüentes, de nomeação para os cargos de administrador judicial ou membro do Comitê de Credores neste ou em outros processos.

A destituição pode dar-se de ofício ou mediante provocação do magistrado por qualquer interessado (art. 31). Naturalmente, embora não expressamente previsto, os direitos ao contraditório e à ampla defesa hão de ser franqueados ao administrador acusado ${ }^{1199}$, bem como a decisão deverá ser devidamente fundamentada ${ }^{1200}$.

Na mesma decisão que destituir o administrador judicial, prescreve a Lei, deverá o juiz nomear o novo integrante do cargo, para evitar solução de continuidade ${ }^{1201}$.

O administrador judicial destituído (o texto de lei é "substituído"1202) deverá prestar contas no prazo de 10 dias na forma do art. $154, \S \S 1^{\circ}$ a $5^{\circ}$, da LREF (art. $\left.31, \S 2^{\circ}\right)$.

\subsubsection{Remuneração}

A lei prescreve critérios para a fixação do valor e da forma de pagamento da remuneração que o magistrado deverá arbitrar em favor do administrador judicial.

\footnotetext{
${ }^{1198}$ Manual de Direito Comercial e de Empresa, v. 3, p. 87.

1199 Fabio Ulhoa COELHO, Comentários à Nova Lei de Falências e de recuperação de Empresas - Lei $n$. 11.101, de 9-2-2005, p. 81;

${ }^{1200}$ Haroldo Malheiro Dulclerc VERÇOSA, Comentários, p. 184.

${ }^{1201}$ Paulo Fernando Campos Salles deTOLEDO, Comentários, p. 80.

1202 Para Paulo Fernando Campos Salles deTOLEDO, o sentido é de destituído (cf. p. 81).
} 
Quanto ao valor, a Lei n. ${ }^{\circ}$ 11.101/05 fixa o teto de 5\% do valor devido aos credores sujeitos à recuperação judicial ou, no caso de falência, do valor de venda dos bens do falido.

Até esse limite, o juiz arbitrará o valor da remuneração segundo os seguintes critérios: (a) capacidade de pagamento do devedor; (b) grau de complexidade do trabalho e (c) os valores pagos no mercado para o desempenho de atividades semelhantes.

Quanto à forma de pagamento, não há critérios legais expressos - de modo que, por exemplo, poderão ser feitos pagamentos mensais ${ }^{1203}$. No entanto, é determinada a reserva de uma alíquota do valor total arbitrado para pagamento apenas após a prestação de conta - que é devida pelo administrador judicial. O problema de técnica legislativa, todavia, é que a norma existente aplica-se apenas ao processo de falência e não tem lugar no caso de recuperação judicial.

De fato, no procedimento liquidatório, prescreve o art. $24, \S 2^{\circ}$, deverá ser reservado o valor de $40 \%$ do total arbitrado, o qual apenas será pago após a prestação das contas pelo administrador judicial na forma dos arts. 154 e 155 da LREF.

A redação final do projeto de lei encaminhado pela Câmara dos Deputados ao Senado Federal previa, segundo anota Paulo Fernando Campos Salles de TOLEDO, a reserva de $20 \%$ do total arbitrado em favor do administrador judicial para que o pagamento apenas fosse feito após a prestação de contas e a apresentação do relatório sobre a execução do plano. Contudo, a lei publicada não prevê tal disciplina - de modo que resta tal lacuna ${ }^{1204}$.

Sendo substituído antes do encerramento dos processos, o administrador judicial fará jus à remuneração proporcional (art. $\left.24, \S 3^{\circ}\right)$.

Todavia, como já visto, na hipótese de renúncia imotivada ou, ainda, de destituição por "desídia, culpa, dolo ou descumprimento das obrigações" ("Ou seja, em todos os casos de destituição" 1205 ) e de rejeição das contas prestadas, a remuneração não será devida (art. 24, $\S \S 3^{\circ}$ e $4^{\circ}$ ). Desse modo, no rigor da lei, não apenas o administrador destituído não receberá o valor faltante, mas ainda, conforme observa Paulo F. C. S. de

\footnotetext{
${ }^{1203}$ Haroldo Malheiro Dulclerc VERÇOSA, Comentários, p. 177.

${ }^{1204}$ Paulo Fernando Campos Salles deTOLEDO, Comentários, p. 65; Ricardo NEGRÃO, Manual de Direito Comercial e de Empresa, v. 3, p. 90.

${ }^{1205}$ Paulo Fernando Campos Salles deTOLEDO, Comentários, p. 66.
} 
TOLEDO, deverá devolver o valor já recebido ${ }^{1206}$.

O pagamento da remuneração ficará a cago ou da massa falida ou devedor em recuperação judicial, conforme o caso. Registre-se que em caso de quebra, o crédito é extraconcursal e tem prioridade sobre os demais créditos dessa natureza, nos termos do art. 84 , inc. I.

\subsubsection{Atribuições}

Na fixação as atribuições do administrador judicial, o legislador vale-se da mesma técnica legislativa empregada no caso do Comitê de Credores: no art. 22, prescreve, em três incisos diferentes, sucessivamente as atribuições e os deveres (I) comuns ambas as espécies de processos concursais, (II) aqueles exclusivas da recuperação judicial e, por derradeiro, (III) aqueles próprios da falência. Naturalmente, o rol do referido artigo não prejudica a previsão de outras atribuições e deveres em outros dispositivos.

De observar, conforme prescreve o caput do art. 22, que o exercício das atribuições legais pelo administrador judicial é feita sob a fiscalização do Comitê de Credores.

Para o exercício de suas funções, poderá o administrador judicial contar com colaboradores. Para sua contração, todavia, necessitará de autorização judicial (art. 22, I, h) e sua remuneração será fixada pelo Juízo (art. 22, § $1^{\circ}$ ). Abaixo, veem-se as atribuições comuns aos processos concursais

Prestação de informação. Na falência ou na recuperação judicial, a lei atribui ao administrador certos deveres de prestar informação aos credores e interessados. Destacam-se as informações relacionadas ao reconhecimento do crédito dos credores.

Desse modo, cabe ao administrador judicial enviar correspondência aos credores integrantes da relação fornecida pelo devedor, quer por ocasião do ajuizamento do pedido de recuperação judicial (art. 51, III) ou de confissão de falência (art. 105, II), quer por determinação do juiz na sentença de quebra (art. 99, III). Deverá informar tais credores da data da decisão de quebra ou de deferimento do processamento da recuperação judicial, bem como o valor, a natureza e a classificação do crédito a cada um deles imputado pelo devedor.

${ }^{1206}$ Comentários, pp. 65-66. 
Em qualquer momento processual, deverá ele prestar as informações pedidas pelos credores interessados (art. 22, I, $b$ ), bem como fornecer a eles extratos dos livros do devedor (que se sujeita ao dever de lavrá-los, nos termos do art. 1.180 e 1.185 do Código Civil) para fins de defesa dos respectivos créditos.

Exigir informações. É atribuição do administrador judicial exigir dos credores, do devedor ou de seus administradores a prestação de quaisquer informações relevantes para o desempenho das próprias atribuições - em particular no procedimento administrativo de verificação do passivo (art. 22, I, $d$ ).

Na hipótese de recusa de prestação de informação, o administrador judicial poderá requerer ao juiz que determine à parte reticente o comparecimento em juízo, sob pena de desobediência, para que o magistrado o interrogue na presença do administrador e colha os depoimentos ("por escrito") (art. 22, $\S 2^{\circ}$ ).

Elaboração de relação de credores e consolidação do QGC. A fase administrativa da verificação de crédito processa-se perante o administrador judicial. A ele incumbe, a partir das informações e documentos fornecidos pelo devedor (primeira relação de credores e livros e documentos disponíveis) e pelos credores, em suas habilitações e divergências, e, ainda, a partir das informações por ele colhidas na forma do art. 22, I, $d$, decidir sobre a "segunda" relação de credores - que, então, será publicada (art. $7^{\circ}, \S 2^{\circ}$, c/c art. $22, \mathrm{I}, d)$.

Em caso de insurgência contra essa relação de credores, inicia-se, então, a fase judicial da verificação de crédito. Caberá ao administrador judicial consolidar o quadro geral de credores, a partir das decisões judiciais modificativas daquela segunda relação de credores (art. 18 e art. 22, I, f), que é, então, assinado pelo Juízo e pelo administrador judicial, sendo encartado nos autos e publicado no órgão oficial (art. 18, parágrafo único).

Requerer convocação de AGC e presidi-la. A assembleia geral de credores, já se analisou, é sempre convocada pelo magistrado. Pode o administrador judicial, no entanto, requerer ao Juízo sua convocação tanto nas hipóteses previstas expressamente pela Lei quanto naquelas em que entender necessária a oitiva dos credores (art. 22, I, $g$ ).

A AGC é, ademais, presidida pelo administrador judicial (art. 37, caput), salvo os casos de incompatibilidade (art. $37, \S 1^{\circ}$ ). 
Manifestar-se nos casos previstos em lei. Outra função do administrador judicial é manifestar-se nos casos previstos pela Lei. São exemplos: (a) o parecer ofertado no processo de impugnação à relação de credores (art. 12, parágrafo único), após manifestados o Comitê e o devedor (art. 12, caput); (b) e decisão em caso de impossibilidade de ser alcançada maioria em deliberação do Comitê de Credores (art. 27, § $\left.2^{\circ}\right)$.

Exercer as atribuições do Comitê de Credores. Na hipótese de inexistência de Comitê de Credores e não havendo incompatibilidade com o exercício das funções que lhe são próprios (hipótese em que as atribuições do órgão serão exercidas pelo Juiz), caberá ao administrador judicial exercer as atribuições daquele (art. 28).

Por outro lado, há atribuições exclusivas da recuperação judicial. De um modo geral, na recuperação judicial, as funções do administrador judicial não são de "administração", mas de fiscalização e zelo pelo regular processamento do feito e cumprimento do plano homologado. Vejam-se as atribuições:

Fiscalização. Cabe ao administrador judicial fiscalizar as atividades do devedor (art. 22, II, a), que lhe deve prestar contas mensalmente a partir do deferimento do processamento (art. 52, IV).

Uma vez homologado judicialmente o plano de recuperação aprovado pelos credores e até o limite de dois anos (art. 63), a fiscalização do administrador judicial recairá também sobre o regular cumprimento do referido.

Apresentação de relatórios e pedido de convolação. Também cabe ao administrador judicial apresentar relatórios mensais sobre a atividade do devedor (art. 22, II, c) e, no encerramento do biênio de que trata o art. 61, caput, o relatório circunstanciado sobre o cumprimento do plano (art. 22, II, d, c/c art. 63, III).

Se, no curso do período de dois anos, houver descumprimento pelo devedor do plano homologado, é atribuição do administrador requerer a convolação da recuperação judicial em falência (art. 22, II, $b$, c/c art. 61, § $1^{\circ}$, e art. 73, IV).

Exercício extraordinário e temporário da administração. Embora não seja função ordinária do administrador judicial a administração do devedor, tendo em vista que este permanece à testa do negócio (art. 64), o eventual desapossamento e afastamento judicial do devedor ensejará a nomeação do gestor judicial pela assembleia geral de credores. Até que decida o órgão competente, contudo, a administração do devedor caberá 
extraordinária e temporariamente ao administrador judicial (art. $\left.65, \S 1^{\circ}\right)$.

No processo falimentar, a atuação do administrador judicial é bem mais extensa. Ante ao desapossamento deste (art. 103), caberá ao auxiliar da Justiça levar a efeito todos os atos materiais e jurídicos concernentes à arrecadação dos bens, liquidação do ativo e pagamento do passivo.

Dever de informar. Explicitando o dever de informar que incube ao administrador judicial, o art. 22, III, a, determina que ele avise aos credores o local, data e horário em que estes terão acesso aos documentos do falido. De ressaltar a necessidade de publicação de que trata o art. 191.

Exame da escrituração do devedor. Deverá o administrador judicial analisar a escrituração do devedor, não apenas para prestar informações e decidir, como visto, as habilitações e divergências, mas também para apurar as causas da falência " $e$ detectar irregularidades eventualmente ocorridas" "1207. De lembrar que a inexistência dos livros ou de parte deles ou, ainda, a ausência de autenticação perante o Registro Público das Empresas Mercantis constitui fato típico (art. 178).

Representação judicial da massa falida. Caberá ao administrador judicial a "representação" da massa falida perante o Judiciário (art. 22, III, c, $2^{\text {a }}$ parte), quer nas ações de que é autora, quer naquelas que figura como ré. Mesmo daquelas iniciadas antes da quebra deve ele ser intimado, sob pena de nulidade (art. 76, parágrafo único). Todas as providências para a conservação de direitos e ações deverão ser por ele tomadas (art. 22, III, 1), bem como requeridas ao Juízo para comprimento da lei (art. 22, III, o).

Deve ainda o administrador judicial relacionar todas essas ações (art. 22, III, c, $1^{\text {a }}$ parte) e poderá ele contratar advogado, sendo os honorários previamente ajustados e aprovados pelo Comitê de Credores (art. 22, III, $n$ ).

Receber e abrir a correspondência dirigida ao devedor. Questão relevante do ponto de vista constitucional é a autorização legal (e o dever) do administrador judicial para receber e abrir as correspondências dirigidas ao devedor (art. 22, III, d). De se questionar se essa providência não constitui ofensa ao direito constitucional de sigilo de correspondência (CF: art. $\left.5^{\circ}, \mathrm{XII}\right)$.

\footnotetext{
${ }^{1207}$ Paulo Fernando Campos Salles de TOLEDO, Comentários, in Paulo Fernando Campos Salles TOLEDO - Carlos Henrique ABRÃO (Coords.), Comentários à Lei de Recuperação de Empresas e Falência, São Paulo, Saraiva, 2010, p. 55.
} 
Tendo em vista a natureza instrumental e, ainda, a circunstância de a correspondência referir-se ao exercício da atividade, defende Paulo F. C. S. de TOLEDO sua constitucionalidade - mesmo quando for aberta correspondência de cunho pessoal ${ }^{1208}$, que, prescreve a lei, deverá ser encaminhada ao devedor.

Relatório circunstanciado e relatórios mensais. Deverá o administrador judicial apresentar relatório sobre as causas e circunstâncias da falência. O prazo legal é de 40 dias, prorrogável por igual período. Entende a doutrina que tal lapso temporal é impraticável $^{1209}$.

Tal relatório deve ainda dar cumprimento ao art. 186, reportando a conduta do falido antes e depois da quebra e indicação de eventuais responsáveis por atos tipificados como crimes "falimentares". Além disso, mensalmente, deverá apresentar relatório que especifique a receita e a despesa (art. 22, III, p).

Arrecadação e avaliação dos bens. Caberá ao administrador judicial arrecadar bens e documentos e avaliar tais bens (art. 22, III, $f$ e $g$ ) - podendo contar, quando incapaz a tanto, com avaliadores por ele contratados com autorização judicial (art. 22, III, h)

Realização do ativo. Caberá ao administrador judicial realizar o ativo (art. 22, III, $i$ ) e, quando se tratar de bens perecíveis ou cuja venda antecipada é vantajosa ou menos dispendiosa, requerer ao Juízo a alienação desde logo (art. 22, III, j).

Pagamento do passivo. Caberá também ao administrador judicial fazer o pagamento dos créditos extraconcursais e, ainda, do passivo concursal (art. 22, III, i), observadas, respectivamente, as regras do art. 84 e 83.

Prevê a lei a possibilidade de remição em benefício da massa e mediante autorização judicial a remição de bens apenhados, penhorados ou legalmente retidos. Todavia, tendo em vista que o produto da venda dos bens gravados com garantia real ou nos processos singulares em que já houver arrematação devem ser vertidos para a massa falida, essa previsão é de difícil aplicação ${ }^{1210}$.

\footnotetext{
${ }^{1208}$ Comentários, p. 56.

${ }^{1209}$ Paulo Fernando Campos Salles de TOLEDO, Comentários, in Paulo Fernando Campos Salles TOLEDO - Carlos Henrique ABRÃO (Coords.), Comentários à Lei de Recuperação de Empresas e Falência, São Paulo, Saraiva, 2010, p. 56.

${ }^{1210}$ Paulo Fernando Campos Salles de TOLEDO, Comentários, in Paulo Fernando Campos Salles TOLEDO - Carlos Henrique ABRÃO (Coords.), Comentários à Lei de Recuperação de Empresas e Falência, São Paulo, Saraiva, 2010, p. 55.
} 
Transação. É possível que o administrador judicial transija sobre direitos e deveres da massa falida - por exemplo sobre crédito que tem a receber e que seja de difícil recebimento. Todavia, isso apenas será possível mediante autorização judicial depois de ouvidos o devedor e o Comitê de Credores (art. 22, § $3^{\circ}$ )

Continuação da atividade. Na hipótese de o juiz determinar a continuação provisória da atividade do falido, prescreve o art. 99, XI, caberá ao administrador judicial o exercício da atividade (cf. art. $150^{1211}$ ), diferentemente do que ocorria no direito anterior - em que deveria ser nomeado um "gerente" (LF: art. 76), tendo em vista que, nos termos da lei, o síndico era um dos credores e, portanto, sem caráter profissional (no exercício dessa função) e pelo risco, então existente, de ele agir em benefício próprio em detrimento dos demais credores ${ }^{1212}$.

Entrega de documentos e bens ao substituto. Na hipótese de substituição do administrador judicial, deve ele entregar os bens e documentos relativos à massa falida ao substituto (art. 22, III, q).

Prestação de contas. Ao final ou quando destituído ou substituído, deve o administrador judicial prestar contas na forma do art. 154 e 155.

\subsubsection{0 . Responsabilidade do administrador judicial}

Em apenas um artigo trata o legislador da responsabilidade do administrador judicial. Ele responderá por atos de dolo ou culpa que cause prejuízo ao devedor, aos credores ou à massa falida (art. 32). A mesma regra vale para o membros do Comitê, salvo os discordantes que consignarem a discordância em ata ${ }^{1213}$.

Trata-se de uma "responsabilidade subjetiva do tipo clássico", como assevere Marlon TOMAZETTE ${ }^{1214}$, embora mais genérica que a prevista pela revogada Lei de Falências. Assemelha-se à responsabilidade dos mandatários, embora, como visto, a

1211 Vera Helena de Melo FRANCO, Comentários, in TOLEDO, Paulo Fernando Campos Salles de ABRÃO, Carlos Henrique (coord.), Comentários à Lei de Recuperação de Empresas e Falências, São Paulo, Saraiva, 2005, p. 416.

1212 Nelson ABRÃO, A Continuação do Negócio na Falência, p. 145/146.

${ }^{1213}$ Paulo Fernando Campos Salles de TOLEDO, Comentários, in Paulo Fernando Campos Salles TOLEDO

- Carlos Henrique ABRÃO (Coords.), Comentários à Lei de Recuperação de Empresas e Falência, São Paulo, Saraiva, 2010, p. 82.

${ }_{1214}$ Comentários, in CORRÊA-LIMA, Osmar Brina - CORRÊA-LIMA, Sérgio Mourão (coord.), Comentários à Nova Lei de Falências e Recuperação de Empresas - Lei n. 11.101, de 09 de fevereiro de 2005, Rio de Janeiro, Forense, 2009. 
natureza jurídica do cargo seja de função judiciária, órgão do processo concursal.

Paulo Fernando Campos SallesTOLEDO entende que deveria ser prevista ainda responsabilidade por violação da lei - incorporando disciplina similar à da Lei 6.404/76. Nesse ponto, o projeto aprovado no Senado Federal regrediu se comparado ao aprovado pela Câmara dos Deputados ${ }^{1215}$.

A responsabilidade, no caso da falência, deve ser apurada já na sentença que rejeita as contas do administrador judicial. Na recuperação judicial, todavia, como já sublinhado, inexiste procedimento específico para esse fim - de modo que caberá ao magistrado, em decisão nos autos, decidir sobre isso.

Todavia, mesmo quando não for objeto de decisão pelo Juízo nos próprios autos, é possível ajuizamento de ação própria para fins de responsabilização do administrador judicial. Sustenta Fabio Ulhoa COELHO que, no caso da falência, desde o decreto de quebra até o encerramento do processo, "somente a massa falida tem legitimidade ativa para responsabilizá-la”. Como o dano é causado à "comunhão de credores", explica, "nenhum deles isoladamente ou mesmo o devedor falido estão legitimado a promoer essa responsabilização" ${ }^{\text {,1216. }}$.

Terminado o processo concursal, então terá legitimidade o credor contanto que, sob pena de não ser legitimado, tenha requerido, no curso daquele - é o que sustenta COELHO - requerido a destituição do nomeado pelo magistrado.

\subsection{Assembleia geral de credores}

O estabelecimento das negociações estruturadas entre as partes envolvidas na recuperação judicial dá-se, como visto, no bojo de um processo judicial. $\mathrm{O}$ benefício decorrente dessa técnica é a possibilidade de essas negociações efetivamente se realizarem, uma vez que o processo é dotado de impulso oficial e preclusão - expedientes que, em conjunto, permitem o avanço de suas diversas fases sem, em regra, possibilidade de regresso a estágio anterior. $\mathrm{O}$ deslinde processual, destarte, torna certa a superveniência de uma decisão acerca da crise, seja ela qual for.

\footnotetext{
${ }^{1215}$ Paulo Fernando Campos Salles de TOLEDO, Comentários, in Paulo Fernando Campos Salles TOLEDO - Carlos Henrique ABRÃO (Coords.), Comentários à Lei de Recuperação de Empresas e Falência, São Paulo, Saraiva, 2010, p. 81.

${ }^{1216}$ Paulo Fernando Campos Salles de TOLEDO, Comentários, in Paulo Fernando Campos Salles TOLEDO - Carlos Henrique ABRÃO (Coords.), Comentários à Lei de Recuperação de Empresas e Falência, São Paulo, Saraiva, 2010, p. 82.
} 
Assim é que, uma vez deferido o processamento da recuperação, o devedor conta com o prazo de sessenta dias para a apresentação do respectivo plano. Essa é a oferta que ele fará à comunhão de credores. É ela que dará efetivamente início às tratativas entre as partes. Na hipótese de inobservância do prazo, é decreta a falência do devedor (art. 53, caput, c/c art. 73, inc. II).

Intimados os credores da apresentação do plano, e contanto que, embora não formado ainda o quadro geral de credores, tenha sido publicada ao menos a segunda relação de credores $\left(\operatorname{art} .7^{\circ}, \S 2^{\circ}\right.$ ), devem estes necessariamente manifestar-se sobre o plano, para acatá-lo ou rejeitá-lo. Inexiste outra opção ${ }^{1217}$.

A rejeição implicará a convolação da recuperação judicial em falência e, assim, terá sido frustrada a via reorganizacional, impondo-se a solução liquidatóriasolutória (art. 56, § $4^{\circ}$, c/c art. 73, III). A aprovação, contudo, acarretará a novação das obrigações sujeitas ao plano (art. 59).

A manifestação dos credores poderá se dar tácita ou expressamente; no primeiro caso, porém, apenas pela aprovação do plano. De fato, em regra, o silêncio apenas produz efeitos jurídicos quando a circunstância ou os usos o autorizam e não se faz necessária a manifestação expressa (CC: art. 111). In casu, contudo, o efeito jurídico da omissão dos credores é previsto explicitamente pela Lei n. ${ }^{\circ} 11.101 / 05$ : se não houver objeções ao plano dentro do prazo legal, ele é aprovado tacitamente (art. 58, caput), cabendo então ao juízo sua homologação nos termos do art. 58 da LREF.

Contudo, em havendo a apresentação de objeção, necessariamente é convocada a assembleia geral de credores, para que ela delibere sobre o plano. Em que pesem a previsão legal e o registro (raro) de ocorrência de aprovação tácita, o mais frequente é que se dê a instauração do órgão colegiado para - nesse que é o locus adequado ao debate e à tomada de deliberações nos entes coletivos e comunhões de interesses - que ele decida.

\subsubsection{Características}

${ }^{1217}$ A única possibilidade alternativa - mas que não consistiria no prosseguimento das negociações - seria a apresentação de pedido de desistência pelo devedor, que depende, como visto, de aprovação dos credores (art. 35, icn. I, al. $d$ c/c art. 52, § $4^{\circ}$ ). 
A assembleia geral de credores é órgão colegiado ${ }^{1218}$ deliberativo $^{1219}$ da comunhão dos credores sujeitos à recuperação judicial e à falência ${ }^{1220}$. De acordo com Jorge LoBo, "é um órgão colegiado deliberativo, convocado e instalado na forma da lei, que tem a função de examinar, debater e decidir as matérias de sua atribuição exclusiva, discriminadas no art. 35, inc. I, e II, da LRE ${ }^{, 1221}$. Tem a mesma natureza e assemelha-se muito à assembleia geral de acionistas das companhias, examinada no capítulo antecedente. Não se faz, por isso, necessário relembrar-se aqui tudo quanto ficou ali assentado - a que se fará, no mais das vezes, tão somente remissão.

Acima já se disse que a assembleia geral de credores é um órgão colegiado deliberativo. Ou seja, conforme aquela classificação examinada no Capítulo precedente, trata-se de um órgão plural do tipo colegial. Isso, porque é formado por pluralidade de membros e sua atuação resulta de deliberação. Deliberação, é o caso de reiterar, é um ato colegial de formação da vontade da comunhão de interesses e, por essa sua natureza, resulta da combinação das manifestações individuais integrantes do órgão. Essas expressões individuais são realizadas por meio do exercício do voto.

Todas essas prerrogativas da assembleia concernem à formação e à expressão da vontade coletiva da comunhão de credores. Conforme salienta, e conforme foi examinado no capítulo precedente, Erasmo Valladão A. e N. FRANÇA, com apoio em H. Wiedemann, enquanto na pessoa natural a formação e a expressão da vontade (i.e., a decisão de praticar ou não um determinado ato jurídico) tem natureza psicológica, nos 'grupos' a formação da vontade (i.e., a deliberação) tem natureza jurídica ${ }^{1222}$, a depender de órgão competente e de procedimento regular. Este órgão deliberativo é geralmente nomeado 'assembleia'1223 (quando não apenas 'reunião' ${ }^{1224}$ ), que, no ensinamento de Plínio Paulo BING, “é uma reunião de pessoas, para um fim determinado ou com interesses comuns, com um instrumento de formação da vontade social, para deliberar sobre

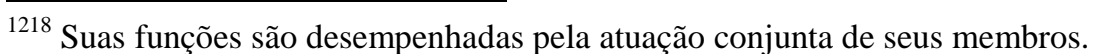

${ }^{1219}$ Método 'assemblear', com formalidades e ritualístia próprias.

${ }^{1220}$ Tem esse entendimento Erasmo Valladão A. e N. FRANÇA, que se fundamenta nas lições de Francesco Carnelutti - para quem a idéia de órgão está vinculada à de interesse comum ou coletivo. In: SoUZA JUNIOR, Francisco Satiro - PITombo, Antônio Sérgio A. de Moraes (coord.), Comentários à Lei de Recuperação de Empresas e Falência, São Paulo, RT, 2007, p. 187. Jorge LOBO também sustenta tratar-se de órgão. In: Paulo Fernando Campos Salles TOLEDO - Carlos Henrique ABRÃO (coord.), Comentários à Lei de Recuperação de Empresas e Falência, São Paulo, Saraiva, 2005, p. 86 e n. 6.

1221 Comentários, in In: Paulo Fernando Campos Salles Toledo - Carlos Henrique ABRÃo (coord.), Comentários à Lei de Recuperação de Empresas e Falência, São Paulo, Saraiva, 2005, p. 86.

${ }^{1222}$ Comentários, in Souza Junior, Francisco Satiro - PITOMBo, Antônio Sérgio A. de Moraes (coord.), Comentários à Lei de Recuperação de Empresas e Falência, p. 188.

${ }^{1223}$ É o nomen iuris empregado no condomínio edilício, na sociedade limitada (com mais de dez sócios), na sociedade anônima etc.

${ }^{1224}$ Como no caso das sociedades limitadas de dez sócios ou menos.
} 
propostas, usando-se para tanto os caminhos estabelecidos em lei, em Estatuto ou em contrato social"

De funcionamento facultativo ${ }^{1226}$, trata-se de órgão hierarquicamente superior $^{1227}$. Suas funções são definidas pelo art. 35 da Lei n. ${ }^{\circ} 11.101 / 05^{1228}$ e são adiante apontadas. Contudo, referente à sua superioridade, destaca-se o poder de nomear e destituir os membros do comitê de credores, o poder de requerer a destituição do administrador judicial (havia previsão de destituição, no projeto de lei aprovado pelo Congresso Nacional, que foi, no entanto, vetada pelo Presidente da República) e, ainda, o de nomeação do gestor judicial.

As atribuições da assembleia geral são as seguintes: (i) deliberar sobre o plano apresentado pelo devedor (para o aprovar, rejeitar ou modificar), (ii) nomear os membros do Comitê de Credores, (iii) nomear o gestor judicial, na hipótese de afastamento do devedor de seus negócios, além de (iv) deliberar sobre "qualquer outra matéria que possa afetar os interesses dos credores" e (v) apreciar pedido de desistência apresentado pelo devedor depois de deferido o processamento da recuperação.

Assim, no caso da recuperação judicial, cumpre à assembleia geral de credores, mediante regular convocação, instalação e deliberação, manifestar validamente a vontade da comunhão de credores nos limites de suas atribuições. O método assemblear, examinado no Capítulo 3, tem igual aplicação - pois que este e aquele são órgãos de mesma natureza.

\footnotetext{
${ }^{1225}$ Direito Assemblear nas Sociedades Mercantis e Civis, Porto Alegre, Sergio Antonio Fabris, 2007, p. 14.

${ }^{1226}$ No processo de recuperação judicial - em que as atribuições da assembleia são mais proeminentes -, a aprovação do plano pode dar-se por ausência de objeção (art. 58). O procedimento especial (e facultativo) para microempresas e empresas de pequeno porte não prevê a convocação de assembleia. Fabio Ulhoa COELHO

${ }^{1227}$ Erasmo Valladão A. e N. FRANÇA, Comentários, in Francisco Satiro SoUZA JUnIOR - Antônio Sérgio A. de Moraes PItombo (coord.), Comentários à Lei de Recuperação de Empresas e Falência, São Paulo, RT, 2007, p. 189. Também Vera Helena de Mello Franco - Rachel SzTAJn, Falência e Recuperação da Empresa em Crise, Rio de Janeiro, Elselvier, 2008, p. 79. Embora não tenha preponderância sobre o administrador judicial, que é nomeado e destituído pelo juiz (art. 31; art. 52, inc. I; e 99, inc. IX; note-se, ademais, os vetos às alíneas 'c' e 'a' dos incisos I e II, respectivamente, do art. 35), a ela cabe constituir dois outros órgãos, o Comitê de Credores (art. 35, I, $b$, e art. 35, II, $b$ ) e, na recuperação, o gestor judicial (art. 35, I, $e, c / c$ art. 34). Ademais, é titular da competência residual para "qualquer outra matéria que possa afetar os interesses dos credores" (art. 35, I, $f$, e II, $d$ ) e a ela compete decidir sobre a recuperação judicial e sobre sua convolação em falência - devendo o juiz, em princípio, observar suas deliberações (cf. Erasmo Valladão A. e N. FRANÇA, Assembleia-Geral de Credores na Lei Falimentar, in Temas de Direito Societário, Falimentar e Direito de Empresa, São Paulo, Malheiros, 2009, p. 11).

${ }^{1228}$ Essencialmente, cabem à AGC, na recuperação judicial, (i) deliberar sobre o plano apresentado pelo devedor (para o aprovar, rejeitar ou modificar), (ii) nomear os membros do Comitê de Credores, (iii) nomear o gestor judicial, na hipótese de afastamento do devedor de seus negócios, além de (iv) deliberar sobre "qualquer outra matéria que possa afetar os interesses dos credores" e (v) apreciar pedido de desistência apresentado pelo devedor depois do deferimento do processamento da recuperação.
} 


\subsubsection{Integrantes e direito de presença, voz e voto}

A assembleia geral de credores é integrada pela comunidade de credores do devedor. Nem todos, contudo, têm direito a voto.

Têm direito a voto aqueles arrolados no quadro geral de credores - ou, na sua ausência, os integrantes da segunda relação de credores ${ }^{1229}$ ou, ainda, se não publicada esta, aqueles constantes da primeira relação ${ }^{1230}$ - e, também, aqueles habilitados por ocasião da realização do conclave ou que tenham os créditos admitidos ou alterados por decisão judicial, inclusive os credores por quantias ilíquidas que tenham obtido reserva de valor (art. 39). Tais credores é que são considerados para fins de verificação do quorum de

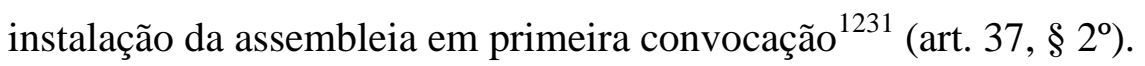

Todavia, não podem votar os credores habilitados de forma retardatária, salvo os decorrentes de relação de trabalho (art, 39, caput, art. 10, § $1^{\circ}$ ). Igualmente não votam aqueles cujos créditos não se sujeitam à recuperação judicial (art. 39, § 1º, c/c art. $49, \S \S 3^{\circ}$ e $4^{\circ}$ ); os credores não atingidos pelo plano apresentado (art. 45, $\S 3^{\circ}$ ); e, ainda, aqueles que tenham relação societária ou de parentesco com o devedor nos termos do art. 43, caput e parágrafo único, da Lei n. ${ }^{\circ} 11.101 / 05$.

De notar, entretanto, que o direito de presença e de manifestação (direito de voz) são franqueados a todos os credores, estejam ou não autorizados a votar ${ }^{1232}$.

Assinala Erasmo Valladão A. e N. FRANÇA ter desejado o legislador que as deliberações da assembleia fossem efetivamente tomadas "em contraditório", na presença dos credores interessados ${ }^{1233}$ - o que, inclusive, no seu entender, afasta a possibilidade de "voto por correspondência, telegrama, telefone, fax, e-mail, etc."1234 Sobre o devedor, é de se observar que a lei brasileira é omissa sobre a obrigatoriedade de

\footnotetext{
${ }^{1229}$ Relação organizada pelo administrador judicial: art. $7^{\circ}, \S 2^{\circ}$.

${ }^{1230}$ Relação que deve instruir o pedido de recuperação judicial: art. 51, III e IV.

1231 Erasmo Valladão A. e N. FRANÇA, Comentários, in Francisco Satiro SouZA Junior - Antônio Sérgio A. de Moraes PITOMBo (coord.), Comentários à Lei de Recuperação de Empresas e Falência, São Paulo, RT, 2007, p. 205.

${ }^{1232}$ Erasmo Valladão A. e N. FrANÇA, Comentários, in Francisco Satiro SouZA JunIOR - Antônio Sérgio A. de Moraes PIтомво (coord.), Comentários à Lei de Recuperação de Empresas e Falência, São Paulo, RT, 2007, pp. 205 (itens 128.1 e 129) e 211. No mesmo sentido: Adalberto SIMÃO FILHO, Interesses transindividuais dos credores nas assembleias gerais,

${ }_{1233}$ Ainda que por representação: art. $37, \S \S 4^{\circ}$ a $6^{\circ}$.

${ }^{1234}$ Erasmo Valladão A. e N. FrANÇA, Comentários, in Francisco Satiro SouZA JunIOR - Antônio Sérgio A. de Moraes Pitombo (coord.), Comentários à Lei de Recuperação de Empresas e Falência, São Paulo, RT, 2007, p. 206.
} 
presença do próprio devedor ${ }^{1235}$, sendo lídimo concluir pela mera faculdade ${ }^{1236}$. De todo modo, o interesse no debate persiste.

Em que pesem os avanços tecnológicos, os debates, assim como nas assembleias societárias, fazem-se importantes. Relembre-se que participantes e o de votantes integram universos que, embora concêntricos, não são sempre coincidentes. $\mathrm{O}$ direito político daqueles primeiros limita-se, assim, ao direito de presença e voz. São esses, portanto, os únicos instrumentos de que dispõem para poder influir na formação da vontade coletiva e no curso da recuperação. Por isso, os debates são previstos e estimulados pela legislação societária.

Ora, se em uma comunhão voluntária de interesses, que tende a perdurar no tempo e cujas assembleias gerais são recorrentes, os debates são tão valorizados, parece que, com mais razão, o devem ser em uma comunhão de interesses forçada, como a decorrente da instauração do concurso recuperacional, em que as assembleias gerais são episódicas - e, no caso da principal matéria de sua atribuição, a decisão sobre o plano de recuperação, ela é única (ainda que, por razões pragmáticas, e sem perda de unidade, ela seja eventualmente suspensa - às vezes por tempos não muito curtos).

De todo modo, a pressão pelo emprego de novos meios na realização de assembleias e na manifestação válida da vontade pelos sócios que se fez sentir no âmbito societário certamente não excepcionará as recuperações judiciais - especialmente as de grande vulto, com credores espalhados pelo Pais ou pelo mundo. De toda sorte, e ainda com supedâneo no que defende Erasmo Valladão A. e N. FRANÇA, mesmo que se admita o a utilização de algum meio, ele deve efetivar os debates em caráter instantâneo (à semelhança dos debates de viva-voz), e jamais epistolar (como o seria por carta ou e-mail, por exemplo).

\subsubsection{Sistema de voto e quorum}

As deliberações da assembleia geral devem ser tomadas, como regra

\footnotetext{
1235 Alberto Camiña MoreIRA, Poderes da Assembleia de Credores, do Juiz e Atividade do Ministério Público, in PAIVA, Luiz Fernando Valente de, Direito Falimentar e a Nova Lei de Falências e Recuperação de Empresas, São Paulo, Quartier Latin, 2005, p. 260.

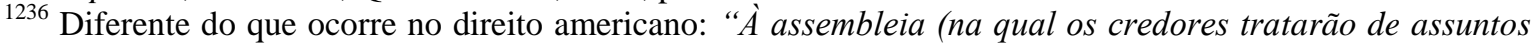
de seu interesses [...]) deverá comparecer o devedor, prestando declarações, sob juramento, respondendo às indagações que lhe forem formuladas pelos presentes." Cf. Paulo Fernando Campos Salles de Toledo, A Empresa em Crise no Direito Francês e Americano, Dissertação de Mestrado, Faculdade de Direito da Universidade de São Paulo, 1987, p. 38.
} 
geral, segundo o princípio majoritário (art. 42), votando cada credor na proporção do seu crédito (art. 35), salvo exceções expressamente previstas. Vigora aqui, como na generalidade das sociedades, o sistema que pondera o valor do voto segundo a participação do votante no risco envolvido. Não se trata, portanto, de voto igualitário por cabeça, mas de voto ponderado.

O quorum, nesses casos, é o de credores representativos, no mínimo, da maioria dos créditos presentes à assembleia e que sejam aptos a votar. Convém observar que, no processo falimentar, a realização de ativos por forma alternativa demanda quorum de credores representativos de $2 / 3$ dos créditos presentes e aptos a votar.

\subsubsection{O problema da separação de classes}

O artigo 41 da Lei n. ${ }^{\circ} 11.101 / 05$ estabelece o seguinte:

“Art. 41. A assembleia-geral será composta pelas seguintes classes de credores:

I - titulares de créditos derivados da legislação do trabalho ou decorrentes de acidentes de trabalho;

II - titulares de créditos com garantia real;

III - titulares de créditos quirografários, com privilégio especial, com privilégio geral ou subordinados."

Essa divisão do órgão deliberativo dos credores em classes é frequente na legislação estrangeira. Todavia, especialmente no sistema americano, é, em geral, com menos rigidez legislativa ${ }^{1237}$. Tencionou o legislador brasileiro, segundo o critério da natureza do crédito (posizione giuridica), aglutinar credores com interesses próximos, ainda que não homogêneos.

De notar que, nas hipóteses em que as deliberações na assembleia dão-se por classes, os credores fundados em relação de trabalho votam com a integralidade de

${ }^{1237}$ F. SEVERINI, I problemi procedurali del concordato preventivo, in DI MARZIO, Fabrizio, Il nuovo diritto della crisi di impresa e del falliimento, Turim, Itaedizioni, 2006, pp. 323/324; Charles Jordan TABB, The Law of Bunkruptcy, pp. 813/814. Jairo SADDI informa: “Em outras jurisdiciones, há muito mais classes de credores; em alguns estados americanos, por exemplo, há doze ou mais delas (tais como crdores bancárioas, credores com arrendamento mercantil, e assim por diante)." Cf. O Comitê e a Assembleia de Credores na Nova Lei Falimentar, in PAIVA, Luiz Fernando Valente de, Direito Falimentar e a Nova Lei de Falências e Recuperação de Empresas, p. 209. 
seus créditos - independente, portanto, do limite de 150 salários mínimos previstos pelo art. 83, inc. I, para fins de pagamento do passivo na falência - e os credores com garantia real votam com o valor do crédito até o limite do valor do bem gravando, sendo contados os votos que superam esse teto entre os quirografários (art. $41, \S \S 1^{\circ}$ e $2^{\circ}$ ).

Essa disposição, quanto aos credores da classe I, é-lhes favorável no caso de aprovação do plano de recuperação: não para formação do quorum previsto pelo art. 45 (já que, nesse caso, a deliberação é tomada 'por cabeça' e não segundo as forças do crédito), mas para o atendimento ao primeiro dos requisitos do quorum alternativo previsto pelo art. 58, $\S 1^{\circ}$, inc.I.

Já a disposição atinente ao credor com garantia real, embora irrelevante para as deliberações tomadas no 'plenário' da Assembleia - segundo a regra do art. 42, caput, $1^{\mathrm{a}}$ parte -, pode fortalecê-los na escolha dos membros do comitê de credores e, especialmente, na deliberação sobre o plano de recuperação, na medida em que lhes oportuniza votar em duas classes diferentes. Nesse particular, portanto, a regra do art. 45 da Lei não dificulta a influência do poder econômico, mas, antes, favorece-a.

Quanto à indicação dos membros do comitê de credores, vislumbra-se, como observa a doutrina, distorção provocada pela divergência verificada entre o disposto no art. 26 e no art. 41 da Lei n. ${ }^{\circ} 11.101 / 05^{1238}$. À luz do art. 44 ("Na escolha dos representantes de cada classe no Comitê de Credores, somente os respectivos membros poderão votar ${ }^{1239,}$,) discordam doutrina e jurisprudência sobre se predominaria a tripartição de um ou de outro artigo.

Assim, resta-nos a análise do mais relevante aspecto relativo à separação dos credores em classes na AGC: a deliberação sobre o plano de recuperação judicial.

\subsubsection{O problema da deliberação estratificada}

A aprovação do plano de recuperação depende do atendimento aos seguintes requisitos, previstos pelo art. 45 da Lei n. $^{\circ}$ 11.101/05: deve ela obter a

1238 Daniel Kalansky Ponczek - Helio Rubens de Oliveira Mendes: "O Comitê de Credores: Funções, Decisões Judiciais mais significativas adotadas no regime da nova Lei em relação ao Tema”, 28.4.2009, item "c".

${ }^{1239^{\circ}}$ Vigorando de qualquer sorte, nas decisões do órgão fracionário, o critério do art. 42 , caput, $1^{\mathrm{a}}$ parte: maioria dos créditos em cada classe. Cf. Erasmo Valladão A. e N. FRANÇA, Comentários, in Francisco Satiro Souza Junior - Antônio Sérgio A. de Moraes PITOMBo (coord.), Comentários à Lei de Recuperação de Empresas e Falência, São Paulo, RT, 2007, p. 216. 
concordância de todas as três classes de credores, sendo a aprovação tomada na classe I pela maioria simples dos credores presentes (independente do valor dos respectivos créditos: regra one man, one vote - art. $45, \S 2^{\circ}$ ) e na classe II e na classe III pela chamada dupla maioria $^{1240}$, i.e., por credores que representem mais da metade do valor total dos créditos presentes à assembleia e, cumulativamente, pela maioria simples dos credores presentes (art. $45, \S 1^{\circ}$ ).

Essa técnica adotada pelo legislador tem o objetivo, por um lado, de evitar distorções na formação da vontade da comunhão - exatamente no desempenho pela AGC de sua principal atribuição.

Deveras, ao seccionar os credores em três classes e exigir o voto afirmativo de todas elas, o legislador equiparou o 'peso' desses grupos na aprovação do plano. Obstou, por conseguinte, que, aplicando-se a regra do caput do art. 42, um determinado credor ou mesmo classe detentor(a) de vultoso crédito 'controlasse' a deliberação, a despeito da vontade dos demais e do devedor.

Ademais, compartimentados os credores (heterogêneos em seus direitos e interesses) em classes diversas, o devedor tem condições mais favoráveis de negociar a aprovação ou mesmo a modificação do plano, se comparada essa situação com negociações estabelecidas com o total da massa de credores.

Evidentemente, nada obsta que devedor e credores estabeleçam tratativas em outras searas - o que decorre da livre iniciativa e da liberdade contratual, resguardas constitucionalmente, e, de qualquer forma, é expressamente ressalvado pela Lei n. ${ }^{\circ}$ 11.101/05, quer na disciplina da recuperação extrajudicial, quer no art. 167. Pondere-se, contudo, que a recuperação judicial já pressupõe uma dificuldade de diálogo entre as partes (agentes econômicos não recorreriam a ela se lograssem obter idêntico resultado por meios menos custosos, como são os acordos privados e, mesmo, a recuperação extrajudicial).

Por isso, sua disciplina, no direito comparado e entre nós, privilegia o estabelecimento de negociações estruturadas (structured bargaining), i.e., a previsão de regras procedimentais cuja observância gera balizas para o comportamento das partes e, assim, favorecem o desenvolvimento das tratativas. Procura-se incentivar o comportamento cooperativo dos credores, de convergência de interesses, em oposição ao

1240 Expressão de Jorge LOBO. In: Paulo Fernando Campos Salles TOLEDO - Carlos Henrique ABRÃO (coord.), Comentários à Lei de Recuperação de Empresas e Falência, p. 102. 
comportamento meramente individualista ${ }^{1241}$.

Já há entre nós estudos acerca do comportamento dos agentes econômicos em tais negociações ${ }^{1242}$. Outras pesquisas na área, em especial aquelas desenvolvidas a partir de dados empíricos, podem auxiliar doutrina e jurisprudência na melhor compreensão do funcionamento dos critérios legais adotados para a aprovação do plano - e mesmo na solução dos conflitos entre classes, tema objeto desse breve estudo.

Em que pesem os benefícios do critério legal adotado - a votação segundo classes de credores -, algumas observações são de rigor.

A primeira refere-se à possibilidade de o credor com garantia real ter parte das deliberações da classe III com o valor do crédito que sobeja o valor do bem gravado. Esse expediente é contrário à diluição do uso do poder econômico e permite ao credor influenciar duas classes distintas.

Ademais, a votação por classes pode permitir, especialmente nas classes II e III, que um credor com crédito insignificante, se analisado à luz da regra do art. 42, pode ser determinante se for o único da classe ou for acompanhado de credores com créditos ainda menores.

No limite, tal credor pode ter verdadeiro poder de veto, mesmo se considerado o quorum alternativo do art. $58, \S 1^{\circ}$, tendo em vista o requisito insculpido em seu inc. III. Eis, aliás, notória fonte de conflitos entre classes de credores na AGC.

Por derradeiro, merece ser observada a regra do art. 73, inc. I, da LREF, que trata da convolação da recuperação judicial já concedida em falência por deliberação da assembleia geral de credores. Nesse caso, o quorum aplicável é o geral previsto pelo art. 42 , não sendo o caso do art. 45 e do art. $58, \S 1^{\circ}$.

\subsubsection{O problema do cram down}

Em razão da heterogeneidade da comunidade de credores e da eventual insuficiência da regra do art. 45 para obstar que o comportamento individualista de certo(s)

\footnotetext{
${ }^{1241}$ Eduardo Secchi Munhoz, Comentários, in Souza Junior, Francisco Satiro - PiTombo, Antônio Sérgio A. de Moraes (coord.), Comentários à Lei de Recuperação de Empresas e Falência, p. 287.

${ }^{1242}$ Citamos, em particular, o artigo "Assembleias de Credores e Plano de Recuperação de Empresas: Uma Visão em Teoria dos Jogos”, de Milton BARossi-FILHO, in Revista de Direito Mercantil, Industrial, Econômico e Finaceiro, v. 137, PP. 233-238.
} 
credor(es) impeçam a aprovação do plano, o legislador previu a possibilidade de o juiz determinar aprovação do plano ainda quando os requisitos acima mencionados não estejam presentes.

É o que disciplina o art. $58, \S \S 1^{\circ}$ e $2^{\circ}$, da Lei n. ${ }^{\circ} 11.101 / 05:$ “ $§ 10$ O juiz poderá conceder a recuperação judicial com base em plano que não obteve aprovação na forma do art. 45 desta Lei, desde que, na mesma assembleia, tenha obtido, de forma cumulativa: I - o voto favorável de credores que representem mais da metade do valor de todos os créditos presentes à assembleia, independentemente de classes; II - a aprovação de 2 (duas) das classes de credores nos termos do art. 45 desta Lei ou, caso haja somente 2 (duas) classes com credores votantes, a aprovação de pelo menos 1 (uma) delas; III - na classe que o houver rejeitado, o voto favorável de mais de 1/3 (um terço) dos credores, computados na forma dos §§ 1 o e 20 do art. 45 desta Lei.§ $2 o$ A recuperação judicial somente poderá ser concedida com base no $\S 1$ lo deste artigo se o plano não implicar tratamento diferenciado entre os credores da classe que o houver rejeitado."

Esse dispositivo, todavia, tem sido alvo de duras críticas da doutrina por não ser suficiente, numa aplicação estrita, para obstar o veto de uma classe e também por destoar bastante do cram down previsto pela legislação estrangeira - particularmente nos Estados Unidos e na Alemanha.

No Capítulo 11 do Bankruptcy Code americano, a deliberação sobre o plano pelas classes dos credores é considerada um passo importante, mas não suficiente para a aprovação da reorganization ${ }^{1243}$.

Na hipótese de veto por parte dos credores, é possível que o juiz o supere e conceda a recuperação ainda assim $^{1244}$. Esse grave poder conferido ao magistrado, todavia, é 'temperado' pelo conjunto de requisitos que devem ser atendidos: o plano não pode implicar unfair discrimination e, necessariamente, deve ser fair and equitable.

O primeiro requisito diz respeito às relações 'horizontais' dos credores: o devedor não pode dividir em classes distintas e oferecer tratamento apartado a credores em situações semelhantes (trata-se de norma análoga à do art. 58, § $2^{\circ}$, da Lei n. ${ }^{\circ}$ $11.101 / 05^{1245}$ ). Já o segundo refere-se às relações 'verticais' (inter-classes) e visa a evitar

\footnotetext{
1243 Charles Jordan TABB, The Law of Bankruptcy, p. 829.

1244 "Este [o cram-down] corresponde à faculdade, outorgada ao juiz, de impor aos integrantes de um alçasse dissidente a aceitação do plano." Paulo Fernando Campos Salles de Toledo, A Empresa em Crise no Direito Francês e Americano, p. 43.

${ }^{1245}$ Eduardo Secchi MunHOZ, Comentários, p. 290.
} 
que haja prevalência de classes subordinadas em prejuízo de classes privilegiadas ${ }^{1246}$. Presentes ambos os requisitos, o juiz pode arbitrar a aplicação do plano.

No Brasil, entretanto, a regra do art. 58, $\S 1^{\circ}$, da LREF restringiu sobremodo a atuação do juiz. Alberto Camiña MOREIRA afirma: " $O$ cram down brasileiro é legalista, fechado, e não dá margem ao juiz para a imposição de plano que possa recuperaar a empresa a despeito da discordância dos credores. "1247

Assim, a regra do art. 58, $\S 1^{\circ}$, constitui verdadeiramente apenas um quorum alternativo àquele previsto no art. 45.

No rigor da lei, a regra subsidiária prevista por aquele dispositivo impõe ao magistrado exclusivamente verificar a ocorrência dos requisitos objetivos concernentes ao escrutínio. Esses critérios não guardam relação direta com a efetiva recuperação da empresa $^{1248}$, mas apenas condicionam a aprovação do plano à obtenção de certo número de votos favoráveis à proposta.

Nesse contexto, inexiste abertura legal para exercício pelo magistrado de um juízo de mérito sobre a concessão da recuperação judicial - fundado na situação econômico-financeira da empresa - e a superação de eventual veto imposto por parte dos credores.

Ainda mais grave - aponta Eduardo Secchi MuNHOZ -, as regras sobre a aprovação do plano segundo a regra do art. $58, \S 1^{\circ}$, não oferecem proteção nem sequer contra eventual inversão da ordem de pagamento entre classes diferentes ${ }^{1249}$. Inexiste, na Lei n. $^{\circ} 11.101 / 05$, controle sobre eventual unfair discrimination presente no plano aprovado pelo quorum alternativo.

Nada obstante, o $\S 2^{\mathbf{o}}$ do mesmo artigo, na hipótese de presentes o requisitos do cram down, impõe ao magistrado a verificação de inexistência de

\footnotetext{
$\overline{1246}$ Carolina S. J. BATISTA - Paulo F. CAMPANA FILHO - Renata Y. MiYAZAKI - Sheila C. N. CEREZETTI resumem: "Conclui-se, assim, que o plano deve ser fair and equitable para proteger cada classe de credores contra perdas involuntárias de ordem de pagamento com relação a outras classes de prioridade distinta. ” In Revista de Direito Mercantil, Industrial, Econômico e Financeiro, v. 143, p. 209. Trata-se da aplicação do princípio da absolute priority rule. Cf. Eduardo Secchi MunHOZ, Comentários, in SouZA JunIOR, Francisco Satiro - Piтомво, Antônio Sérgio A. de Moraes (coord.), Comentários à Lei de Recuperação de Empresas e Falência, p. 290.

${ }^{1247}$ PaIVA, Luiz Fernando Valente de, Direito Falimentar e a Nova Lei de Falências e Recuperação de Empresas, p. 259.

${ }^{1248}$ Eduardo Secchi Munhoz, Comentários, in Francisco Satiro Souza Junior - Antônio Sérgio A. de Moraes Piтомво (coord.), Comentários à Lei de Recuperação de Empresas e Falência, São Paulo, RT, 2007, p. 289.

${ }^{1249}$ Eduardo Secchi Munhoz, Comentários, in Souza Junior, Francisco Satiro - PITOMBo, Antônio Sérgio A. de Moraes (coord.), Comentários à Lei de Recuperação de Empresas e Falência, p. 291.
} 
discriminação entre credores da mesma classe, sob pena de não aprovação do plano.

Em todo caso, malgrado a redação do referido dispositivo ${ }^{1250}$, o entendimento é de que a aplicação do cram donw brasileiro, na hipótese de verificados seus requisitos legais, constitui dever do juiz e não mera faculdade ${ }^{1251}$.

De todo modo, essa atuação 'burocrática' do magistrado - conformada aos estritos termos legais - aponta para uma potencial inação diante de eventual conflito entre classes de credores e que pode redundar na frustração da regra contida no art. 47 da Lei n. ${ }^{\circ} 11.101 / 05$.

Mauro Rodrigues PENTEAdo sublinha a antítese entre a função social da empresa e a soberania dos credores nas recuperações de empresa ${ }^{1252}$.

Embora, à luz da Lei n. ${ }^{\circ} 11.101 / 05$ pareça que a decisão caberá apenas aos credores, entende ser demasiado atribuir tamanho poder a eles "sem os necessários contrapesos". Afinal, completa, "a ninguém é dado ignorar o peso do poder econômico no mercado e a necessidade de contrabalançar essa realidade insuprimível, exteriorizada em seus vários seguimentos. ",1253

De notar, pois, que a legislação nacional dispensou ao magistrado instrumental bem menos efetivo que o conferido pelo Chapter 11 ao Judiciário americano. Centralizando de modo exacerbado nos credores a decisão fundamental sobre a recuperação, a solução brasileira potencialmente enseja situações de conflito cuja resolução, à falta de uma autoridade com expressos poderes, está a exigir exercício de investigação e especulação da doutrina.

\subsection{Abuso de voto e conflito de interesses}

Edurado Secchi MunHOz faz alusão, por analogia, ao abuso de voto previsto pelo art. 115 da Lei 6.404/76. Com efeito, sua aplicação à hipótese da recuperação de empresas exigiria a obrigação dos credores de votar não exclusivamente em seu

1250 "§ 1 lo O juiz poderá conceder a recuperação judicial com base em plano que não obteve aprovação na forma do art. 45 desta Lei, desde que, na mesma assembleia, tenha obtido, de forma cumulativa: (...)”'

${ }^{1251}$ Idem.

${ }^{1252}$ Mauro Rodrigues PENTEAdo, Comentários, in Francisco Satiro SouZA JunIOR - Antônio Sérgio A. de Moraes Piтомво (coord.), Comentários à Lei de Recuperação de Empresas e Falência, São Paulo, RT, 2007, pp. 72-73.

${ }^{1253}$ Mauro Rodrigues Penteado, Comentários, in Francisco Satiro SouZA Junior - Antônio Sérgio A. de Moraes Pitombo (coord.), Comentários à Lei de Recuperação de Empresas e Falência, São Paulo, RT, 2007, pp. 74-75. 
interesse, mas em função dos valores prescritos pelo art. 47 da Lei n. ${ }^{\circ}$ 11.101/05. Cogitase, assim, de aplicação ao âmbito concursal de instituto desenvolvido para o ambiente societário - que apresenta substanciais distinções, já examinadas, com a comunhão de credores subjacentes aos processos concursais.

Nesse sentido, o próprio MunHOZ assinala que "no sistema da recuperação, em vez de constituir-se o instituto do voto abusivo, desenvolveu-se o instituto do cram down, concebido justamente para permitir que o juiz possa interferir, superando o veto ao plano imposto por uma classe de credores" ${ }^{1254}$. Por isso, o cram down americano é acompanhado de parâmetros objetivos para a superação do veto de parte dos credores segundo a função pública do processo de recuperação - diferentemente do que sucede em nossa legislação, cujos critérios, como visto, são substancialmente mais pobres e estão a exigir, em seu entender, revisão pelo legislador ${ }^{1255}$.

Na mesma linha, Erasmo Valladão A. e N. FRANÇA lamenta a Lei n. ${ }^{\circ}$ 11.101/05 não ter tratado de voto abusivo - crítica em que é acompanhado de Newton DE LUCCA $^{1256}$. Nesse caso, seria preciso vincular o interesse dos credores ao interesse da própria recuperação - o que, de qualquer sorte, oferece dificuldade, já que não existe uma noção concreta de interesse comum dos credores.

Nada obstante, o arcabouço normativo existente a respeito do abuso de direito autorizam sua aplicação também nesse caso. Também milita a favor a disciplina existente em matéria societária.

A adoção, portanto, do abuso do direito de voto para solução os potenciais conflitos entre classes de credores na recuperação judicial demanda, portanto, inafastavelmente, o estabelecimento de parâmetros. Devem eles ser, por um lado, suficientemente objetivos para que os agentes envolvidos tenham ciência exata dos limites do exercício de seu direito.

Por outro lado, não podem ser a tal grau estritos para o exercício do

\footnotetext{
1254 Eduardo Secchi Munhoz, Comentários, in Francisco Satiro SouZA Junior - Antônio Sérgio A. de Moraes PiтомBo (coord.), Comentários à Lei de Recuperação de Empresas e Falência, São Paulo, RT, 2007,, p. 292.

1255 Eduardo Secchi Munhoz, Comentários, in Francisco Satiro Souza Junior - Antônio Sérgio A. de Moraes Pitombo (coord.), Comentários à Lei de Recuperação de Empresas e Falência, São Paulo, RT, 2007, , p. 292.

${ }^{1256}$ Abuso do Direito de Voto de Credor na Assembleia Geral de Credores Prevista nos Arts. 36 a 45 da Lei 11.101/2005, in ADAMEK, Marcelo Vieira von, Temas de Direito Societário e Empresarial Contemporâneos - Liber Amicorum Prof. Dr. Erasmo Valladão Azevedo e Novaes França, São Paulo, Malheiros, 2011, pp. 646-647.
} 
direito que terminem por lesar, substancialmente, o direito constitucional - e legítimo - do agente econômico à persecução de seu crédito.

Questão controversa é saber se a identificação desses parâmetros exigiria reforma da lei - como sugere o MuNHOZ, por exemplo - ou se poderia decorrer de reiteradas decisões dos tribunais a esse respeito.

Ainda no âmbito das AGCs, Erasmo Valladão A. e N. FRANÇA analisa hipóteses de anulação das deliberações por ocorrência de conflito de interesses - como tal se caracterizando os casos "em que o interesse individual de determinado credor poderá ser substancialmetne conflitante com da coletividade,1257.

Com apoio em Wilhelm UHLENBRUCK, ele arrolada algumas hipóteses que, doutrinariamente, deliberações da AGC vêm sendo admitidas como de conflito de interesses. Assim é o caso daquelas que "causam prejuizo desproporcional, inadequado, para uma parte dos credores" - critério que, entendemos nós, aproxima-se da doutrina americana acerca do unfair discrimination e do fair and equitable. Bem semelhantes são os casos em que as deliberações favorecem particularmente um credor (em especial, os privilegiados ou com garantia real ou mesmo terceiros) em detrimento da comunhão. Também as deliberações que não são úteis para ninguém e aquelas que, ainda segundo ele, favorecem o devedor ou terceiros sem nenhum benefício para a massa ${ }^{1258}$ são consideradas conflitantes com o interesse da comunhão de credores.

Tais hipóteses não ensejariam proibição de voto, mas, em tese, qualificariam conflito substancial de interesse. Como exemplos concretos, cita Erasmo Valladão A. e N. FRANÇA a hipótese da montadora de automóveis que vota pela quebra de sua concessionária, para o fim de passar a concessão a terceiros. Também é o caso do credor que tem interesse na quebra do devedor que é seu concorrente. De qualquer modo, tais parâmetros e exemplos têm raiz doutrinária e, eventualmente, podem ter repercussão jurisprudencial, mas, rigorosamente, não se encontram disciplinados pela Lei n. ${ }^{\circ}$ $11.101 / 05$.

Também por isso remanesce dúvida sobre a sanção decorrente do conflito: implicaria a anulação da deliberação, tal como previsto pelo $\S 4^{\circ}$ do art. 105 da Lei n. $^{\circ} 11.101 / 05$, ou apenas a responsabilidade por perdas e danos, como disciplina os art.

\footnotetext{
${ }^{1257}$ Erasmo Valladão A. e N. FRANÇA, Comentários, in Francisco Satiro SouZA JUnIOR - Antônio Sérgio A. de Moraes PIтоMBo (coord.), Comentários à Lei de Recuperação de Empresas e Falência, São Paulo, RT, 2007, p. 192.

${ }^{1258}$ No caso de falência.
} 
1.010, $\S 3^{\circ}$, e art. 1.017, parágrafo único, do Código Civil.

A Câmara Especial de Falências e Recuperações Judiciais de Direito Privado do Tribunal de Justiça de São Paulo teve oportunidade de examinar a questão. No agravo de instrumento n. 601.295-4/1-00, julgado em 5/5/2009, a agravante (Viação Aérea São Paulo S.A. - VASP) interpôs recurso contra sentença de primeira instância que convolara a recuperação judicial em falência após deliberação nesse sentido de assembleia geral de credores convocada para esse fim.

A agravante alegou, entre outros fundamentos, a "nulidade dos votos dos principais credores da VASP na Assembleia Geral", pois que "houve muitos votos nulos em razão de conflito de interesses de credores com a coletividade dos demais credores, dando como exemplo a situação da INFRAERO e da GOL; aquela pretendia recuperar as áreas concedidas à VASP [e, portanto, na argumentação da agravante estaria impedida de votar na $\mathrm{AGC}]$, e esta, sua concorrente, tem interesse em fortalecer sua posição no mercado".

Entendeu, todavia, o relator, Des. Pereira Calças, no que foi acompanhado pelos demais integrantes da turma (Des. Romeu Ricupero e Des. José Roberto Lino Machado), que a Infraero, ao postular a retomada de suas áreas, "nada mais fez do que exercer suas atribuições legais" e "obviamente não houve abuso de direito e o voto da Infraero não se maculou de nulidade em razão de ter ela, pura e simplesmente, cumprido suas atribuições legais, ao pleitear, na via judicial, a devolução das inúmeras e enormes áreas públicas cedidas à VASP".

Quanto à potencial nulidade do voto da GOL, o voto do relator é peremptório: "Da mesma forma, nenhum vício atingiu os votos dos credores previdenciários (AEROS), trabalhistas em geral e inclusive de empresas correntes." $\mathrm{E}$ acrescentou a transcrição da opiniou iuris da Procuradoria de Justiça: "Todos os credores buscam tanto na recuperação, quanto na falência, a minimização de seus prejuízos. (...)Se a agravante, decorridos três anos desde o requerimento de recuperação não apresentou qualquer condição de se reintegrar à economia, não há que se falar em confronto ou nulidade de votos, mormente se a razão de decidir não se encontra fundamentada exclusivamente em assembleia geral." .

E assim concluiu a esse respeito o Relator: "Em razão disso, de rigor, a rejeição da alegação de nulidade dos votos dos maiores credores que, na AssembleiaGeral votaram pela conversão da recuperação judicial em falência, já que inexiste 
qualquer elemento para se afirmar a abusividade do direito de voto ou a existência de conflito de interesse a justificar a deliberada pretensão de quebra a [da] empresa recuperanda.".

Dessa maneira, ao menos no caso em exame, verifica-se que a Câmara Especial do TJSP não reconheceu conflito de interesses, mesmo no voto de empresa concorrente concomitantemente credora da devedora. De qualquer sorte, na fundamentação do acórdão, não houve rejeição à possibilidade de configuração de tal conflito, mas apenas o reconhecimento de que, no caso concreto, ele não se deu ${ }^{1259}$.

\subsection{Voto do credor pela falência e abuso de voto}

$\mathrm{Na}$ ausência, criticada pela doutrina, de disposições específicas sobre abuso de voto e de conflito de interesse em voto proferido em assembleia geral de credores, particularmente na deliberação sobre o plano de recuperação judicial, é preciso invocar não apenas as disposições gerais do Código Civil, mas, também, as contribuições advindas do direito societário, especialmente do estudado art. 115 da Lei n. ${ }^{\circ}$ 6.404/76.

Esta última disposição é, como se viu alhures, a aplicação concreta e específica a uma posição jurídica tipicamente societária (o voto em assembleia) daquela mesma e geral previsão constante do Código Civil. Com efeito, a violação da interesse social de que trata o art. 115 da LSA nada mais é do que a terceira modalidade de abuso de direito previsto pelo art. 187 do Código Civil.

Na medida em que a Lei n. ${ }^{\circ}$ 6.404/76 funcionalizou o direito de voto do acionista de sociedade anônima, ele acresceu ao complexo de posições jurídicas subjetivas ativas uma posição passiva, consistente no dever de observar, em seu exercício, não exclusivamente o próprio interesse, mas também o interesse social. Reitere-se não se tratar de transmudar o direito subjetivo em poder funcional, mas em funcionalizar aquele primeiro, sem lhe desnaturar, no entanto. Ele não perde a natureza, suas características essenciais e composição, mas o titular fica adstrito por mais um limite - atinente ao fim econômico e social que a legislação lhe impõe.

Dessa maneira, o votante que, no exercício de seu direito político que

${ }^{1259}$ Posição semelhante foi tomada pelo mesmo órgão no julgamento em 1/6/2010 do agravo de instrumento n. 994.09.282275-1, de que foi relator o Des. Romeu Ricupero, sendo Agravante Constutora Brasil Central Araguais e Agravada a Varig Logistica S.A. 
tem lugar na assembleia geral de acionistas, infringe o interesse social de que trata $o$ aludido art. 115 viola o "fim econômico e social" imposto pelo legislador àquela posição jurídica (o voto). A infração ao art. 115 da lei especial é, portanto, também infringência do que dispõe a regra geral do art. 187 do Código Civil - não por desrespeito à boa-fé ou aos bons costumes, mas por extrapolar os limites econômicos e sociais da posição jurídica.

Ora, a matéria objeto da tese, o voto em deliberação sobre o plano de recuperação judicial, é em tudo semelhante ao que tem lugar nas assembleias societárias das companhias.

$\mathrm{O}$ art. 47 da Lei n. ${ }^{\circ} 11.101 / 05$ aflige ao credor o dever de votar não apenas conforme os interesses pessoais, mas também em atendimento à função social da empresa. Não é, naturalmente, que aqueles não possam ser perseguidos. Também aqui não se deu a desnaturação do direito (subjetivo) de voto, mas tão somente sua funcionalização.

Note-se que a vinculação determinada pelo art. 47 da LREF não é a confluência do interesse do credor ao interesse do devedor. Essa coincidência pode até mesmo acontecer. Mas ela não é imposta pelo dispositivo em comento. O que ele determina é a busca pela função social da empresa, isto é, da atividade empresarial - que apenas cumpre sua função, se é mantida, como fonte produtora: o complexo de bens organizado é explorado para a produção e circulação de bens e serviços ao mercado.

Pode, pois, suceder de a decisão que favorece a função social contraria o devedor. Nesse conflito, deve o votante optar por aquele primeiro.

E a hipótese tem cabimento, porque, inovando radicalmente em relação ao direito pretérito, o legislador de 2005 introduziu na falência, além da finalidade solutória (atendimento aos interesses dos credores, na medida das forças da massa falida objetiva), que é própria da liquidação, também o atendimento à função social. E não apenas

A matéria ora em exame encontra-se muito próxima daquela prevista pela Lei de Sociedades por Ações, pois assim lá como aqui o debate se trava acerca do abuso de uma posição jurídica específica: o voto.

Verifica-se, portanto, que a Lei n. ${ }^{\circ}$ 11.101/05 atribuiu à falência novas finalidades, notadamente a preservação da função social do conjunto de bens que integram a massa falida. Mais que isso, seu regramento prevê um conjunto expressivo de medidas que visam a dar cumprimento àquele princípio que o art. 75 enuncia. 
Assim, é equivocada a ideia de que a solução liquidatória-solutória, decidida pelos credores (e, eventualmente, por apenas uma classe deles ou até mesmo por um único credor), impediria ou mesmo dificultaria o cumprimento da função social da “empresa”, se comparada à opção recuperacional.

Primeiro, porque a solução reorganiativa não assegura necessariamente a mantença da empresa. Depois, porque a falência, como concebida pela Lei n. ${ }^{\circ}$ 11.101/05, não é o fim inarredável da empresa, mas tão-somente o afastamento compulsório de seu titular. Em se assumindo esse pressuposto, não encontra fundamento a concepção como abusivo o voto do credor que foi decisivo para a deliberação da quebra. Com efeito, nesse caso, não há nenhum dos requisitos formais de abusividade de voto, uma vez que não se congita de violação da boa ou dos bons costumes e o exercício, nesses termos, do aludido direito não infringe suas finalidades econômicas ou mesmo sociais. É legítima a opção do credor, no exercício do voto determinante para a quebra, porque tão-somente o resguardo de seus interesses egoísticos (que é objetivado, no caso) não constitui, por si só, abuso e porque os efeitos da quebra - que decorre desse voto determinante- não implicam obrigatoriamente a frustração da preservação da fonte produtiva.

O entendimento contrário (de que é abusivo o voto determinante para a quebra do devedor), com efeito, encontra estribo em uma concepção de falência que está em descompasso com as novas dimensões do instituto - que já não mais acarreta o esfacelamento da organização produtiva, mas, antes, viabiliza a preservação do arranjo produtivo e de todos os efeitos socialmente positivos que sua manutenção decorrem, com o desiderato de valorizar o complexo produtivo ou minorar a desvalorização que o desmantelamento deste inevitavelmente provocaria.

Dessa maneira, o voto pela quebra do devedor, por si mesmo, não constitui violação dos limites econômicos e sociais do direito e, portanto, isoladamente, não pode ser considerado um abuso de direito. 
RESUMO

O presente trabalho trata do abuso de voto na assembleia geral de credores que decide sobre o plano de reorganização apresentado pelo devedor na recuperação judicial. O trabalho ressalta que a função social da empresa é objetivo também da falência, conforme disposto no art. 75 da Lei n. ${ }^{\circ}$ 11.101/05. Assim, o voto contrário ao plano não pode ser considerado, de per se, abusivo.

Para tratar do tema, examina-se antes a figura do abuso de direito na teoria geral (capítulo segundo) e o abuso de voto nas companhias (capítulo terceiro). Por fim o tema é analisado no âmbito da recuperação judicial. 


\section{ABSTRACT}

The object of this thesis is the abuse of voting at general meetings of creditors that decides on the reorganization plan submitted by the debtor under reorganization process. The work emphasizes that the social function of the enterprise is also a goal of bankruptcy, according to art. 75 of Law no. 11.1010 of 2005 . Thus, voting against the plan may not be considered as abusive.

The thesis also examines the abuse of rights in the general theory (chapter two) and abuse of voting in companies (third chapter). Finally the subject is analyzed in the context of reorganization law. 


\section{RIASSUNTO}

Il presente lavoro è accerca del'abuso di diritto di voto nelle assemblee generali dei creditori che decidere sul piano di riorganizzazione presentato dal debitore in fallimento. Il lavoro sottolinea la funzione sociale della società è ache il obiettivo dell fallimento, ai sensi dell'art. 75 della legge n. 11.101/05. In questo modo, il voto contro il piano di riorganizzazizone non può essere considerato di per sè un abuso del'diritto.

Per analizzare il problema, prima esamina la figura dell'abuso nella teoria general del diritto (capitolo due) e l'abuso di voto nelle società (terzo capitolo). Infine, l'argomento viene analizzato nel contesto di fallimento. 


\section{BIBLIOGRAFIA}

AbBADESSA, Pietro, Nuovo regole in tema di procedimento assembleare e tutela delle minoranze, in Rivista delle società, v. 47, n. 1, janeiro-fevereiro de 2002, pp. 170-180.

Abbagnano, Nicola, Dicionário de Filosofia, São Paulo, Martins Fontes, 2000.

Abrão, Carlos Henrique, Pedido de Restituição na Concordata e na Falência, São Paulo, Leud, 1991.

., Comentários, in TOLEDO, Paulo Fernando Campos Salles - ABRÃO,

Carlos Henrique (Coords.), Comentários à Lei de Recuperação de Empresas e Falência, São Paulo, Saraiva, 2010, pp. 259-394.

ABRão, Nelson, Da Ação Revocatória, São Paulo, Leud, 1980.

., A Continuação do Negócio na Falência. São Paulo, Leud, 1998.

., Os Credores na Falência, São Paulo, Leud, 1998.

., O Novo Direito Falimentar - Nova Disciplinar Jurídica da Crise Econômica a Empresa, São Paulo, RT, 1985.

., O Síndico na Falência, São Paulo, Leud, 1999.

., Direito Bancário, São Paulo, Saraiva, 2002.

ADAMEK, Marcelo Vieira Von, Abuso de minoria em Direito Societário - Abuso das Posições Subjetivas Minoritárias, tese de doutorado, Faculdade de Direito da USP, São Paulo, mimeo, 2010.

, Responsabilidade dos Administradores de S/A e as Ações Correlatas, São Paulo, Saraiva, 2009.

Adler, Barry e. - BAird, Douglas G. - JACKson, Thomas H., Cases, Problems, and Materials and Bankruptcy, Nova York, New York Foundation Press, 2007.

Alberti, Alberto Maffei, Commentario breve alla legge fallimentare, Milão, CEDAM, 
2000.

AlmeIDA, Amador Paes de, Curso de Falência e Recuperação de Empresa, São Paulo, Saraiva, 2008.

AlmeIDA, Gustavo Milaré, Anotações sobre o Princípio da Função Social da Empresa na Doutrina e na Jurisprudência Brasileria, in Revista de Direito Mercantil, Industrial, Econômico e Financeiro, v. 153/154, pp. 240-286.

Álvares, Walter T., Curso de Direito Falimentar, Belo Horizonte, Sugestões Literárias, 1982.

Amaral, Francisco, Direito Civil - Introdução, Rio de Janeiro, Renovar, 2008. ., Os Atos Ilícitos, in O Novo Código Civil - Estudos em Homenagem ao Prof. Miguel Reale, coord. Domingos Franciulli Netto - Gilmar Ferreira Mendes Ives Gandra da Silva Martins, São Paulo, LTr, 2003, pp. 147-163.

Ambrosini, Stefano - Demarchi, Paolo Giovanni, Il nuovo concordato preventivo e gli accordi di ristrutturazione dei debiti, Milão, Giuffrè, 2005.

Andrade, Manuel A. Domingues de, Teoria Geral da Relação Jurídica, v. 1, Coimbra, Almedina, 1974.

ANDRAde, Ronaldo Alves, Comentários aos Artigos 35 a 46, in Comentários à Nova Lei de Recuperação de Empresas e de Falências, coord. Newton De Lucca - Adalberto Simão Filho, São Paulo, Quartier Latin, 2005, pp. 175-200.

ANDrighi, Fátima Nancy, Comentários, Comentários, in Osmar Brina CORRÊA-LiMA Sérgio Mourão CoRrêA-LimA (coord.), Comentários à Nova Lei de Falência e Recuperação de Empresas, Rio de Janeiro, Forense, 2009, pp. 488-519.

Aragão, Leandro Santos de, Assembleia-Geral de Credores: E Agora? Um Diálogo sobre a Comunhão de Credores e o Direito Societário, in Direito Societário e a Nova Lei de Falências e Recuperação de Empresas, Rodrigo R. Monteiro de Castro - Leandro Santos de Aragão (coord.), São Paulo, Quartier Latin, 2006, pp. 270-309.

Aragão, Paulo Cezar - Buchamar, Laura, A Assembleia Geral de Credores na Lei de Recuperação e Falências, in A Nova Lei de Falências e de Recuperação de Empresas - Lei n. 11.101/05, coord. Paulo Penalva Santos, Rio de Janeiro, Forense, 2007, pp. 109-128. 
AraúJo, José Francelino de, Comentártios à Lei de Falências e Recuperação de Empresas, São Paulo, Saraiva, 2009.

AsCARELl, Tullio, Contratto plurilaterale; comunione di interessi; società di due soci; morte di um socio in una società personale di due soci, Rivista trimestrale di diritto e procedura civile, ano VII (1953), Milão, Giuffrè, pp. 721-745.

., Sui poteri della maggioranza nelle società per azione ed alcuni loro limiti, in Rivista del diritto commerciale, ano XLVIII (1950), $1^{\text {a }}$ parte, pp. 169-197.

., Interesse sociale e interesse comune nel voto, in Rivista trimestrale di diritto e procedura civile, ano V (1951), Milão, Giuffrè, pp. 1145-1167.

., Problemas das Sociedades Anônimas e Direito Comparado, São Paulo, Saraiva, 1945.

Ascensão, José de Oliveira, Direito Civil - Teoria Geral, v. 3, São Paulo, Saraiva, 2010.

AsQuINI, Alberto, I battelli del Reno, in Rivista delle società, ano IV, fascículo 4-5, julhooutubro de 1959, pp. 617-633.

Aulete, Caldas, Dicionário Contemporâneo da Língua Portuguesa, VV. 1-5, Rio de Janeiro, Delta, 1985.

Ávila, Humberto, Teoria dos Princípios - Da Definição à Aplicação dos Princípios Jurídicos, São Paulo, Malheiros, 2011.

Azevedo, Álvaro Villaça, Código Civil Comentado, v. 2, São Paulo, Atlas, 2003.

Banco Mundial, Principles and Guidelines for Effective Insolvency and Creditor Rights Systems, in Revista de Direito Mercantil, Industrial, Econômico e Financeiro, v. 122, pp. 75-167.

BAPTISTA, Ezio Carlos, Comentários aos Artigos 21 ao 34, in Comentários à Nova Lei de Recuperação de Empresas e de Falências, coord. Newton De Lucca - Adalberto Simão Filho, São Paulo, Quartier Latin, 2005, pp. 151-174.

Barossi-FiLho, Milton, Assembleias de Credores e Plano de Recuperação de Empresas: Uma Visão em Teoria dos Jogos, in Revista de Direito Mercantil, Industrial, Econômico e Finaceiro, v. 137, pp. 233-238. 
BARreto, Julio, O Conflito de Interesses entre a Companhia e seus Administradores, Rio de Janeiro, Renovar, 2009.

BAS, Francisco Junyent, La figura del concordato, in Martín Arecha (coord.), Els Voto em las Sociedades y los Concursos, Buenos Aires, Legis, 2007, pp. 131-166.

Batista, Carolina S. J. - Campana Filho, Paulo F. - Miyazaki, Renata Y.- Cerezetti, Sheila C. N., A Prevalência da Vontade da Assembleia Geral de Credores em Questão: o Cram Down e a Apreciação Judicial do Plano Aprovado por Todas as Classes. In: Revista de Direito Mercantil, Industrial, Econômico e Financeiro, v. 143, p. 209.

Berle Jr., Adolf - MeAns, Gardner, A Moderna Sociedade Anônima e a Propriedade Privada, trad. Dinah de Abreu Azevedo, São Paulo, Abril Cultura, 1984.

Bessone, Darcy, Instituições de Direito Falimentar, São Paulo, Saraiva, 1995.

BetTi, Emilio, Teoria Geral do Negócio Jurídico, v. 1, Coimbra, Coimbra, 1969.

Beviláqua, Clóvis, Código Civil Comentado, v. 1, Rio de Janeiro, Francisco Alves, 1956.

BeZerra FILHo, Manoel Justino, Lei de Falências Comentada, São Paulo, RT, 2003. ., Lei de Recuperação de Empresas e Falências Comentada, São Paulo, RT, 2009. ., Jurisprudência da Nova Lei de Recuperação de Empresas e Falências, São Paulo, RT, 2006.

BING, Plínio Paulo, Direito Assemblear nas Sociedades Mercantis e Civis, Porto Alegre, Sergio Antonio Fabris, 2007.

Bonfatti, Sido - Censoni, Paolo Felice, Manuale di Diritto Fallimentare, Milão, Cedam, 2004.

BorbA, José Edwaldo Tavares, Direito Societário, Rio de Janeiro, Renovar, 2010.

Boulos, Daniel M., Abuso de Direito no Novo Código Civil, São Paulo, Método, 2006.

Branco, Elcir Castelo, Abuso (verbete), in Enciclopédia Saraiva do Direito, v. 2, São Paulo, Saraiva, pp. 21-31.

BRunet, Andree, Propos critiques sur Le projet de reforme du droit français de la faillite, 
in Revista de Direito Bancário e do Mercado de Capitais, ano 10, n. 36, abril-junho de 2007, pp. 107-183.

CalçAs, Manoel de Queiroz Pereira, Do Pedido de Restituição e dos embargos de terceiro, in Revista de Direito Bancário e do Mercado de Capitais, ano 10, n. 36, abril-junho de 2007, pp. 260-277.

CÂMARA, Paulo et all, Conflito de Interesse no Direito Societário e Financeiro, Coimbra, Almedina, 2009.

CAMPINHO, Sérgio, Falência e Recuperação de Empresa - O Novo Regime da Insolvência Empresarial, Rio de Janeiro, Renovar, 2009.

Carvalho, William Eustáquio de, O Abuso no Poder de Voto na Recuperação Judicial de Microempresas e Empresas de Pequeno Porte no Brasil, in Revista de Direito Empresarial, n. ${ }^{\circ}$ 13, janeiro-junho de 2010, Curitiba, Juruá, pp. 125-138.

Carvalho Filho, José dos Santos, Manual de Direito Administrativo, Rio de Janeiro, Lumen Juris, 2007.

Carvalho Neto, Inacio de, Abuso do Direito, Curitiba, Juruá, 2009.

Carvalho Santos, José Manuel, Código Civil Brasileiro Interpretado, v. 2, Rio de Janeiro, Freitas Bastos, 1988.

Carvalhosa, Modesto. Comentários à Lei de Sociedades Anônimas, v. 2, São Paulo, Saraiva, 2009. Acordo de Acionistas, São Paulo, Saraiva, 1984.

Carvalhosa, Modesto - LatorracA, Nilton, Comentários à Lei das Sociedades Anônimas, v. 3, São Paulo, Saraiva, 2003.

CAStro, Rodrigo R. Monteiro de, A Administração das Sociedades Anônimas em Recuperação Judicial, in Direito Societário e a Nova Lei de Falências e Recuperação de Empresas, Rodrigo R. Monteiro de Castro - Leandro Santos de Aragão (coord.), São Paulo, Quartier Latin, 2006, pp. 188-217.

Castro Filho, José Olímpio de, Abuso do Direito no Processo Civil, Rio de Janeiro, Forense, 1960. 
Catapani, Márcio Ferro, Conceito e Função Atual das Assembleias-Gerais das Sociedades Anônimas, in Revista de Direito Empresarial, n. ${ }^{\circ}$ 8, julho-dezembro de 2007, Curitiba, Juruá, pp. 155-169.

, Os Contratos Associativos, in Direito Societário Contemporâneo I, Erasmo Valladão A. e N. França (coord.), São Paulo, Quartier Latin, 2009, pp. 87-103.

Cavalieri Filho, Sergio, Programa de Responsabilidade Civil, São Paulo, Atlas, 2009.

CEREzetTI, Sheila Christina Neder, O Papel dos Credores no Bankruptcy Code, in Revista de Direito Mercantil, Industrial, Econômico e Financeiro, v. 153/154, pp. 164-188.

A Recuperação Judicial de Sociedades por Ações - O Princípio da Preservação da Empresa na Lei de Recuperação e Falência, tese de doutorado, Faculdade de Direito da USP, São Paulo, mimeo, 2010.

ClÁudio, Maximilianus - FÜHRER, Américo, Roteiro das Falências, Concordatas e Recuperações, São Paulo, RT, 2005.

Coelho, Eduardo de Melo Lucas, A Formação das Deliberações Sociais - Assembleia Geral das Sociedades Anônimas, Coimbra, Coimbra Ed., 1994.

Coelho, Fábio Ulhoa, Curso de Direito Comercial - Direito de Empresa, v. 2, São Paulo, Saraiva, 2012.

., Curso de Direito Comercial - Direito de Empresa, v. 3, São Paulo, Saraiva, 2012.

., Comentários à Lei de Falências e de Recuperação de Empresas, São Paulo, Saraiva, 2011.

., Código Comercial e Legislação Complementar Anotados - À Luz do Novo Código Civil, São Paulo, Saraiva, 2011.

., O direito à restituição de recursos fornecidos por bancos estrangeiros ao financiamento à exportação na falência do banco repassador nacional, in Revista de Direito Bancário e do Mercado de Capitais, ano 10, n. 36, abril-junho de 2007, pp. 200-213.

., Princípios do Direito Comercial - Com Anotações ao Projeto de Código Comercial, São Paulo, Saraiva, 2012. 
., Falências: Principais Alterações, in Revista do Advogado AASP, v. 83, setembro de 2005, pp. 51-55.

COMPARATO, Fábio Konder, Aspectos Jurídicos da Macro-empresa. São Paulo, RT, 1970. ., O Seguro de Crédito, São Paulo, RT, 1968.

., Direito Empresarial, São Paulo, Saraiva, 1990.

., Novos Ensaios e Pareceres de Direito Empresarial, Rio de Janeiro, Forense, 1981.

Comparato, Fábio Konder - SAlomão Filho, Calixto, O Poder de Controle na Sociedade Anônima, Rio de Janeiro, Forense, 2005.

CordeIro, Antonio Menezes, S.A. Assembleia Geral e Deliberações Sociais, Coimbra, Almedina, 2006.

., Da Boa-Fé no Direito Civil, Coimbra, Almedina, 2007.

Correa, Alexandre Augusto de Castro, Abuso de Direito (Direito Romano) (verbete), Enciclopédia Saraiva do Direito, v. 2, São Paulo, Saraiva, pp. 48-58.

Coutinho de Abreu, Jorge Manuel, Do Abuso de Direito - Ensaio de um Critério em Direito Civil e nas Deliberações Sociais, Coimbra, Almedina, 2006.

CunHA, Rodrigo Ferraz Pimenta da, Estrutura de Interesses nas Sociedades Anônimas Hierarquia e Conflitos, São Paulo, Quartier Latin, 2007.

., O Exercício de Voto na Sociedade Anônima, in Direito Societário Desafios Atuais, Rodrigo R. Monteiro de Castro - Leandro Santos de Aragão (coord.), São Paulo, Quartier Latin, 2009, pp. 241-278.

Cunha de SÁ, Fernando Augusto, Abuso de Direito, Lisboa, Ministério das Finanças, 1973.

DARDES, Francesca, Interpretazione delle deliberazioni assembleari secondo buona fede, in Rivista del diritto commerciale, ano CV (2007), $2^{\mathrm{a}}$ parte, pp. 187-206.

DAsso, Ariel Ángel, Decreto Concursal Comparado, t. I e II, Buenos Aires, Legis, 2009. 
., Tendencias Actuales del Derecho Concursal, Buenos Aires, Ad Hoc, [s.d.].

., La exclusión de la base de cómputo de las conformidades y la regla de La

mayoría concursal, in Martín Arecha (coord.), Els Voto em las Sociedades y los Concursos, Buenos Aires, Legis, 2007, pp. 95-130.

De LuCCA, Newton, Abuso do Direito de Voto de Credor na Assembleia Geral de Credores Prevista nos Arts. 36 a 45 da Lei 11.101/2005, in ADAMEK, Marcelo Vieira Von (coord.), Temas de Direito Societário e Empresarial Contemporâneos - Liber Amicorum Prof. Dr. Erasmo Valladão Azevedo e Novaes França, São Paulo, Malheiros, 2011, pp. 645-666.

., Comentários, in Newton DE LuCCA - Adalberto Simão FILHO, Comentários à Nova Lei de Recuperação de Emprestas e de Falências, São Paulo, Quartier Latin, 2005, pp. 13-70.

., Comentários, in Osmar Brina CORRÊA-LIMA - Sérgio Mourão CORRÊALIMA (coord.), Comentários à Nova Lei de Falência e Recuperação de Empresas, Rio de Janeiro, Forense, 2009, pp. 29-72.

Didier JR., Fredie - ZANeti JR., Hermes, Curso de Direito Processual Civil - Processo Coletivo, v. 4, Salvador, Juspodium, 2009.

DINIZ, Almachio, Da Fallencia, São Paulo, Saraiva, 1930.

DinIZ, Gustavo Saad, Subcapitalização Societário, tese de doutorado, Faculdade de Direito da USP, São Paulo, mimeo, 2007.

DuARTE, Henrique Vaz, Questões sobre Recuperação e Falência, Coimbra, Almedina, 2004.

Duarte, Nestor, Comentários, in Min. Cezar Peluso (coord.), Código Civil Comentado, Barueri-SP, Manole, 2009, pp. 140-143.

DuArte, Teófilo de Castro, O Abuso do Direito e as Deliberações Sociais - Ensaio Jurídico, Coimbra, Coimbra, 1955.

Eco, Umberto, Como se faz uma tese, trad. port. de Gilson César Cardoso de Souza, São Paulo, Perspectiva, 2005, pp. IX-174 
EstradA, Federico G., El Acreedor en el Concurso Preventivo, Buenos Aires, ERREPAR, 2005.

Ferraz Jr., Tercio Sampaio, Introdução ao Estudo do Direito - Técnica, Decisão, Dominação, São Paulo, Atlas, 1994.

FERreIRA, Keila Pacheco, Abuso do Direito nas Relações Obrigacionais, Belo Horizonte, Del Rey, 2007.

FERreIRA, Waldemar, Tratado de Direito Comercial, v. 15, São Paulo, Saraiva, 1966.

FARENGA, Luigi, La riforma del diritto fallimentare in Italia: uma nuova visione del mercato, in Rivista del diritto commerciale, ano CVI (2008), $1^{\text {a }}$ parte, pp. 251-261.

FAZZIO JR., Waldo, Lei de Falência e Recuperação de Empresas, São Paulo, Atlas, 2008.

FERES, Marcelo Andrade, Comentários, in Osmar Brina CORRÊA-LiMA - Sérgio Mourão CORRÊA-Lima (coord.), Comentários à Nova Lei de Falência e Recuperação de Empresas, Rio de Janeiro, Forense, 2009, pp. 758-799.

Fernandes, Luís A. Carvalho, Teoria Geral do Direito Civil, v. 1, Lisboa, Universidade Católica Editora, 2007.

FERnANDES Neto, Guilherme, A Suspensão de Deliberação Social e o Abuso do Direito de Voto, in Revista do Advogado AASP, v. 36, março de 1992, pp. 45-58.

FERRARI, Aldo, L'abuso del diritto nelle società, Milão, Giuffrè, 1998.

FERRI, Giuseppe, Dal confltto di interessi agli interessi degli amministratori - Profili di Sistema , Rivista del diritto commerciale, ano 2006, $1^{\mathrm{a}}$ parte, pp. 661-772.

., Eccesso di potere e tutela delle minoranze, in Rivista Del diritto commerciale, ano $1934,1^{a}$ parte, pp. 723-746.

FonsecA, Priscila Corrêa da, Suspensão de Deliberações Sociais, São Paulo, Saraiva, 1986.

FradA, Manuel A. Carneiro da, Renovação das Deliberações Sociais, Coimbra, Almedina, 1987.

FrAnÇA, Erasmo Valladão A. e N., Comentários, in Francisco Satiro de SoUZA JR. - 
Antonio Sérgio A. de Moraes Pitombo (coordenadores), Comentários à Lei de Recuperação de Empresas e Falência. Lei 11.101/2005, São Paulo, RT, 2007, p. 186217.

, A Assembleia-Geral de Credores na Nova Lei Falimentar, in Temas de Direito Societário,Falimentar e Teoria da Empresa, São Paulo, Malheiros, 2009, pp. 4-26.

., Conflito de Interesses nas Assembleias de S.A., São Paulo, Malheiros, 1993. ., Invalidade das Deliberações de Assembleia das S/A, São Paulo, Malheiros, 1999.

FrANÇA, Rubens Limongi, Abuso de Direito (verbete), Enciclopédia Saraiva do Direito, v. 2, São Paulo, Saraiva, pp. 45-48.

FRANCO, Vera Helena de Mello - SZTAJn, Rachel. Falência e recuperação da empresa em crise - Comparação com as Posições do Direito Europeu, Rio de Janeiro, Elsevier, 2008.

Gambino, Agostino, La disciplina del conflitto di interessi del socio, in Rivista del diritto commerciale, ano LXVIII (1969), $1^{\mathrm{a}}$ parte, pp. 371-425.

Gardino, Adriana Valéria Pugliesi, A Evolução do Tratamento Jurídico da Empresa em Crise no Direito Brasileiro, dissertação de mestrado, Faculdade de Direito da USP, São Paulo, mimeo, 2006.

GENTILI, Aurelio, Abuso Del diritto, giurisprudenza tributaria e categorie civilistiche, in Rivista del diritto commerciale, ano CVII (2009), $1^{\text {a }}$ parte, pp. 403-421.

GINES, Adriana Cambronero, The New Spanish Insolvency Legislation (22/2003 insolvency act of 9 July), in Revista de Direito Bancário e do Mercado de Capitais, ano 10, n. 36, abril-junho de 2007, pp. 160-183.

Girolamo, Fabrizio Di, Comentário à Decisão “TRIBUNALE NAPOLI - 25 maggio 2004 (ord.) - TRICOMI Instruttore - Molinaro e altro c. Radio Zeta F.M. s.r.l., in Rivista del diritto commerciale, ano CV (2007), $2^{\mathrm{a}}$ parte, pp. 133-177. 
, Comentário à Decisão “TRIBUNALE NAPOLI - 25 maggio 2004 (ord.) TRICOMI Instruttore - Molinaro e altro c. Radio Zeta F.M. s.r.l., in Rivista del diritto commerciale, in Rivista del diritto commerciale, ano CII (2004), $2^{\text {a }}$ parte, pp. 325-356.

GoMes, Orlando, Introdução ao Direito Civil, Rio de Janeiro, Forense, $1999^{1260}$.

GouvÊA, João Bosco Cascardo de, Recuperação e Falência - Lei $n^{o}$ 11.101/2005. Rio de Janeiro, Forense, 2009.

Grau, Eros Roberto, A Ordem Econômica na Constituição de 1988, São Paulo, Malheiros, 2010.

GRIPPO, Giovanni, Deliberazione e Collegialità nella Società per Azioni, Milão, Giuffrè, 1979.

GuERrA, Alexandre, Responsabilidade Civil por Abuso do Direito, São Paulo, Saraiva, 2011.

GuerrerA, Fabrizio, Abuso del voto e controllo 'di correttezza' sul procedimento deliberativo assembleare, in Rivista delle società, ano 47, janeiro-fevereiro 2002, fascículo $1^{\circ}$, pp. 181-284.

GuERrEIRO, José Alexandre Tavares, Conflitos de Interesse entre Sociedade Controladora e Controlada e entre Cooligadas, no Exercício do Voto em Assembleias Gerais e Reuniões Sociais, in Revista de Direito Mercantil, Industrial, Econômico e Financeiro, v. 51, pp. 29-32.

., Direito de Retirada: Um Limite ao Princípio Majoritário na Sociedade Anônima, in Revista de Direito Mercantil, Industrial, Econômico e Financeiro, v. 151/152, pp. 13-21.

Guimarães, Márcio Souza, O Ministério Público no Novo Sistema de Insolvência Empresarial - A Habilitação e a Impugnação de Créditos, in A Nova Lei de Falências e de Recuperação de Empresas - Lei n. 11.101/05, coord. Paulo Penalva Santos, Rio de Janeiro, Forense, 2007, pp. 31-64.

GuIMARÃES, Maria Celeste Morais, Recuperação Judicial de Empresas - Direito Concursal Contemporâneo, Belo Horizonte, Del Rey, 2001.

GuIZI, Giuseppe, Le decisioni dei soci: profili tipologici, in Rivista del diritto commerciale,

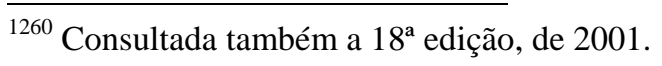


ano CII (2004), $1^{\text {a }}$ parte, pp. 1001-1019.

Hansmann, Henry, The Ownership of Enterprise, Cambridge, Belknap Press, 2000.

HironaKa, Giselda Maria Fernandes Novaes (coord), O Ensino Jurídico e a Produção de Teses e Dissertações, São Paulo, Edgard Blucher, 2008

Houaiss, Antonio - Vilar, Mauro de Salles, Dicionário Houaiss da Língua Portuguesa, Rio de Janeiro, Objetiva, 2001.

ImHOF, Cristiano, Lei de Falências e de Recuperação de Empresas e sua Interpretação Jurisprudencial, Florianópolis, Conceito Editorial, 2009.

Instituto DELA EnCiClopedia ItAliana, Abuso del diritto (verbete), in Enciclipedia Giuridica, v. 1, Roma, 2007, pp. 1-7.

JAEGER, Pier Giusto, L'interesse sociale, Milão, Giuffré, 1964. ., L'interesse sociale rivisitato (quarant'anni dopo), in Giurisprudenza commerciale, parte I, 2000. ., Il voto 'divergente’ nella società per azioni, Milão, Giuffrè, 1976.

JORDÃO, Eduardo, Abuso de Direito, Salvador, Juspodium, 2006.

Josserand, Loius, Del Abuso de los Derecho y Otros Ensayos, Santa Fé de Bogotá, Temis, 1999. , L'esprit des droits ed de leur relatività, Paris, Dalloz, 1939.

JunQueIRA, André Luiz, Invalidação de Assembleias de Condomínio, in Revista de Direito Privado, ano 9, n. 34, abril-junho de 2008, pp. 12-39. 
Kelsen, Hans, Teoria Pura do Direito, Coimbra, Armênio Amado, 1984.

La Rosa, Antonio Pavone, Diritto di voto e diritto di annullamento delle deliberazioni assembleari, in Rivista trimestrale di diritto e procedura civile, ano VII (1953), Milão, Giuffrè, pp. 912-928.

LAURO, Massimo Di, Il nuovo diritto fallimentare che fine ha fatto la grande riforma, in Il diritto falimentare e delle società commerciali, ano LXXX, n. 5, setembro-outubro de 2005, pp. 793-797.

Lautenschläger, Milton Flávio de Almeida Camargo, Abuso do Direito, São Paulo, Atlas, 2007.

LaZZAReschi Neto, Alfredo Sérgio, Lei das Sociedades por Ações Anotada, São Paulo, Saraiva, 2006.

LAZZARINI, Alexandre Alves, A Recuperação Judicial de Empresas: Alguns Problemas na sua Execução, in Revista de Direito Bancário e do Mercado de Capitais, ano 10, n. 36, abril-junho de 2007, pp. 93-106.

LEÃEs, Luiz Gastão Paes de Barros, Impedimento de Voto em Assebléia, in Pareceres, v. 2, São Paulo, Singular, 2004, pp. 771-775.

., Abuso de Minoria em Aumento de Capital, in Pareceres, v. 2, São Paulo, Singular, 2004, pp. 1211-1225.

, Abuso de Poder da Minoria, in Pareceres, v. 2, São Paulo, Singular, 2004, pp. 1243-1256.

., Convalidação e Revogação de Deliberações Asssembleares, in Pareceres, v. 2, São Paulo, Singular, 2004, pp. 1315-1336.

., Debêntures Conversíveis em Ações, in Pareceres, v. 2, São Paulo, Singular, 2004, pp. 778-779.

LevadA, Cláudio Antonio Soares, Anotações obre o abuso do direito, in Revista dos Tribunais, São Paulo, ano 80, v. 667, maio de 1990, pp. 44-50.

LIBERTINI, Mario, Impresa e finalità sociale. Riflessioni sulla teoria della responsabilità sociale dell'impresa, in Rivista delle società, ano 54 (2009), janeiro-fevereiro 2009, 
fascículo $1^{\circ}$, pp. 1-33.

LiMA, Alvino, Culpa e Risco, São Paulo, RT, 1999.

LisboA, Marcos de Barros et all., A Racionalidade Econômica da Nova Lei de Falências e de Recuperação de Empresas, in Luiz Fernando Valente de PAIVA (coord.), Direito Falimentar e a Nova Lei de Falências e Recuperçaão de Empresas, São Paulo, Quartier Latin, 2005, pp. 29-60.

LisboA, Roberto Senise, Contratos Difusos e Coletivos, São Paulo, RT, 1997.

LoBo, Jorge, Da assembleia geral de credores, in TOLEDO, Paulo Fernando Campos Salles - ABRÃO, Carlos Henrique (Coords.), Comentários à Lei de Recuperação de Empresas e Falência, São Paulo, Saraiva, 2010, p. 94-208.

.,Direito Concursal, Rio de Janeiro, Forense, 1998.

., Da Recuperação da Empresa no Direito Comparado, Rio de Janeiro, Lumen Juris, 1993.

LORENTE, Javier A., Dos cuestiones radicales derivadas de La tendência actgual ampliatoria de lãs causales de exclusión de voto, in Martín Arecha (coord.), Els Voto em las Sociedades y los Concursos, Buenos Aires, Legis, 2007, 167-186.

LorenZETTI, Ricardo Luis, Nuevas Fronteras del Abuso de Derecho - Situaciones Jurídicas Lesivas de Libertades; Tutela de Mercado y Amparo, in Revista dos Tribunais, v. 723, ano 85, janeiro de 1996, pp. 53-65.

LuMIA, Giuseppe, Elementos de teoria e ideologia do direito, São Paulo, Martins Fontes, 2003.

LunA, Everardo da Cunha, Abuso de Direito, Rio de Janeiro, Forense, 1988.

LunARDI, Fabrício Castagna, A Teoria do Abuso de Direito no Direito Civil Constitucional: Novos Paradigmas para os Contratos, in Revista de Direito Privado, ano 9, n. 34, abril-junho de 2008, pp. 104-136.

MACARIO, Francesco, Insolvenza, crisi d'impresa e autonomia contrattuale - Appunti per una ricostruzione sistemática delle tutele, in Rivista delle società, ano 53 (2008), fascículo $1^{\circ}$, janeiro fevereiro de 2008, pp. 102-147. 
Machado, Nelson Marcondes, Assembleia Geral de Credores e seus Conflitos com a Assembleia Geral de Acionistas, in Direito Societário e a Nova Lei de Falências e Recuperação de Empresas, Rodrigo R. Monteiro de Castro - Leandro Santos de Aragão (coord.), São Paulo, Quartier Latin, 2006, pp. 148-163.

MACHADO, Rubens Approbato (Coord.). Comentários à nova lei de falências e recuperação de empresas. São Paulo: Quartier Latin, 2005.

MAMEDE, Gladston, Falência e Recuperação de Empresas, vol. 04, São Paulo, Atlas, 2008.

MAndel, Julio Kahan, Da Convolação da Recuperação Judicial em Falência, in Revista de Direito Bancário e do Mercado de Capitais, ano 10, n. 36, abril-junho de 2007, pp. 241-259.

MAnge, Renato, O Administrador Judicial, o Gestor Judicial e o Comitê de Credores na Lei $n^{\circ}{ }^{11.101 / 05}$, in , in A Nova Lei de Falências e de Recuperação de Empresas Lei n. 11.101/05, coord. Paulo Penalva Santos, Rio de Janeiro, Forense, 2007, pp. 6574.

MARChI, Eduardo C. Silveira, Guia de Metodologia Jurídica - Teses, Monografias e Artigos, Lecce, Del Griffo, 2002.

MARtíneZ, Roberto García, Derecho Concursal, Buenos Aires, Abeledo-Perrot, 1997.

MARTINI, Angelo de, La tutela delle minoranze nel controllo giudiziario sugli atti delle società, in Rivista del diritto commerciale, ano LI (1953), $1^{\text {a }}$ parte, pp. 26-49.

Martins, Fran, Comentários à Lei das Sociedades Anônimas, v. 1, Rio de Janeiro, Forense, 1977.

Martins, Pedro Baptista, O Abuso do Direito e o Ato Ilícito, Rio de Janeiro, Freitas Bastos, 1941.

Martins, Ricardo Marcondes, Abuso de Direito e a Constitucionalização do Direito Privado, São Paulo, Malheiros, 2010.

Martins-Costa, Judith, Os Campos Normativos da Boa-Fé Objetiva: As Três Perspectivas do Direito Privado Brasileiro, in AzEVEDo, Antonio Junqueira -TORRES, Heleno Taveira Torres e CABone, Paolo (coord.), Princípios do Novo Código Civil Brasileiro e Outros Temas - Homenagem a Tullio Ascarelli, São Paulo, Quariter 
Latin, 2010, pp. 393-427.

A Boa-Fé no Direito Brasileiro - Sistema e Tópica no Processo Obrigacional, São Paulo, RT, 2000.

Melo, Gisele Luciane de Oliveira Lopes, A Função Social da Empresa como Parâmetro de Legalidade, in Revista de Direito Empresarial, n. ${ }^{\circ}$ 4, julho-dezembro de 2005, Curitiba, Juruá, pp. 277-317.

Mello, Marcos Bernardes de, Teoria do Fato Jurídico - Plano da Existência, São Paulo, Saraiva, 2000.

Mendes, Octavio, Fallencias e Concordatas, São Paulo, Saraiva, 1930.

Milani, Mario Sergio, Lei de Recuperação Judicial, Recuperação Extrajudicial e Falência Comentada, São Paulo, Malheiros, 2011.

Mondini, P.F., Principo di buona fede e voto assembleare: una importante pronuncia della Corte di Cassazione tedesca, in Rivista delle società, ano 55 (2010), fascículo $5^{\circ}$, setembro-outubro de 2010, pp. 1201-1202.

MoreIRA, Alberto Camiña, Poderes da Assembleia de Credores, do Juiz e Atividade do Ministério Público, in Direito Falimentar e a Nova Lei de Falências e Recuperação de Empresas, coord. Luiz Fernando Valente de Paiva, São Paulo, Quartier Latin, 2005, pp.247-275.

, Alberto Camiña, Contrato de swap e falência de instituição financeira, in Revista de Direito Bancário e do Mercado de Capitais, ano 10, n. 36, abril-junho de 2007, pp. 80-92.

Moreira Alves, José Carlos, Direito Romano, v. 1, Rio de Janeiro, Forense, 1998.

Mota Pinto, Carlos Alberto da, Teoria Geral do Direito Civil, Coimbra, Coimbra, 1991.

MunHOZ, Eduardo Secchi. Do procedimento de recuperação judicial. In: SOUZA JUNIOR, Francisco Satiro de: PITOMBO, Antonio Sérgio A. de Moraes (Coords.). Comentários à lei de recuperação de empresas e falência. Lei 11.101/2005, São Paulo, RT, 2007, p. 270-319.

., Anotações sobre os Limites do Poder Jurisdicional na Apreciação do Plano de Recuperação Judicial, in Revista de Direito Bancário e do Mercado de 
Capitais, ano 10, n. 36, abril-junho de 2007, pp. 184-199.

NeGrão, Ricardo, Manual de Direito Comercial e de Empresa, v. 3, São Paulo, Saraiva, 2011.

, Aspectos Objetivos da Lei de Recuperação de Empresas e de Falências, São Paulo, Saraiva, 2009.

, A Eficiência do Processo Judicial na Recuperação de Empresa, São Paulo, Saraiva, 2010.

., Recuperação Judicial, in Paulo Penalva SAntos, A Nova Lei de Falências e de Recuperação de Empresas - Lei $n^{o} 11.101 / 05$, Rio de Janeiro, Forense, 2007, pp. 129-156.

Nery Jr., Nelson - Nery, Rosa Maria de Andrade, Código Civil Comentado, São Paulo, RT, 2006.

Nunes, Luiz Antonio Rizzatto, Manual de Monografia Jurídica - Como se faz Uma monografia - Uma Dissertação - Uma Tese, São Paulo, Saraiva, 1997.

NuSDeO, Fabio, Curso de Economia - Introdução ao Direito Econômico, São Paulo, RT, 1997.

OAEGUI, Julio, Voto concordatário: desplazamiento, via y oportunidad procesal, in Martín Arecha (coord.), Els Voto em las Sociedades y los Concursos, Buenos Aires, Legis, 2007, pp. 187-204.

PaCheCo, José da Silva, Das Disposições Preliminares e das Disposições Comuns à Recuperação Judicial e à Falência, in A Nova Lei de Falências e de Recuperação de Empresas - Lei n. 11.101/05, coord. Paulo Penalva Santos, Rio de Janeiro, Forense, 2007, pp. 1-18.

., Processo de Recuperação Judicial, Extrajudicial e Falência, Rio de 
Janeiro, Forense, 2009.

PAIVA, Luiz Fernando Valente de. Apresentação do plano de recuperação pelo devedor e a atuação dos credores. In: Revista do Advogado. A nova lei de falências e de recuperação de empresas. Ano XXV, n. 83. São Paulo, 2005.

PATTI, Salvatore, Abuso del diritto (verbete), in Digesto delle discipline privatische sezione civile, Torino, UTET, 1987, pp. 1-8.

PeiXoto, Euler Cunha, Comentários, in Osmar Brina CoRRÊA-Lima - Sérgio Mourão CORRÊA-Lima (coord.), Comentários à Nova Lei de Falência e Recuperação de Empresas, Rio de Janeiro, Forense, 2009, pp. 962-999.

Penteado, Mauro Rodrigues, Comentários, in Francisco Satiro de SouZA JR. -Antonio Sérgio A. de Moraes Pitombo (Coords.), Comentários à lei de recuperação de empresas e falência. Lei 11.101/2005. São Paulo, RT, 2007, p. 57-143. .,Comentários, in Osmar Brina CoRrÊA-LiMA - Sérgio Mourão CorRÊALima (coord.), Comentários à Nova Lei de Falência e Recuperação de Empresas, Rio de Janeiro, Forense, 2009, pp. 159-189.

PEREIRA, Caio Mario da Silva, Instituições de Direito Civil, v. 1, Rio de Janeiro, Forense, 2006.

PereIRA, Guilherme Döring Cunha, Alienação do Poder de Controle Acionário, São Paulo, Saraiva, 1995.

Peres, Tatiana Bonatti, Abuso do Direito, in Revista de Direito Privado, ano 11, n. 43, julho-setembro de 2010, pp. 9-71.

PERIN Junior, Ecio, Curso de Direito Falimentar e Recuperação de Empresas, São Paulo, Método, 2006.

PInTo Junior, Mario Engler, A Teoria dos Jogos e o Processo de Recuperação de Empresas, in Revista de Direito Bancário e do Mercado de Capitais, v. 31, ano 9, janeiro-março de 2006, pp. 63-79.

PISANI, Luca, Il principio di maggioranza nella nuova disciplina della transformazione di società di persone, in Rivista del diritto commerciale, ano CIII (2005), $1^{\mathrm{a}}$ parte, pp. 371-398. 
Piscitello, Paolo, Concessione abusiva del credito e patrimônio dell'impreditore, in Rivista di diritto civile, ano LVI (2010), n. 5, $1^{\text {a }}$ parte, pp. 655-675.

PLANIOL, Marcel, Traitè élémentaire de droit civil, t. II, Paris: Librariei Générale de Droit \& de Jurisprudence, 1907, p. 281.

Pontes De Miranda, Francisco Cavalcanti, Tratado de Direito Privado, t. 1, Rio de Janeiro, Borsoi, 1970. ., Tratado de Direito Privado, t. 2, Rio de Janeiro, Borsoi, 1970. ., Tratado de Direito Privado, t. 4, Rio de Janeiro, RT, 1974.

ProençA, José Marcelo Martins, Os Novos Horizontes do Direito Concursal - Uma Crítica ao Continuísmo Prescrito pela Lei 11.101/2005, in Revista de Direito Mercantil, Industrial, Econômico e Financeiro, vol. 151/152, pp. 37-64.

PURIFICAÇão, Carlos Alberto da, Recuperação de Empresa e Falência Comentada, São Paulo, Atlas, 2011.

REAle, Miguel, Lições Preliminares de Direito, São Paulo, Saraiva, 1999. ., Visão Geral do Código Civil, in: Gisele de Melo Graga Tapai (coord.), Novo Código Civil brasileiro - Estudo Comparativo com o Código Civil de 1916, Constituição Federal, Legislação Codificada e Extravagante, São Paulo, RT, 2003, pp. 9-19.

Rego, Marcelo Lamy, Pedido de Procuração para Votar, in Direito Societário - Desafios Atuais, Rodrigo R. Monteiro de Castro - Leandro Santos de Aragão (coord.), São Paulo, Quartier Latin, 2009, pp. 315-342.

Requião, Rubens, Curso de Direito Falimentar, v. 1 (atual. por Rubens Edmundo Requião), São Paulo, Saraiva, 1998.

., Curso de Direito Falimentar, v. 2 (atual. por Rubens Edmundo Requião), São Paulo, Saraiva, 1995. ., Abuso de direito e fraude através da personalidade jurídica 'disregard doctrine' (verbete), in Enciclopédia Saraiva do Direito, v. 2, São Paulo, Saraiva, pp. 58-82. 
., Curso de Direito Comercial, v. 1, São Paulo, Saraiva, 2009.

., Curso de Direito Comercial, v. 2, São Paulo, Saraiva, 2009.

Resigno, Pietro, L'abuso del diritto, in Rivista di diritto civile, ano XI (1965), $1^{\text {a }}$ parte, pp. 205-290.

RESTIFFE, Paulo Sérgio, Recuperação de Empresas, Barueri, Manole, 2008.

RICHARD, Enfrín Hugo, Voto a aceptación de propuestas concursales irritas: Legitimación e intereses contrario, in Martín Arecha (coord.), Els Voto em las Sociedades y los Concursos, Buenos Aires, Legis, 2007, pp. 205-232.

Richard, Efraín Hugo - MALdonAdo, César - Álvarez, Norma Beatriz, Suspensíon de acciones y fuero de atracción em los concursos, Buenos Aires, Astrea, 1994.

RIBEIRo, Renato Ventura, Direito de Voto nas Sociedades Anônimas, São Paulo, Quartier Latin, 2009.

, Aplicação de Novas Tecnologias nas Assembleias Gerais de Sociedades Anônimas, Direito Societário - Desafios Atuais, Rodrigo R. Monteiro de Castro Leandro Santos de Aragão (coord.), São Paulo, Quartier Latin, 2009, pp. 279-300.

Rodrigues, Sílvio, Direito Civil - Parte Geral, v. 1, São Paulo, Saraiva, 1999.

Romano-Pavoni, Giuseppe, Le deliberazione delle assemblee delle società, Milão, Giuffrè, 1951.

Rojas JR., Luis Manuel, El Derecho de Voto em La Sociedad Anónima, México, Editorial Jus, 1945.

Rosenvald, Nelson, Comentários, in Min. Cezar Peluso (coord.), Código Civil Comentado, Barueri-SP, Manole, 2009, pp. 456-460.

SADDI, Jairo. Assembleia de credores: um ano de experiência da nova Lei de Falências. Uma avaliação, in Revista de Direito Bancário e do Mercado de Capitais, ano 10, n. 36, abril-junho de 2007, pp. 214-223.

., O Comitê de credores na nova lei de Falências. In: Revista do Advogado. A nova lei de falências e de recuperação de empresas. Ano XXV, n. 83. São Paulo, 
2005.

., Considerações sobre o Comitê e a Assembleia de Credores na Nova Lei Falimentar, in Direito Falimentar e a Nova Lei de Falências e Recuperação de Empresas, coord. Luiz Fernando Valente de Paiva, São Paulo, Quartier Latin, 2005, pp.199-219.

., Suspensão e Invalidação da Assembleia de Credores na Nova Lei de Falências, in Direito Societário e a Nova Lei de Falências e Recuperação de Empresas, Rodrigo R. Monteiro de Castro - Leandro Santos de Aragão (coord.), São Paulo, Quartier Latin, 2006, pp. 26-57.

., Assembleia de Credores: Um Ano de Experiência da Nova Lei de Falências - Uma Avaliação, in Revista de Direito Bancário e do Mercado de Capitais, ano 10, n. 36, abril-junho de 2007, pp. 214-223.

SAldANHA, Nelson Nogueira, Assembleia (verbete), in Enciclopédia Saraiva do Direito, v. 8, São Paulo, Saraiva, pp. 192-193.

SAlomão FILHO, Calixto, Recuperação de empresas e interesse social, in: SOUZA JUNIOR, Francisco Satiro de - PITOMBO, Antonio Sérgio A. de Moraes (Coords.), Comentários à lei de recuperação de empresas e falência. Lei 11.101/2005, São Paulo, RT, 2007, p. 43-54. ., A sociedade unipessoal, São Paulo, Malheiros, 1992. ., O Novo Direito Societário, São Paulo, Malheiros, 2011.

SALVATI, Gioavanna Giada, L'ammissibilità del método assembleare nelle società di persone, in Il diritto falimentare e delle società commerciali, ano LXXX, n. 2, marçoabril de 2005, pp. 386-407.

SANTAGATA, Renato, Interlocking directorates ed 'interessi degli amministratori' di società per azioni, in Rivista delle società, ano 54 (2009), março-junho 2009, fascículo $2^{\circ}-3^{\circ}$, pp. $310-346$.

Santi Romano, Princípios de Direito Constitucional Geral, trad. Maria Helena Diniz, São Paulo, RT, 1977. ., L'ordinamento giuridico - Studi sul conccetto, Le fonti e i caratteri del diritto - Parte prima, Pisa, Cav. Mariotti, 1917. 
SAntos, Paulo Penalva, Comentários, in Osmar Brina CorRÊA-Lima - Sérgio Mourão CORRÊA-Lima (coord.), Comentários à Nova Lei de Falência e Recuperação de Empresas, Rio de Janeiro, Forense, 2009.

Santos, Roseli Rêgo, A Recuperação de Empresa e a Função Social da Empresa na Lei

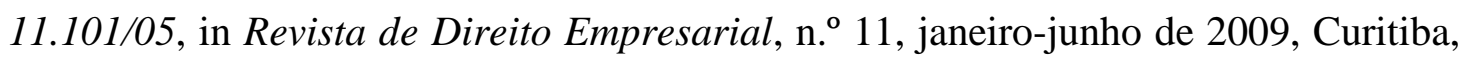
Juruá, pp. 159-178.

SCHWARTZ, Alan, The Law and economics approach to corporate bankruptcy, in Revista de Direito Bancário e do Mercado de Capitais, ano 10, n. 36, abril-junho de 2007, pp. 55-79.

SEnNA, Andressa Paula, O Abuso de Direito e a Litigância de Má-Fé como Impeditivos à Marcha Processual e ao Resultado Justo da Prestação Jurisdicional, in Revista de Direito Privado, ano 10, n. 40, outubro-dezembro de 2009, pp. 9-59.

SENA, Giuseppe, Il voto nella assemblea della società per azioni - Parte generale, Milão, Giuffrè, 1958.

SEVERINI, F., I problemi procedurali del concordato preventivo, in DI MARZIO, Fabrizio, Il nuovo diritto della crisi di impresa e del falliimento, Turim, Itaedizioni, 2006.

SEverino, Antônio Joaquim, Metodologia do Trabalho Científico, São Paulo, Cortez, 2002.

Simão FILHO, Adalberto, Comentários, in Comentários à Nova Lei de Recuperação de Empresas e de Falências, coord. Newton De Lucca - Adalberto Simão Filho, São Paulo, Quartier Latin, 2005, pp. 389-483.

., Interesses transindividuais dos credores nas assembleias gerais e sistemas de aprovação do plano de recuperação judicial, in in DE LUCCA, Newton DOMINGUES, Alessandra de Azevedo (coord.), Direito Recuperacional, São Paulo, Quartier Latin, 2009, pp. 32-64.

Silva, João Calvão - Rodrigues, Frederico Viana, Os Novos Paradigmas do Direito Concursal: Uma Análise Jus-comparatística sob o Prisma do regime Português, in Revista de Direito Bancário e do Mercado de Capitais, ano 10, n. 36, abril-junho de 2007, pp. 224-240.

STANGHELLINI, Lorenzo, Le crisi di impresa fra diritto ed economia - Le procedure di 
insolvenza, Bolonha, Il Mulino, 2007.

SzTAJn, Rachel, Da Recuperação Judicial, in SOUZA JUNIOR, Francisco Satiro de: PITOMBO, Antonio Sérgio A. de Moraes (Coords.). Comentários à lei de recuperação de empresas e falência. Lei 11.101/2005, São Paulo, RT, 2007, p.219269.

, Notas sobre as Assembleias de Credores na Lei de Recuperação de Empresas, in Revista de Direito Mercantil, Industrial, Econômico e Financeiro, v. 138, pp. 53-70.

., Comentários, in Paulo Fernando Campos Salles Toledo - Carlos Henrique ABRÃo (Coords.), Comentários à Lei de Recuperação de Empresas e Falência, São Paulo, Saraiva, 2010, pp. 492-551.

., Comentários, in Comentários, in Francisco Satiro de SouZA JR. - Antonio Sérgio A. de Moraes Pitombo (coordenadores), Comentários à Lei de Recuperação de Empresas e Falência. Lei 11.101/2005, São Paulo, RT, 2007, pp. 219-269.

TABB, Charles Jordan, The Law of Bankruptcy, Nova Iorque, Foundation, 1997.

Theodoro Júnior, Humberto, Comentários ao Novo Código Civil, v. 3, tomo 2, Rio de Janeiro, Forense, 2005.

., Curso de Direito Processual Civil, v. 1, Rio de Janeiro, Forense, 2001.

TOMASETti JúnIOR, Alcides, Abuso da Firma ou Razão Social (sociedade simples), in Enciclopédia Saraiva do Direito, v. 2, São Paulo, Saraiva, pp. 34-39.

., A 'propriedade privada' entre o Direito Civil e a Constituição, in Revista de Direito Mercantil, v. 126, p. 123.

Toledo, Paulo Fernando Campos Salles, Comentários, in TOLEDO, Paulo Fernando Campos Salles - ABRÃO, Carlos Henrique (Coords.), Comentários à Lei de Recuperação de Empresas e Falência, São Paulo, Saraiva, 2010, pp. 49-141. ., A Desconsideração da Personalidade Jurídica na Falência, in Revista de Direito Mercantil, Industrial, Econômico e Financeiro, v. 134, pp. 222-233. , A Empresa e o Empresário no novo Código Civil, in Arruda Alvim, 
Joaquim Portes de Cerqueira César, Roberto Rosas, Aspectos Controvertidos do novo Código Civil - Escritos em Homenagem ao Ministro José Carlos Moreira Alves, São Paulo, RT, 2003, pp. 495-506.

., Lei de Falências - Alienação de Estabelecimento da Concordatária, in Revista de Direito Mercantil, Industrial, Econômico e Financeiro, v. 128, pp. 275286.

., A Disciplina Jurídica das Empresas em Crise no Brasil: Sua Estrutura Institucional, in Revista de Direito Mercantil, Industrial, Econômico e Financeiro, v. 122, pp. 168-172.

., A Preservação da Empresa, Mesmo na Falência, in DE LUCCA, Newton

- DOMINGUES, Alessandra de Azevedo (coord.), Direito Recuperacional, São Paulo, Quartier Latin, 2009, pp. 517-534.

., Parecer - Recuperação Judicial - Sociedades Anônimas - Debêntures Assembleia Geral de Credores - Liberdade de Associação - Boa-fé Objetiva - Abuso de Direito - Cram Down - Par Conditio Creditorum, in Revista de Direito Mercantil, Industrial, Econômico e Financeiro, n. 142, pp. 263-281.

., A Empresa em Crise no Direito Francês e Americano, dissertação de mestrado, Faculdade de Direito da USP, São Paulo, mimeo, 1987.

., Modificações Introduzidas na Lei das Sociedades por Ações quanto à Disciplina da Administração das Companhias, in Reforma da Lei das Sociedades Anônimas: Inovações e Questões Controvertidas da Lei n. ${ }^{\circ}$ 10.303, de 31.10.2001, coord. Jorge Lobo - Antonio Kandir, Rio de Janeiro, Forense, 2002, pp. 423-452.

., O Conceito de Propriedade e os Bens do Falido, in Revista dos Tribunais, v. 678, abril de 1992, pp. 57-64. Disponível em <http://www.revistadostribunais.com.br/>. Consultado em 15/2/2012, às 15 h50.

., Da Personificação da Massa Falida, in Revista de Direito Mercantil, Industrial, Econômico e Financeiro, v. 78, p. 46-51.

., Recuperação judicial, a principal inovação da Lei de Recuperação e Empresas - LRE, in Revista do Advogado AASP, v. 83, setembro de 2005, pp. 98-106. 
TRuffat, E. Daniel, No existe em el derecho argentino nada que pueda denominarse 'derecho de voto' em lo referido a la solución concordatária, in Martín Arecha (coord.), Els Voto em las Sociedades y los Concursos, Buenos Aires, Legis, 2007, pp. 233-250.

VAISER, Lidia, El abuso Del derecho em los procesos concursales, Buenos Aires, Ad Hoc, 2008.

VAlverde, Trajano de Miranda, Comentários à Lei de Falências, v. 1, Rio de Janeiro, Forense, 2001.

., Comentários à Lei de Falências, v. 2, Rio de Janeiro, Forense, 2001.

., Comentários à Lei de Falências, v. 3, Rio de Janeiro, Forense, 2001.

VÁsqueZ, Gabriel - VILloldo, Marcelo, Sobre los sujeitos impedidos de pronunciarse com respecto a una propuesta concursal (com especial consideración de quién, cómo, cuándo y dónde articular esta questión), in Martín Arecha (coord.), Els Voto em las Sociedades y los Concursos, Buenos Aires, Legis, 2007, pp. 251-295

Venosa, Sílvio de Salvo, Direito Civil - Parte Geral, São Paulo, Atlas, 2009.

VerÇosA, Haroldo Malheiros Duclerc, Bancos Centrais no Direito Comardo - O Sistema Financeiro Nacional e o Banco Central do Brasil, São Paulo, Malheiros, 2005.

., Comentários aos artigos 21 a 34 da Lei n. 11.101/05, in Comentários à Lei de Recuperação de Empresas e Falências, coord. Francisco Satiro de Souza Jr. Antônio Sérgio A. de Moraes Pitombo, São Paulo, RT, 2007, pp. 163-186.

., O status jurídico do Controlador e dos Administradores na Recuperação Judicial, in Revista de Direito Mercantil, Industrial, Econômico e Financeiro, n. 143, pp. 21-38.

., Curso de Direito Comercial, v. 2, São Paulo, Malheiros, 2006.

Vítolo, Daniel Roque, Acuerdos Preventivos Abusivos o em Fraude a La Ley, Buenos Aires, Rubninzal- Culzoni, 2009.

, Elementos del derecho concursal, Buenos Aires, Ad Hoc, 2008. 
WALD, Arnold, Comentários ao Novo Código Civil, v 14, Rio de Janeiro, Forense, 2005.

Warren, William D. - Bussel, Daniel J., Bankruptcy, Nova Iorque, New York Foudantion Press, 2002.

Watanabe, Kazuo, Comentários aos artigos 80 e 81, in AA.VV., Código de Defesa do Consumidor Comentado pelos Autores do Anteprojeto, Rio de Janeiro, Forense Universitária, 2007.

YAssim, Assad Amadeo, Considerações sob Abuso de Direito, in Revista dos Tribunais, v. 538, ano 69, agosto de 1980, pp. 16-23.

Xavier, Vasco da Gama Lobo, O Conteúdo da Providência de Suspensão de Deliberações Sociais, Coimbra, Coimbra, 1978.

ZANINI, Carlos Klein, Comentários, in SOUZA JUNIOR, Francisco Satiro de PITOMBO, Antonio Sérgio A. de Moraes (coordenadores), Comentários à Lei de Recuperação de Empresas e Falência. Lei 11.101/2005, São Paulo, RT, 2007, pp. 337-356. 